Fall 1962

\title{
1962 Miracle Yearbook
}

\section{Cedarville College}

Follow this and additional works at: https://digitalcommons.cedarville.edu/yearbooks

Part of the Higher Education Commons, Organizational Communication Commons, and the Public Relations and Advertising Commons

\section{Recommended Citation}

Cedarville College, "1962 Miracle Yearbook" (1962). Yearbooks. 8.

https://digitalcommons.cedarville.edu/yearbooks/8

This Book is brought to you for free and open access by DigitalCommons@Cedarville, a service of the Centennial Library. It has been accepted for inclusion in Yearbooks by an authorized administrator of DigitalCommons@Cedarville. For more information, please contact digitalcommons@cedarville.edu. 


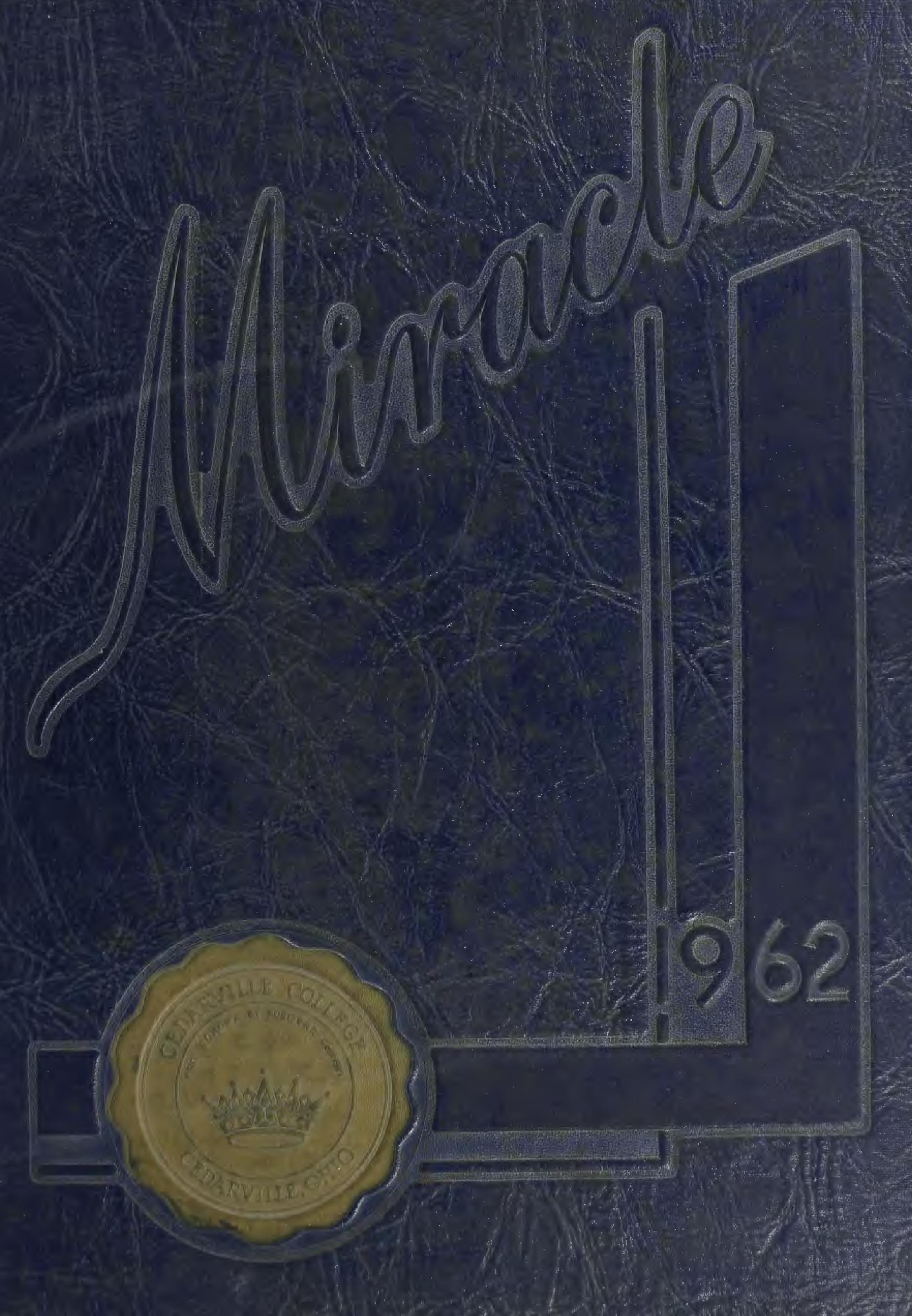




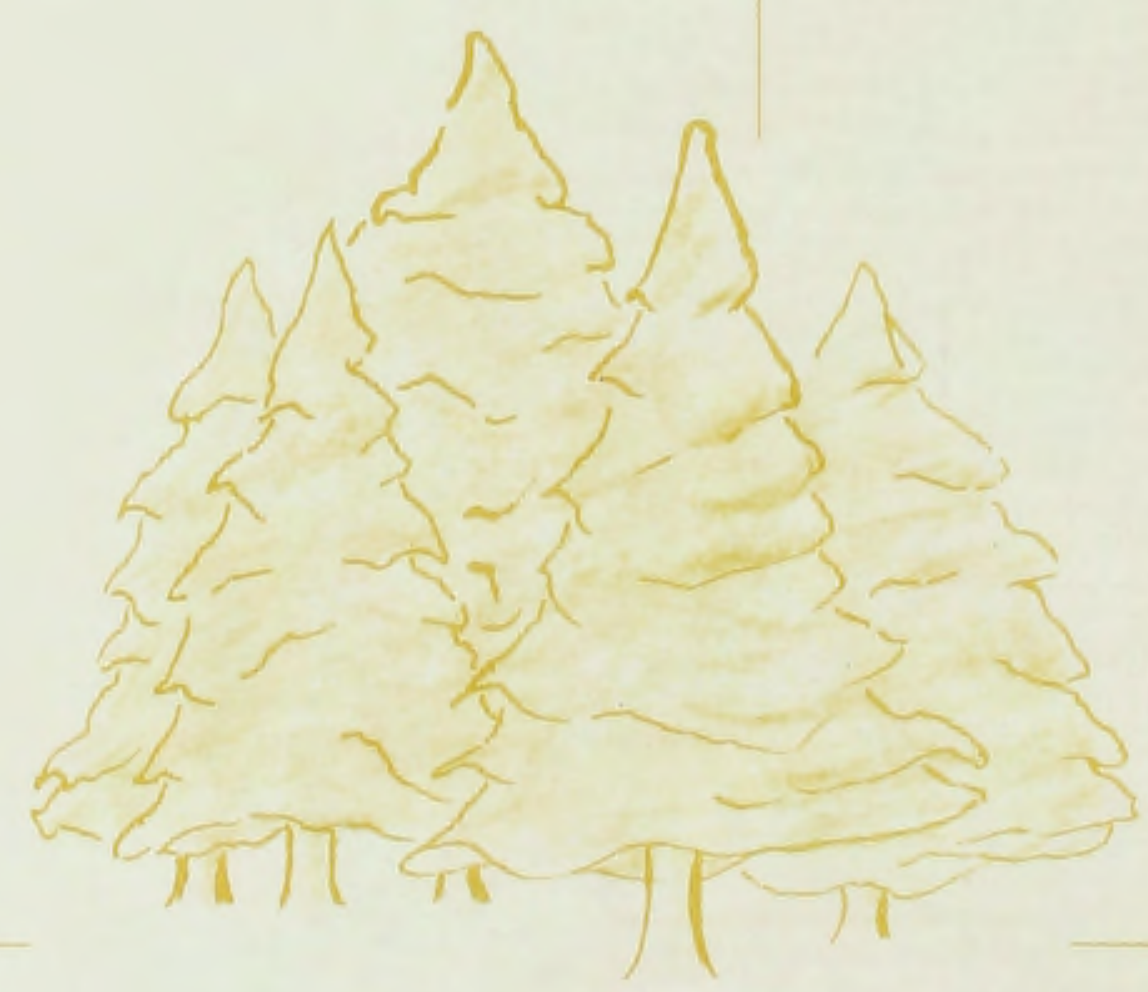

$1887=1962$ 


Jane Ginz, Editor

Beverly Woods, Business Manager 

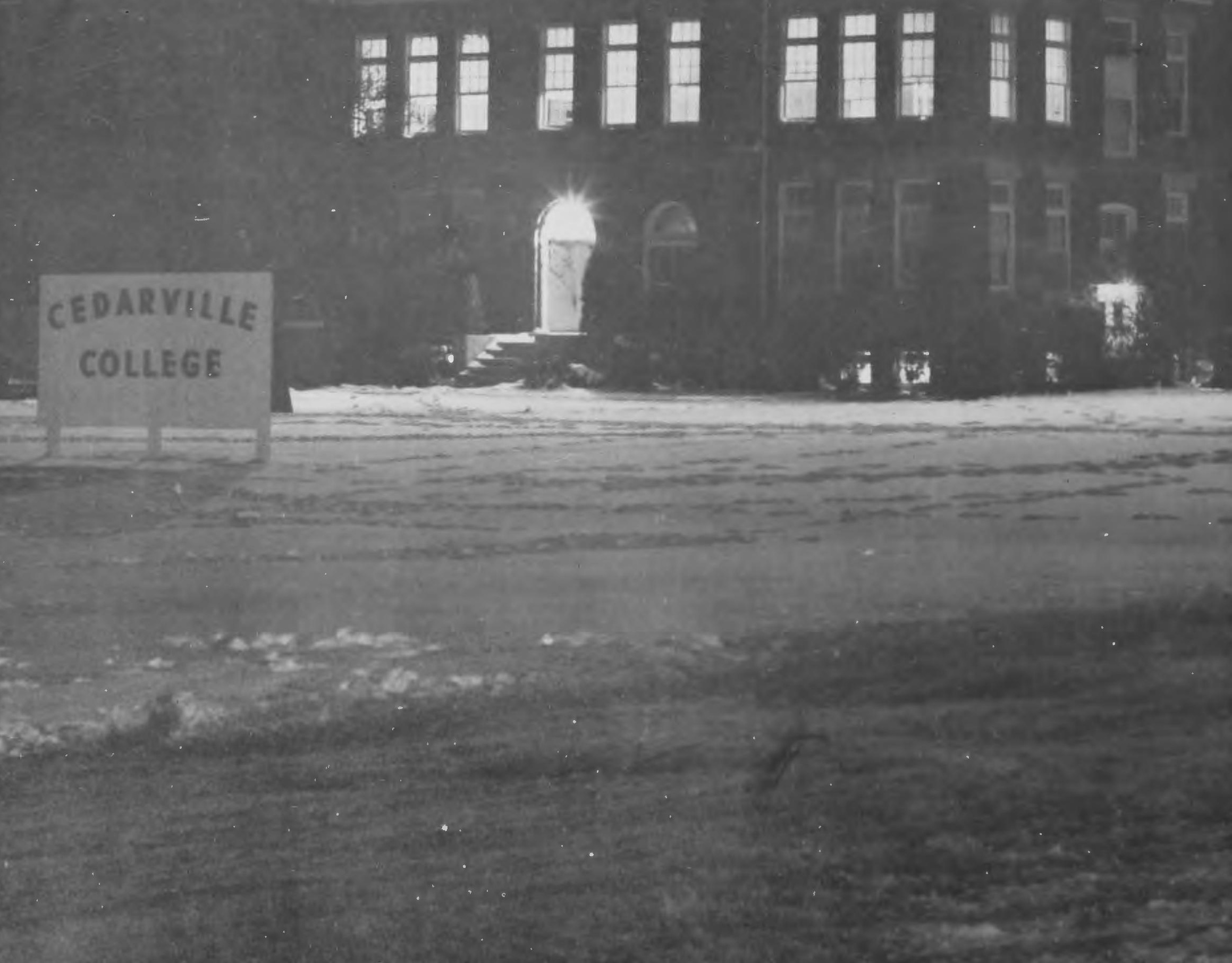

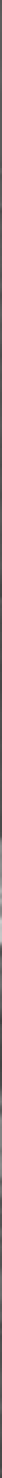

tit

A yearly purtlication of

Cedumille College

Cedanville. Ohio 


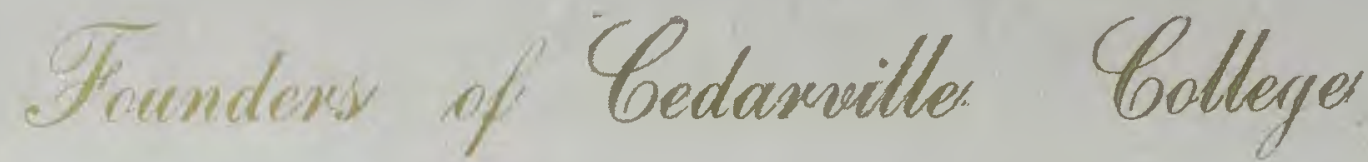

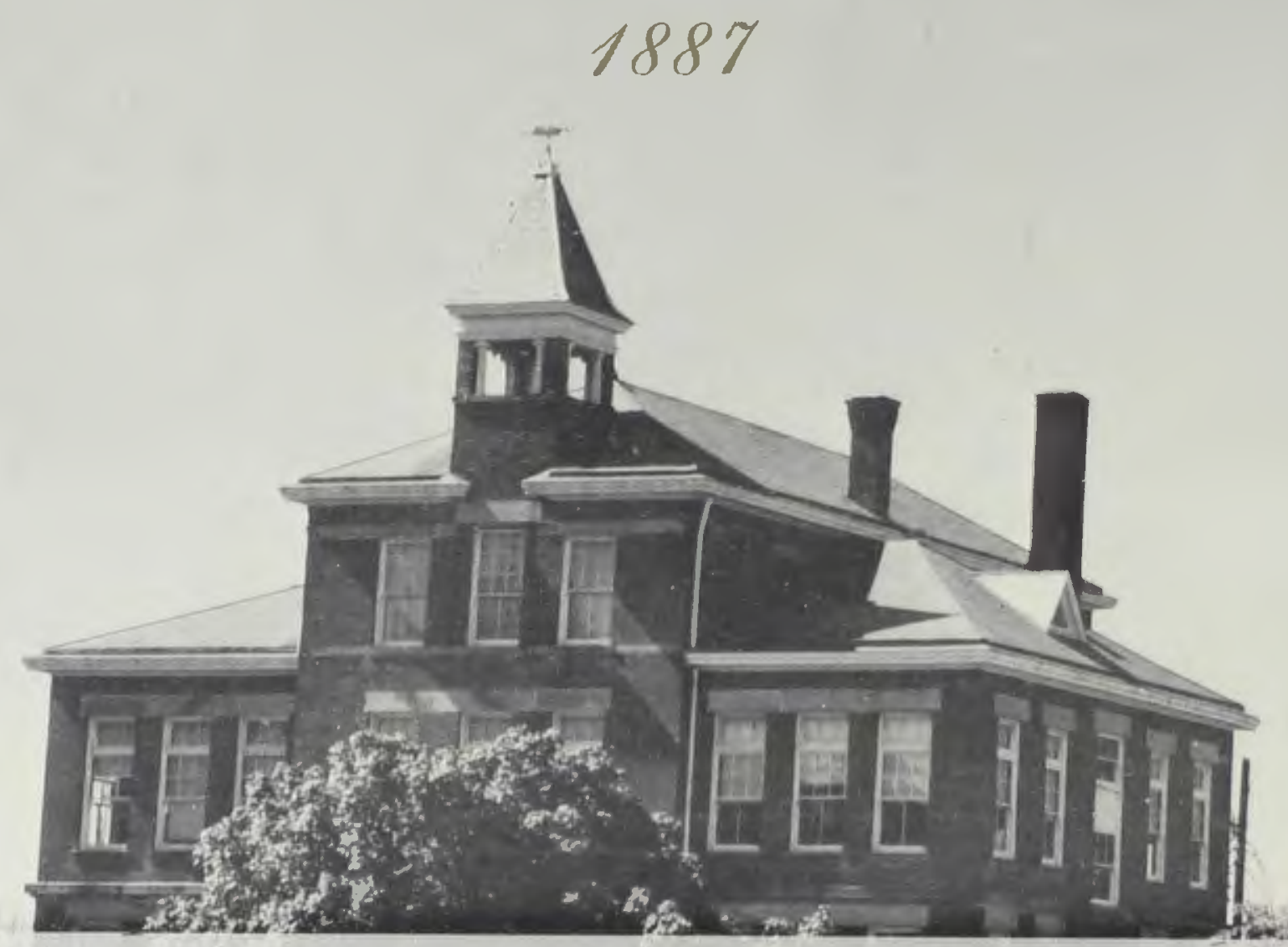

On the observance of the seventy-fifth anniversary of Cedarville College, it is good that we remember those who were led of the Lord to establish this school. "Cedarville College was founded with the sublime object in view of advancing the interest of God on earth, for the training of young men for the Gospel ministry, and for the education of young men and women for missionary service both at home and abroad."

It was with these objects in mind that a group of Godly men met with the desire to establish a liberal arts college for Christian young people. The College, founded in 1887, was controlled by the Reformed Presbyterian Church. 


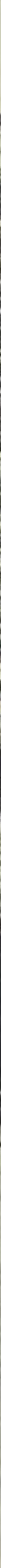




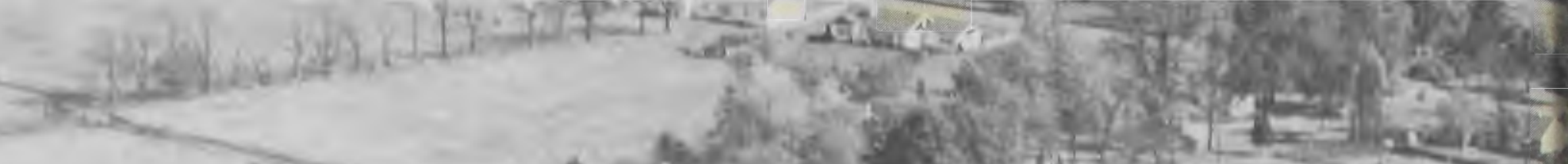
(3)

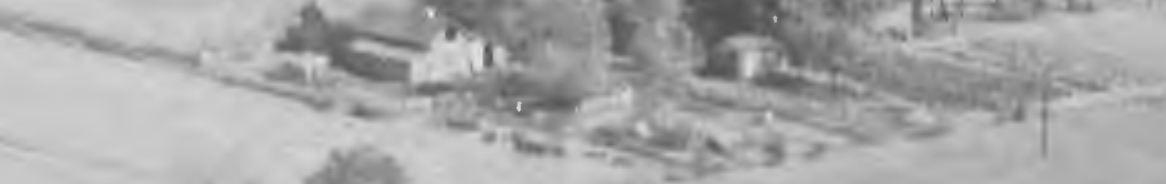

$$
\begin{aligned}
& \text { T>: }
\end{aligned}
$$

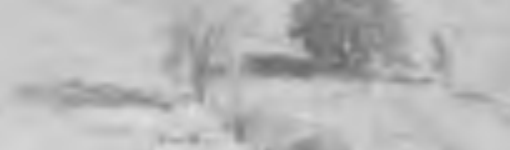
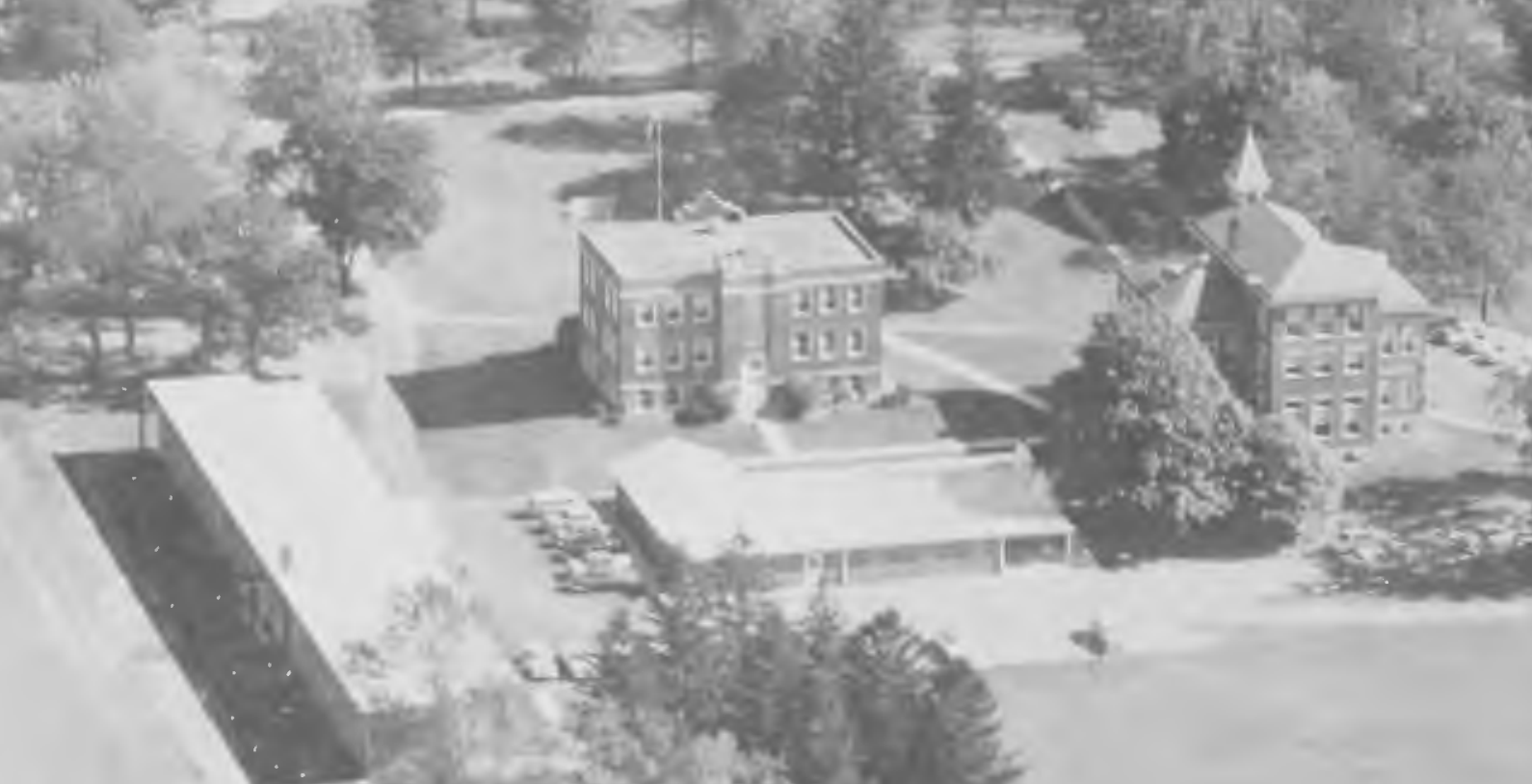

$x^{2} x$ $2 x^{2}+20$ 

Announcing our campus to all who pass on Route 72 , is the blue and white shadow box presented by the Class of '58. Proudly we look across our main campus where we have spent another year.

From Main Street we enter our campus through the gates which state the purpose for our school - "For the Word of God and the Testimony of Jesus Christ."

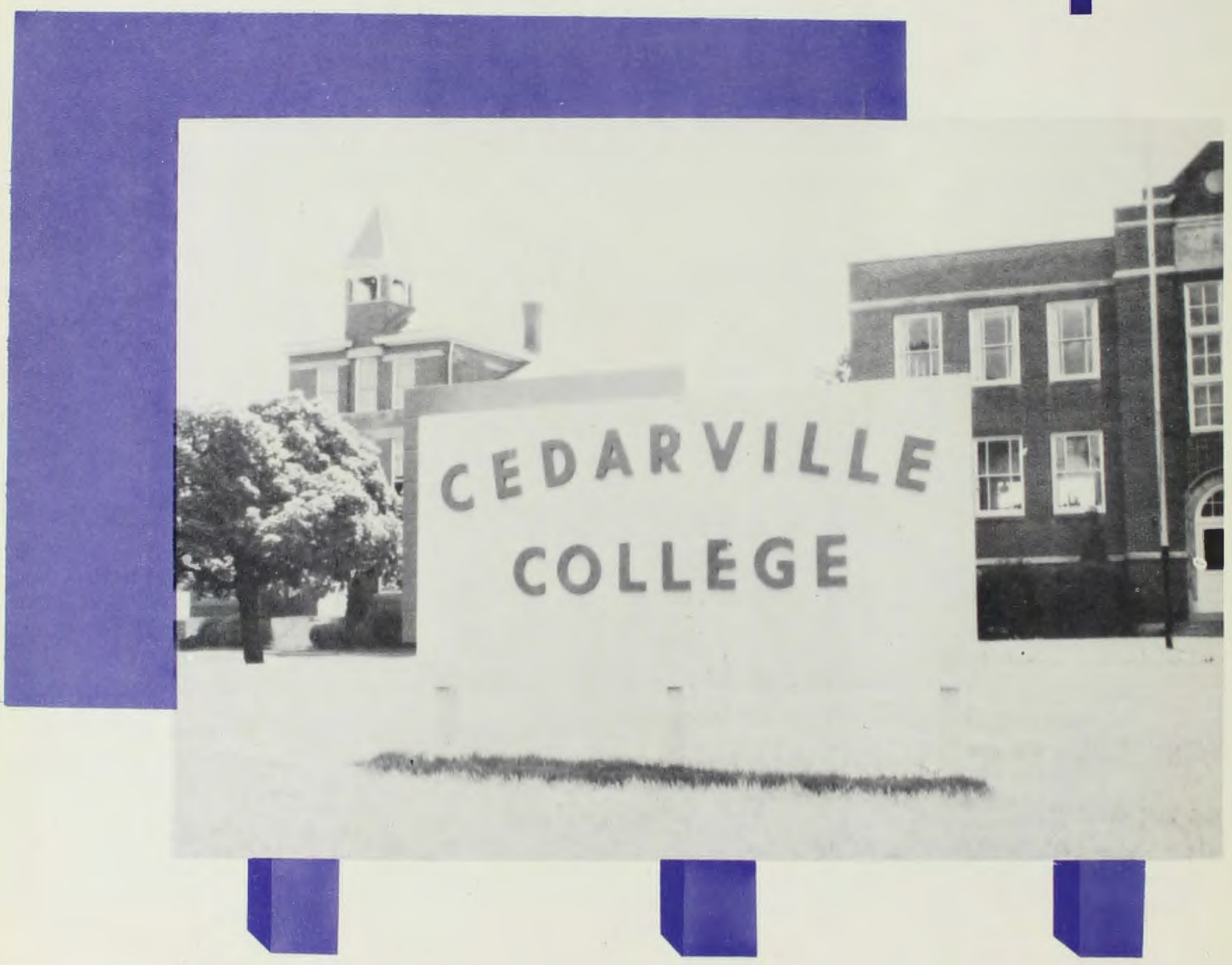




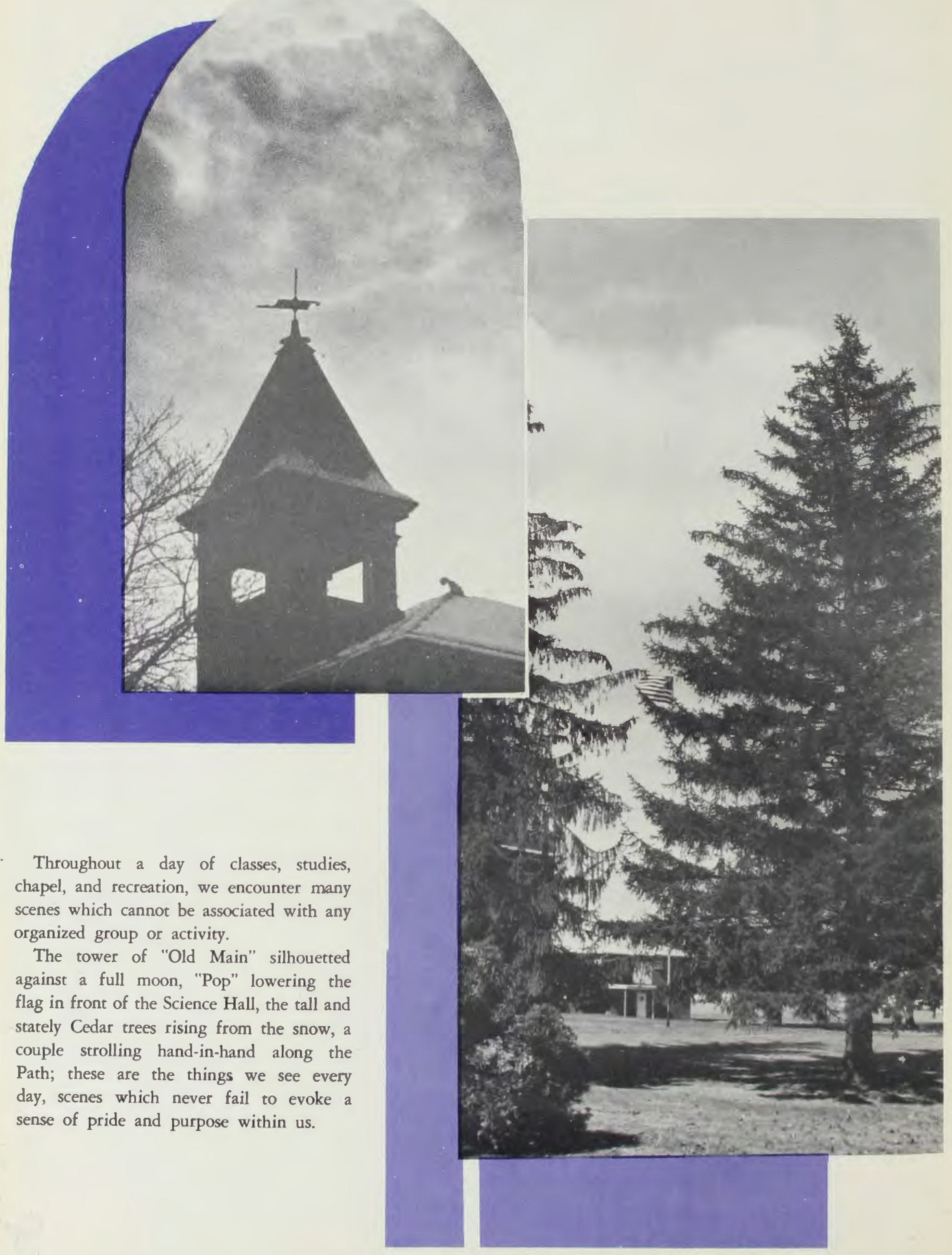


The time and seasonal changes make these scenes more impressive. These common scenes will linger in our memory long after we forget all the final exams and frivolity of college life.

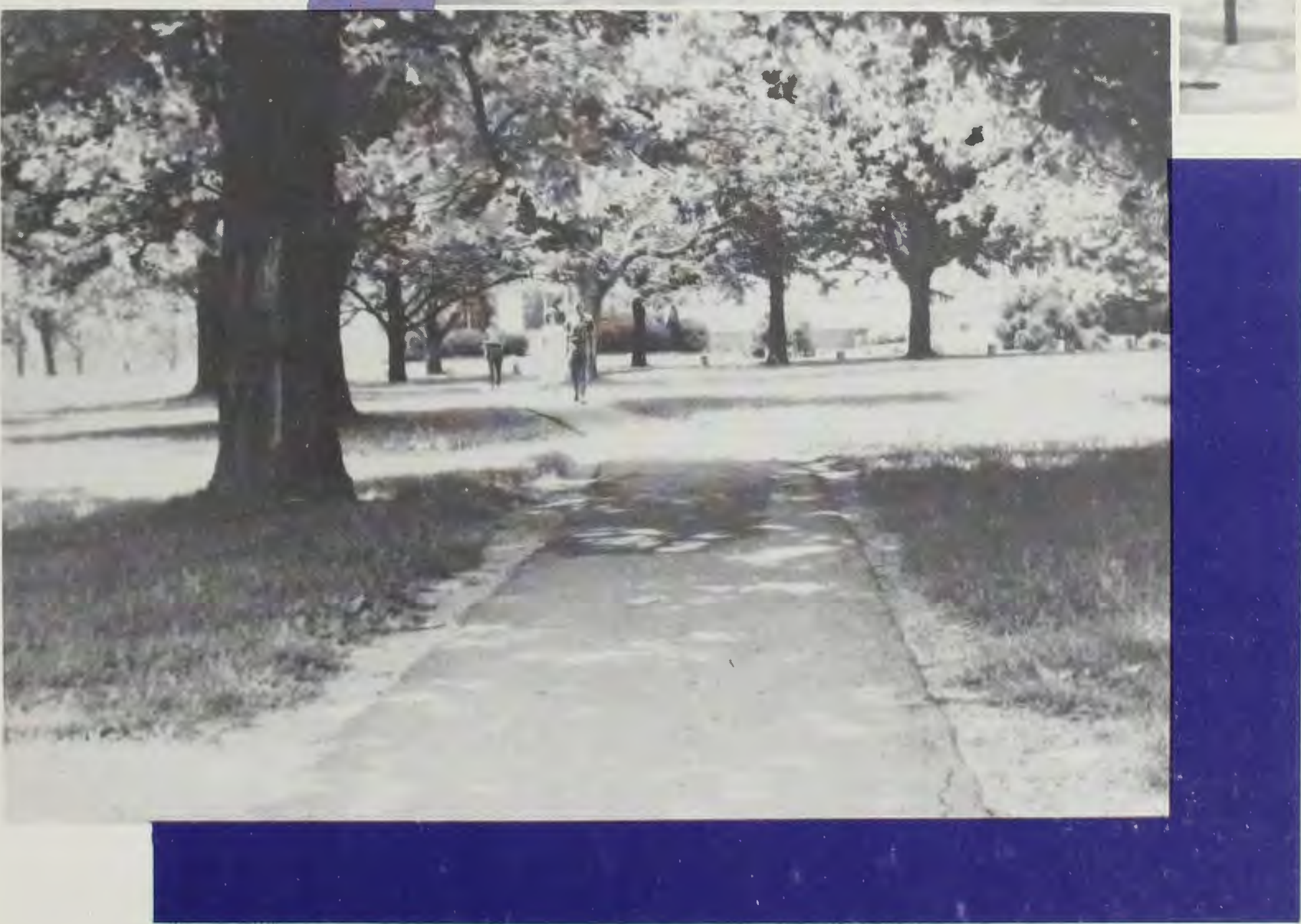




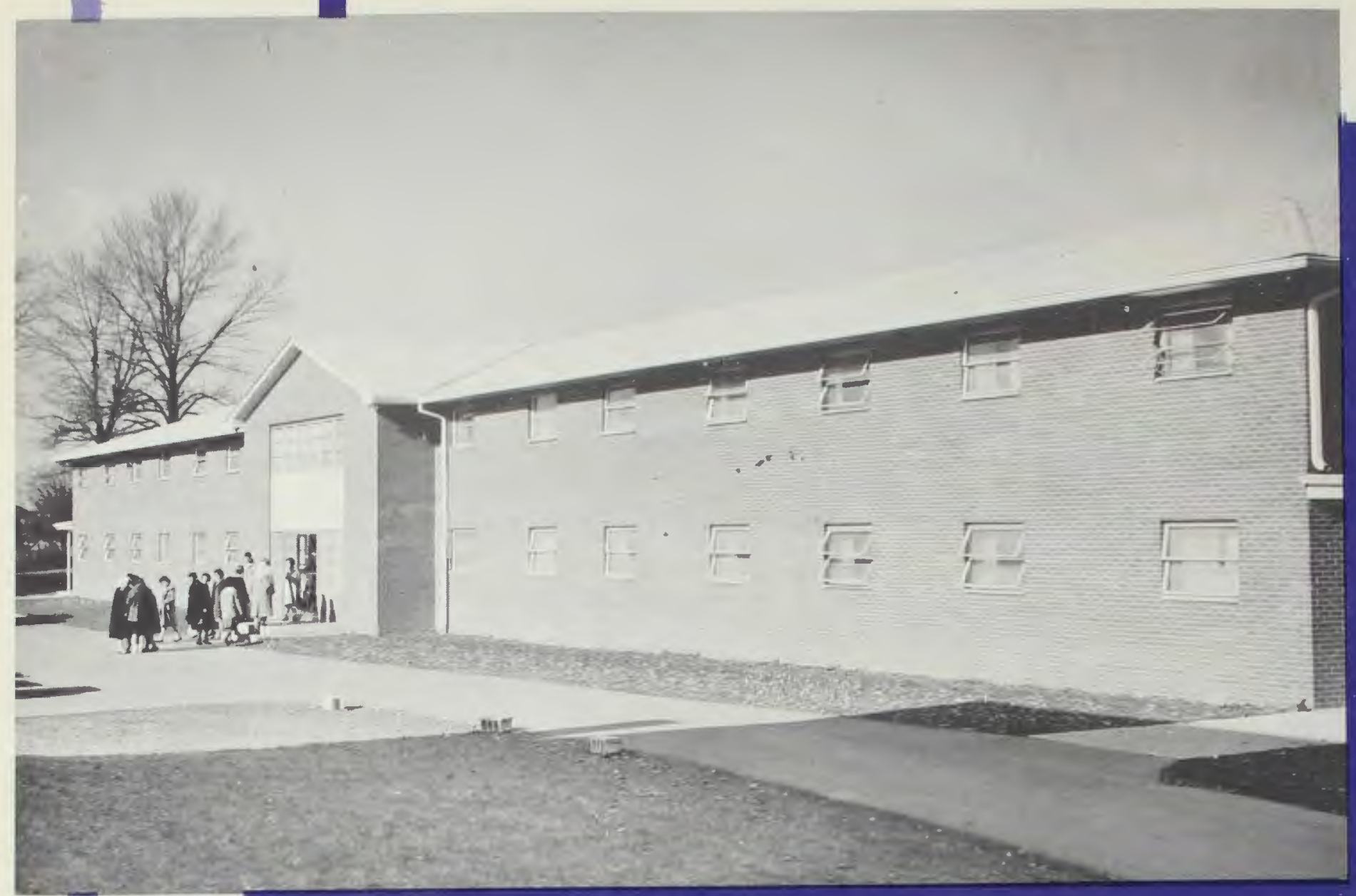

Providing an immediate refueling stop for itinerant scholars is the college cafeteria. We have spent many hours discussing exams, studying, laughing - and eating here. We can never forget the times we ran wildly from dorm to cafeteria trying to get an early meal card because we had a 7:00 committee meetıng or because that special person ate early.

When the crowd gradually diminishes at 7:30 and the doors close for another day, the work continues. On into the night a corps of students wash floors, tables and dishes to prepare for the coming day. 

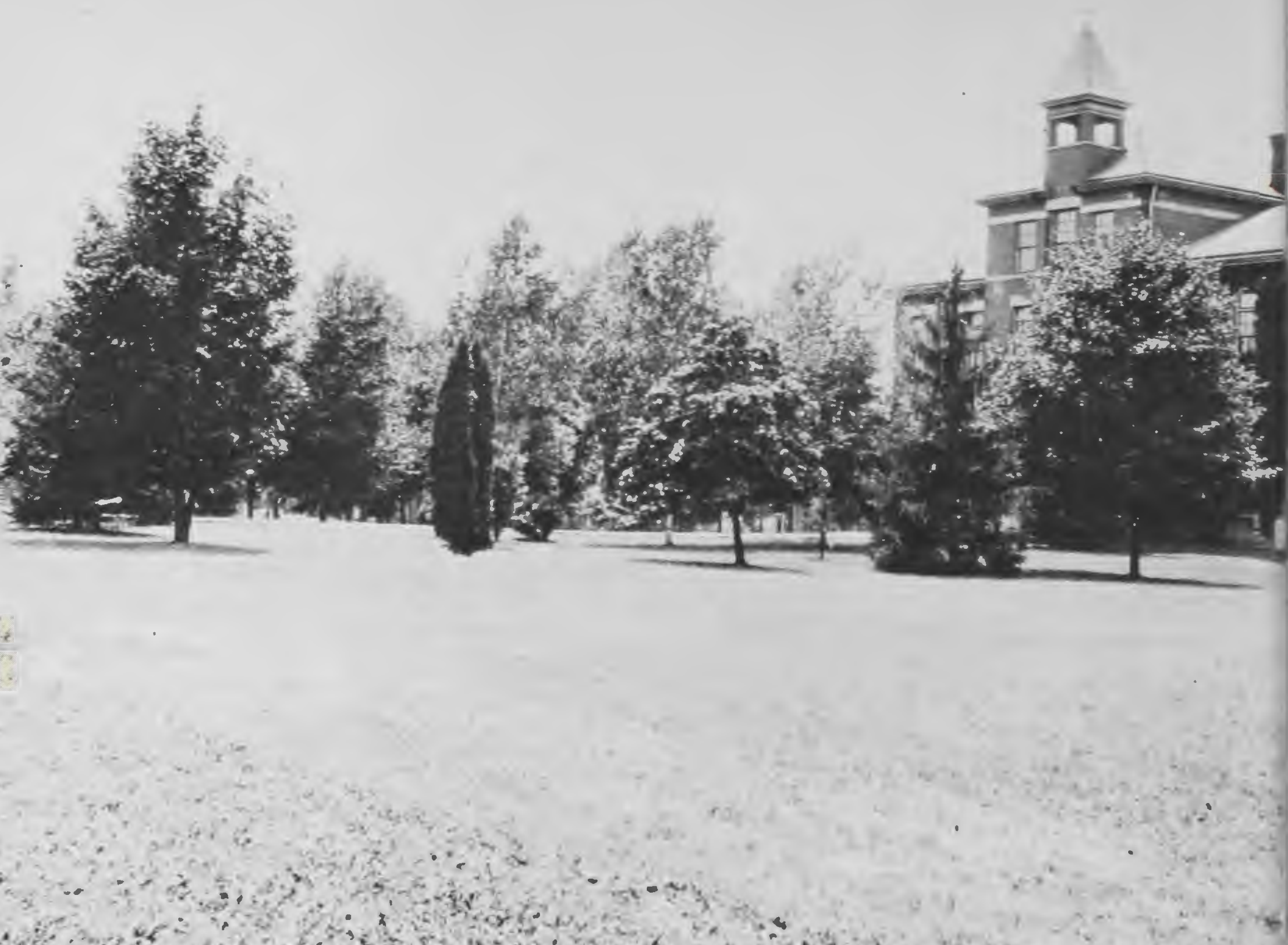

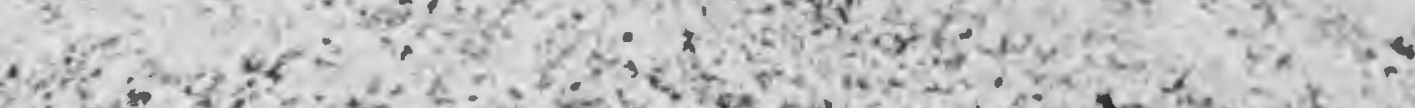

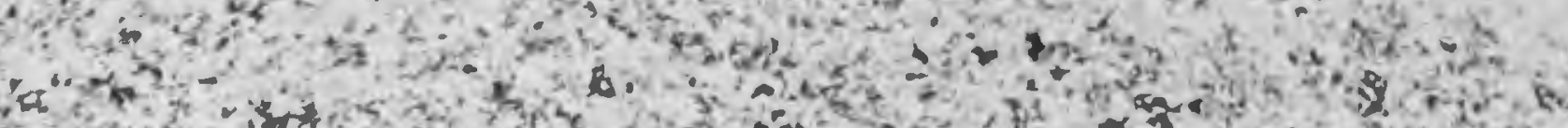

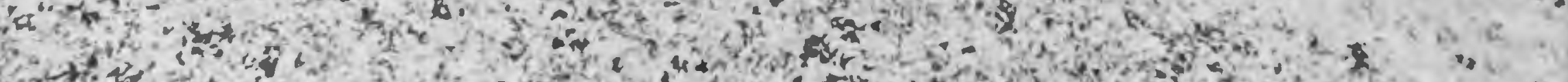

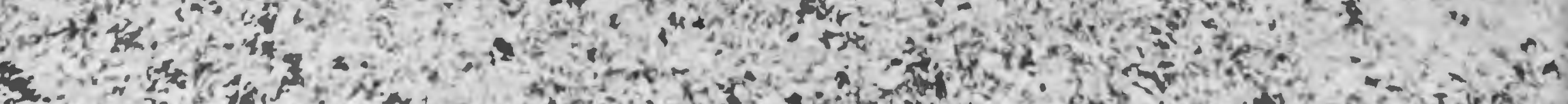
4.

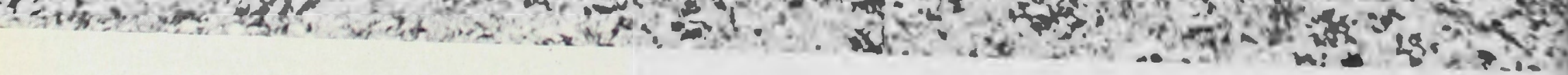


We are proud of our heritage. Many of us haven't known anything of the sacrifices and of the principles which brought our school into being, but in this 75 th year, as we take a long look over the past, we are encouraged through the examples of the early leaders of the college to continue to be a Christian College true to the Word. Within our hearts we find gratitude for our inheritance. 


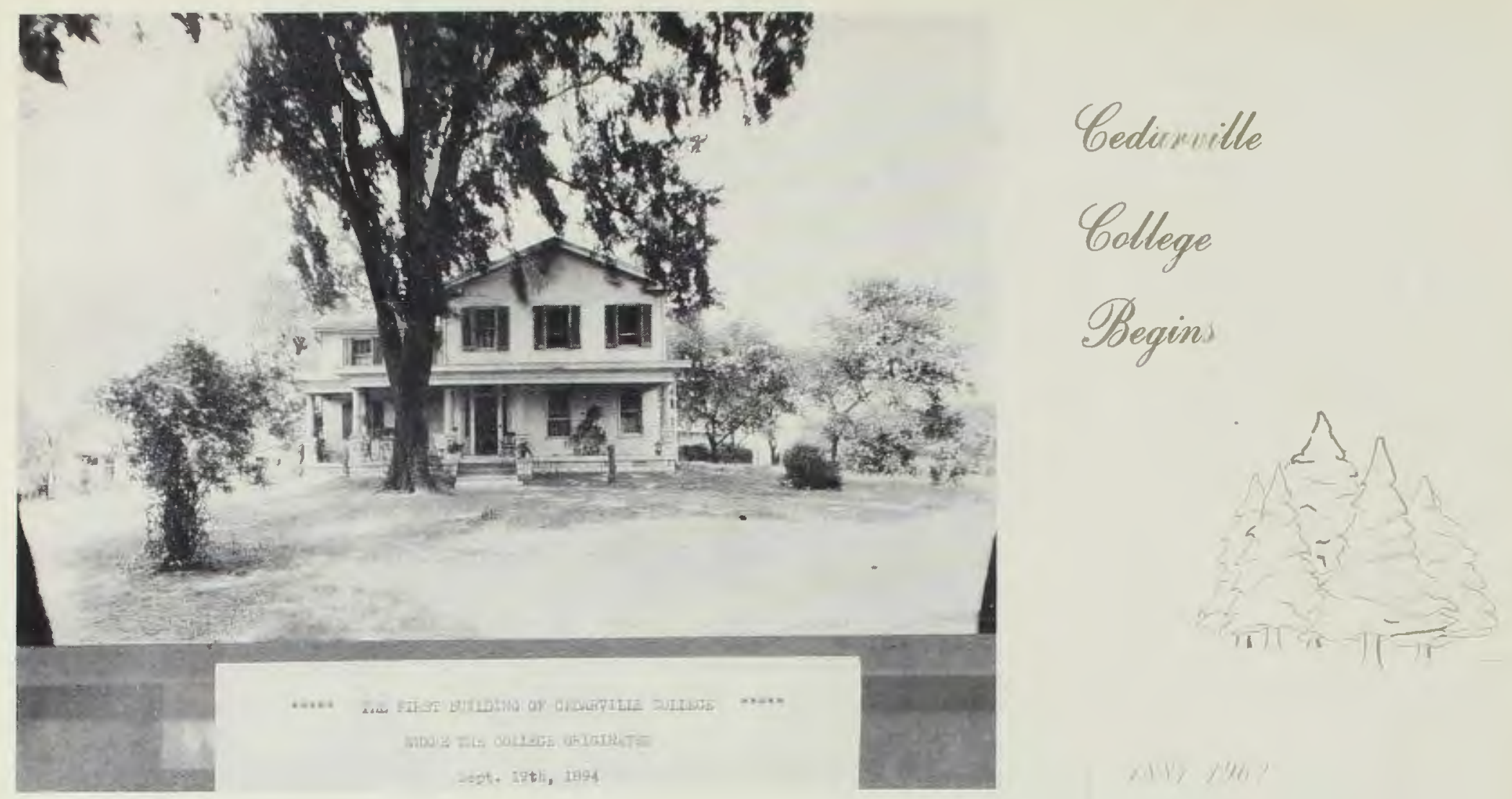

The home of Rev. Hugh Macmillan where the first classes of Cedarville College were held in 1894.

\section{ANNUAL CATALOGUE}

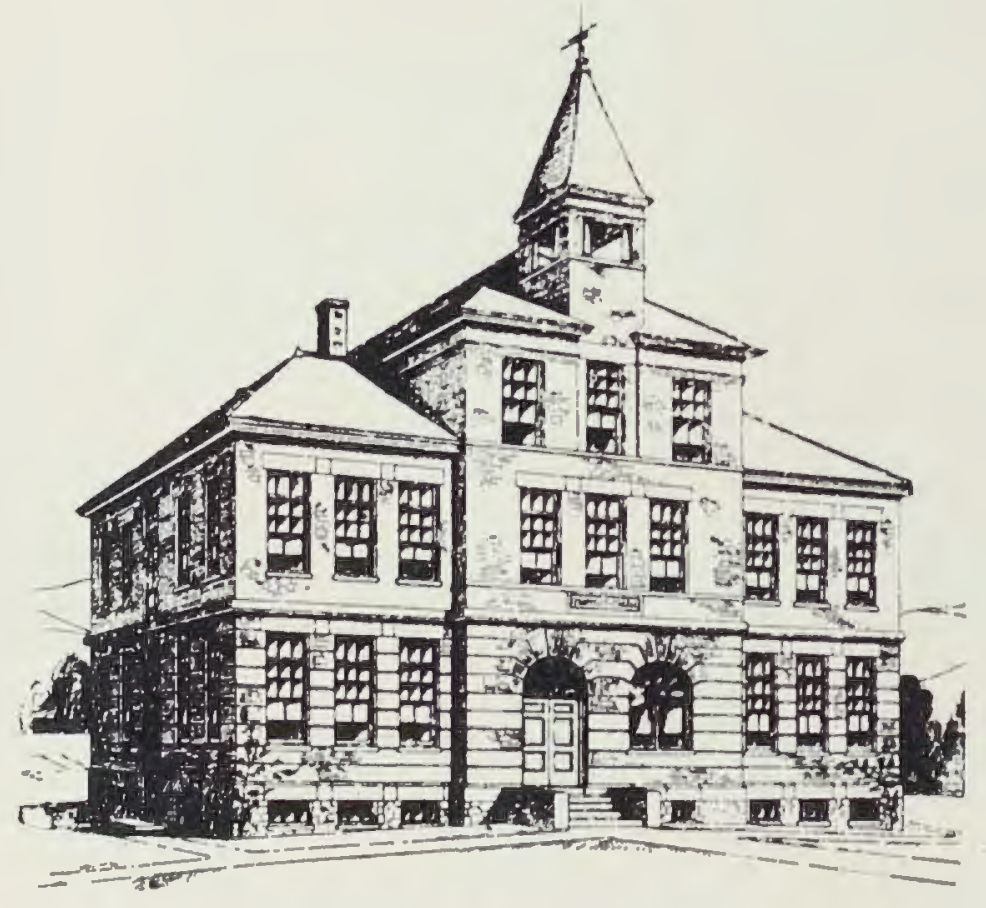

\section{CEDARVILLE COLLEGE,}

$1895=96$
At Duanesburgh, New York, in May of 1879, the General Synod of the Reformed Presbyterian Church decided to establish a liberal arts college. By the will of William Gibson, an elder in the First Presbyterian Church, Cincinnati, a bequest of $\$ 25,000$ was left in 1886 to found the college at Cedarville, Greene County, Ohio. On January 26, 1887, Cedarville College was chartered by the state of Ohio. At the meeting of the General Synod held in Coulterville, Illinois, in May, 1894, the Synod, upon the recommendation of the board of trustees, elected Dr. McKinney first President of Cedarville College. The board chose a faculty, and on Wednesday, September 19, 1894, the college was formally opened for instruction to thirty-six students in the fi1 ${ }_{\llcorner}$old mansion (above) formerly occupied by Dr. Hugh McMillan's Academy. The quarters proving too small for the work, the new building was erected and entered the following year, 1895. 


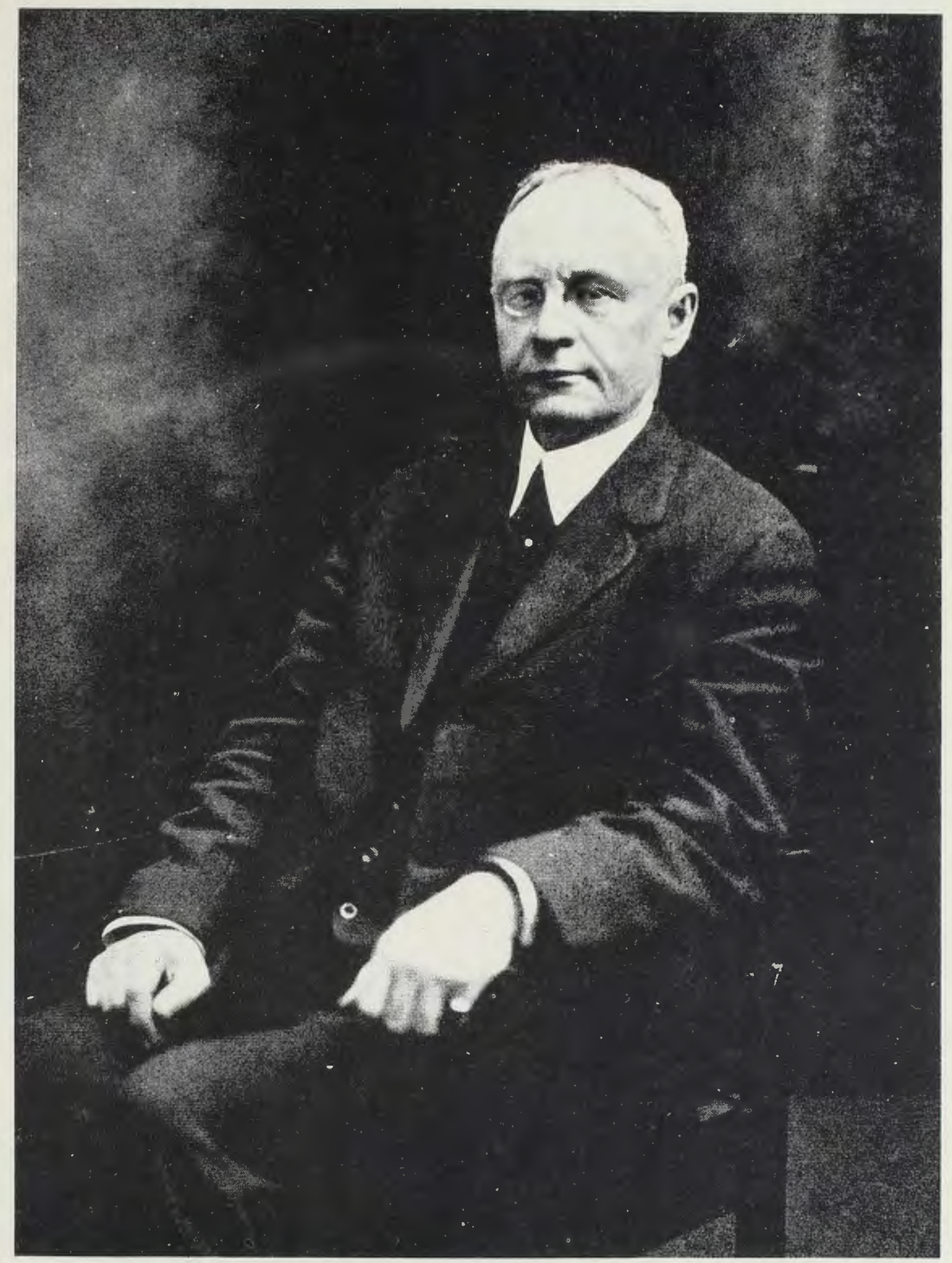

\section{Rev. David McKinney, D.D., LL.D., President}

Rev. David McKinney, D.D., first President of Cedarville College was pastor of the First Reformed Presbyterian Church of Cincinnati, Ohio, at the time of his appointment by the Synod. Dr. McKinney was born in Philadelphia, May 20, 1860, and received his education in the Philadelphia public schools, the University of Pennsylvania and the Reformed Presbyterian Theological Seminary. In May, 1895, Wittenberg College conferred upon him the degree of Doctor of Divinity.

At the time that Dr. McKinney was elected president, the college was largely a prospective institution. While he continued to serve as pastor of his congregation in Cincinnati, he took hold of the college work with such energy and determination that from a plan on paper it evolved into a reality. His zeal continued through the twentyone years that he served as president. After his resignation in 1915, he served as President Emeritus until his death in 1934. 


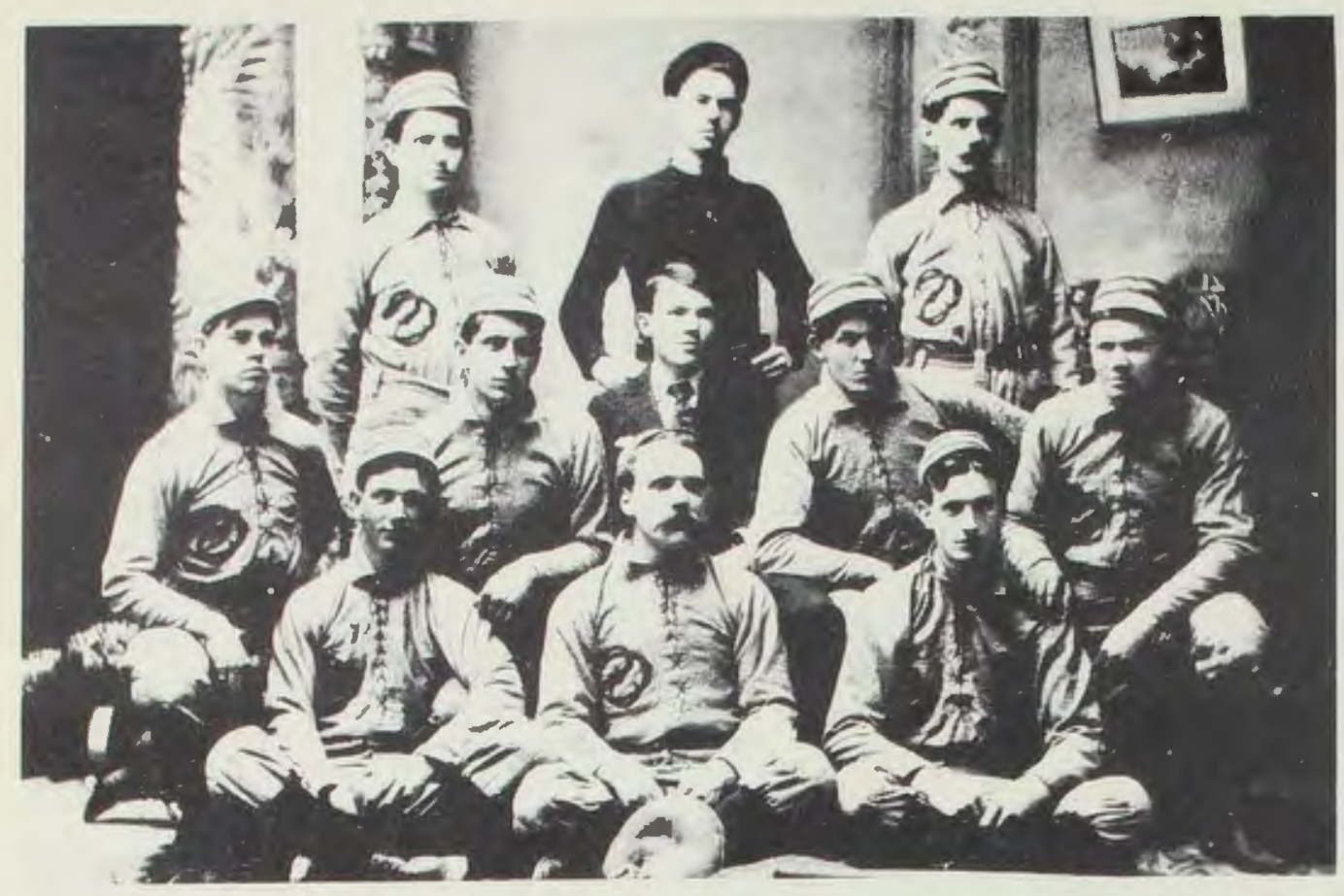

The first men's baseball team (1896) defeated Xenia and broke even with Antioch.

The history of athletics began simultaneously with the history of the college, for, while no athletic organization was sponsored and financed by the college in the early days, neither was it discouraged. The students, inclined to display their skill on the gridiron and diamond, were given all encouragement and the interest which these students had for developing their abilities is manifested by the fact that they were willing to employ a coach at their own expense.

In 1902, Mr. W. J. Alford presented the college trustees with the church building and grounds vacated by the Reformed Presbyterian Congregation, and desired that it be used as a gymnasium. It was equipped with complete apparatus for physical education and indoor athletics.

The college boasted basketball teams of both sexes. The Xenia Gazette of 1897 carried these words to its readers: "Since basketball has become the leading sport in all colleges, both among the girls as well as the boys, the Cedarville College classes have organized teams. The college girls ... play a very lady-like game of basketball... One feature of their playing is their clever pass work; another, their accuracy in throwing for goals; in fact, they play the game as it should be played. We will also say that this game will be strictly moral and first class in every respect, and no lady need be backward about attending."

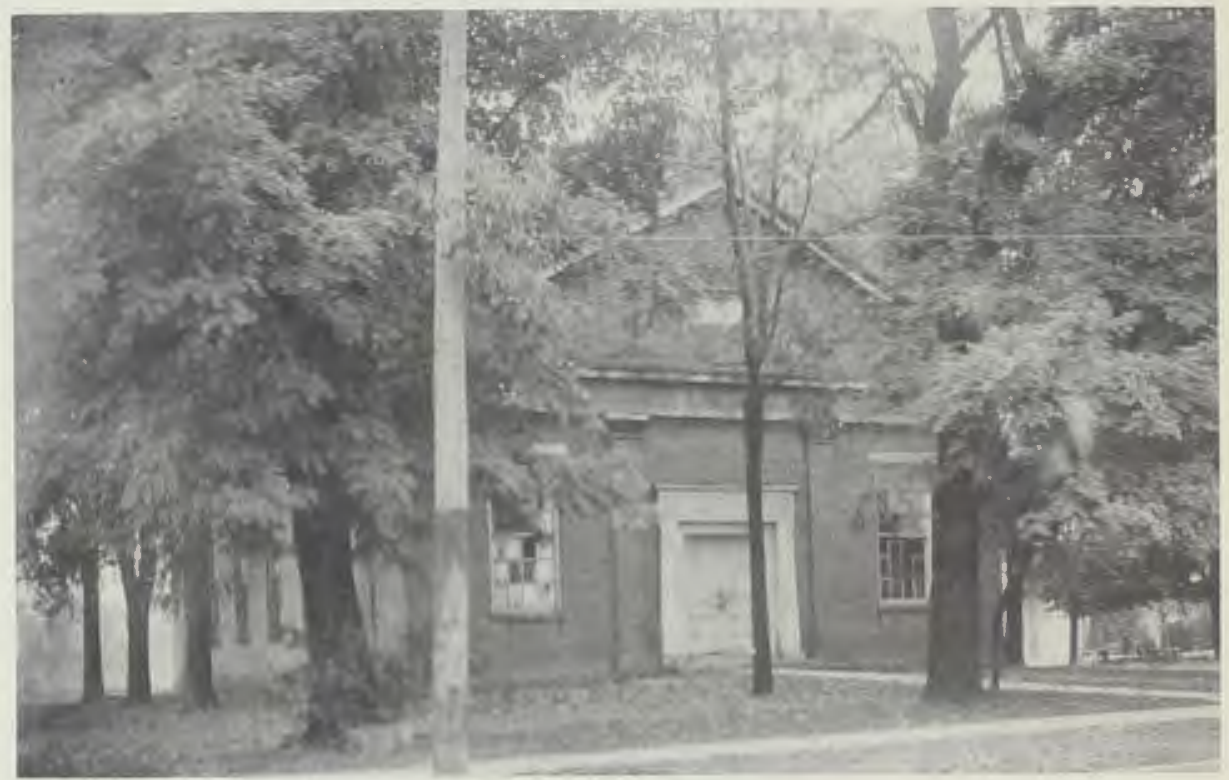

Alford Memorial Gym, 1902.

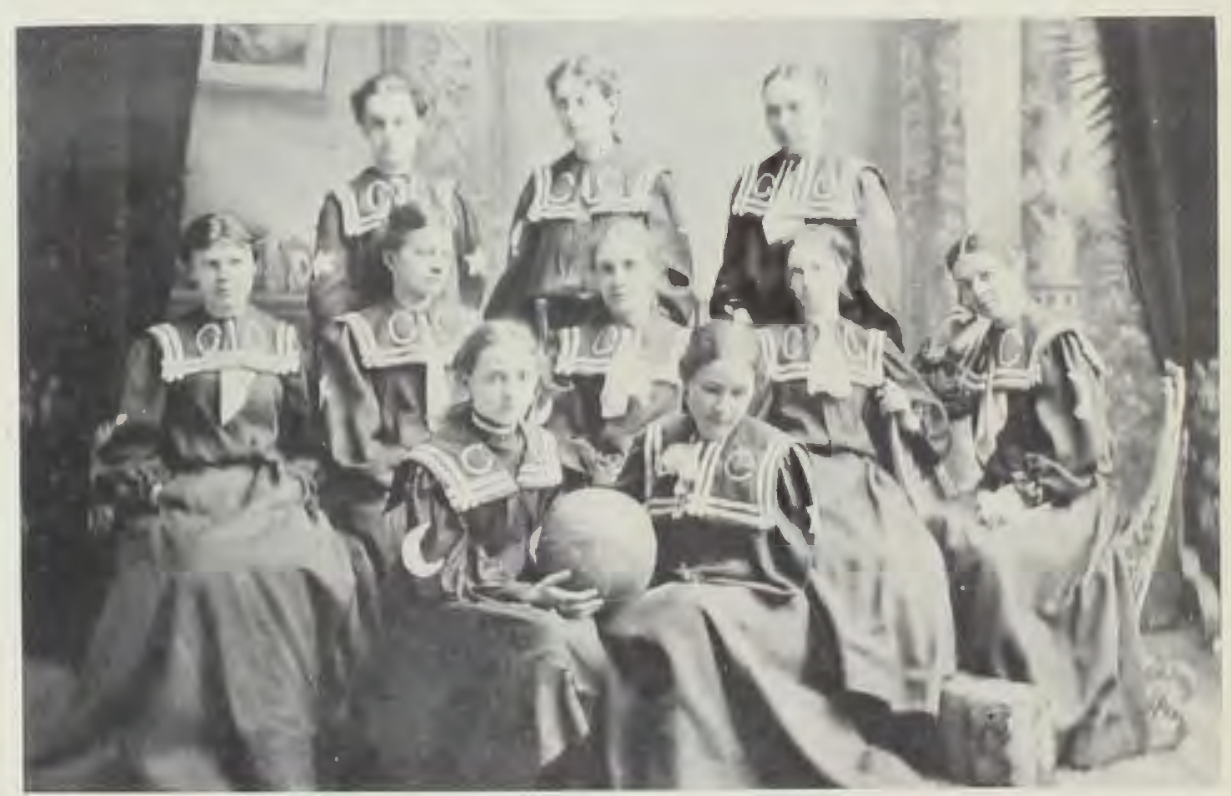

Cedarville College women's basketball team of 1898, the first in Greene County. TOP ROW, Left to Right: Anna Orr (Mrs. Robert Wilson), Alice Bromagem (Mrs. F. A. Jurkat), Bessie Hopping (Mrs. Carl Paull). SECOND ROW: Bertha Knott, Fanny Townsley (Mrs. Wallace Iliff), Jennie Morton (Mrs. T. R. Turner), Nellie Ustick, Mary Little (Mrs. Frank Murphy). FRONT ROW: Vera Andrew (Mrs. John Harvey), Nelle Lervis (Mrs. Nelson Clark). 


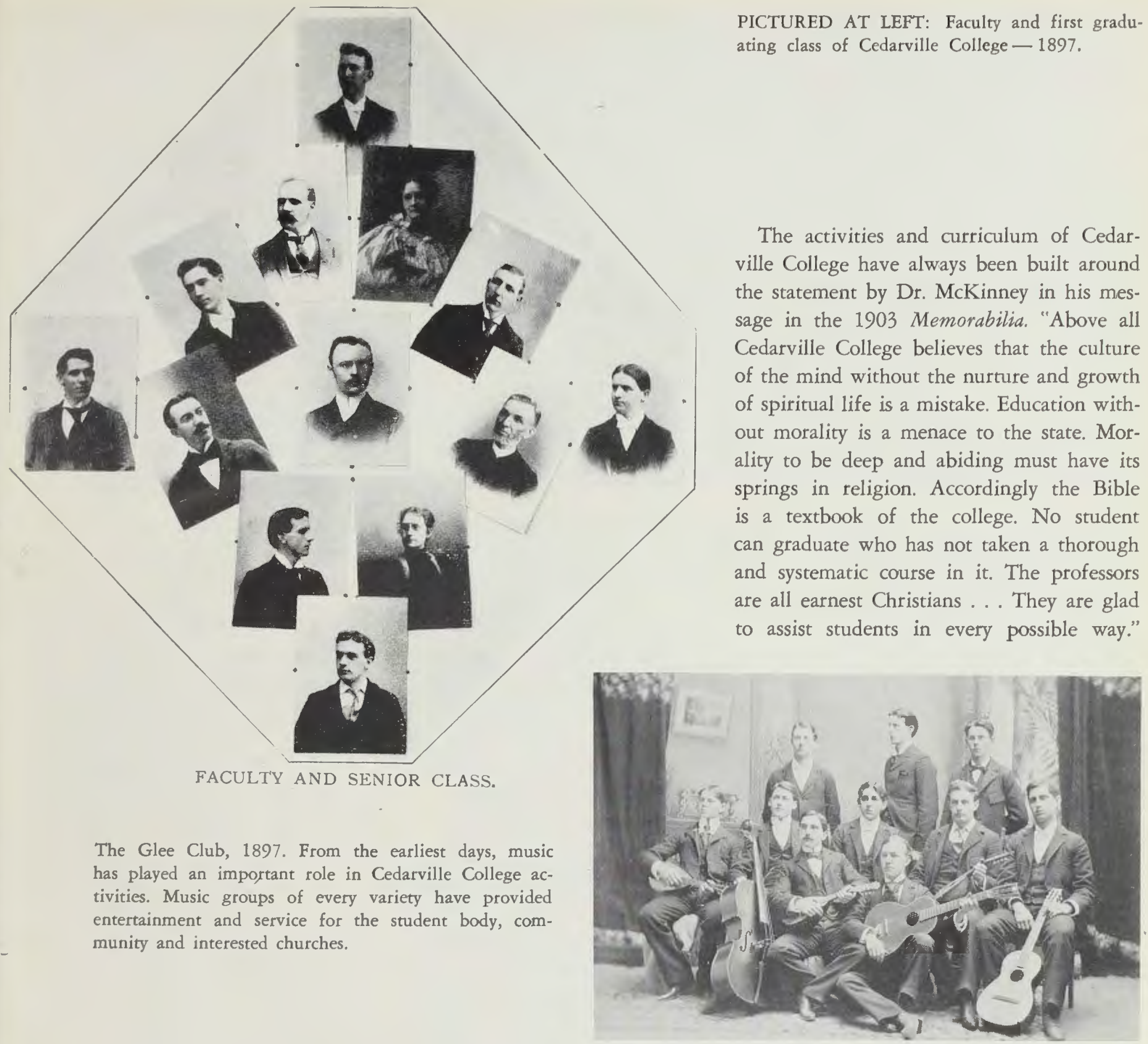

Dr. McKinney's interest in Bible training by no means dulled his interest in secular education. Through the efforts of Dr. McKinney and the Honorable Whitelaw Reid, Andrew Carnegie offered Cedarville College a gift equal to sum it could raise for an endowment. Twelve thousand dollars was secured within one year, and the present library building was completed in the fall of 1908.

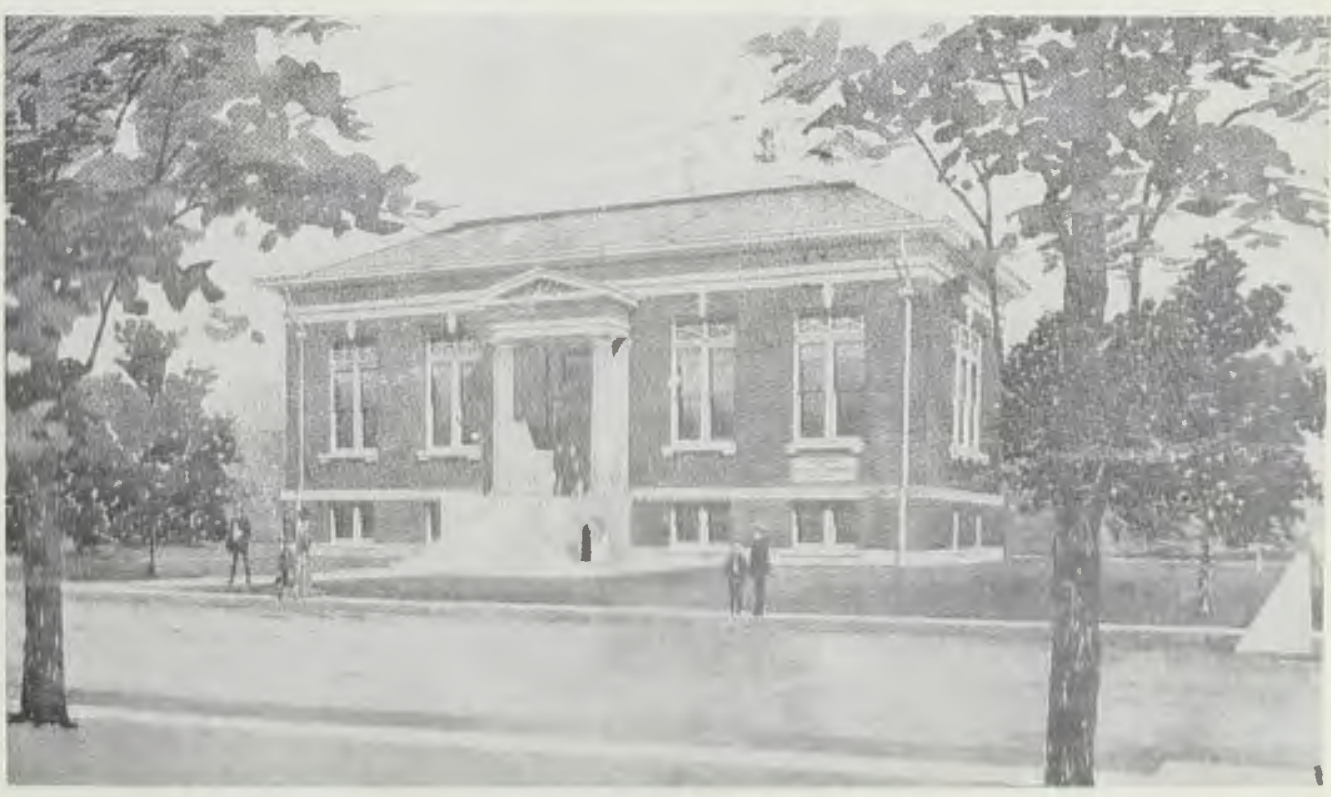

Architect's sketch of Carnegie Library. 


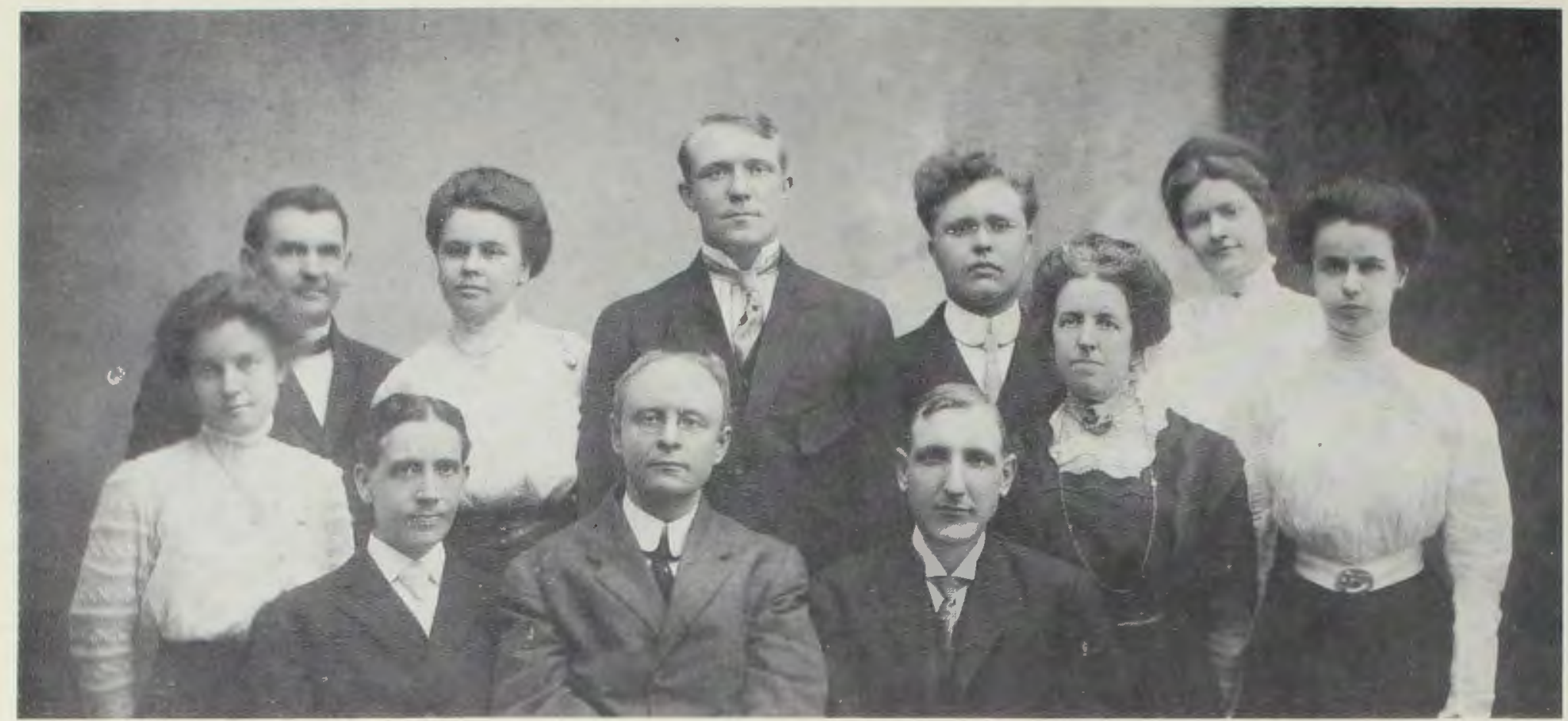

Cedarville College Faculty, 1910. Left to right, top row: P. S. Morgan, Ada Allen, Coach Palmer, LeRoy Allen, Florence Williamson. Second Row: Agnes Smith,

In 1897, the first Cedarville College annual, a small paperbound book called the Imago, was published. The next yearbook, the Memorabilia, published by the junior class, did not appear until 1903. The Gavelyte, begun in 1906 by the Gavel Club, was a monthly publication containing articles and poems written by the students. In 1911, a group of students published the
Florence Russel, Jeanette Orr. Front Row: W. R. McChesney, President McKinney, F. A. Jurkat.

Gavelyte Annual, the third yearbook of the college. No other yearbooks were published for the next four years. When the 1915 Cedrus was produced, the long line of continuous yearbook publication was begun. The name Cedrus was continued until 1954 when the name was changed to Miracle.

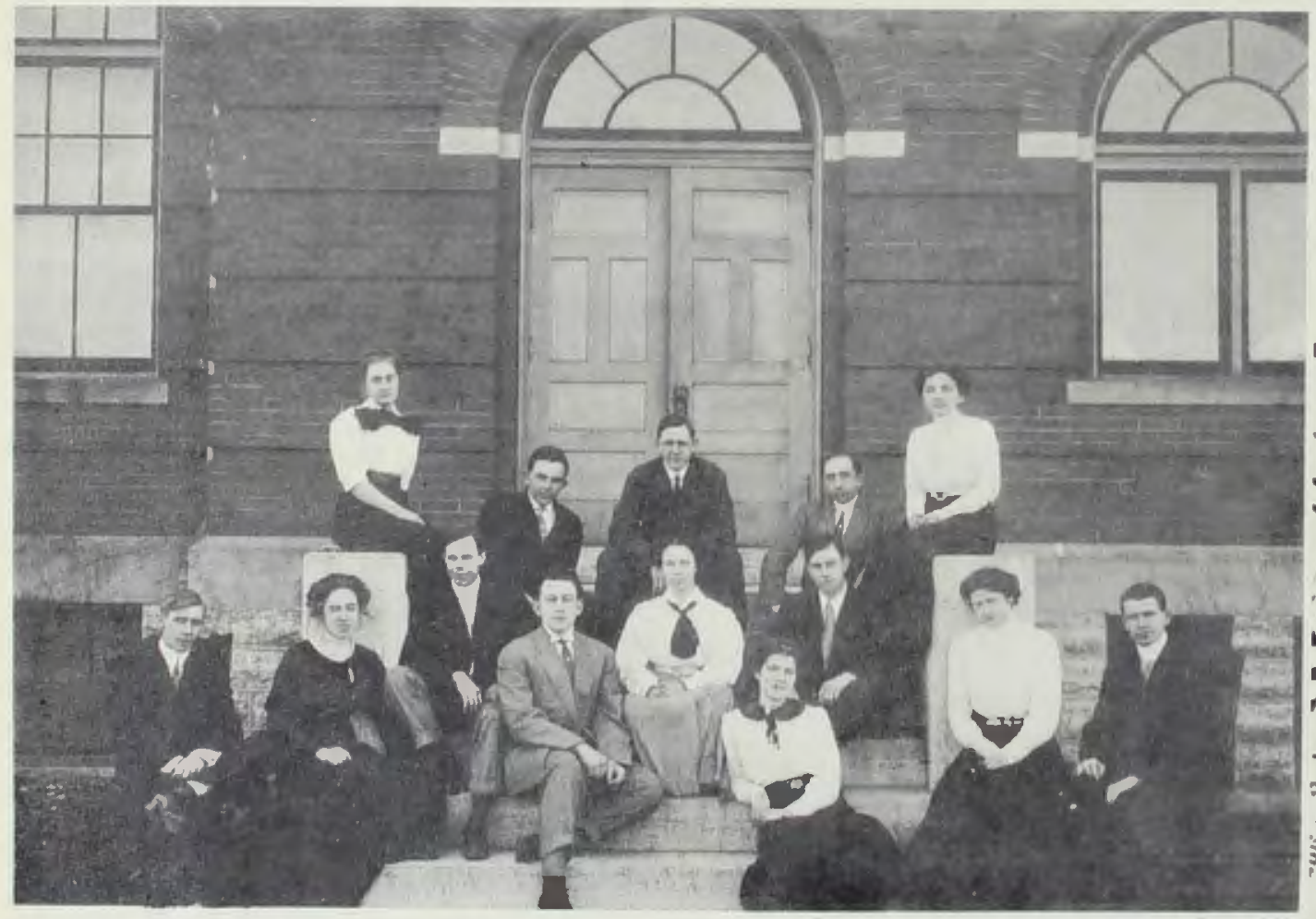

Gavelyte Staff, 1911

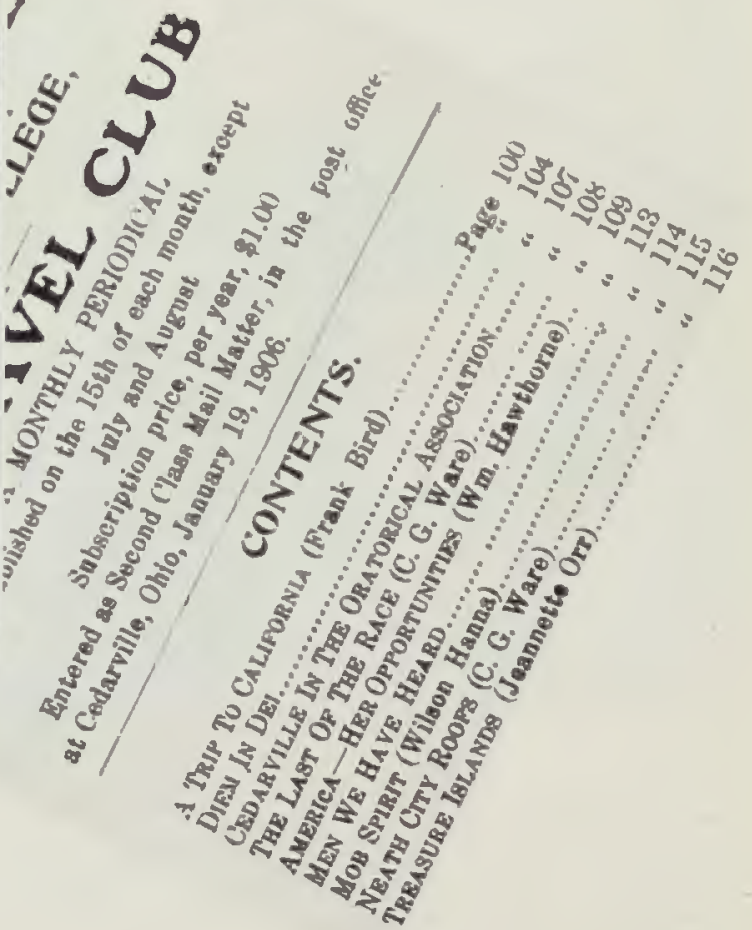




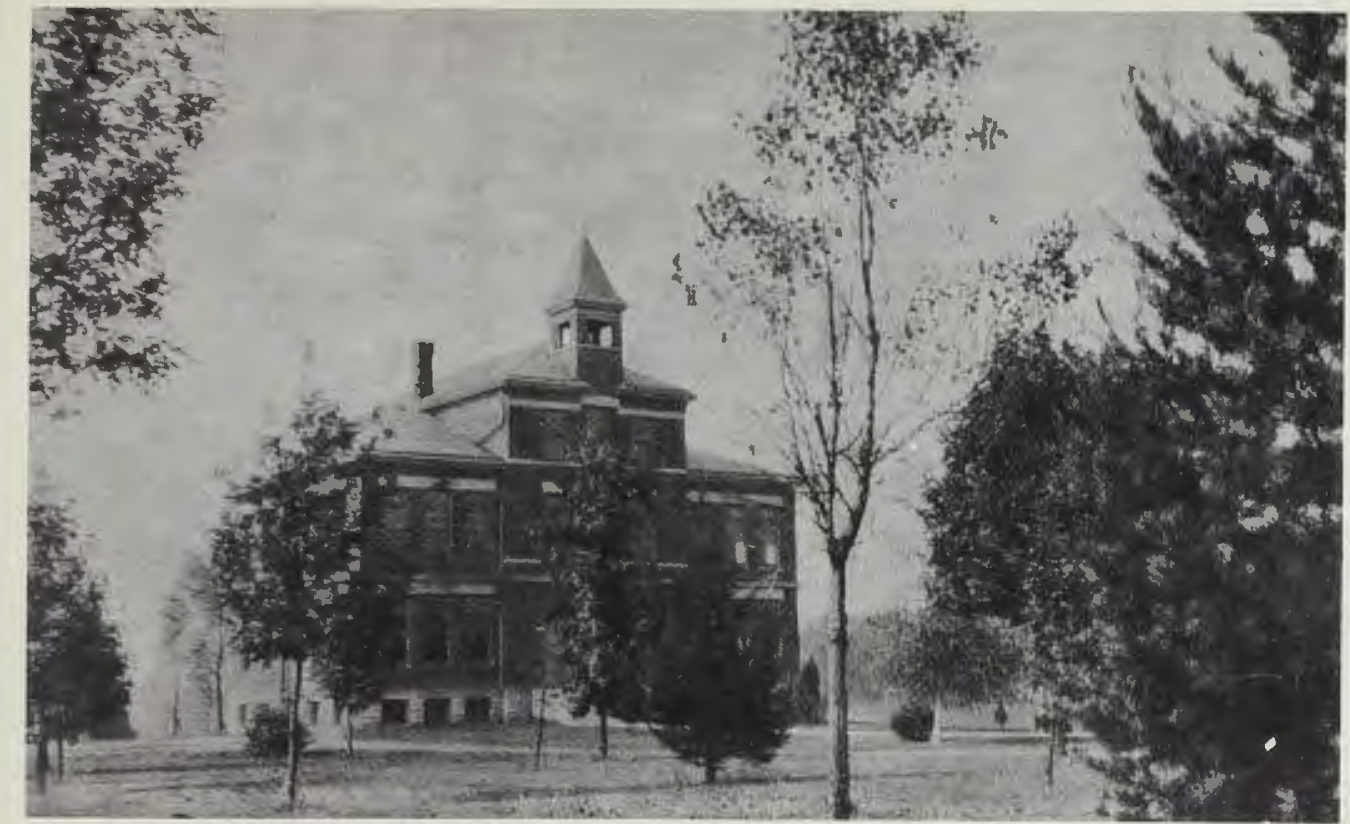

As the years passed, the campus began to take shape: the gymnasium was acquired, the library was built, and trees were planted to beautify the campus. A college $\mathrm{had}$ emerged from ground that yet a few remember as fertile farm land. Godly people had given sacrificially to build a Christian college.

The administration building - College $\mathrm{Hall}$ - as it appeared in 1910.

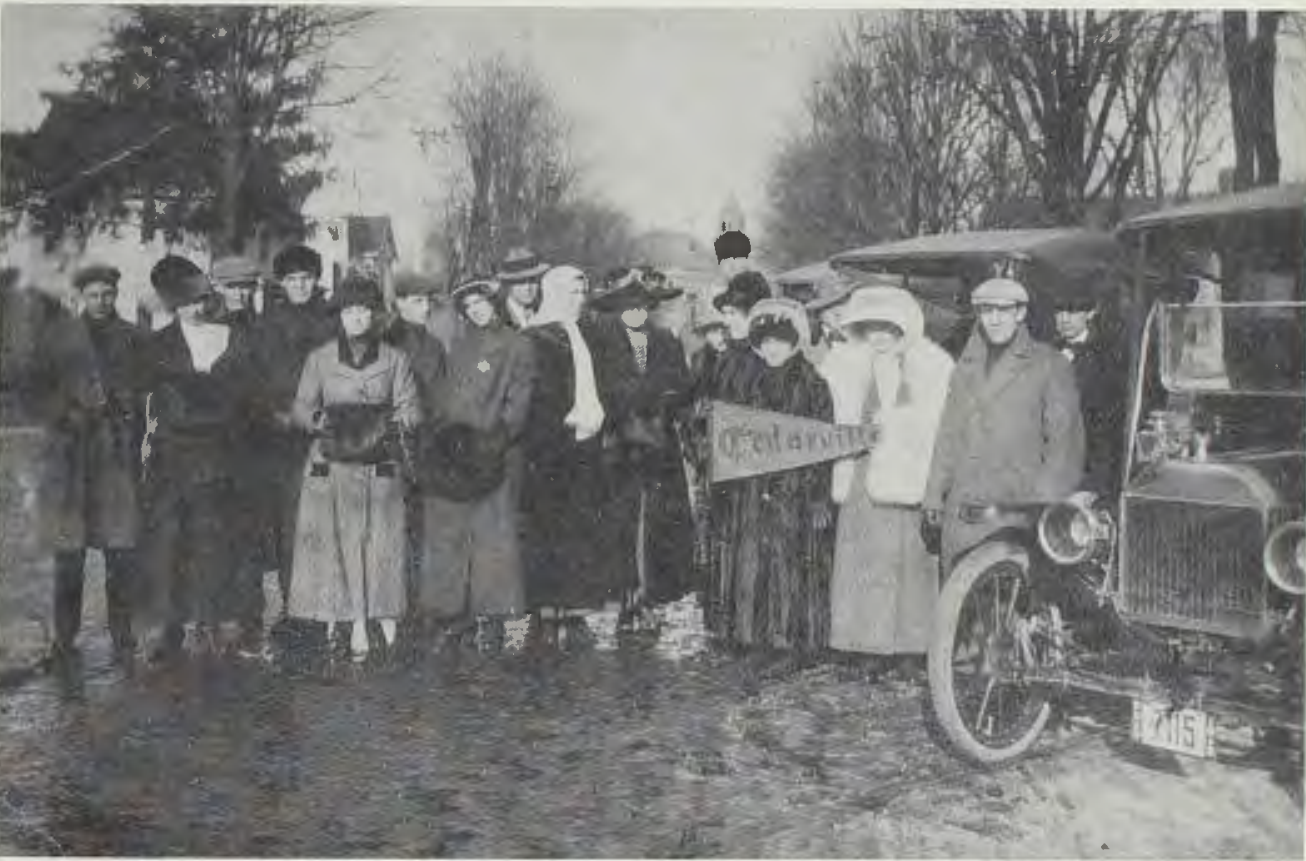

A loyal group of students gathers to follow the team to an away game.

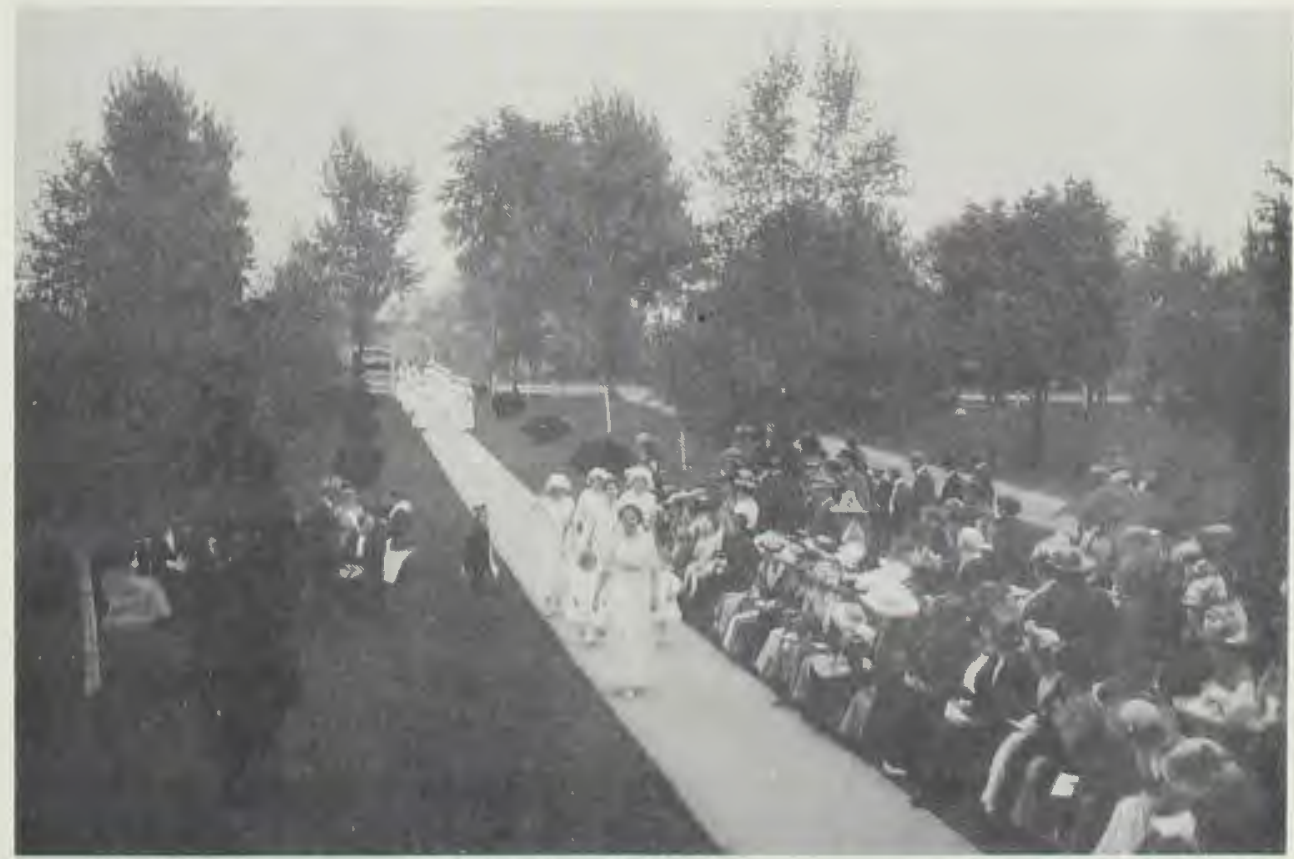

Not only was the physical appearance taking shape, the spirit of the college was becoming apparent: traditions were established, enthusiasm was generated, and loyalty was demonstrated by a growing alumni. The students took an interest in their athletic teams, following them around the state to cheer them on to victory. In 1911, the faculty decided to set apart a special day - Cedar Day - in the spring of the year, when the community and the college would both join in a good time.

The whole town turned out for the annual Cedar Day festivities. 
T.

S. 70 a

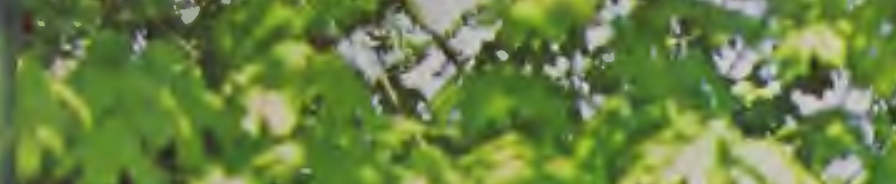

\section{.}

ax

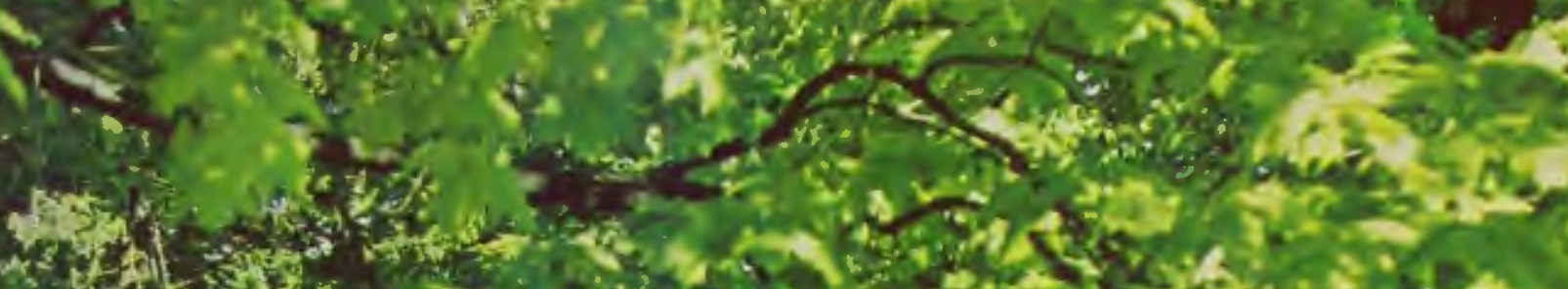

a

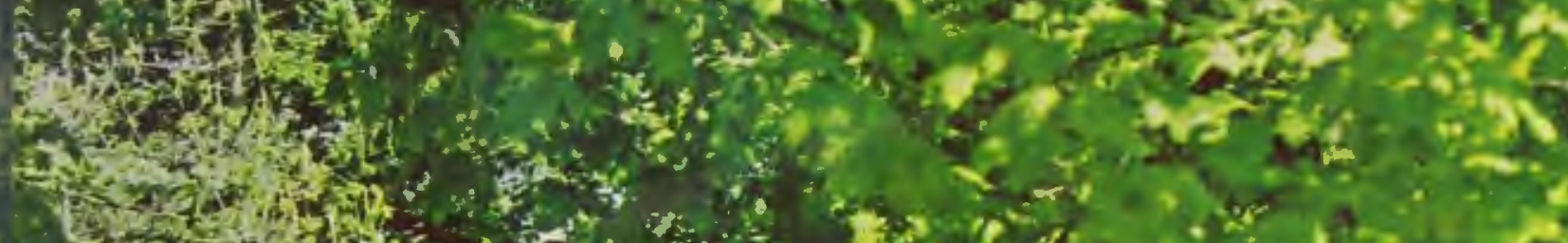

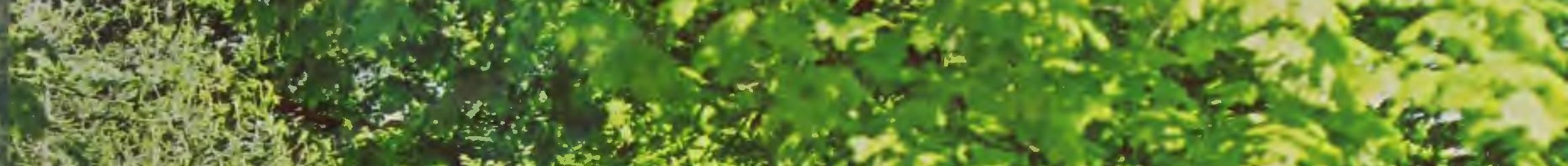

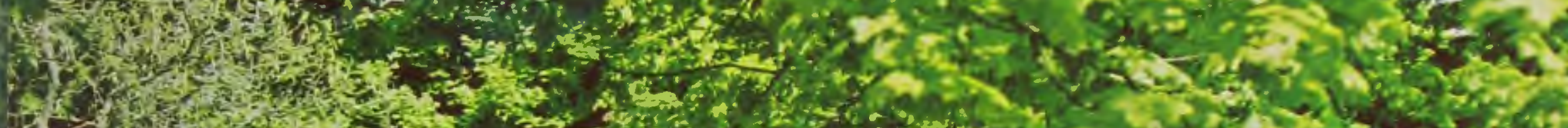

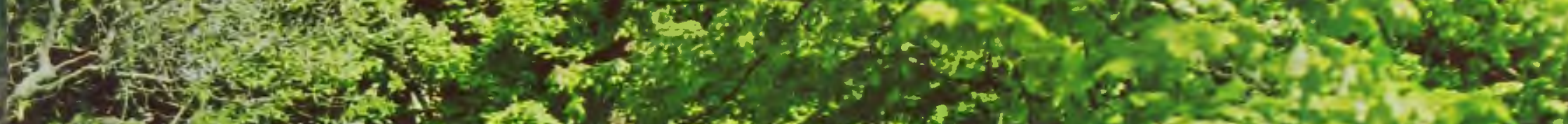

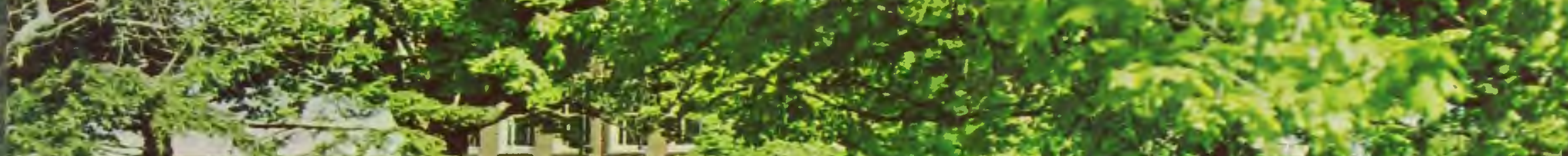

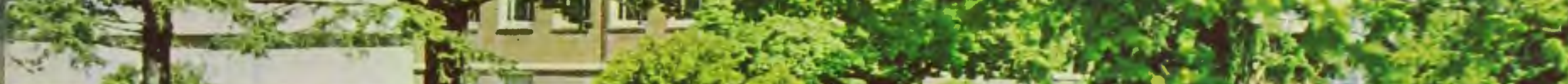
CH. SF in.

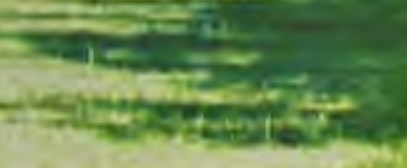

Buter

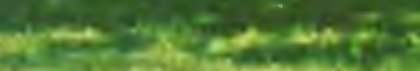

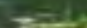

m.

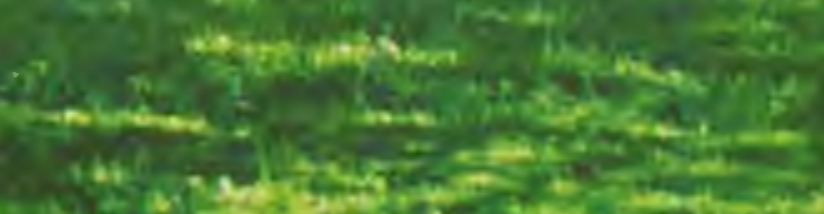

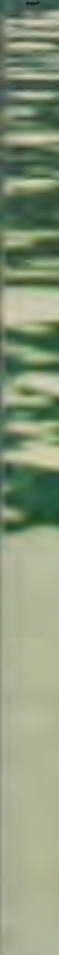

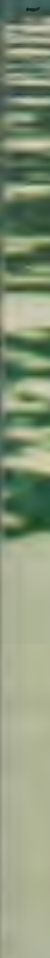

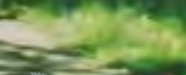

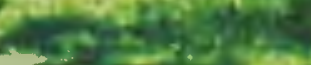

a

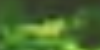

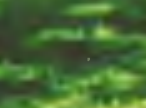
$=$

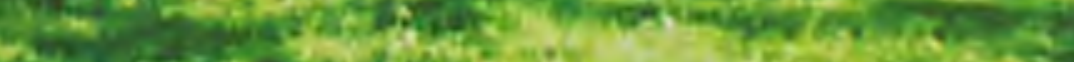
2.

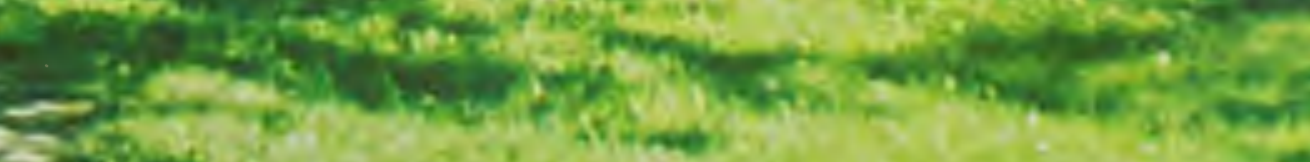

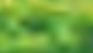
sudents their attitudes, their ideas, their lle College what it is. 


\section{The Gedarville Fterald.}

\section{Inauguration Of Dr. M'Chesniey}

\section{Most Important Event Is the His- tory of Cedarville Colls - Has}

Devoted Nearly $25 \times$ Yea

to Institution' $\mathrm{S}$, $\cdots$
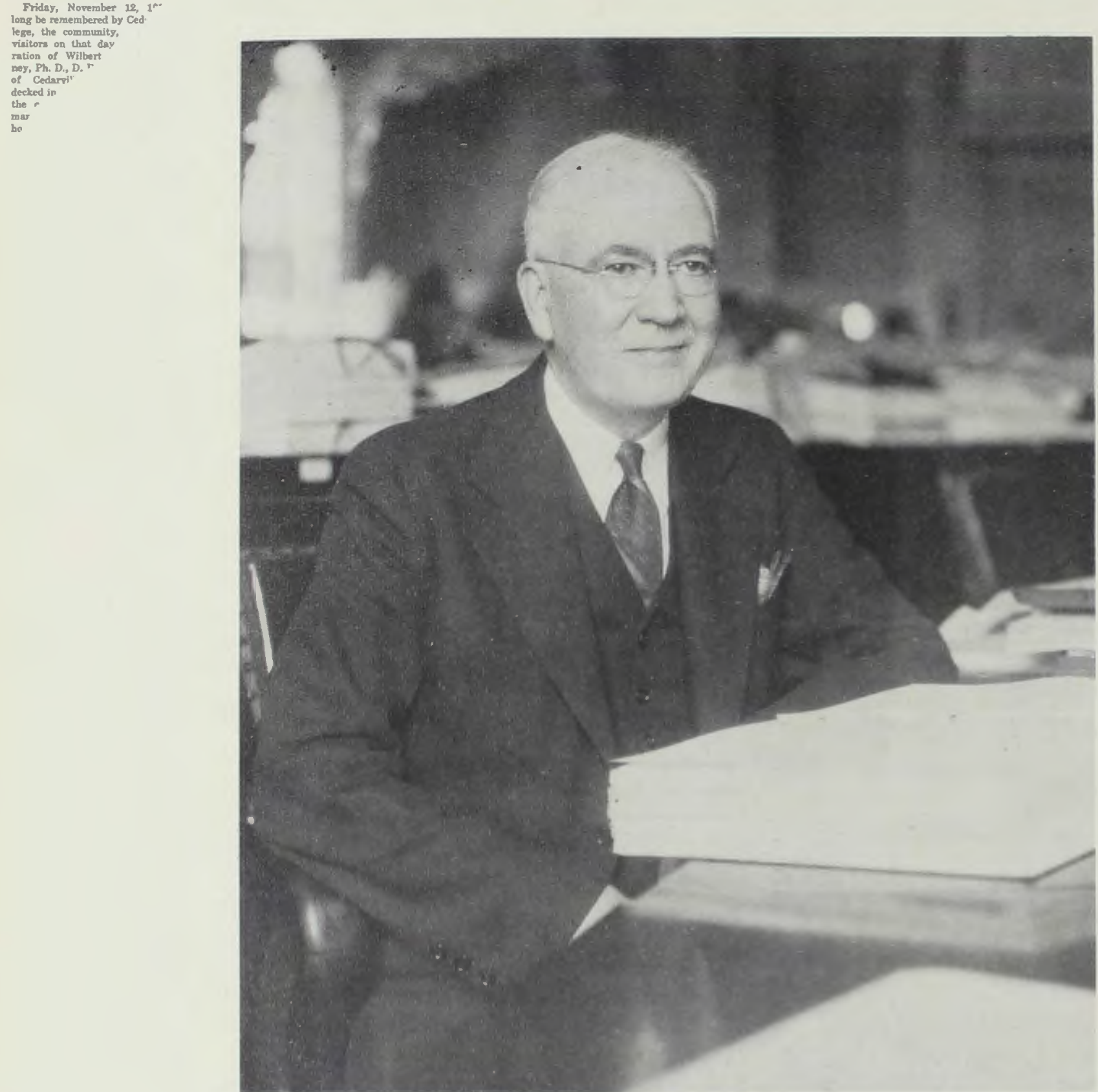

Wilbur Renwick McChesney, the second president of Cedarville College, was born July 7, 1871, in Lawrence County, Pennsylvania. He had an unquenchable thirst for knowledge and refused to allow anything to prevent his attaining the best education available. He studied at Franklin College where he received his A.B. degree in 1892, and his M.A. in 1894. Dr. McChesney was honored with the degree D.D. by Tarkio College in 1915. Called to Cedarville College in 1894 as the first professor of ancient languages, he was chosen to succeed Dr. McKinney as president in 1915. For several years, Dr. McChesney served as a representative from Greene County to the Ohio State Legislature. 


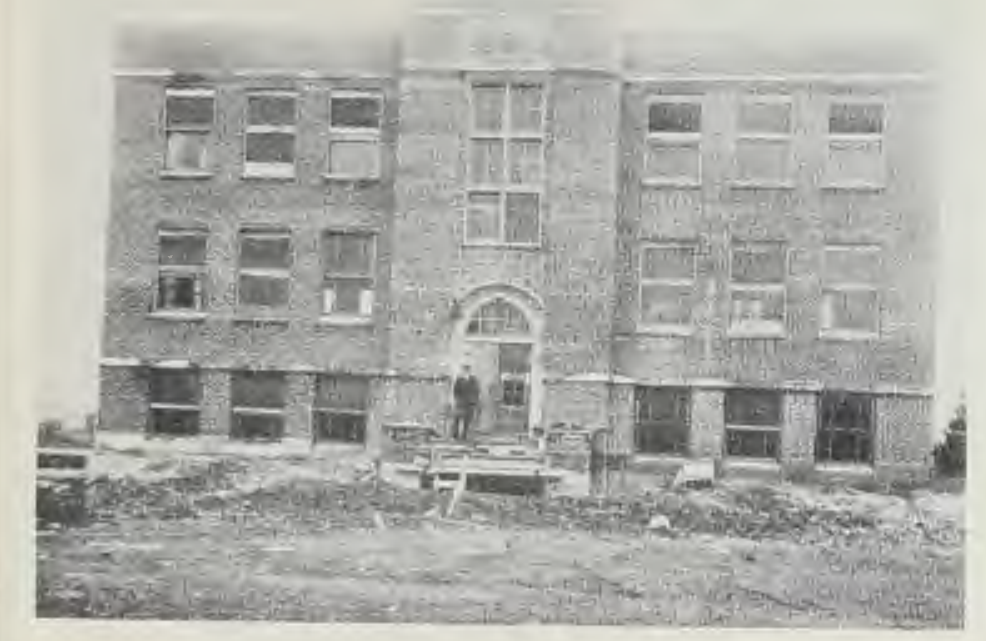

Fodesinelle

Science Hall in construction, 1922.

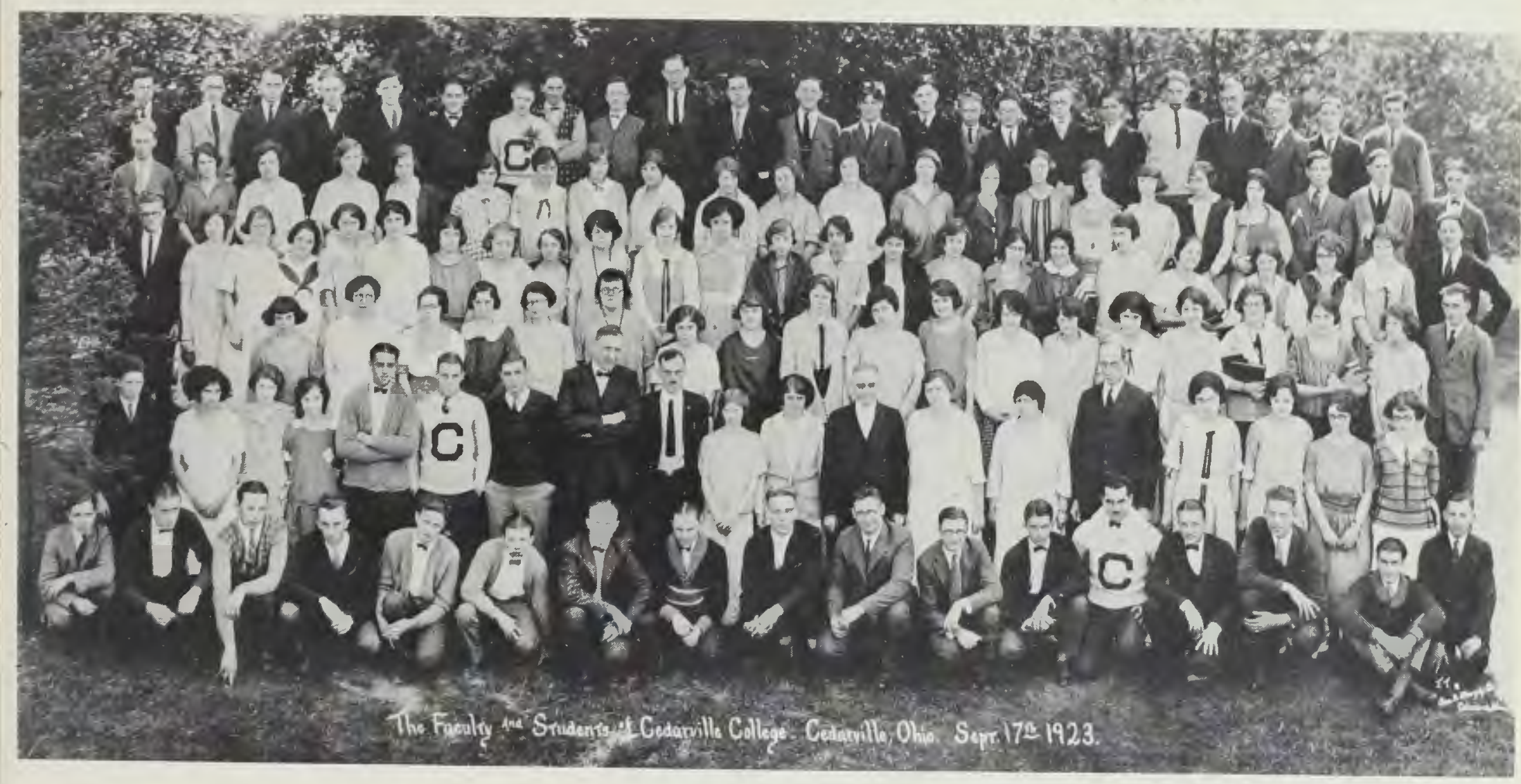

Dr. McChesney's administration was marked by growth and expansion. During these years the student body increased in size from fifty in 1915 to 102 in 1923. A science building containing laboratories and classrooms was erected and the music department expanded.

In 1928, the General Synod, by unanimous vote, gave all control, ownership, title, and vested rights of Cedarville College to the board of trustees and their successors forever.

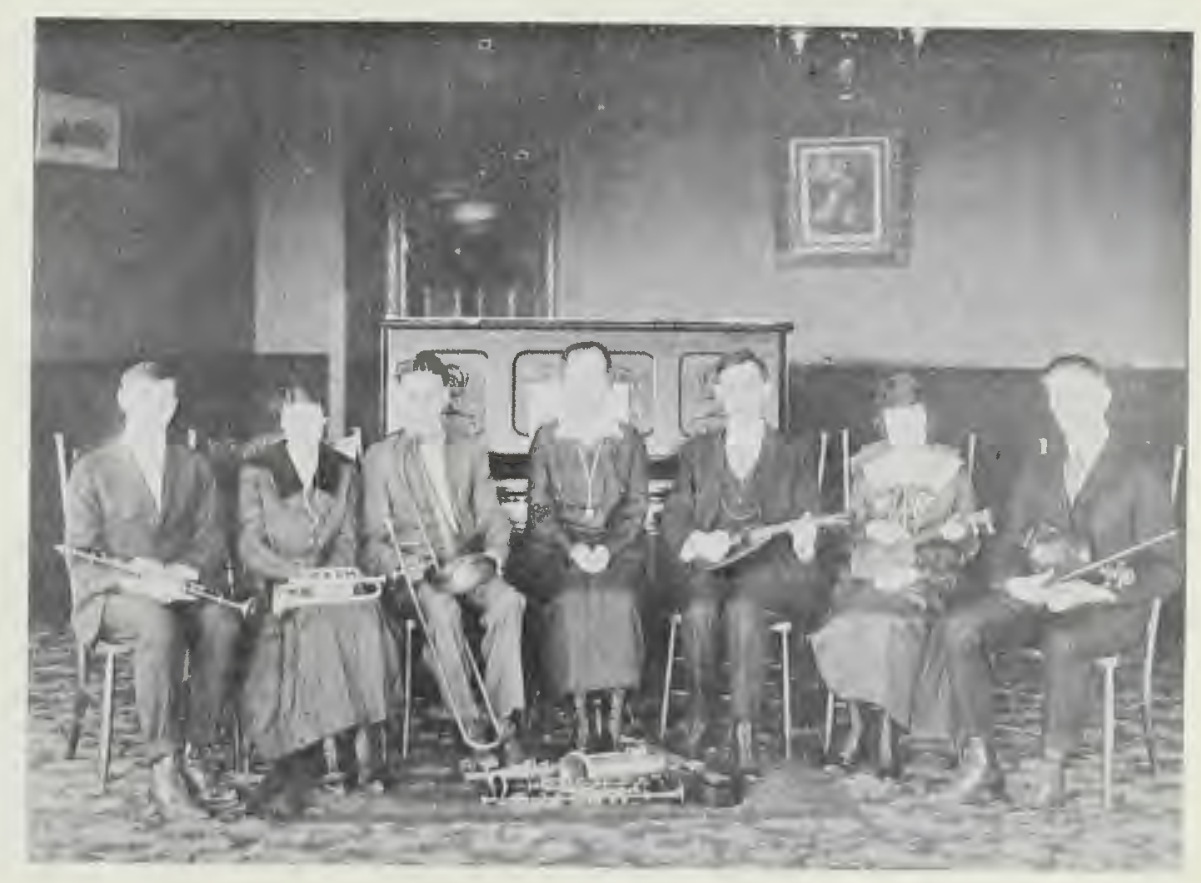

The Cedarville College Music-Makers, 1918. 


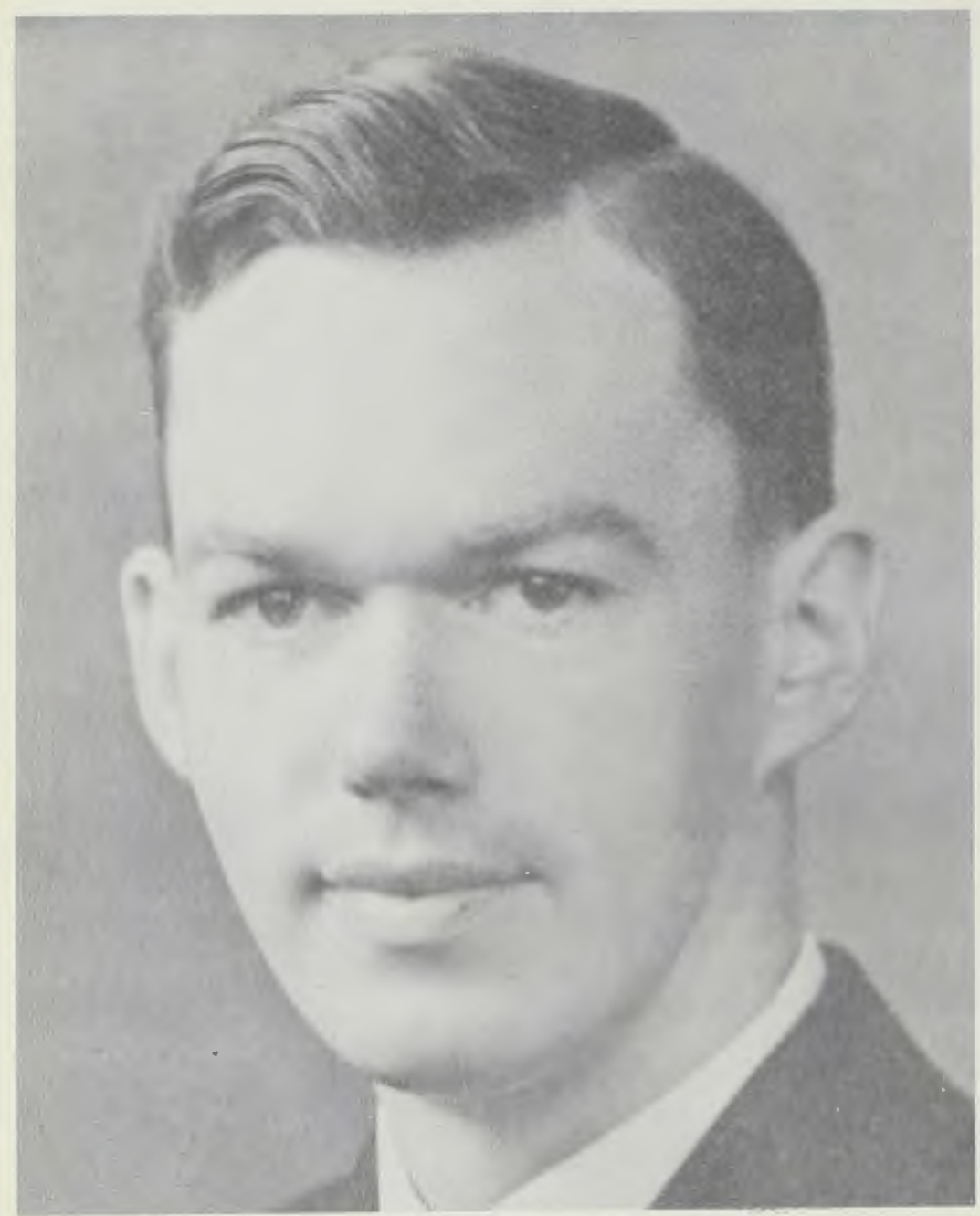

Third president, Walter Smith Kilpatrick, 1940-1942.

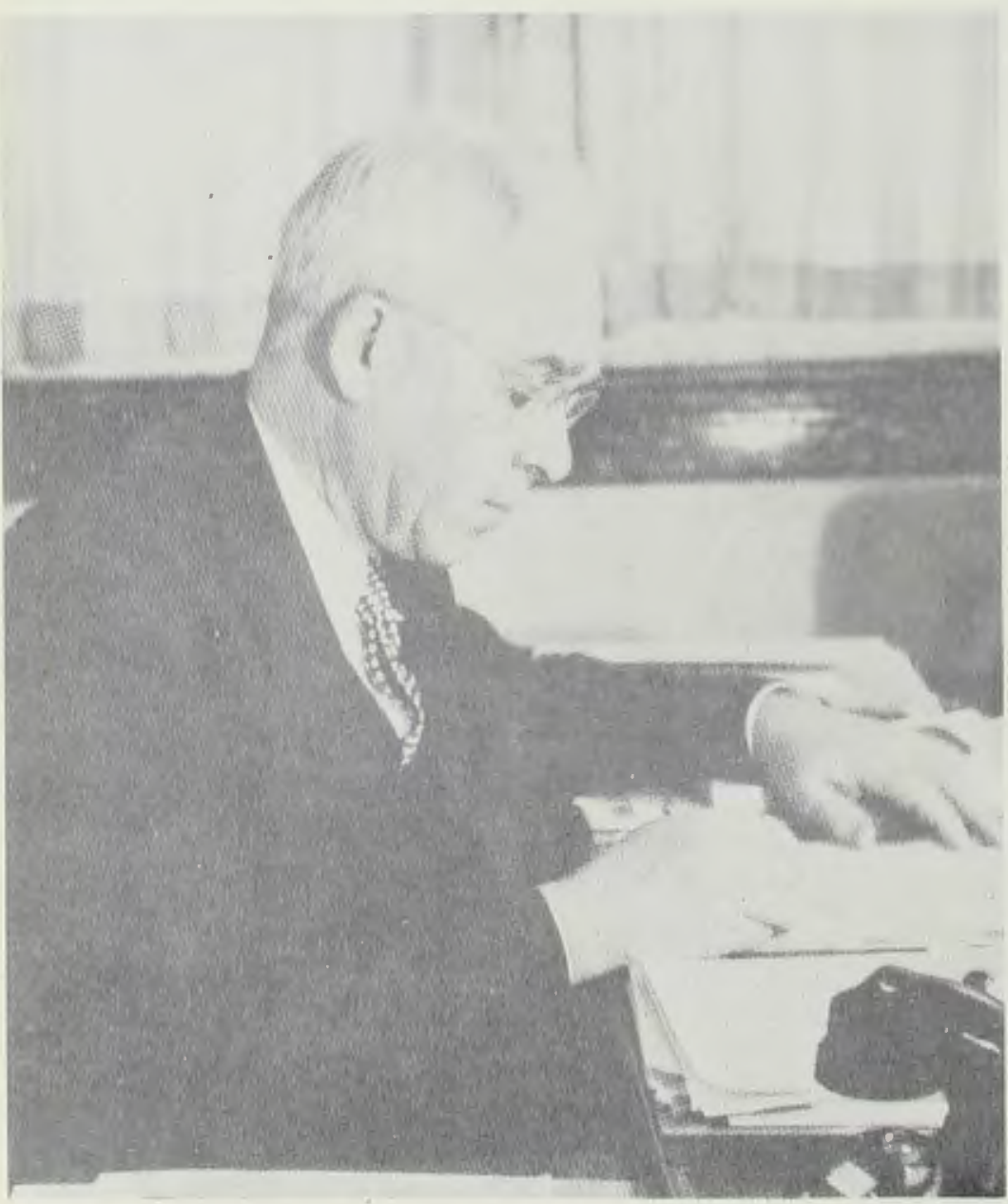

Fourth president, Ira D. Vayhinger, 1942-195
The Reverend Walter Smith Kilpatrick was chosen by the board of trustees to succeed Dr. McChesney-as president of Cedarville College. He was twenty-six years old at the time of his appointment, the youngest college president in the United States. A magna cum laude graduate of Cedarville College (1934), Mr. Kilpatrick received his Th.B. from Western Theological Seminary and was awarded the Marvin Memorial Fellowship for the highest standing in his class. He received his M.A. degree from the University of Pittsburgh and completed his residence requirements there for the Ph.D. degree. He studied in Europe for three semesters before being called to assume his new duties at Cedarville.

Under Mr. Kilpatrick's administration, the college purchased its first residence hall. Harriman Hall, located on the comer of Main and Chillicothe Streets, was named in memory of Dr. W. P. Harriman, a Cedarville alumnus and member of the board of trustees at the time of his death in March, 1959. In addition to being a home for college girls, the dorm was used as a social center.

Ira D. Vayhinger was appointed president of Cedarville College by the board of trustees in October, 1942. Born in Delaware, Ohio, Mr. Vayhinger attended school at Osgood and was graduated from Moores Hill College. He was connected with the financial department of the Presbyterian Church and was business manager of the college at the time of his appointment to the presidency.

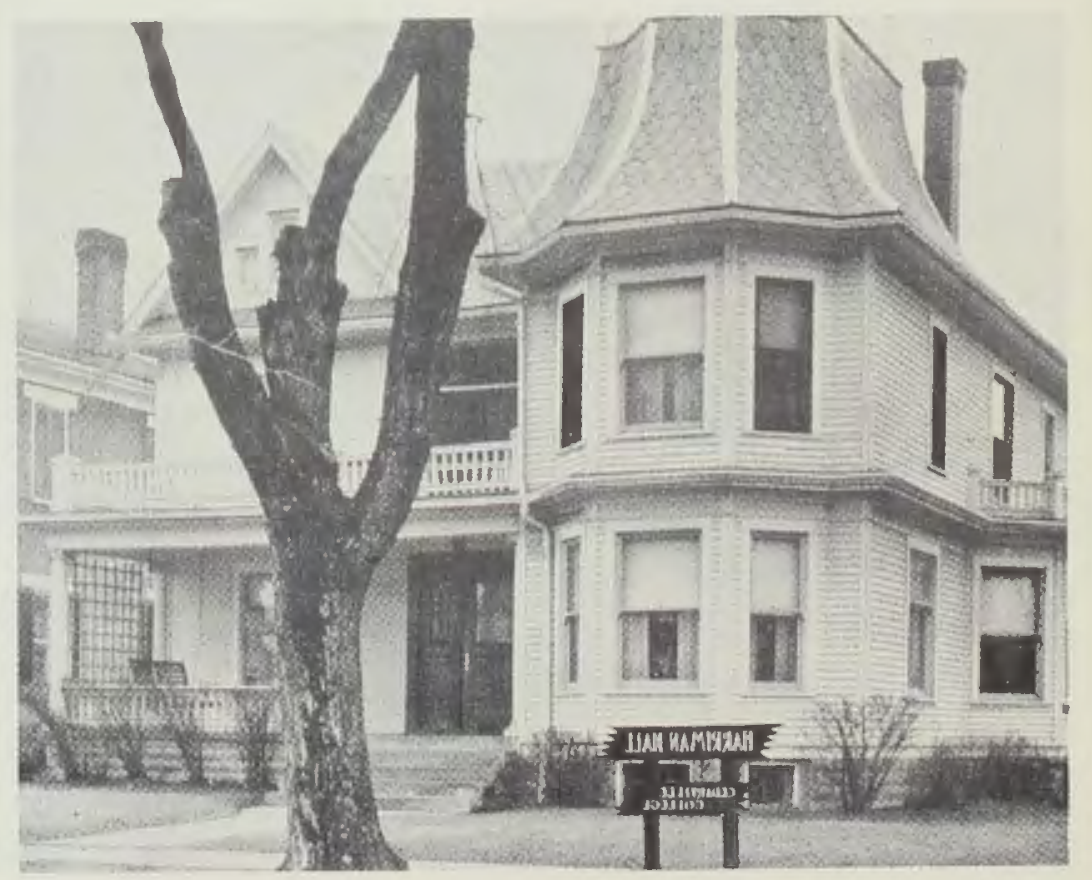

Harriman residence, purchased in 1940 


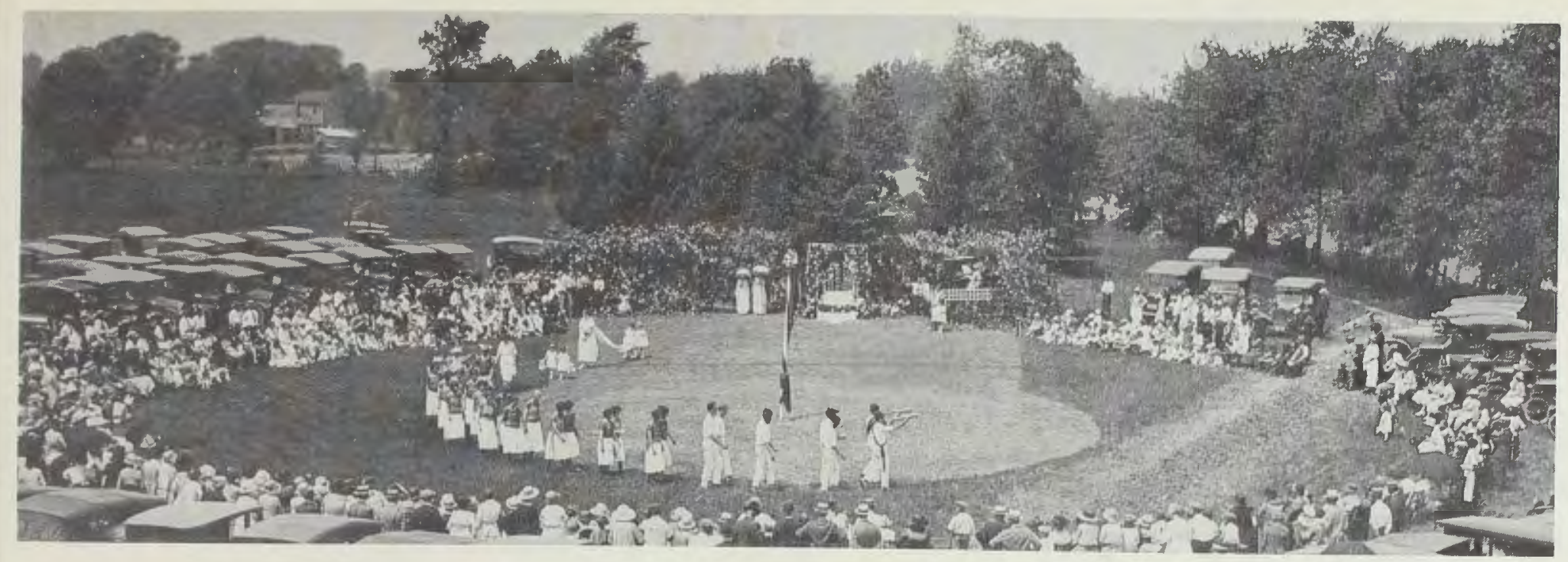

The annual Cedar Day celebration, 1923.

The first observance of Cedar Day was so successful that the celebration of Cedar Day became an established custom which continued until the year 1957. The faculty regarded Cedar Day as the day of all year when the community and the college joined in wholesome fun and pleasure. The people of the community regarded Cedar Day much as they regarded the fourth of July. It was a general holiday when businesses were closed, farm work was abandoned, baskets were filled and the whole family came to spend the day on the college campus.
A person who served the college under every adminstration including the present and through every changing circumstance until February, 1954, was Dr. Frank A. Jurkat. Dr. Jurkat's six-and-ahalf foot frame on the pathway crossing the campus was a familiar sight to hundreds of students who grew to love and respect him during his fifty-eight years with the college. The way his students felt about him is well expressed in the 1951 Cedrus which was dedicated to him. "We dedicate this, the 1.951 Cedrus, to him because, although a man of prodigious learning, he wears that learning lightly; because, like Yorick, he is a man of infinite jest; because an hour of one of his classes is a delight to those who share it, when not only mind and spirit are fed with wit and wisdom, but the flesh, too, is sustained by the cookies and candy that he carries up the path in his market basket along with books - and, above all, because he is loved and greatly admired, and remembered by his students long after their other teachers have been forgotten."

In April of 1954, Dr. Jurkat was called to be with the Lord whom he served; but his influence is still felt on the campus, not only by those who knew him personally, but even by those who knew him only through the memories of others.

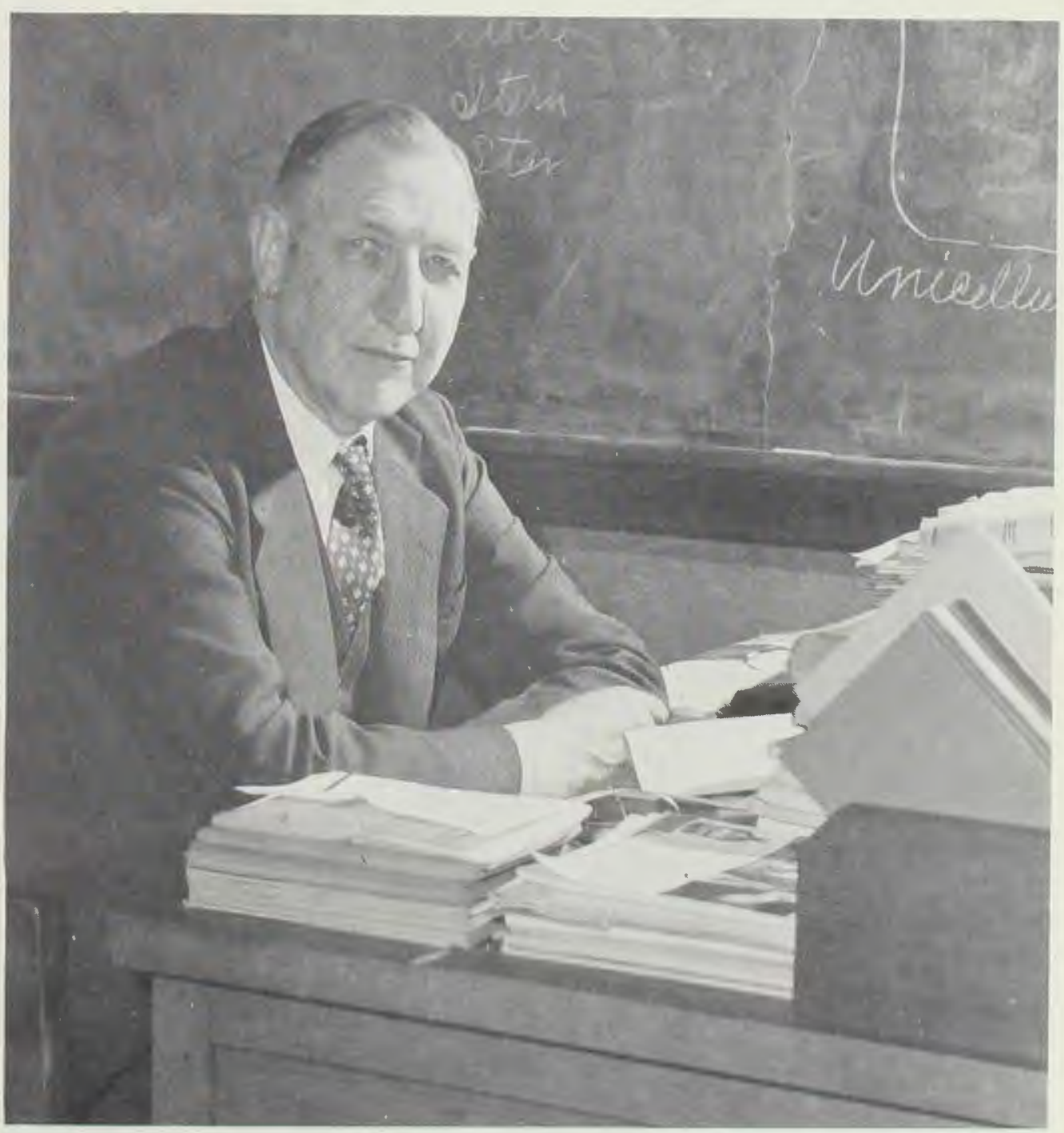

Dr. Jurkat, friend to all. 


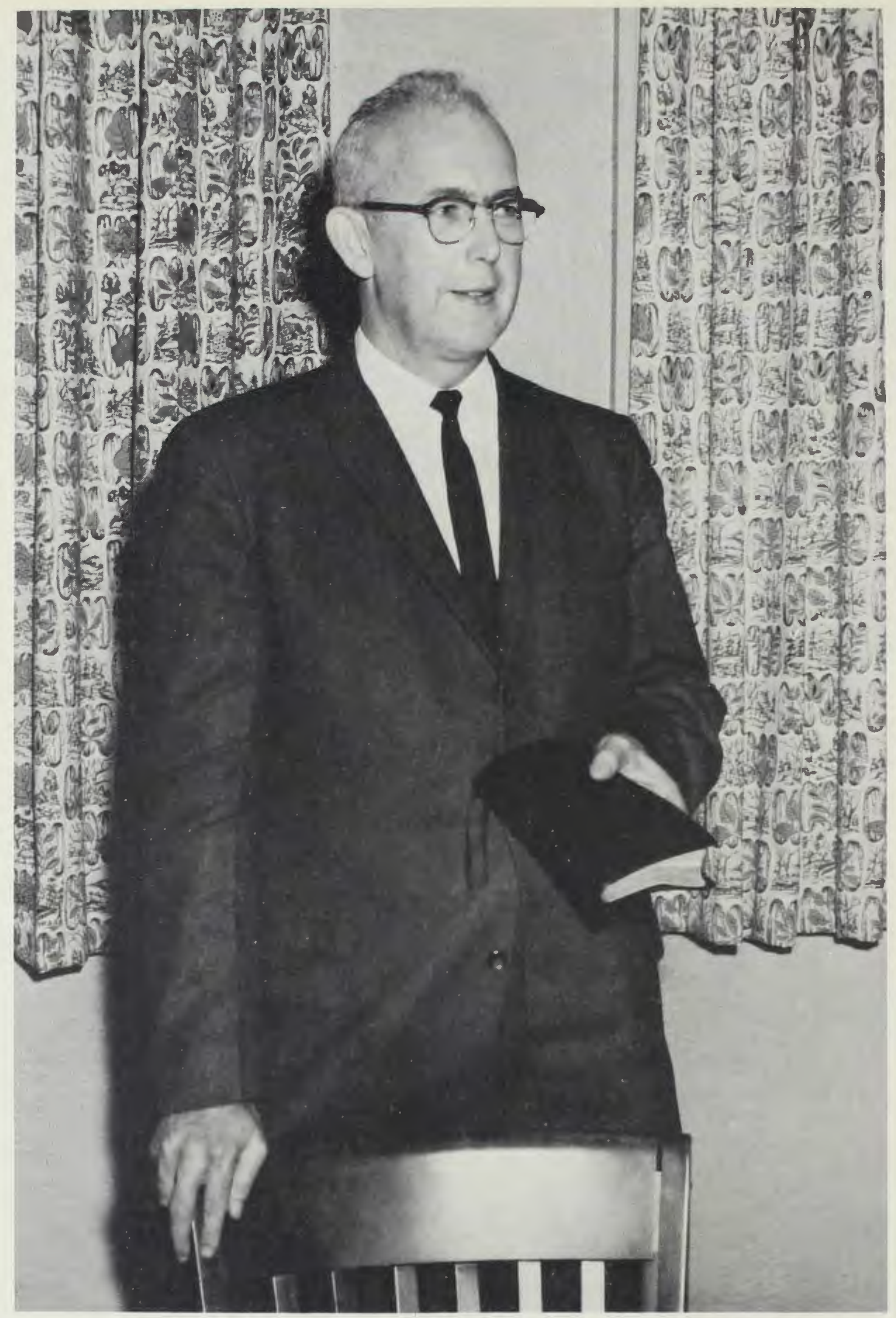

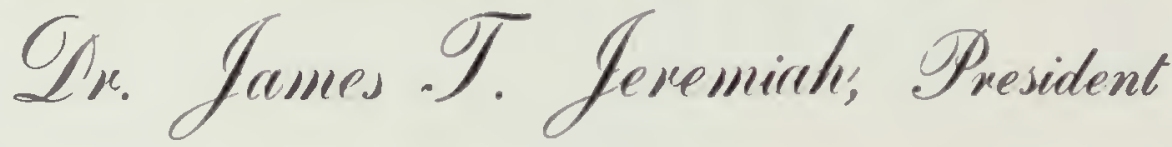

For the past seven years James $T$. Jeremiah has ably led Cedarville College. A graduate of Baptist Bible Seminary in Johnson City, New York, and Central State College in Wilberforce, Ohio, Dr. Jeremiah held three pastorates before becoming affiliated with Cedarville College. Responsible positions on the Council of Fourteen of the General Association of Regular Baptist Churches, the Ohio Independent Baptist Council and the Mid-Missions Council further prepared him for his position at the college. In June 1961, Central State College conferred upon Dr. Jeremiah the honorary Doctor of Divinity degree in recognition of his contributions in the fields of religion and education. In addition to regular administrative duties which include representing the school and raising funds, and his outside interests such as Mid-Missions, Dr. Jeremiah maintains an active interest and contact with the student body. In spite of his busy schedule, the president reads the daily announcements in chapel, follows athletic teams even to away games, and is always available to the students for informal chats. 
Suluxe ===

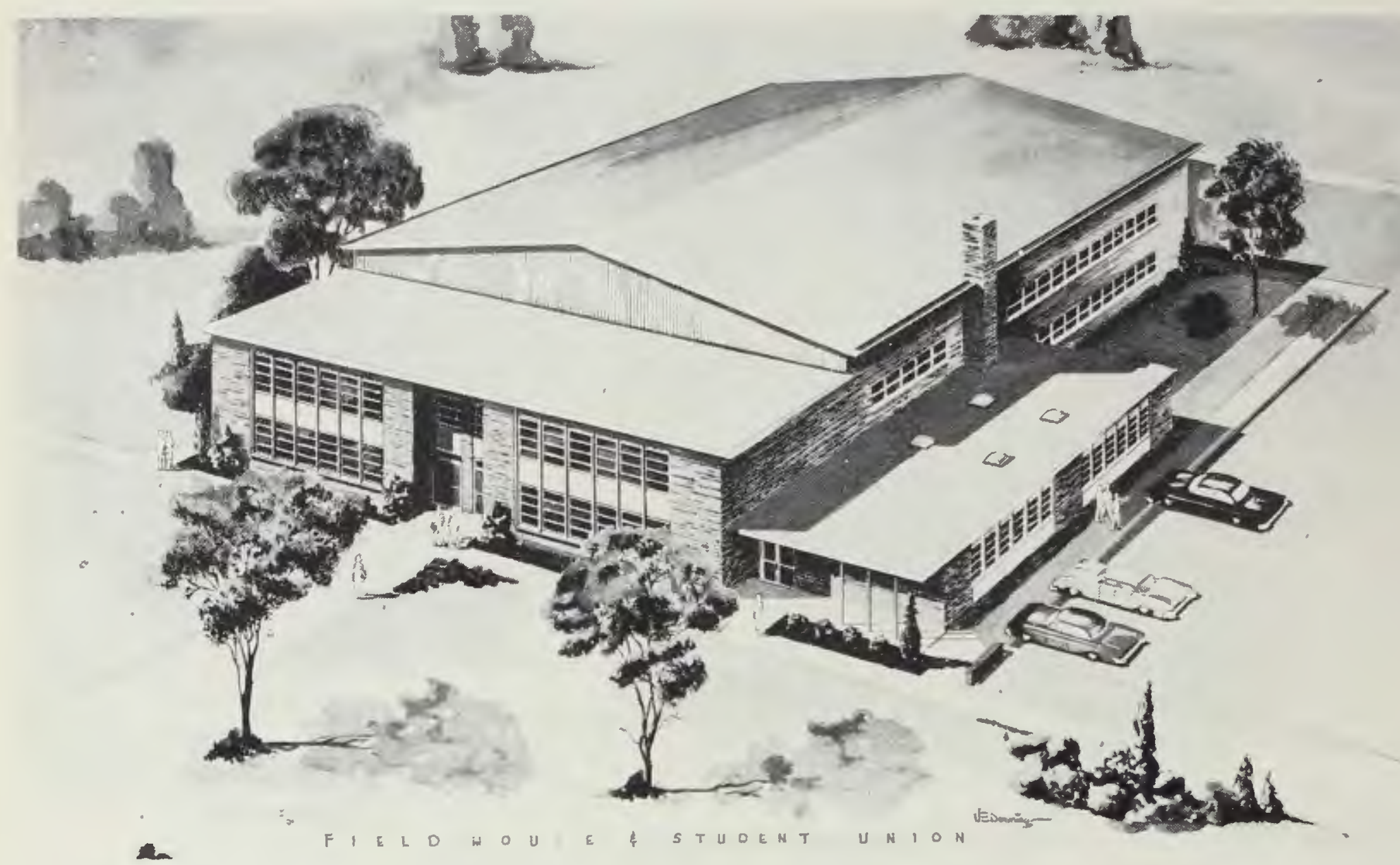

A part of the student body, 1961-1962.

The school year 1961-1962 saw the largest student body ever enrolled in Cedarville College. Even the greatly improved facilities were not adequate enough to accommodate the 450 students who flooded the campus. The board of trustees, anticipating this problem, commissioned an architect to draw up a building which would do the most to alleviate the crowded campus situation. Thus, the Student Center building proposed in the spring of 1961. This structure will accommodate class and banquet rooms, a book store, snack shop, gymnasium, and will leave other campus buildings free to provide classrooms, dormitory rooms, and a chapel large enough to seat the entire student body and faculty. The completion of this much needed building is dependent solely on alumni, interested friends of the college, and churches.

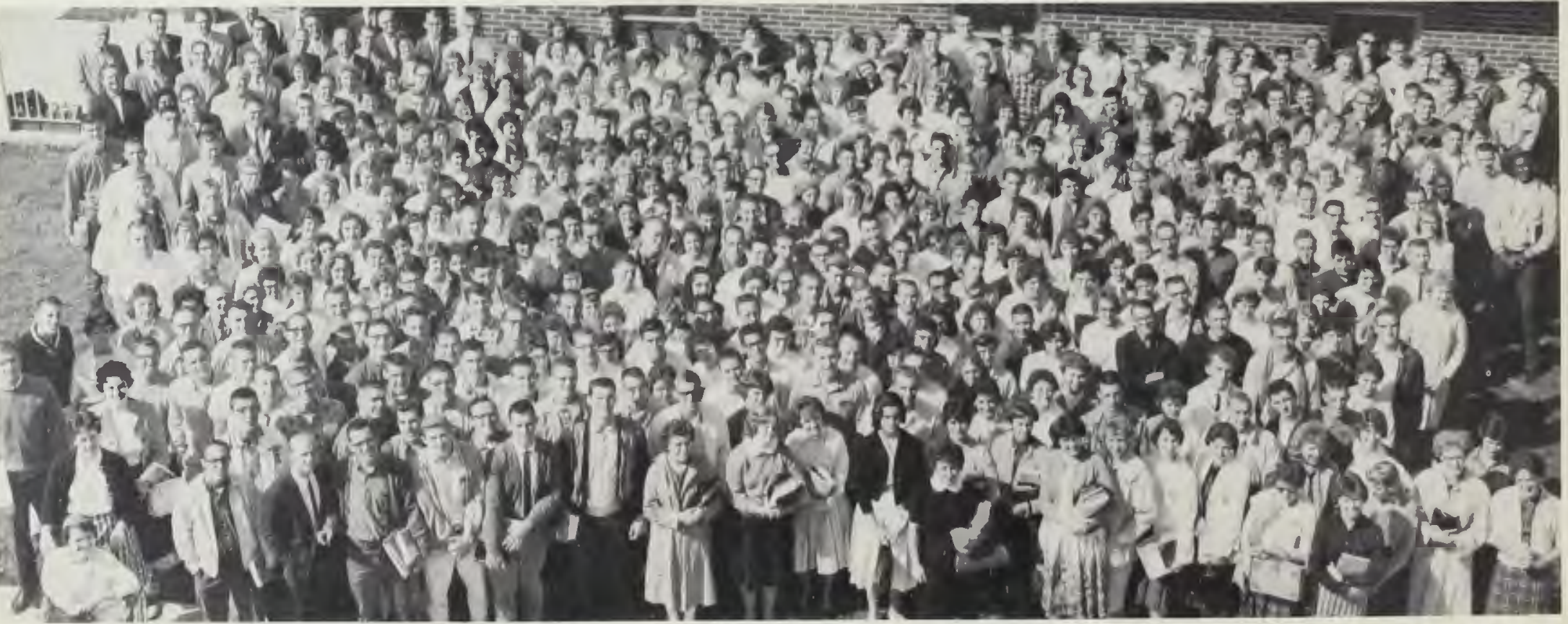




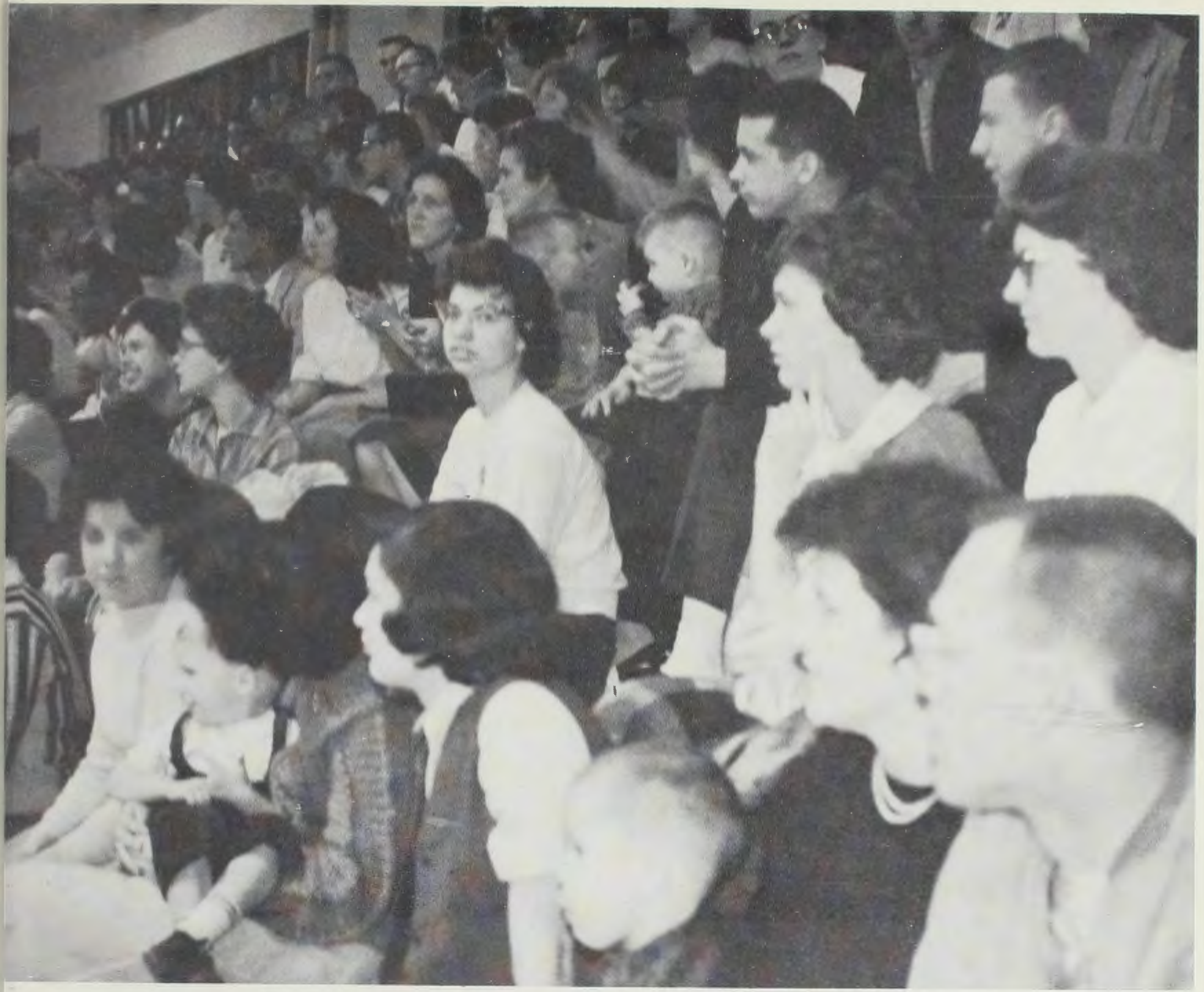

Buildings and academic policies are not the only hings that compose a college; the students and their pirit make the college what it is. Although attitude and pirit are intangible, from their effects we can see the lirection that they take. In Cedarville the spirit of the tudents has shown itself in many ways. The attitude oward the community was shown by the Student Council which sponsored successful Bloodmobile visits in October nd January. School spirit was displayed when students participated in completely repainting the gym under the direction of the Varsity "C" Club and by voting to assess themselves ten dollars each semester toward the Student Center Fund. Not only does spirit flourish within the school, Cedarville spirit lives on in the lives of alumni. November 18 saw the largest group of alumni ever return to the college for the most extensive Homecoming to be planned by the school. 


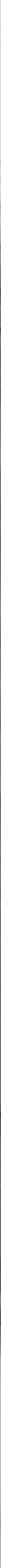




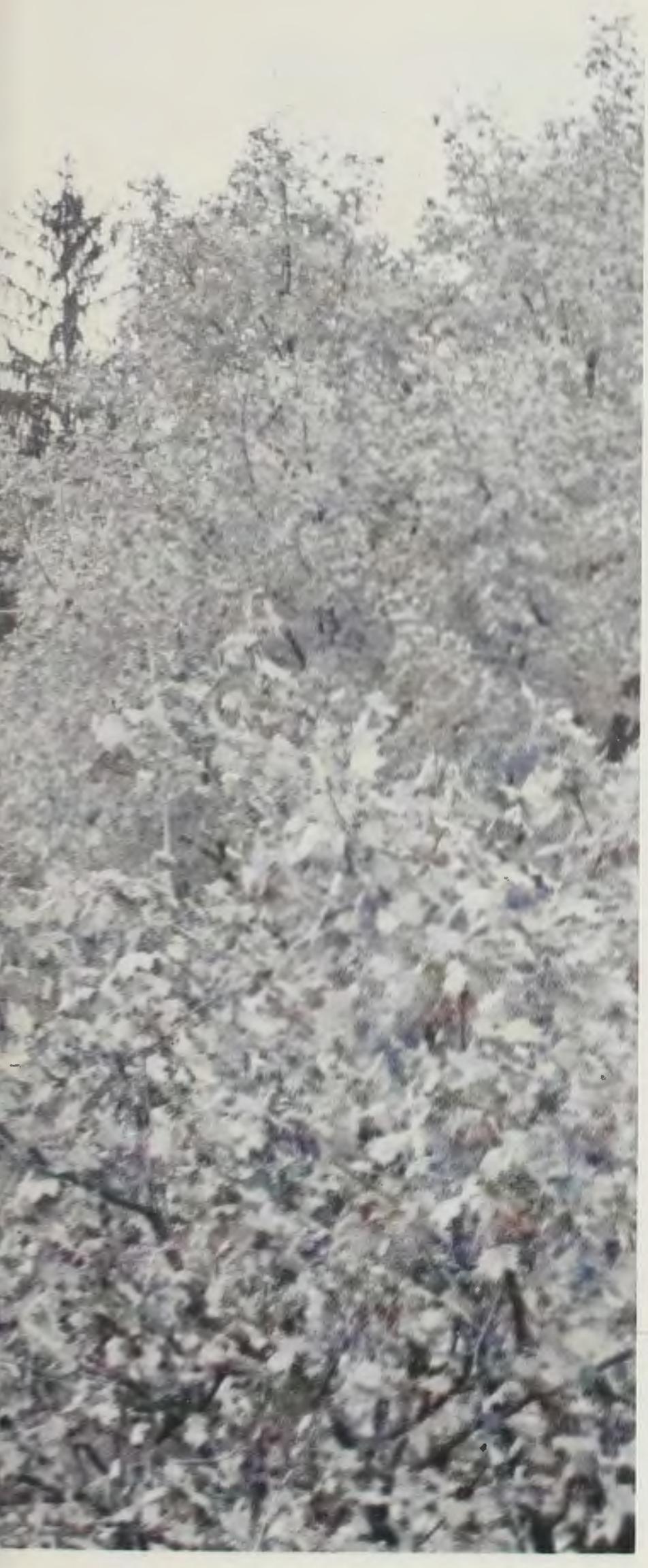

"Old Main", the earliest name for the Administration Building, is the scene of many administrative activities. Here we spend many hours in the Registrar's office trying to straighten out our second semester schedule or waiting with trepidation to see why the Dean put a conference slip in our mail box. We chat with President Jeremiah near the drinking fountain, and catch a glimpse of what goes on in the offices we seldom enter. Here, also, are filed away our permanent records long after we have left our classes to find our place in the world.

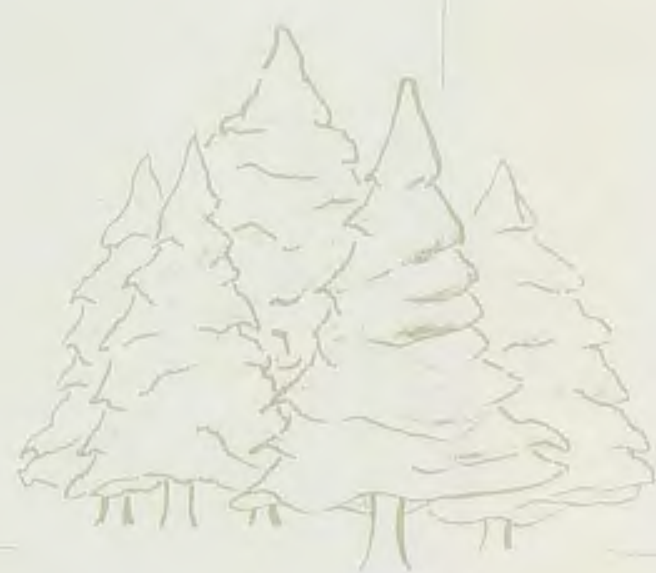




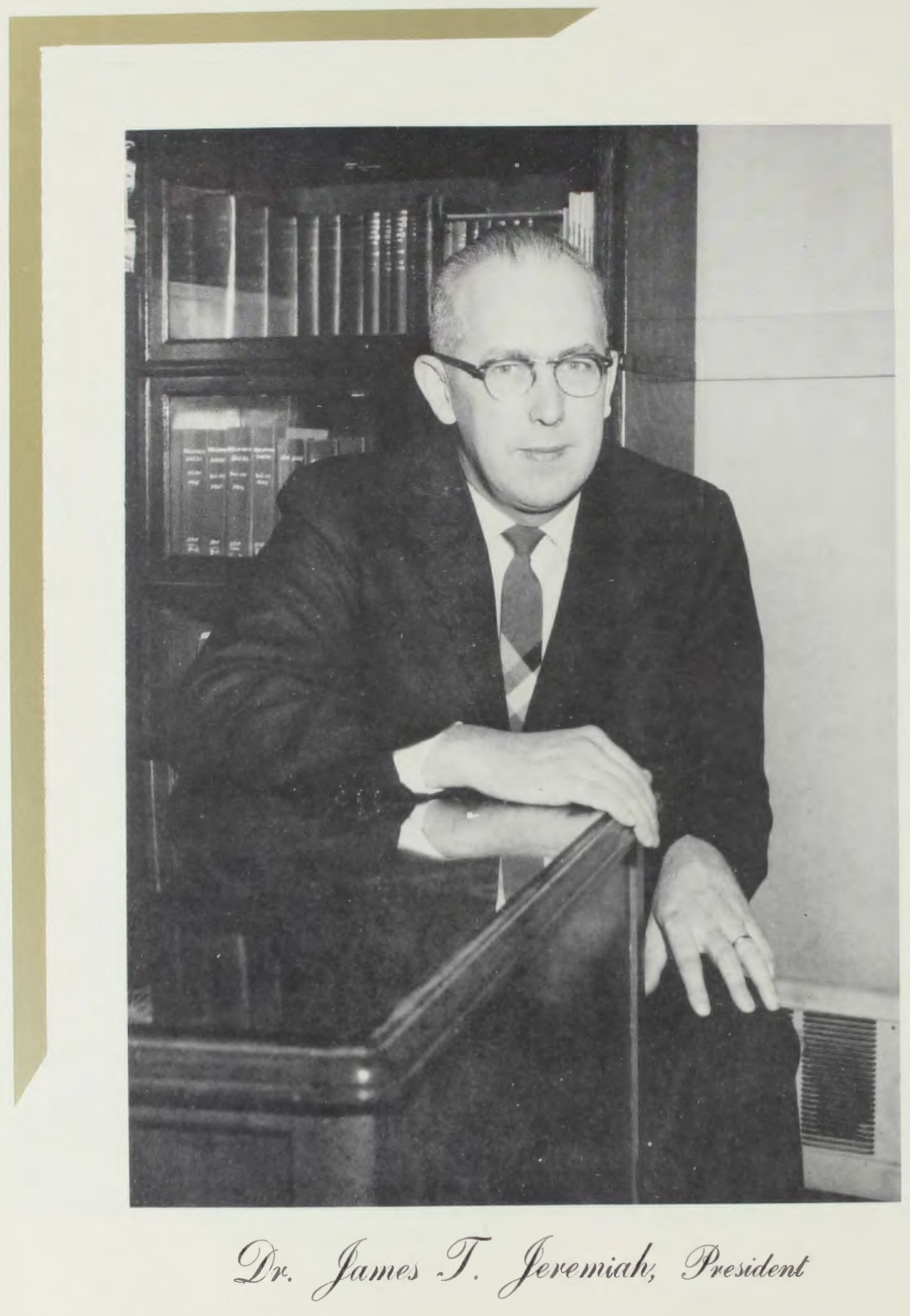




\section{The President's. Llessage}

College catalogs are interesting publications. It is seldom that we are privileged to read one printed prior to the turn of the century. One of the earliest Cedarville catalogs is dated 1897-98.

The spiritual tone of the college in those early days is seen in a statement found in that edition: "On each Wednesday morning the students conduct a college prayer meeting, which all the students are required to attend."

Now, as we celebrate the seventy-fifth anniversary of our college, we dedicate ourselves anew to carry out the purposes of the founders of Cedarville College. The daily chapel is the spiritual center of our college life. We shall endeavor to maintain this practice and we pray God will help us to be true to "the Word of God and the testimony of Jesus Christ." 


\section{Administration}

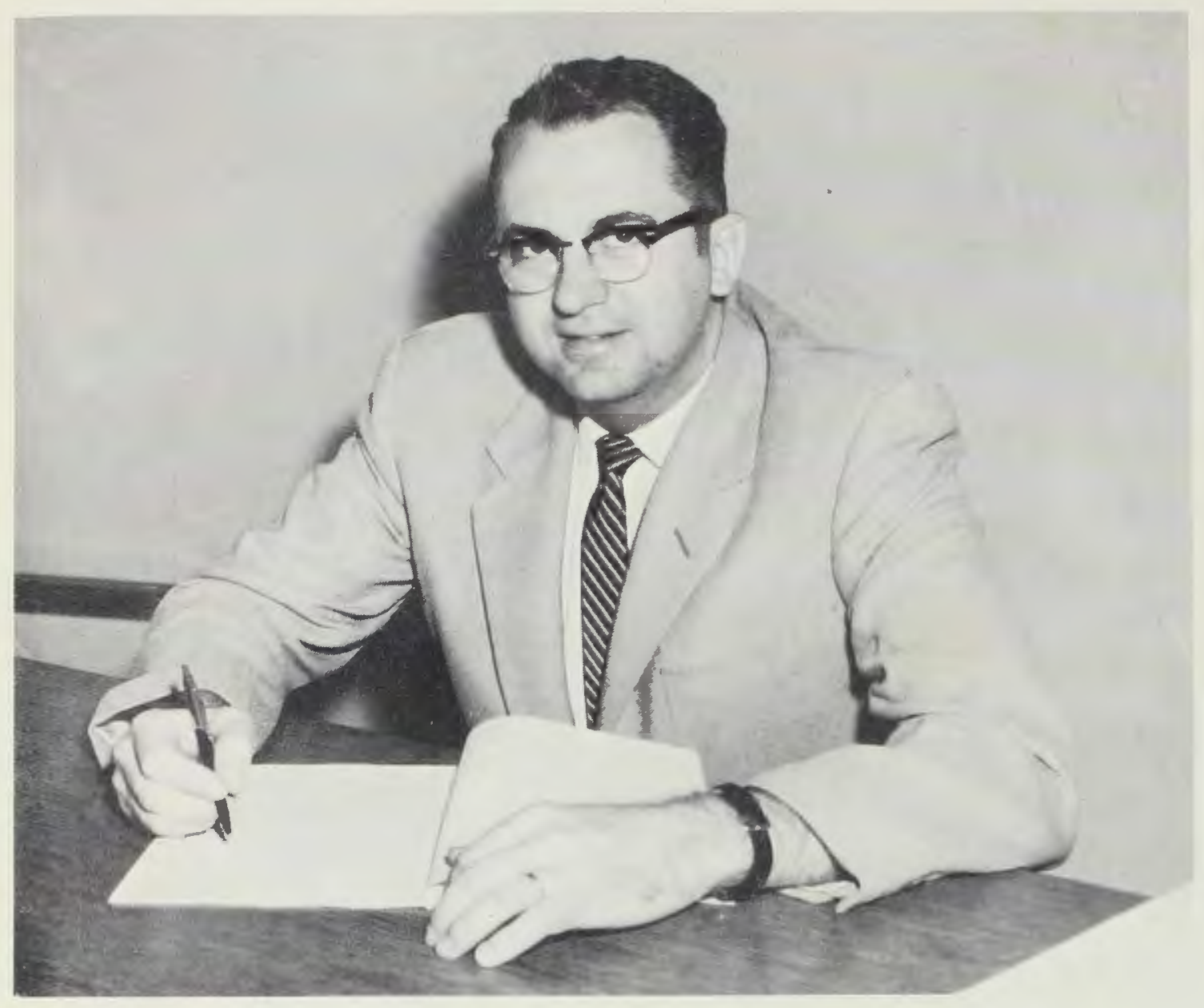

Richard T. McIntosh, Dean of Students.

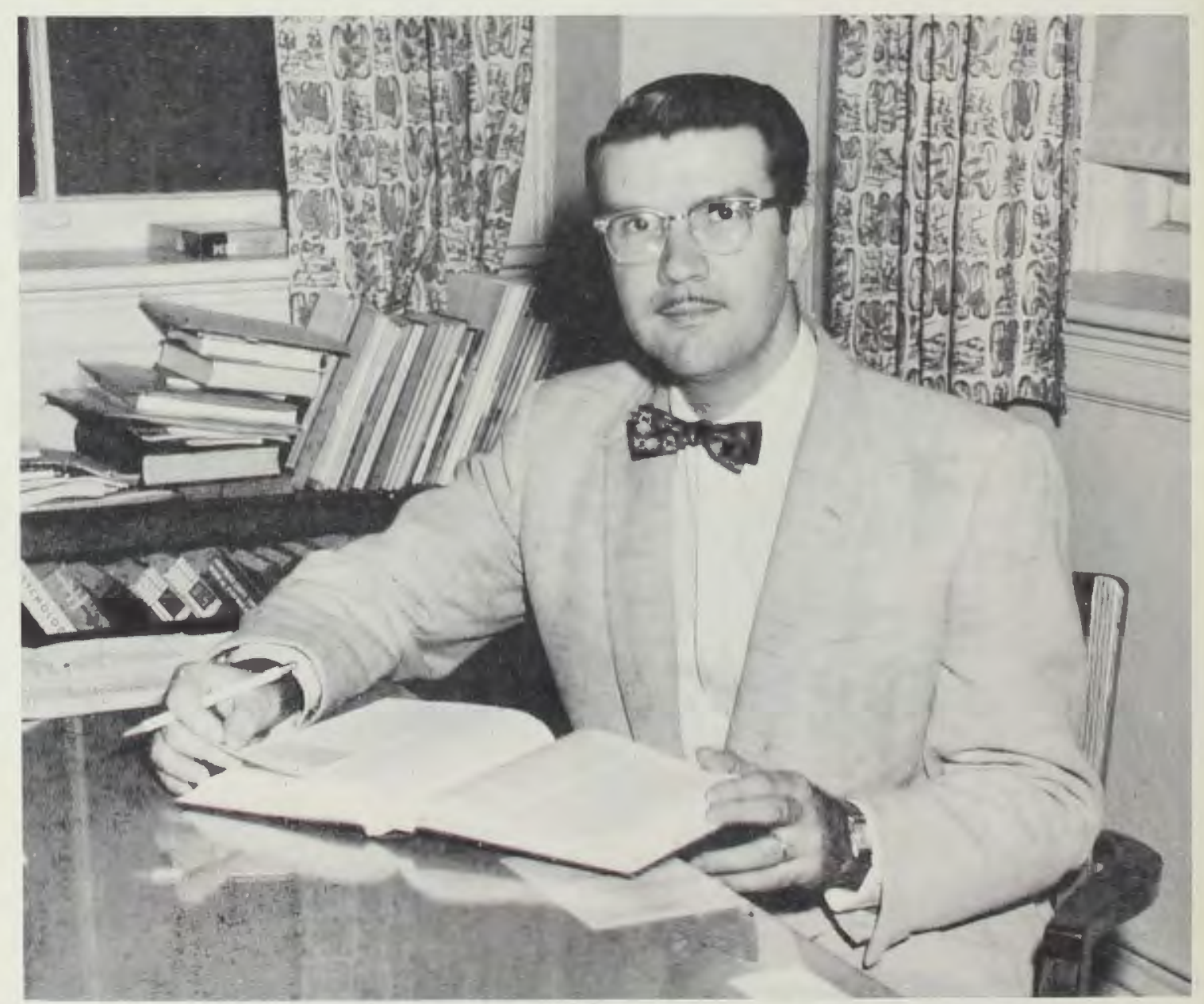

Carol L. Barker, Registrat. 


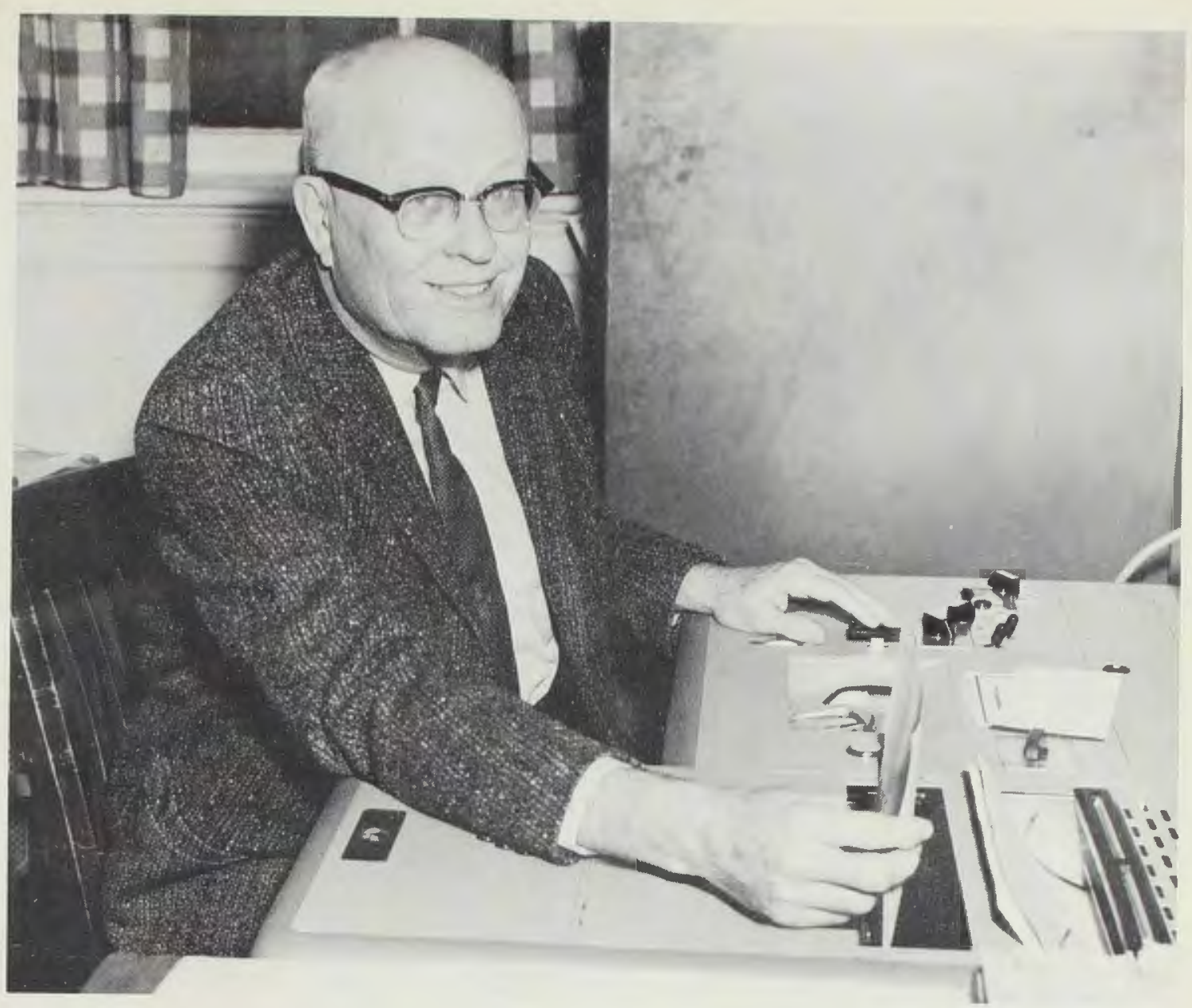

Dr. Clifford R. Maddox, Academic Dean.

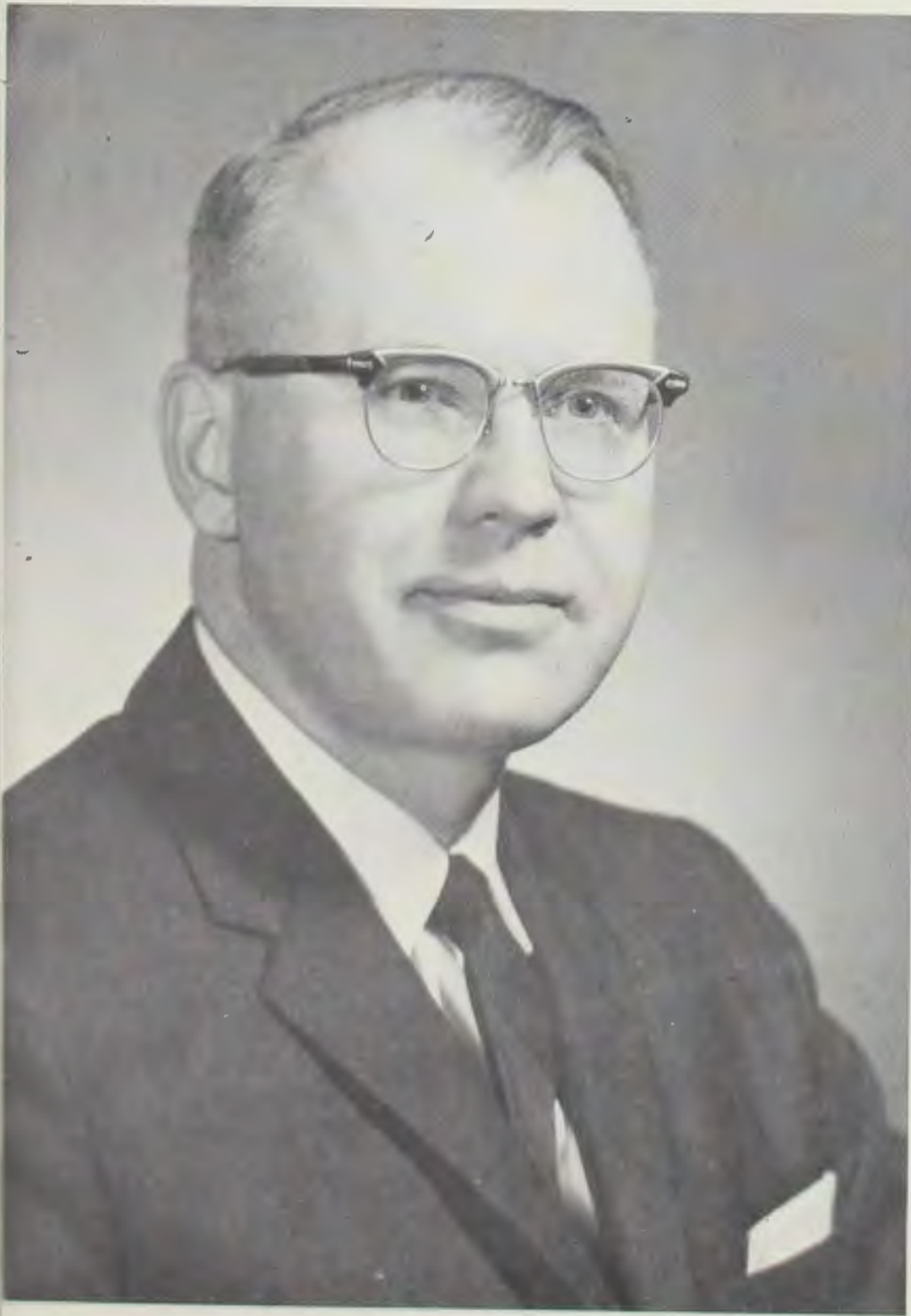

George L. Boyd, Treasurer. 


\section{Board of Trustees}

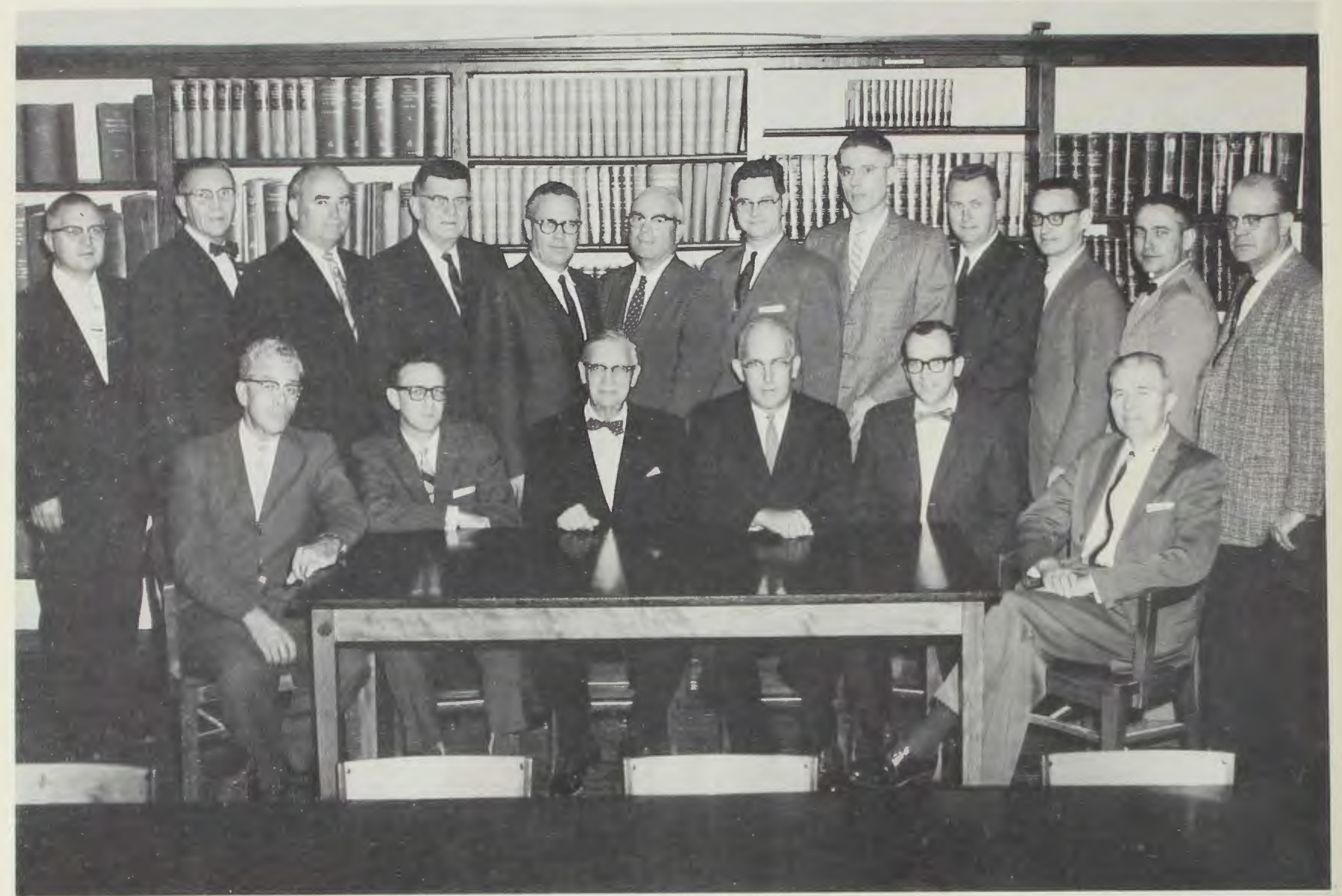

TOP ROW, Left to Right: Mr. John Draxler, Rev. George Bates, Mr. James Richardson, Mr. Rudolph Bedford, Mr. George O'Bryon, Mr. Charles Barth, Rev. Gerald Smelser, Mr. Arthur Dyke, Mr. J. Dale Murphy, Mr. Roy Guenin, Dr. Jack Cline, Rev. Glenn H. Davis. FRON'T ROW: Mr. William Patterson, Rev. William A. Brock, Vice-Chairman;
Dr. George S. Milner, Chairman; Dr. James 'T. Jeremiah, Rev. Thomas Younger, Secretary; Rev. Earl V. Willetts. NOT PICTURED: Mr. George L. Boyd, Treasurer; Mr. Norman Chappell, Rev. Alfred Colwell, Dr. Fred E. Milkie, Rev. Kenneth A. Muck, Rev. Wilber Rooke, Mr. Eugene Smith, Mr. Charles Wallace, Rev. Donald Woodby.

\section{Executive Committee}

George S. Milner Chairman

William A. Brock Vice-Chairman

Thomas Younger Secretary

George Boyd Treasurer

James T. Jeremiah
Clifford R. Maddox William Patterson Earl V. Willetts Arthur F. Williams 
Those in the business office have the distinct privilege of handling all the money of the college. All business transactions are done here In the publication room, the monthly College Bulletin is published as well as many other advertising materials. This year the college post office has been enlarged greatly.

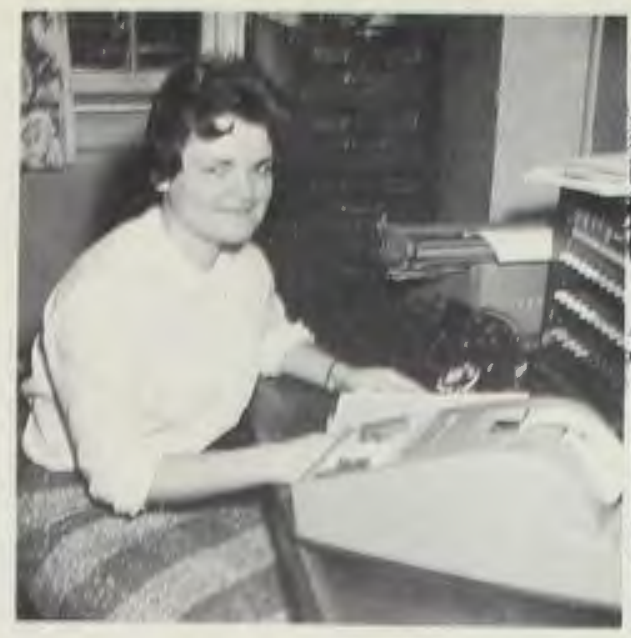

Marjory Hes

Cashier

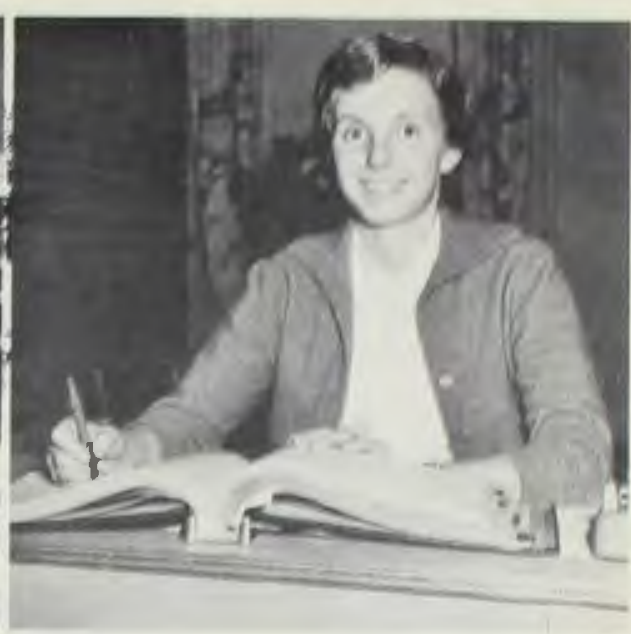

Elinor Marshall

Bookkeeper
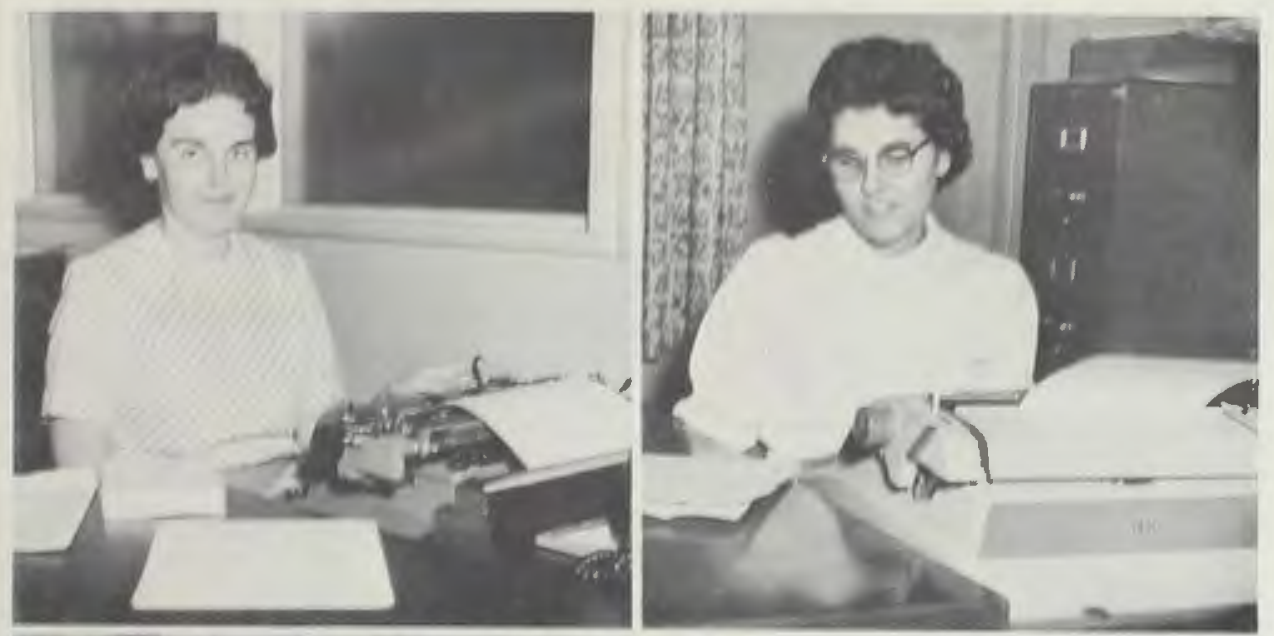

Gerry White

Secretary to the Registrar

Margaret Spaulding

Secretary to the President
Office

Staff
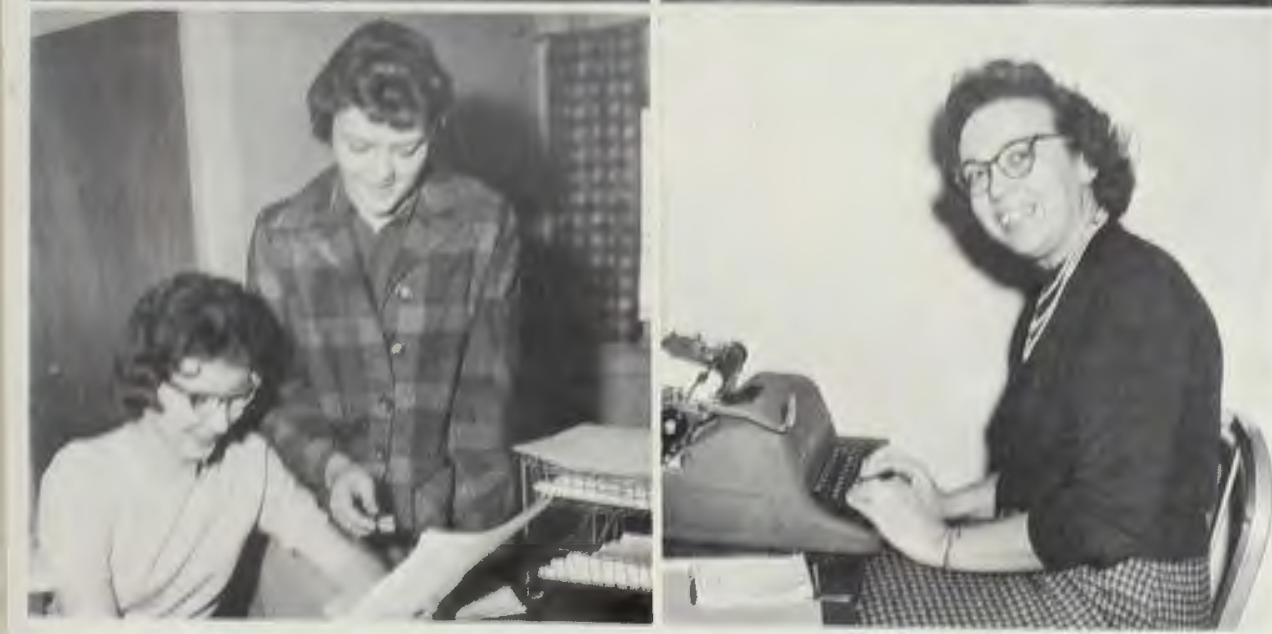

Beverly Woods and Maryalice Jeremiah

Secretaries to the Academic Dean

Jeane Hartzell

Secretary to the Dean of Students

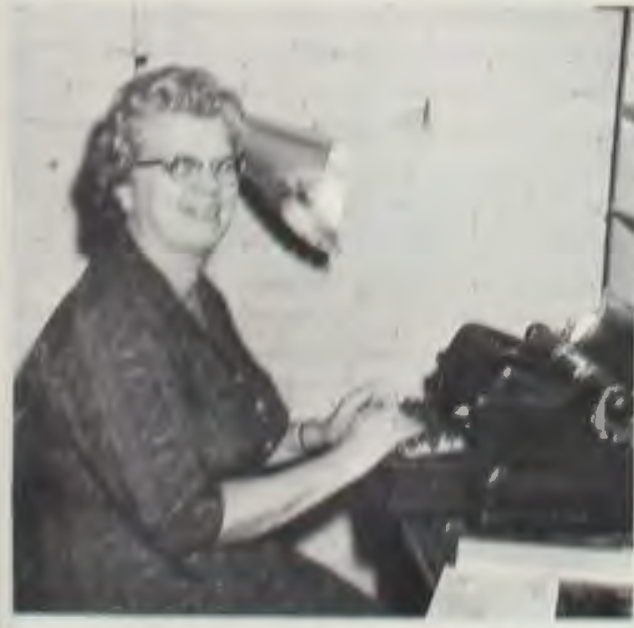

Mrs. Elmore

Publications

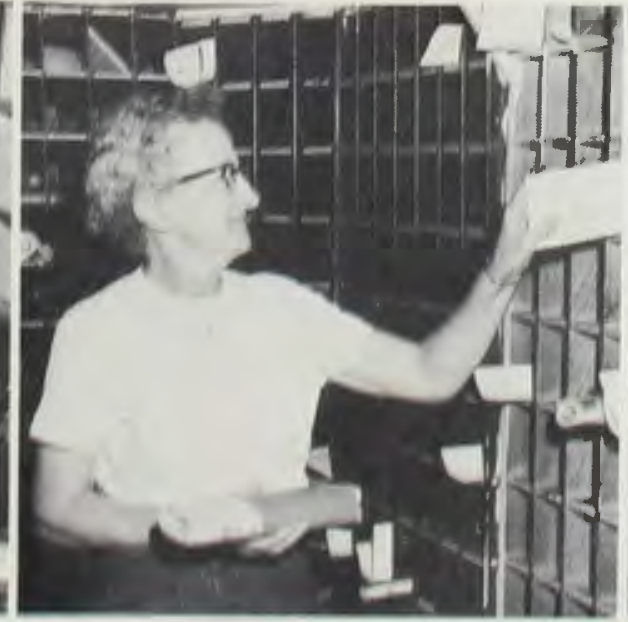

Mrs Ruth Underwood

Manager of College Post Office

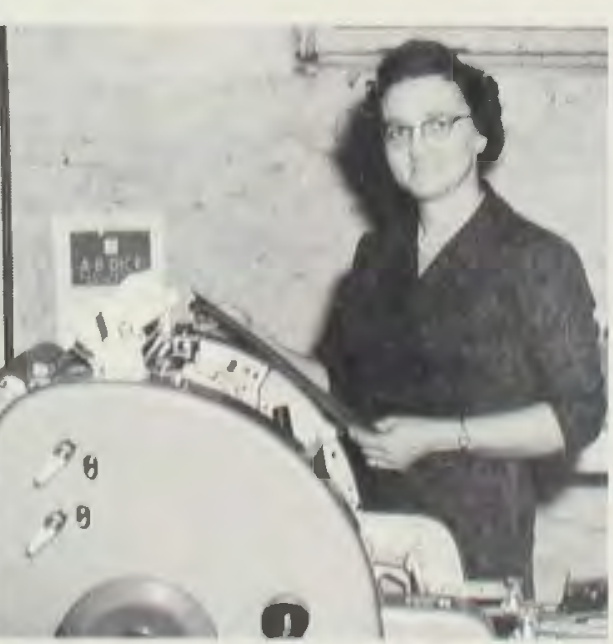

Mrs. Jeremiah

Publications 


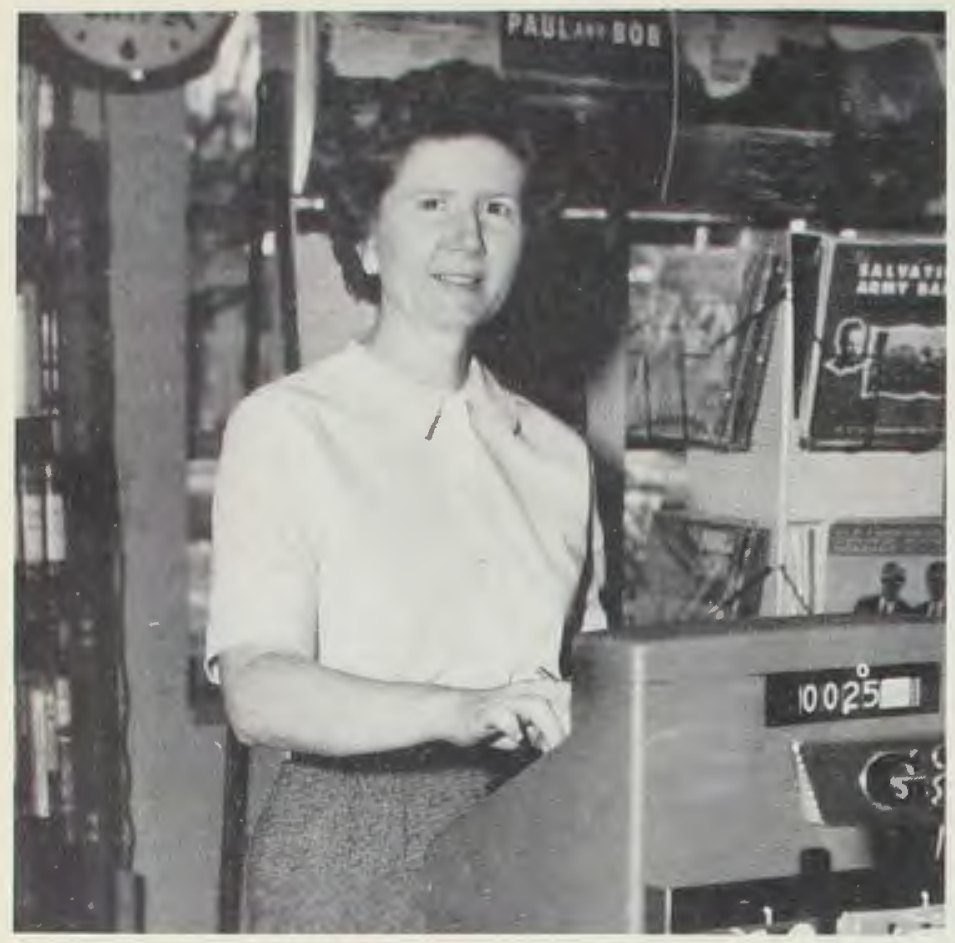

\section{Bookstore}

One of the most active places on the Cedarville College campus is the College Bookstore. In addition to books, stationery, and records the Bookstore has cosmetics, drugs, and Cedarville College supplies for sale. Perhaps the most important service of the Bookstore to some of our students, however, is the snack bar.

Bernice Mick - Manager

Mrs. Harmon Bergen (above), Mrs. Ralph Gale (not pictured) - Assistants.

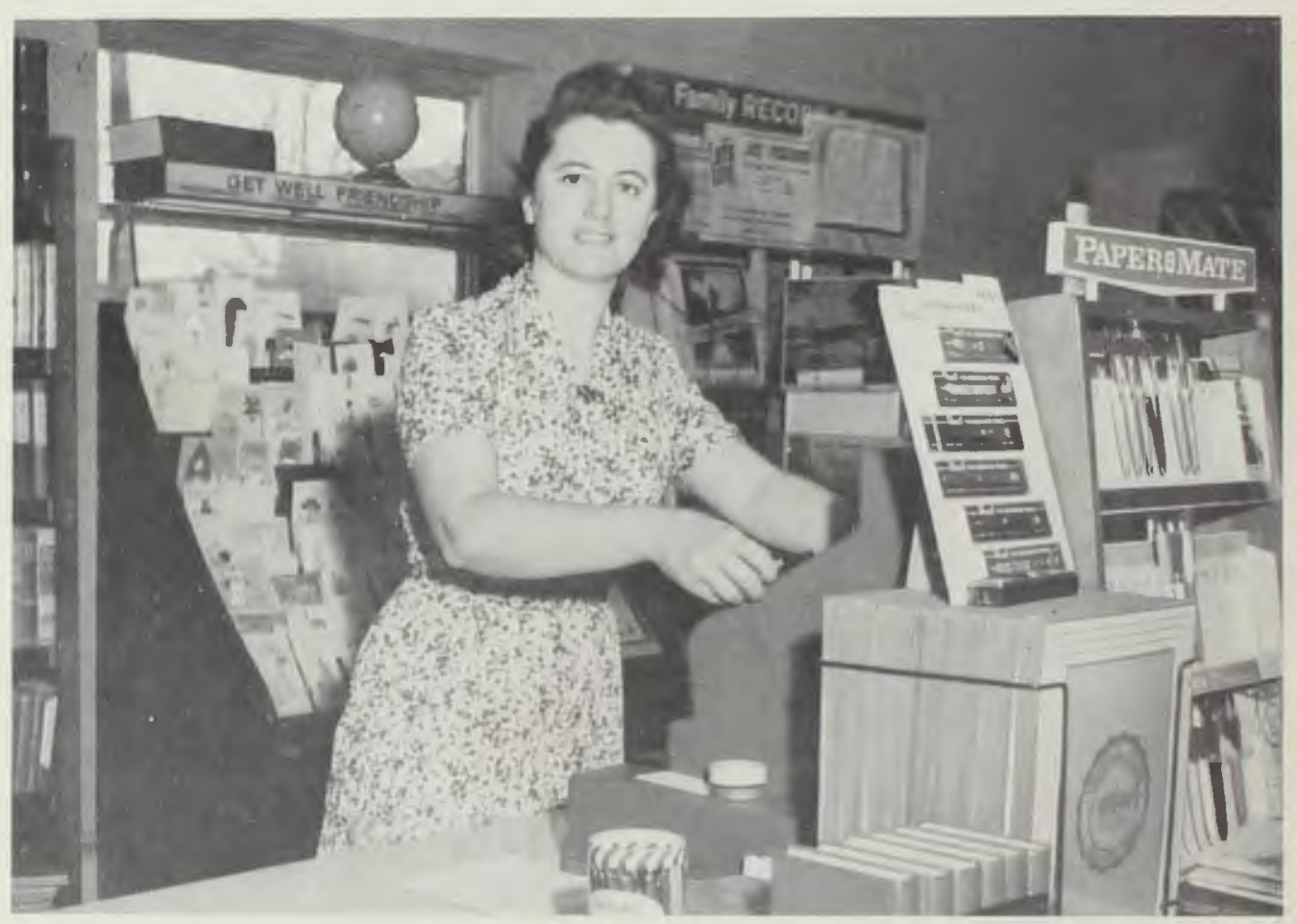

Carolyn Coppock and Sandy Zerby, - Student Help.

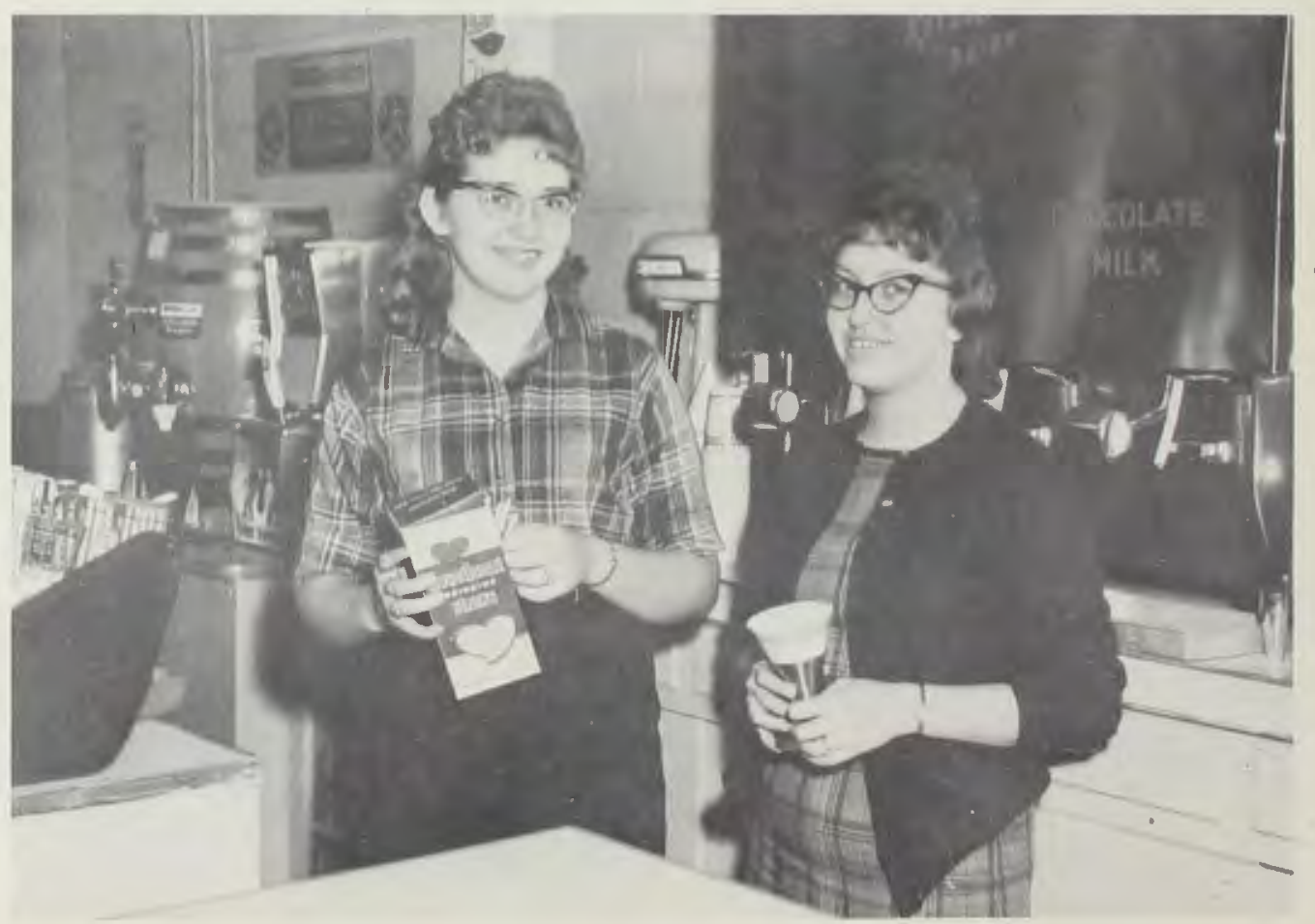




\section{Library}

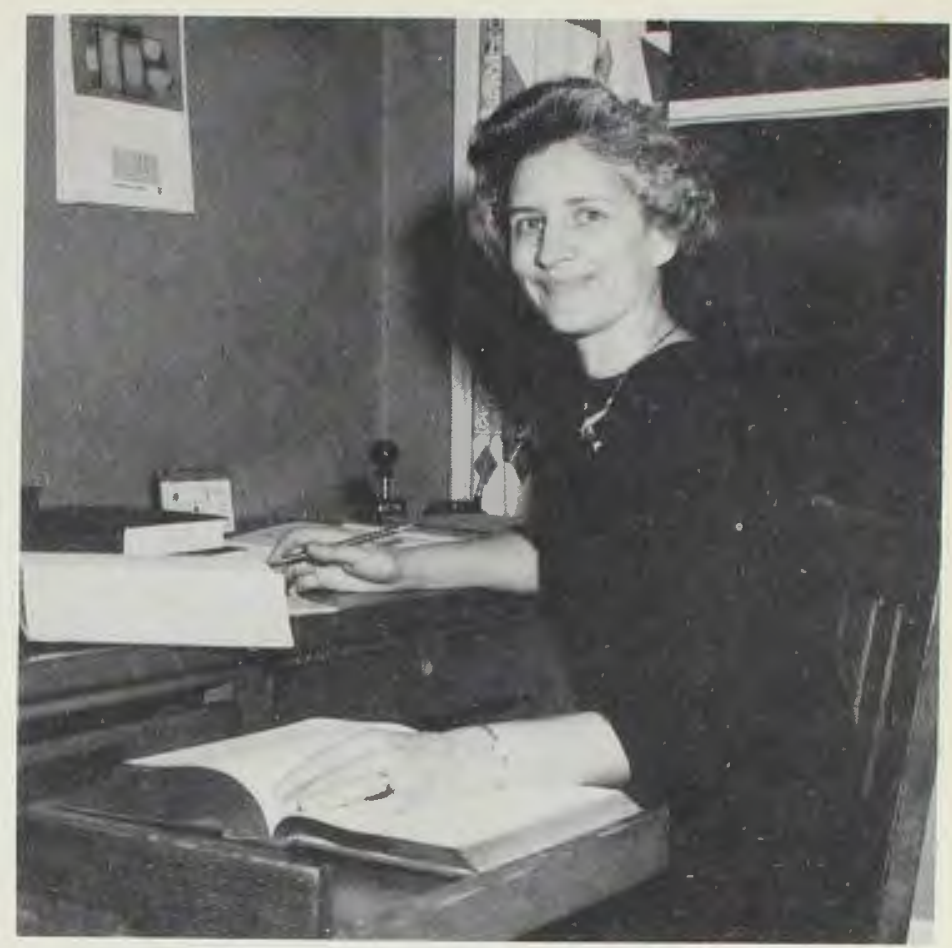

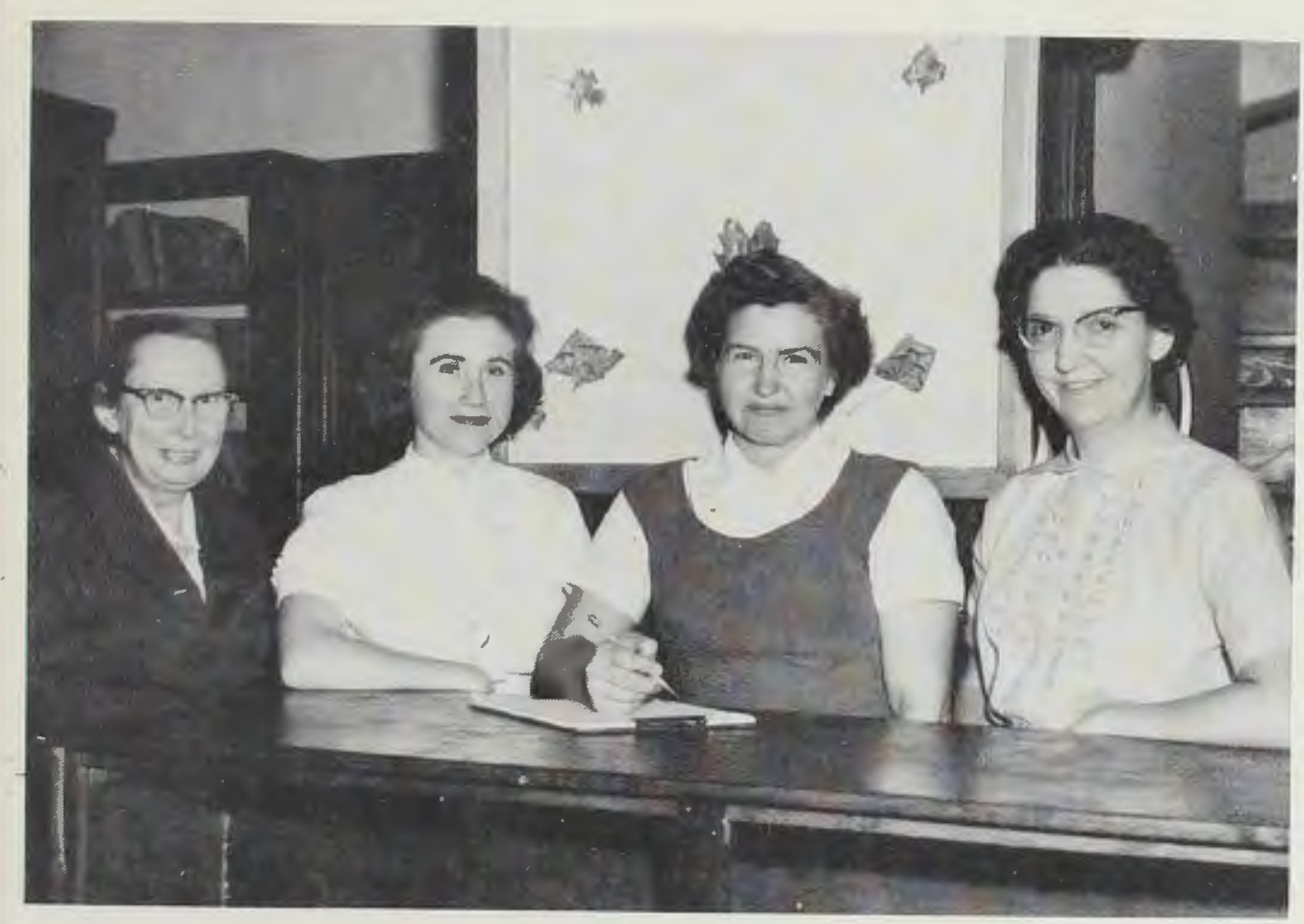

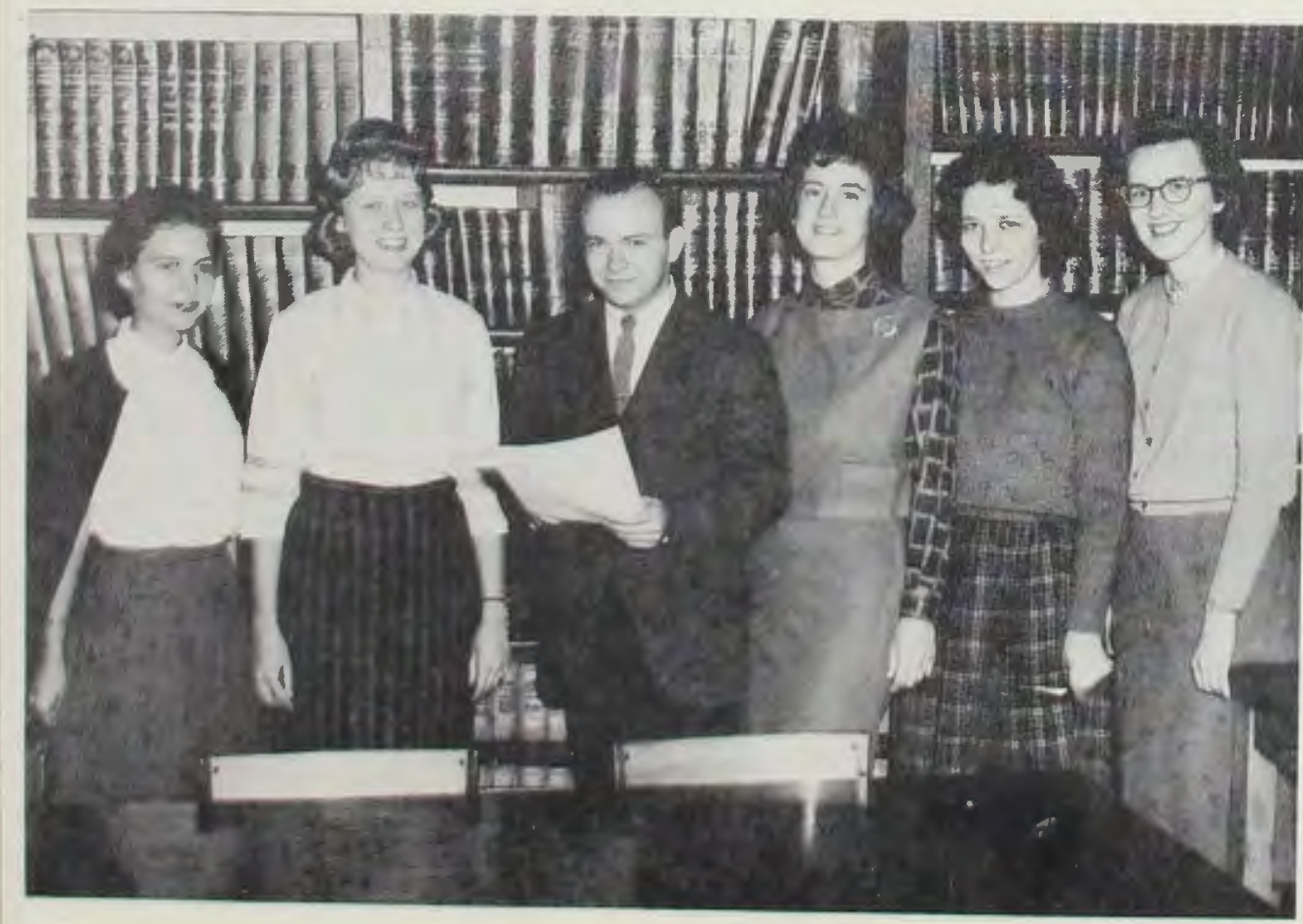

Mrs. Alberta Chaffee Head Librarian
ASSISTANTS - Mrs. Esther Ruder, Mrs. Patricia Thornton, Mrs. Bonnie Alexander, Mrs. Ida St. Clair.
STUDENT HELP - Elaine Jordan, Nancy Wray, John Ingram, Judy Goff, Peggy Buerer, Bonnie Jackson. 


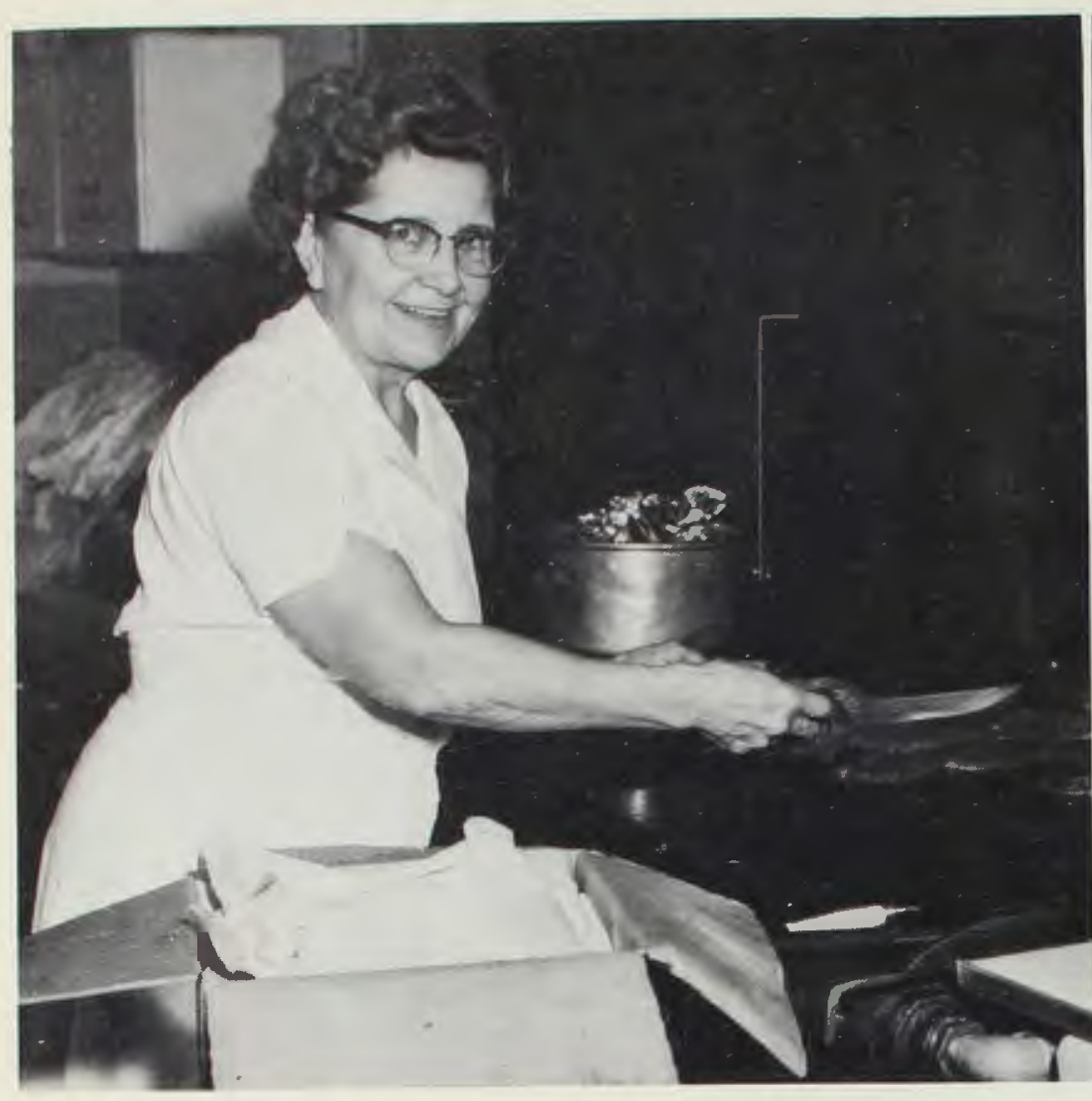

Mrs. Jessie Shirley - Head Cook.

\section{Cafeteria Staff}

In addition to giving us three good meals a day, the cafeteria staff works extra hard by giving us an annual Christmas dinner and monthly birthday cakes. A new feature in the cafeteria is the "professors' table."

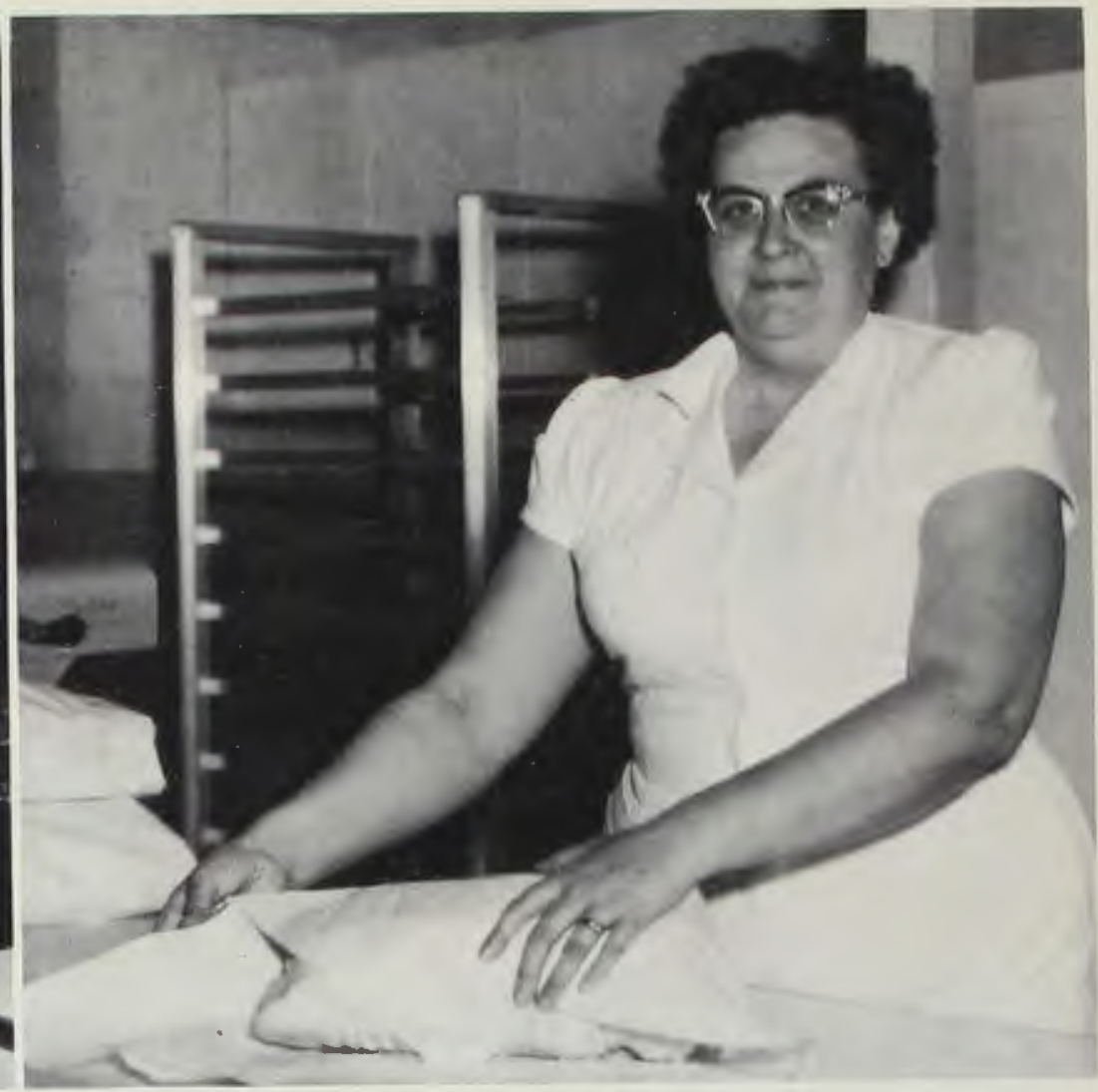

Mrs. Betty Tarter - Manager.

The faculty is served by members of the cafeteria staff - perhaps this is one reaon for the increased cafeteria staff this year.

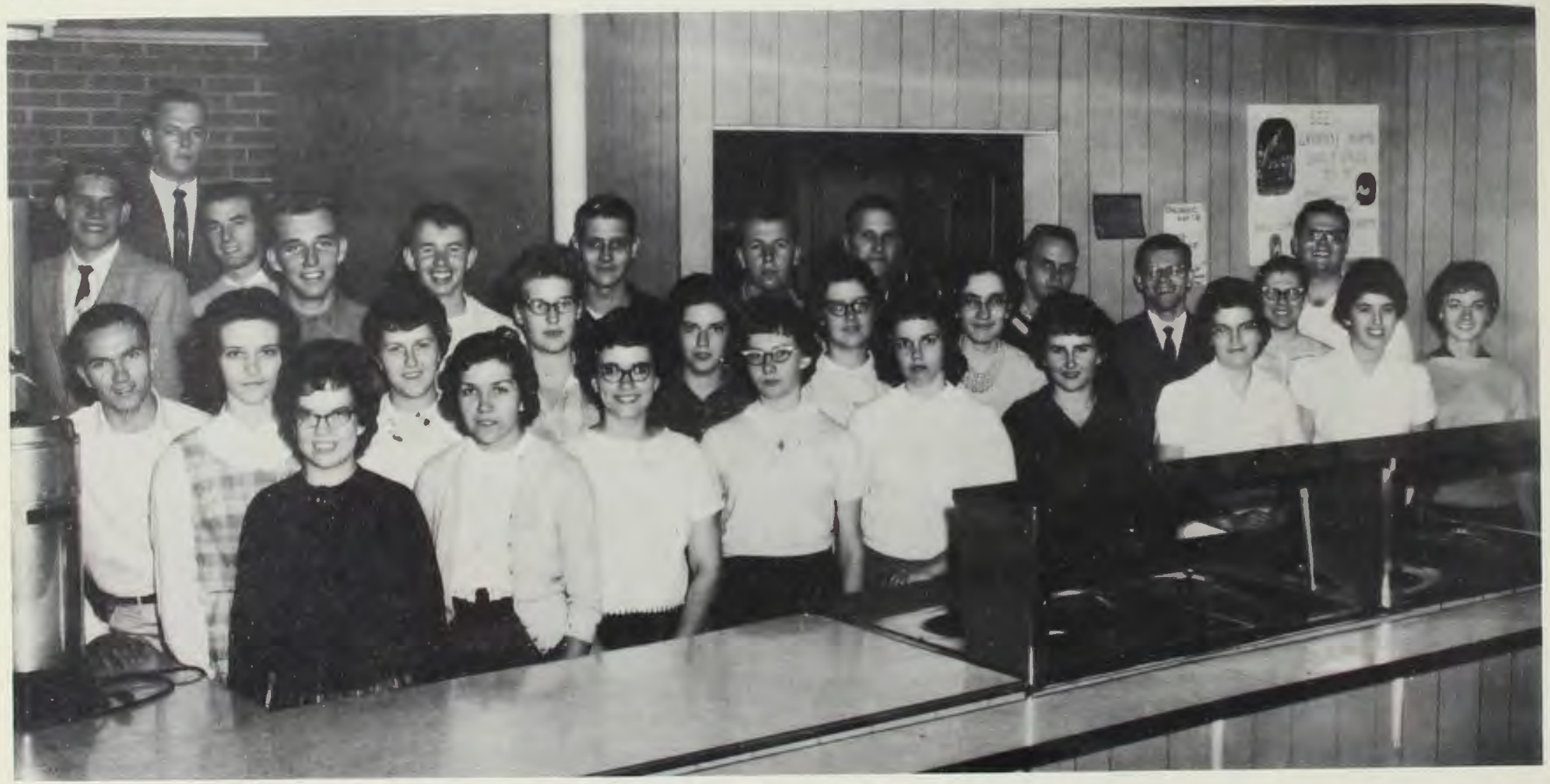

STUDEN'T HELP - TOP ROW, Left to Right: Mervin Ziegler, Richard Rich, Tony Nicholas, Dave Werner, Ronnie McDugle, John Wolfe, Phil Grant, Bill Lobsiger, Steve Luyben, Keith Webster, Hope Marie Willie, Joe Lloyd. SECOND ROW: Howard Day, Nancy Buerer, Elsie Himsel,
Sue Geyser, Elaine Adams, Judie Smith, Judy Bird. FIRST ROW: Shirley Goodman, Ruth Ann Schlosser, Edna Shrider, Sharon Addleman, Sally Bender, Shirley Jean Sichting, Jeri Wickell, Pat Smith, Cathy Shelton. 


\section{Maintenance}

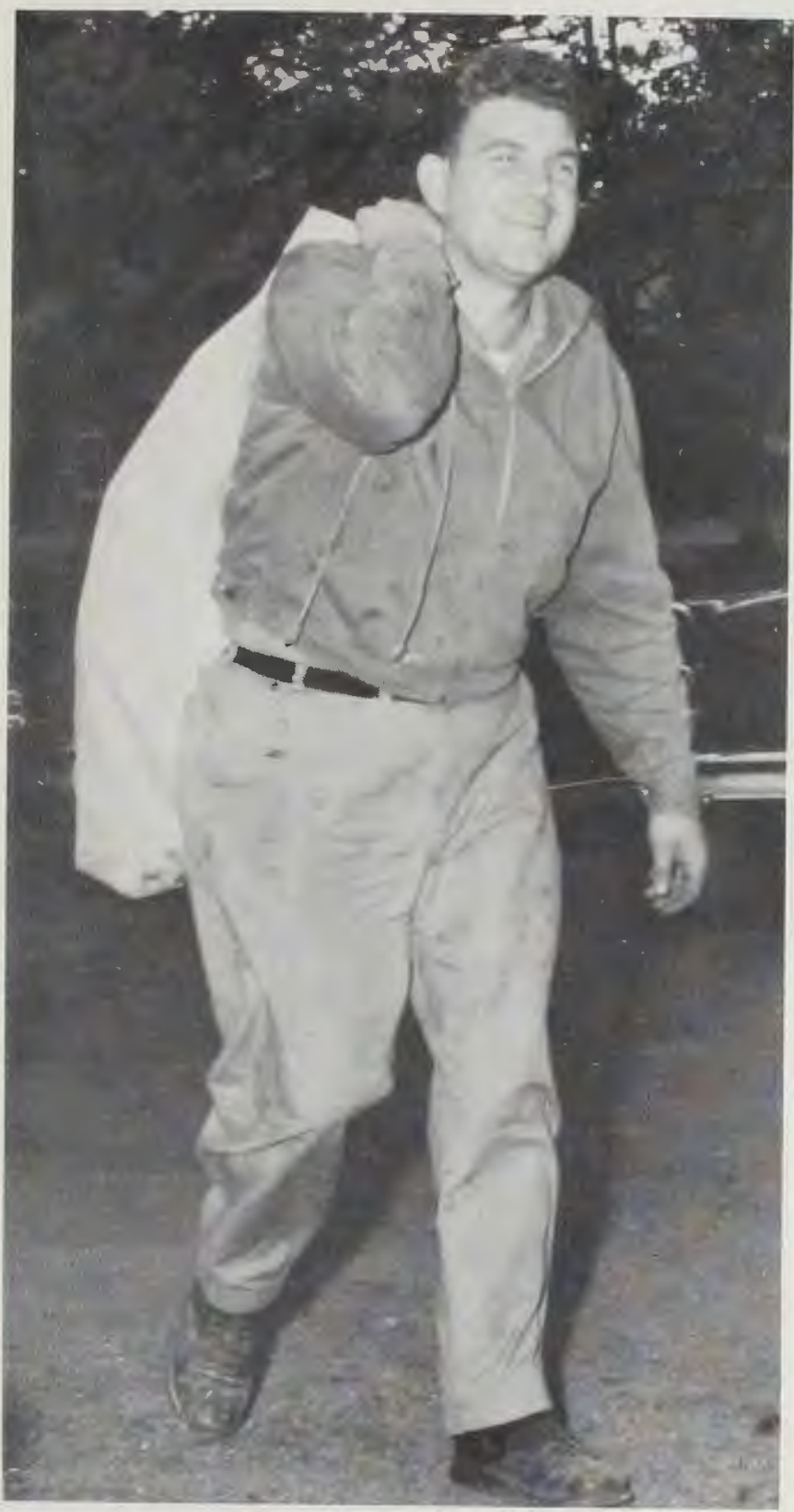

Charles Tarter

The Maintenance Department is kept busy all year long. Those on the staff during the school year work hard keeping the buildings and campus clean and in good working order. Those here during the summer months remodel and repair present buildings and help in the construction of new buildings.

Mr. Tarter, in addition to his maintenance work, delivers the college mail from the Cedarville Post Office.
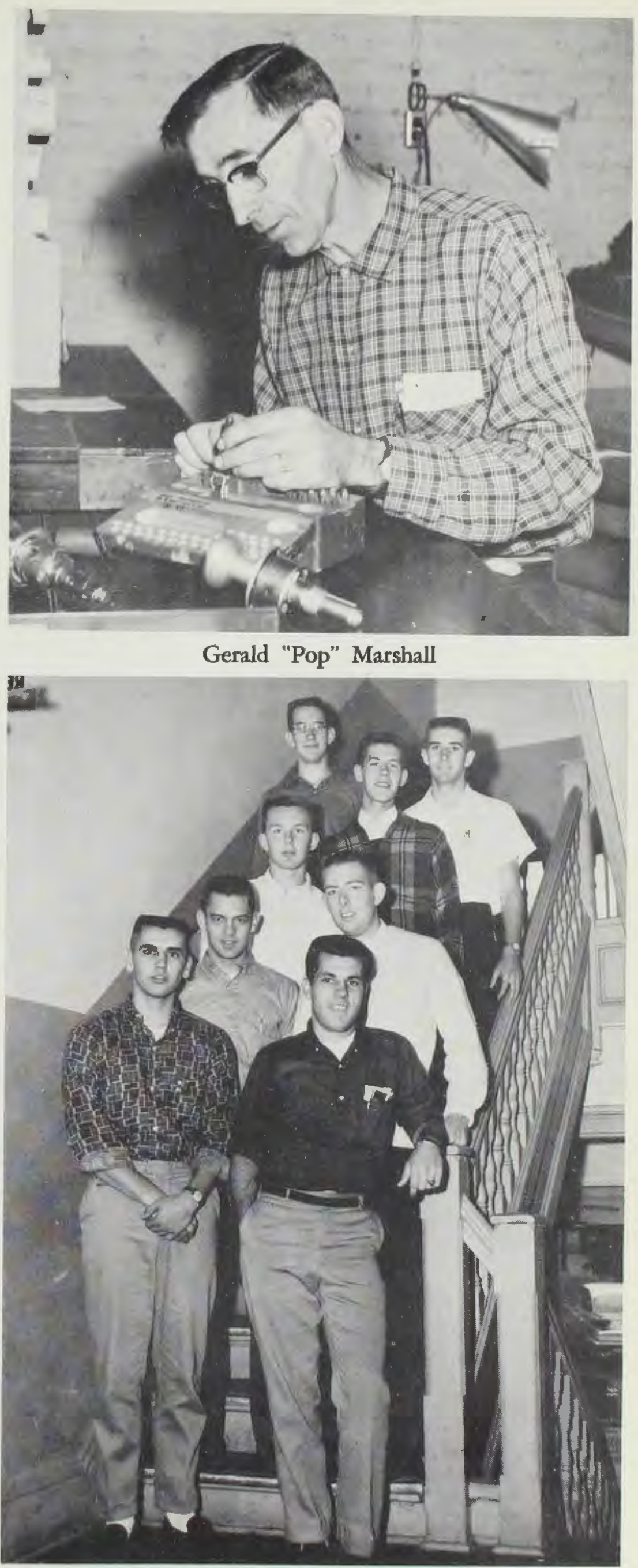

TOP ROW, Left to Right: Dave Rifenberick, Elvin King. SECOND ROW: Dave Taylor. THIRD ROW: Paul Carlson. FOURTH ROW: Jay Moore, Jim Hamilton. FRONT ROW: Warren Burnside, Tony Rotondi. 


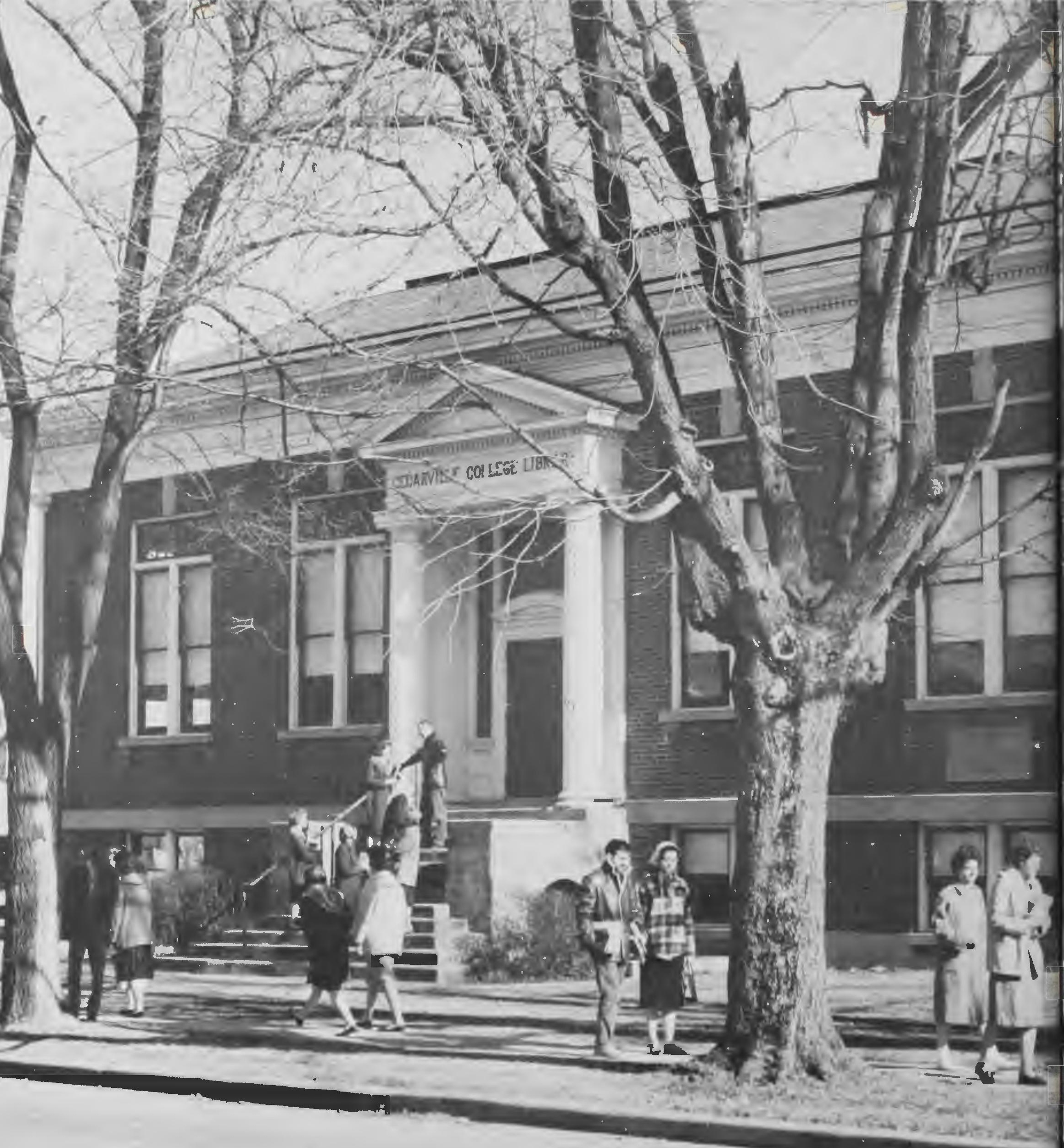




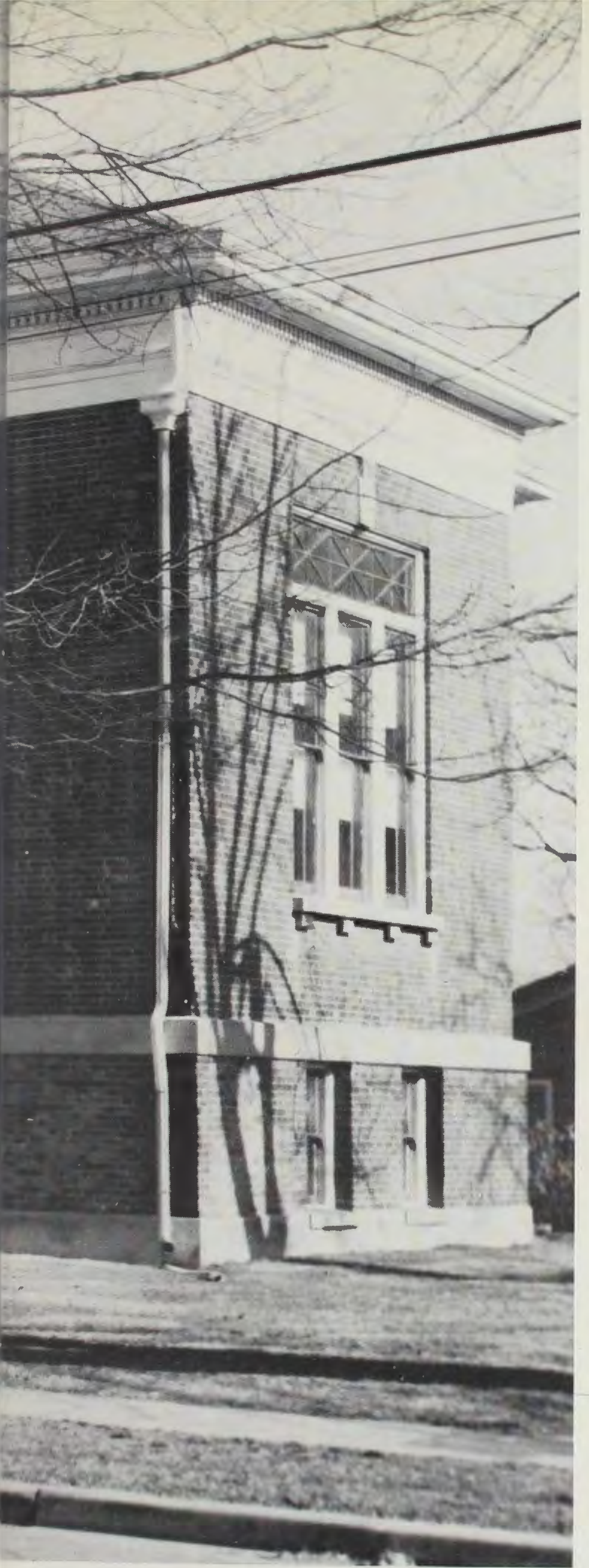

As freshmen we were sure that knowledge could be acquired in the lecture room; now we realize that attending chilly winter lectures in Ad 23 is not enough. Facts are presented to us by our professors but they do not become a part of us until we make them such by hours of research at the library and numerous lab sessions. Teaching, studying and experimentation - classroom, library and laboratory combine to give us knowledge. 


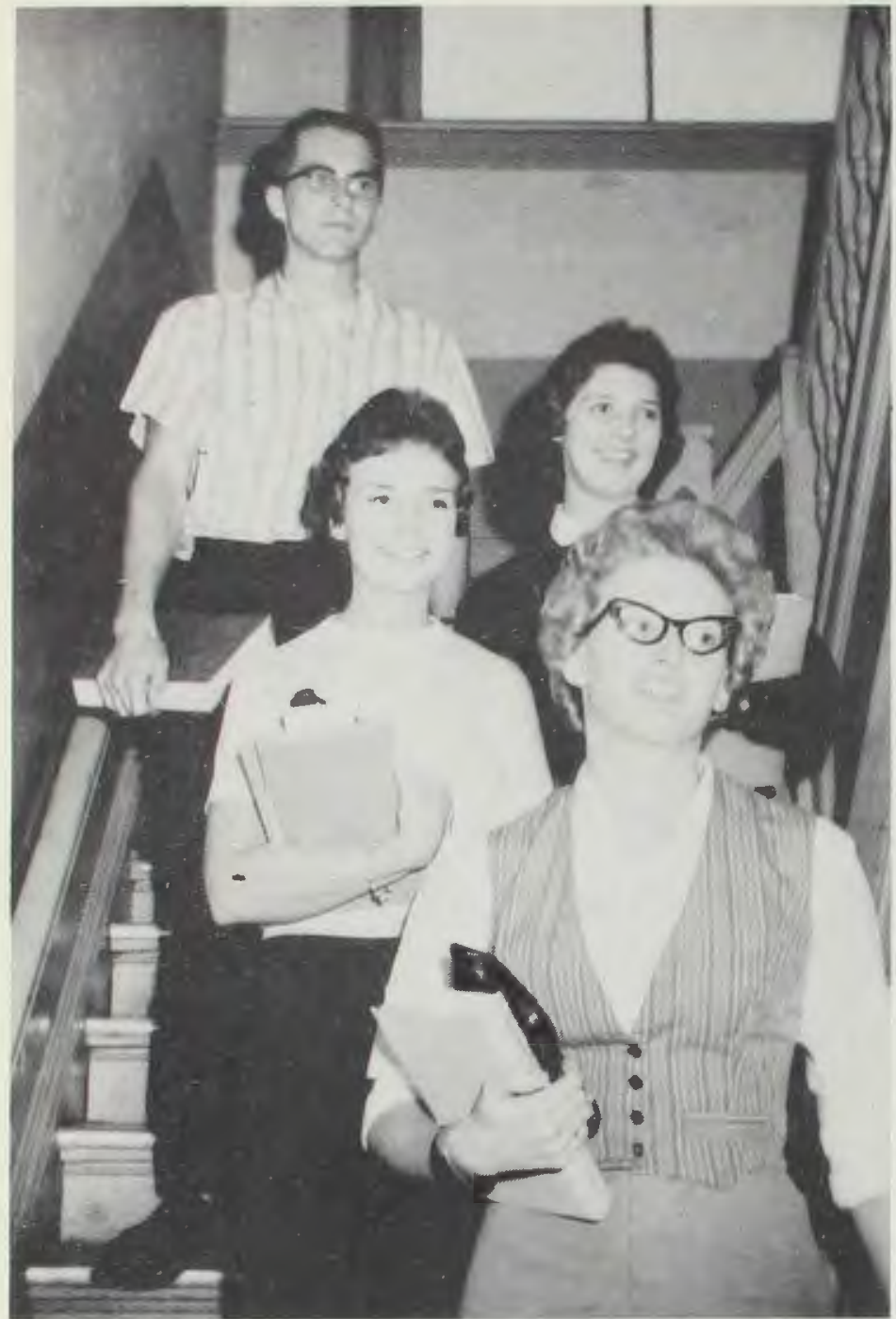

ACADEMICS

We run from place to place, from building to building going to our classes, but then comes ten o'clock when we pause from the busy rush and walk toward Milner Chapel.

In chapel we find the real blessing of the Lord each day. Special artists, pastors, and evangelists bring the Word of God to us. Attending chapel, as vital a part of Cedarville College as the class, is required of all.

This keeps us slim ' $n$ ' trim - from the faculty offices on the 3rd floor to Room 3 of the Administration Building.

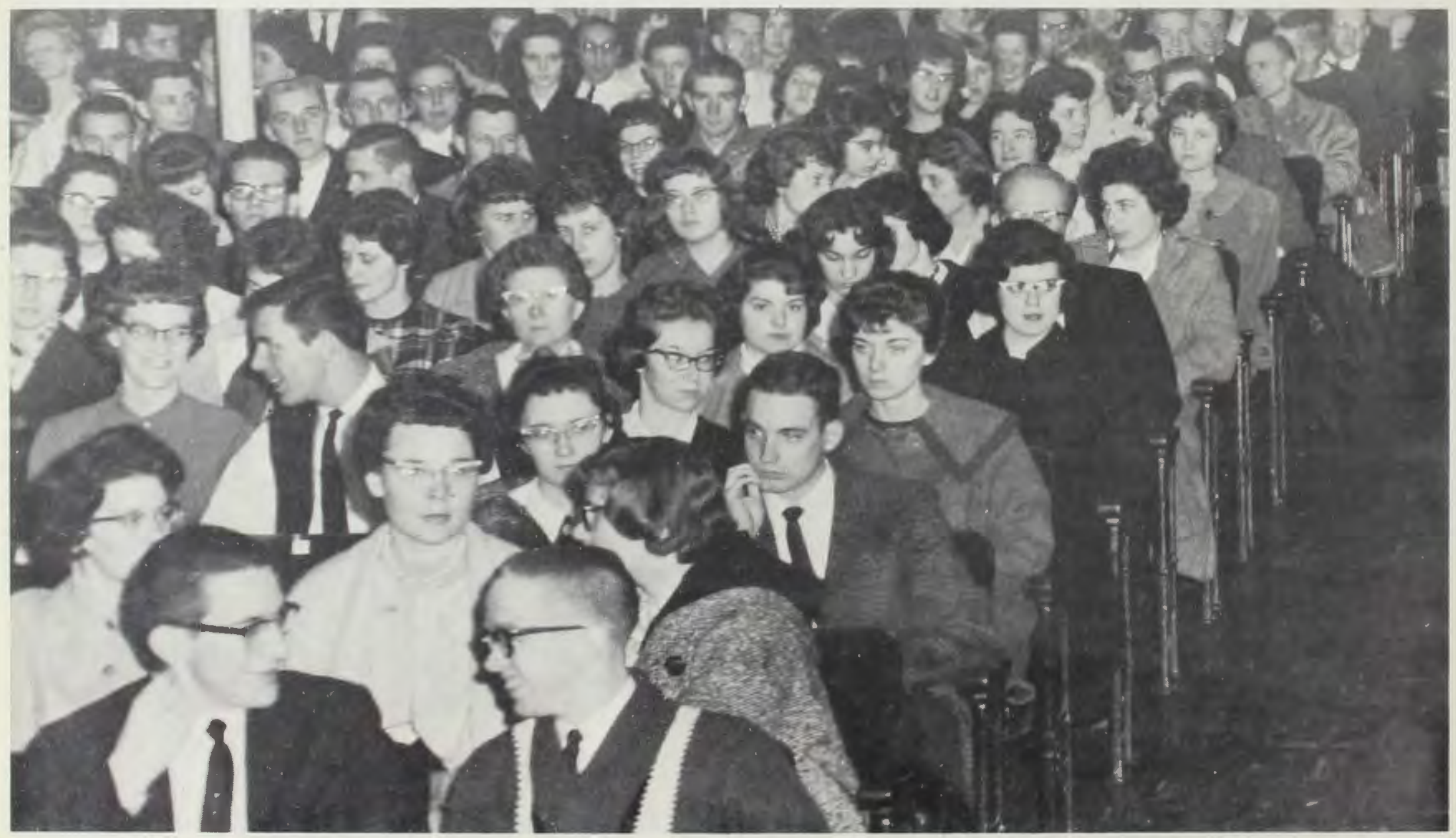

Our souls are refreshed as we spend an hour in worship with fellow students and faculty. 
Jean Fisher, M.R.E.

Christian Education

Robert Gromacki, Th.M.

Bible, Apologetics

Advisor of Freshman Class

Advisor of Future Pastors' Fellowship

\section{Division}

of

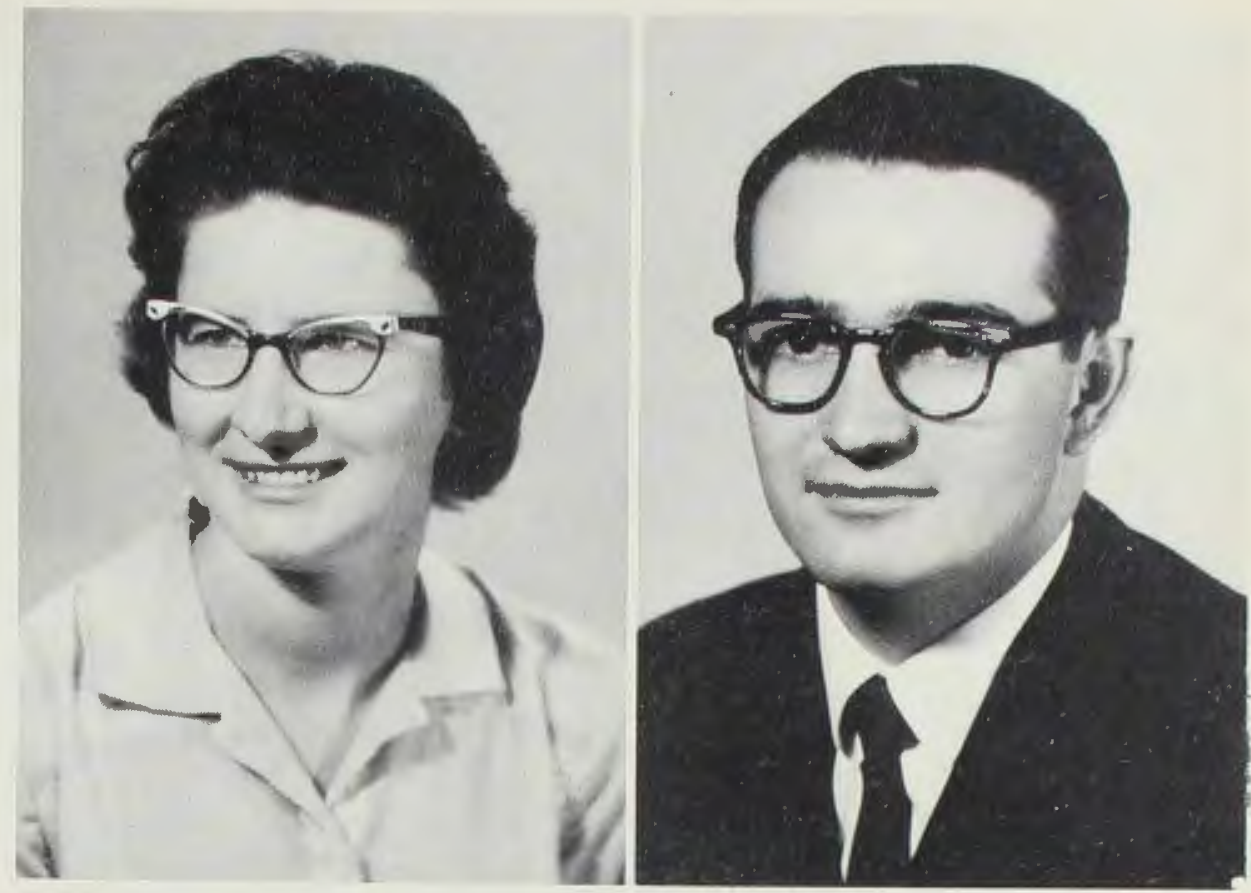

\section{Biblical}

\section{Education}

James Jeremiah, A.B., D.D.

Bible Doctrine

Baptist History and Polity

George Lawlor, Th.M.

Leave of Absence
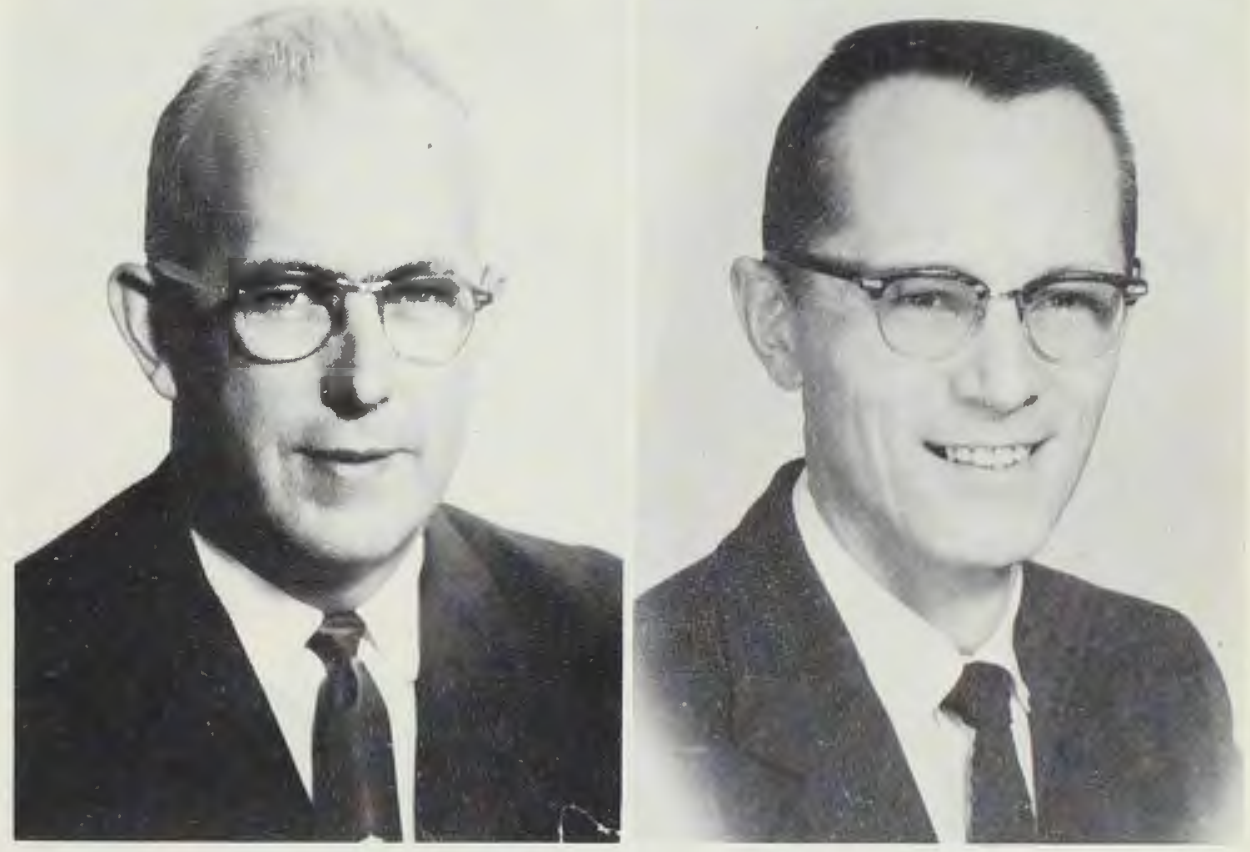

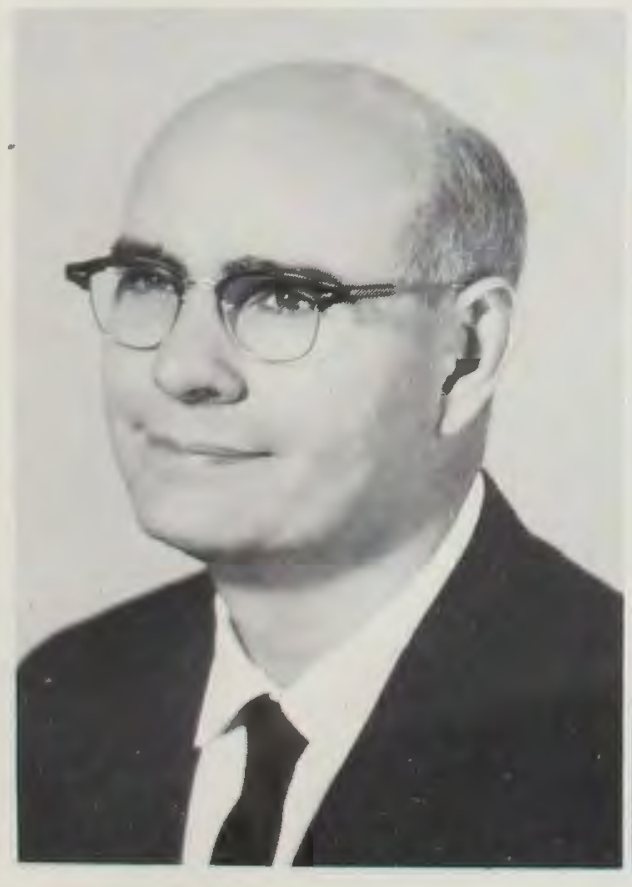

Cleveland McDonald, M.Litt. Social Science

Advisor of Fellowship of

World Missions

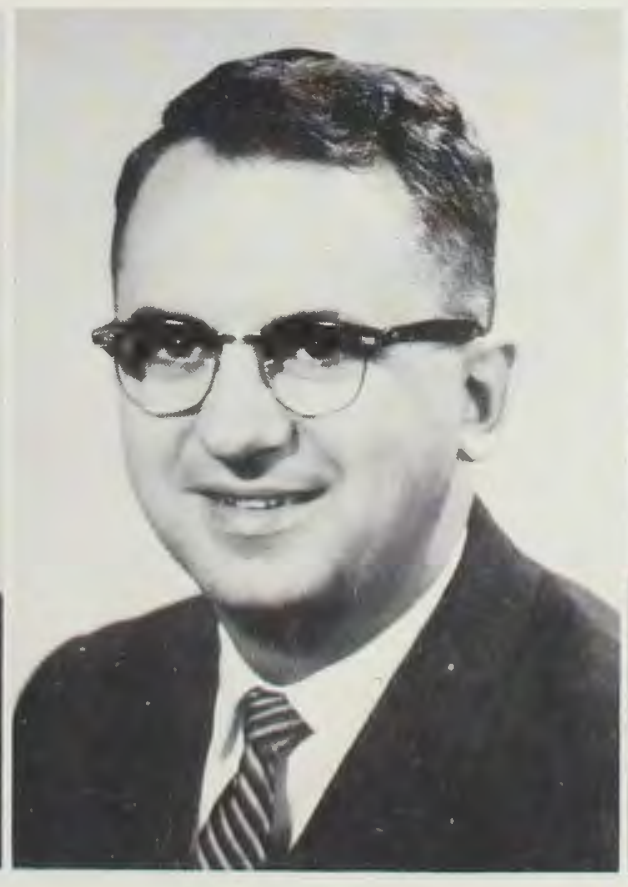

Richard MeIntosh, A.B., B.D. Bible, Greek Exegesis Advisor of Student Council

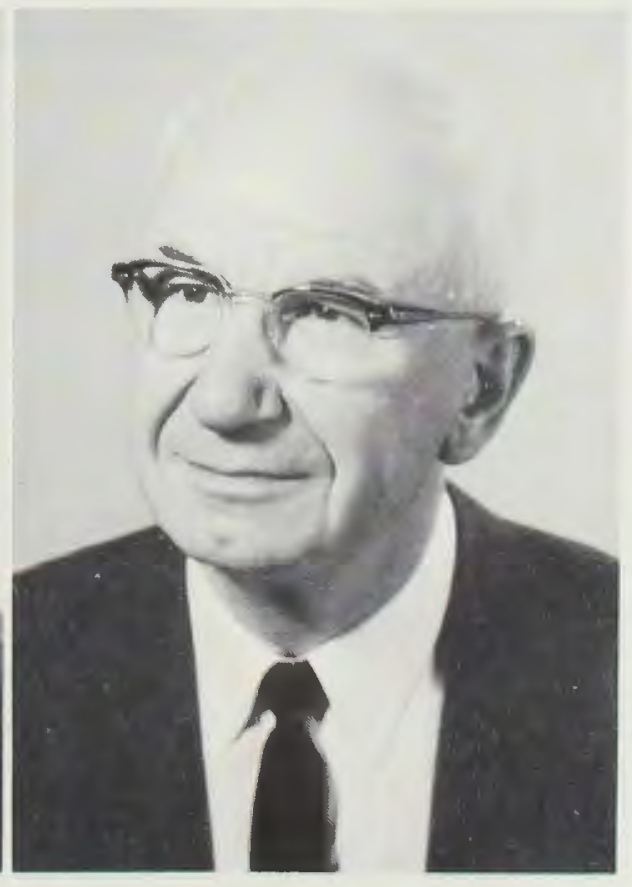

Arthur Williams, A.B., D.D. Bible, Theology 


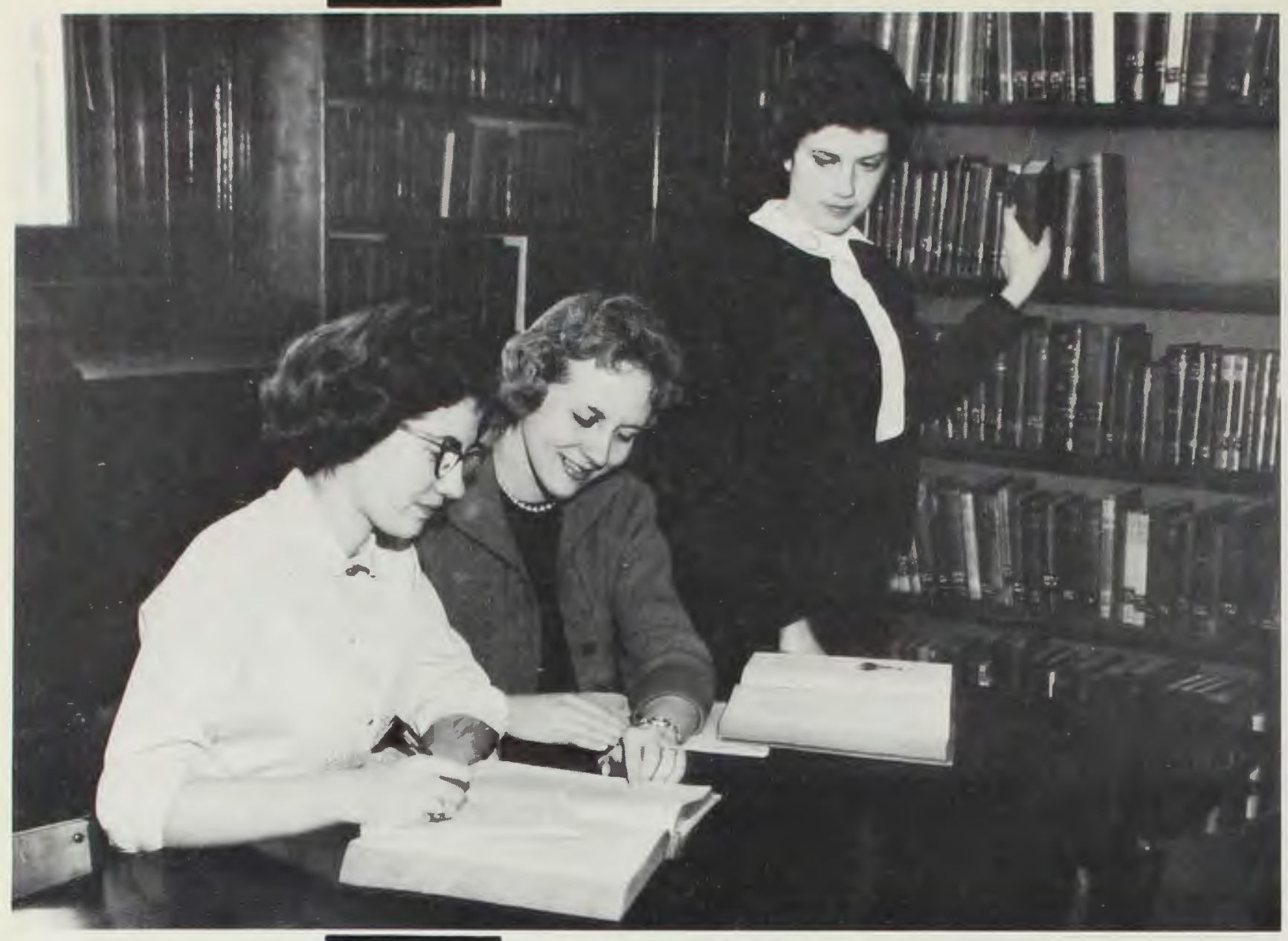

ACADEMICS

Biblical

Education

The members of Dr. Jeremiah's Baptist History and

Polity class spend time at the college library reading required books.

One great advantage of attending a Christian college of liberal arts is the Bible instruction the student receives from those to whom the Word is precious. The instructors in this division are godly men who patiently and capably guide us to a greater understanding of our Saviour and God's Word.

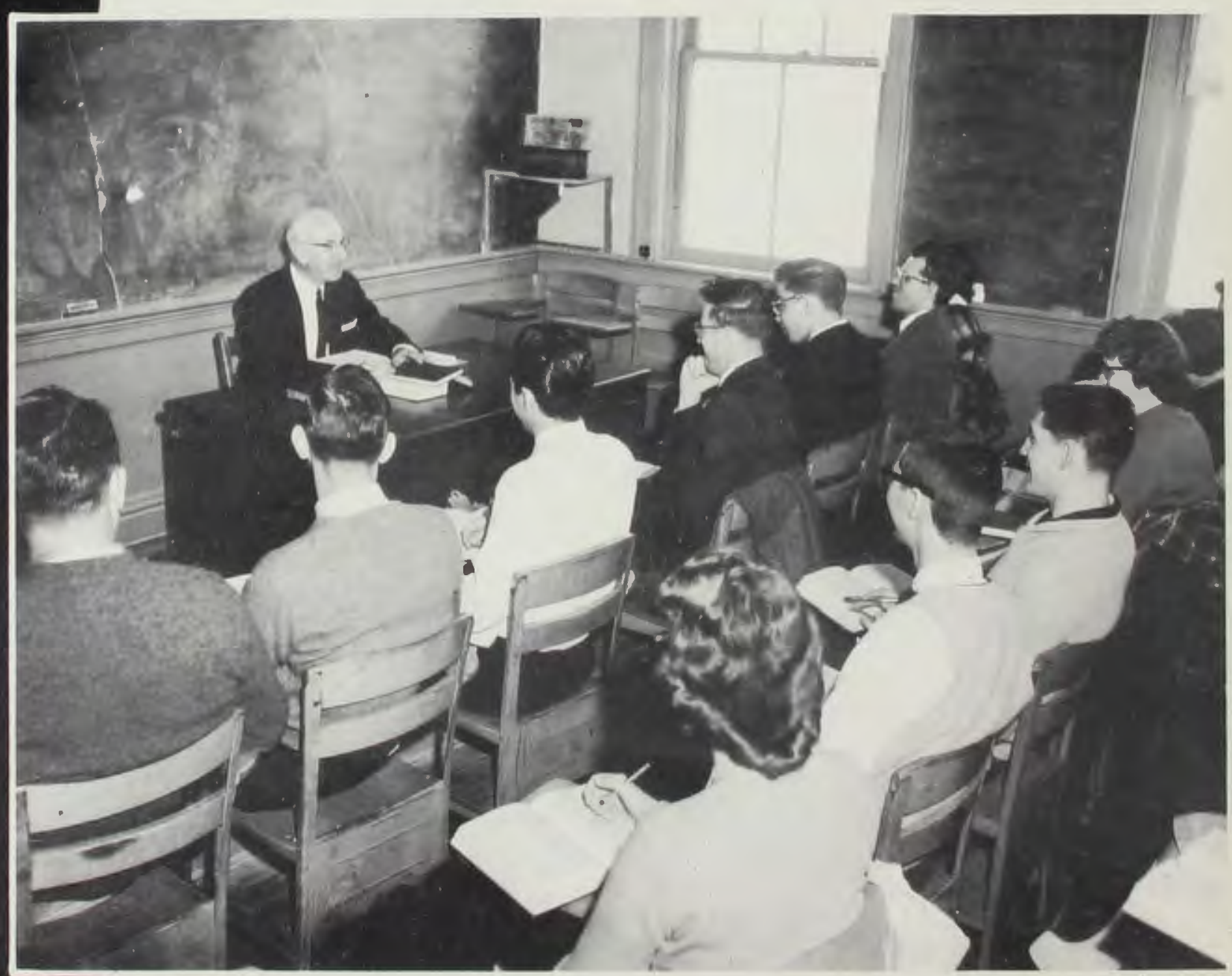

Gathering every weekday at 12:00 noon could become commonplace, but the students 


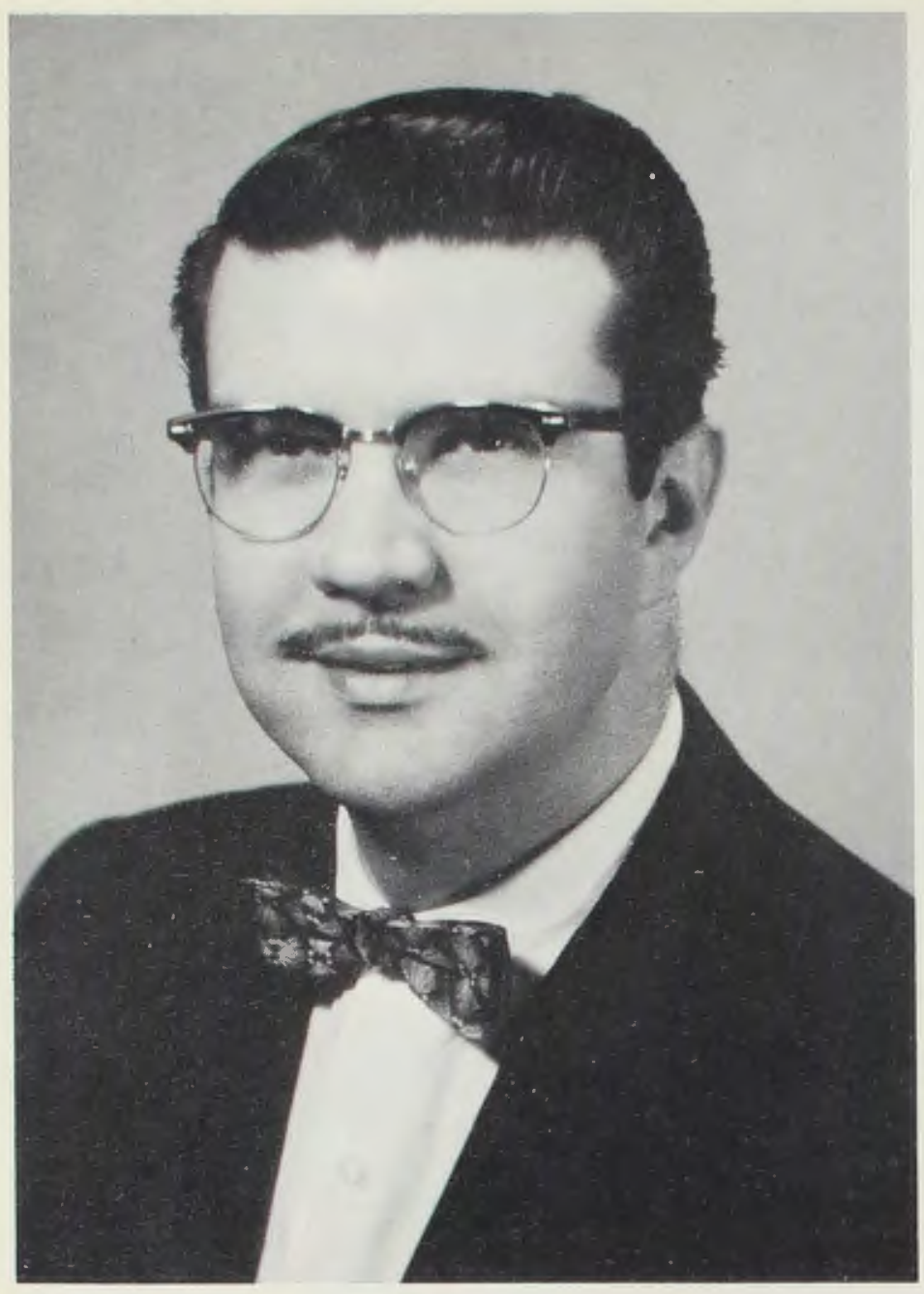

Carol Barker, B.A.

Psychology

\section{Division}

\section{of \\ Psychology and Education}

Mr. Barker, our registrar, is new to the department. His presence on the staff has increased the number of courses offered in the division of Psychology and Education, such as Psychology of Perception and Psychology of Language and Thinking. 
Along with general class work, students this year attend lab periods, and many work in the offices of $\mathrm{Mr}$. Barker and Dr. Maddox, which gives them much needed experience in this field.

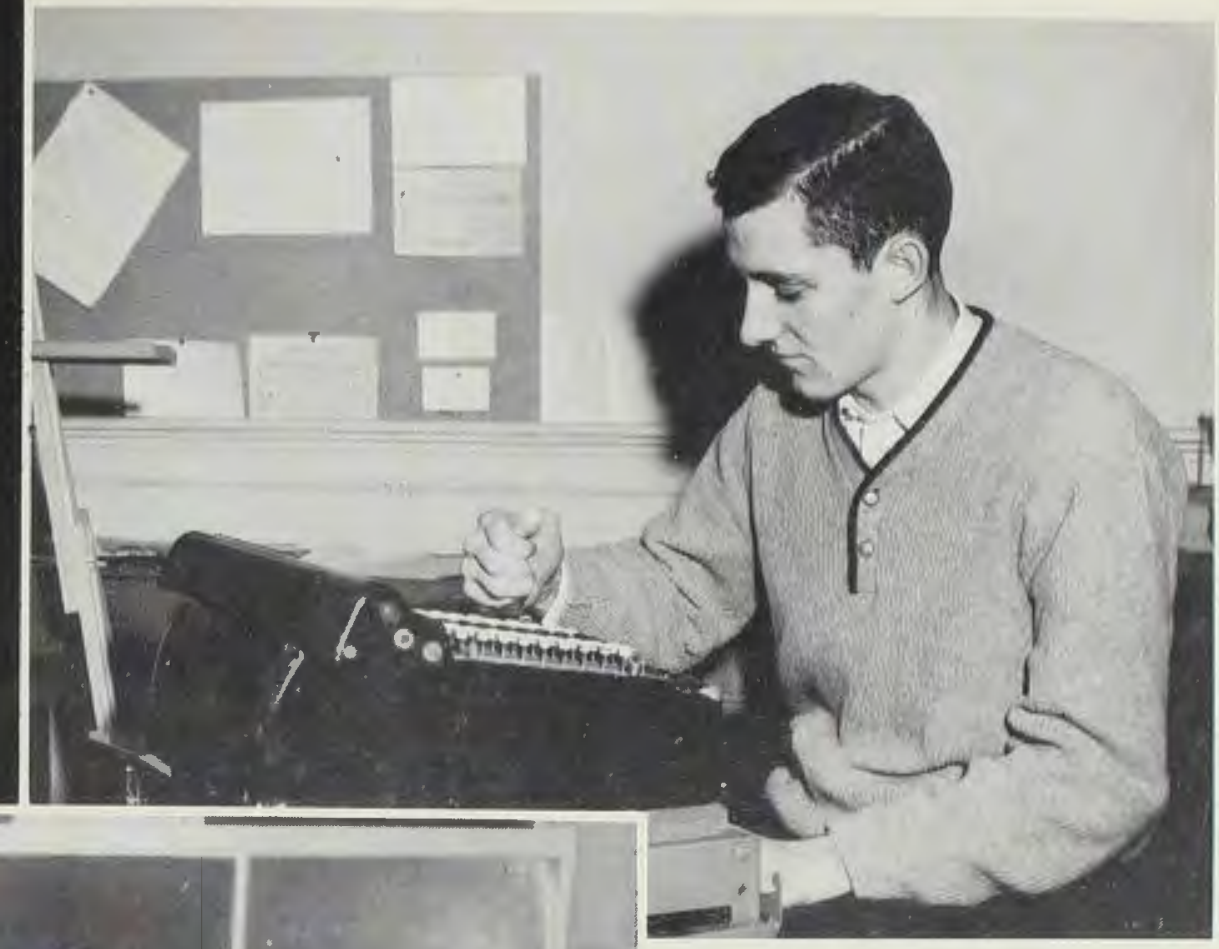

Jim Sprague spends many hours working in the office of Dr. Maddox compiling statistics.

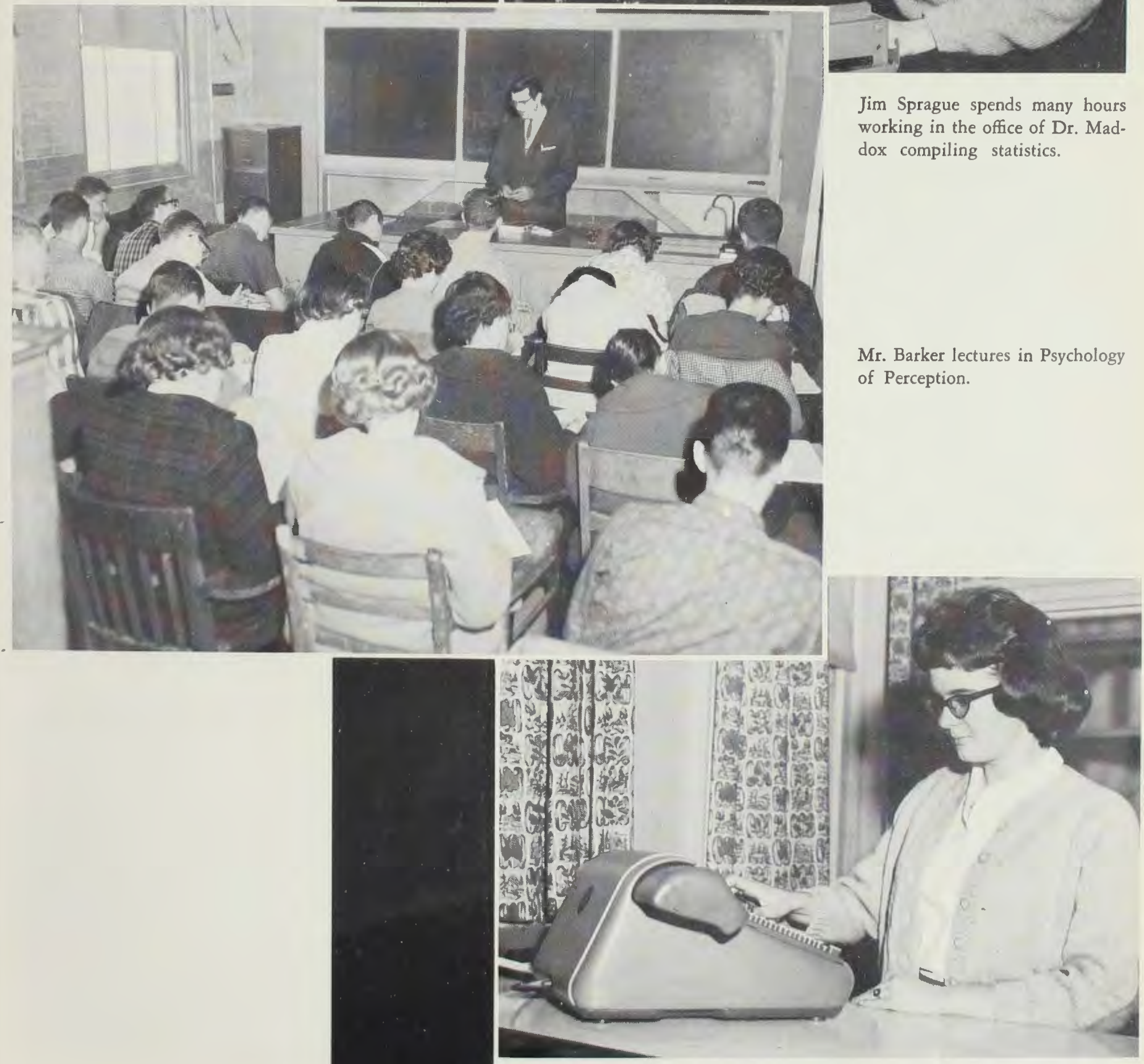

Carole Boren works with the Registrar as part of the requirements for this course on Behavioral Statistics. 


\title{
Division of Health
}

\author{
and
}

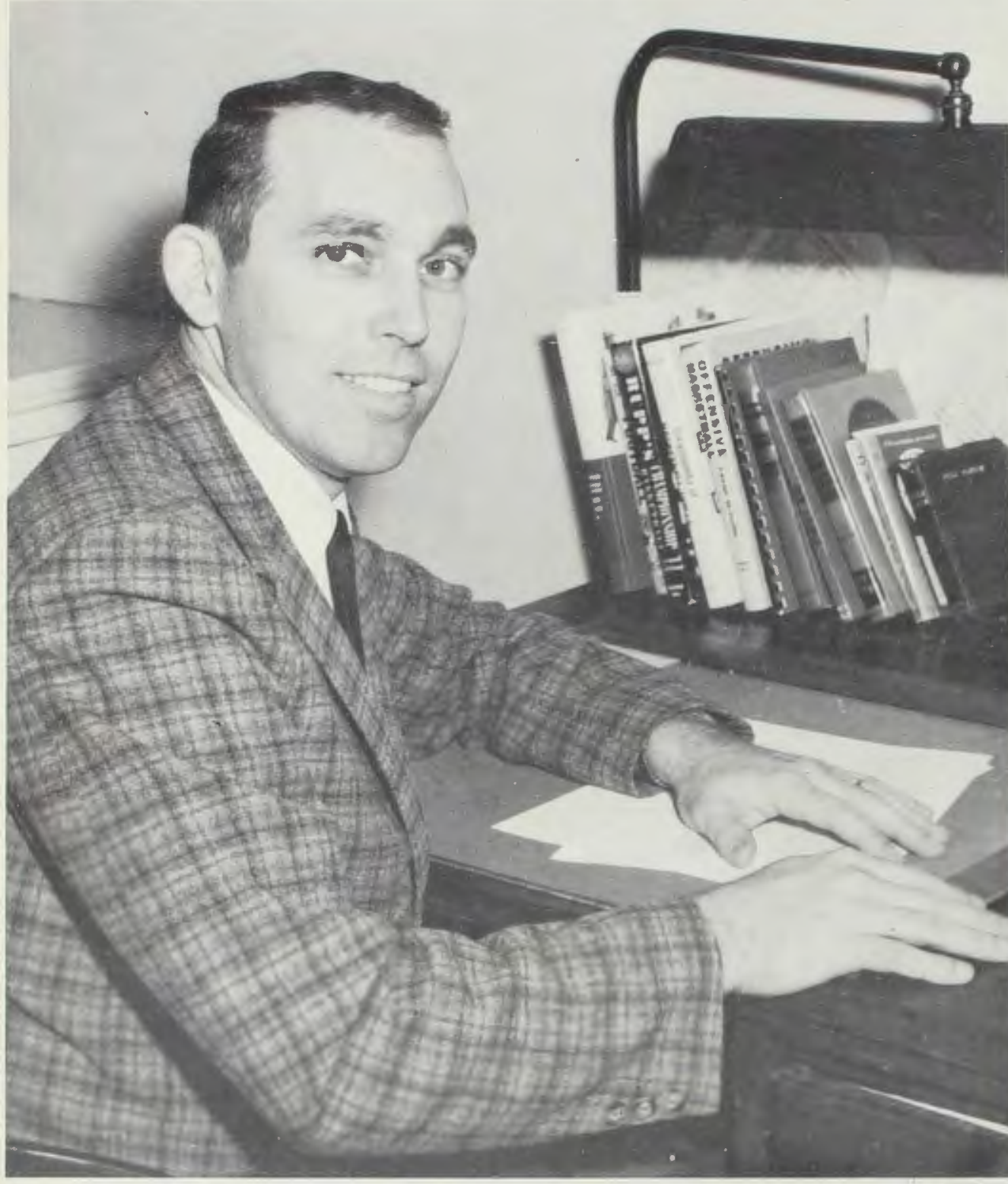

\section{Physical}

\section{Education}

Donald Callan, M.S.

Coaching

The scene of the majority of classes in this department has been greatly enhanced since the present gymnasium underwent many helpful changes early in the Fall. The now more collegiate atmosphere makes it much more pleasant to face an 8:00 physical education class. Several new pieces of equipment have been purchased to provide students the best possible education. This department has also supported a system planned to give all - students, faculty, and staff-a chance to get that much needed exercise. There are times reserved in the gym for different groups to participate in planned activities, such as: basketball, trampolene, and table tennis.
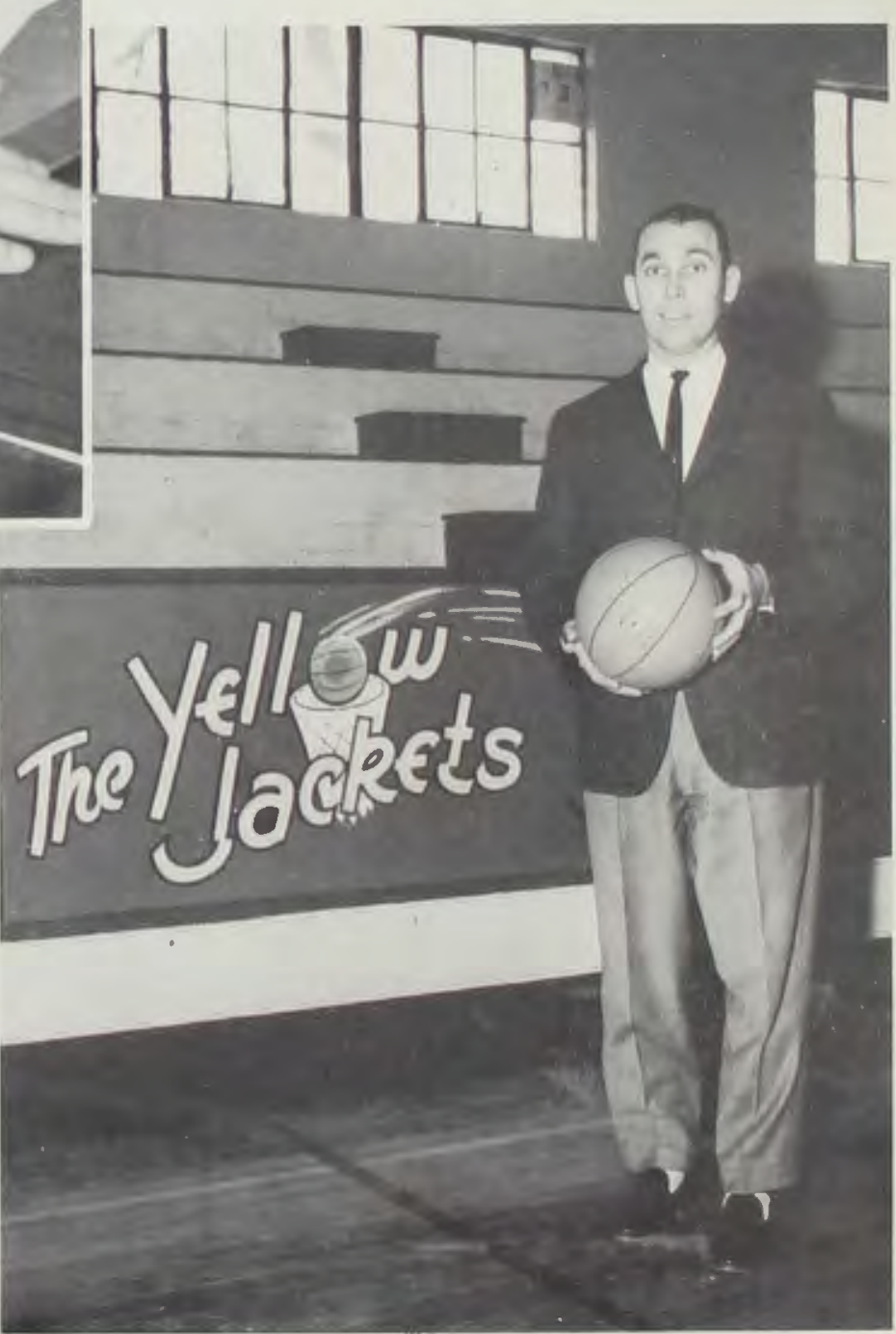

The "coach" spends most of his spare time in gymnasium with the "boys." 


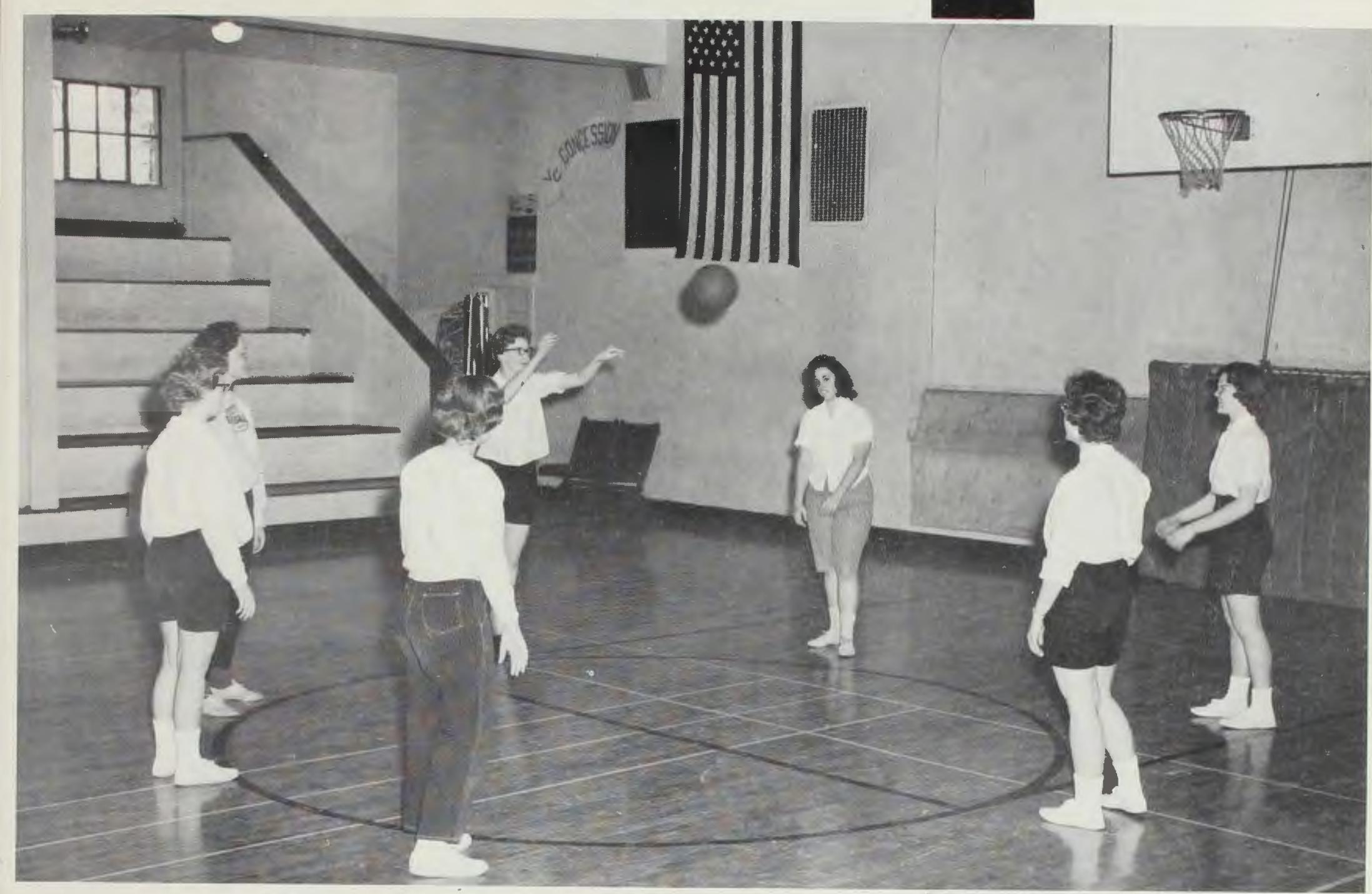

Girls in the 8:00 physical education class do some drills to improve their passing activities.

This year Coach Callan turned his girls' Physical Education classes over to two student teachers: Janet McClish and Dolly Kidd.

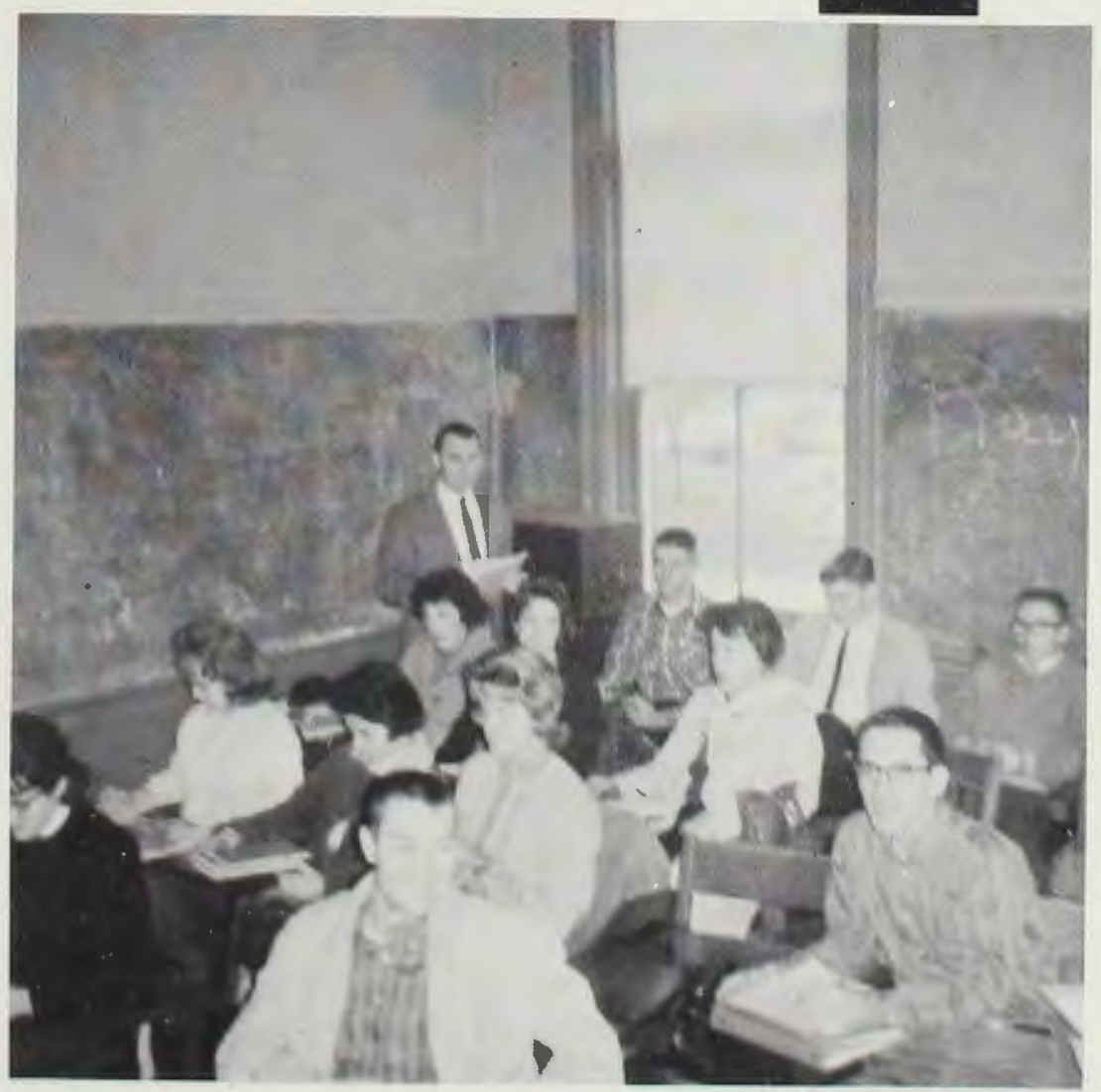

Small classes in courses especially for majors and minors in physical education allow time and energy needed by individual students. 


\section{Division of Language and Literature}

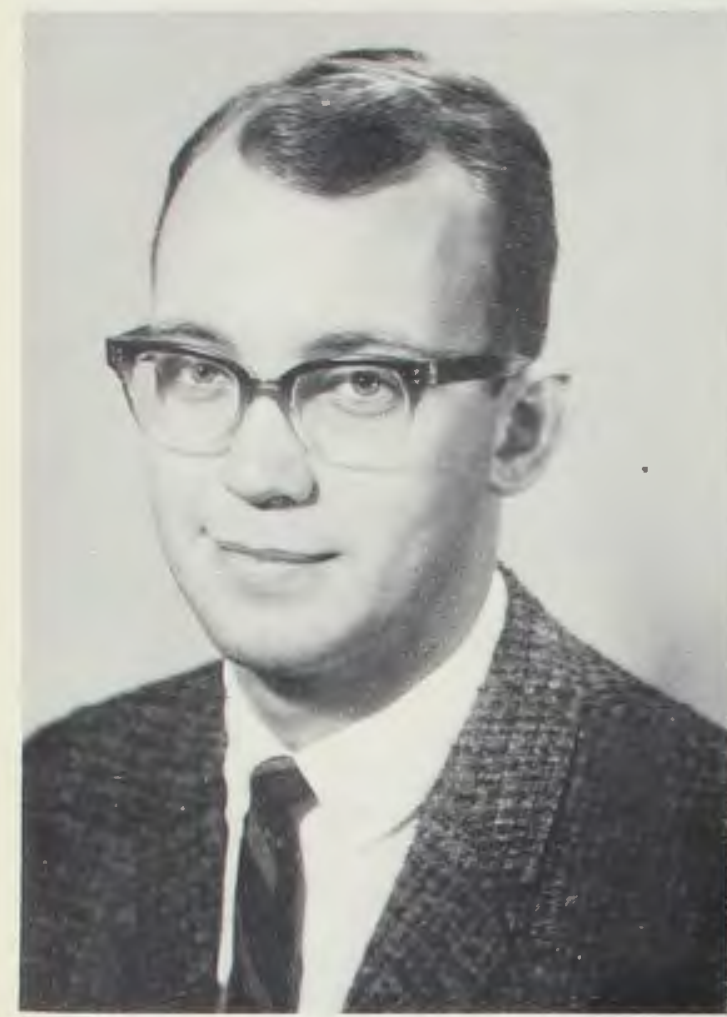

Raymond Bartholomew, M.A.

Freshman Composition, Advanced English Courses

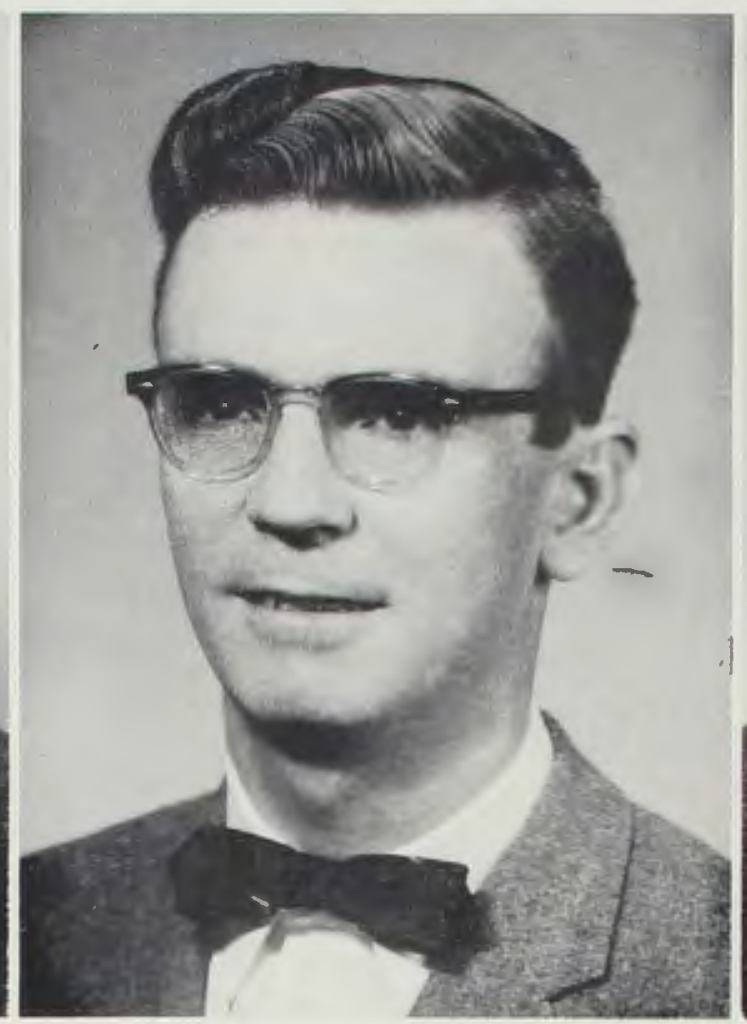

Harmon Bergen, B.A.

Foreign Languages

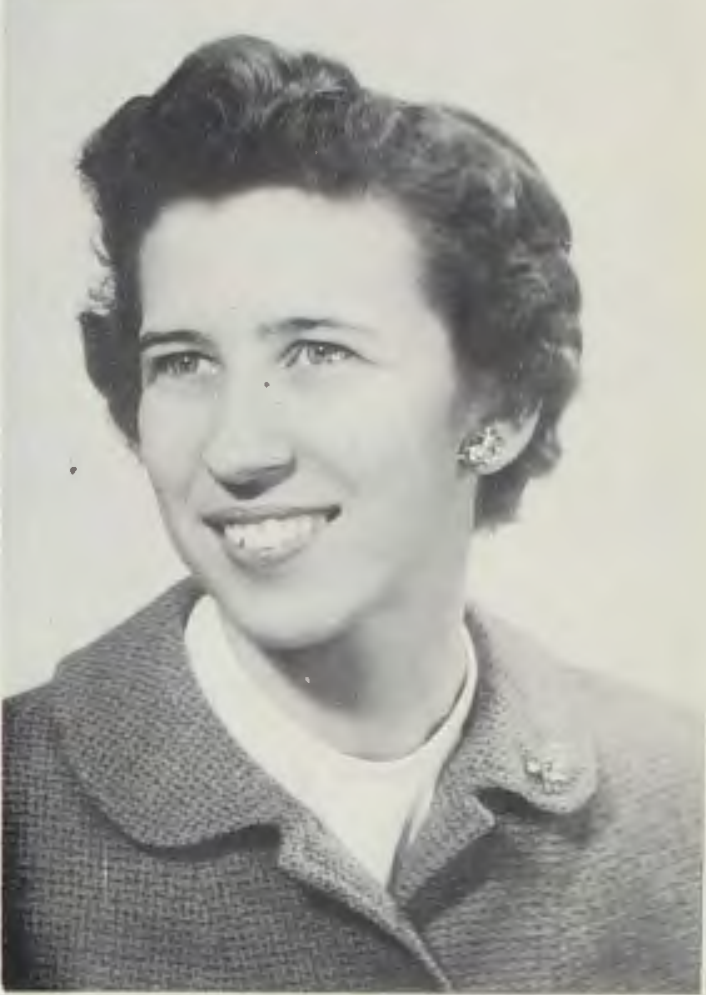

Ruth Kantzer, M. A.

Freshman Composition, American Literature

Advisor of Miracle staff

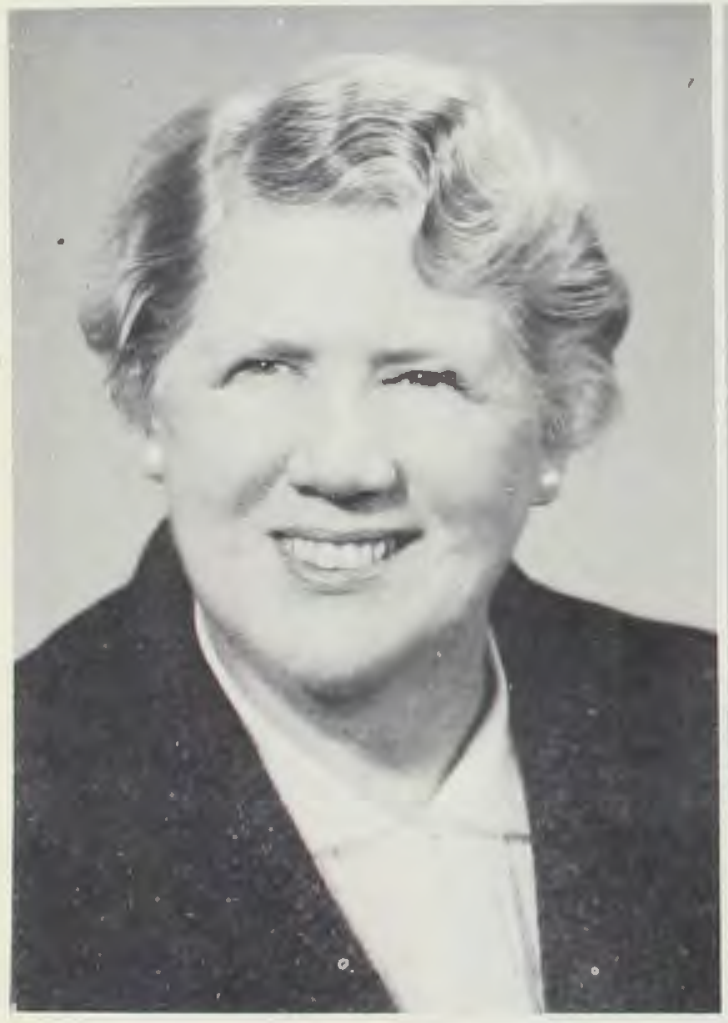

Miriam Maddox, M.A.

Speech I, Debate

Advisor of Gamma Chi, Advisor of Sock 'N' Buskin

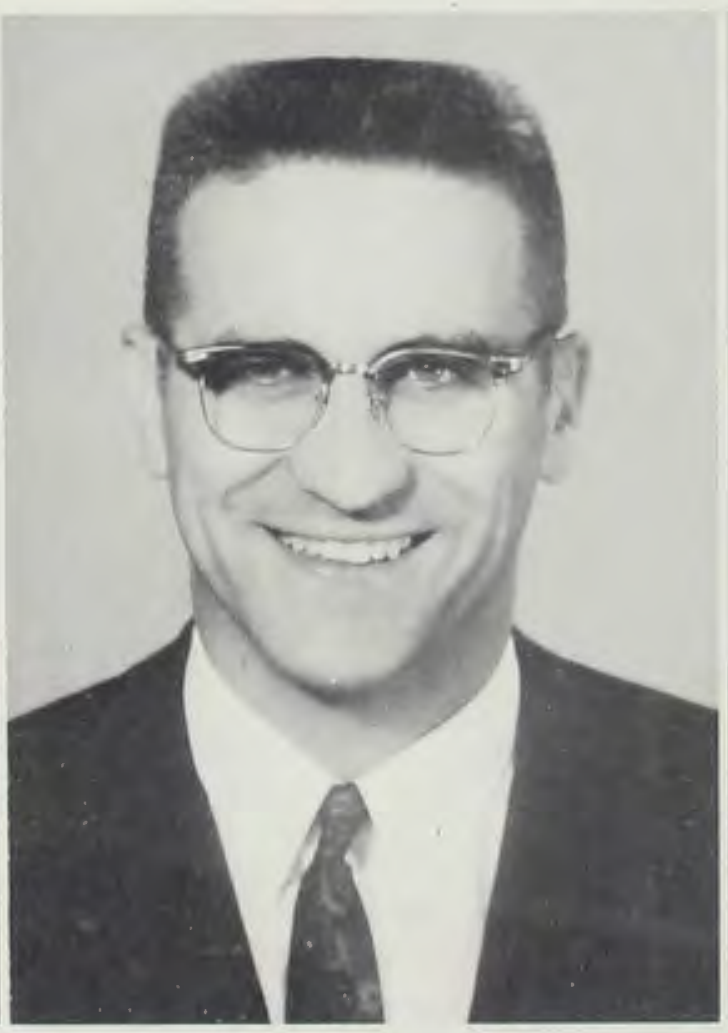

John Reed, M.A.

Speech I, Advanced Speech courses

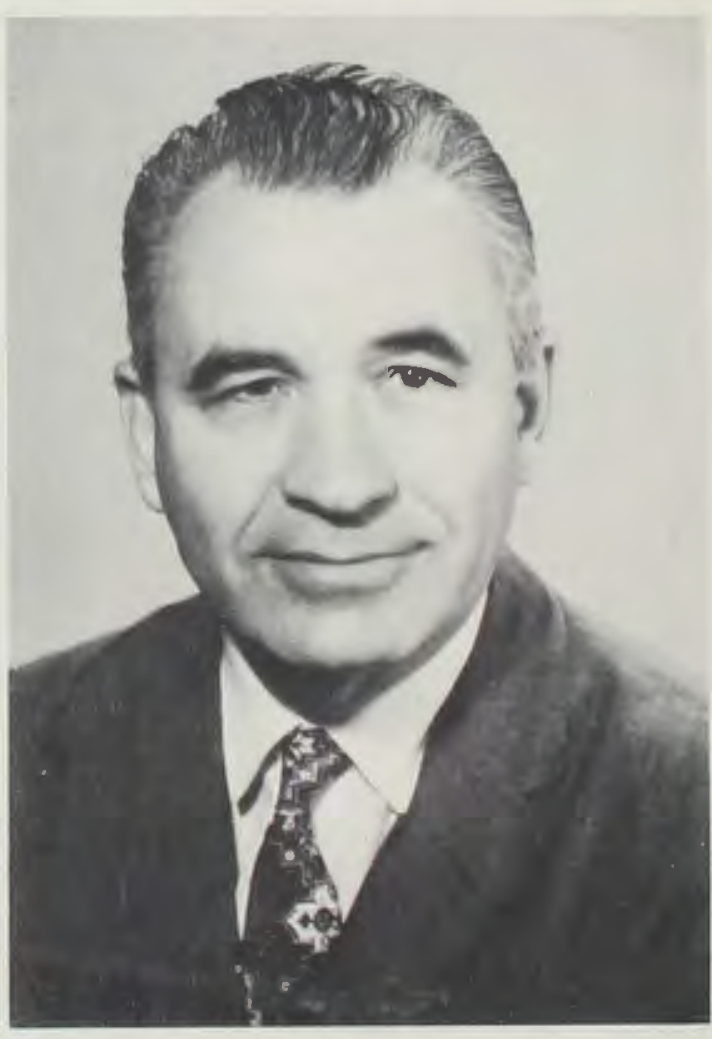

James Russell, M.A.

Freshman Composition, Art Advisor of Whispering Cedars 
There have been some changes in the foreign language department this year. For the first time students have been able to get a minor in German. Mr. Bergen is still using the proven method of tapes for his beginning language students. To make the tapes easily accessible for the maximum number of hours, this year the system is set up in the audio-visual room in the library.

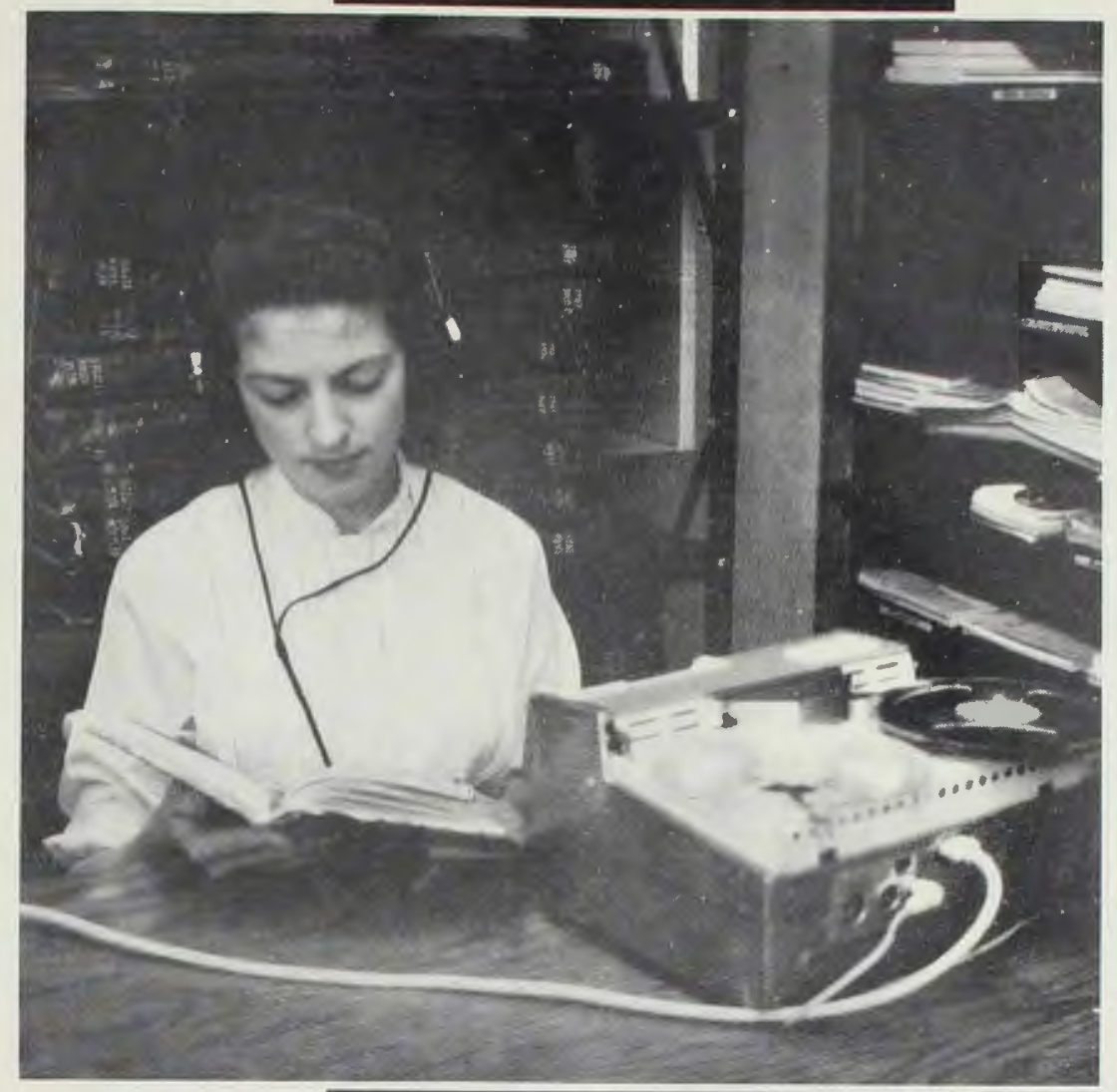

June Golden, an elementary French student, studies her French by hearing it spoken on tapes provided in the library.

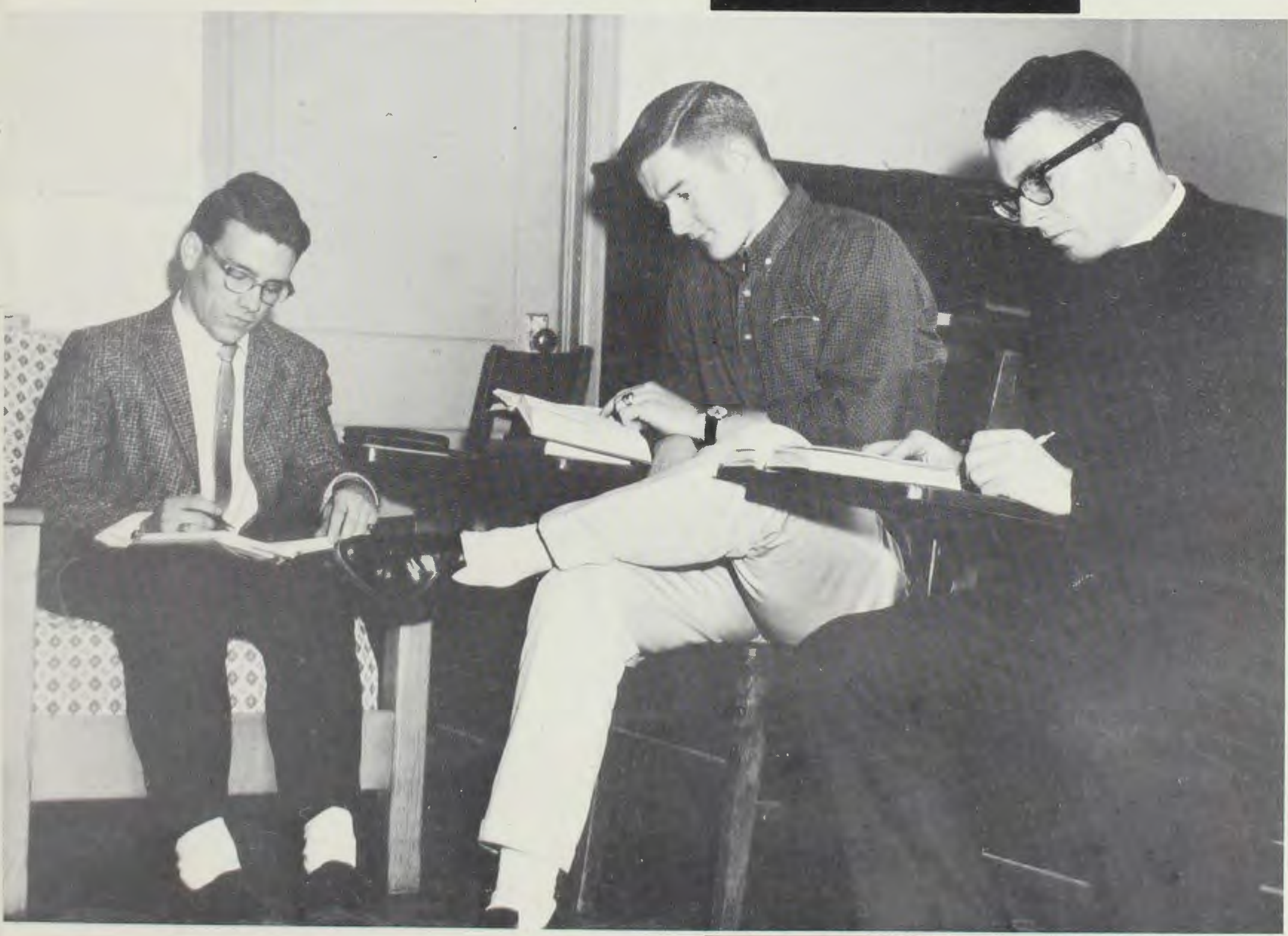

Every morning before the eight o'clock Greek Class-Spanish students find members of New Testament Greek class using the Spanish room as a study hall. 


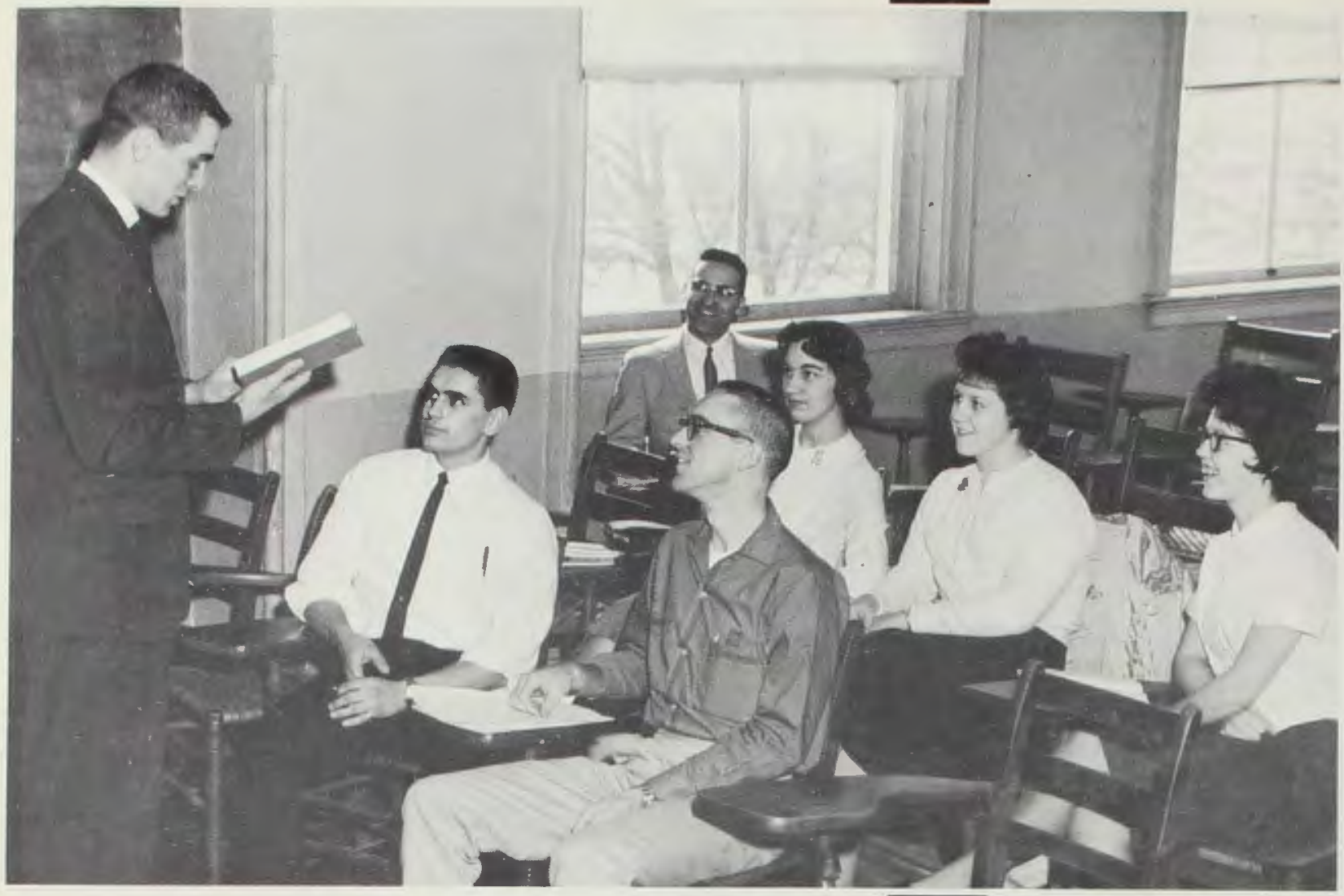

ACADEMICS

Language

Literature

Students of Mr. Reed's Interpretive Reading

class enjoy the adventure of expressive reading.

Great improvements are being made in our speech department. This year we are offering a minor in speech with plans for a major next year. Mr. Reed, who just came to C. C. this year, and Mrs. Maddox share the departmental duties. New classes such as Principles of Discussion, Debate, and Interpretive Reading provide the student interested in this field, a good, interesting schedule of classes.

This is the first year that Cedarville College has included debate in its curriculum and activities. The national college debate question being used is Resolved: that Labor organizations should be under the jurisdiction of anti-trust legislation. Our teams will meet teams from Ohio State University here at Cedarville this Spring and we will participate in a Tournament in Cincinnati in April.

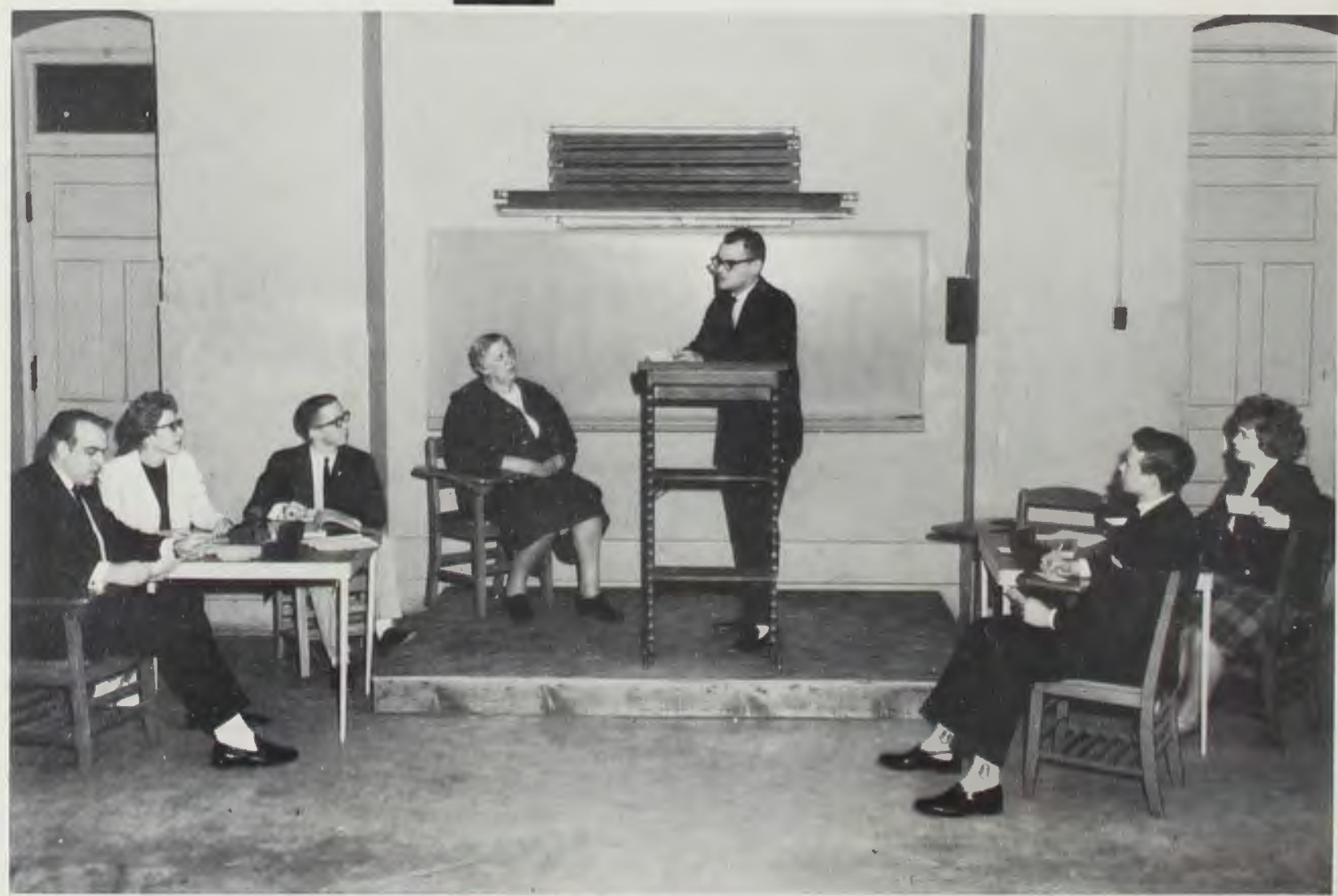

Larry Baker presents his argument on Labor to the opposing team. 
With seven sections of Freshman English, instructors of this department shared the task of teaching composition to 175 Freshmen. In addition to his art classes, Mr. Russell had three sections, while Miss Kantzer and Mr. Bartholomew each taught two. Alternating yearly with English Literature, American Literature class was first offered this year in two large sections taught by Miss Kantzer. Majors and minors had a variety of offerings in Mr. Bartholomew's courses in Milton and The Seventeenth Century, The English Language, The English Novel, and Restoration
and Eighteenth Century.

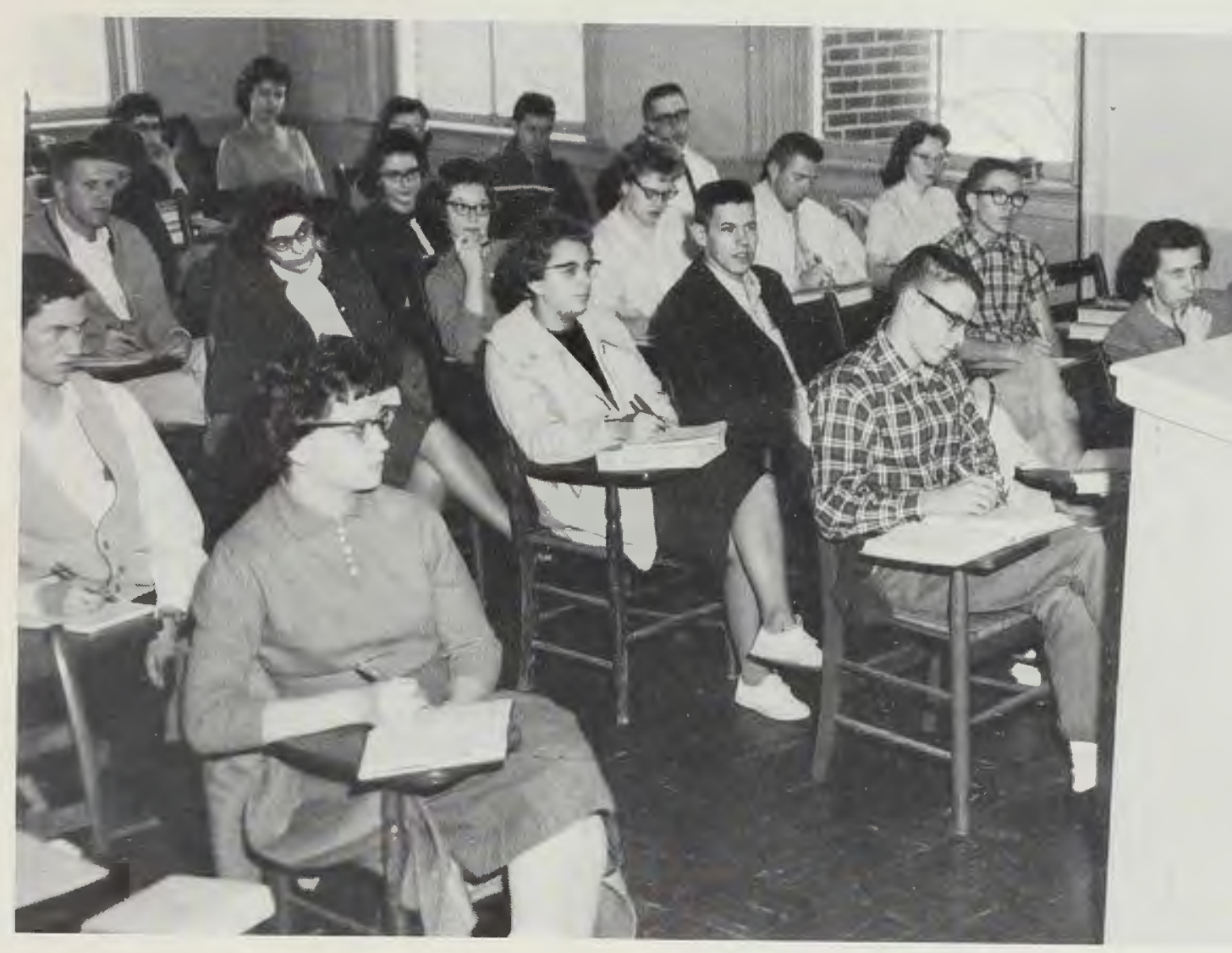

Sally Bender begins her Whitman report in the eleven o'clock section of American Literature.

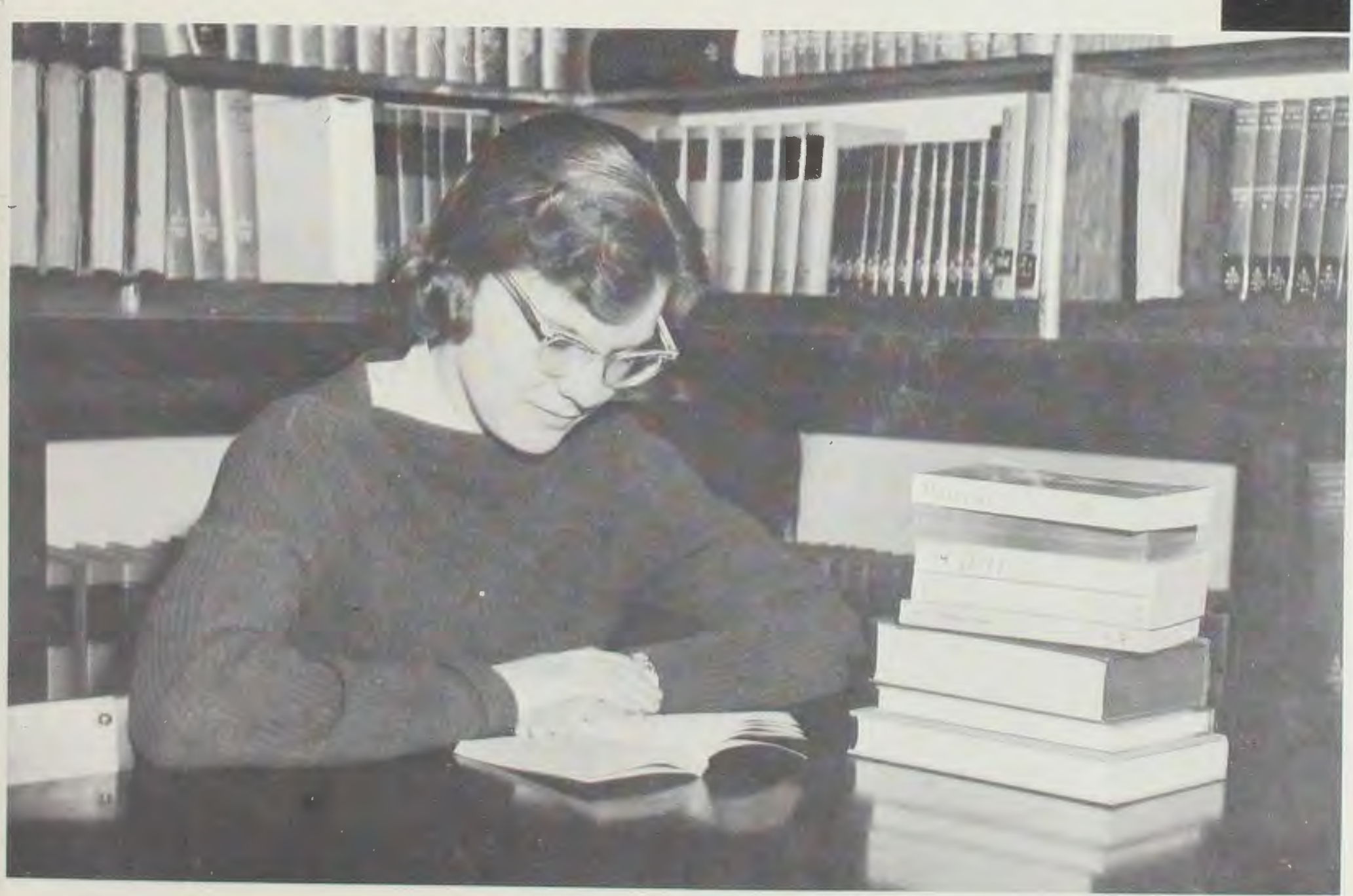

Nancy Smith settles down to read the first of the eleven required novels for Mr. Bartholomew's English Novel class. 


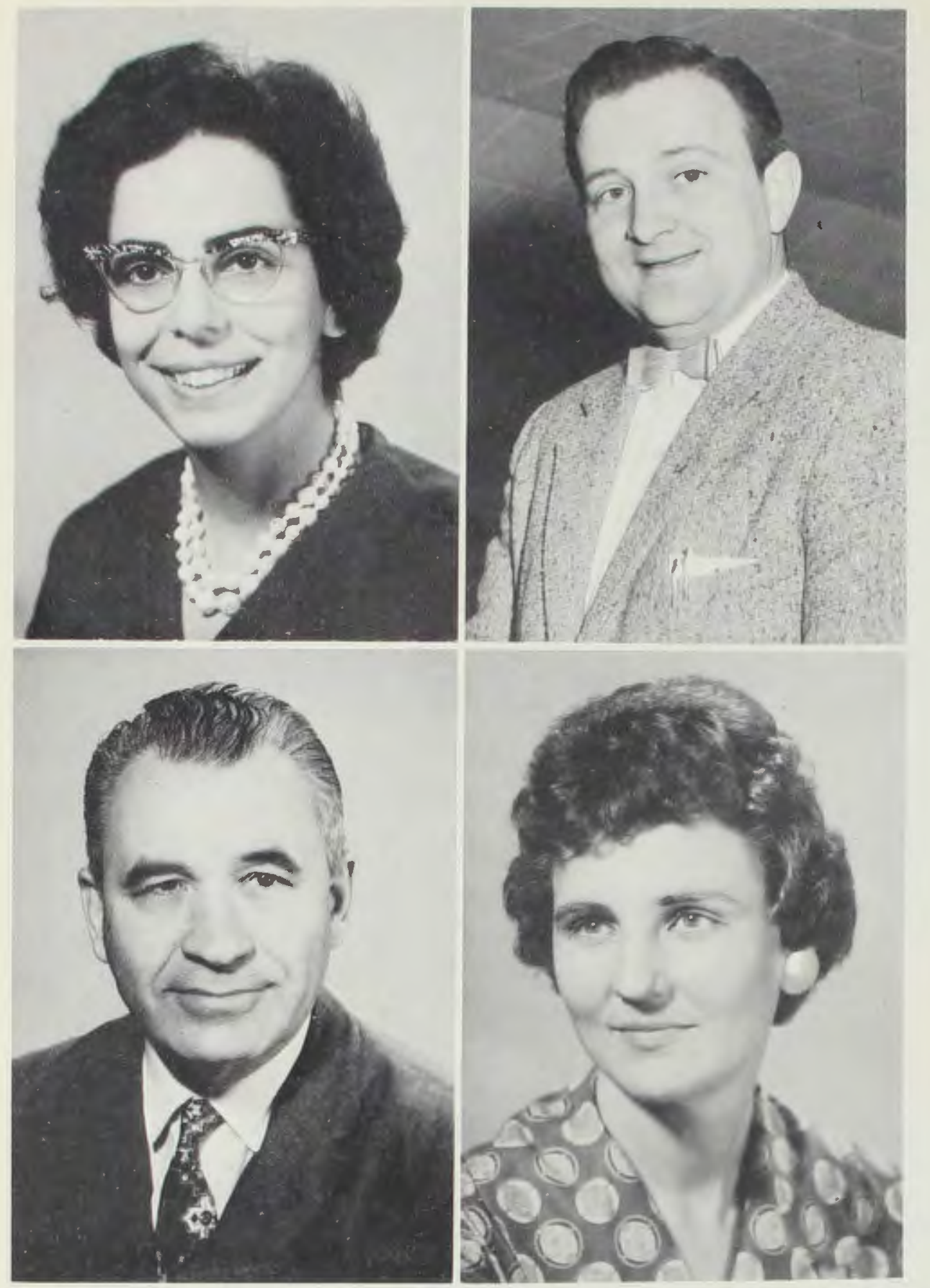

Rebecca Cooke, B.S.

Piano, Voice

Richard Cooke, M.S.

Vocal Music

Choralaires director, first semester, College Choir director, first semester, Co-Advisor of Modern Music Masters

\section{Division}

\section{of}

\section{Fine}

\section{Arts}

James Russell, M.A.

Art, Freshman Composition

Ruth Smith, M.A.

Piano, Music History and

Theory

Choralaires director, second semester

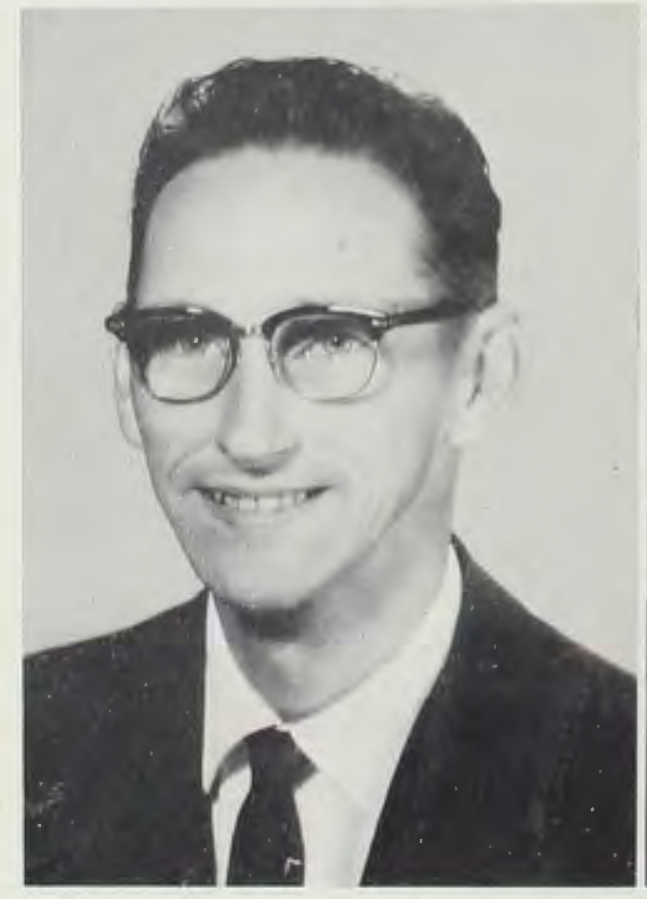

William Thornton, M.S. Instrumental Music Chamber Band Director

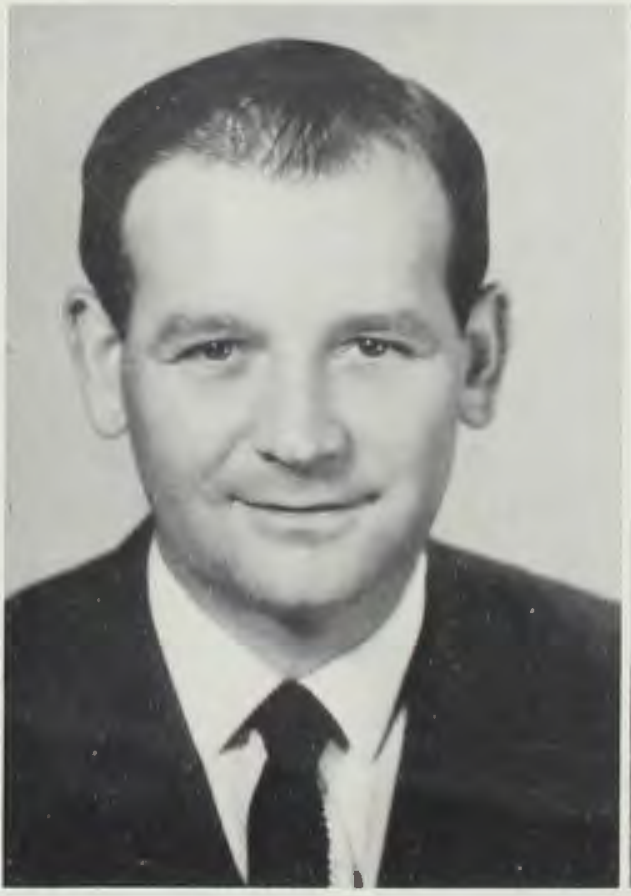

Warren Webber, M.Mus.Ed. Instrumental Music

College Choir director, second semester, Co-Advisor of Modern Music Masters

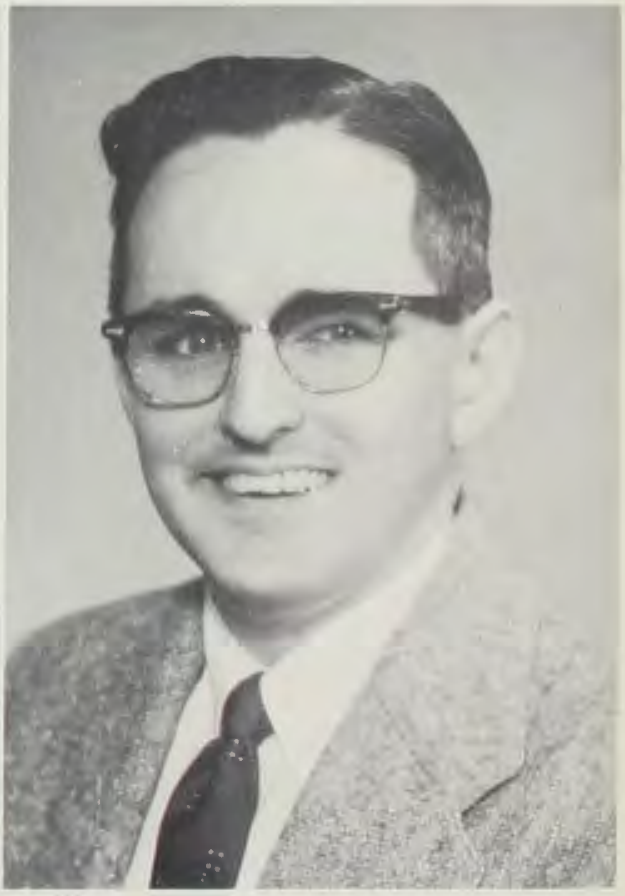

George Zinn Vocal Music Chapel Choir Director 


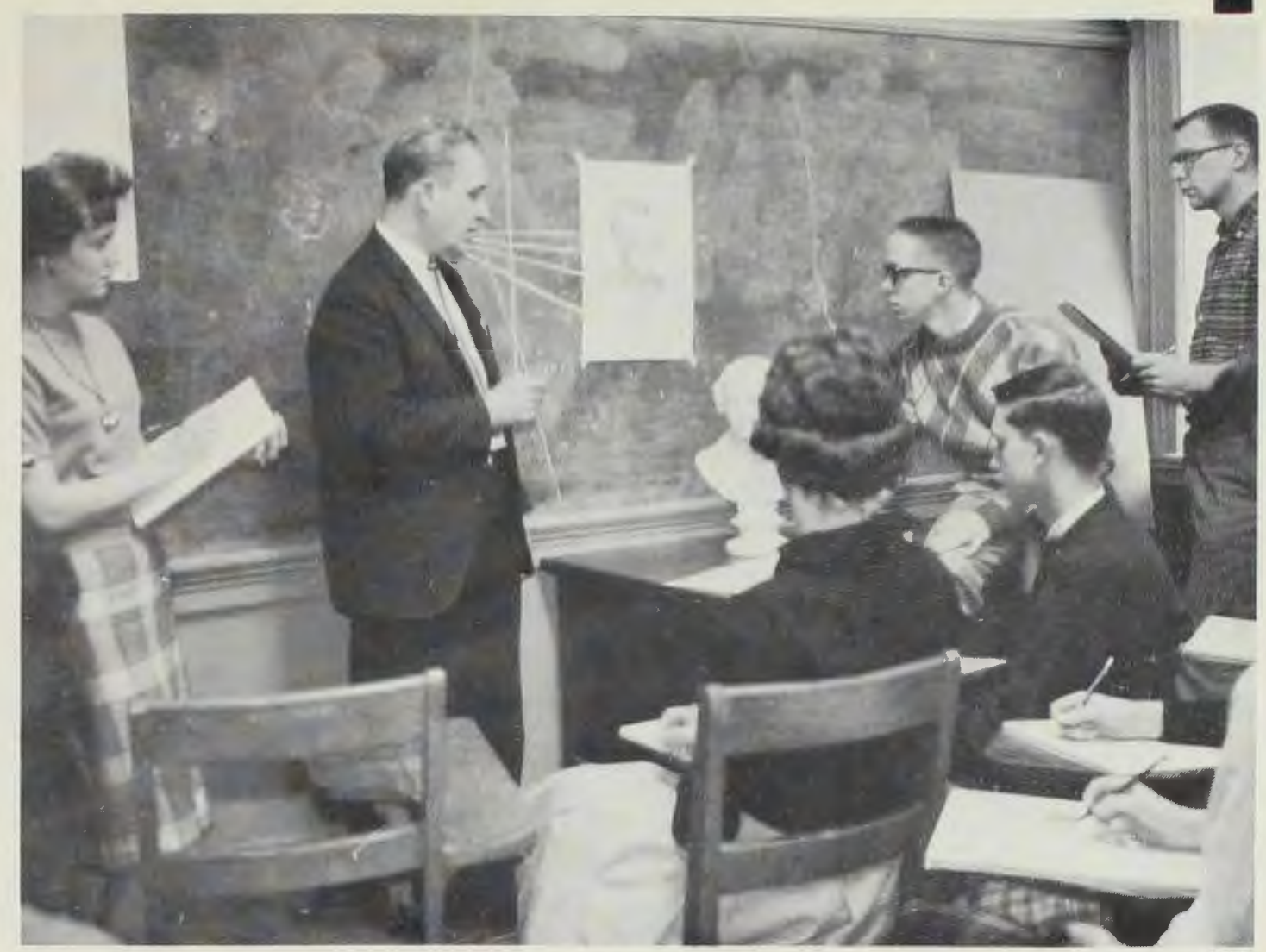

Mr. Russell illustrates shading by observing the shape and curvature of a statue.

The Division of Fine Arts now not only contains music, but this year has an art course. Mr. James Russell, new to Cedarville College this year, has twenty students in his first year art class. The Music department has undergone some changes as all departments have. Miss Smith has joined the staff and instructs courses such as Modern Music History along with private piano lessons. Mr. and Mrs. Richard Cooke left at the close of first semester to continue graduate work at Indiana University.

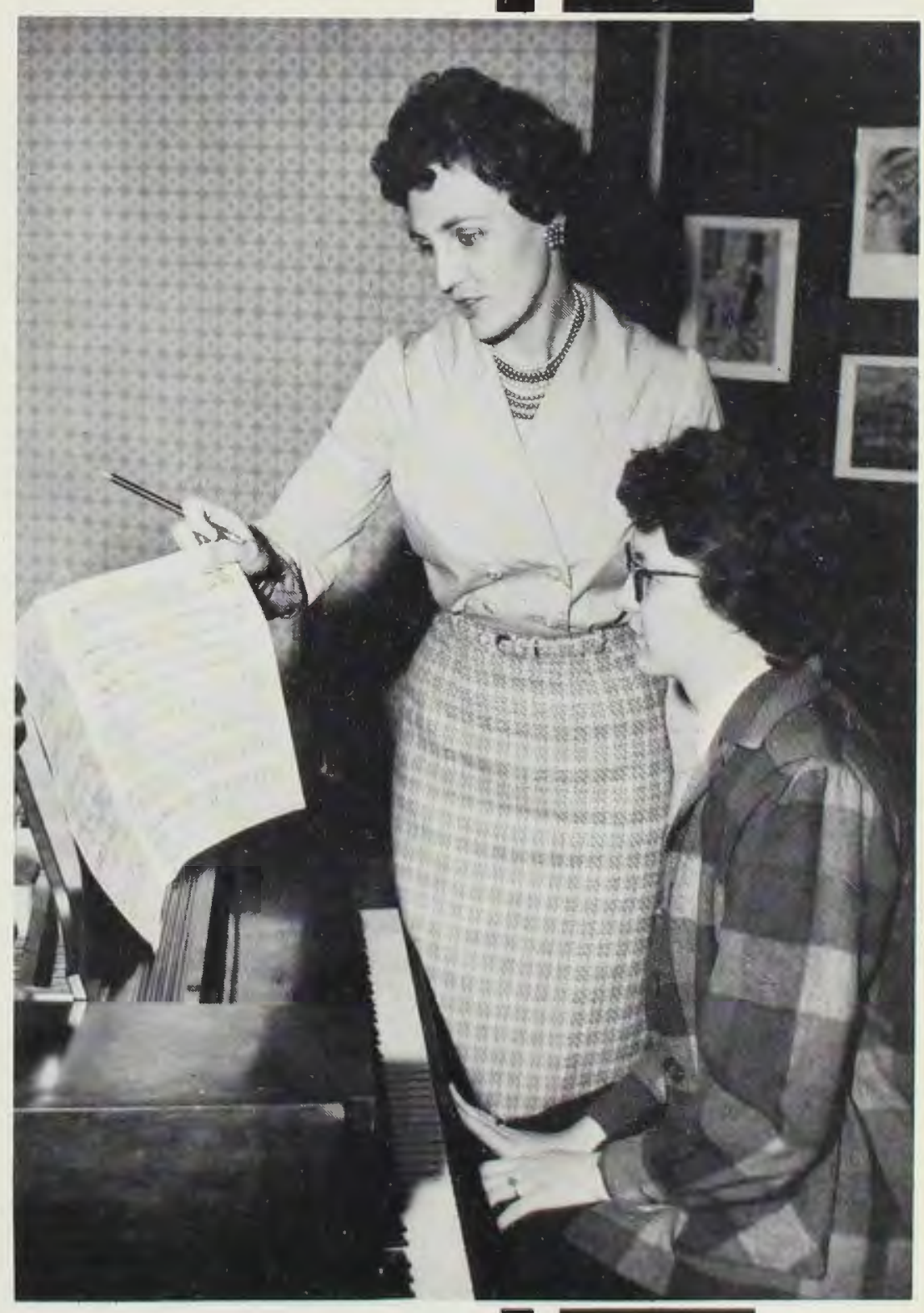

In her studio at Sticka House, Miss Smith instructs a music student. 
After training in Song Leading taught by $\mathrm{Mr}$. Thornton, students attempt to direct the song service in Chapel.

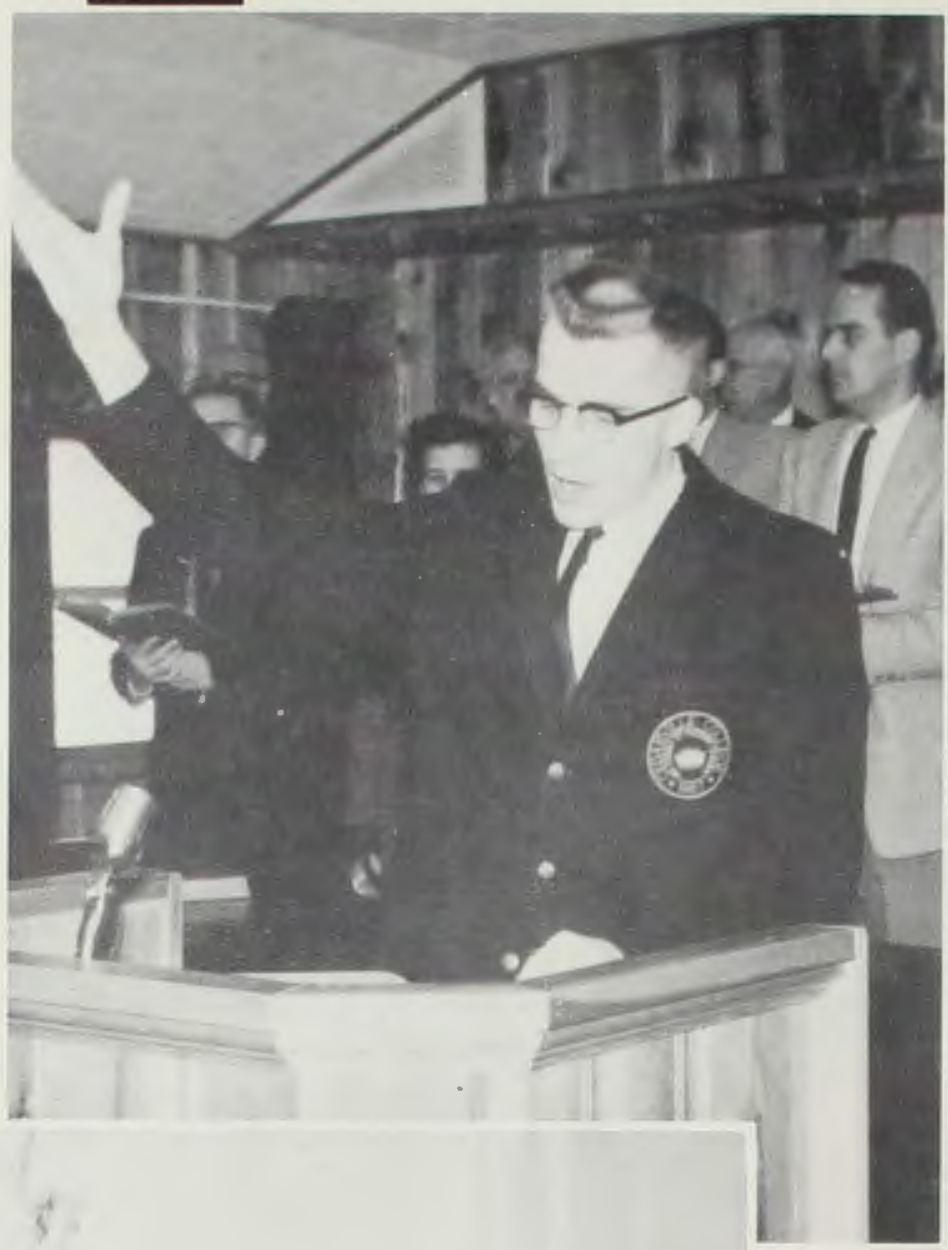

ACADEMICS

Fine Arts
The Music Department has many responsibilities other than instructing in the classroom. The students represent the college in choirs, quartets, trios, and solos. Each day in chapel students prepare special music and provide instrumental accompaniment for chapel singing.

Paul Gathany, a Junior, is the general electronic technician for the Music Department.

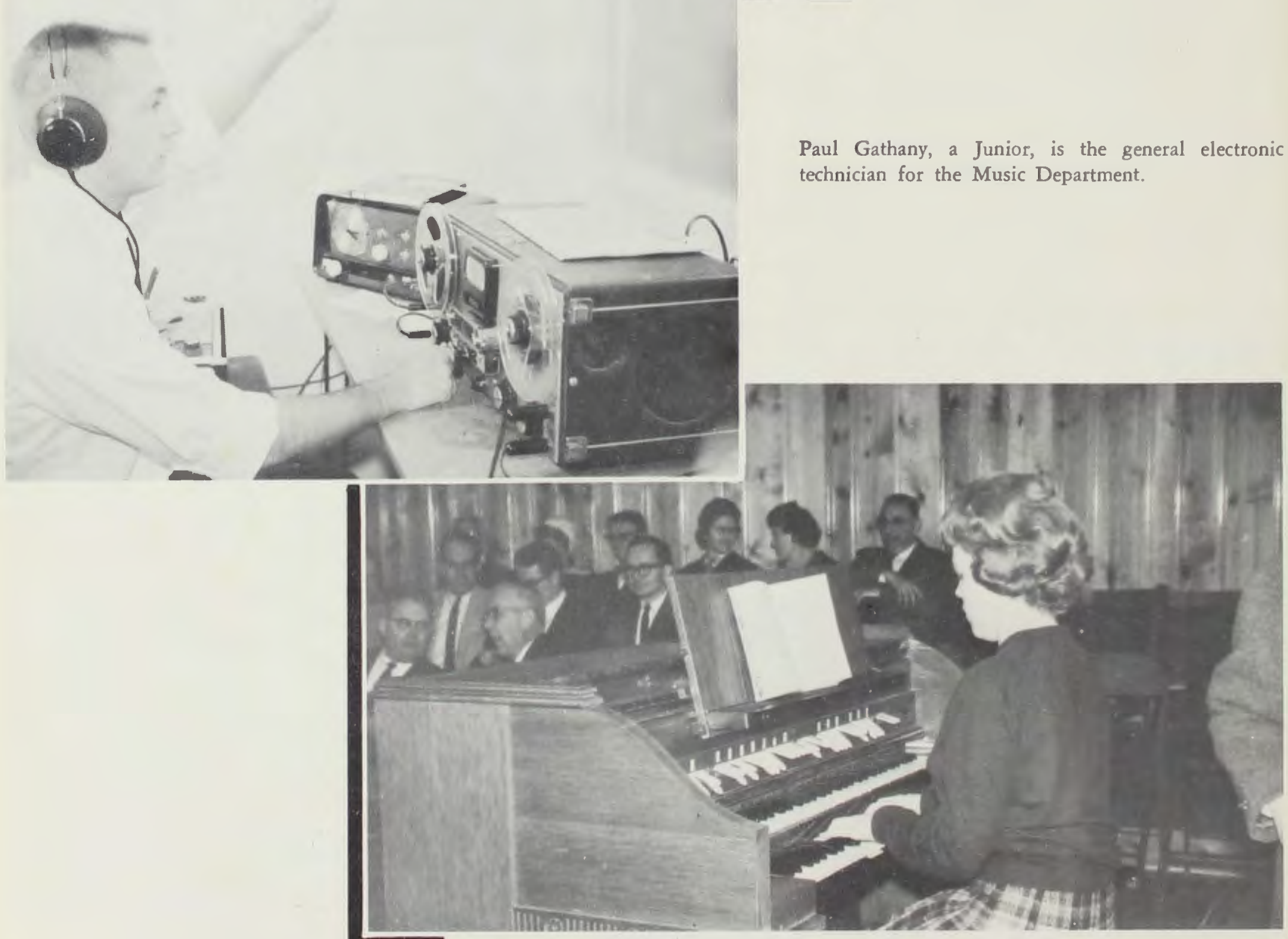

Barb Miller plays the organ for a morning chapel service. 


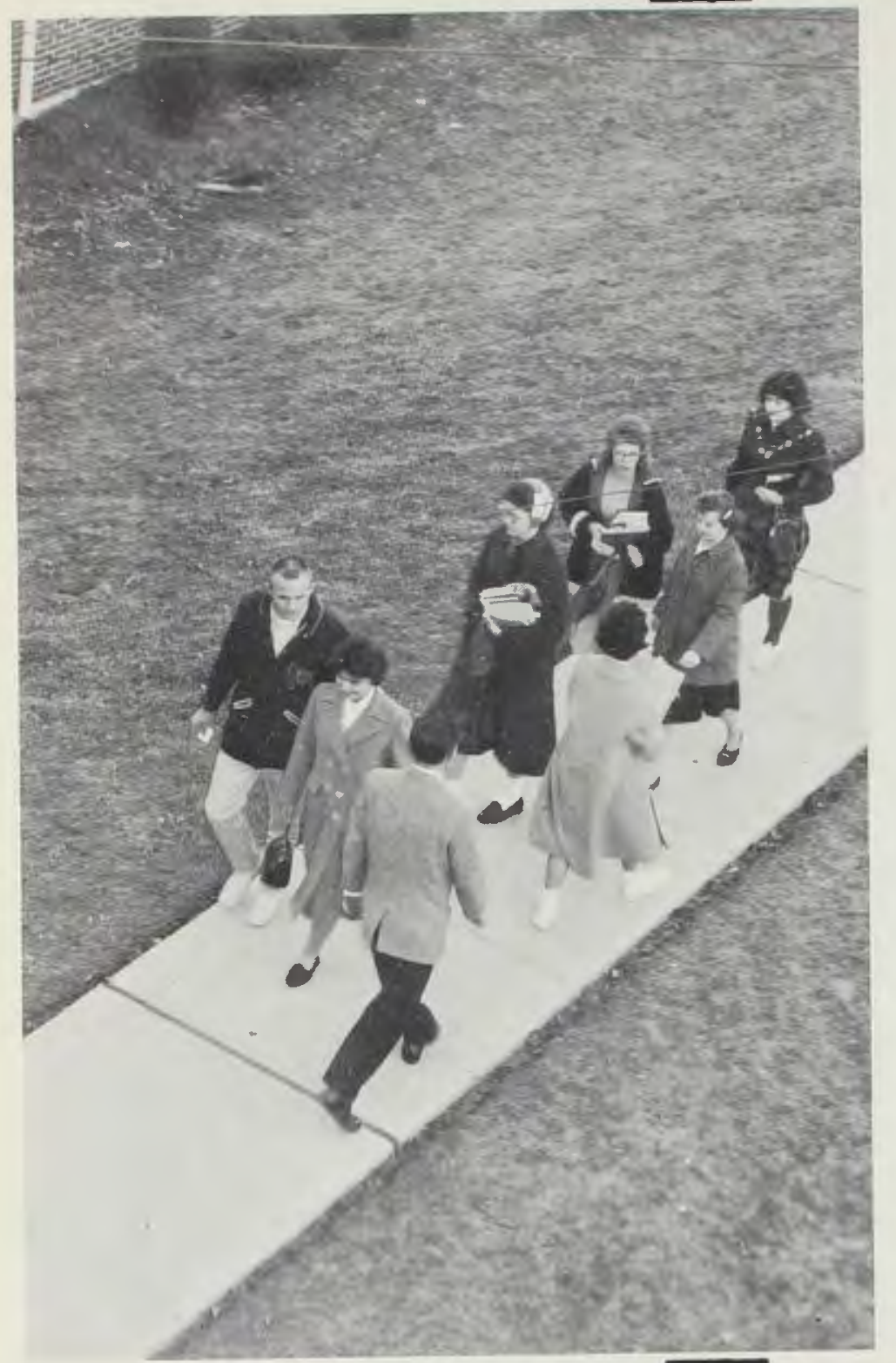

ACADEMICS

Science

Most of the classes of this department are held in Science Hall. Students of Mr. Elmore and Mr. Frye are seen making many trips over to the lab to work on an experiment or to observe life under a microscope. Both of these men are new to this department this year.

Students and faculty alike join the mad rush to get to the next class in the allotted ten minutes.

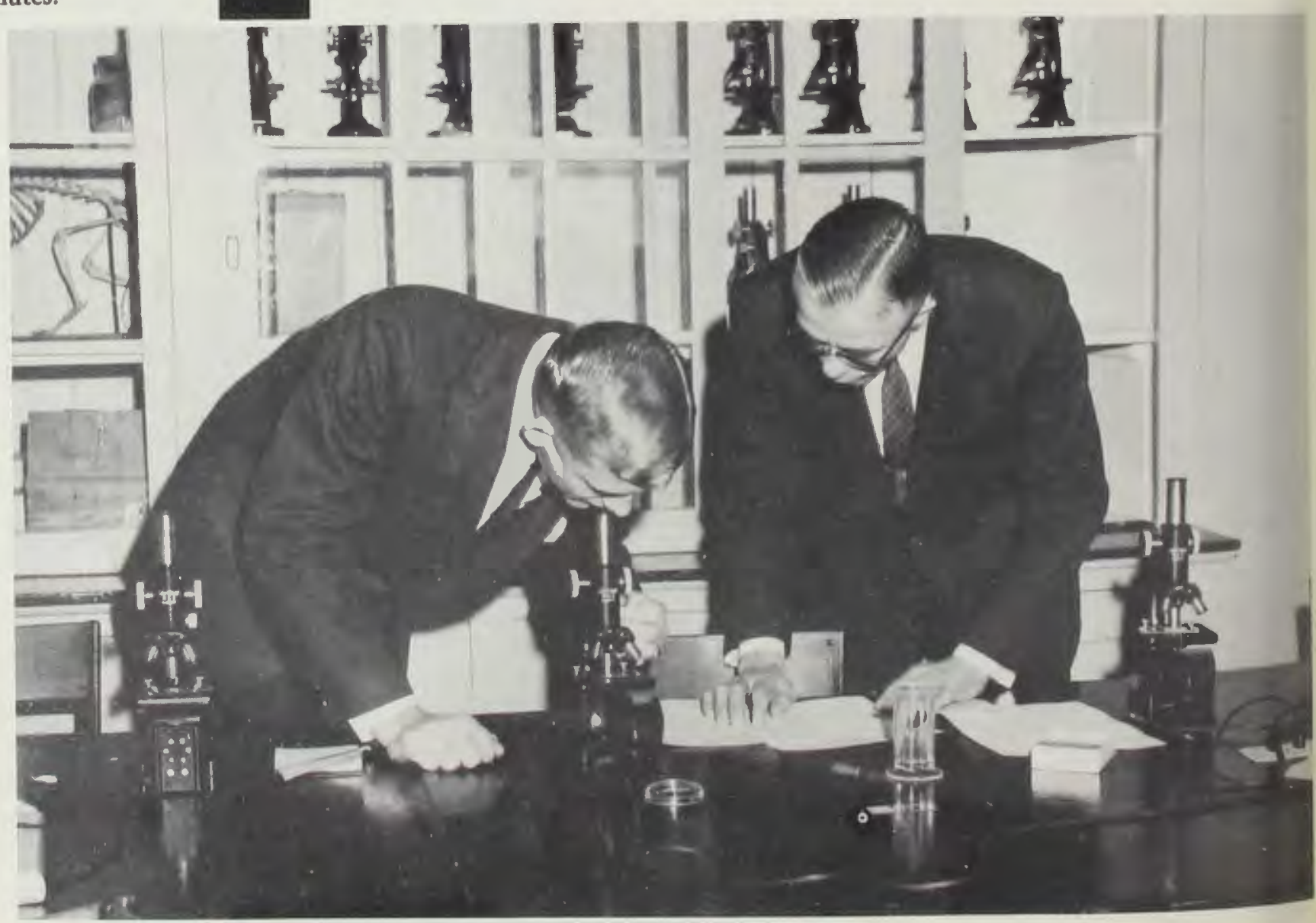

Mr. Elmore watches Val Roloff as he regulates the microscope with the fine adjustment screw. 


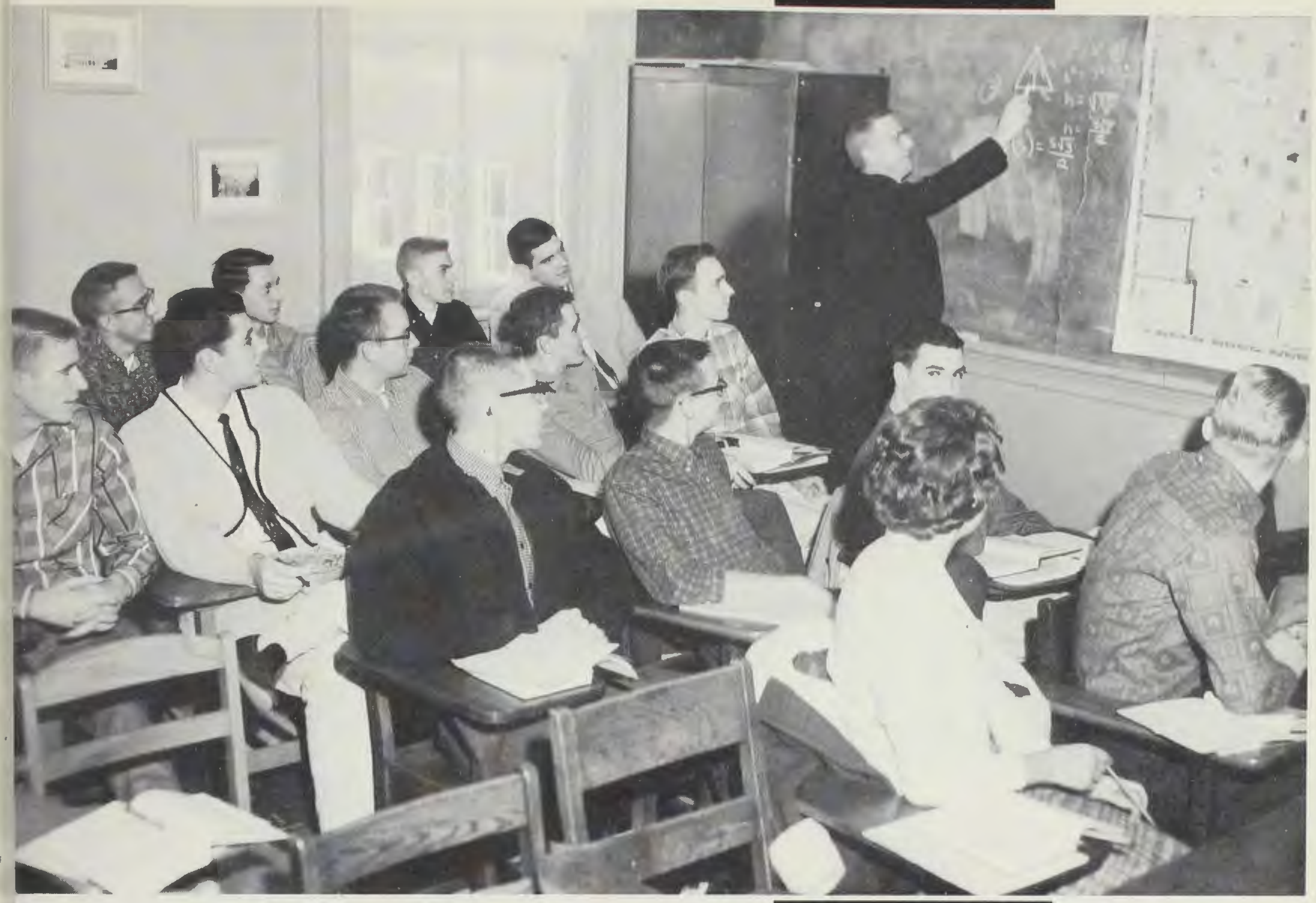

Mr. Frye demonstrates to his Plane Trigonometry Class the formula for finding the height of an isosceles triangle by square root.

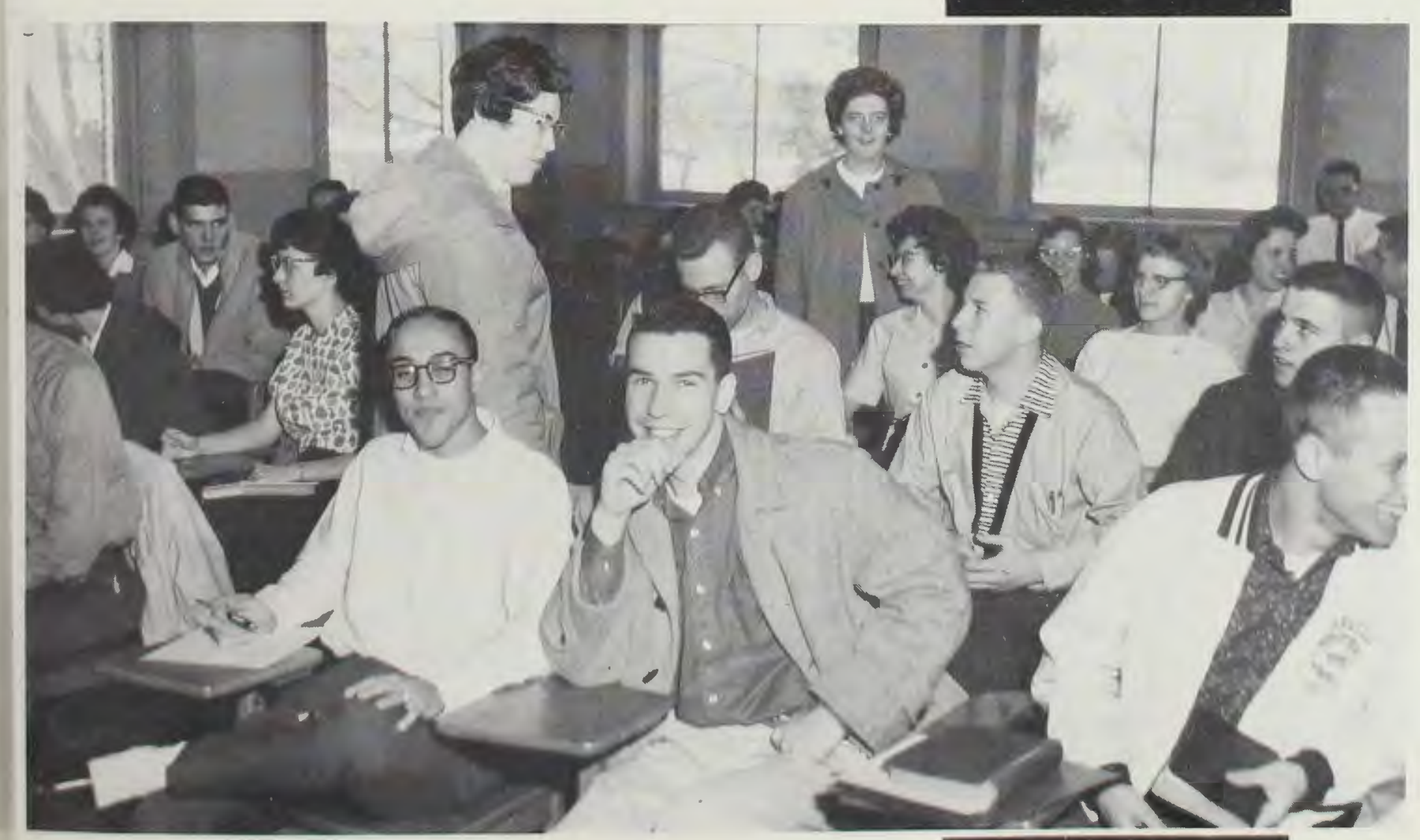

A glimpse at the Physical Science class a few minutes before their instructor, Mr. Frye, arrives to begin class. 


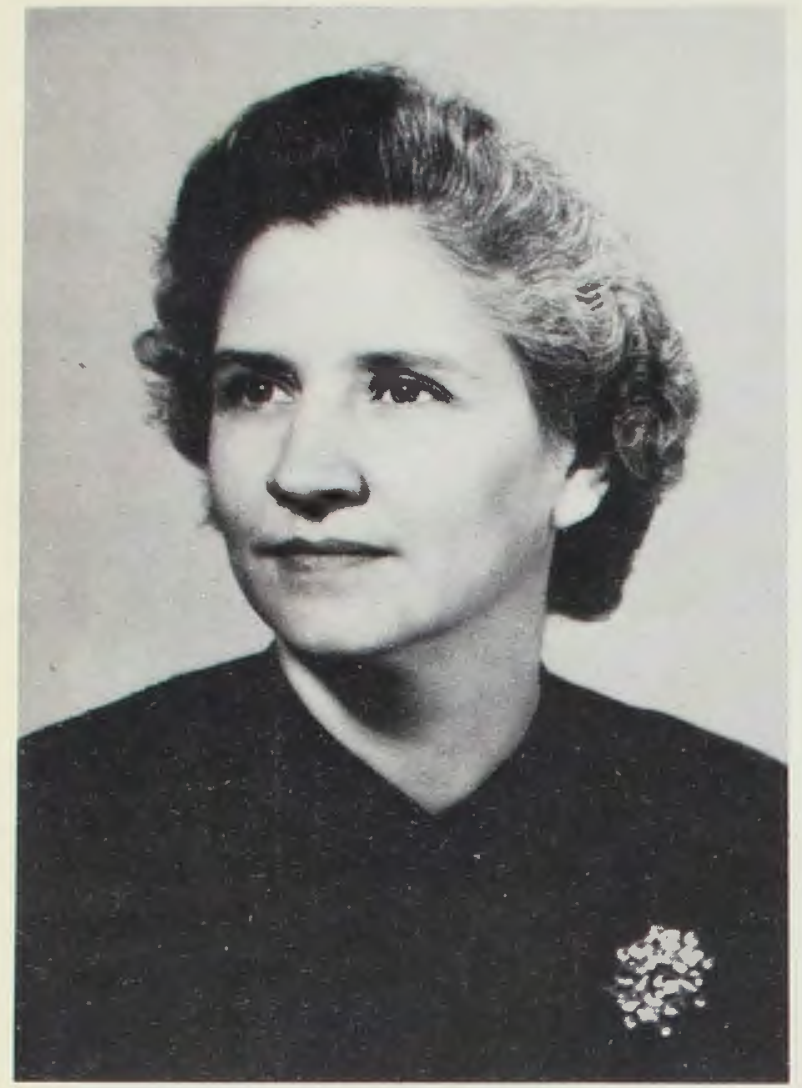

Alberta Chaffe, A.B.

Library Science

Librarian

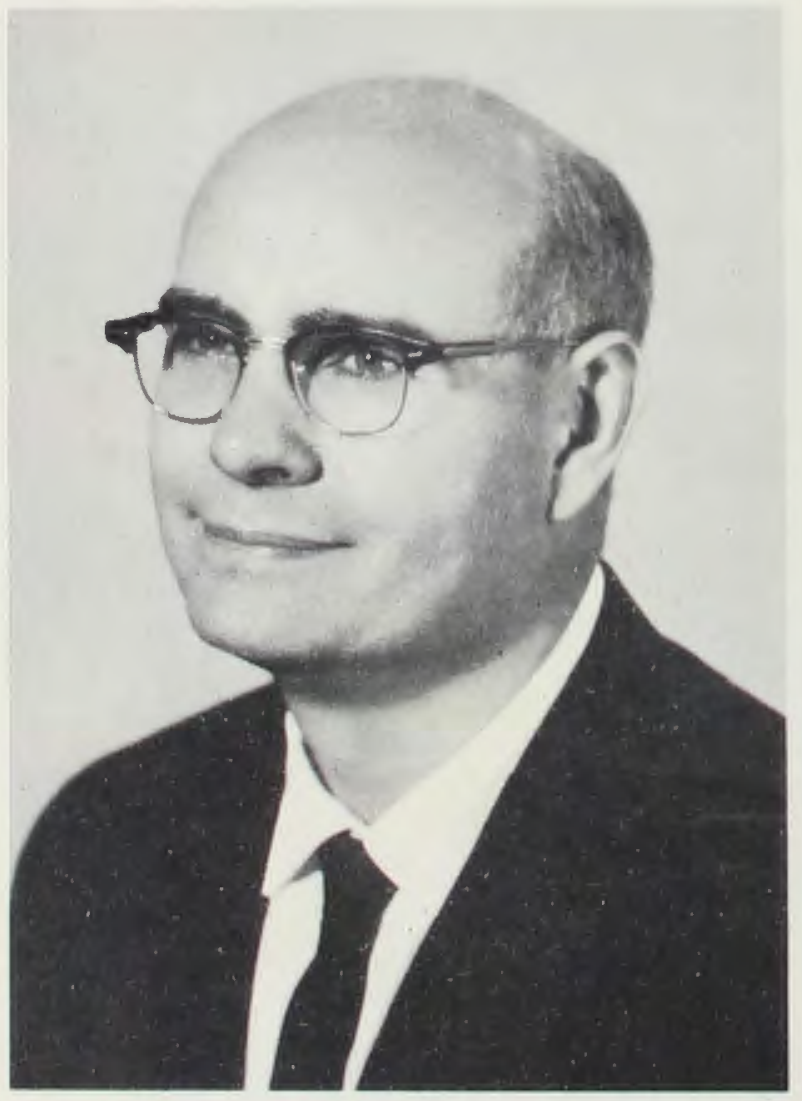

Cleveland MacDonald, M.Litt.

Social Science

Advisor of Fellowship of World Missions

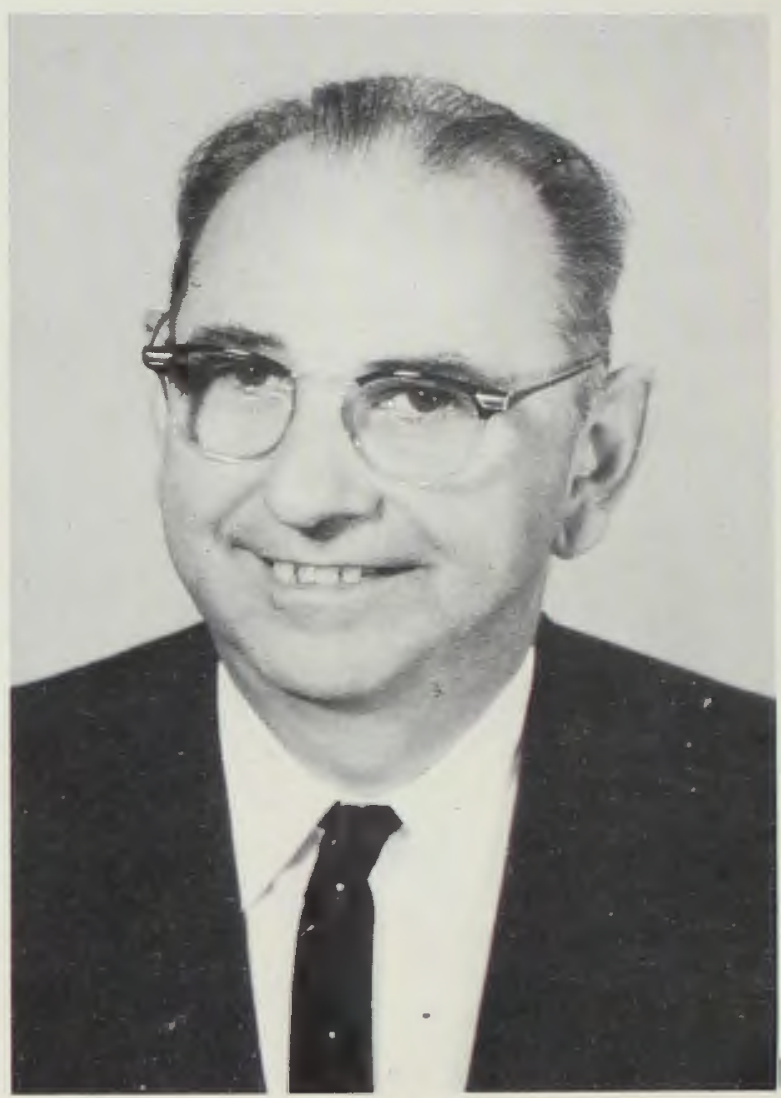

Ralph Gale, M.A. History

\section{Division of}

\section{Social Science}




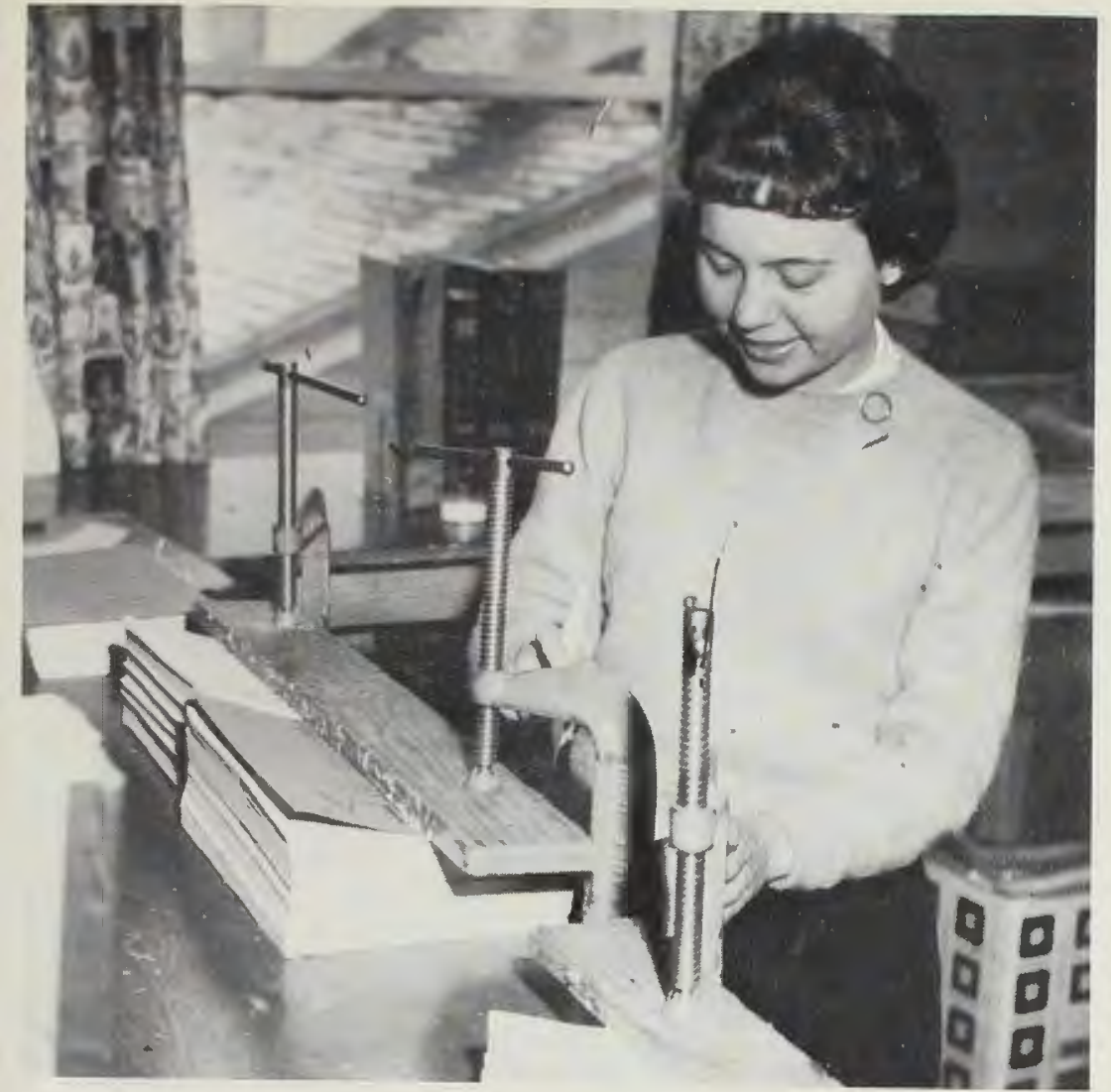

Elaine Jordan binds several volumes together for quick reference.

It seems that this year almost every student on the Cedarville College campus is taking one of the general history courses. Mr. Gale has so many students in his American History class and his Western Civilization class that it has been impossible to meet in a classroom to accommodate one hundred students at one time. The Chapel, where usually one finds only music students, has become the scene for these two history courses.

Mr. McDonald, returning this year from a leave of absence, is busy instructing courses in social work and history.

Interest in Library Science is increasing as Mrs. Chaffe offers a variety of practical library experiences along with class instruction.

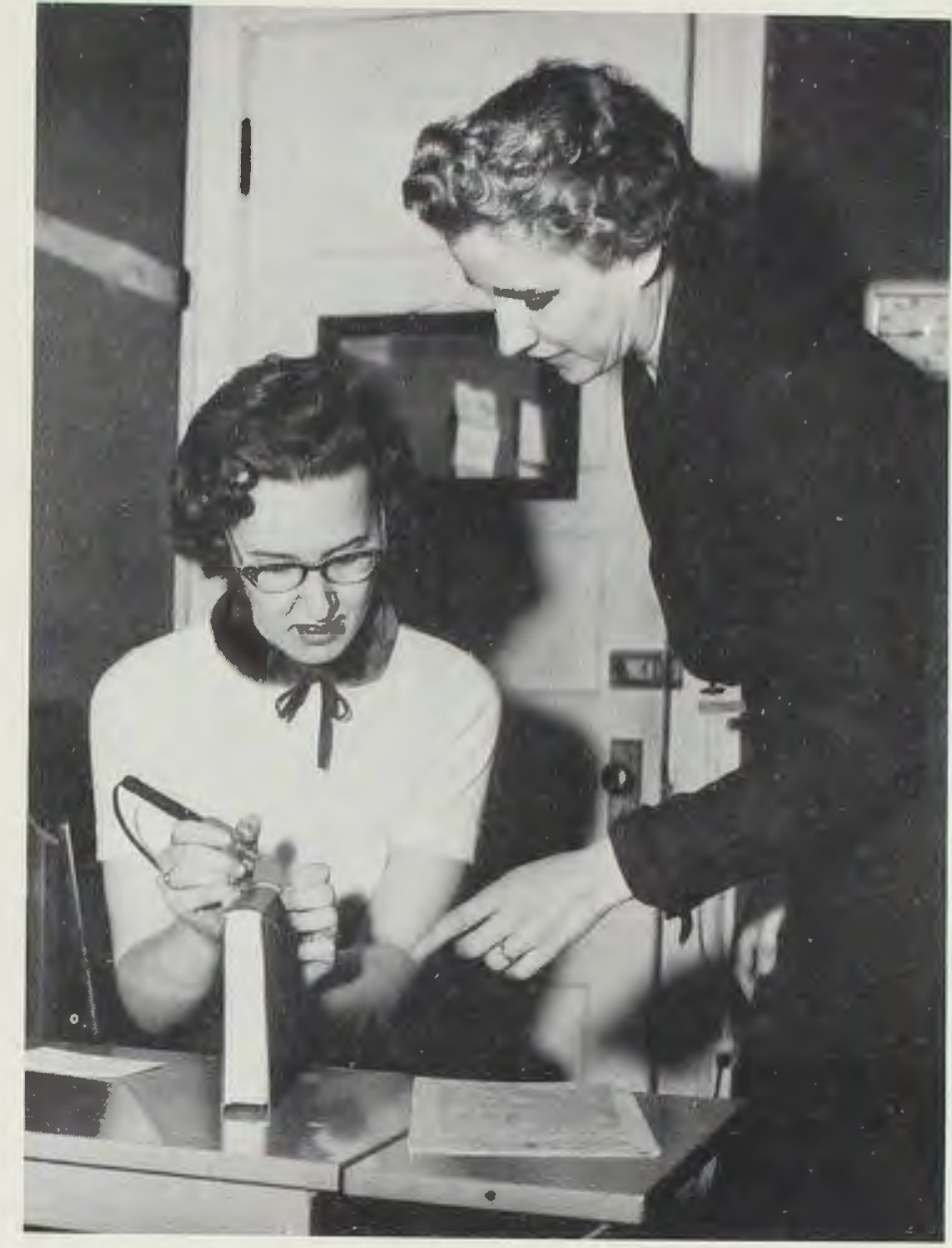

Bonnie Jackson classifies a book for the first time under the direction of Mrs. Chaffe.

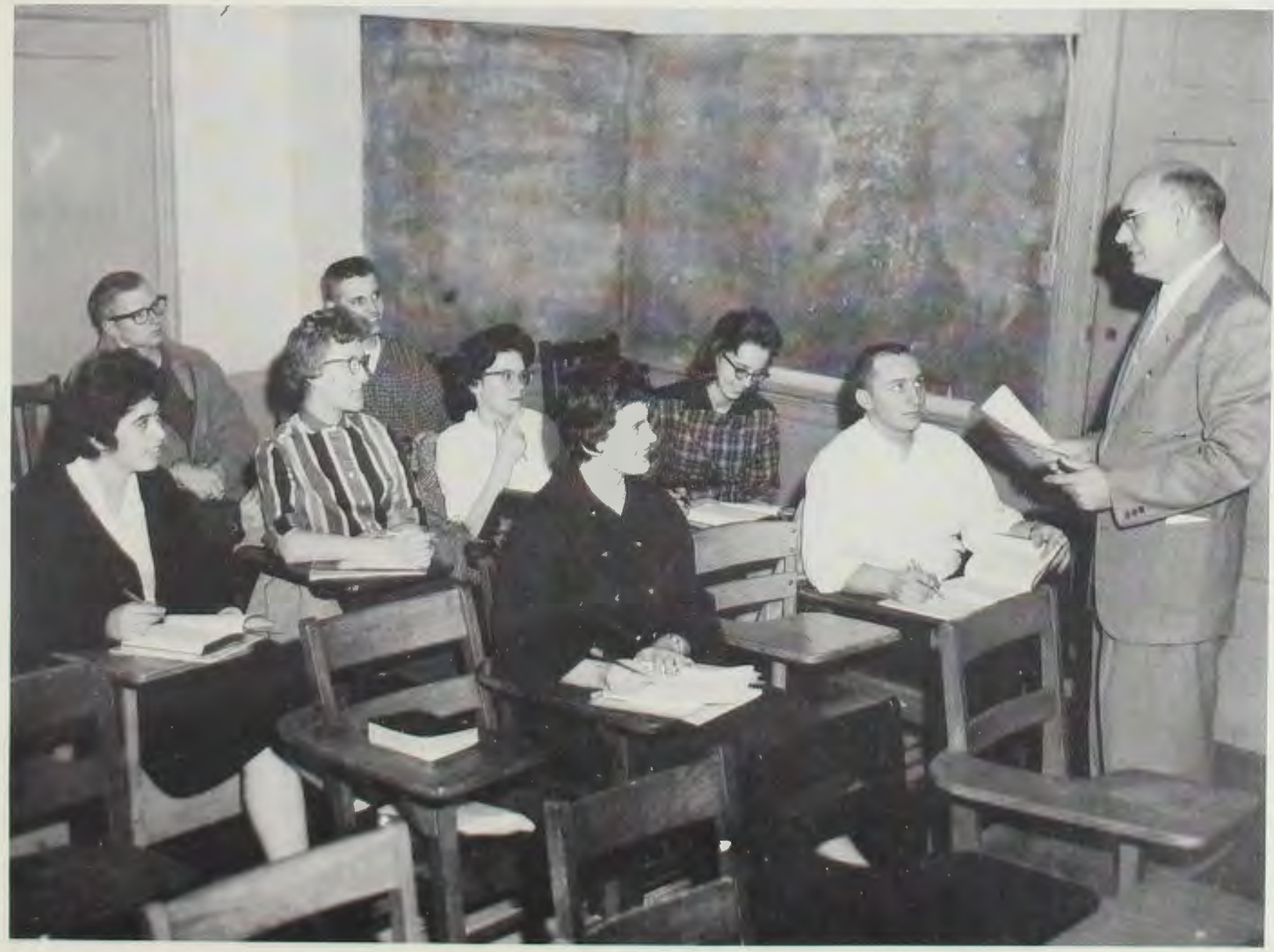




\section{Division of}

\section{Business}

\section{Administration}

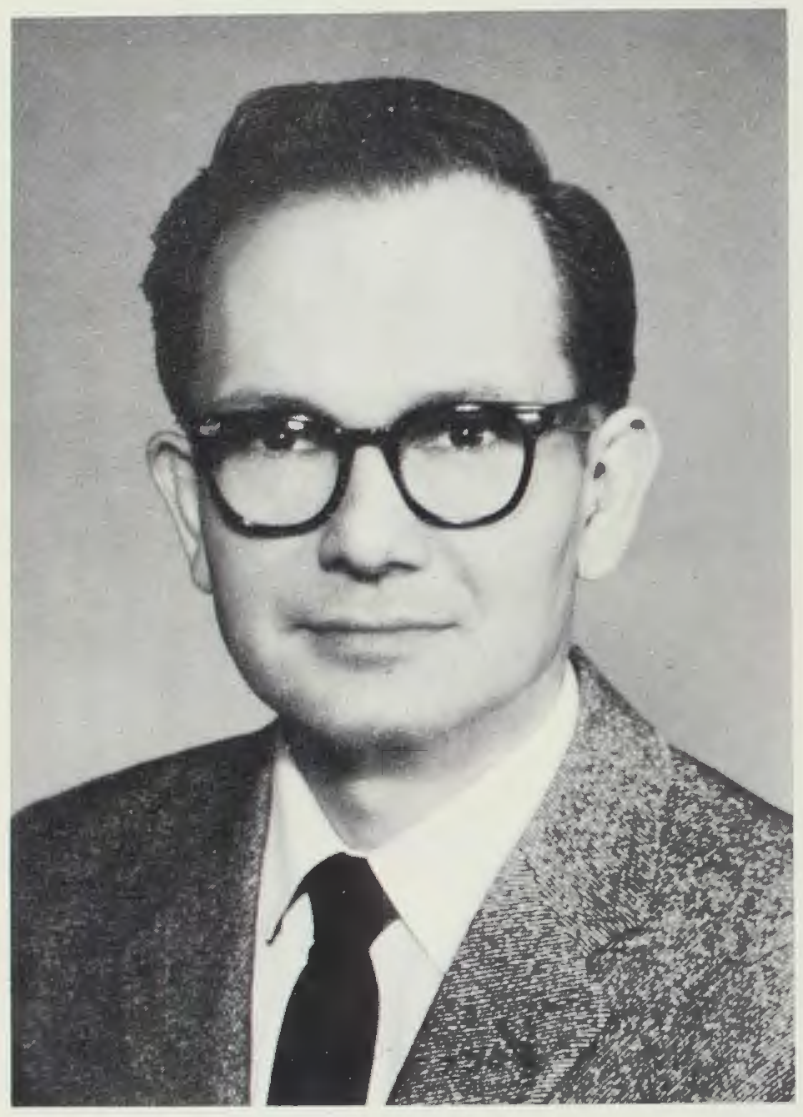

Kenneth St. Clair, B.S.

Accounting, Auditing

Junior Class Advisor

Ardeth Webber, B.S.

Typing, Shorthand, Dictation

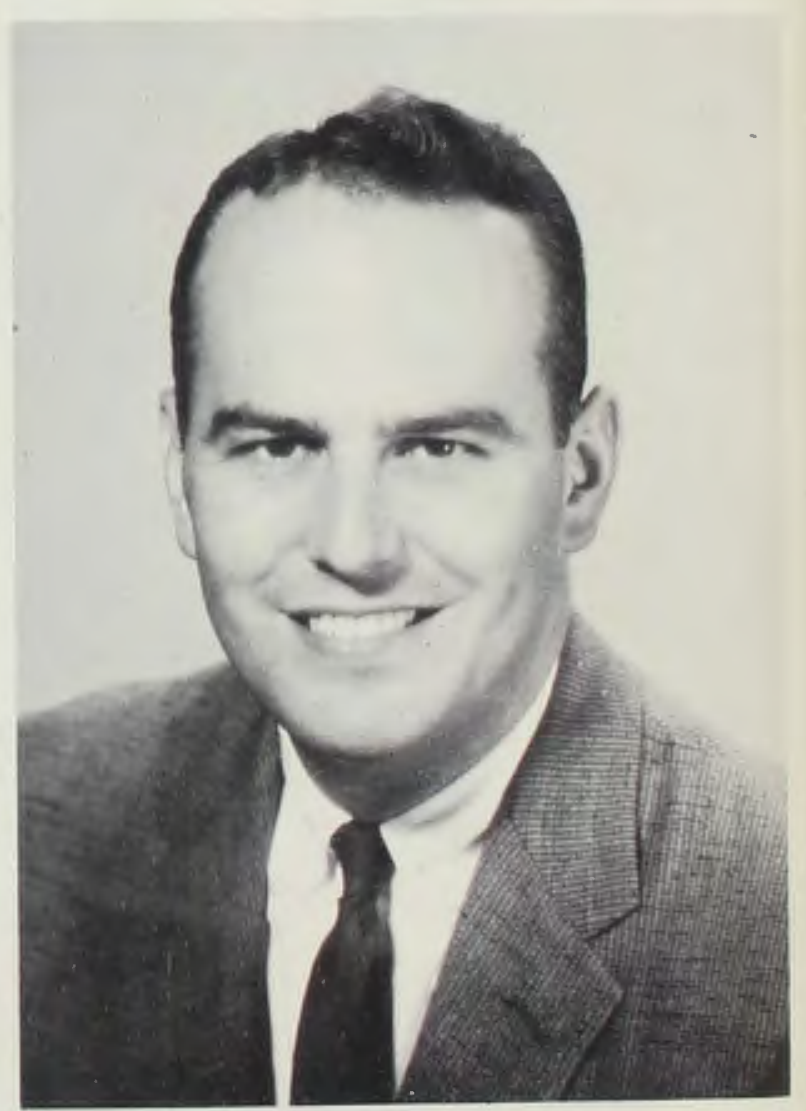

Rodney Wyse, M.S.

Economics, Management

Faculty Quartet 


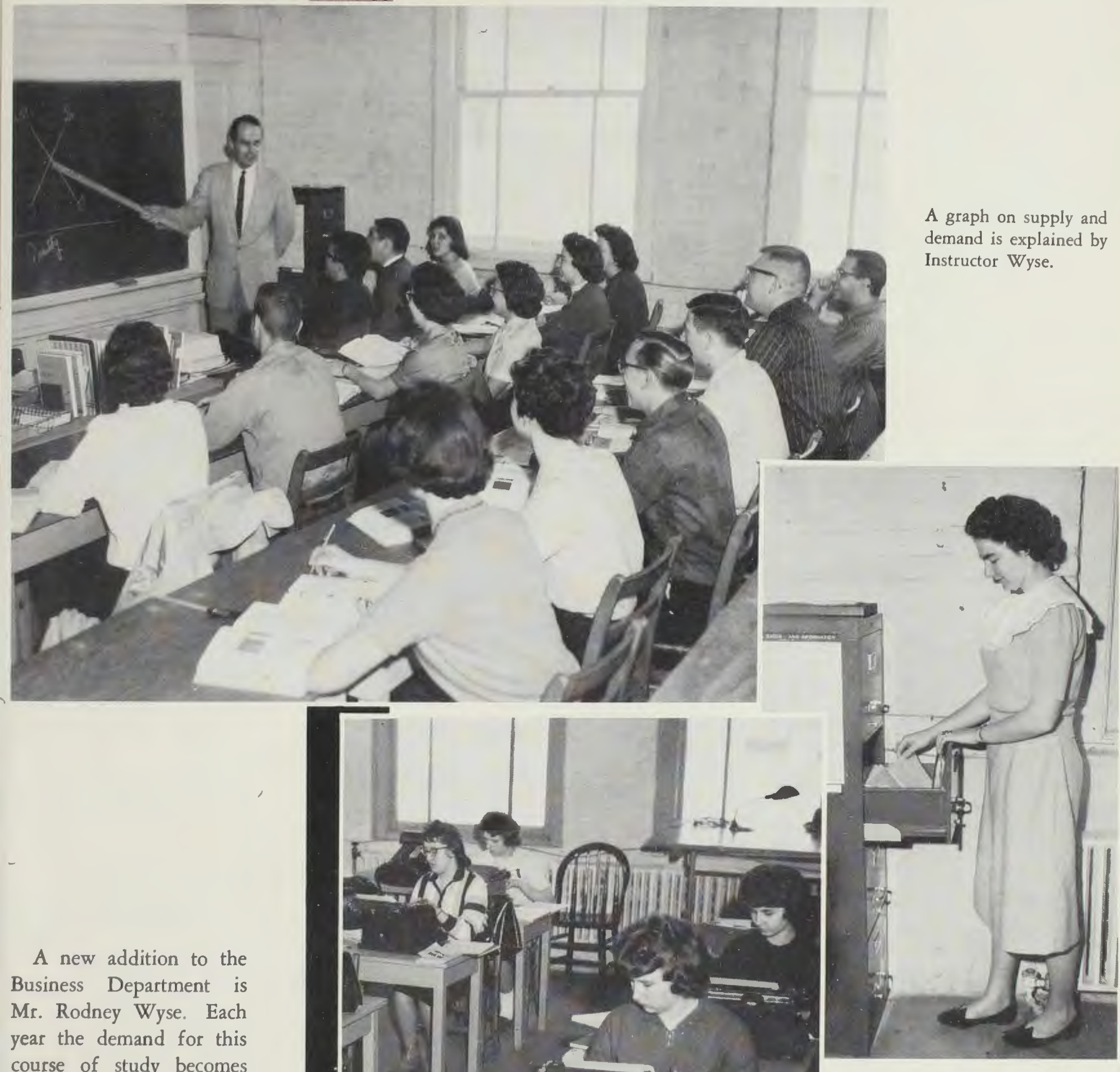
course of study becomes larger as students see the opportunities in the business world. 


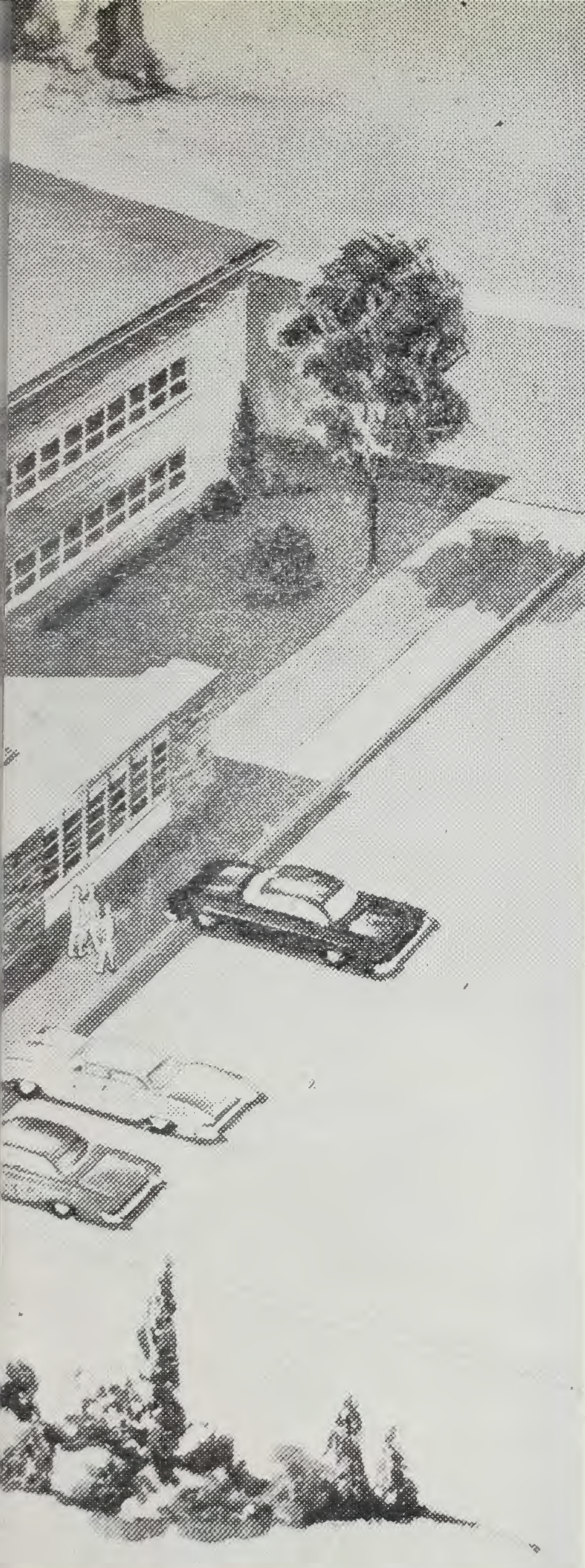

We await with anticipation the completion of our Student Center, the hub of student activity. Here we will spend many hours discussing foreign policy and eschatology, or playing basketball or simply relaxing over a coke after a difficult exam. 


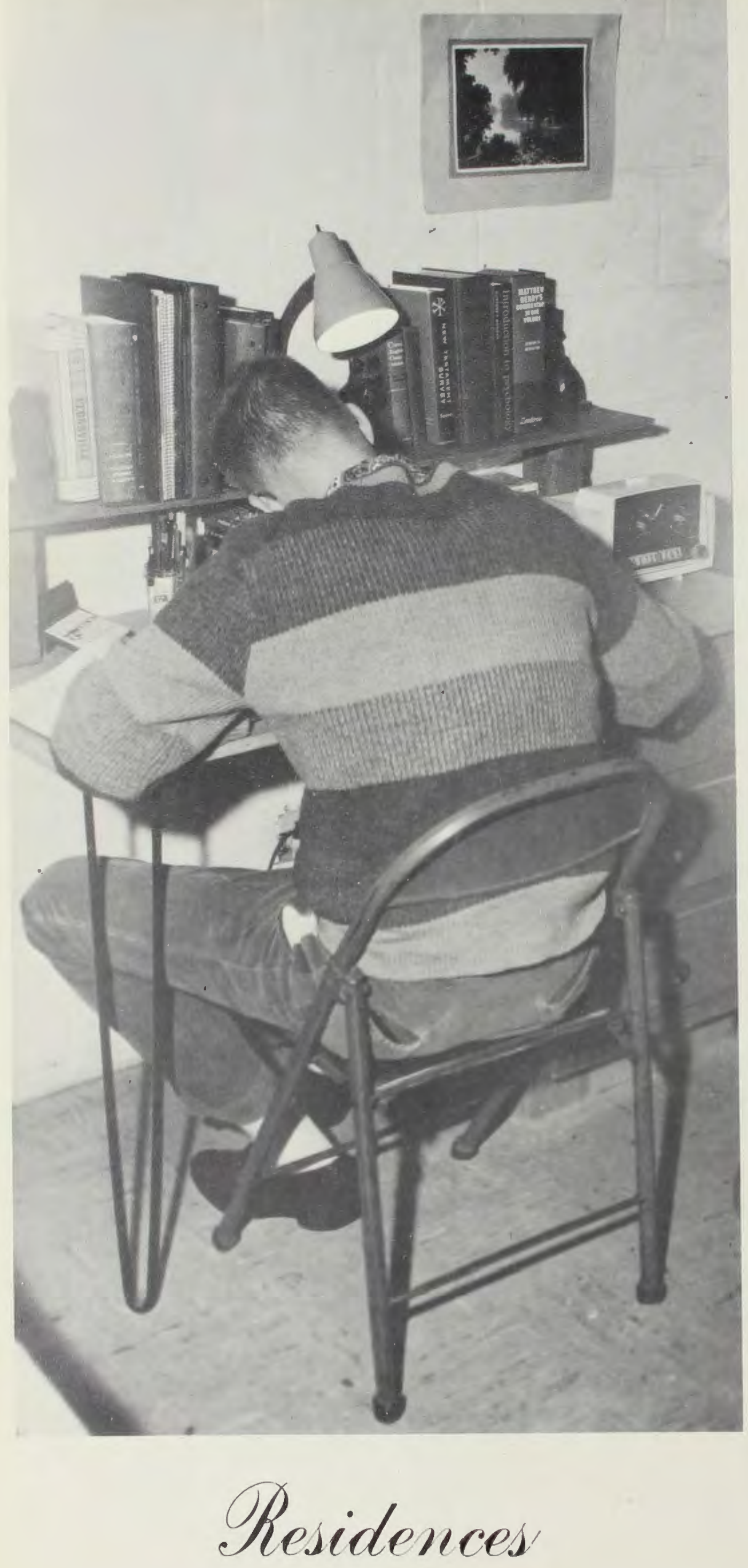




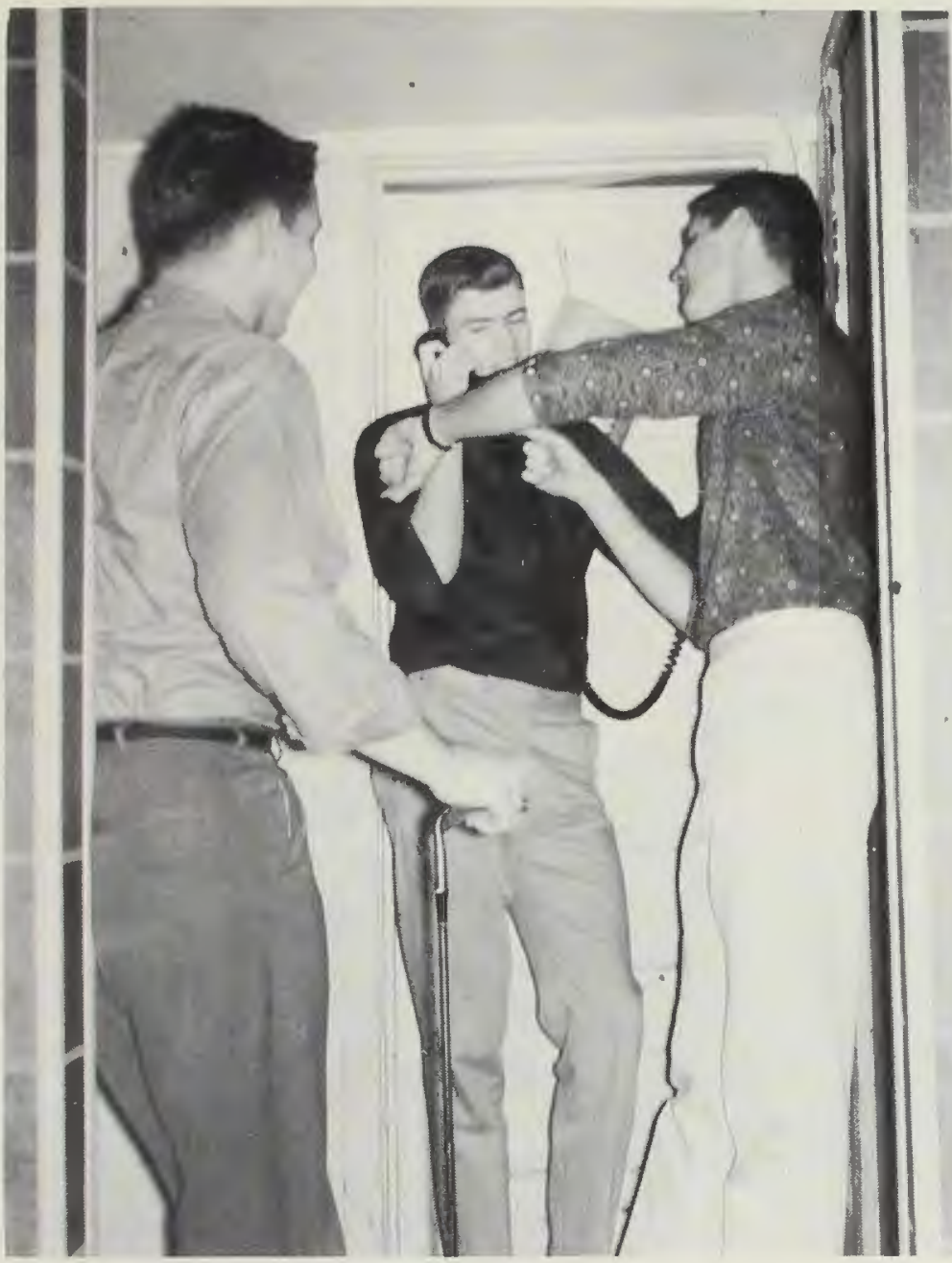

\section{Bethel Hall}

Guarded by a single stately cedar tree, Bethel Hall borders the campus on the northern side. Its newly remodeled walls contain men from each of the four classes and from as many diversified interests. Athletes, class officers, vocal students, bookworms, each add their personalities to make the "Bethel Royals" a unit.

Rich Blumenstock and Jerry Stadt find it difficult to wait until Rod Lane finishes talking to bis girl.

The boys may be talking about something as common as a Bible Doctrine quiz or as earth shaking as nuclear warfare. Who can tell by their faces?

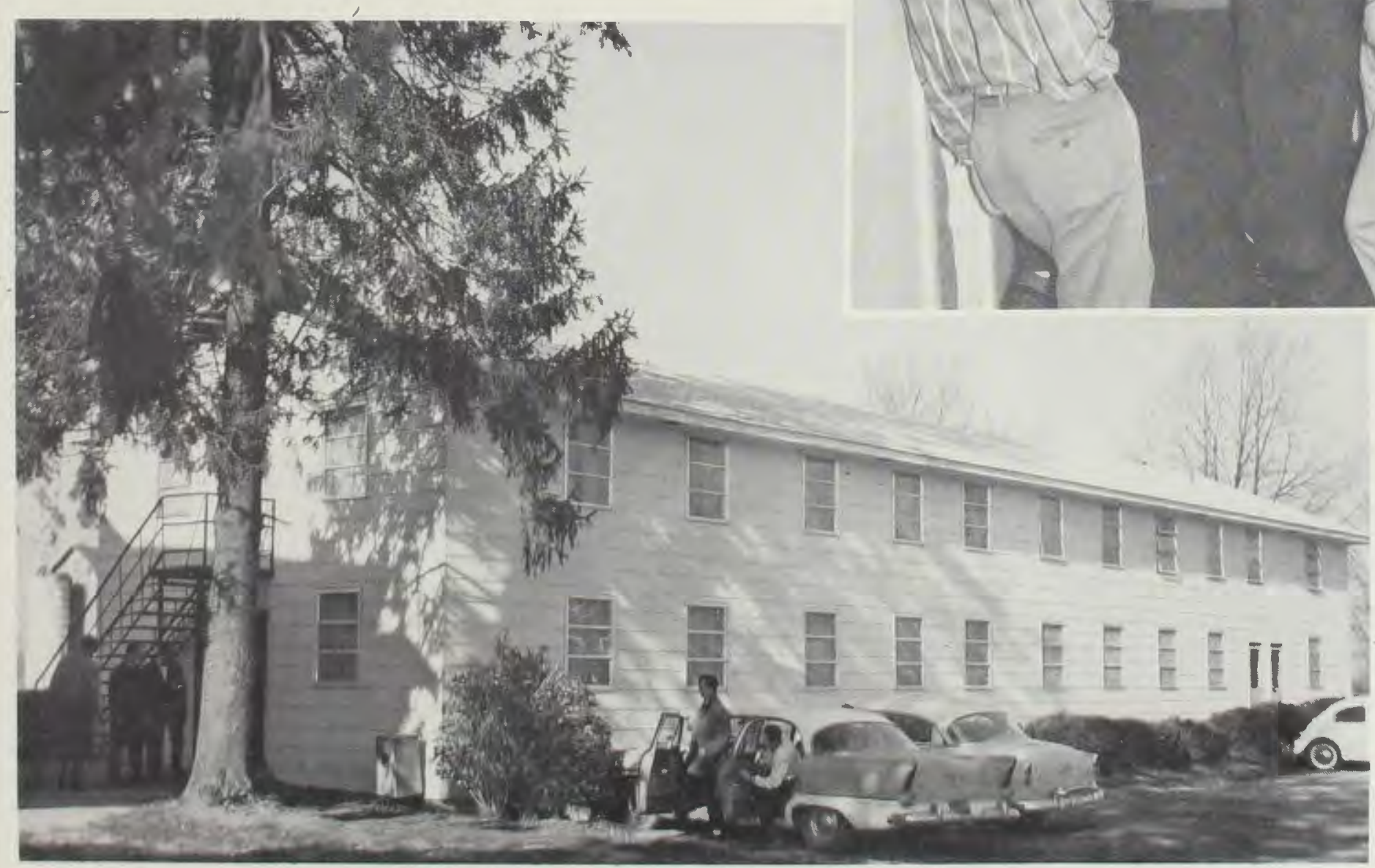




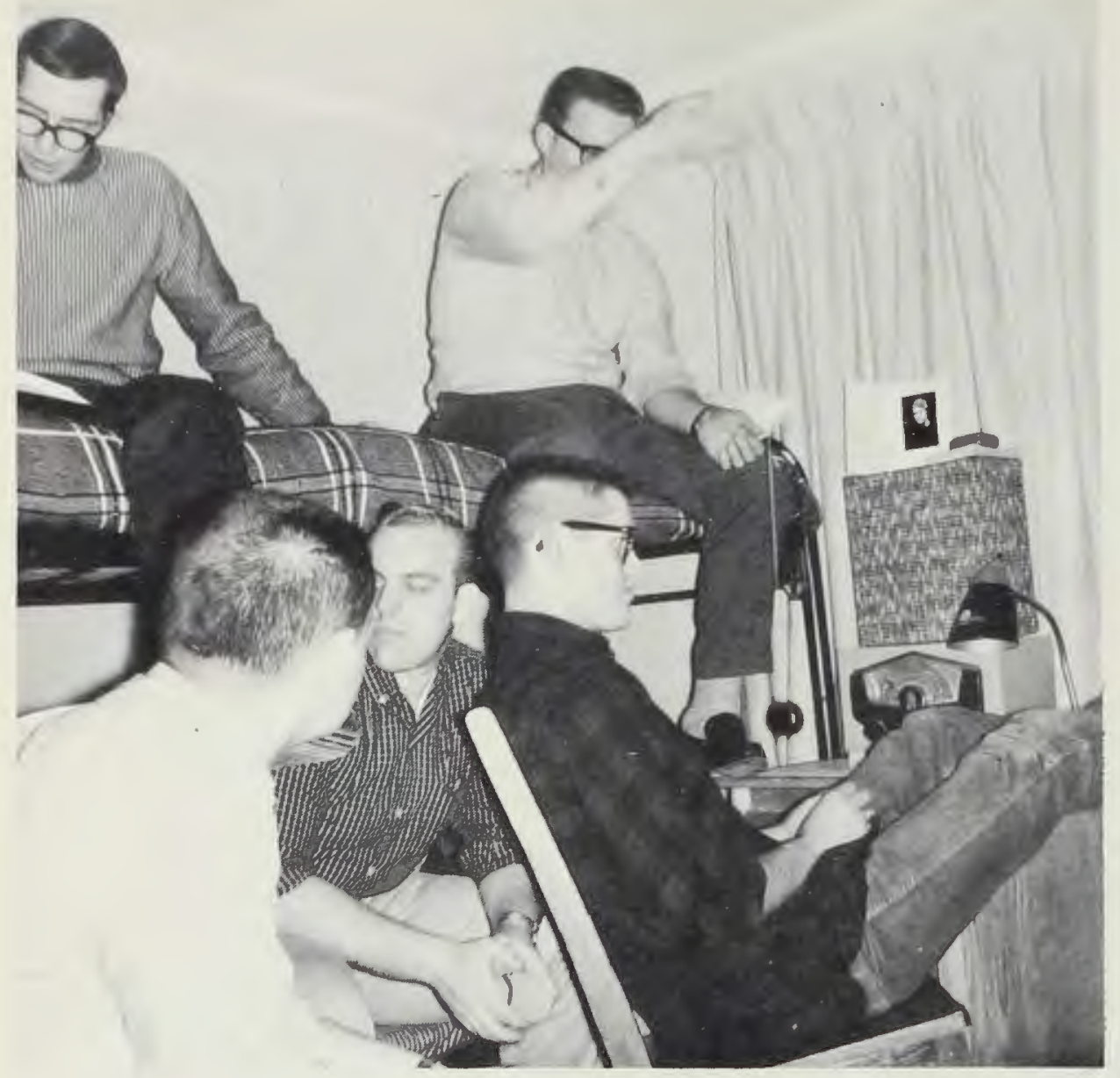

"The natives are restless tonight."

\section{Men's Dorm}

The College Bookstore and Student Lounge share their temporary facilities with the rugged individualists of the campus. The fact that the favorite game of the residents is bowling down Pepsi bottles with a shot can be witnessed by any group who has tried to conduct an evening meeting in the lounge below. Home of gentlemen and scholars, the Bookstore Dorm manages to maintain a casual atmosphere just within the frame of college regulations.
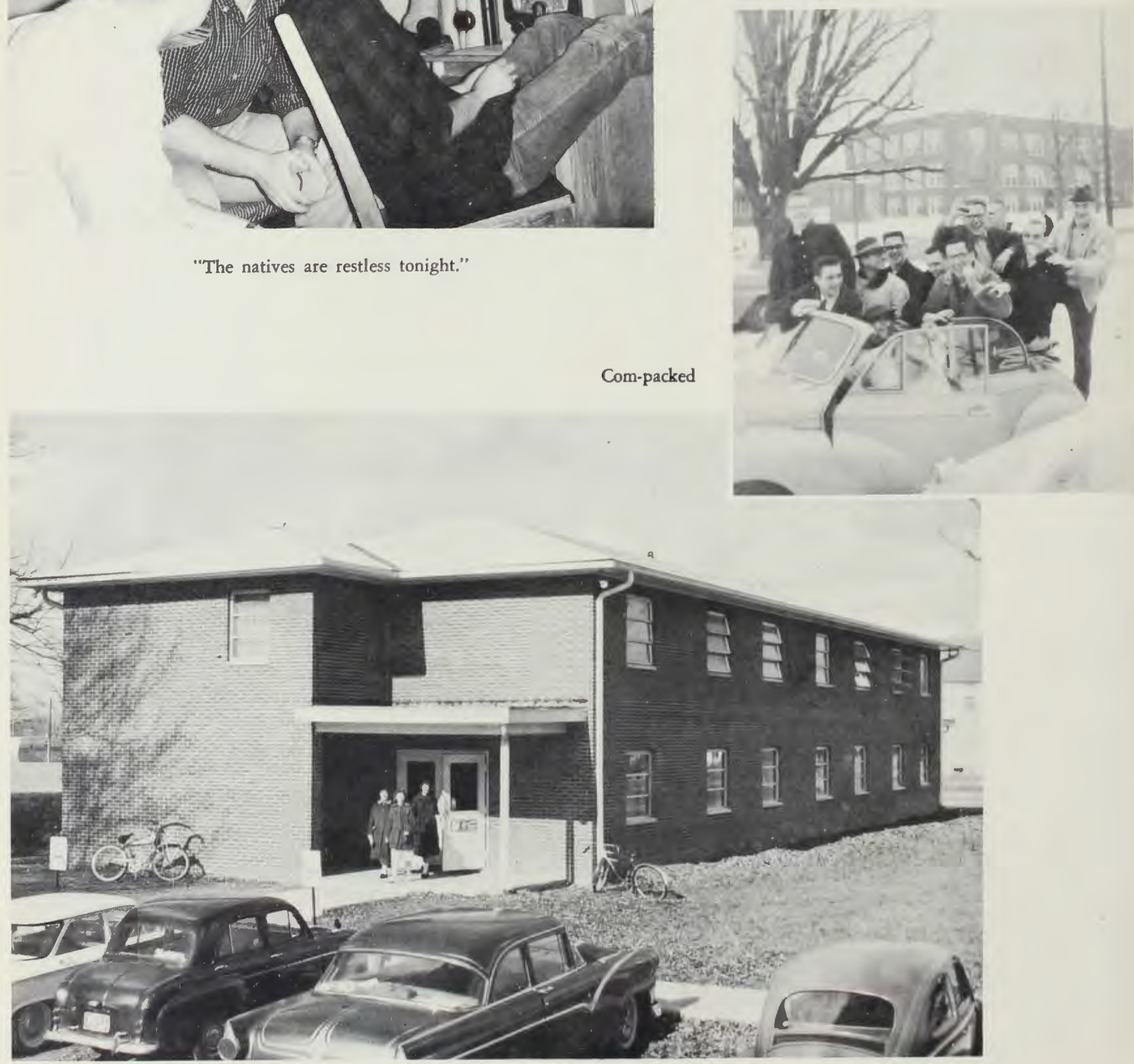
The dormitory located the farthest away from the main campus is affectionately known as "The Shack" by its twenty-four residents. The back lawn which slopes to "Massey Creek" is the scene of snowball fights in the winter and touch football games in the spring. The list of popular indoor activities is topped by shaving cream and water fights; nevertheless, senior Keith Webster, head monitor for two years and still cracking the whip, manages to keep the boys in line.

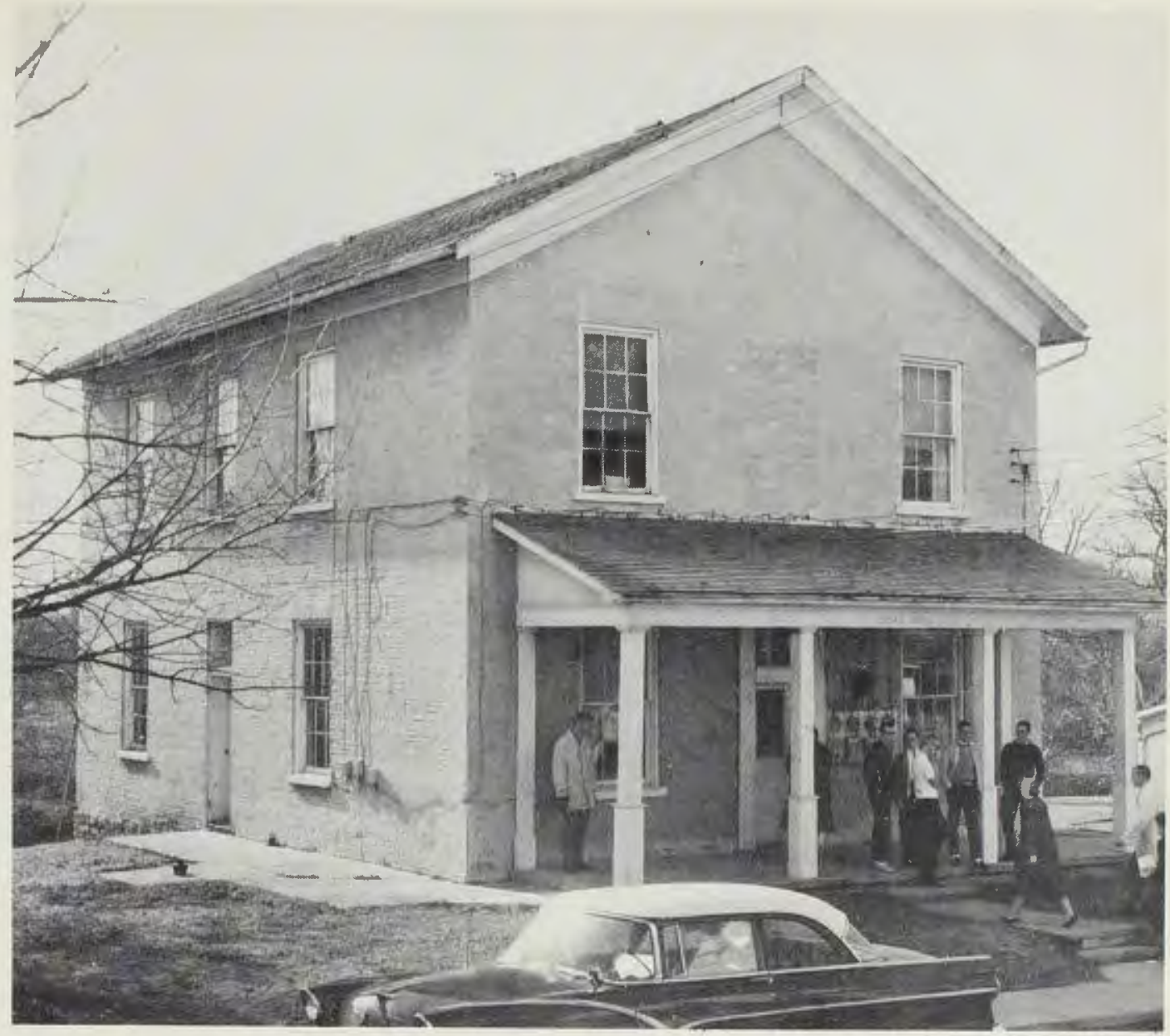

\section{Cedar Hall}

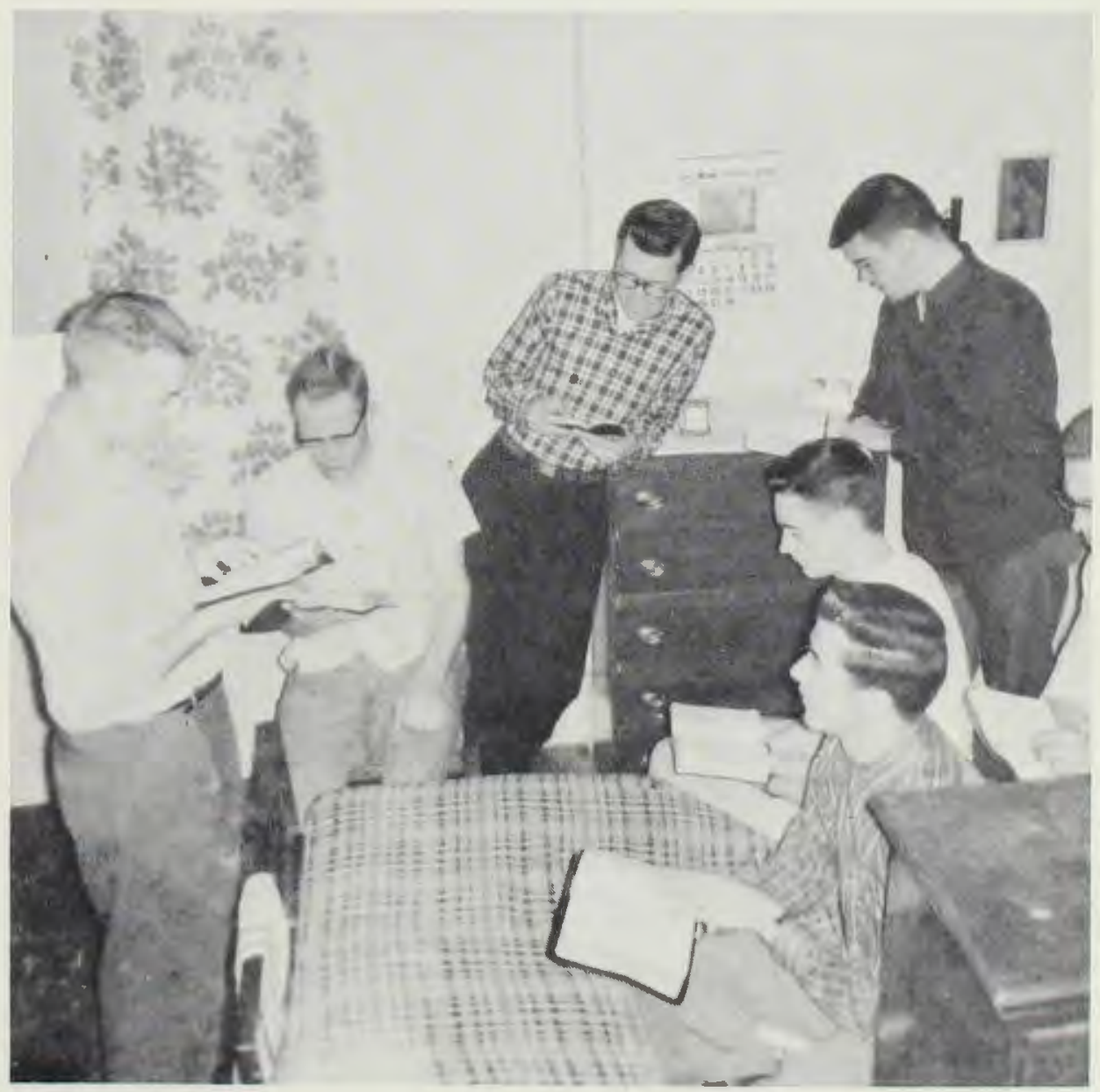

An important element in dorm harmony is the weekly devotional time. Here Larry Czerniak leads in scripture reading.

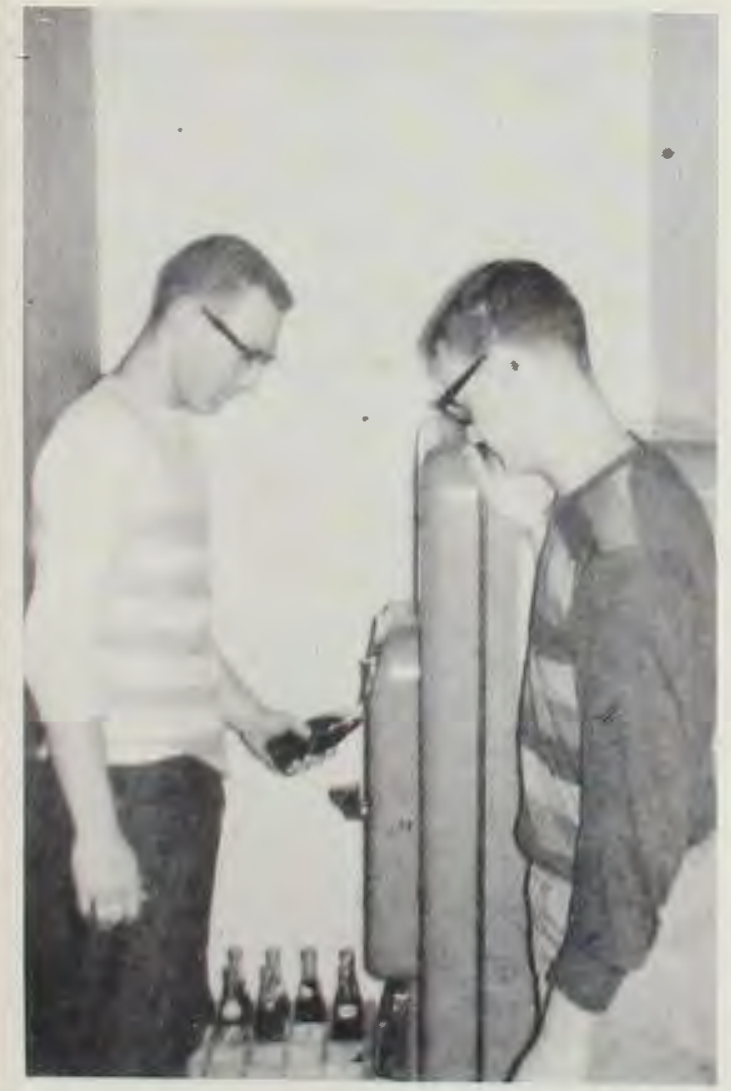

"The Pause That Refreshes" 


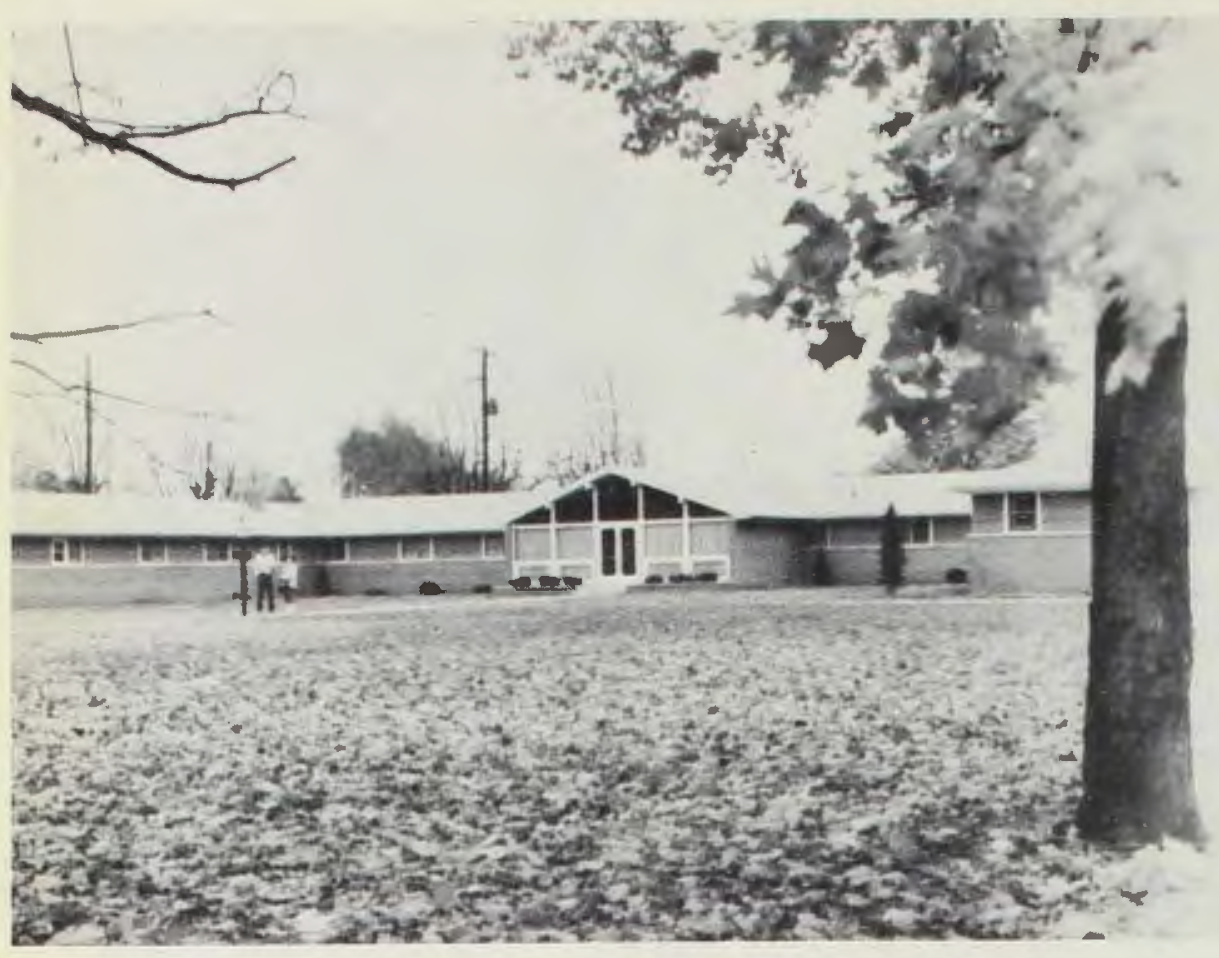

Faith Hall with its low modern structure is a comfortable home for sixty Cedarville co-eds. Most of the activity that goes on within centers about the lounge. During the day it is occupied almost constantly by gentlemen callers, but after hours it becomes a women's domain for late evening studying and group reducing exercises. The pop machine keeps everyone dieting; room checks keep everyone tidy, while dorm counselors, Bonnie Nash, Bobbie Unzicker, Nancy Warkentine, and Betty Schultz, keep residents in line by enforcing curfews and study hours.

\section{Faith Hall}

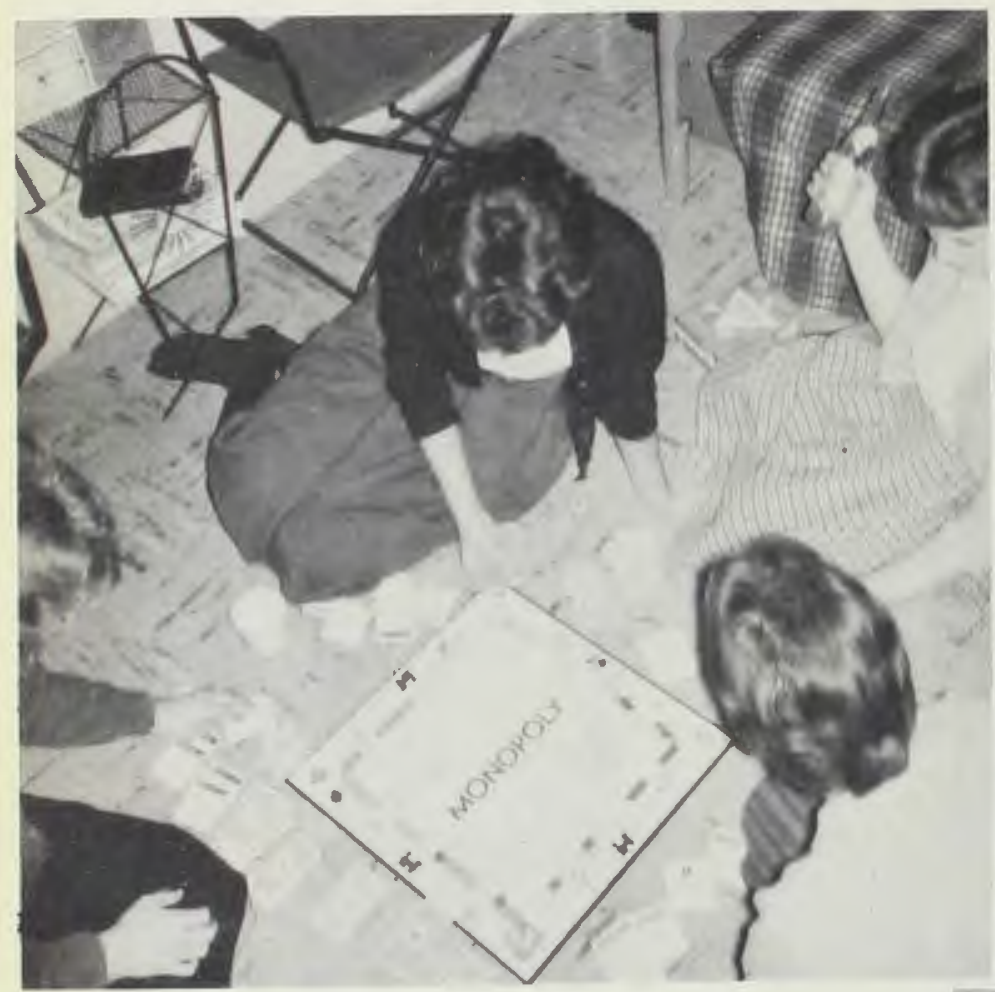

"Go directly to jail, do not pass GO, do not collect '200'."

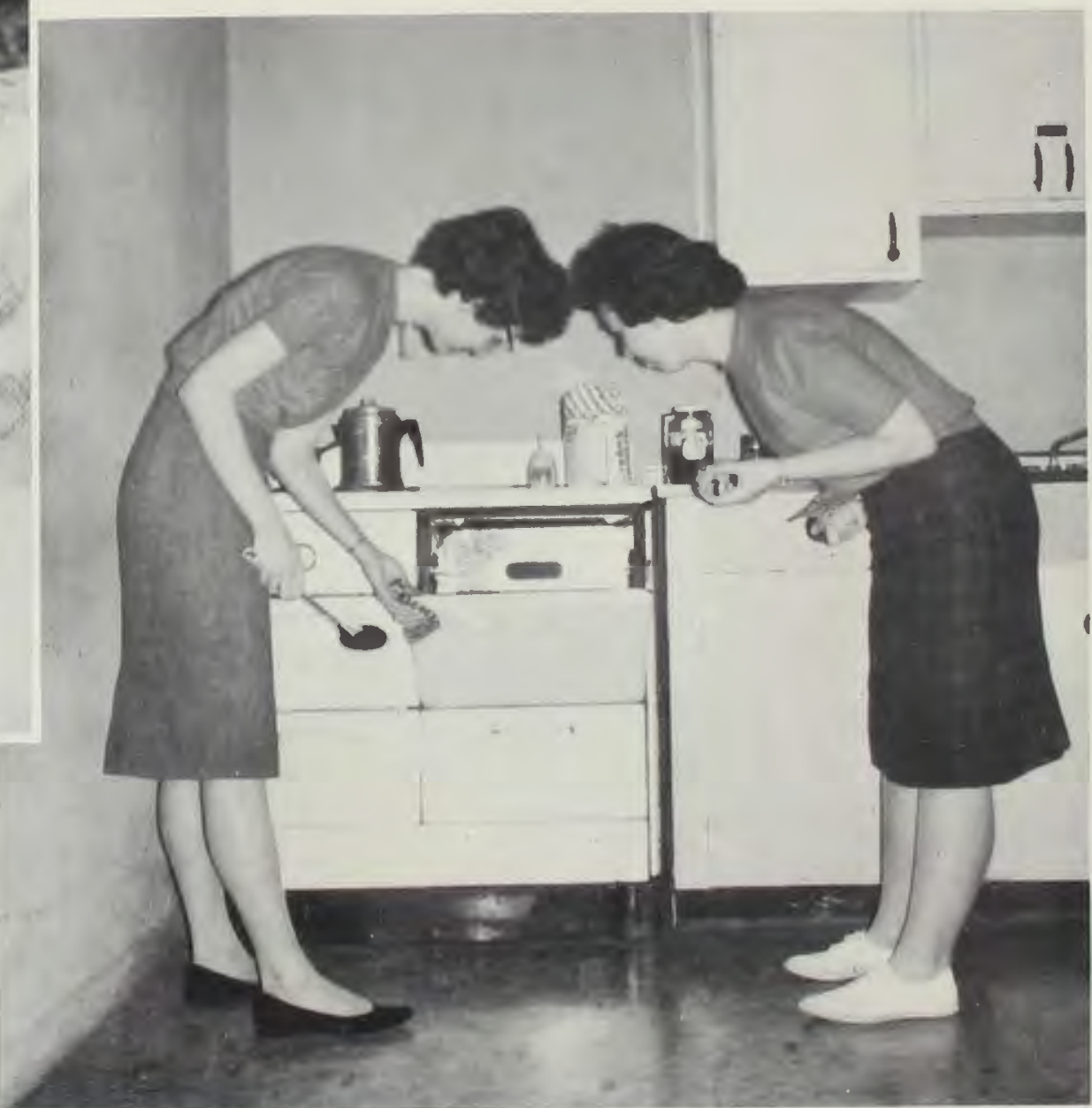

Whether it be a pizza or a chocolate cake you know that it will make evening studying considerably more tolerable. 


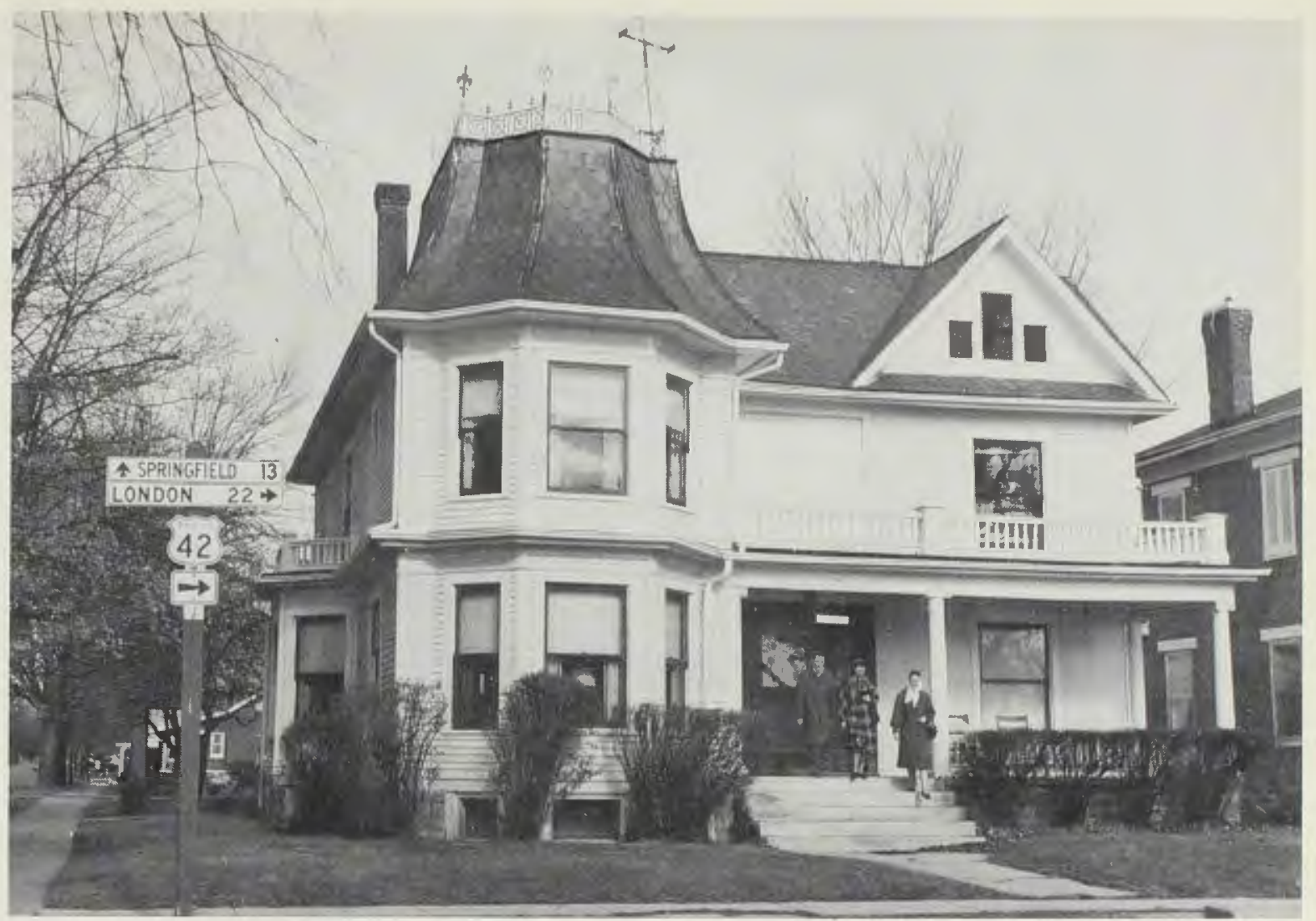

Harriman Hall, the first building purchased by the college for use as a dormitory, originally housed women. In more recent years it has become a popular residence hall among upperclass men because of its homey atmosphere and its proximity to both the college library and the Pizza House. An added attraction among the "Harriman Hurricanes" and their friends is the front porch swing-especially in the spring.

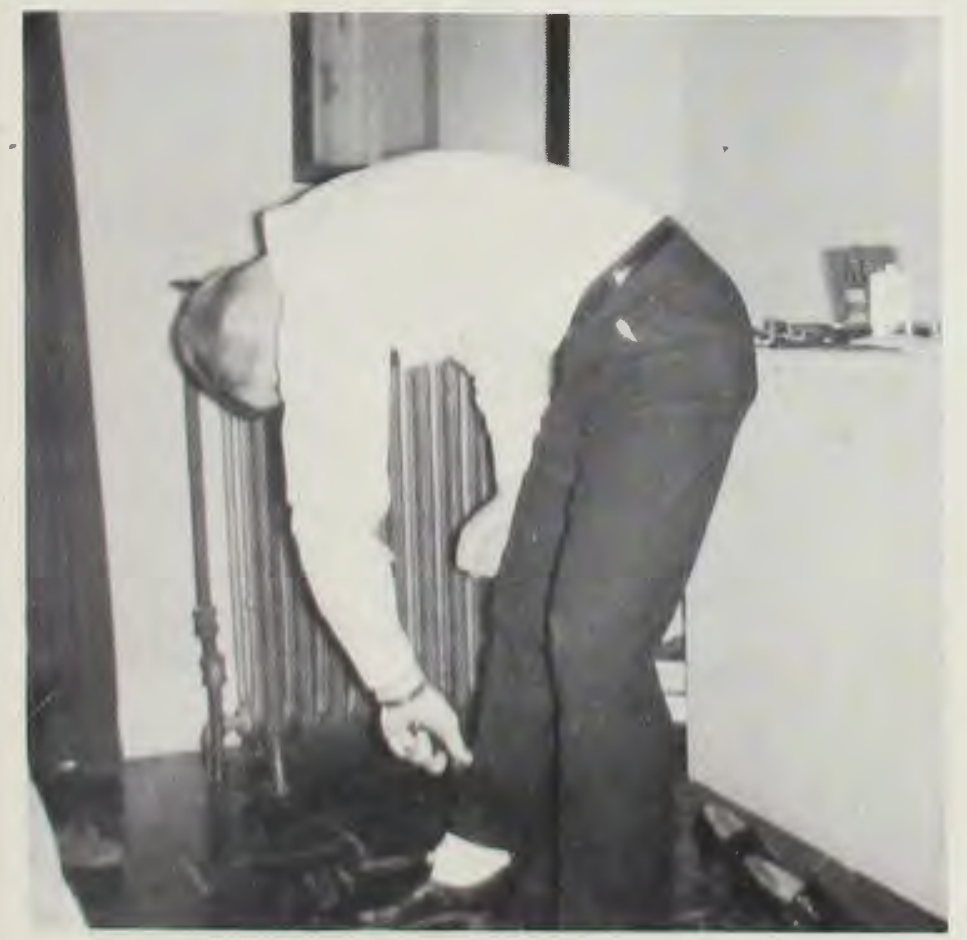

Ken Swigart gives an extra special brush for an extra special date.

\section{Harriman Hall}

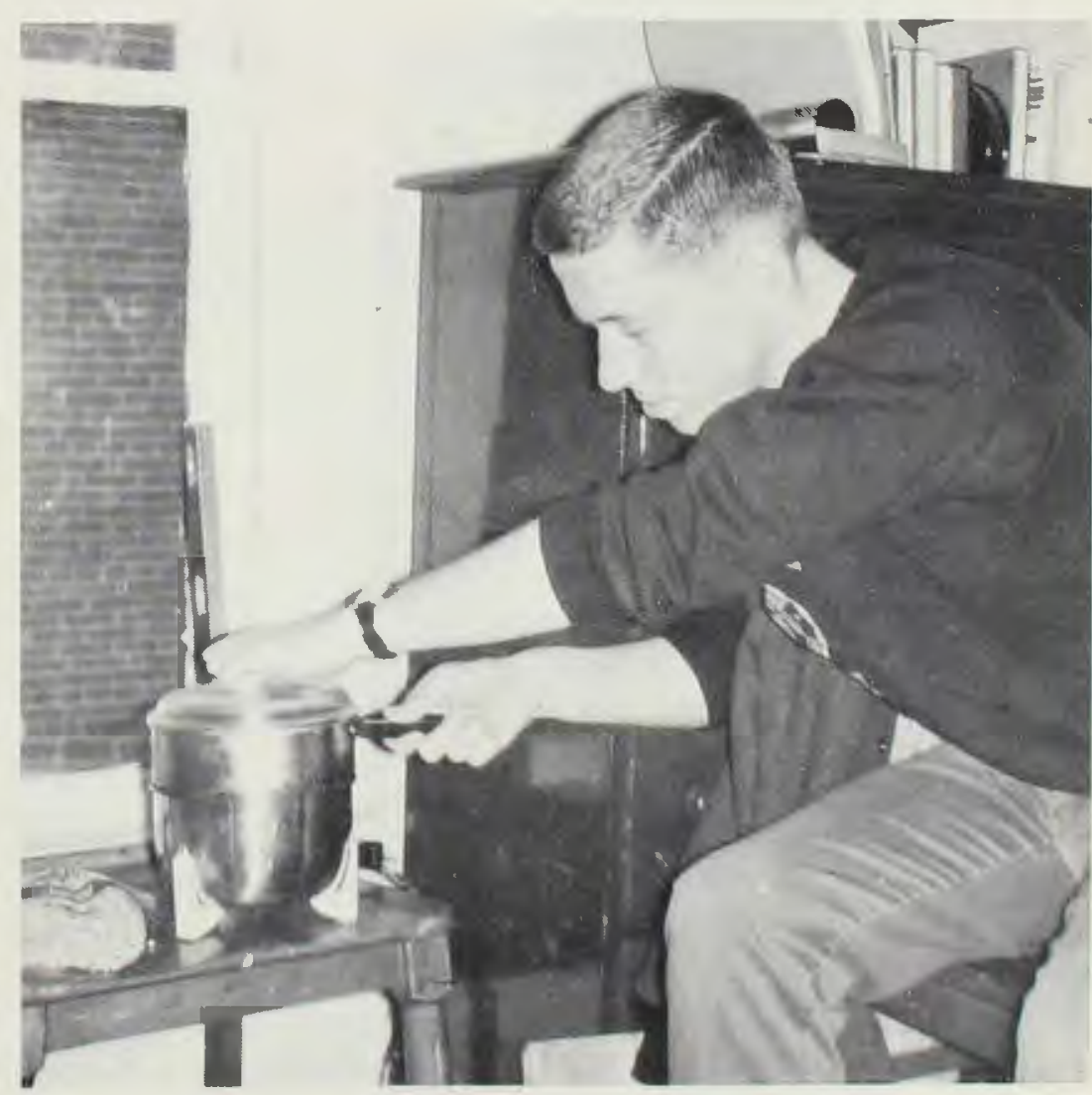

Hank Cook finds that cooking isn't as difficult as they sayin a pop-corn popper. 


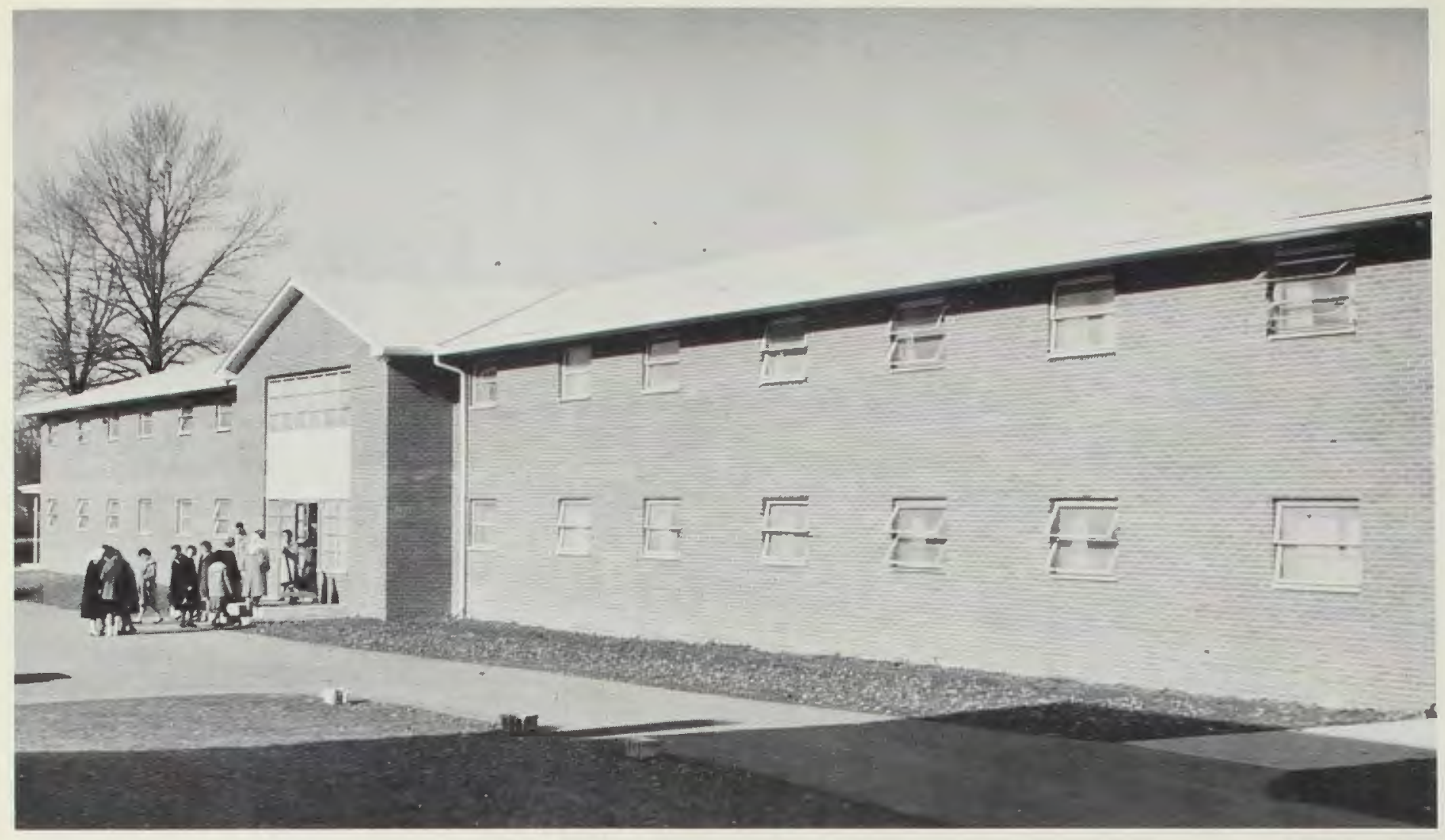

Standing near the traditional pines and housing mostly freshmen women stands the New Women's Dormitory. Looking at its calm exterior one finds it difficult to believe that inside the five counselors: Lois Bayless, RosaLee Albrecht, Mary Goodwin, Joyce Walker, and Sharon Addleman and 150 coeds are making the rooms bustle with activity. Residents find that its position on campus has many advantages - not only is it near to classtoom buildings, it also provides an excellent fifty-yard line view of the football field during the intramural season.

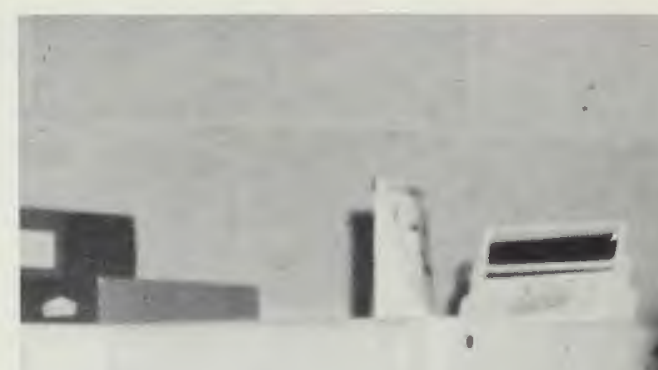

\section{New Dorm}

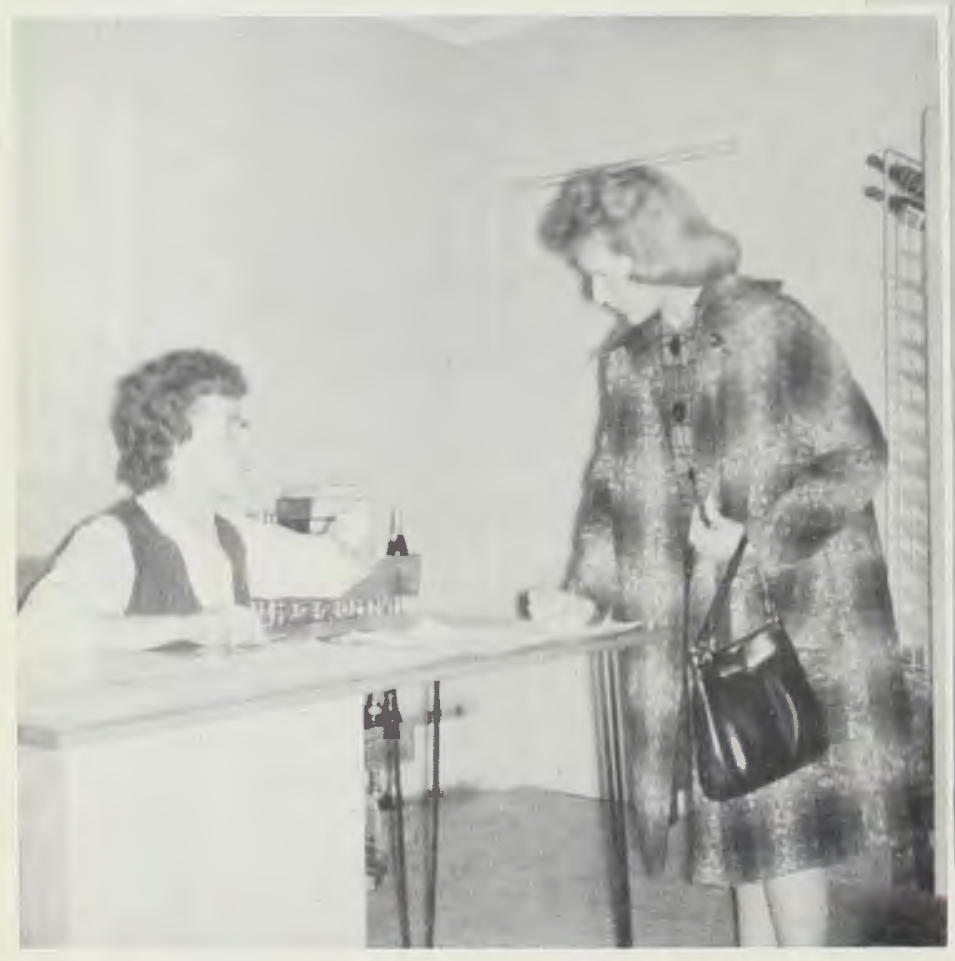

Joyce Walker can't understand why Carol Henson never manages to sign-in on time. 


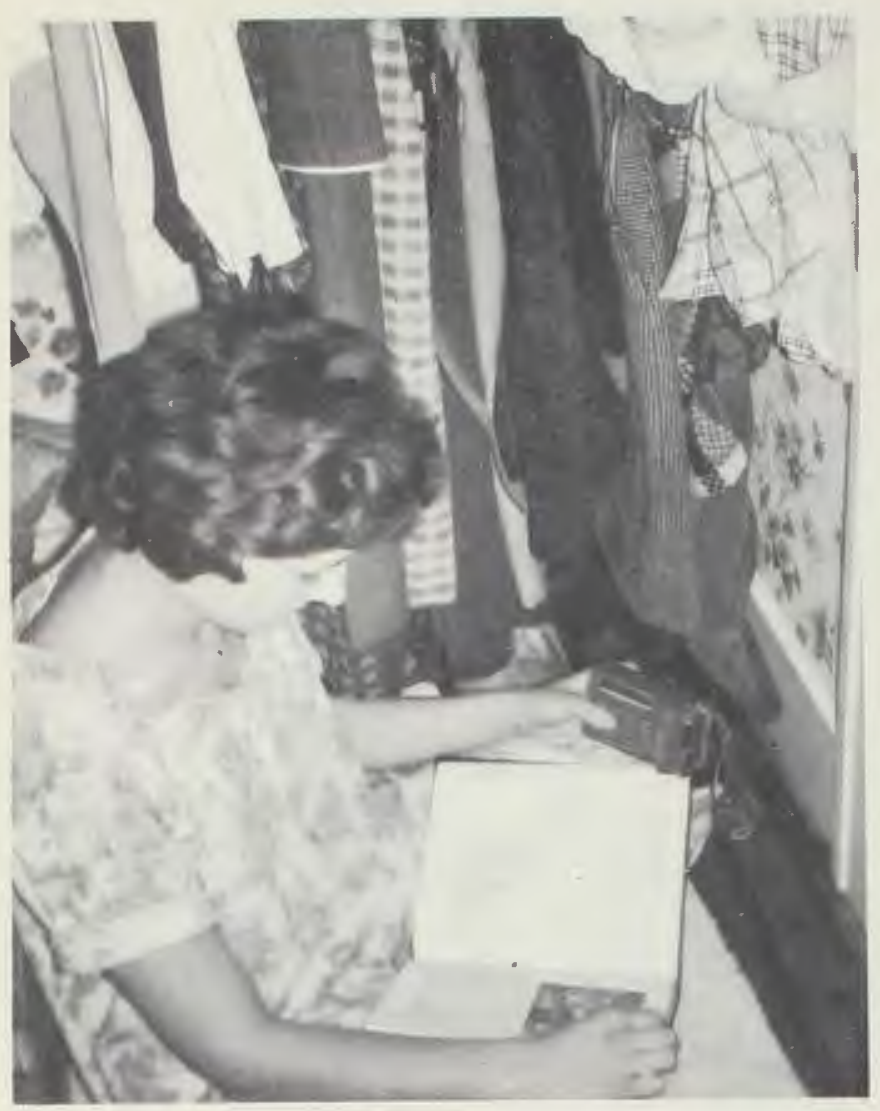

Carol Hell finds that sometimes the only quiet nook for study is the clothes closet.

Across the street from the gymnasium is Sticka House, purchased in 1961 to accommodate the music department and twelve women residents. Its hall echoes friendly chatter mingled with busy typewriters and high fidelity

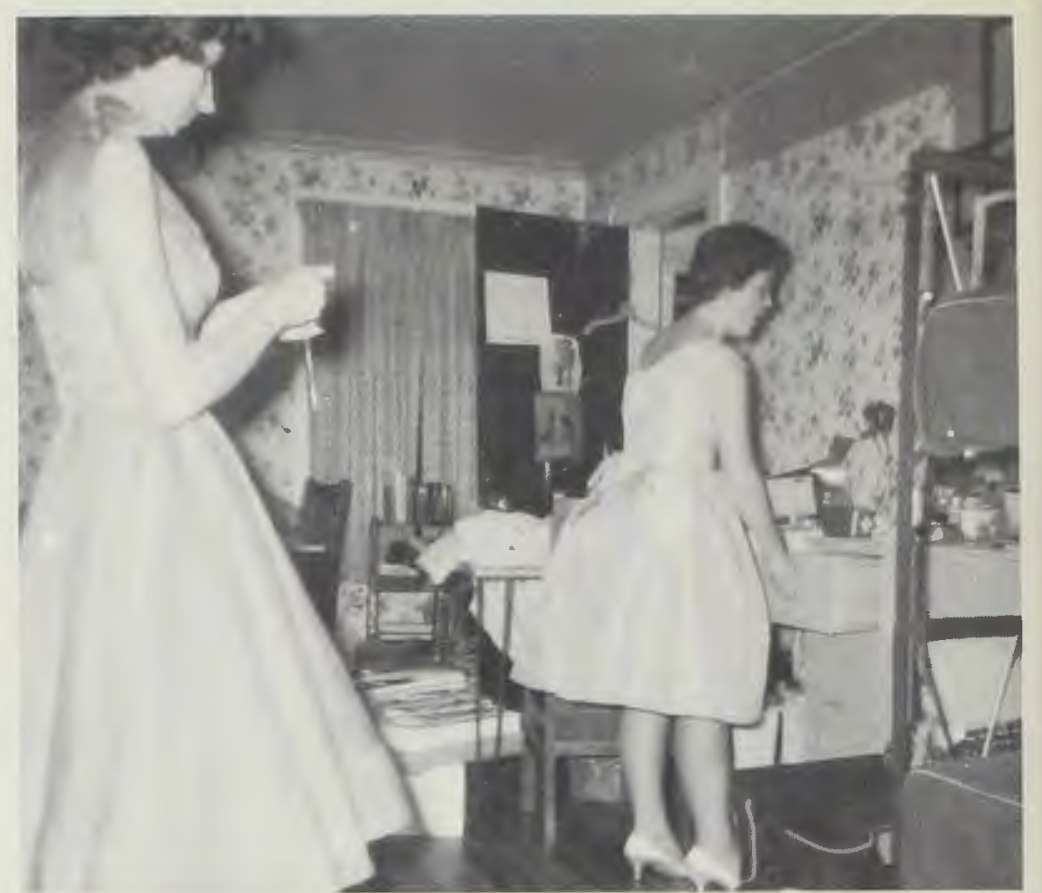

One wonders how Hazel Brovont and Lois Kennedy manage to look so lovely at the banquet after dressing in such utter confusion.

\section{Sticka House}

sound from the music studios below. In spite of their merry parties and ingenious pranks, in the midst of daily college routine, the residents manage to maintain the homey atmosphere of the dorm.

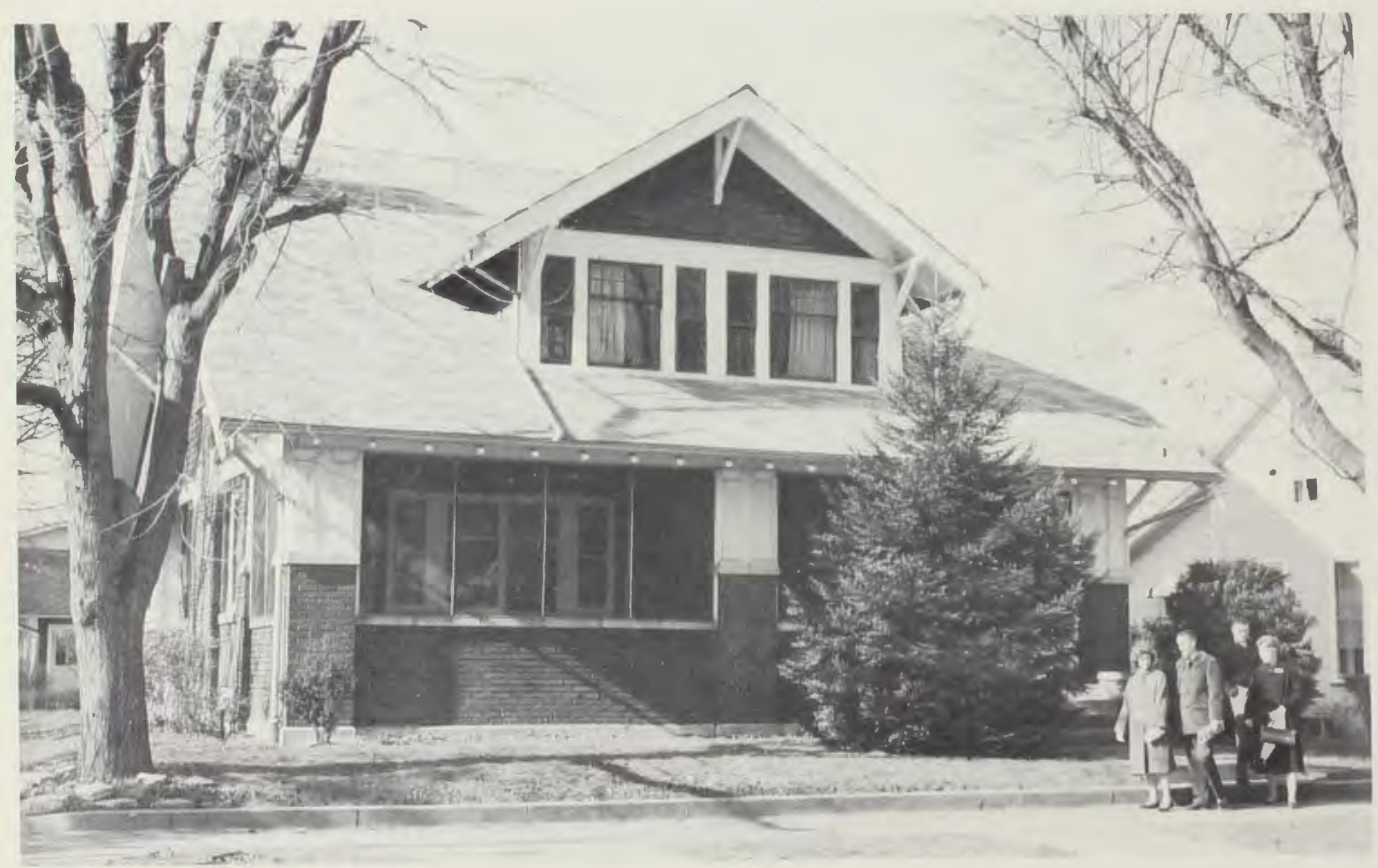



both men and women. Limited dormitory space necessitates a small percentage of students finding homes away from the campus. These rooms give their occupants the opportunity to live in a quiet atmosphere conducive to concentrated study without elimiand relaxation with roommates, music or parties.

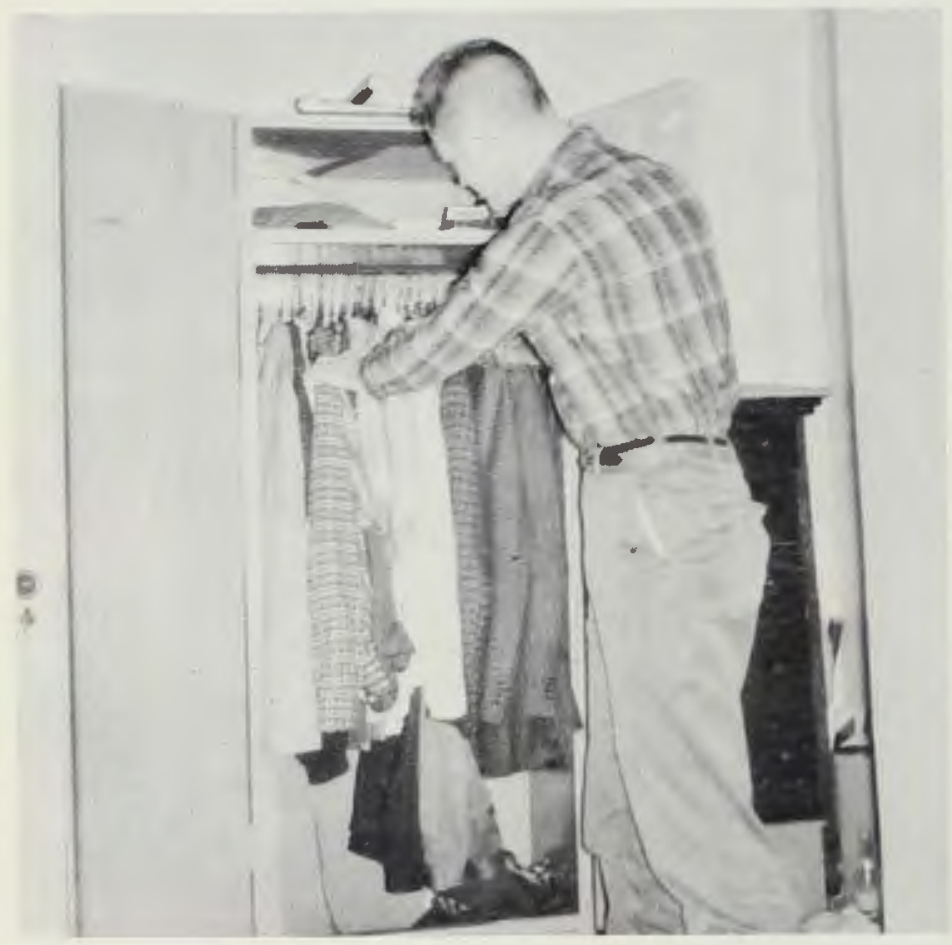

Choosing the right jacket for dinner is important because she eats early too.
Off-campus living at Cedarville is popular with nating the chance to spend a few moments in fun

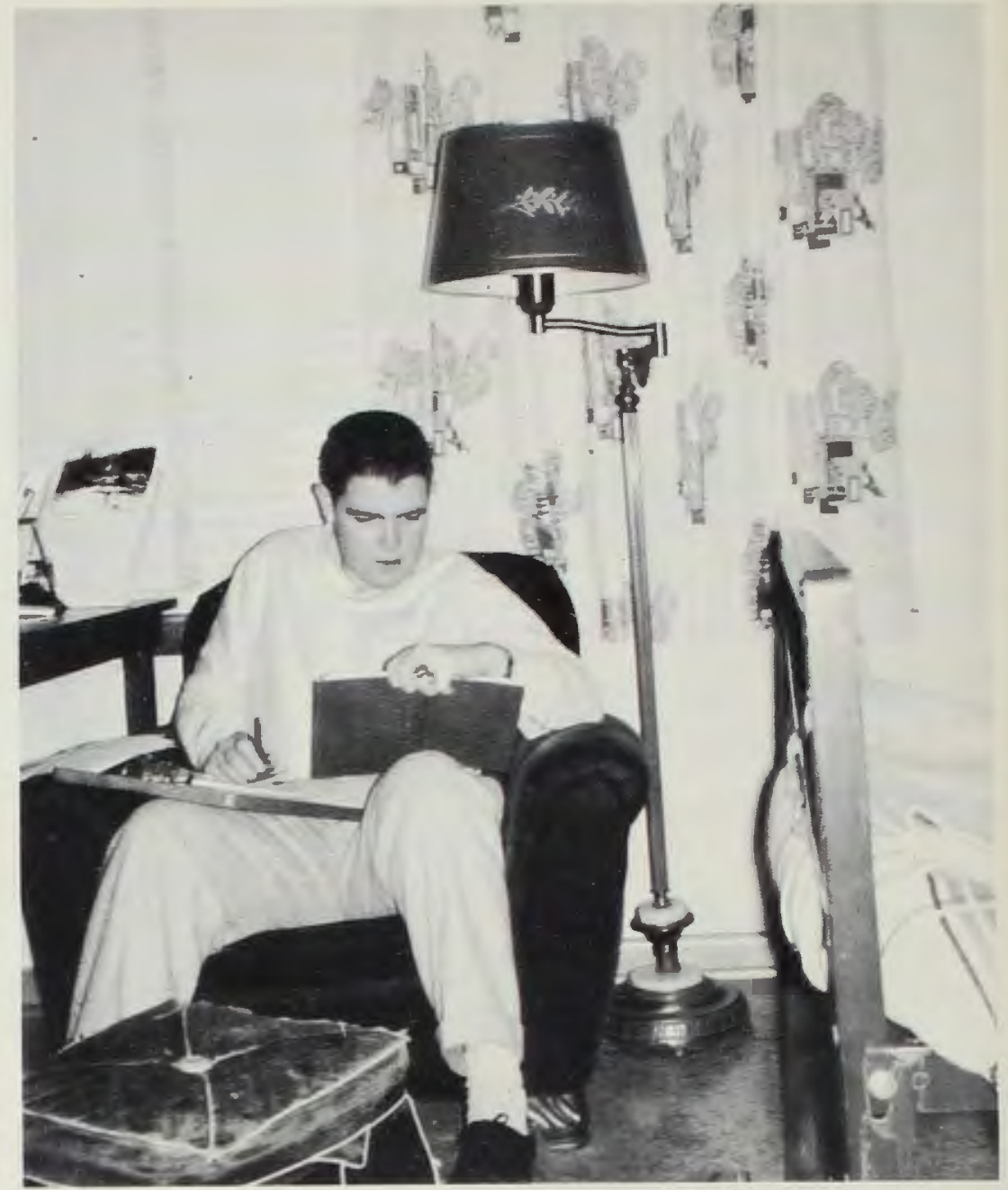

Aided by three off-campus necessities - a foot rest, an easy chair, and a pencil to chew on-, Dave Woodman pursues with diligence his study of Greek.

\section{Off-Campus}

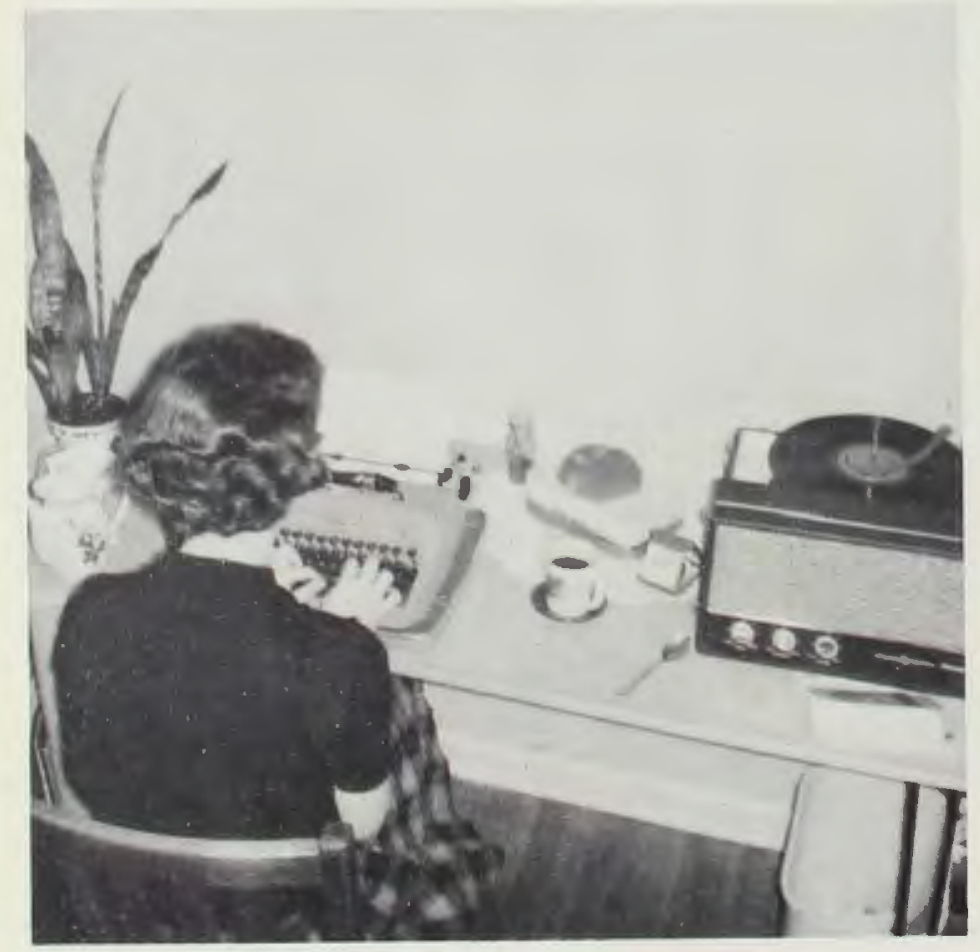

Supplied with the indispensable element-coffee - Betty Smith can even tackle a term paper.

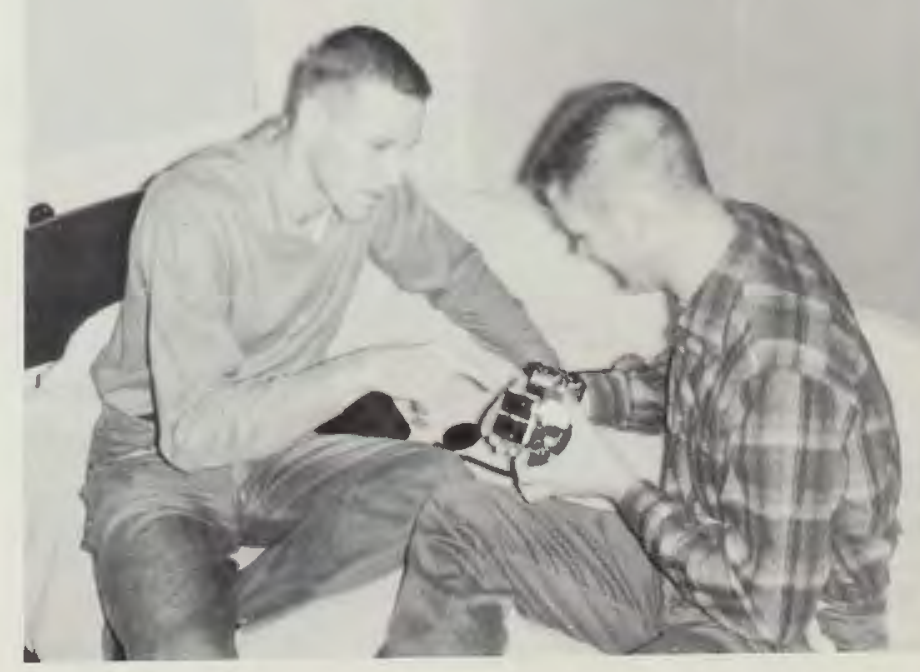

Enjoying a study-break, Bill Lobsiger and Jim Walker discuss the merits of a Christmas gift. 


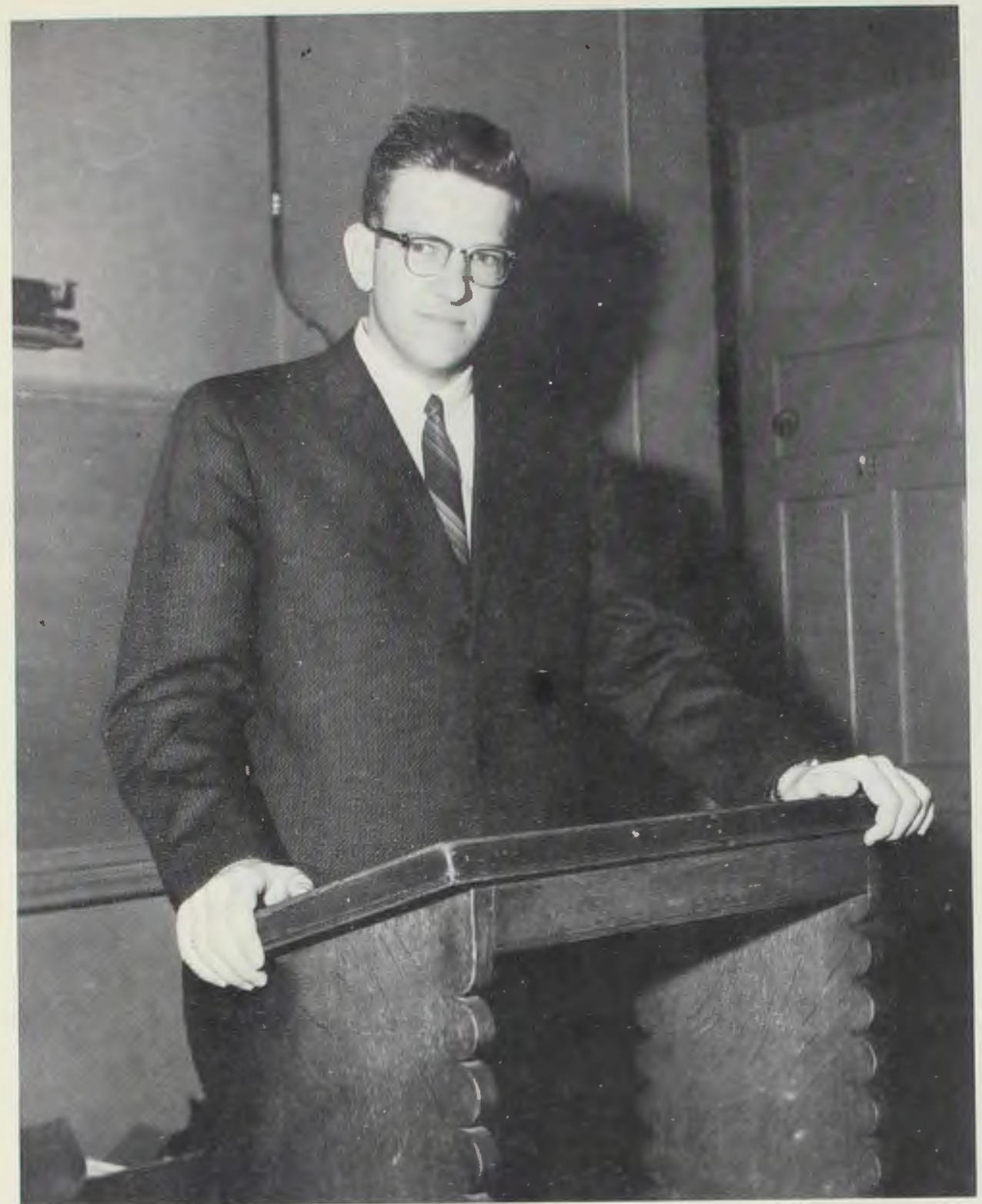

Bob Domokos, President

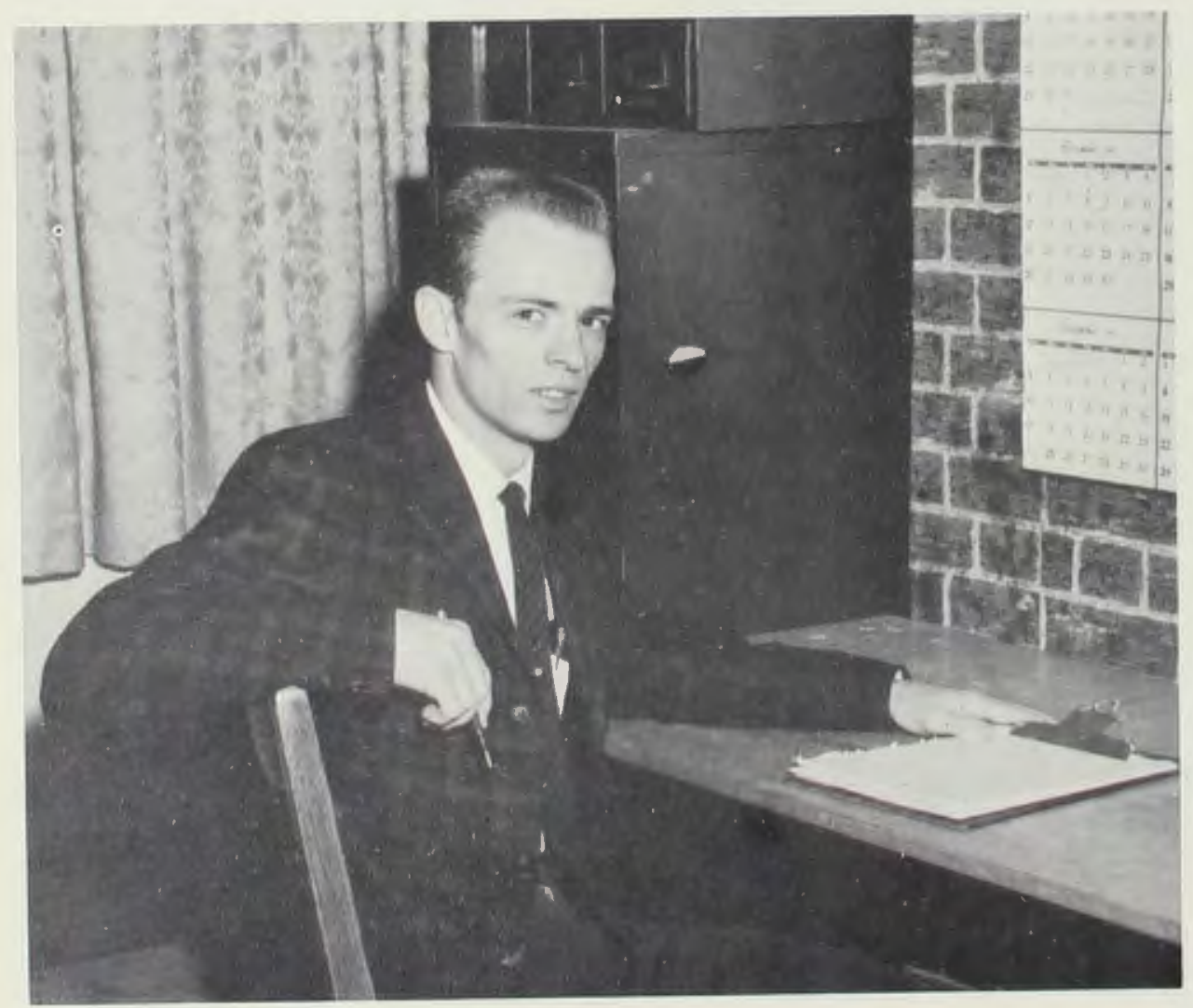

Ted Ocheltree looks over plans for the student body project.

\section{Student}

\section{Council}

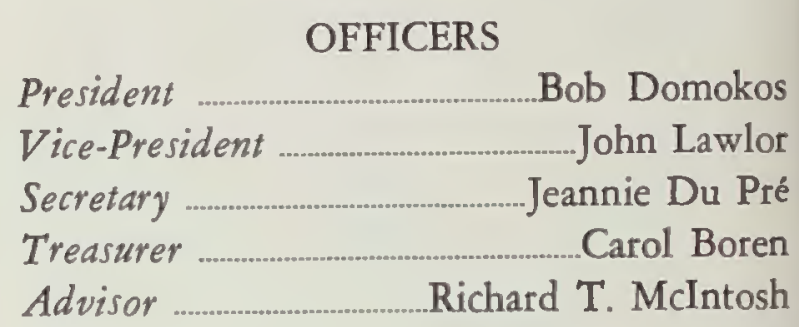

During the first semester the student body elected Sam Canine and Ted Ocheltree as Student Body Project Co-Chairmen. They were responsible for the planning and promoting of the funds, which the students voted to put into the general student center fund. The aim of the project, which ran from February 19th until May 23rd, was for each student to give three cents a day for six days a week. The money was tossed into the wishing-well displays located in the dining hall, the Administration building, and the College bookstore. 


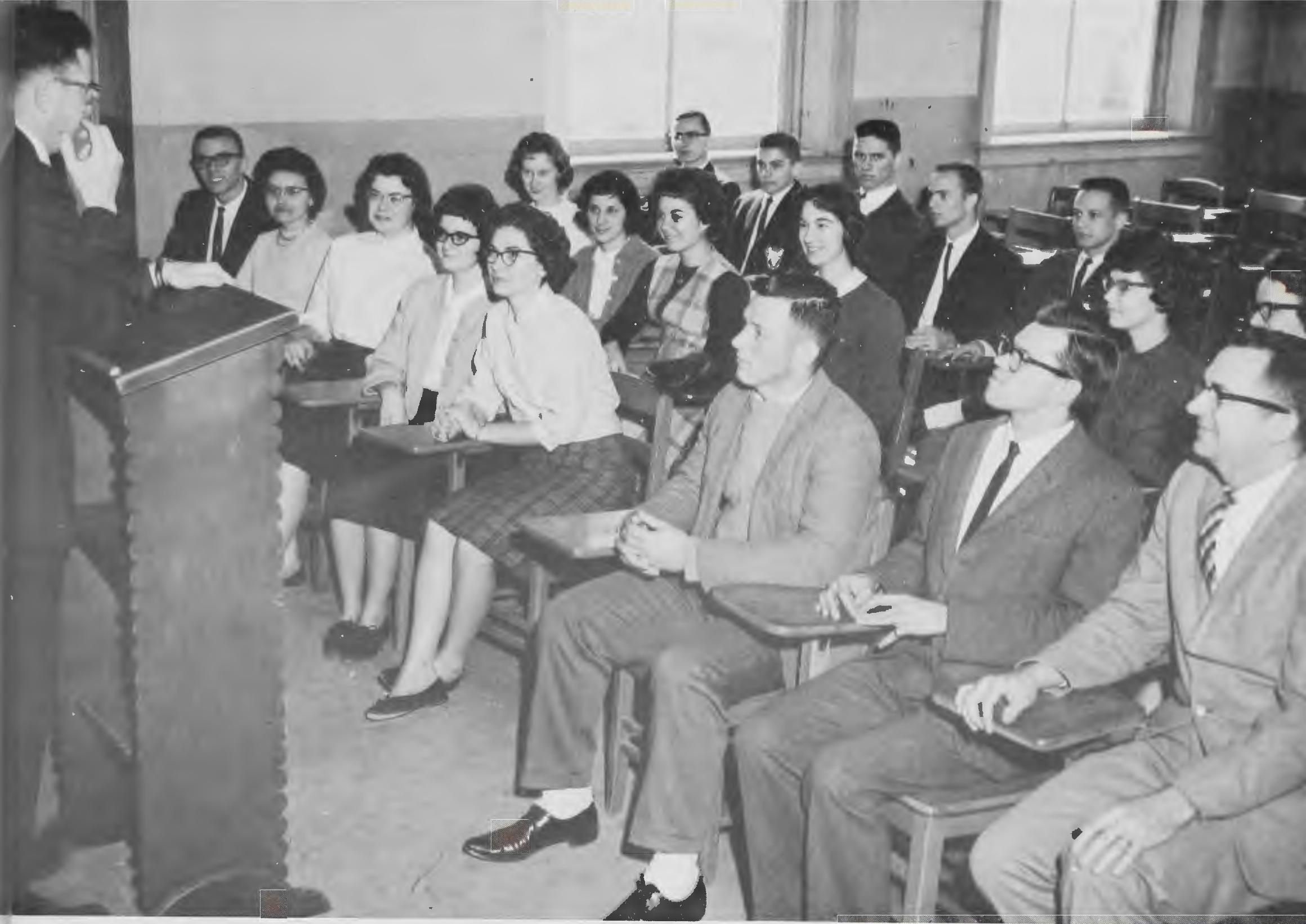

TOP ROW, Left to Right: Paul Reno, Mark Haseltine, Don Tennant, Ted Ocheltree, Jøhn Lawlor. SECOND ROW: Louann Wall, Dolly Kidd. FIRST ROW: Dave Warren, Patricia Schonscheck, Jane Ginz, Carol Boren, Bonnie Nash, Richard Rich, Keith Mundhenk, Pat Adams, Jeannie Du Prè, Nancy Shimits, Betty

Webster, Mr. Richard T. McIntosh. AT PODIUM, Bob Domokos.

The Student Council, which "is the representative assembly of the student body," had a busy and fruitful year. A few of the goals accomplished for the year were the purchasing of a new bulletin board for the Administration Building, helping to promote school activities, and acting as local sponsor for the Bloodmobile, which paid two visits, on October 16 and on January 18 , to the village. They also furnished transportation to Cedarville from Xenia, Springfield, and Dayton for incoming students at the start of each semester.

Don Tennant and John Lawlor were sent as representatives by the Student Council to the regional meeting of the American Association of Evangelical Schools in Greenville, Indiana; during the Thanksgiving holidays. 


\section{Alpha Chi}

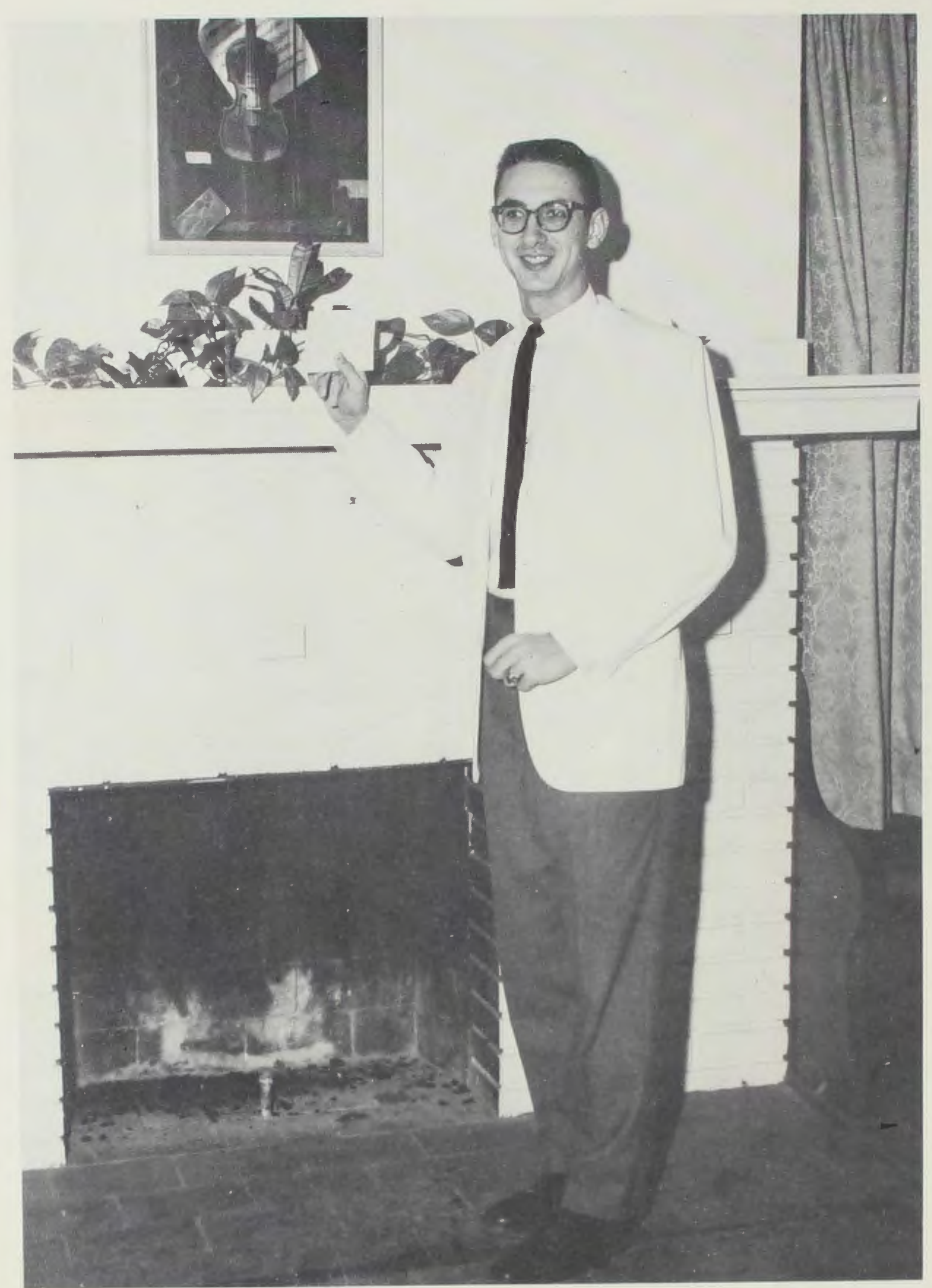

Dave Earnhart, President

Alpha Chi, the men's society on Cedarville campus, planned and presented the annual Thanksgiving banquet again this year. They were assisted by Miss Ruth Smith and Mr. John Reed who directed the program of the evening. As a part of their first semester program, two films, "The D. E. W. Line" and "Seconds for Survival," were shown. 


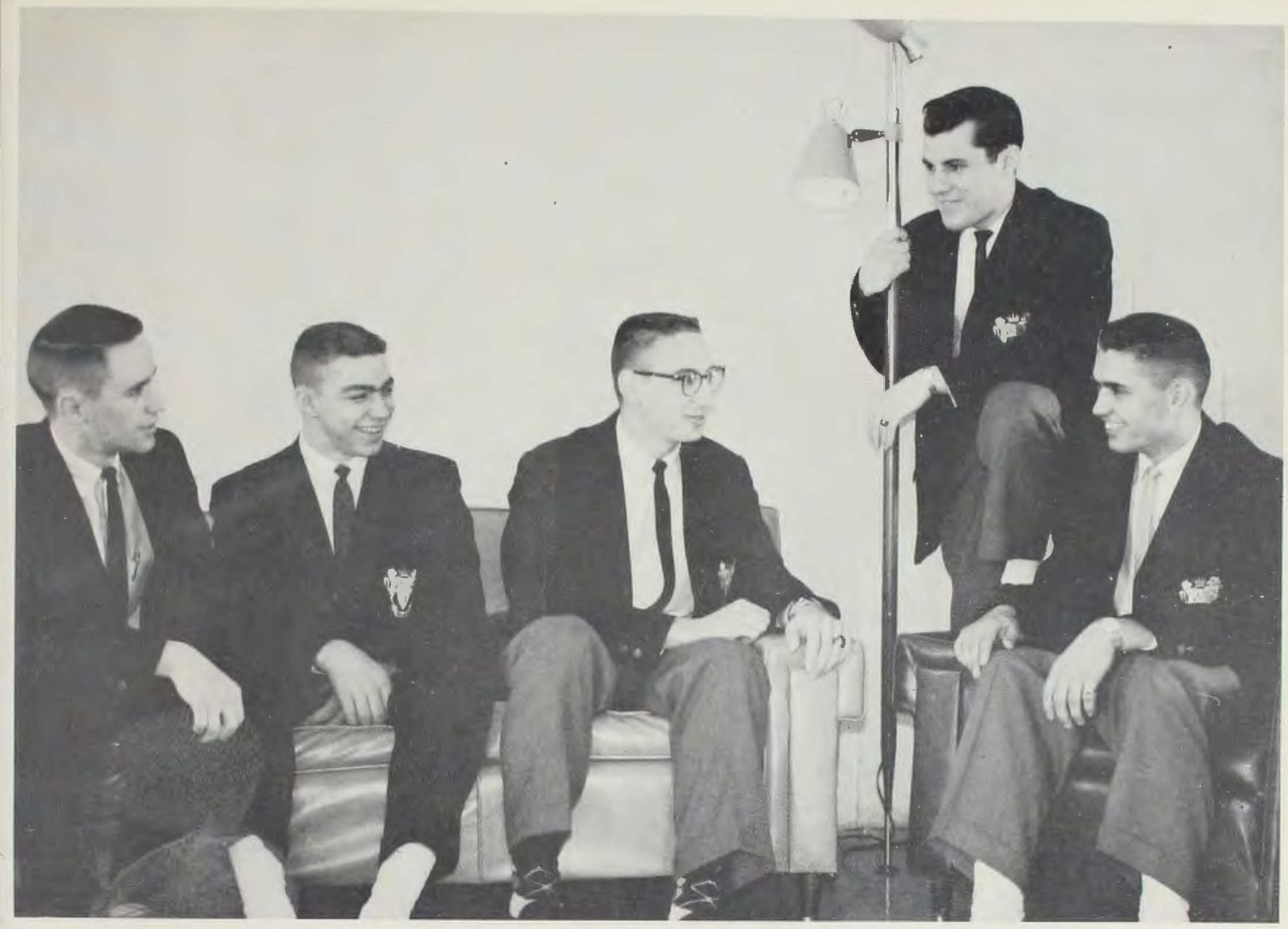

Left, to Right: Otis Stone, Gordon Finley, Dave Earnhart, Tony Rotondi, Warren Burnside.

\section{OFFICERS}

President Vice-President Secretary-Treasurer Chaplain

Parliamentarian Student Council Representative

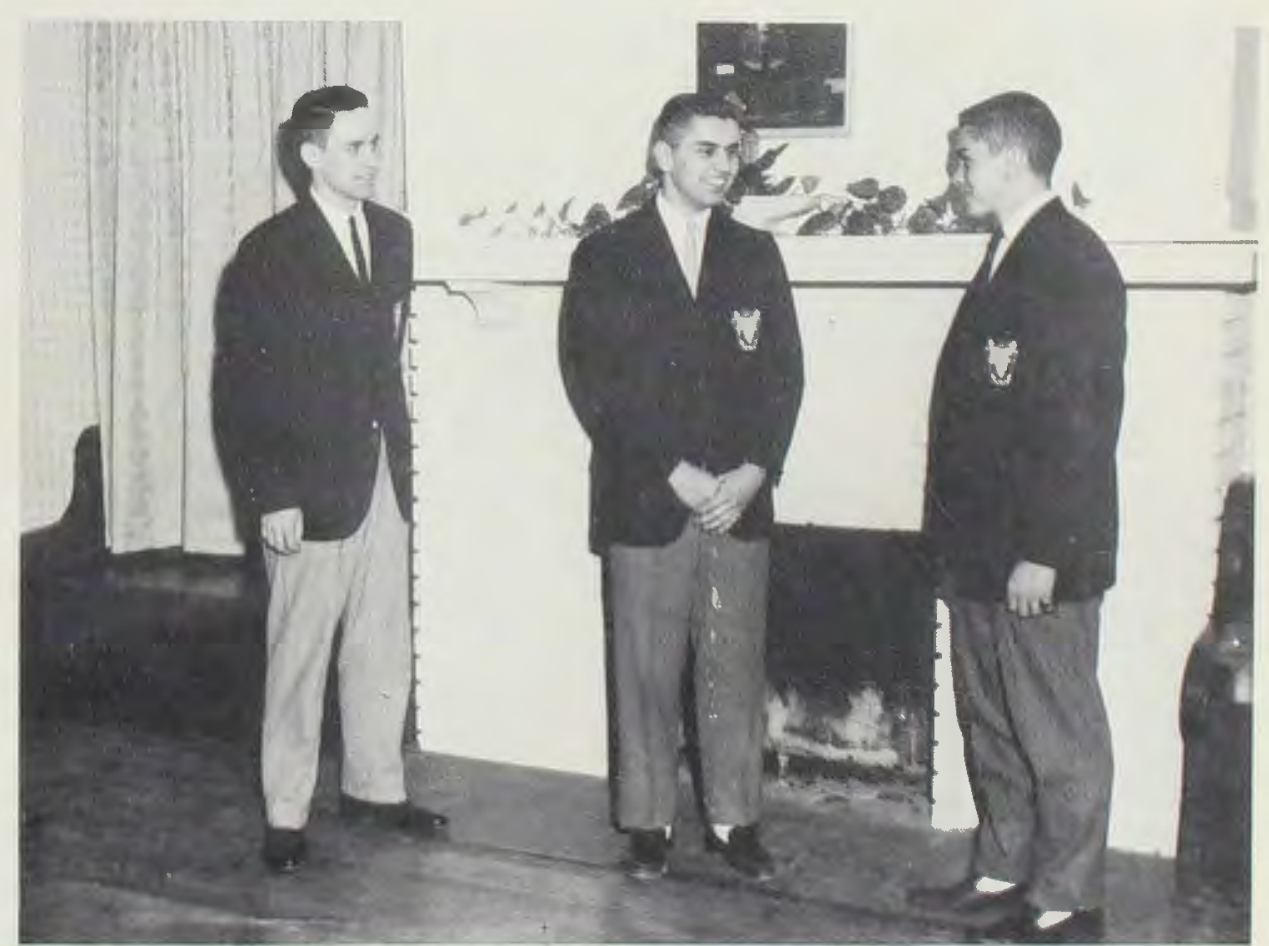

Left to Right: Otis Stone, Vice-President; Warren Burnside, SecretaryTreasurer; Mark Haseltine, Student Council Representative. 


\section{Gamma Chi}

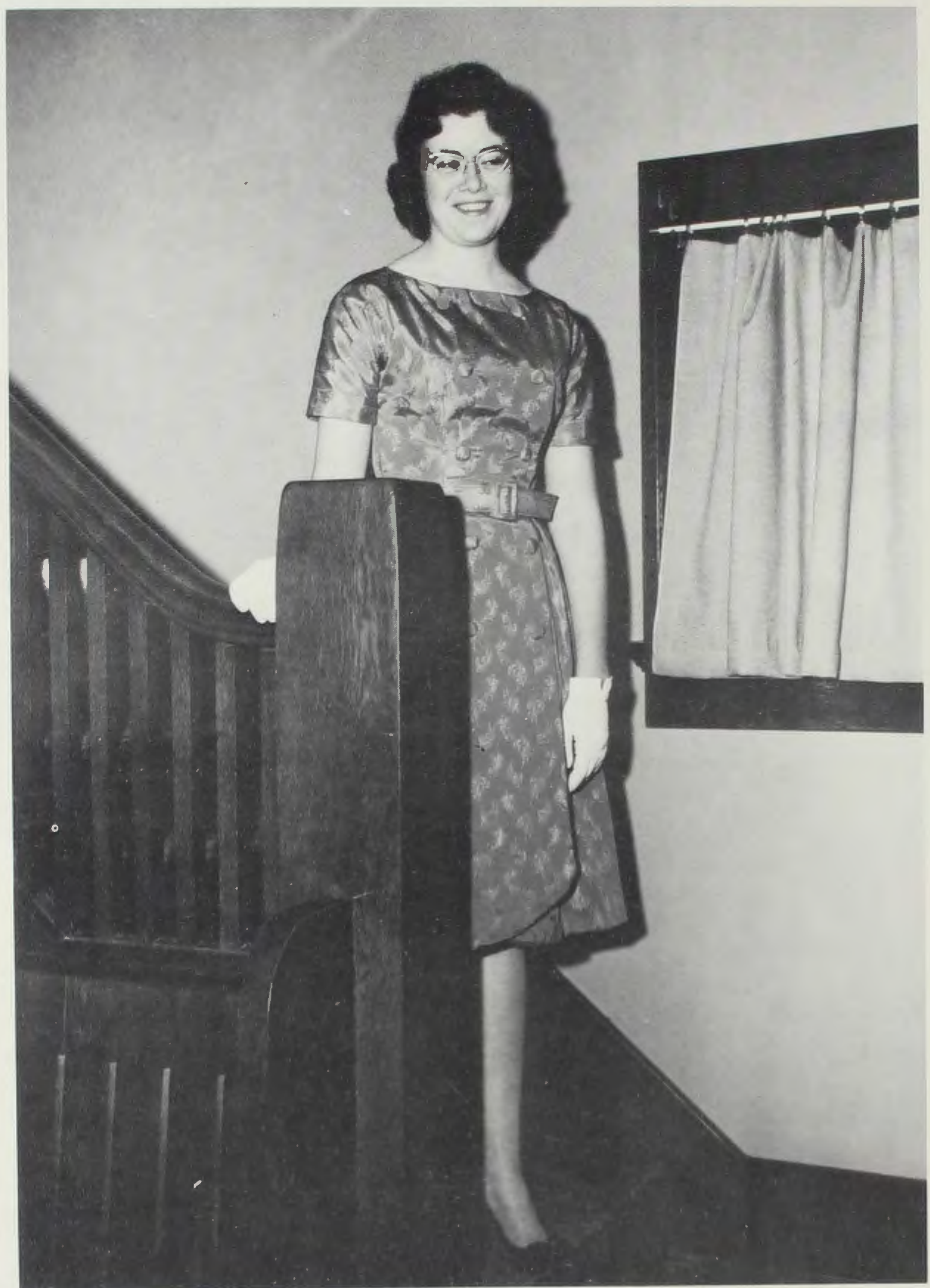

Jane Ginz, President

Gamma Chi, one of our oldest organizations on campus, has had a very successful year. They began their activities in October with an Autumn Reception for new students. Their first annual Alumni Tea was held November 18th during the Homecoming weekend. December found the executive committee planning a faculty-student Christmas party. In keeping with their purpose of promoting literary and cultural activities, the club sponsored the film "MacBeth" in March. Their advisor, Mrs. Maddox, entertained the women of the club with a buffet dinner in April at her home. In May new officers were elected and installed.

The big event of the year for "girls of Gamma Chi" is the winter semi-formal banquet, which they sponsored in February. The planning committee, composed of Rosa Lee Albrecht, Donna Finley, Betty Smith, Bonnie Nash, Margaret Stowell, and Lois Jacobson, began their work in November to make an evening to remember. 


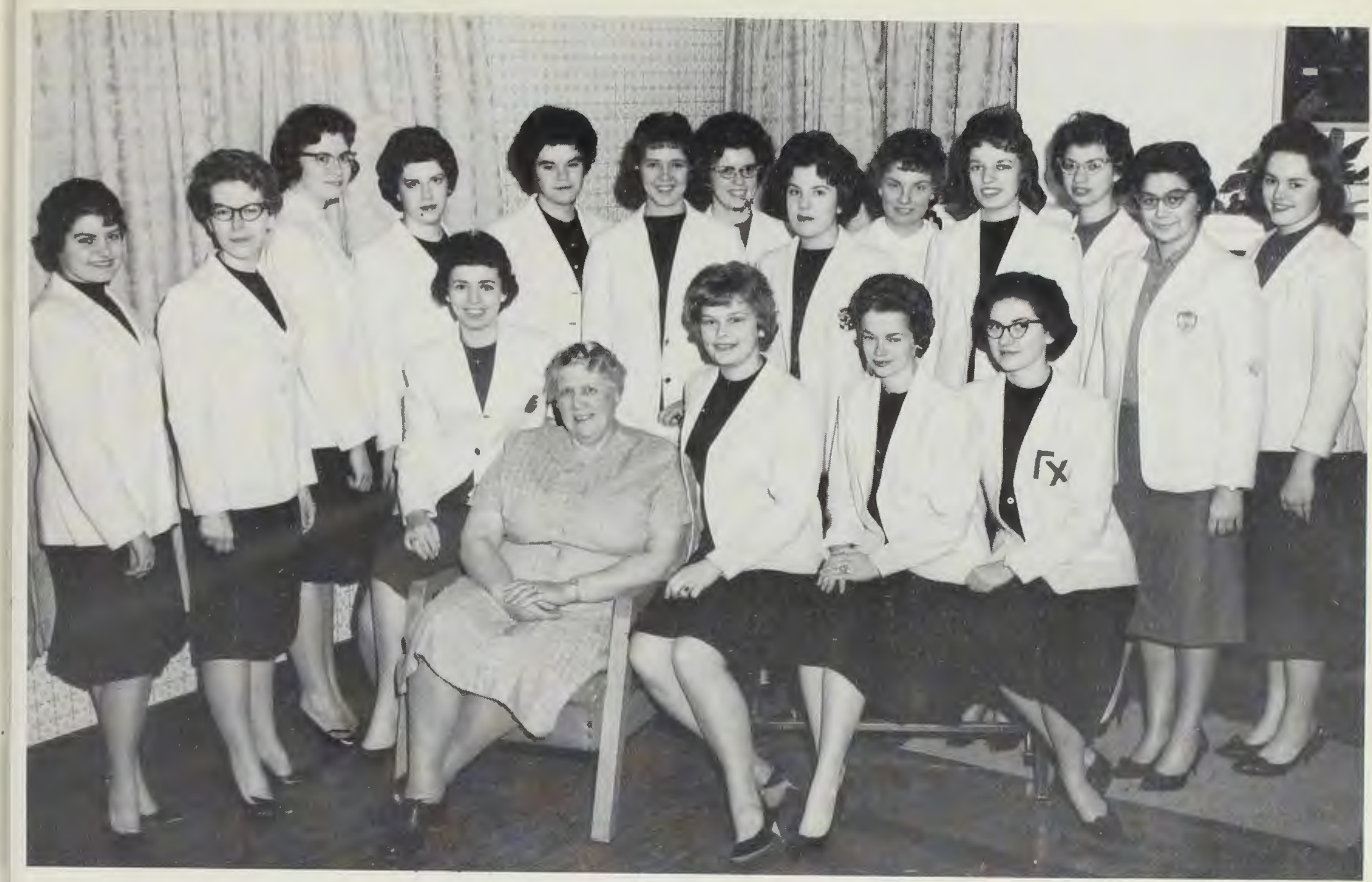

TOP ROW, Left to Right: Pat Terry, Rita Millikin, Jane Ginz, Elaine Adams, Sue Fullhart, Joan Bryant, Shirley Byrd, Donna Johns, Penny Brown. SECOND ROW: Irene
Lane, Sarah Balke, Michal Geeting, Donna Finley. FRONT ROW: Pat Barrett, Mrs. Maddox, Margaret Stowell, Judy Dadisman, Bonnie Nash.
President

Tice-President

Jane Ginz RosaLee Albrecht iecretary

reasurer

ocial Chairman

Shirley Byrd

Donna Finley Margaret Stowell Program Chairman

Sue Fullhart 'arliamentarian

'tudent Council Rep.

Pat Barrett

Bonnie Nash Mrs. Maddox

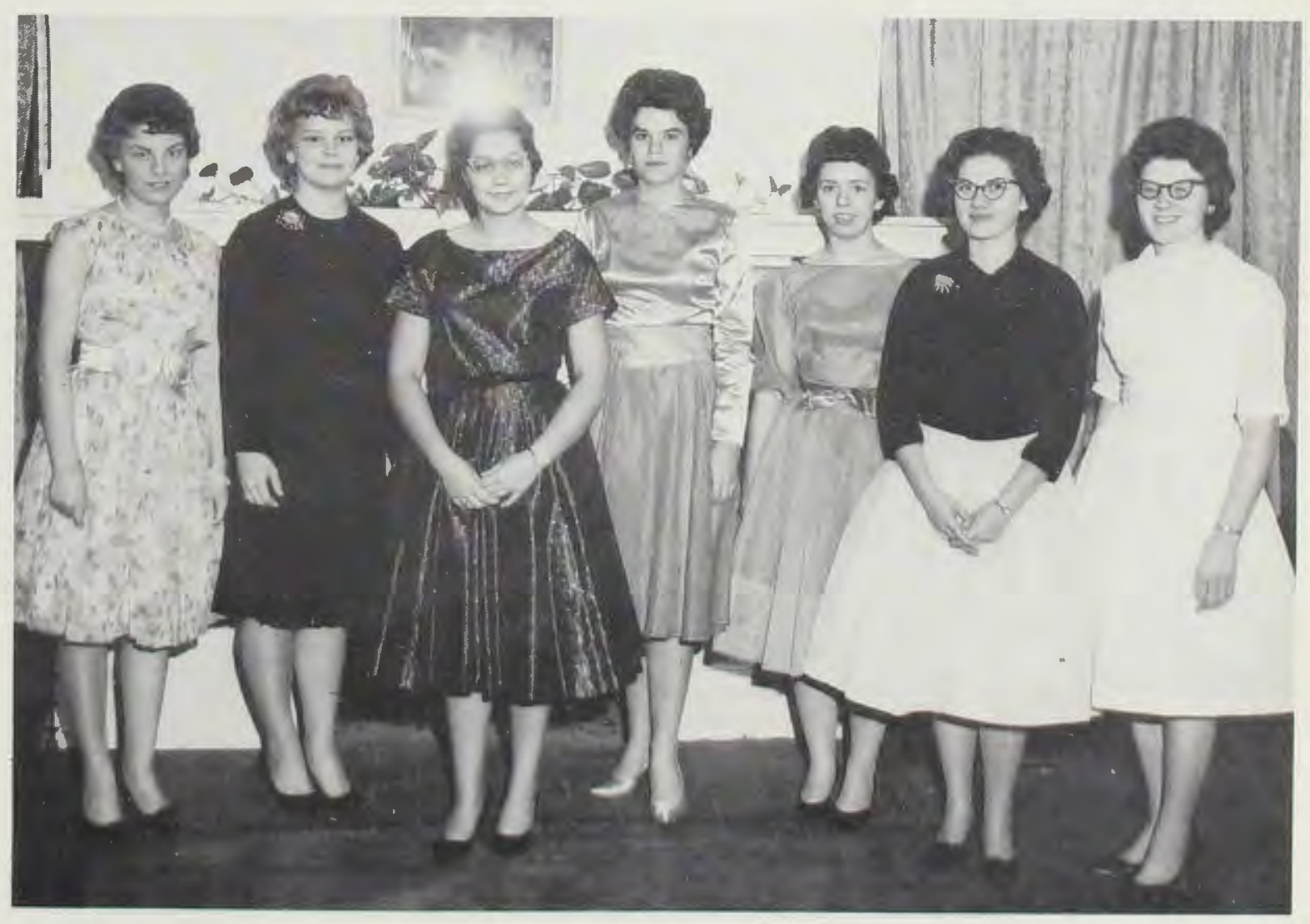

Left to Right: Shirley Byrd, Margaret Stowell, Donna Finley, Sue Fullhart, Pat Barrett, Bonnie Nash, RosaLee Albrecht. 


\section{Kappa Delta XI}

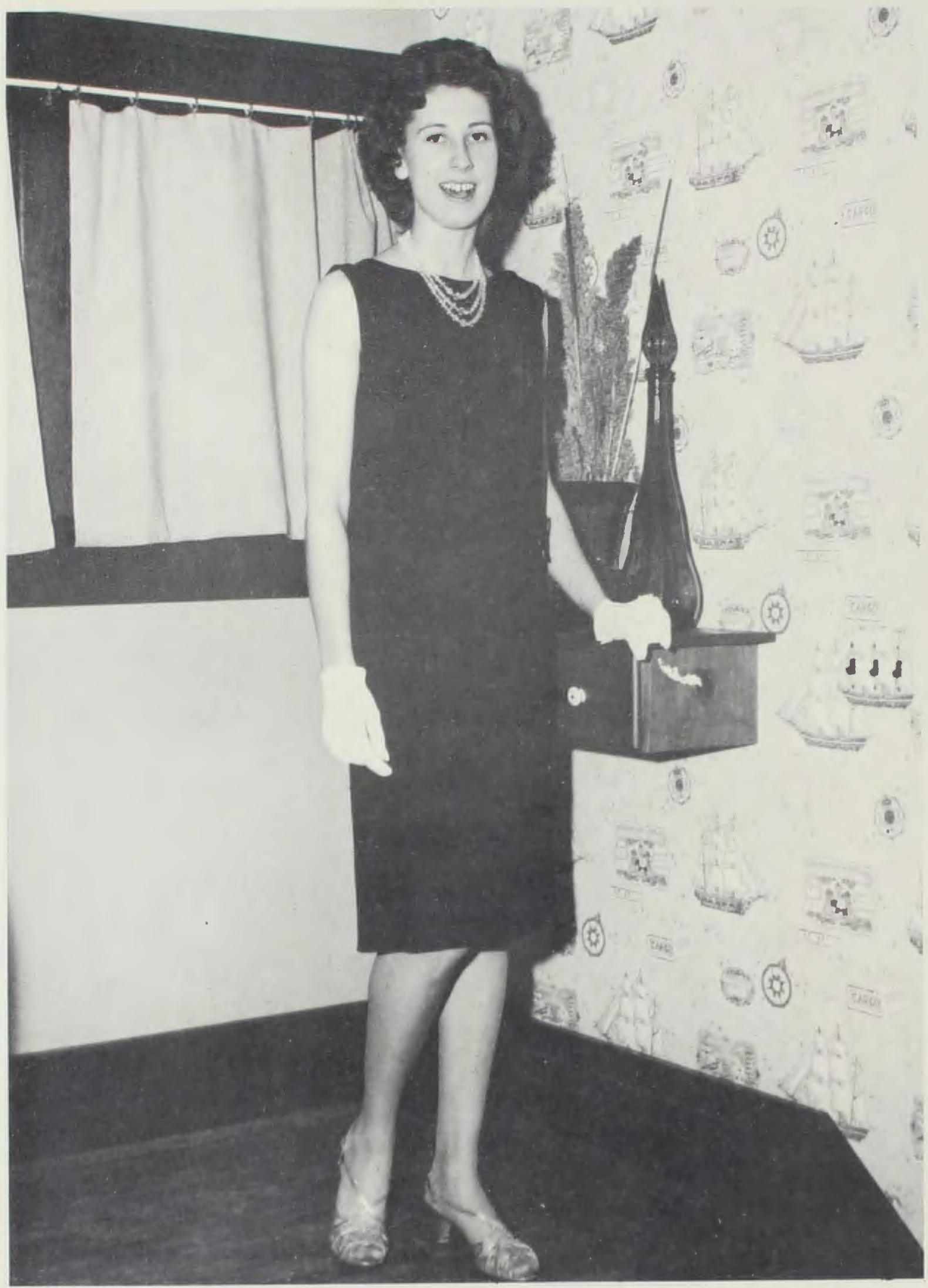

Hazel Brovont, President

Kappa Delta Xi is a newly organized women's literary society for sophomore, junior, and senior girls. Special activities of the year included sponsoring an all-school party, the Kandy Kane Kaper, in December, attending the Art Institute in Springfield during February, and attending a bridal show sponsored by Lazarus of Columbus in April. Regularly scheduled meetings featured a discussion on diamonds sponsored by Braun's Jewelers of Xenia, and hints on social etiquette of a pastor's wife by Mrs. Niles Fisher of Emmanuel Baptist Church in Dayton.

The club members earned over fifty dollars from the coat and hat check concession that they sponsored at all of the home basketball games this season. 


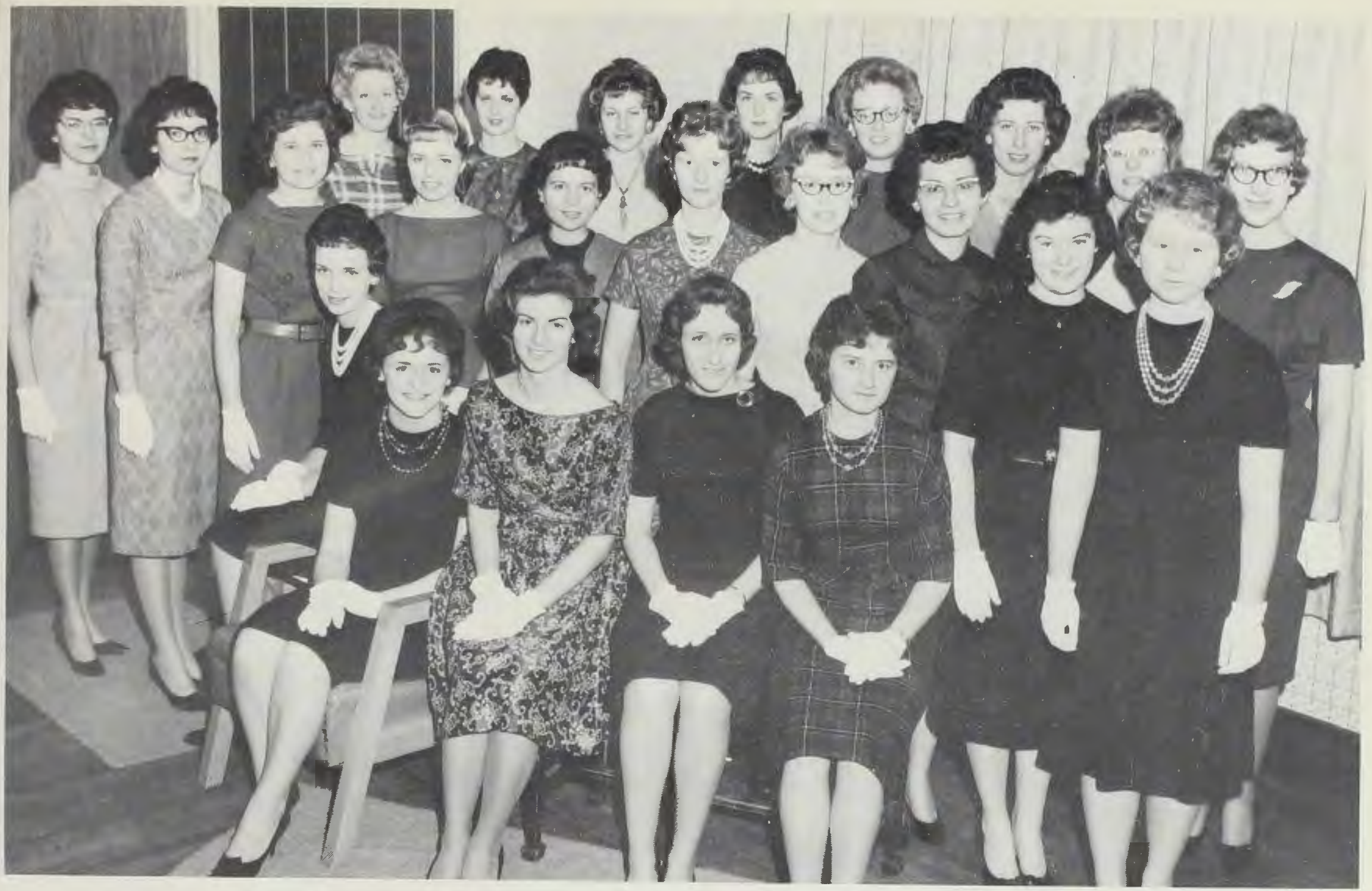

TOP ROW, Left to Right: Bette Adamson, Flo Cannon, Judy Siplock, Carole Lanius, Barb Adamson, Hazel Brovont, Clara Quiter, Barb Hemenway. SECOND ROW: Betty Wall, Pat Micka, Carole Hell, Donna Davis, Elaine Jordon,
Lois Duddleston, Joan Johnson, Beverly Lyon, Judy Gingell Faye Haas. FRONT ROW: Donna Thompson, Bobbie Unzicker, Sandy Shanks, Joan Carter, Betty Schultz.
President

Vice-President

Hazel Brovont

Donna Thompson

Secretary

Treasurer

Donna Davis

Co-Social Chairmen

Barb Adamson

Carole Lanius Pat Micka

\section{Parliamentarian}

Chaplain

Carole Hell

Student Council Representative Advisor

Betty Wall Mrs. Callan

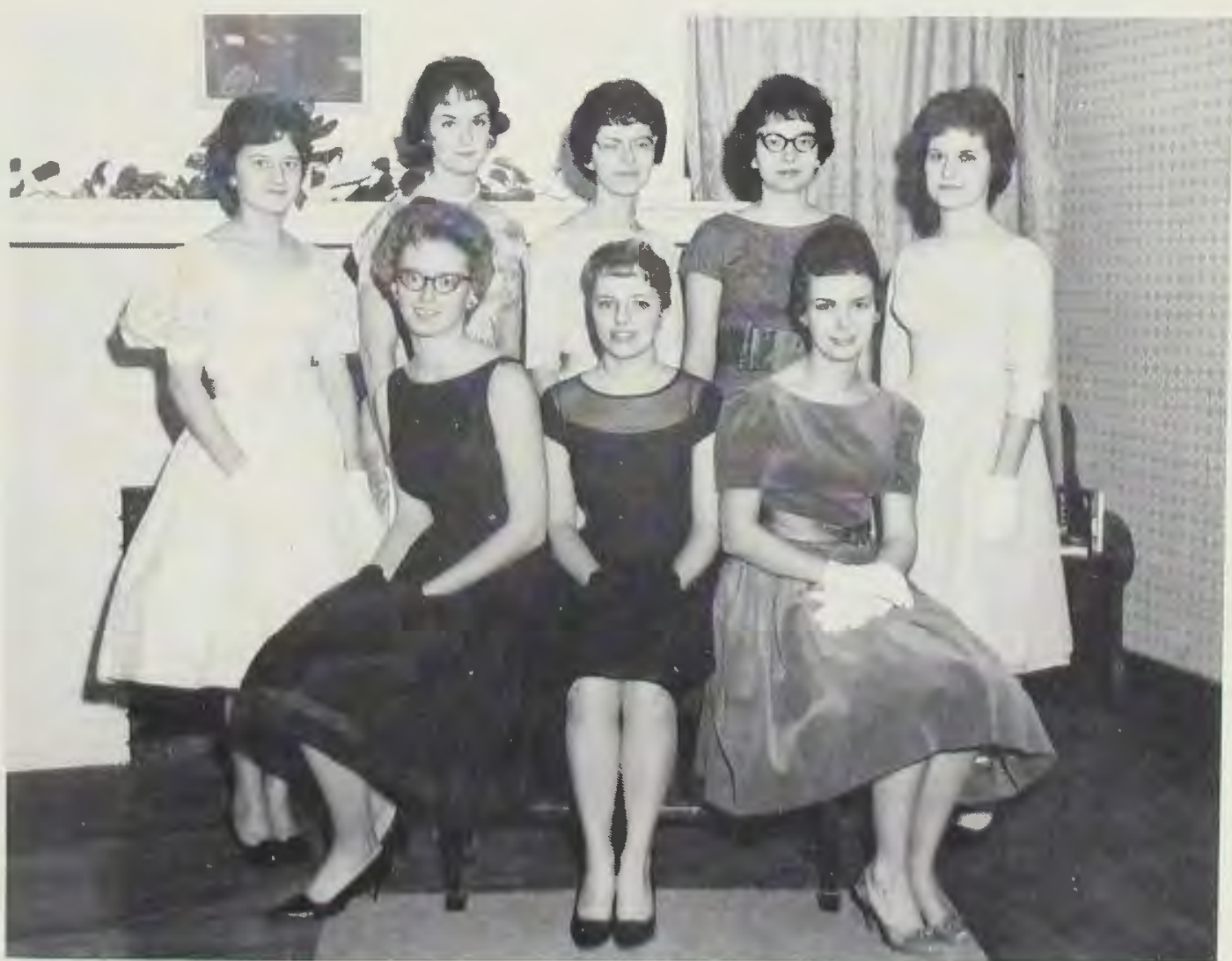

TOP ROW, Left to Right: Betty Schultz, Carole Lanius, Betty Wall, Pat Micka, Carole Hell. FRONT ROW: Barb Adamson, Donna Davis, Donna Thompson. 


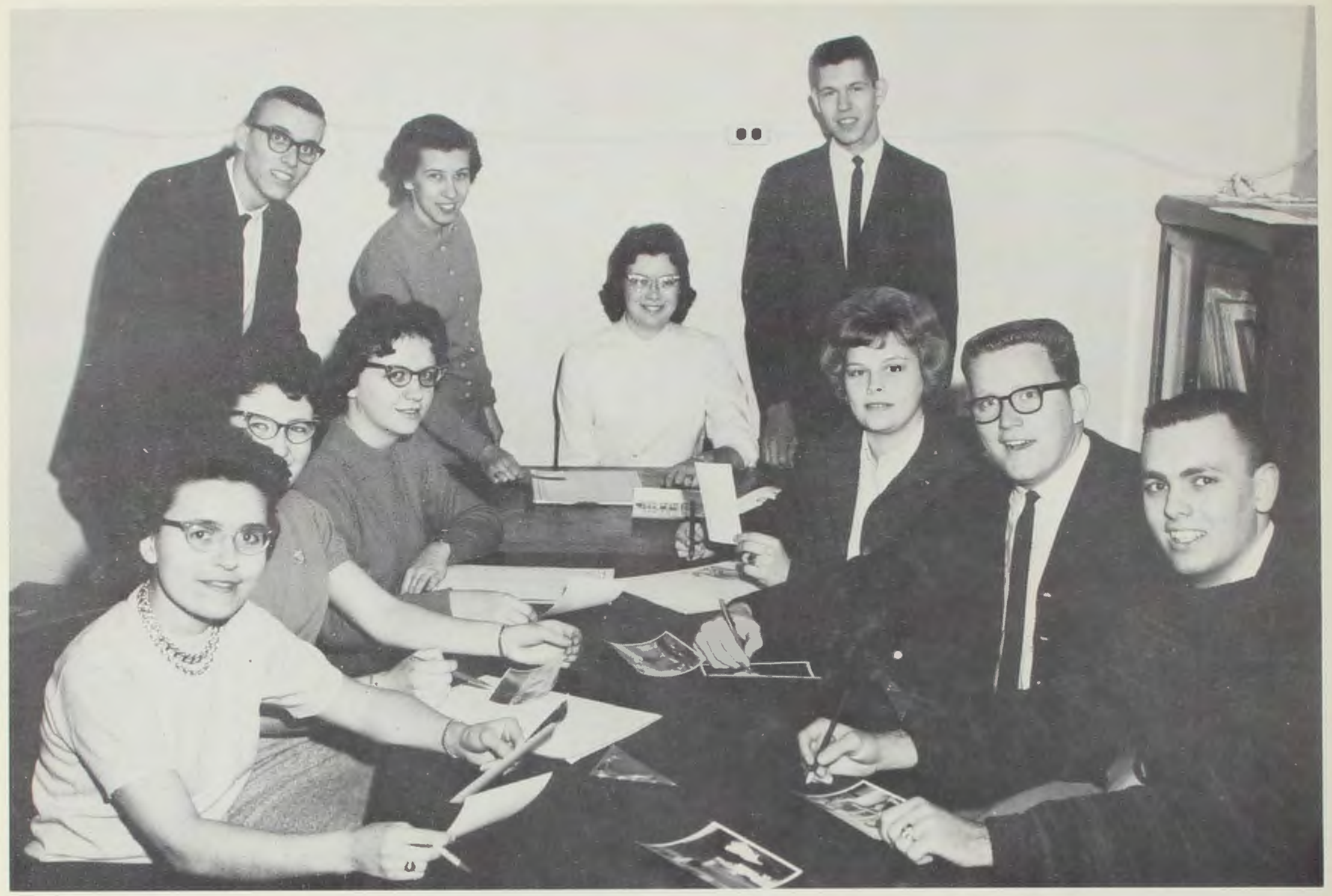

Patricia Schonscheck, Bev Woods, Lois Bayless, Dave Warren, Miss Kantzer, Jane Ginz,

Dave Taylor, Margaret Stowell, Rich Davidson, Bob Fidler.

\section{The}

\section{Miracle}

Returning to the campus in September with enthusiasm Editor Jane Ginz was determined to beat the second class rating the 1961 "Miracle" received in Associated Collegiate Press Competition among colleges. Bent on publishing the best yearbook ever in the 75-year history of Cedarville College, the staff pitched in to produce a heritage section to be printed in large quantities for use as a publicity brochure. While affording the students an opportunity to learn the history of the college and to get better acquainted with people of the community, this assignment proved to be an enjoyable experience.

\section{STAFF}

Editor Jane Ginz

Business Manager. Bev Woods Art Editor Dave Taylor Copy Editor. Margaret Stowell Sports Editor Bob Fidler Advertising Manager ....................................... Rich Davidson Assistant to Advertising Manager.................Lois Bayless Typist Patricia Schonscheck Photographer Dave Warren Advisor Miss Ruth Kantzer 
When prospective members of the yearbook staff applied last spring, they wondered why such questions as "how many hours will you be taking" and "what are your other obligations" were asked. Having sacrificed dates and jam sessions in order to meet deadlines, members of the staff have no wonder about the questions now as this last deadline goes to press.

Regular Tuesday evening meetings throughout the year kept the staff constantly working on the year-long job.
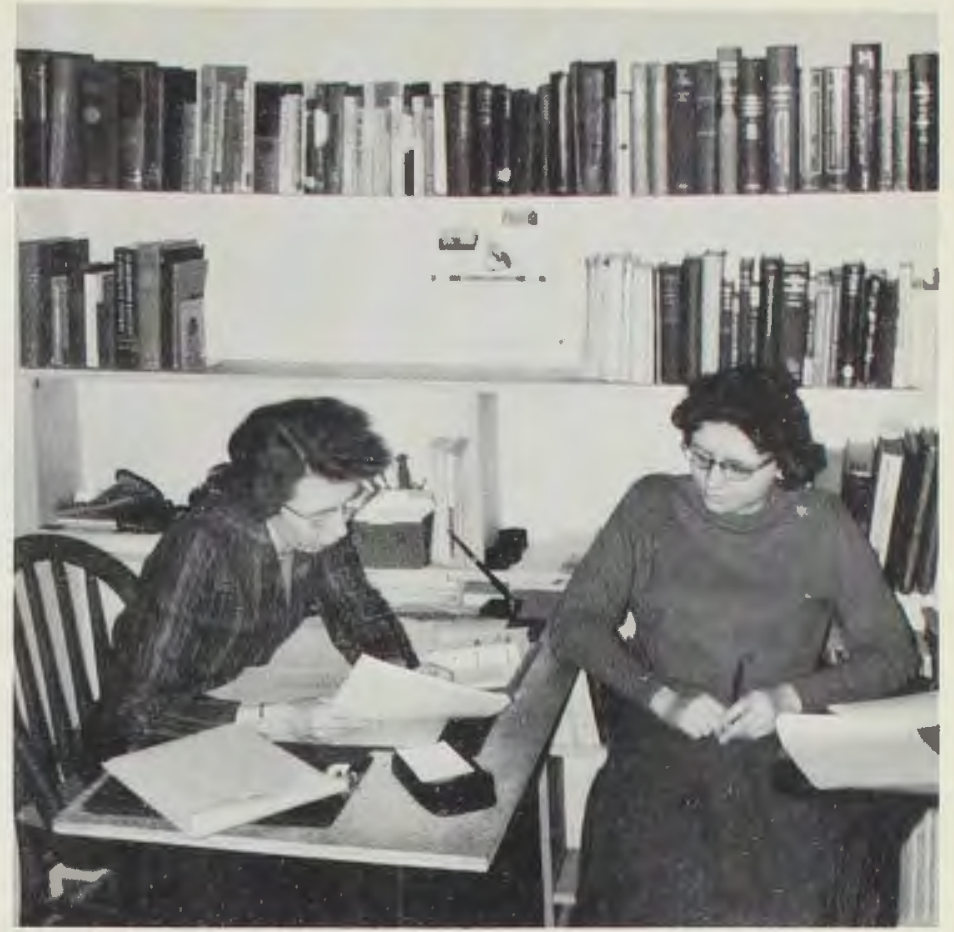

Sports-editor, Bob Fidler, caught the staff in action at a Tuesday night work night. Here our art editor, Dave Taylor, goes over a layout with Jane Ginz, Editor-in-Chief. Rich Davidson works away at his advertising copy.

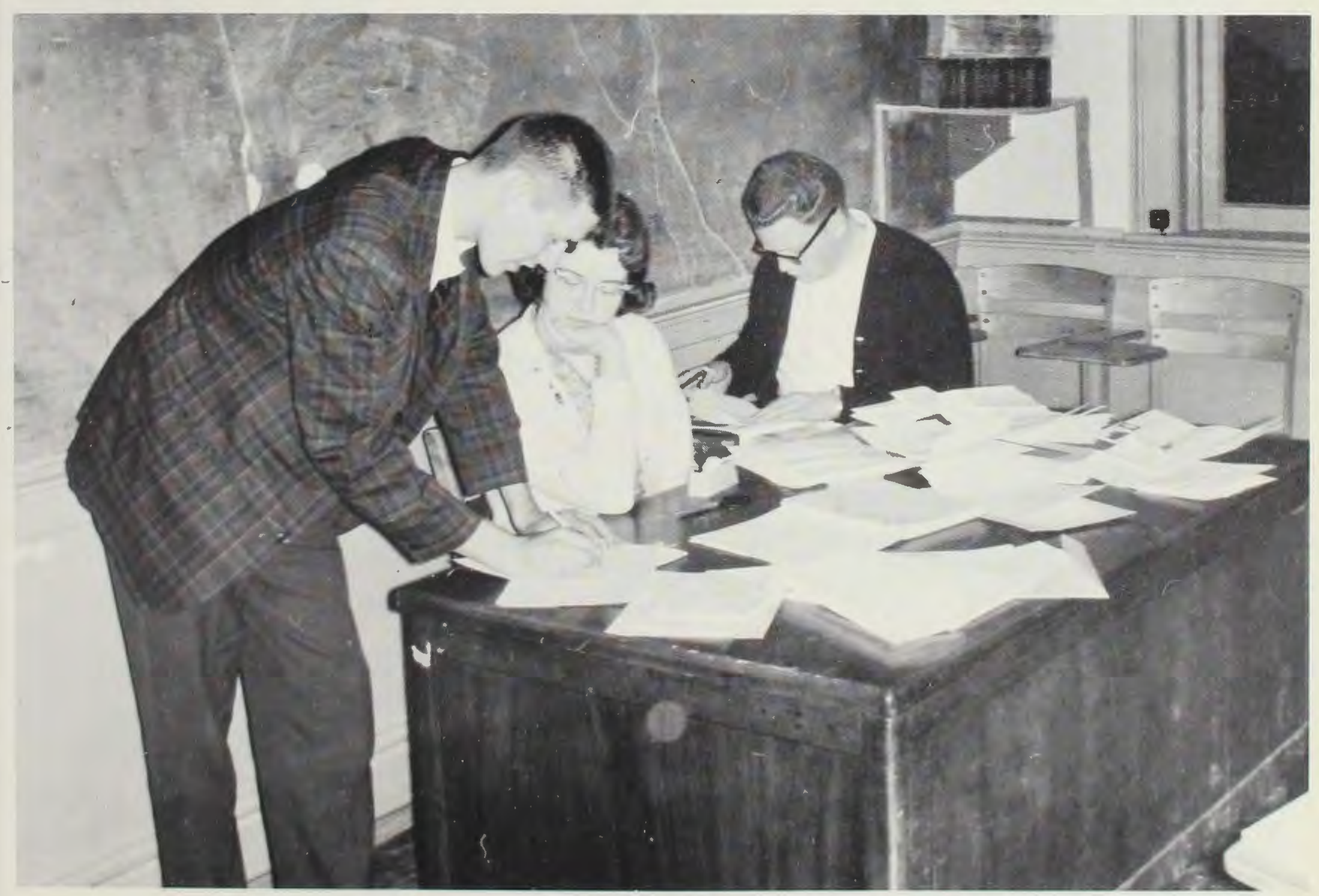

Lois Bayless seeks approval of temporary layouts from Miss Kantzer. 


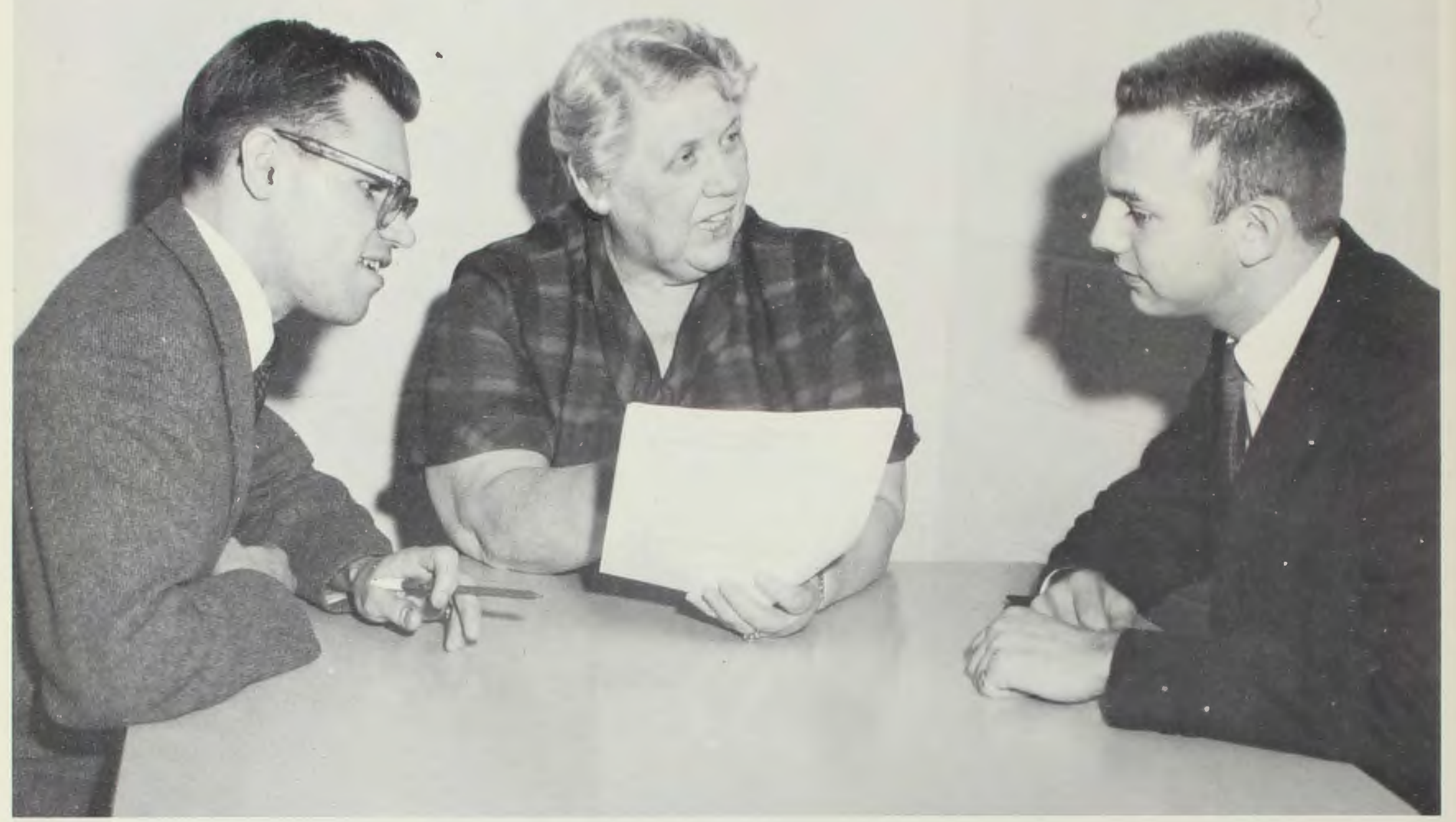

Keith Webster, Mrs. Maddox, Advisor, and Paul Gathany.

\section{Sock ' $n$ '}

\section{Buskin}

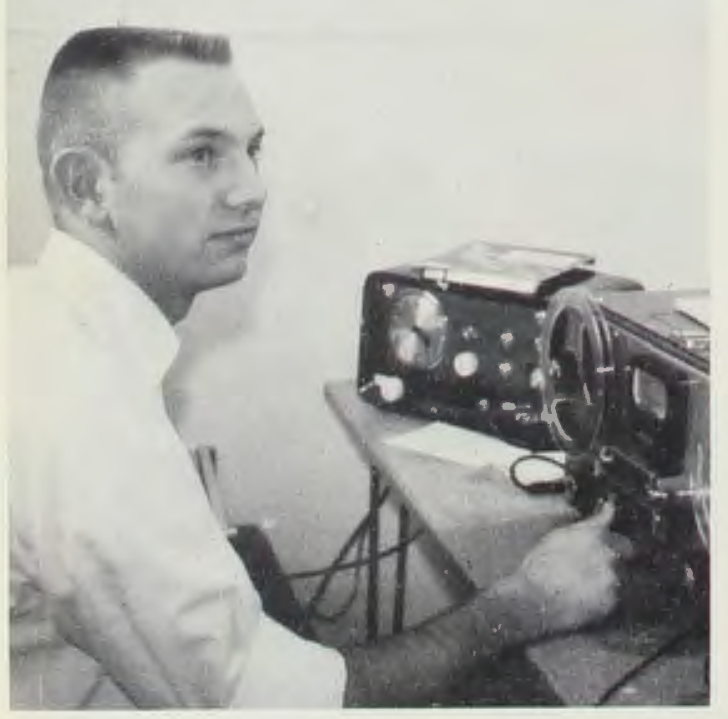

Paul Gathany's knowledge of electronics has proved valuable in the production of plays.

Sock ' $n$ ' Buskin has been changed and reorganized this year. Because of this transition a full program for the year was not developed. Nevertheless, its two remaining members, Keith Webster and Paul Gathany, continued their service to the school through the avenues provided by the club.

Advised by Mrs. Maddox, a group of interested students changed the point system, set up a constitution, and made further plans for the future development of the club. 


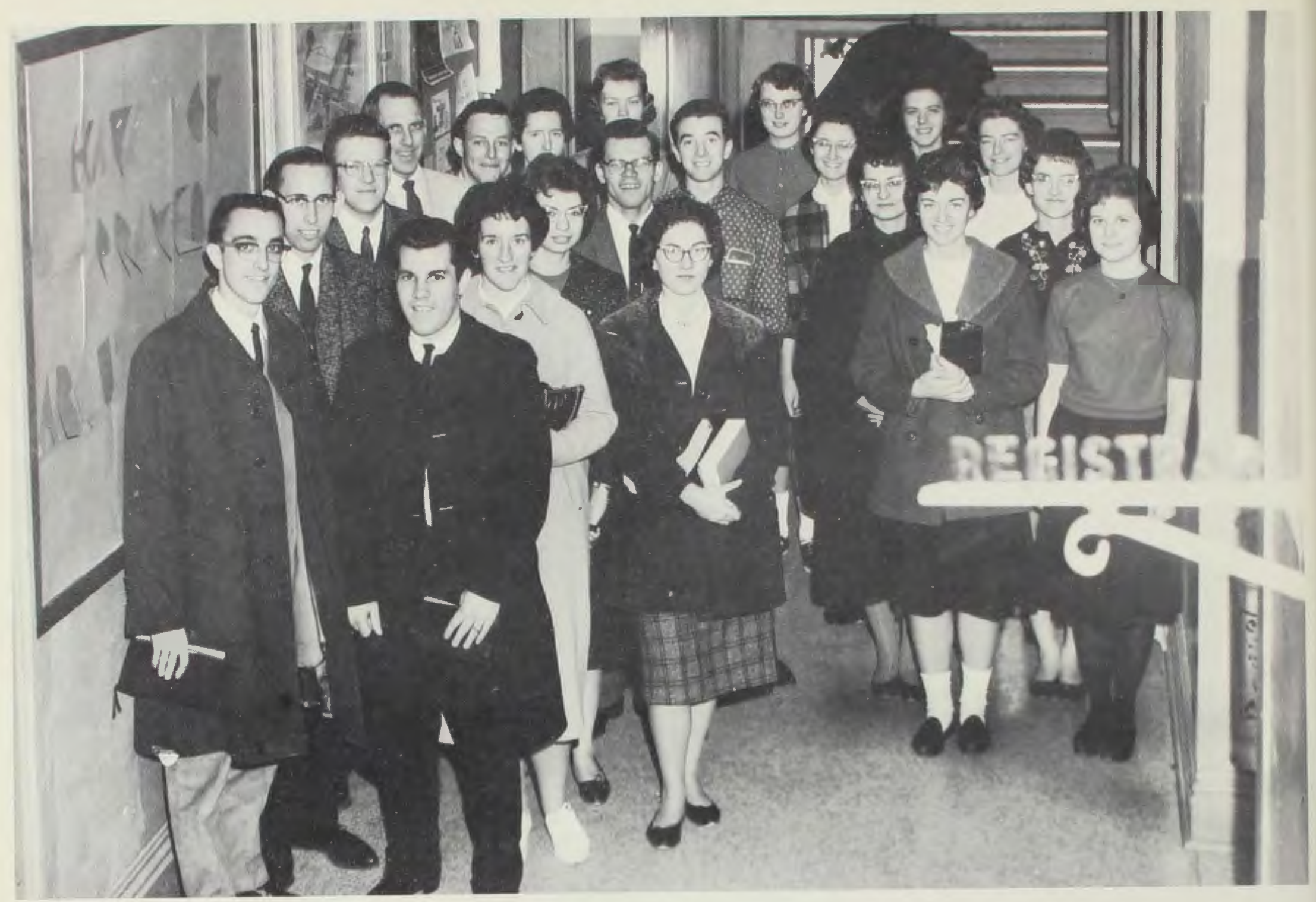

Left to Right: Marv Stephens, Tony Rotondi, Lauren Schenck, Barb Slavens, Bonnie Nash, Bob Domokos, Donna Johns, Cathy Shelton, Carole Hell, Gerald Wagnitz, Keith
Webster, Beverly Lyon, Julie Petrie, Richard Rich, Betty McKeehan, Tony Nicklas, Carol Brown, Charlene Ressler, Irene Benson, Mollie Schmitt, Sandy Kirisits.

\section{Fellowship of}

\section{World}

Fellowship of World-Missions meets each morning Monday through Friday at 7:30 for prayer meetings for missionaries around the world. President Lauren Schenck devised a system of rotation by last names whereby the club could be divided into small bands praying for each of the four world sections: North America, South America, Africa, and Europe-Asia. The fellowship, cooperating with the Grace Baptist Church of Cedarville, sponsored the annual missionary conference April 4th through 8th.

\section{Missions}

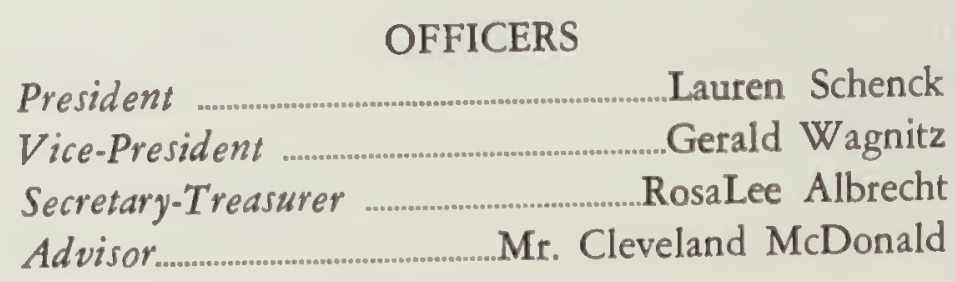




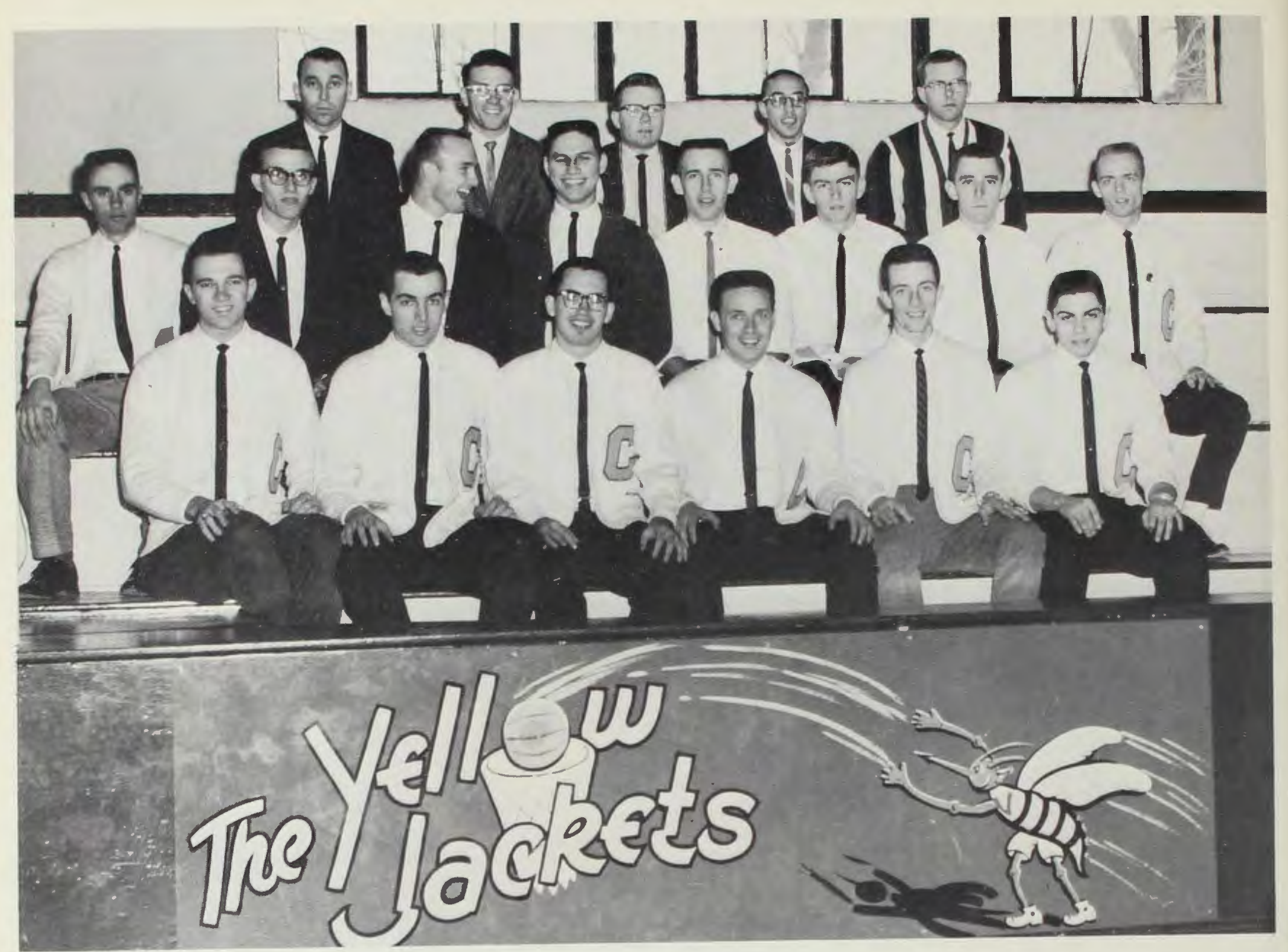

TOP ROW, Left to Right: Mr. Callan, Al Biddle, Tom Evans, Tom DeLanzo, Jerry Peifer. SECOND ROW: Otis Stone, Dave Warren, Bob Ellis, Don Tennant, Dennis Mc-
Donald, Rod Lane, Jim Sprague, Ted Ocheltree. FRONT ROW: Jack Moffat, Dave Jeremiah, Bill Elder, Dave Lewis, Norris Smith, Mark Haseltine.

\section{Varsity}

Another active club on campus this year has been Varsity " $C$ ". They have accomplished their aim of boosting the team's and the spectators' morale by sponsoting the painting of the gym, taking care of the concession stand at the home games, and being responsible for the church basketball tournament in March. The club buys each member a Varsity " $C$ " sweater after he earns two letters and a jacket after he earns three. This year they put their excess funds into the general student center fund.

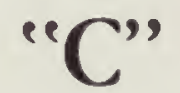

\section{OFFICERS}

1st Semester President. ..Jim Grafton

2nd Semester President,

Vice-President Mark Haseltine

Secretary Rod Lane

Treasurer Norris Smith

Chaplains Dave Jeremiah Jack Moffat

Student Council Representative. .Ted Ocheltree 


\section{Pep Club}

\section{OFFICERS}

President

Vice-President

Secretary

Treasurer

Student Council Representative.
Warren Burnside Jay Moore

Bobbie Unzicker Dave Jensen Ardith Cayton
The Pep Club, our newest organization on campus, is to insure "regular, enthusiastic support of the team." The fortyfive members went all-out in support through new cheers. Flashcards, which spelled out "Cedarville Jackets," were used in the Cedarville cheering section for the first time.

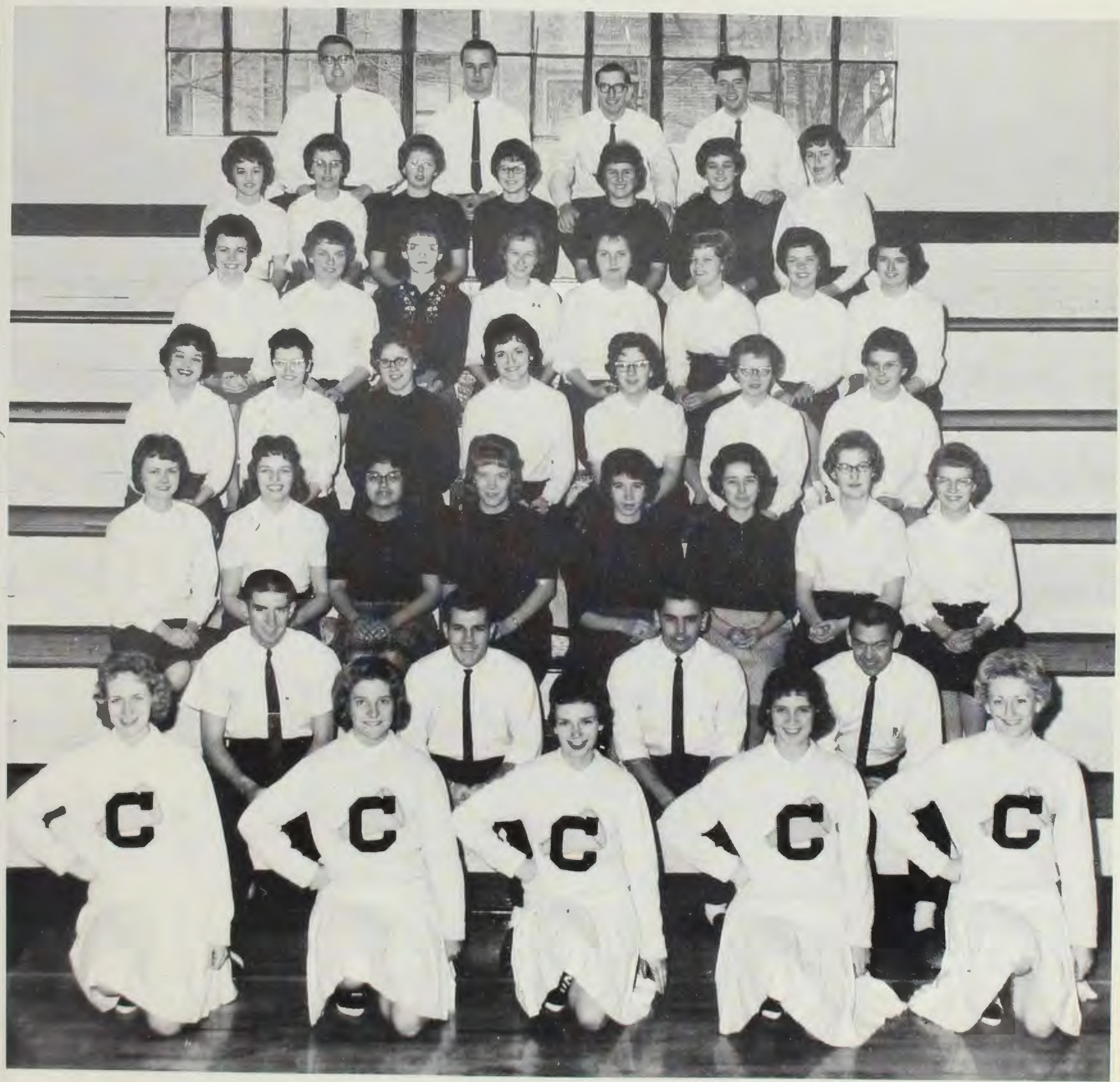

TOP ROW, Left to Right: Gary Johnson, Joe Osborne, Bob Baldock, Dave Jensen. SECOND ROW: Marian Rothwell, Helen Wing, Pat Versluis, Shirley Jean Sichting, Vicki Curcio, Mary Goodwin. THIRD ROW: Jeneen Williams, Shirley Byrd, Julie Petrie, Louann Mundhenk, Judy Tobias, Nancy Kettell, Sue Fennell, Dorothy Lightly. FOURTH ROW: Kathy Alberter, Sharon Ackerman, Jo-an
Nelson, Bobbie Unzicker, Sharlene Wellman, Susan Martin, Gayle Gordon. FIFTH ROW: Ardith Cayton, Michal Geeting, Julia Olivas, Connie Ward, Sylvia Wing, Sue Bartheld, Sue Geyser, Mary Ellen Powell. SIXTH ROW: Elvin King, Tony Rotondi, Warren Burnside, Jay Moore. FRONT ROW: Judy Lachman, Pat Kaster, Donna Thompson, Irene Lane, Bette Adamson. 


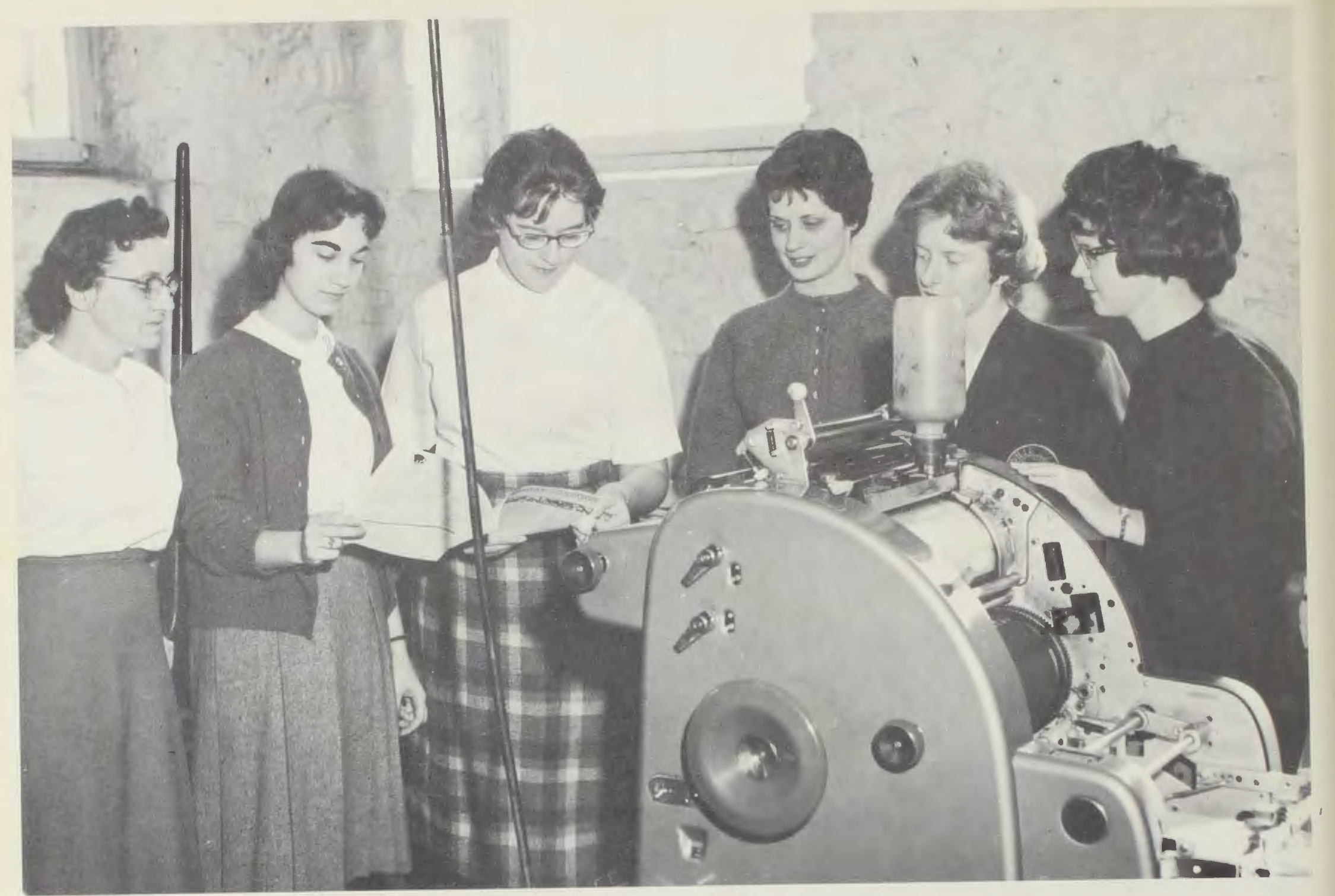

\section{Whispering}

Cedars

Whispering Cedars, enlarged and revised, this year was printed on campus by Mrs. Jeremiah. The paper, produced and published by the students, appeared three times during the first semester. Students on the staff first semester only were Jan Amos, Faye Doctor, Ginny Hindman, and Jay Moore.

STAFF

Editor

Reporters
Nancy Shimits Mary Blann

Flo Cannon

Lois Duddleston

Carol Dykstra

Suzanne Geyser

Bonnie Hammeck 


\section{Modern Music Masters}

Modern Music Masters is a national organization to recognize college students with outstanding musical ability. Members are chosen on the basis of leadership, scholarship, cooperation, service, and character. Officers are: President, Sam Canine; Vice-President, Carol Brown; Secretary, Elayne Howard; Treasurer, Judy Lachman; Historian, Donna Finley; and Sponsor, Mr. R. A. Cooke.

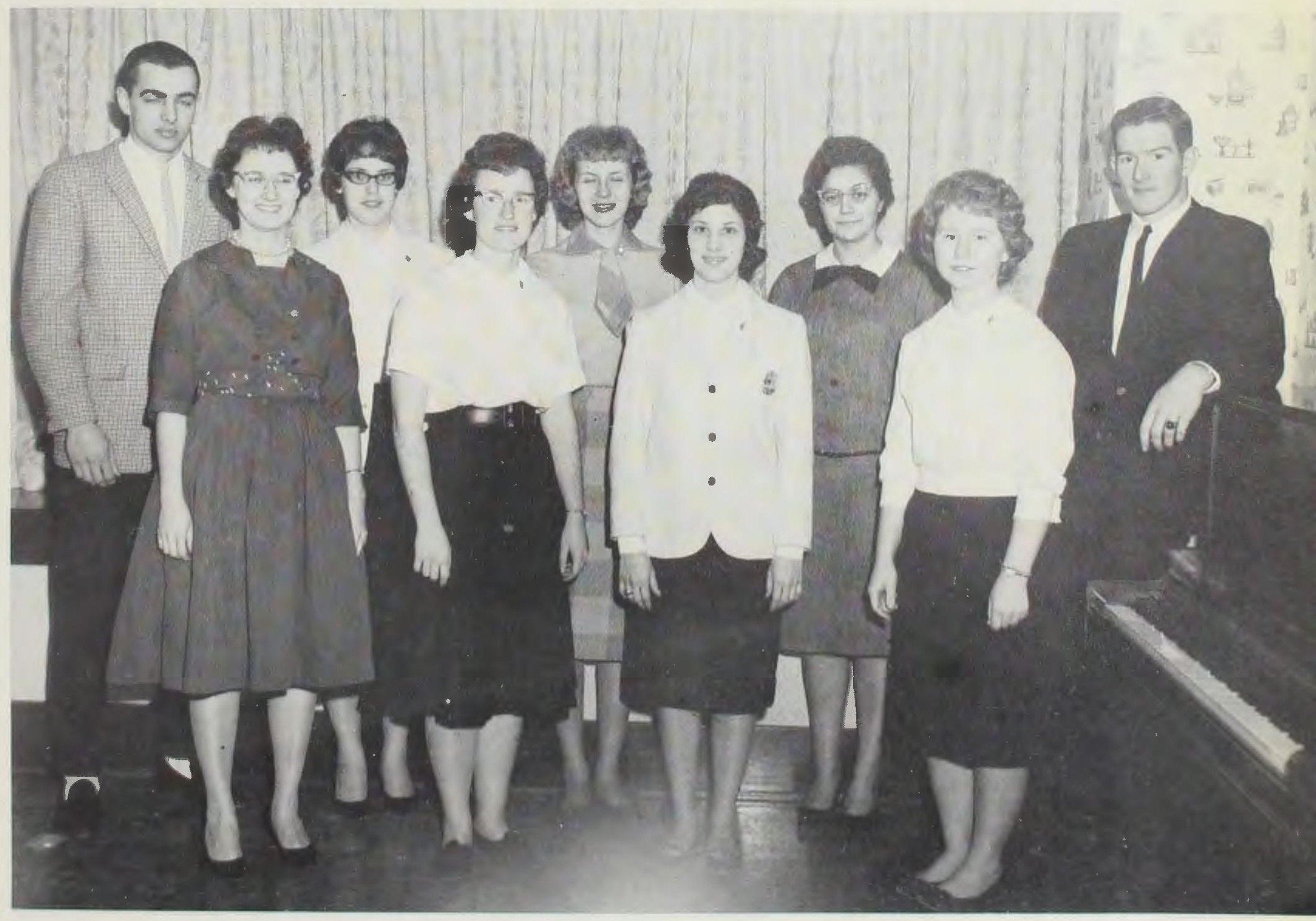

FRONT ROW, Left to Right: Carol Brown, Joyce Walker, Pat Adams, Faye Haas. BACK ROW: Dave Jeremiah,
Elayne Howard, Judy Lachman, Donna Finley, John Morgan. NOT PICTURED: Sam Canine. 

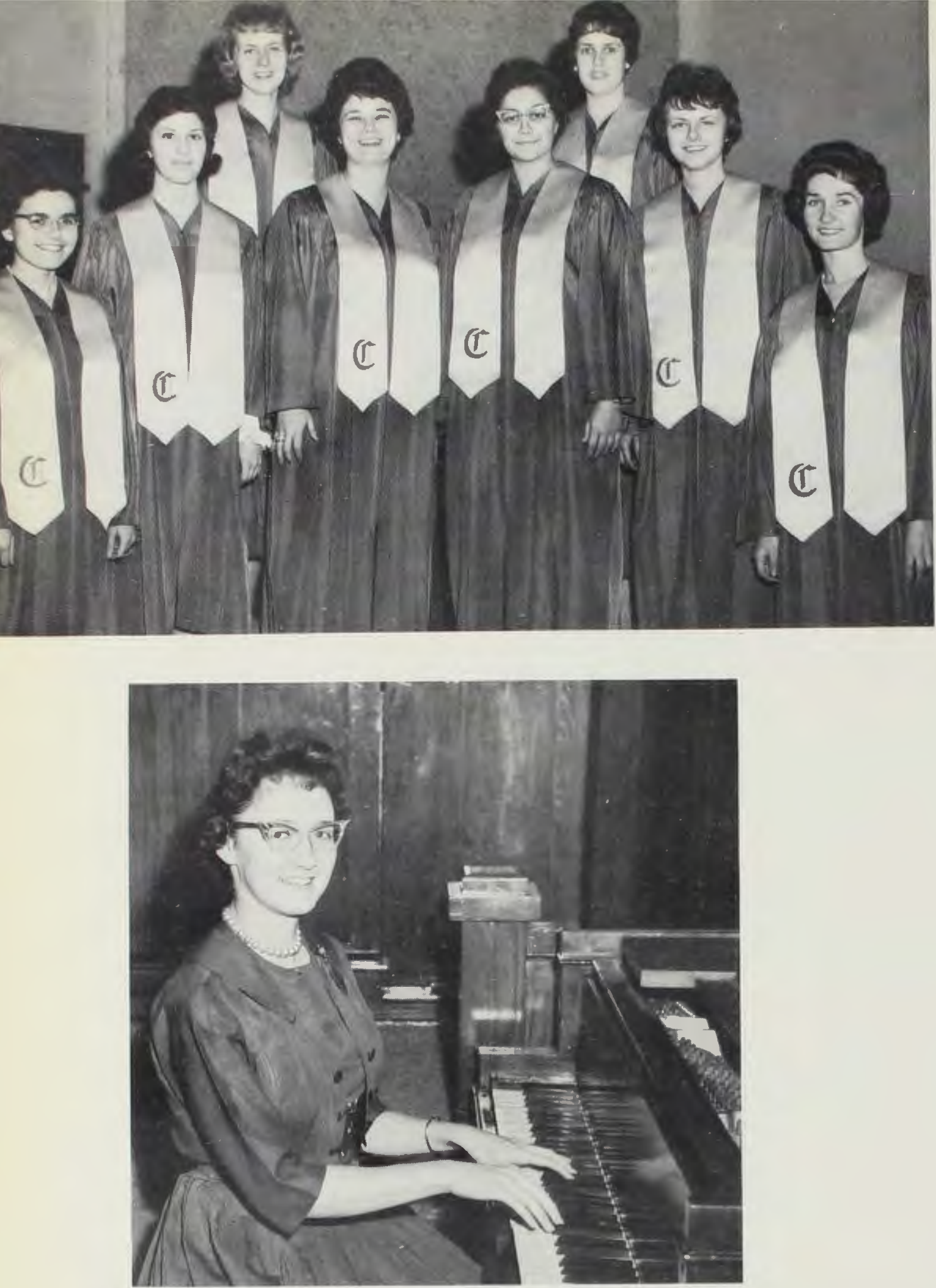

Carol Ann Brown, Pianist.
SOPRANOS - TOP ROW, Left to Right: Judy Lachman, Elayne Howard. FRONT ROW: Pat Schonscheck, Pat Adams, Judy Michaels, Donna Finley, Ardith Cayton, Sharon Marks.

\section{College}

Choir
ALTOS - TOP ROW, Left to Right: Maryalice Jeremiah, Sharon Brown, Bonnie Nash, Helen Wing, Vickie Curcio. FRONT ROW: Sh a r o n Addleman, Rita Millikin, Donna Thompson, Ruth Johnson, Ruth DeVay.

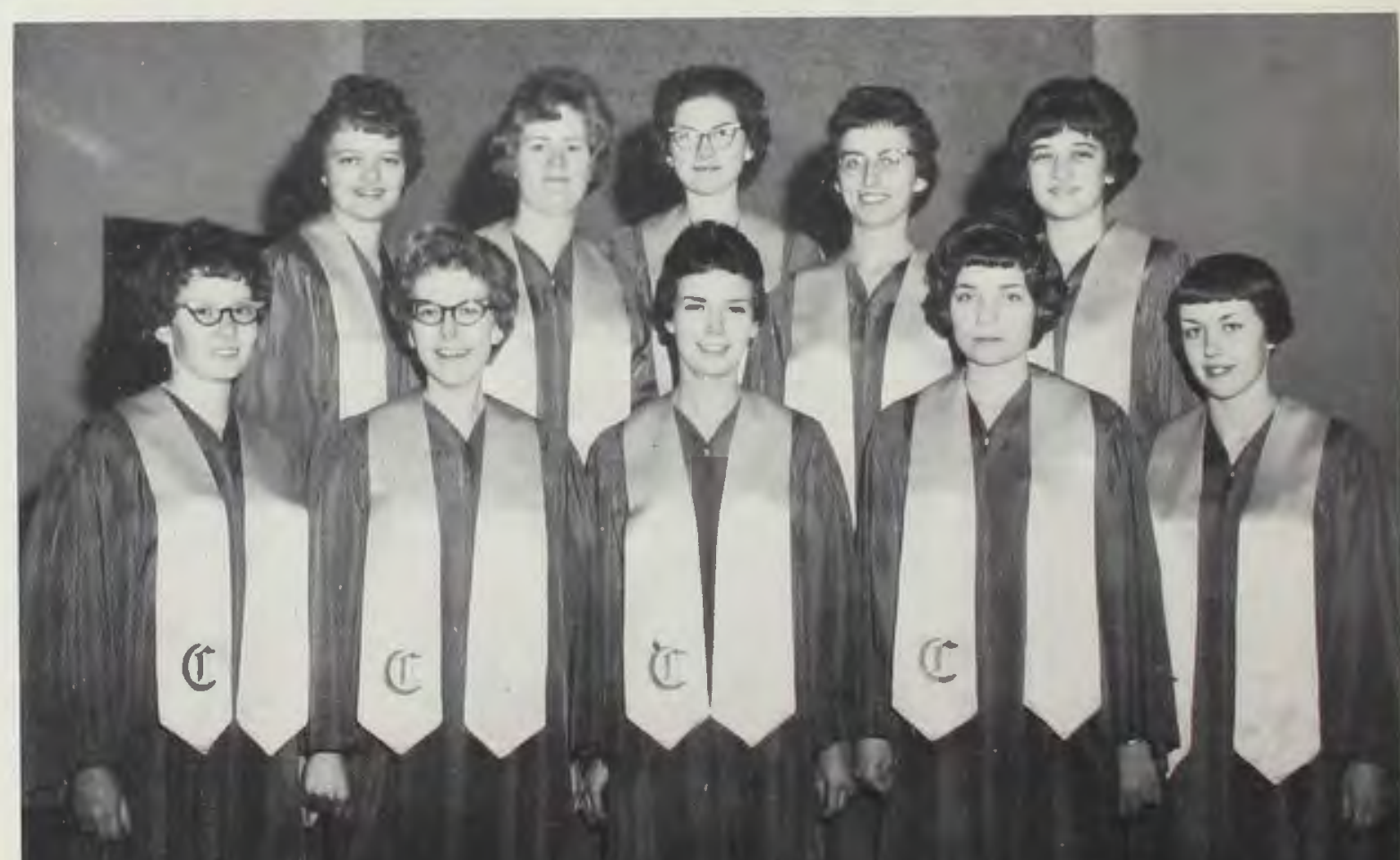


TENORS - TOP ROW, Left to Right: Rich Davidson, Dave Jeremiah. FRONT ROW: Ken Swigart, Steve Nimmo, Dave Fisher, Dave Warren, Gorden Finley, Larry Czerniak.

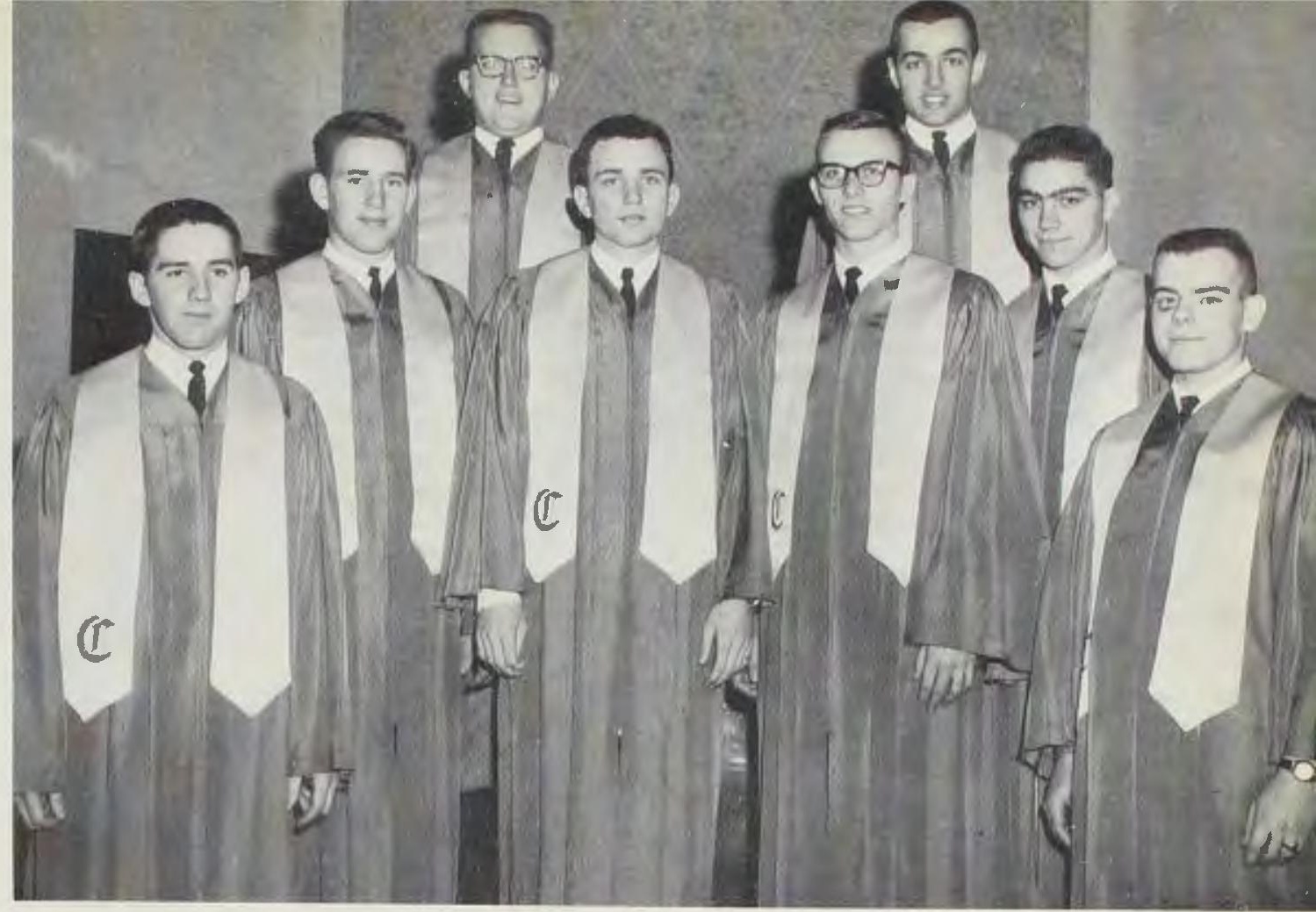

The College Choir, under the direction of Mr. Richard A. Cooke and Mr. Warren S. Webber, presents the Word of God through music to churches in Ohio and neighboring states. The Choir performed in two Christmas concerts at the Grace Baptist Church, and gave a concert of their own on May 8. The highlight of the year was the annual two-week tour held during Easter vacation when the Choir visited churches in Ohio, Indiana, and Michigan.

Officers of the Choir are: Sam Canine, President; Carole Boren, Vice-President; Elayne Howard, Secretary; Judy Lachman, Treasurer; Donna Finley, Historian.

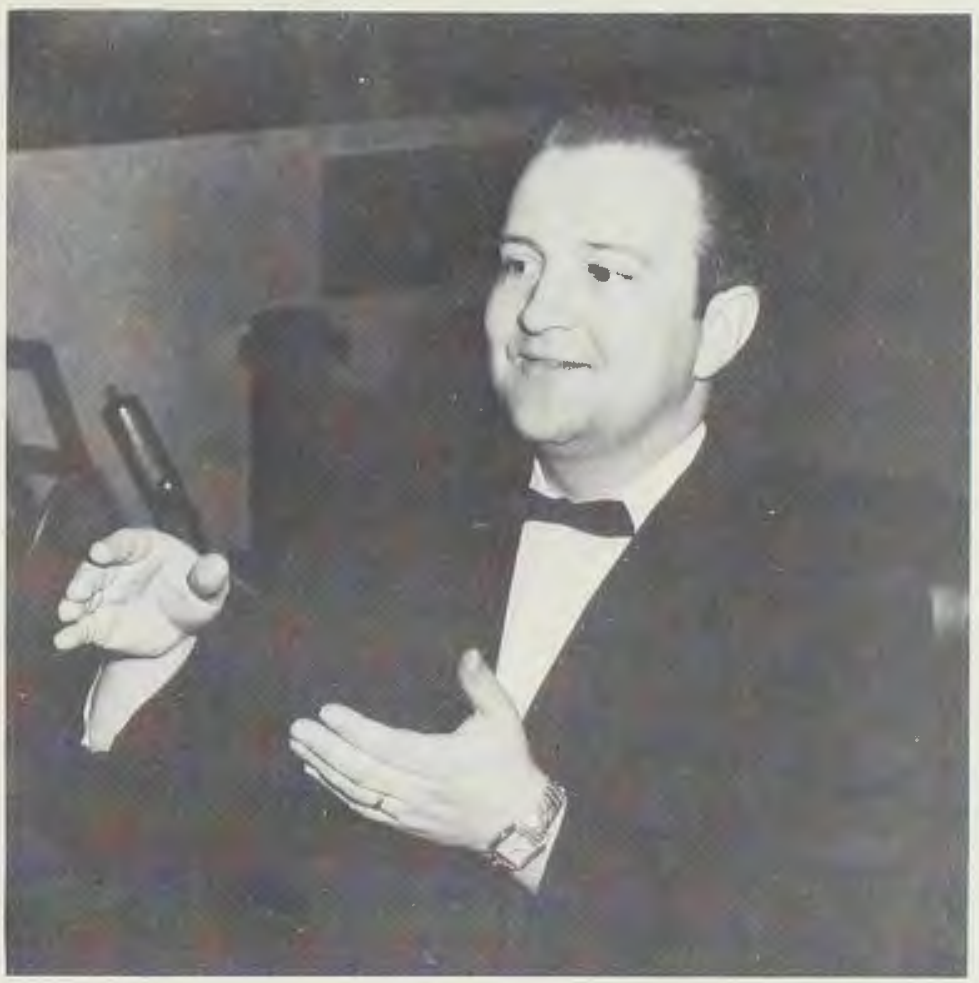

Mr. Richard A. Cooke, Director.

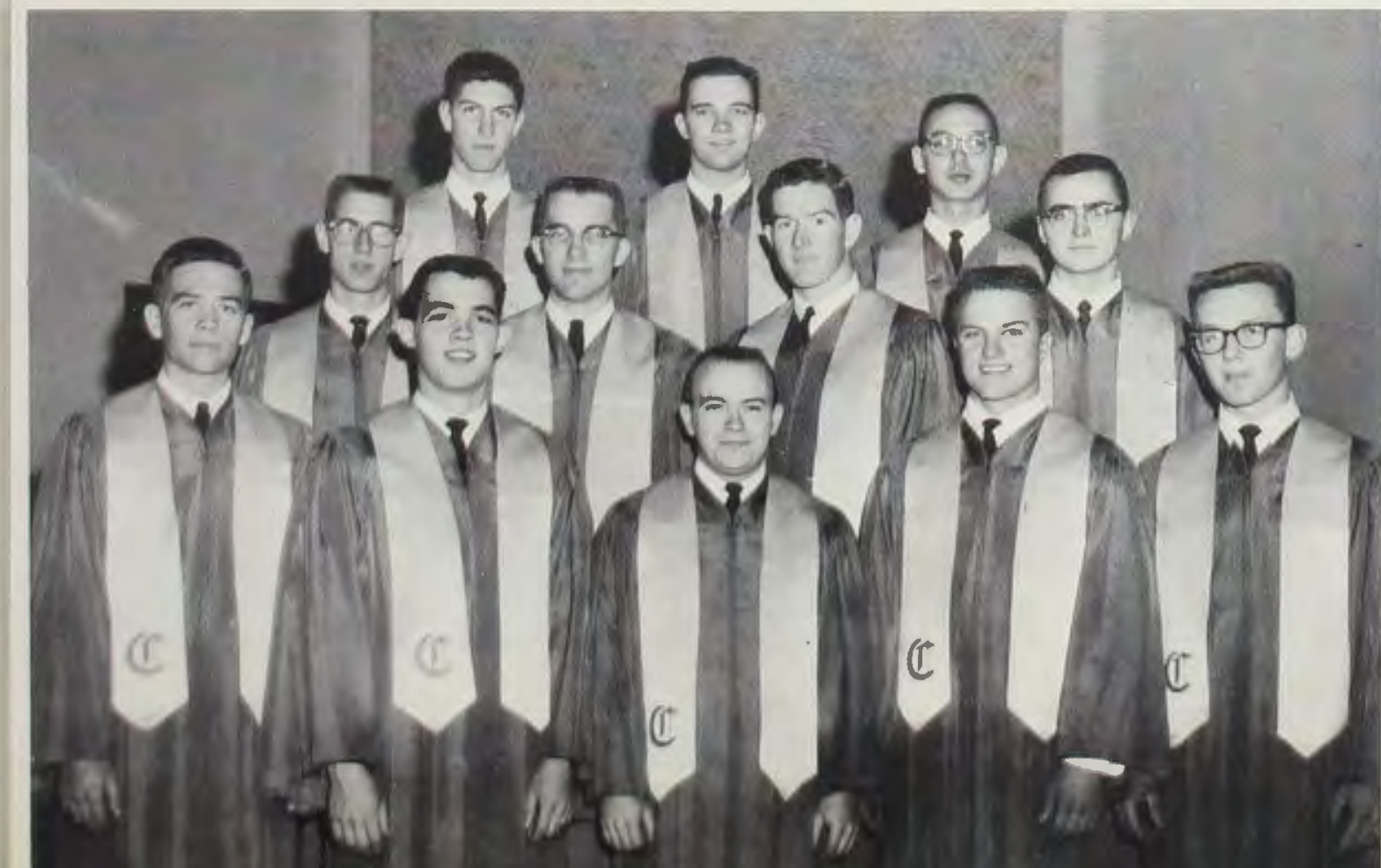

BASSES - TOP ROW, L e $t \mathrm{t}$ to Right: Jerry Stadt, Jack Moffat, Dave Earnhart. SECOND ROW: Dave Trumbull, Ralph W e r ne r, John Morgan, Paul Reno. FRON'T ROW: Roger O'Bryon, Marv Hollenbeck, John Ingram, Lynn Jefson, Paul Carlson. 


\section{Annual}

\section{Spring}

\section{Choir Tour}

MARCH 22 - APRIL 3, 1961

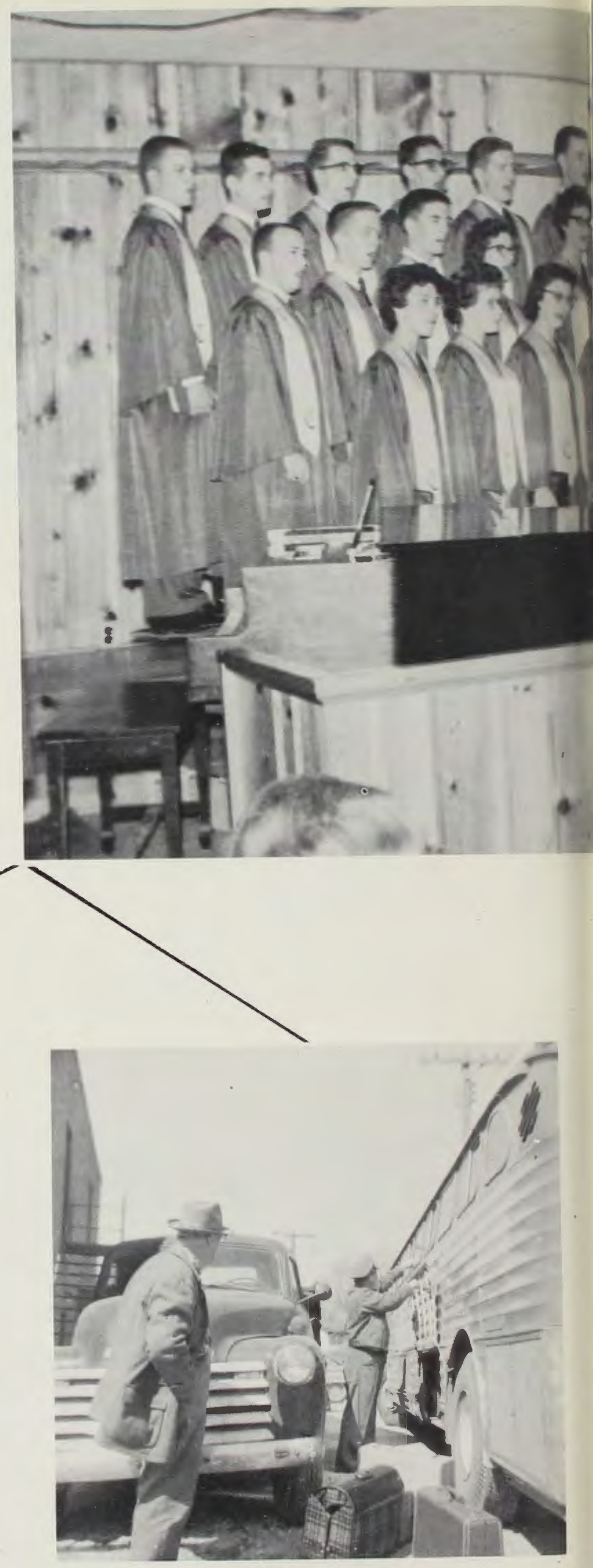

"Scottie", the bus driver, loads the last bit of luggage as the choir begins another day of travel.
Signs like this one made bus-weary choir members feel welcome as they entered another townthis time, Waterloo, Iowa. 


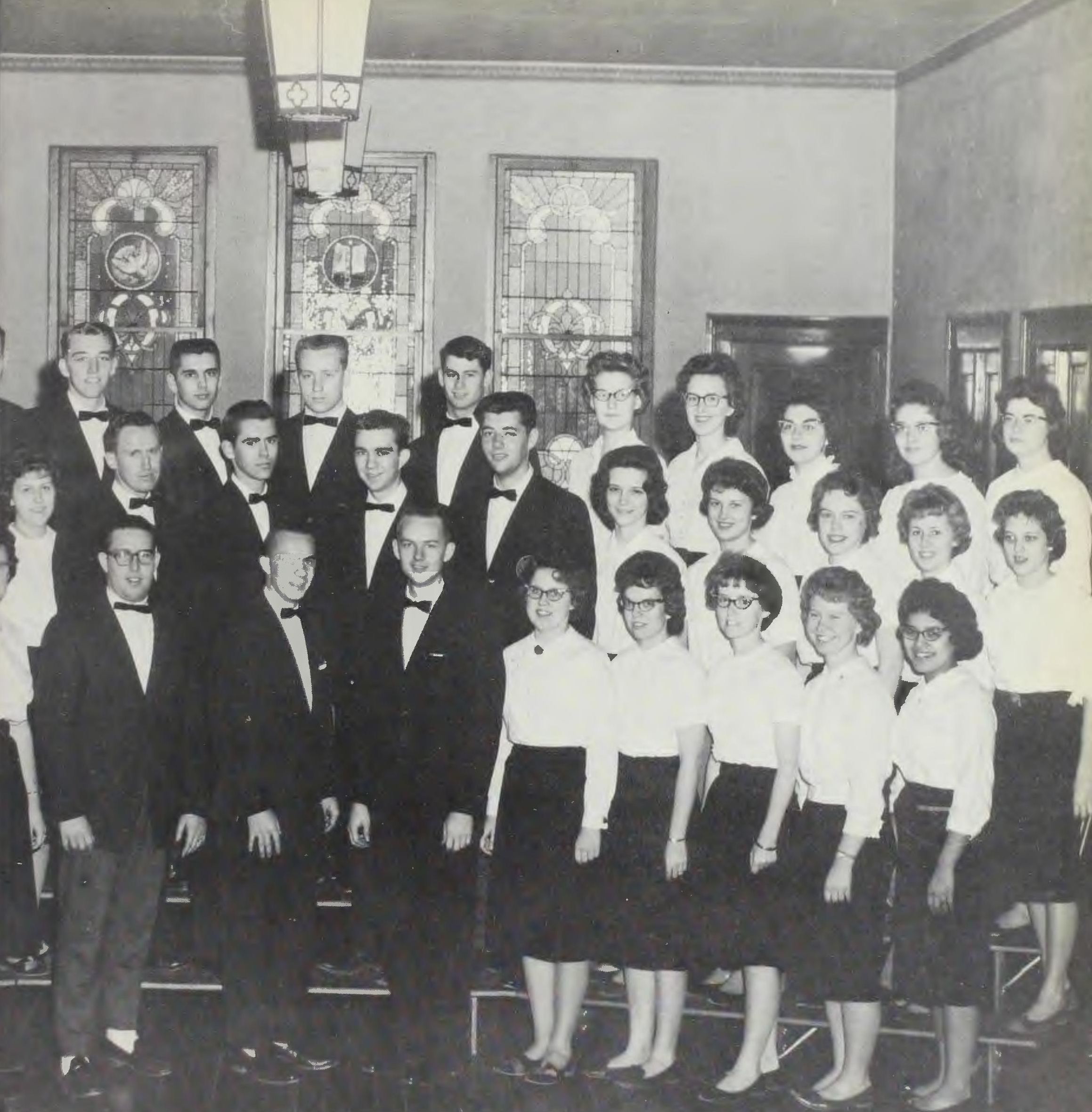

TOP ROW, Left to Right: Jan Davis, Mary Cunningham, Judy Walborn, Eleanor Smelser, John Wolfe, Dave Werner, Warren Burnside, Al Merwald, Stan Seevers, Sue Geyser, Bonnie Jackson, Lea Ann McNamara, Carolyn Coppock, Jane Ginz. SECOND ROW: Eve Tennant, Sue Eckert, Martha Ammons, Mary Ellen Floyd, Elsie Himsel, Robert Edwards, Jeff Coy, Ron Mathis, Dave
Jensen, Nancy Buerer, Martha Crull, Barbara Miller, Elizabeth Price, Sue Newcomer. FRONT ROW: Joanne Neely, Betty Smith, Judy Couwenhoven, Phyllis Irish, Joyce Walker, Phil Olsen, Chet Russell, Bill Washburn, Jo-an Nelson, Shirley Goodman, Joàn Carter, Faye Haas, Julia Olivas. 


\section{Chamber Band}

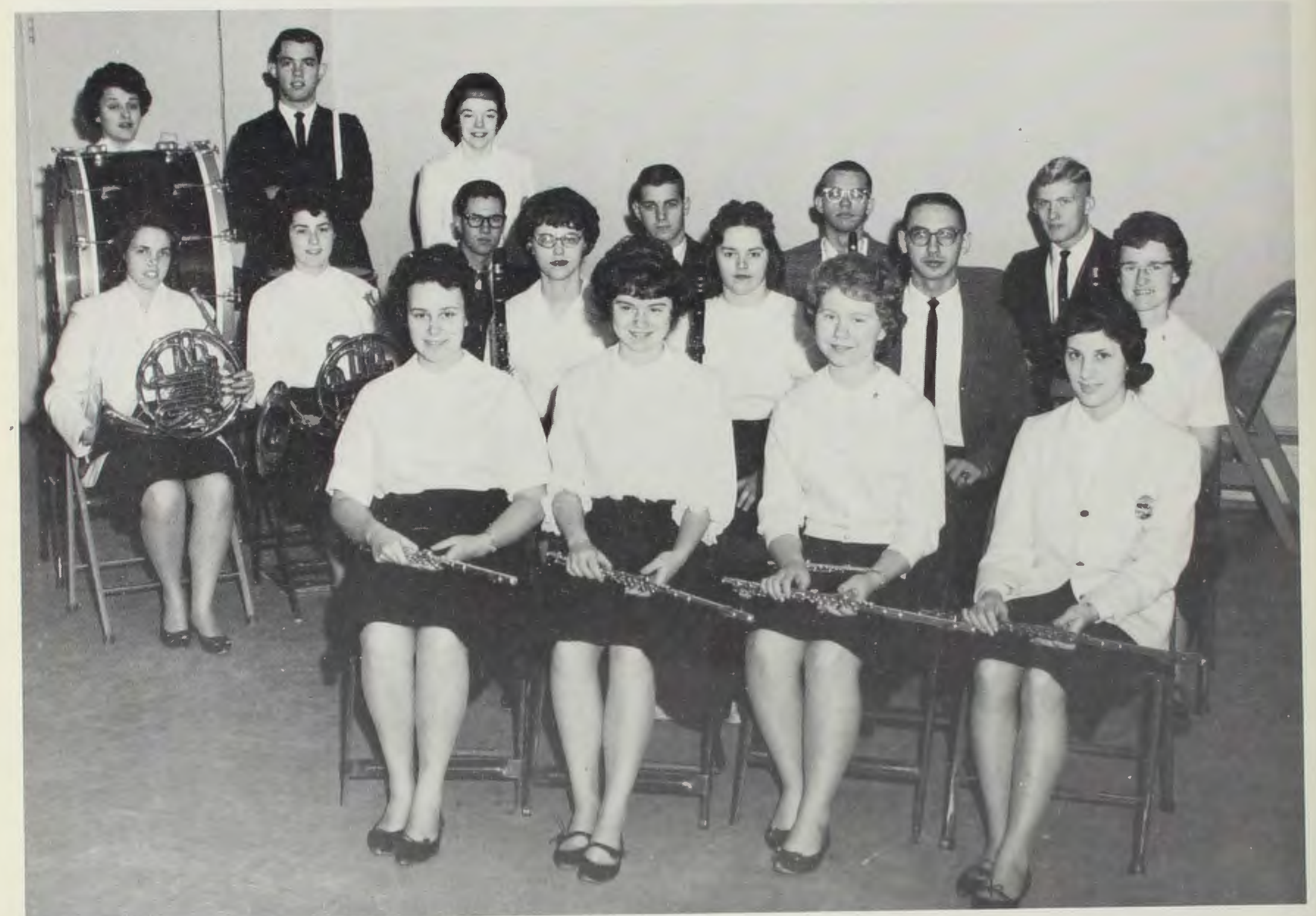

WOODWIND AND PERCUSSION SECTIONS-TOP ROW, Left to Right: Faye Doctor, Marv Hollenbeck, Martha Ammons. SECOND ROW: Sally Bender, Martha Motts, Gordin Chitty, Bob Auffort, Bill Riter, Val Roloff.
THIRD ROW: Bonnie Hammack, Penny Brown, Dave Earnhart, Joyce Walker. FRONT ROW: Sue Eckert, Gladys Ross, Faye Haas, Pat Adams.

Under the direction of Mr. William D. Thornton, the Chamber Band provided various programs throughout the year, and aided in the enthusiasm at all home basketball games. The programs included four Christmas concerts: one at Blessed Hope Baptist in Springfield, one at Cedar-Cliff High School, and two at Grace Baptist Church in Cedarville. The Springfield concert marked the first out-of-town venture in the history of the Band. The Band also presented a Spring concert.

Officers of the Band are: President, Dave Earnhart; Vice-President, Phil Grant; Librarian, Nancy Smith; Manager, Bob Auffort, Assistant Manager, Val Roloff. 

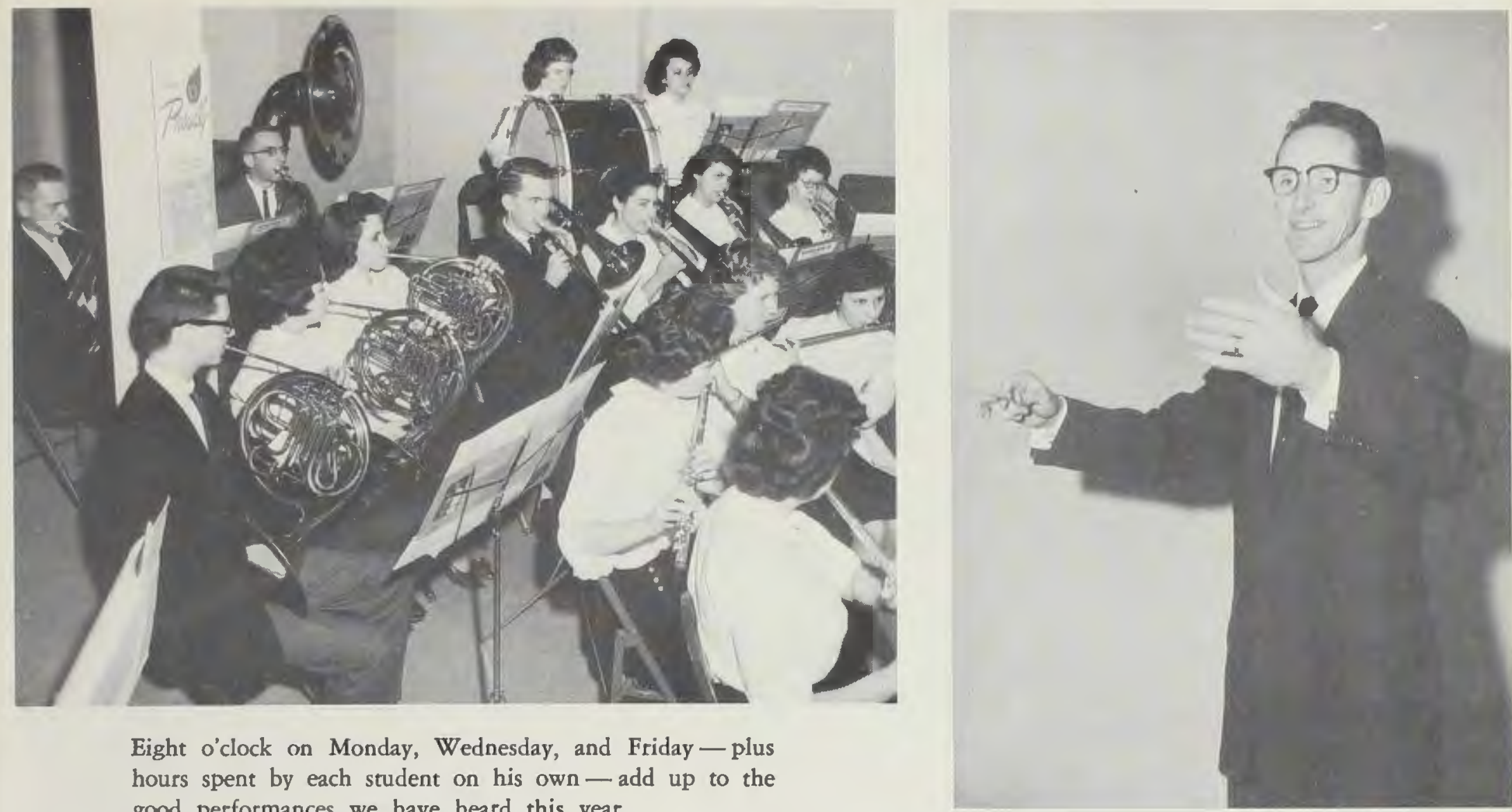

Eight o'clock on Monday, Wednesday, and Friday - plus hours spent by each student on his own - add up to the good performances we have heard this year.

Mr. William D. Thorton, Director.

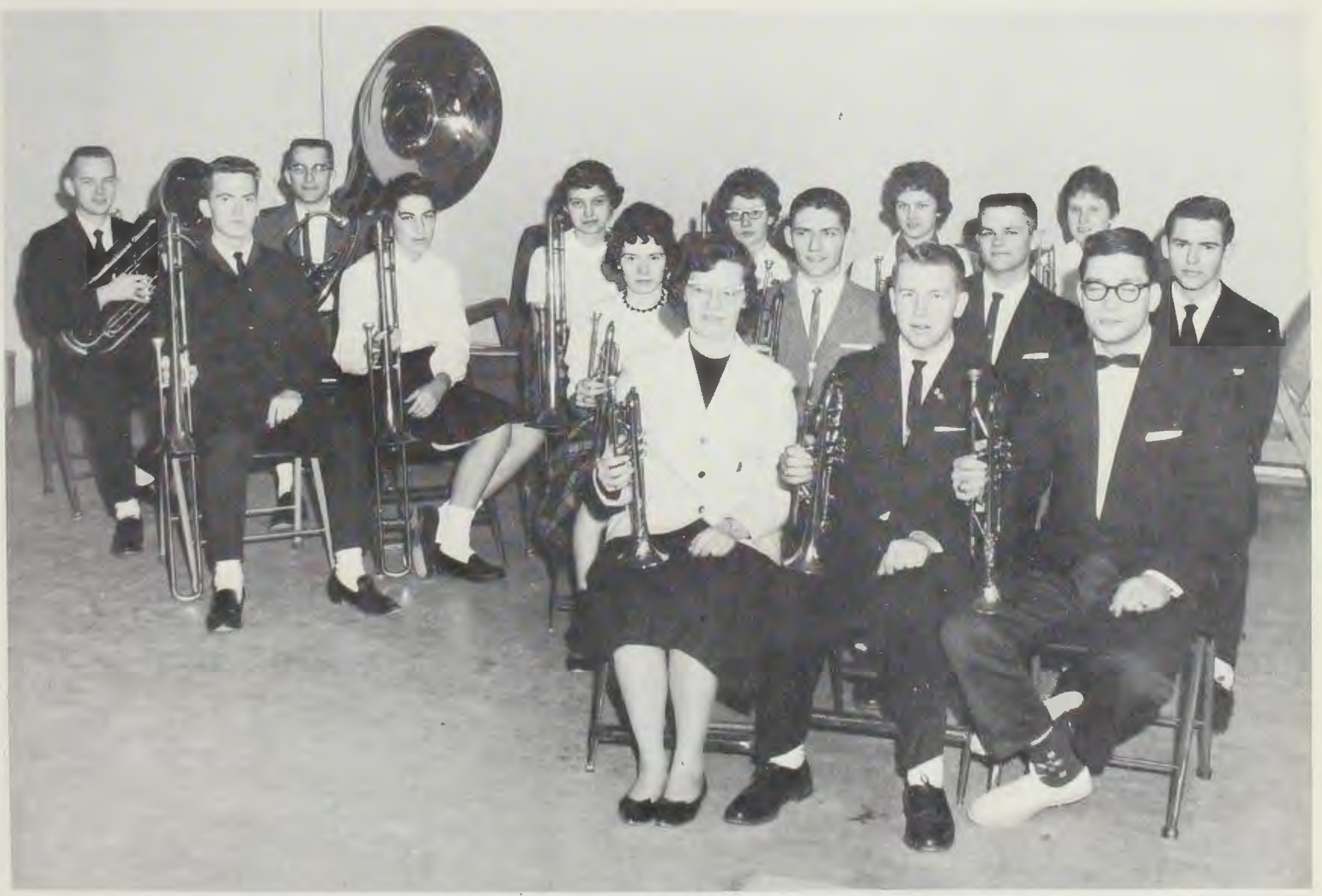

BRASS SECTION - TOP ROW, Left to Right: Bill Washburn, Ralph Werner, Jackie Sidle, Sharon Addleman, Martha Crull, Winnie Freytag. SECOND ROW:
Duane Bales, Sue Johns, Janice Addleman, Bob Reynolds, Jim Walker, Jeff Coy. FRON'T ROW: Nancy Smith, Phil Grant, Steve Boalt. 


\section{Choralaires}

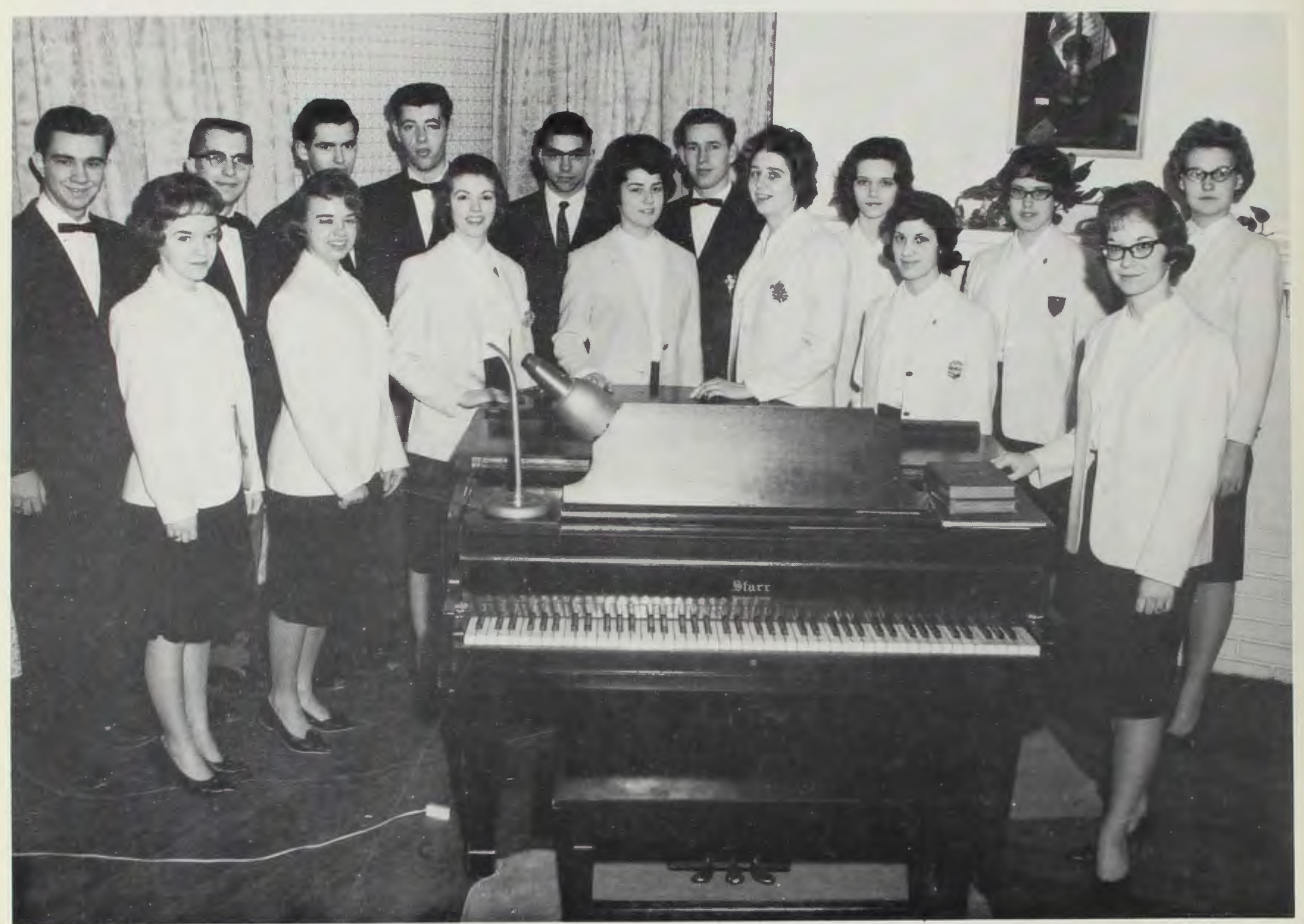

TOP ROW, Left to Right: Ron Mathis, Ralph Werner, Jeff Coy, Dave Jensen, Gorden Finley, Steve Nimmo, Nancy Buerer, Elayne Howard, Sue Geyser. FRONT
ROW: Martha Ammons, Judy Couwenhoven, Ju ne Golden, Martha Motts, Mary Cunningham, Pat Adams, Betty Smith, pianist.

The Choralaires, a new musical group on the campus, made their debut at the Alumni banquet during Homecoming weekend. They also performed at the Lion's Club benefit for the new gym, and at the Gamma Chi winter banquet. "Say it with Music" "Inch Worm" "Old Fashioned Walk" and "Long Long Way from Home" and other popular numbers are included in their program. Mr. Cooke and Miss Smith directed the group.

Officers of the Choralaires are: President, Steve Boalt; Vice-President, Gordon'Finley; SecretaryTreasurer, Elayne Howard. 


\section{Quartets}

KINGSMEN QUARTET - Sam Canine, Ralph Werner, Roger O'Bryon, Dave Jeremiah, Rich Davidson, pianist.

MIXED QUARTET - Steve Nimmo, Donna Finley, Sharon Brown, Gorden Finley, Elayne Howard, pianist.

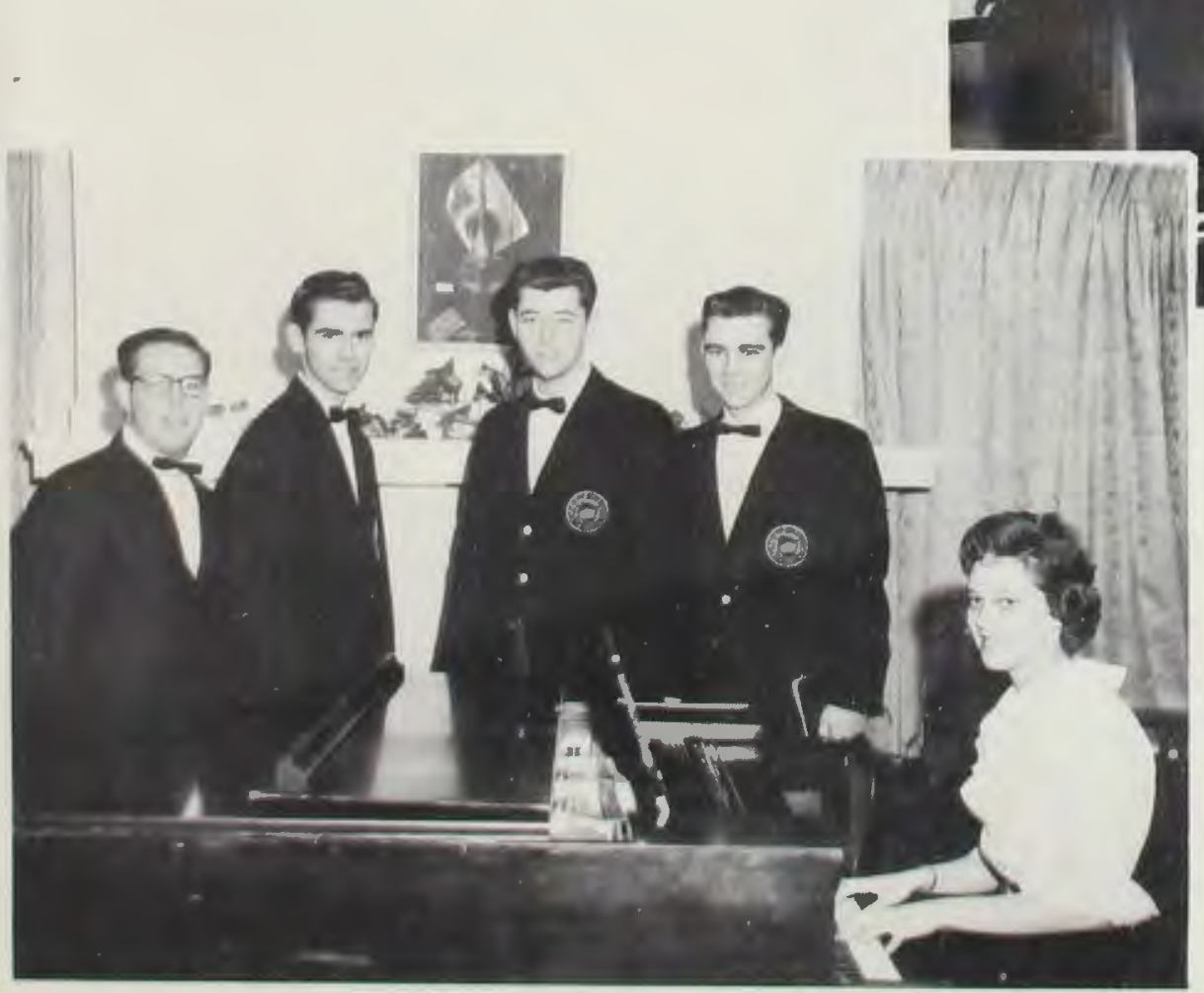

CRUSADERS QUARTET - D a v Earnhart, Dave Fisher, Vance Ashley, Lynn Jefson, Marv Hollenbeck, pianist.

\section{而}
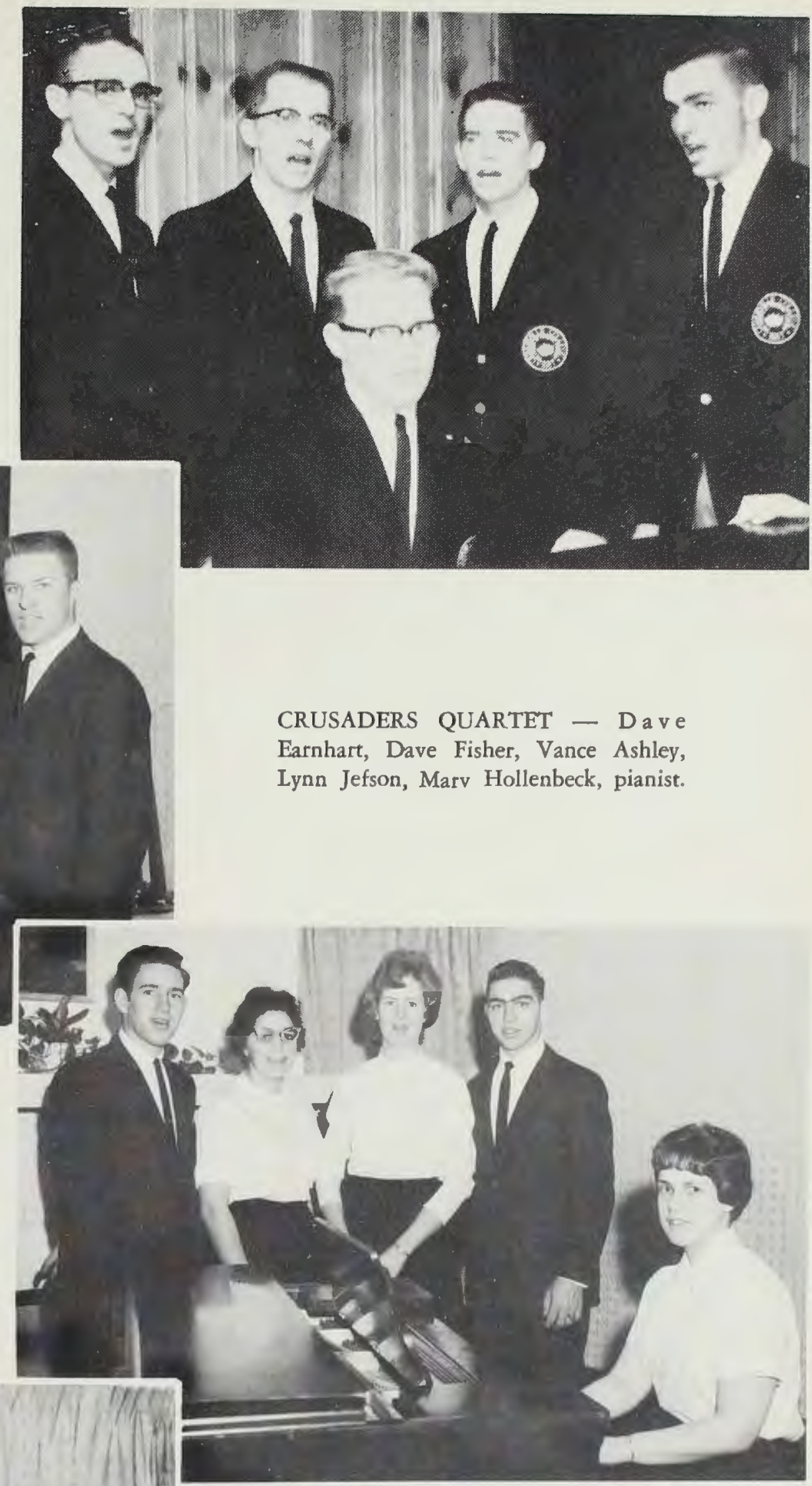

\section{CHAPEL CHOIR QUARTET - Phil} Olsen, Jeff Coy, Dave Jensen, Ron Marhis, Sue Newcomer, pianist. 


\section{Ladies Trios}

MELODY-AIRES - Phyllis Irish, pianist, Martha Ammons, Judy Couwenhoven, Martha Crull.

COLLEGE CHOIR TRIO - Ruth Johnson, Sharon Marks, Vickie Curcio, Shirley Byrd, pianist.

MELODY-ETTES - Martha Motts, Judy Michaels, Barbra Miller, Martha Short, pianist.

Quartets, trios, and small ensembles provide talented students with a chance to use their abilities for God and to represent our school. Last summer, the Kingsman Quartet traveled throughout the eastern United States, while the Harmonettes, a ladies trio, sang in the mid-west. During the current school year, ten of these small ensembles were engaged in Christian service.
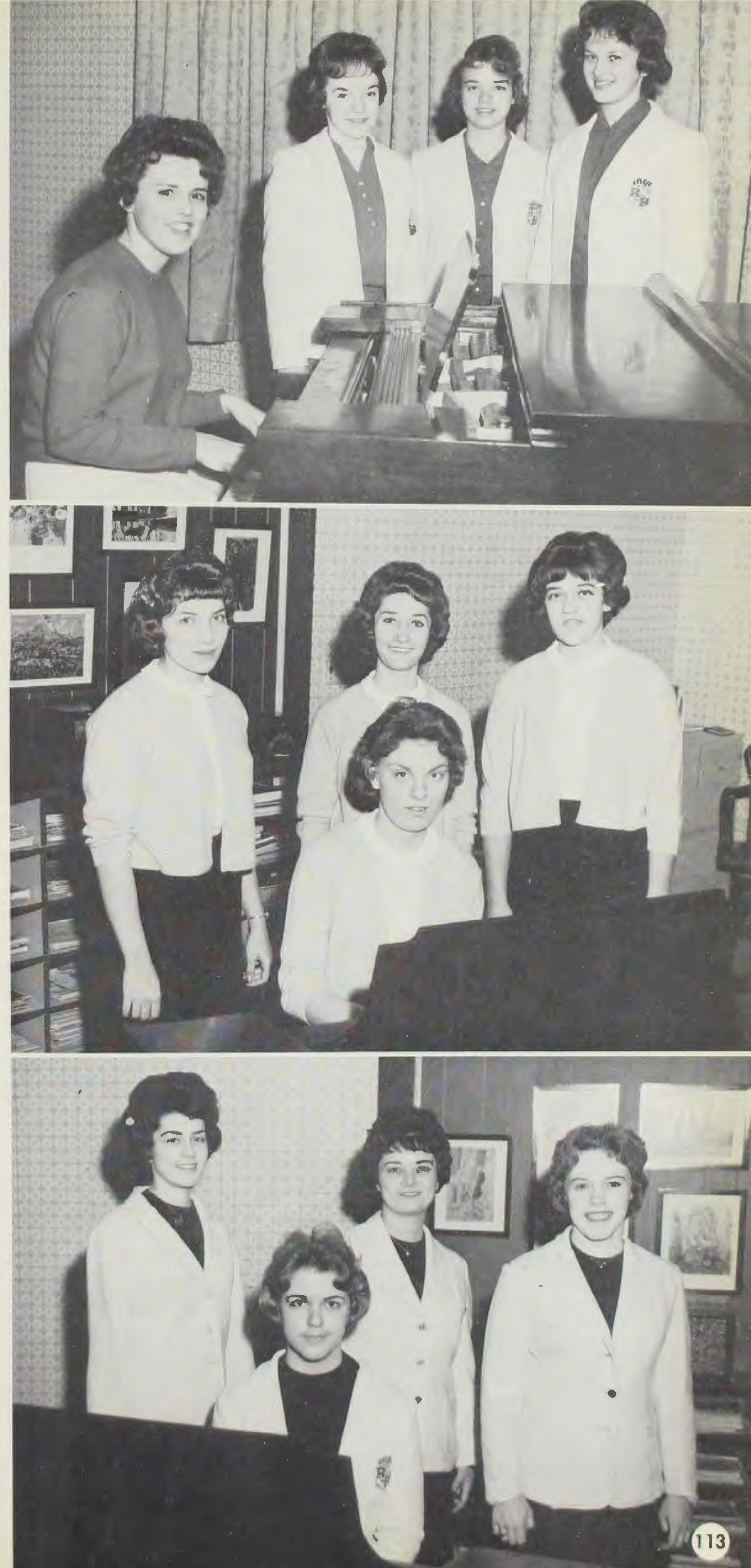

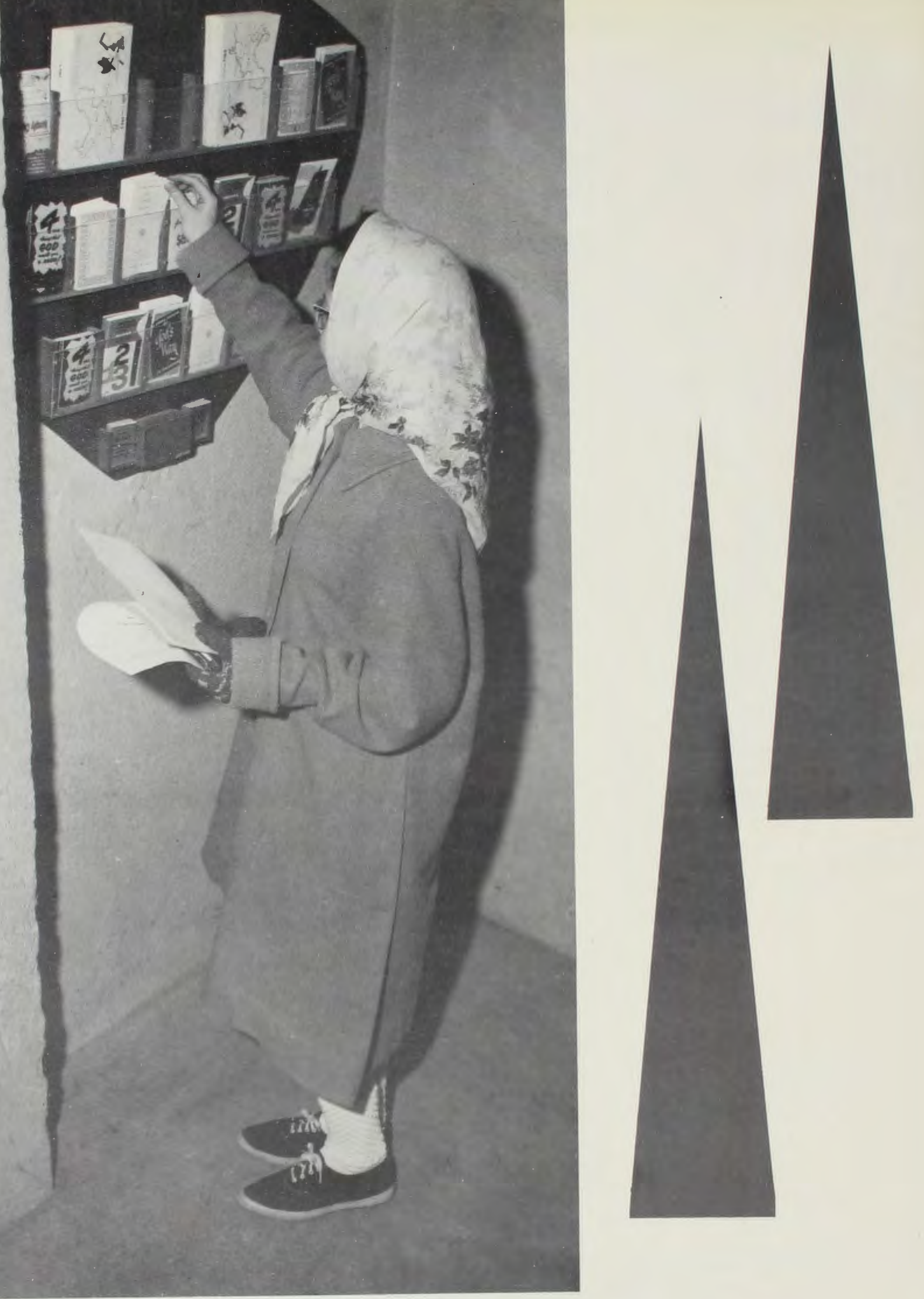

Christian Semice 


\section{Student Pastors}

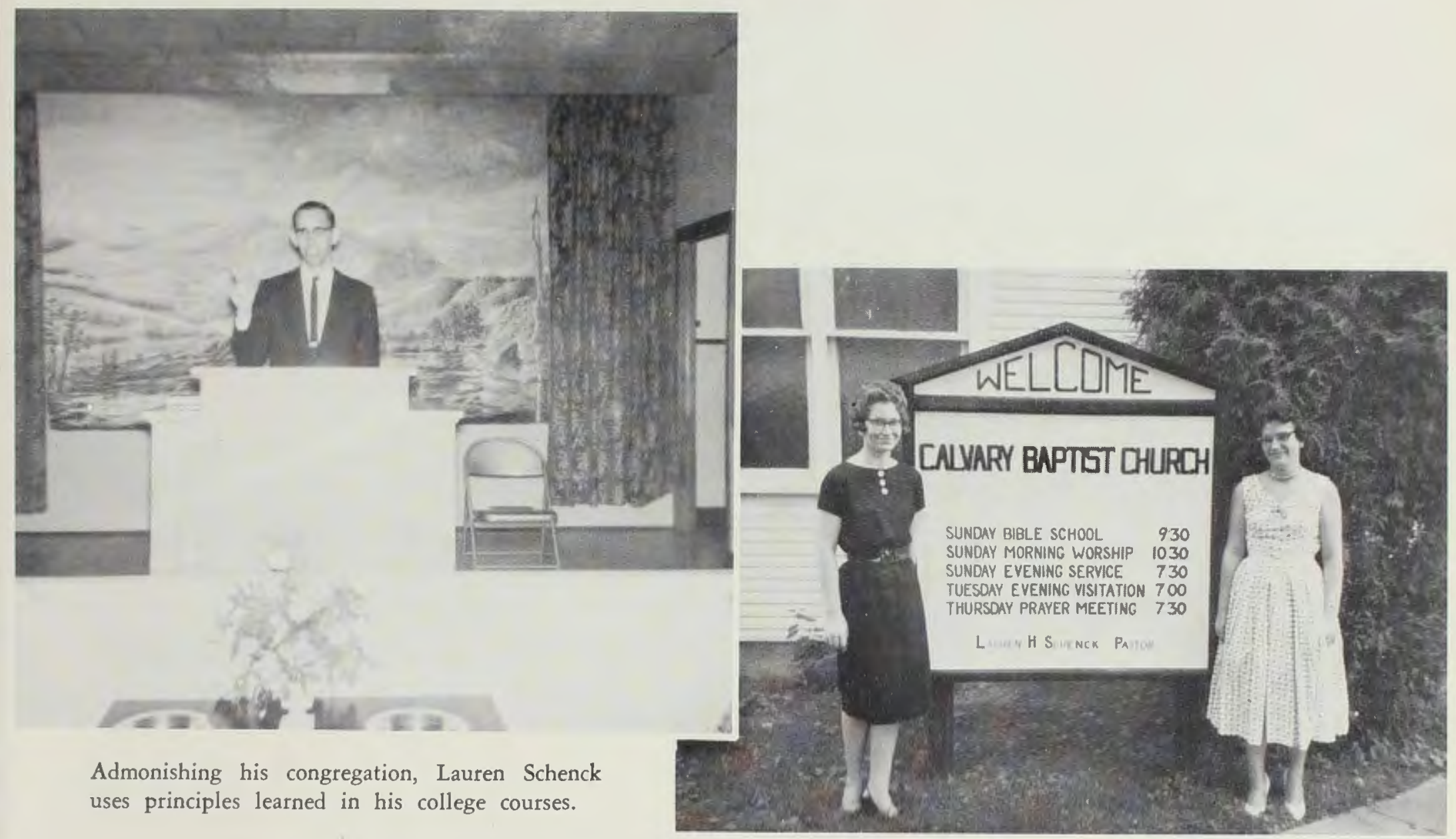

Betty Smith and Jeri Wickell, college students, assist the student pastor with the children's work.

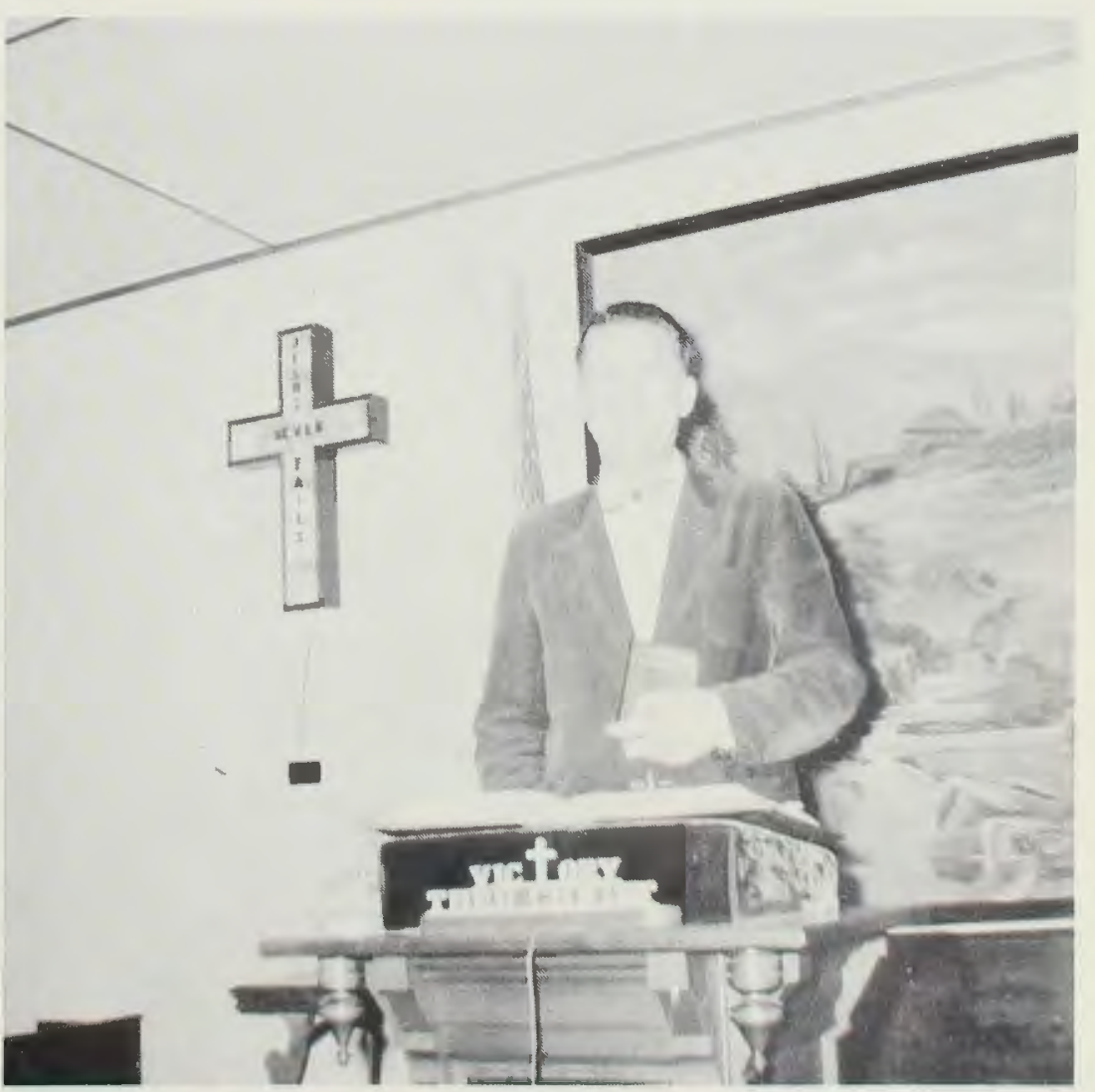

Senior Wilton Alexander conducts his weekly Bible Class instructing believers in the faith. 


\section{Music Directors}

Seven area churches employ students as music directors. In this position some of the students are responsible for planning the total music program of the church, others lead choirs and congregational singing; all the music directors must transfer classroom facts into practical usage, and this experience is invaluable.

Carol Davis, freshman, accompanies the choir of the First Reformed Church of Xenia which is under the direction of Bill Washburn.
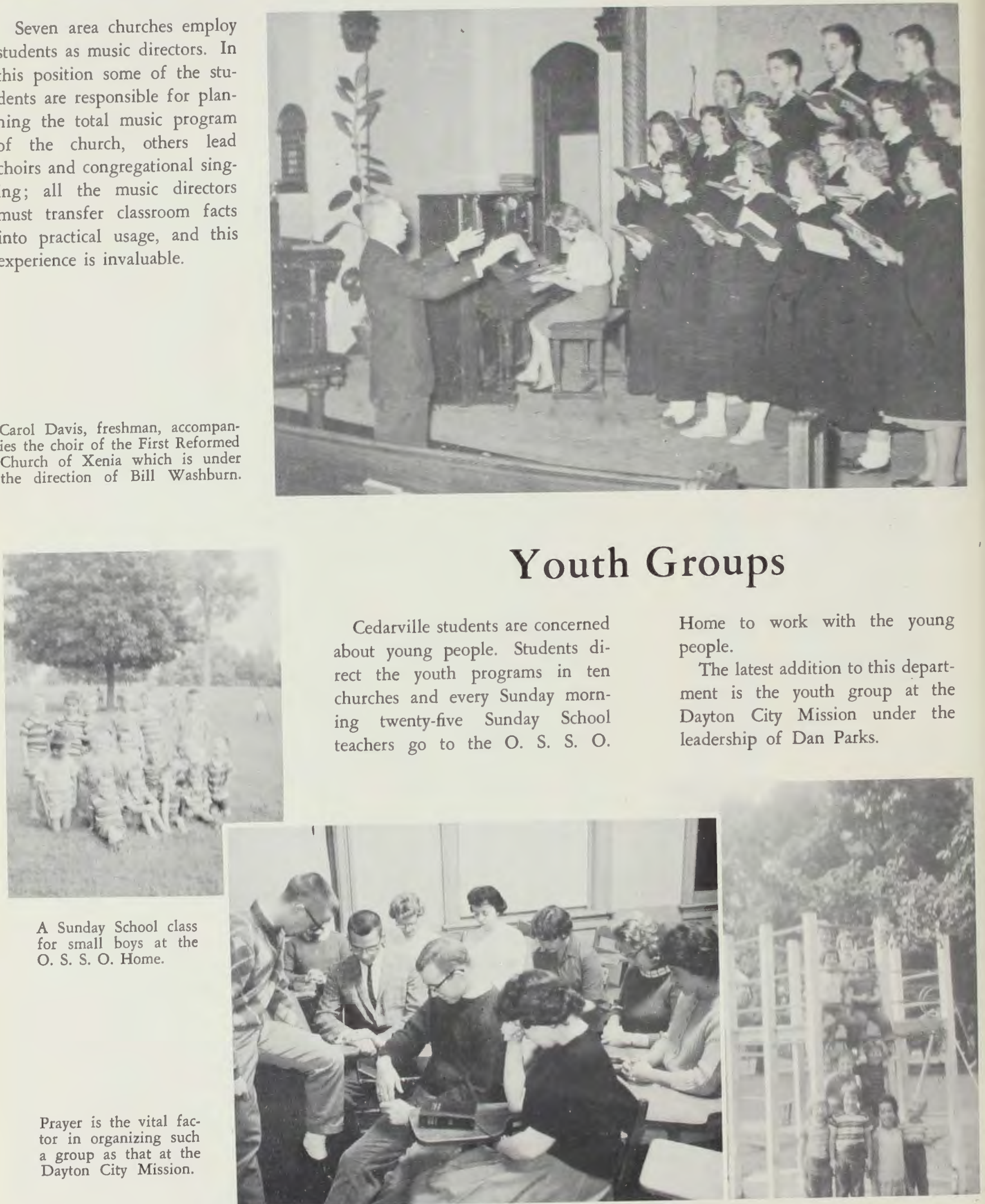

A group of small girls who live in the Peter Pan House of the O. S. S. O. Home. 


\section{Bible}

\section{Clubs}

Barbara Blackburn, Jerry Stafford, and Pat Kaster conduct this club every Thursday afternoon in near-by Xenia.

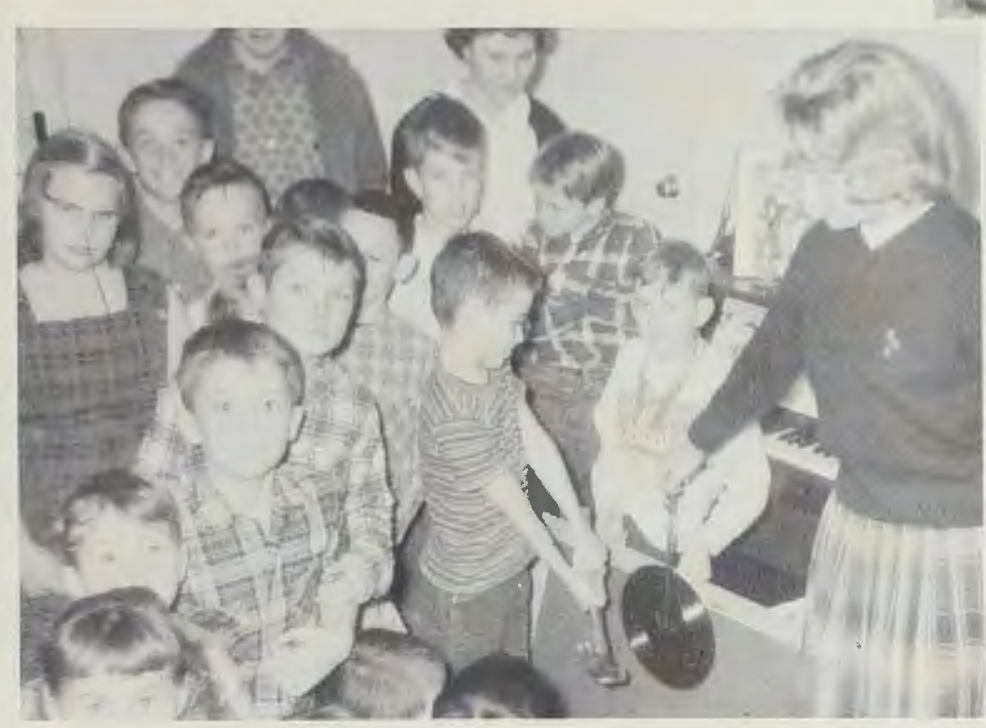

Breaking an attendance record is fun in more ways than one.

\section{Jail}

\section{Services}

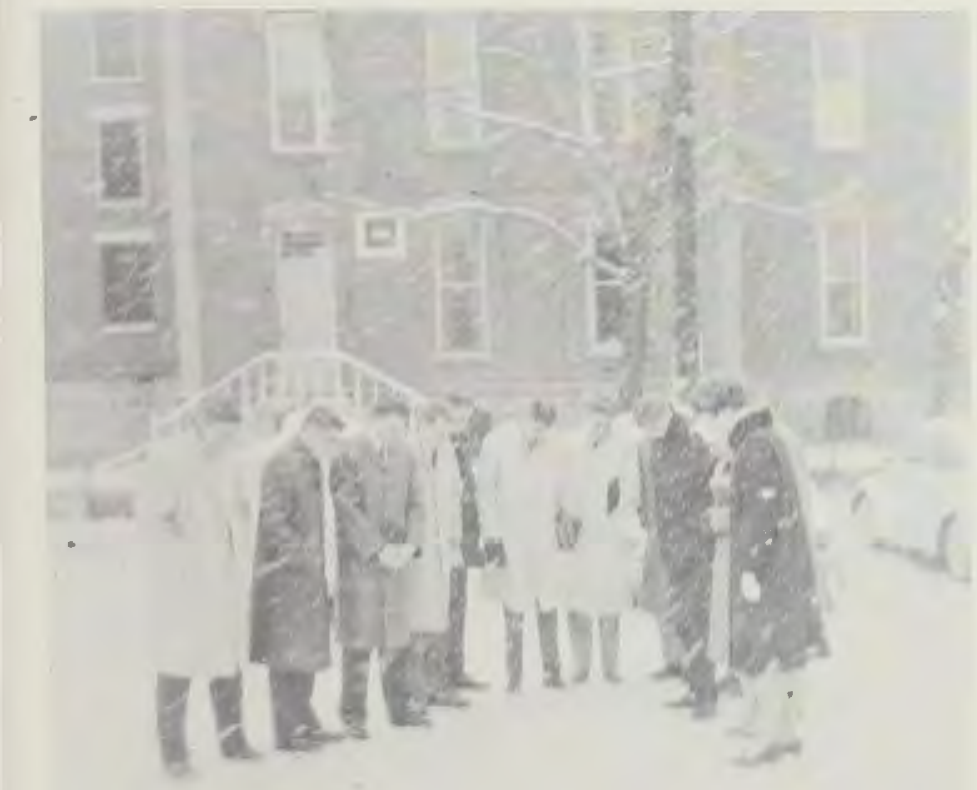

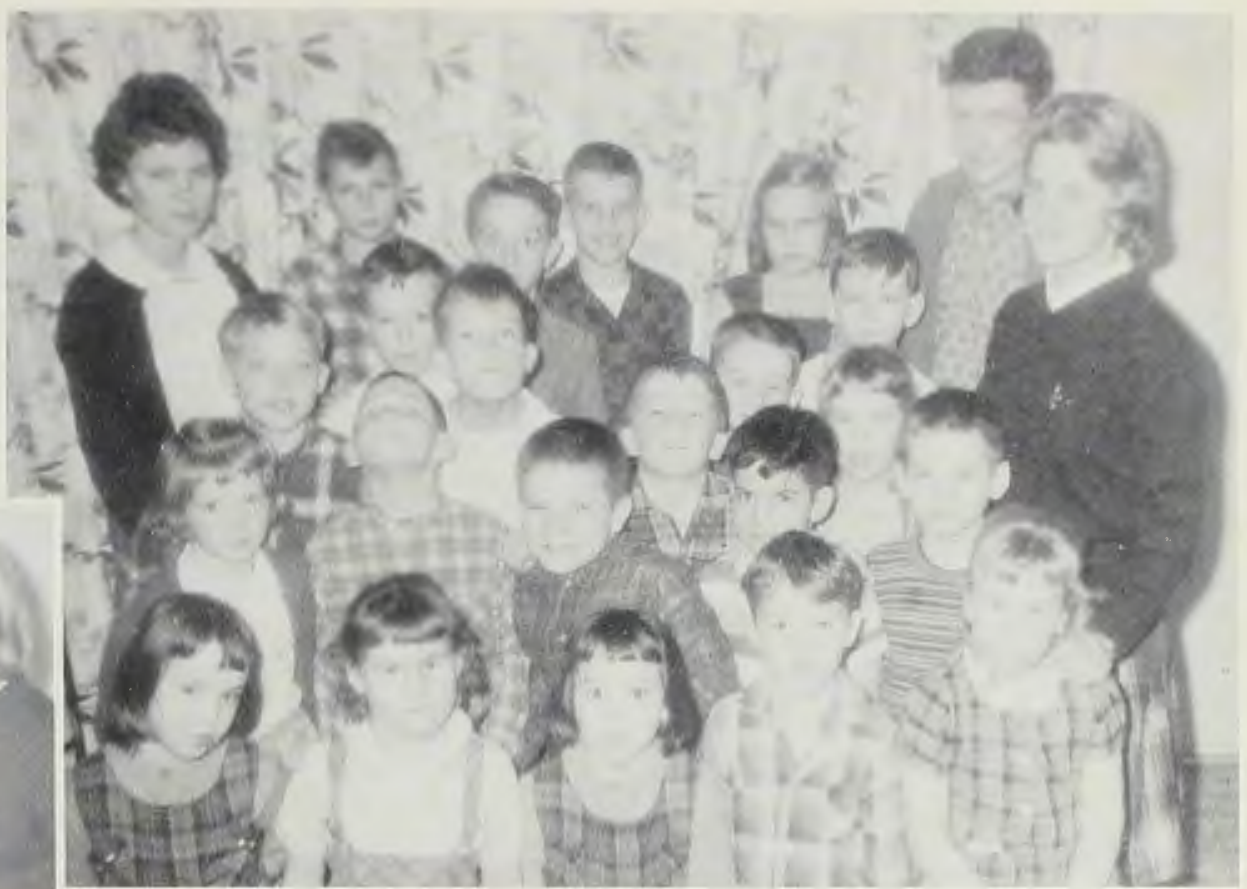

Under the direction of Joan Reiter, a Senior, ten Bible Clubs are conducted in private homes and churches throughout the community. Over thirty students teach, play the piano, and keep records in these clubs which are teaching many unreached boys and girls the Word of God.

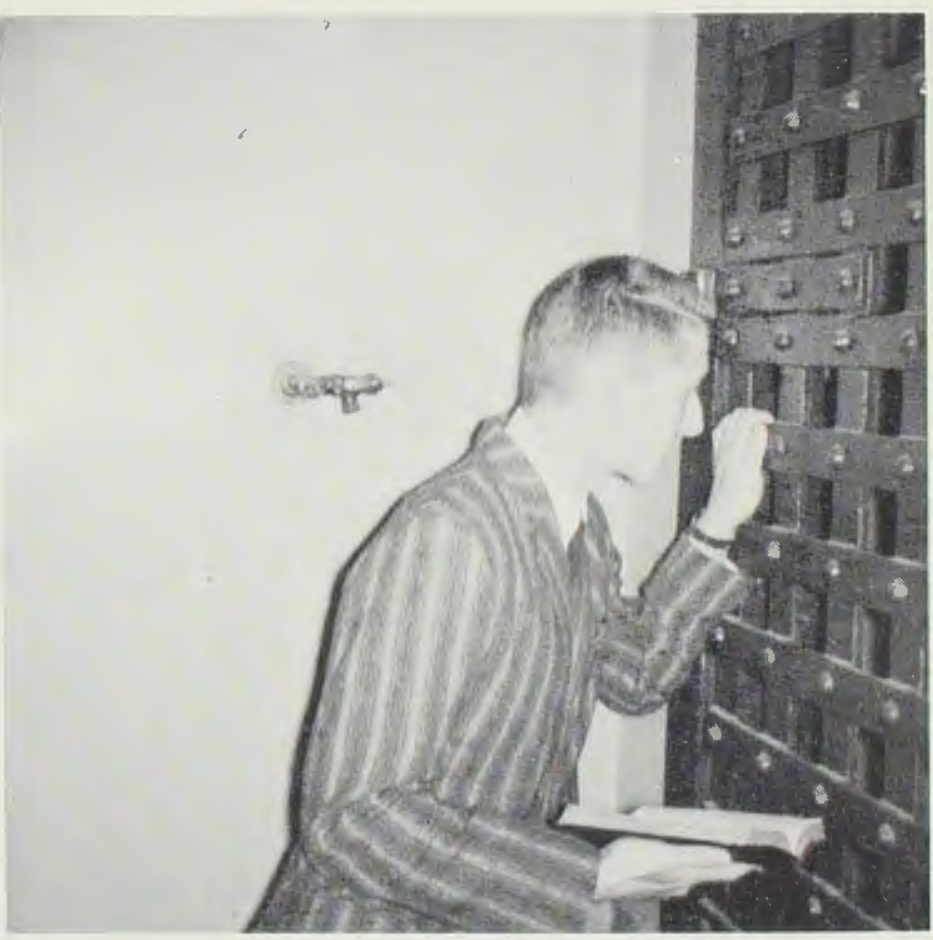

Sam Adamson earnestly deals with an inmate about his soul.

Every Sunday morning of the Academic year students conduct services and personal work at a municipal and a county jail. Ten students are assigned to the Xenia Jail and twenty-one go to the Clark County Jail in Springfield. 


\section{Old Folks Home}

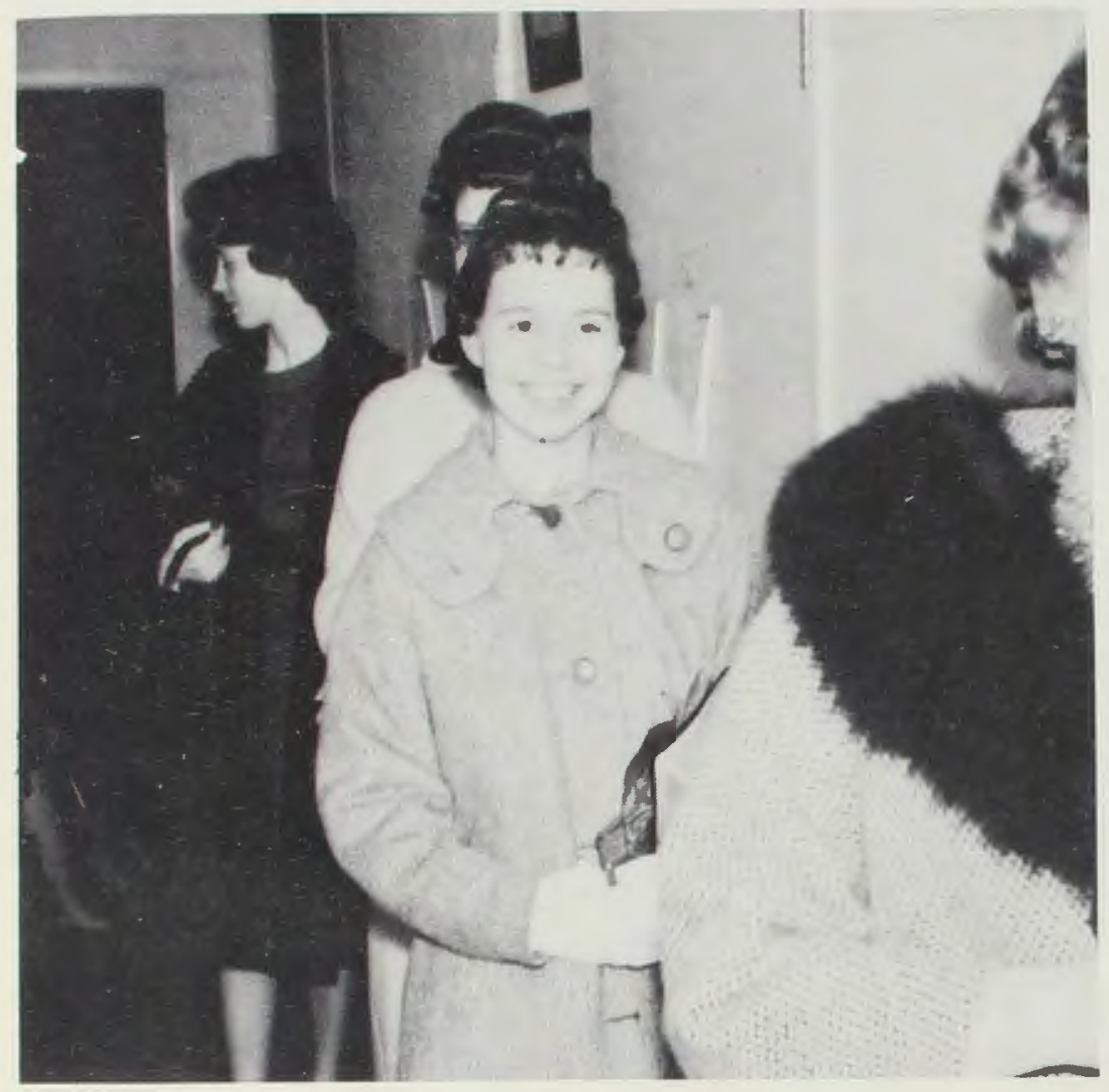

Six county and private homes for the aged host Cedarville students each week. The sixtytwo collegians participating in this phase of Christian Service conduct public meetings and room-to-room visitation telling these elderly and often neglected people of a hope in Christ. Although this work is very difficult, our Lord promises that His Word shall not return unto Him void.

Our cheery smiles do more to tell others of the happiness

we find in Christ than many words which we could say.

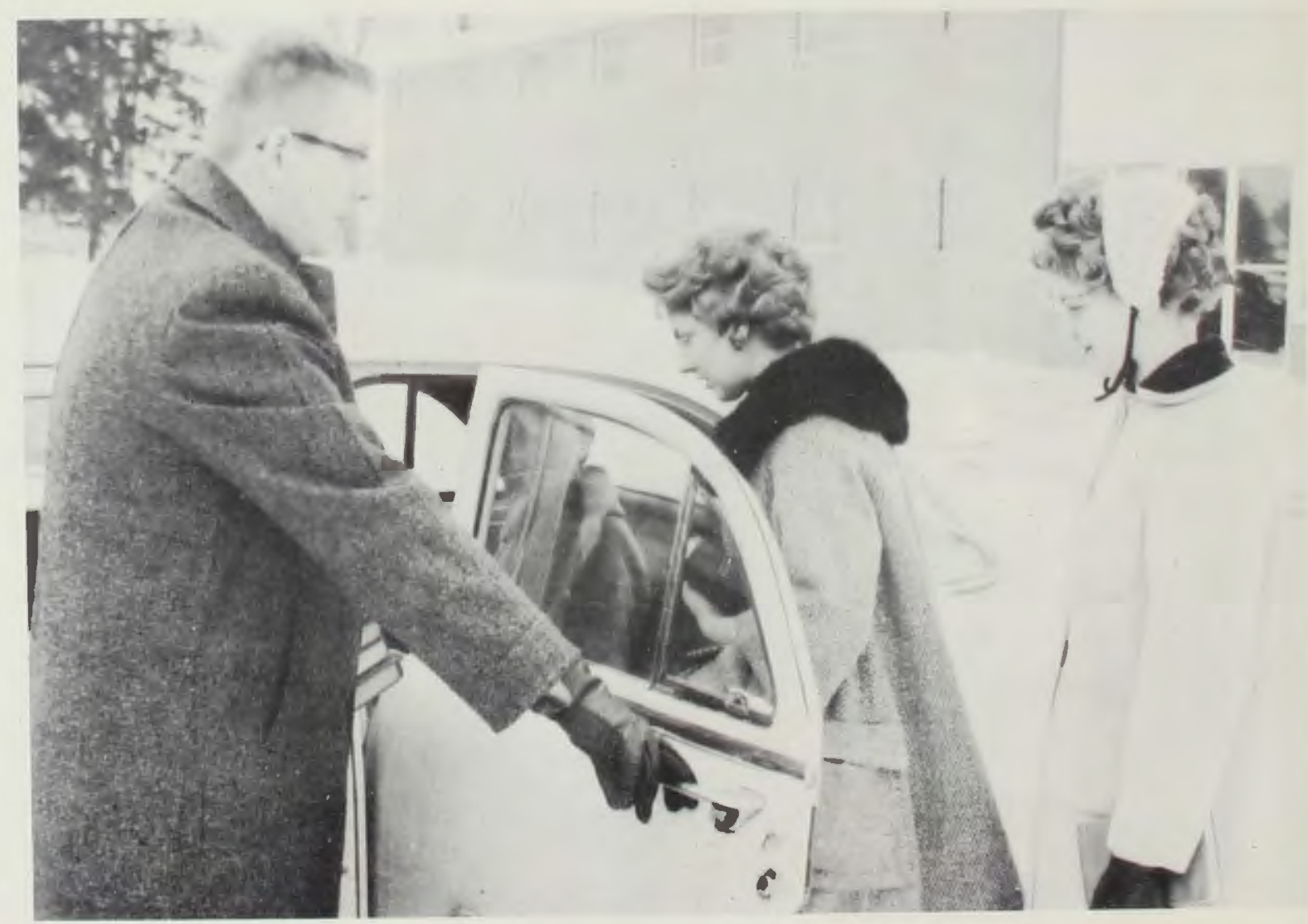

Trips to and from Christian Service assignments include planning future meetings, getting to know group-mates better, and fun. 


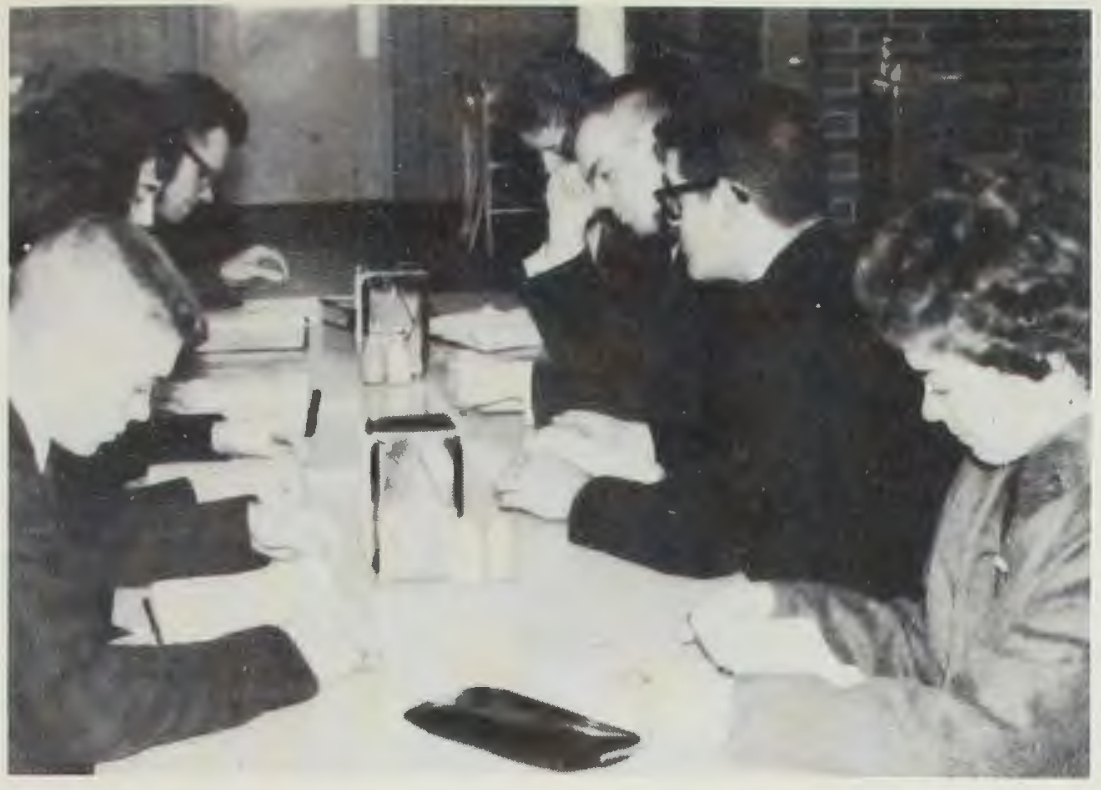

Personal preparation of the individual life and heart is the most important factor.

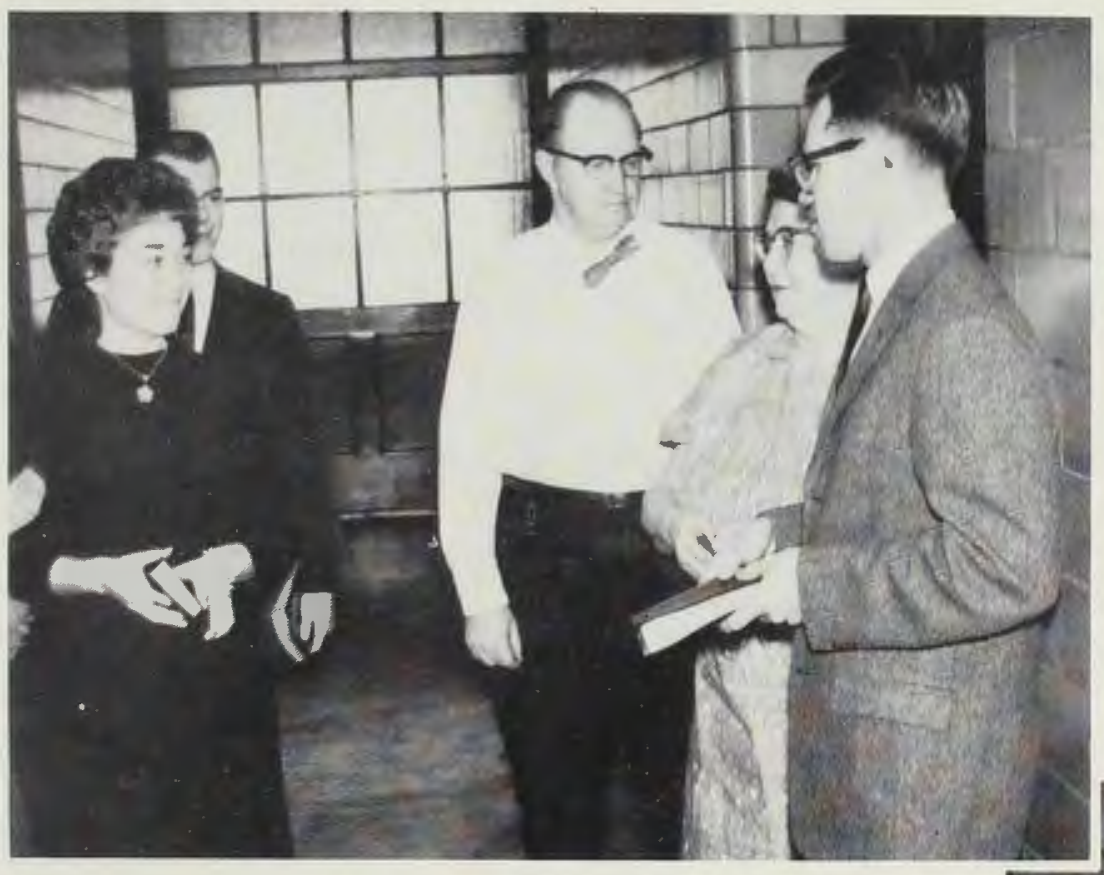

A briefing session upon arrival helps the group get its bearings.

Juvenile delinquency is a widely recognized problem in our society. Believing that Christ is the answer, Cedarville students give their valuable time to visit the detention home in Springfield. These students become a part of the detention home program-they are given some access to confidential case histories and allowed to mingle freely with the young people for personal work.

\section{Detention Home}

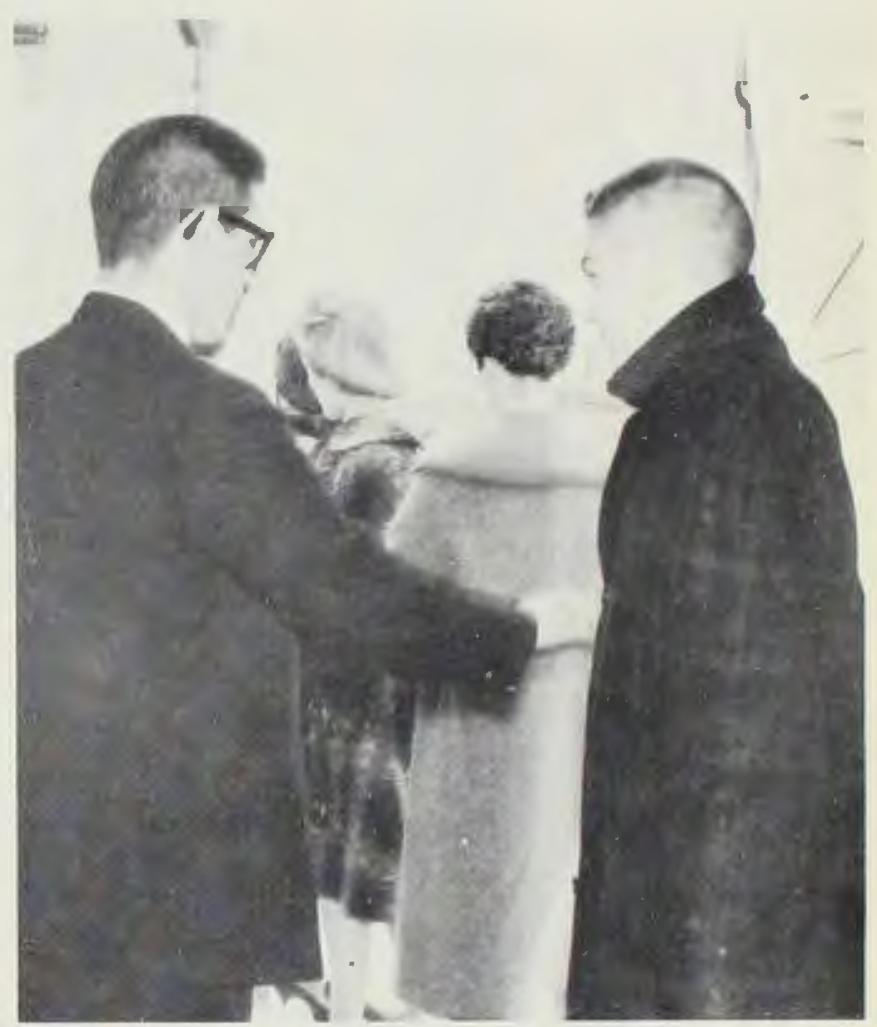

Exchange of ideas and approaches dominates the conversation going to Springfield.

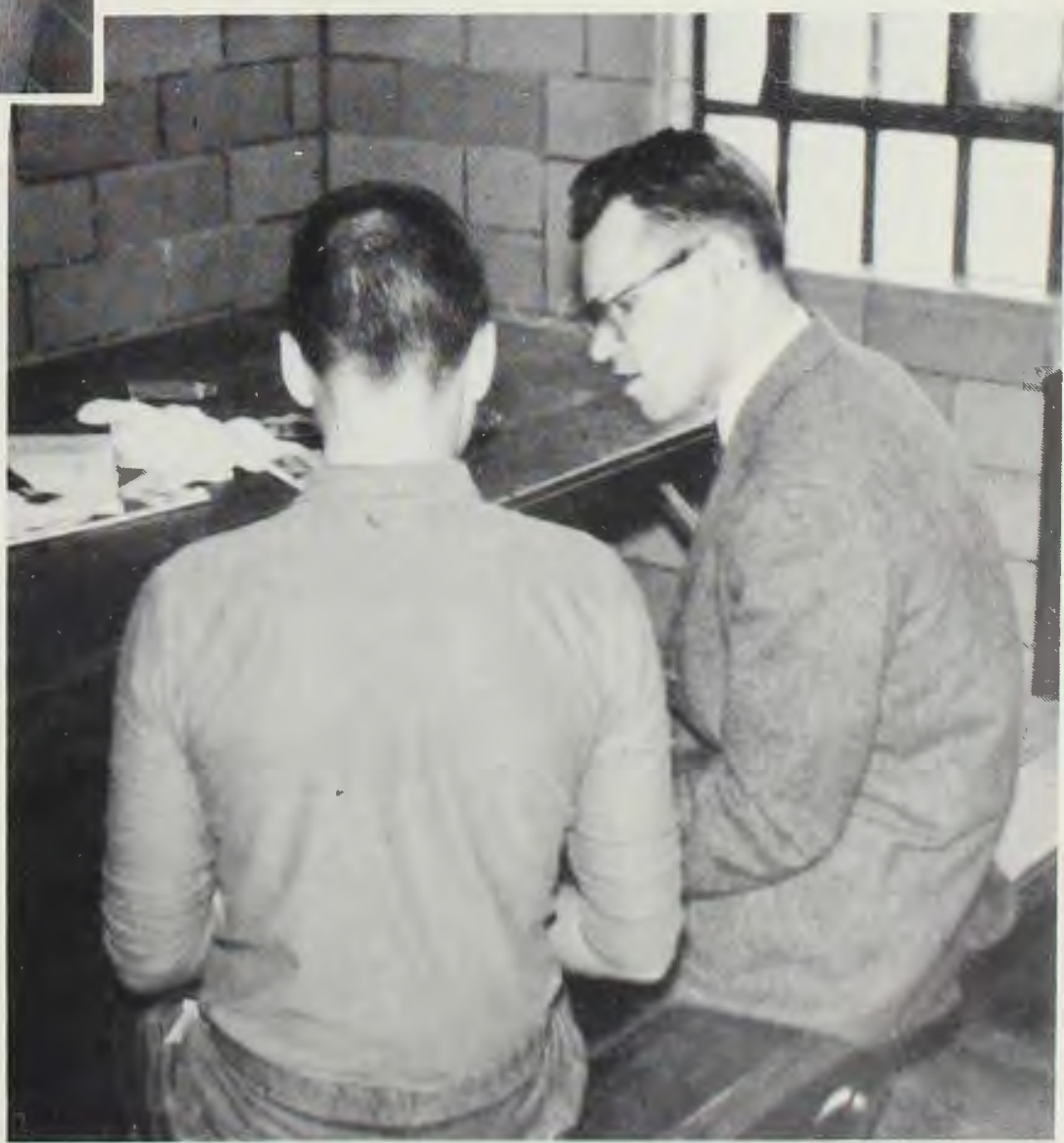

Personal contact, the most important element, helps Keith Webster gain this boy's confidence and finally to present him with the plan of salvation. 


\section{At \\ Grace \\ Baptist}

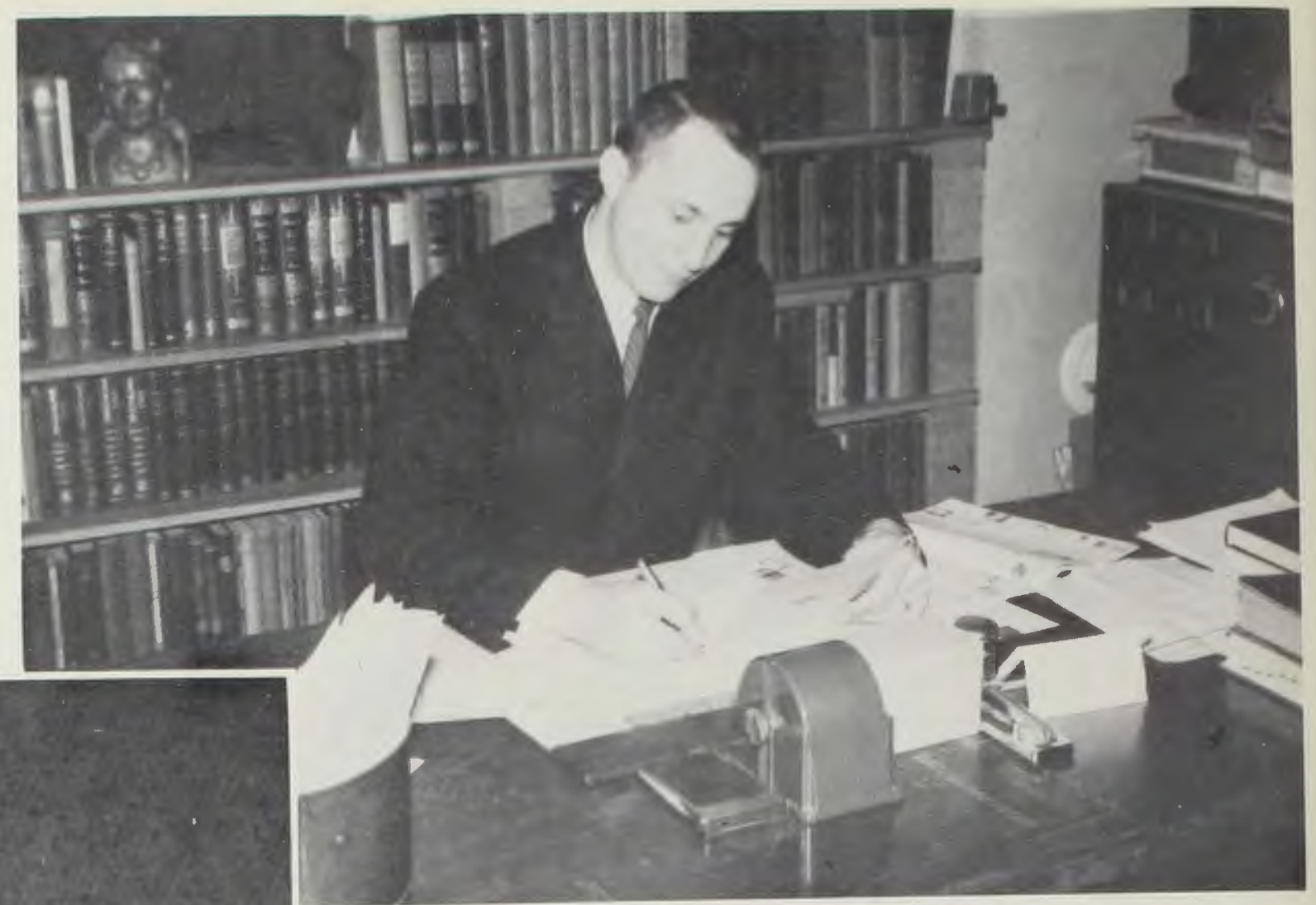

Senior Dave Cochran serves as Sunday School Superintendent.

Using personal abilities to aid others in their worship always brings personal blessing. John Morgan sings an offeratory solo.
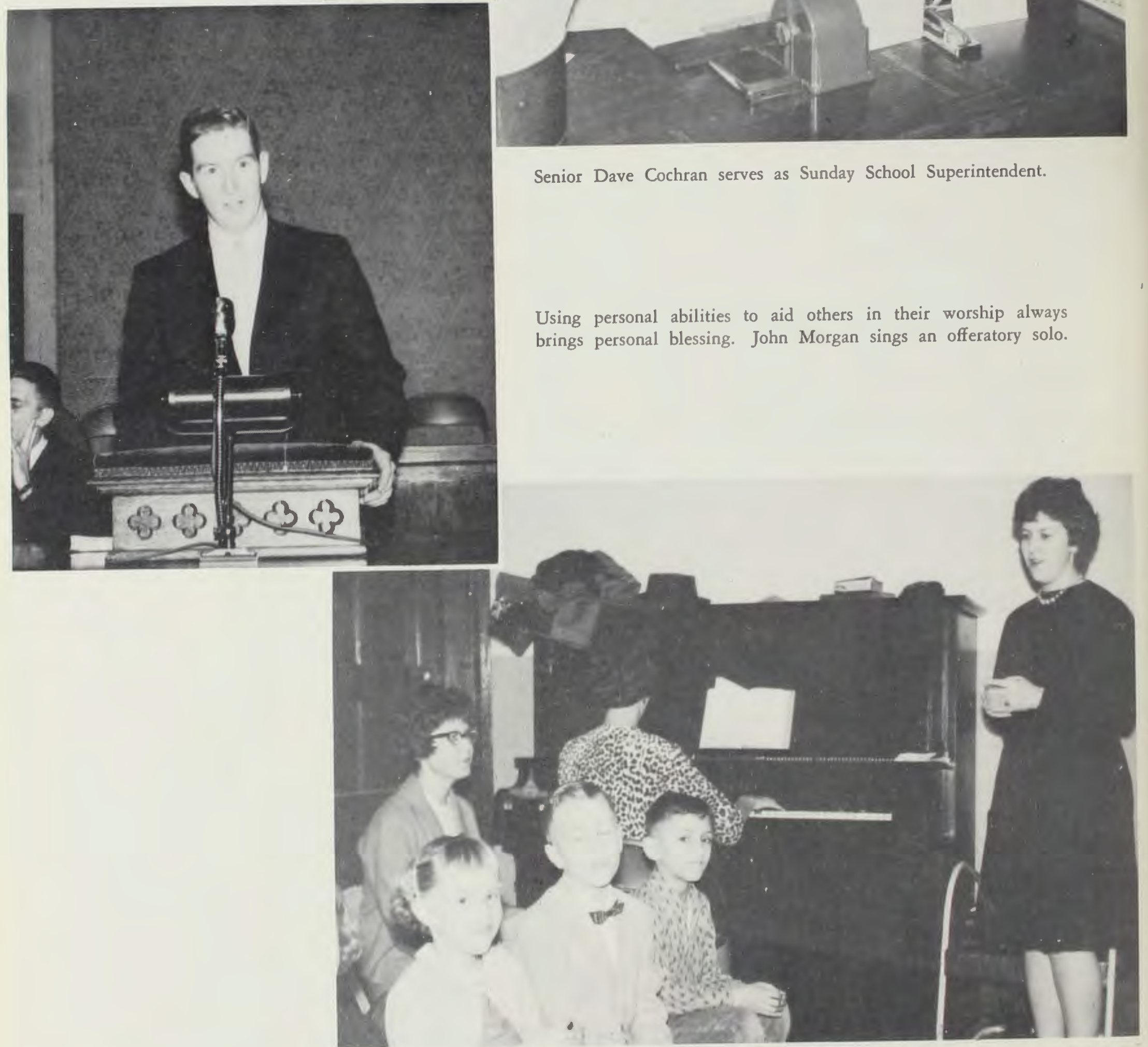

Mary Blann, Helen Wing, and Elsie Himsel work with a Sunday evening youth group. 


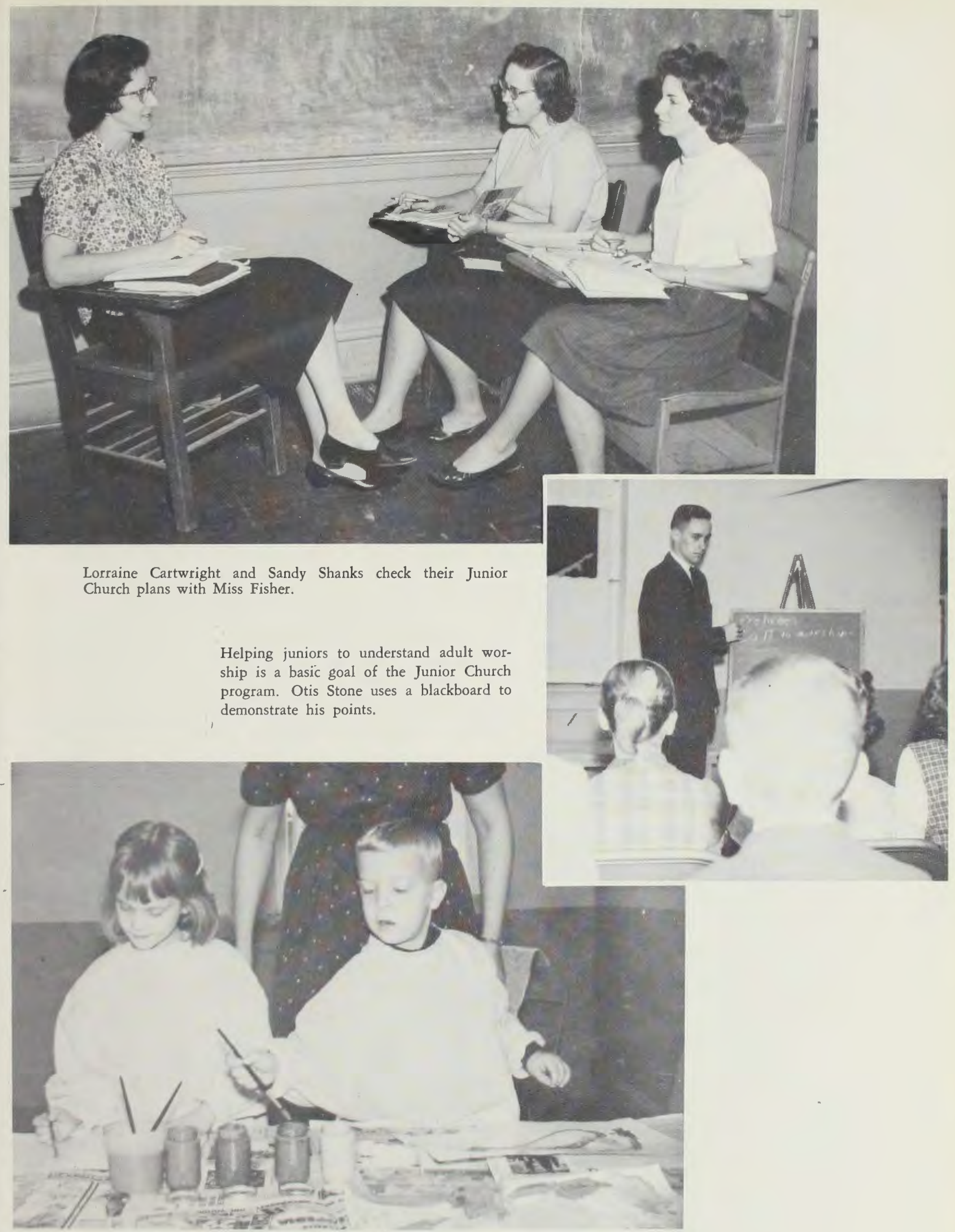

The camera catches faculty children, Becky Turnbull and Scotty Thomson trying

to reproduce a reasonable facsimile of the great fish which swallowed Jonah. 
The church nursery benefits the mother with young children and helps keep the auditorium quiet and more conducive to worship. Charlene Bloemer keeps a watchful eye on the lively youngsters.

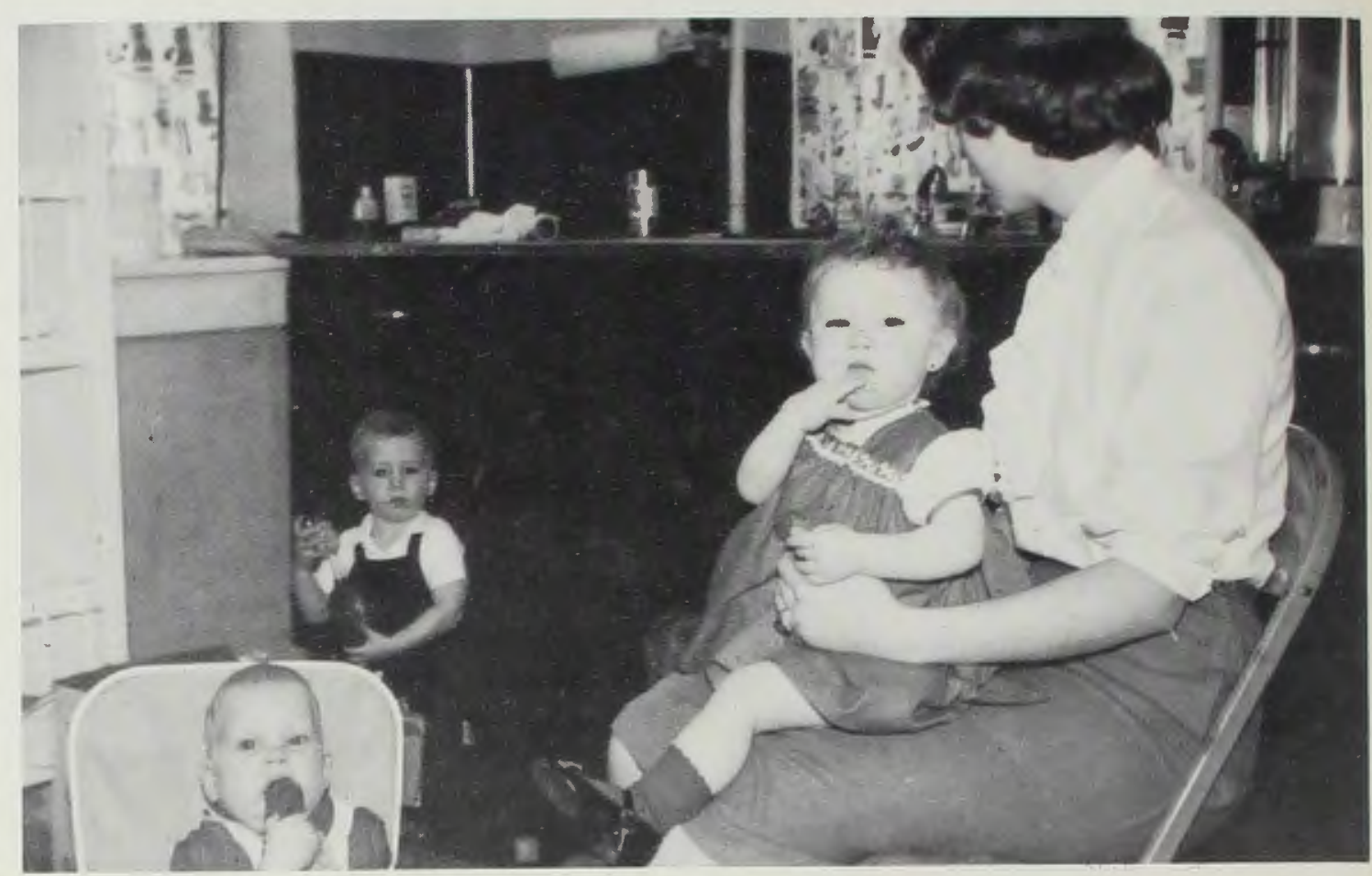

Our local church, Grace Baptist, offers many opportunities for service within our community. Participation in choirs and youth groups, responsible positions in the Sunday School and Junior Church, songleading, usher- ing-all these are important to the church. Not only is service important to the church, it is vital to the spiritual life of the individual. We soon learn that "... it is in giving that we receive ...."

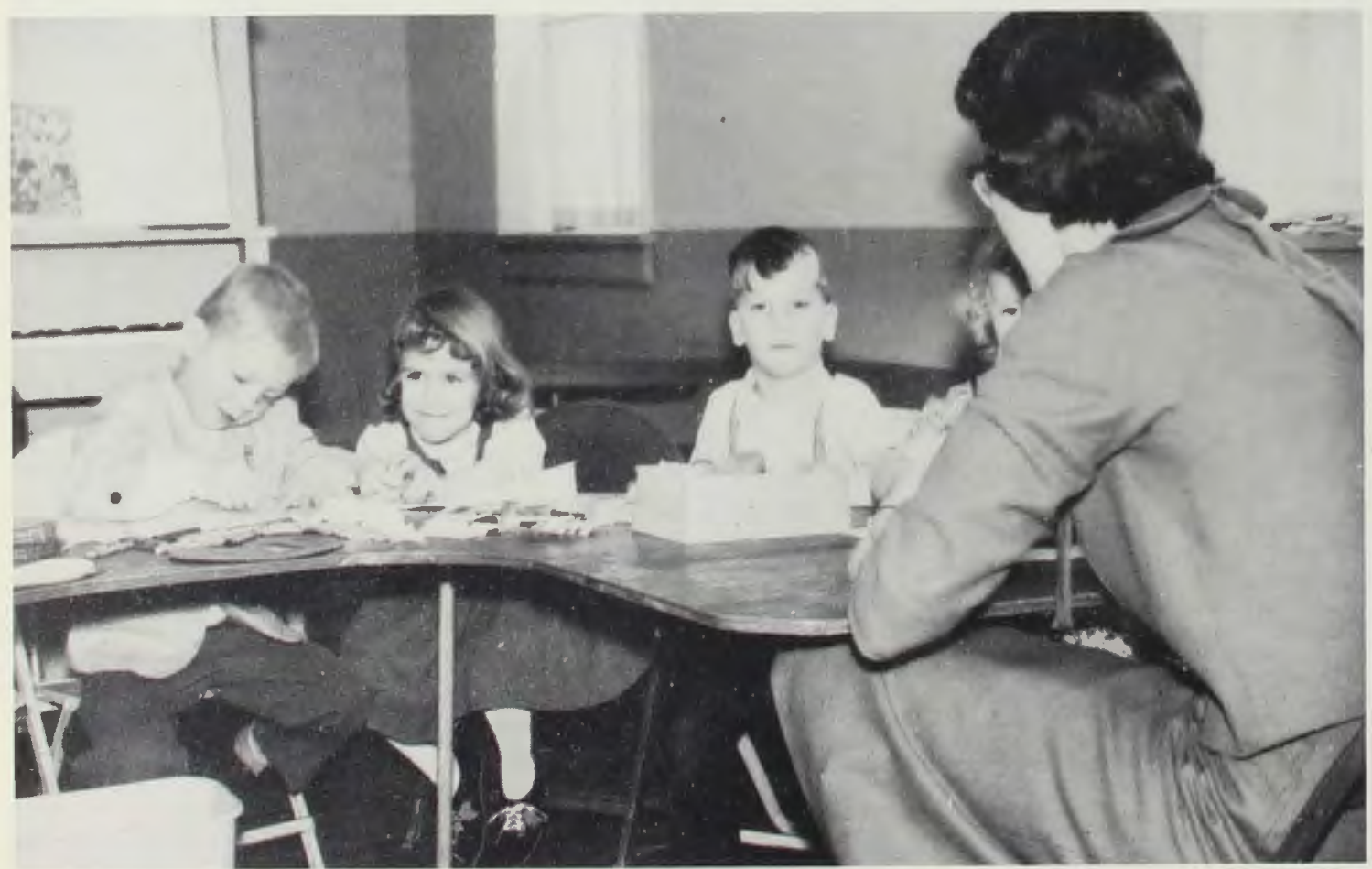

Miss Fisher evaluates the work done by Cedarville students in Beginner Church. 


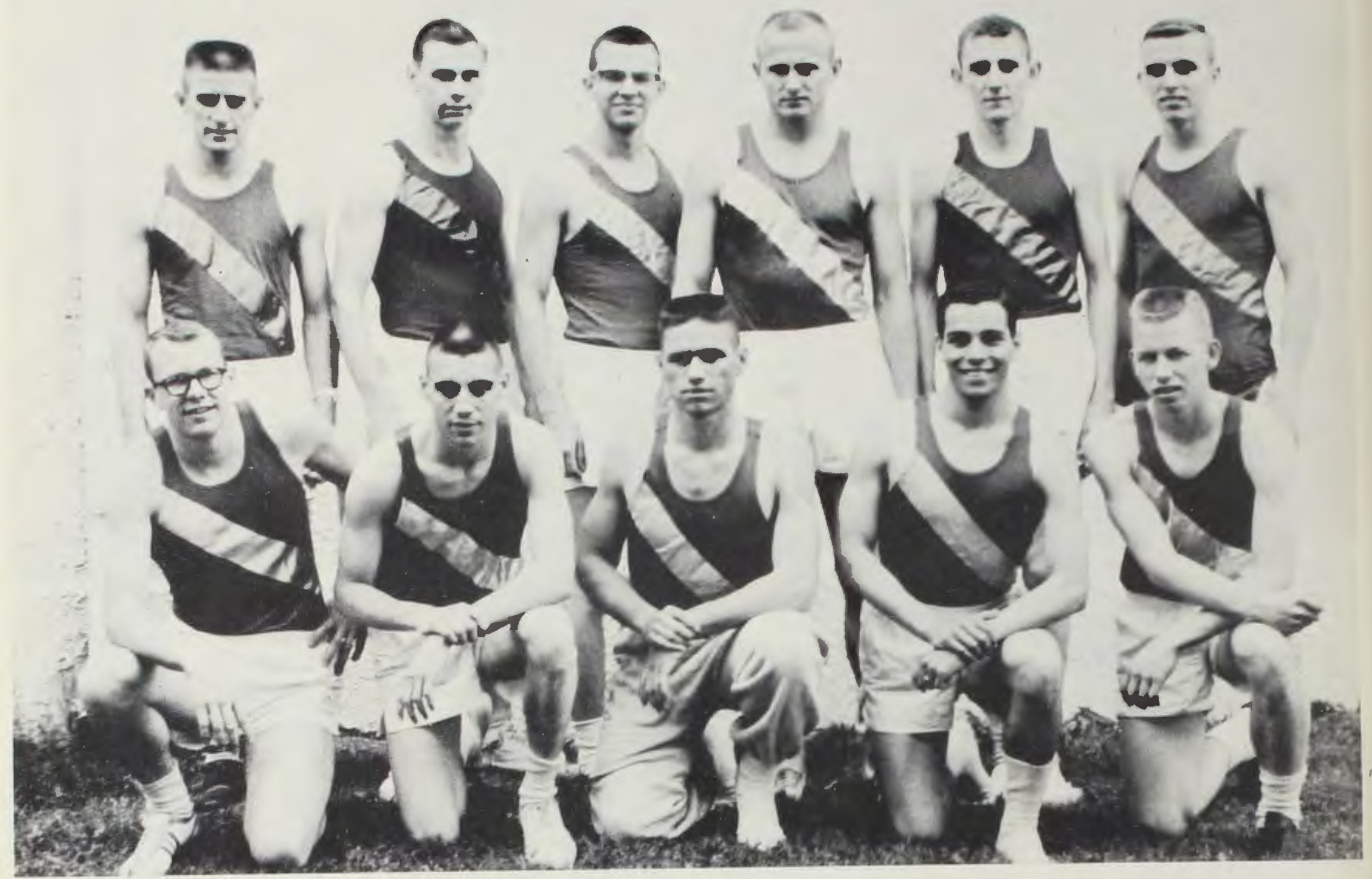

STANDING, Left to Right: Elvin King, Dale Whiting, Bill Riter, Bob Ellis, Jim Sprague, Dave Warren. KNEEL-
ING: Jerry Peifer, Paul Warner, Don Tennant, Ed Villalba, John Justice.

\section{Track}

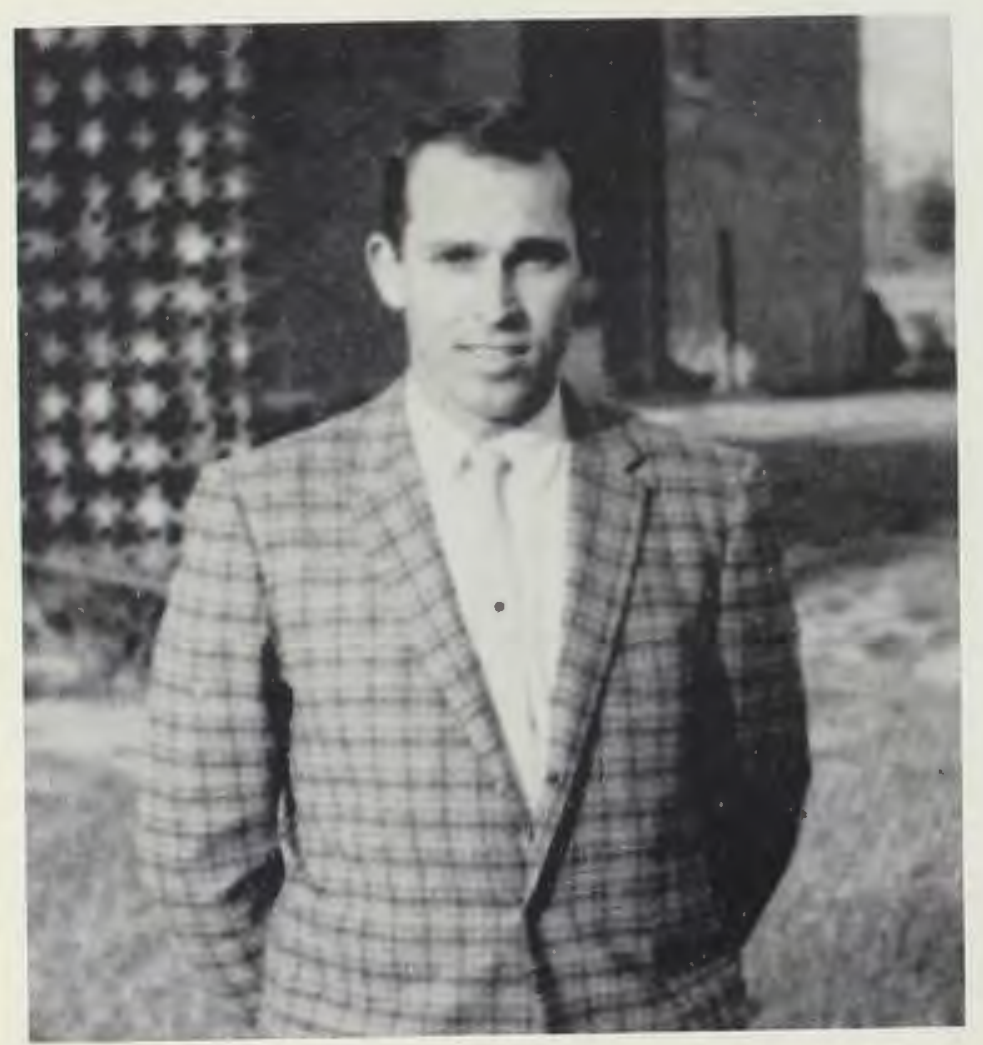

COACH CALLAN

\section{SCHEDULE AND SCORES}

Cedarville 34

Cedarville 38

Cedarville 4

Defiance $641 / 2$ Taylor 92 Kenyon 70 Bluffton $651 / 2$ Cedarville $451 / 2$ Wilmington 41 - Ohio Northern $741 / 2$ Cedarville 40 Defiance 104 


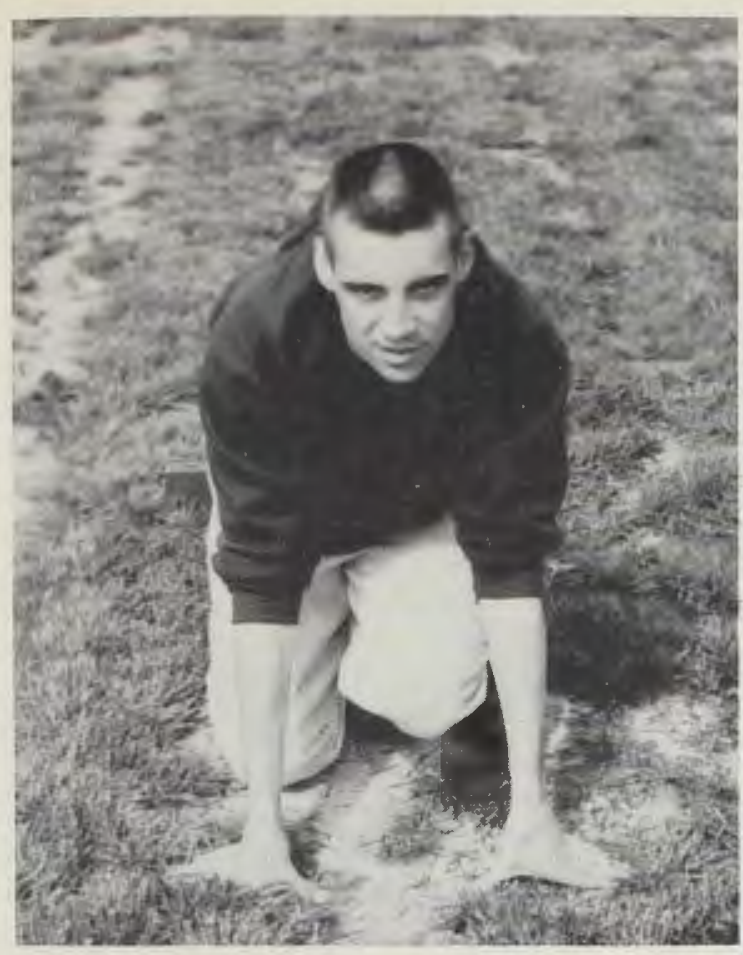

Paul Warner

100 yard dash

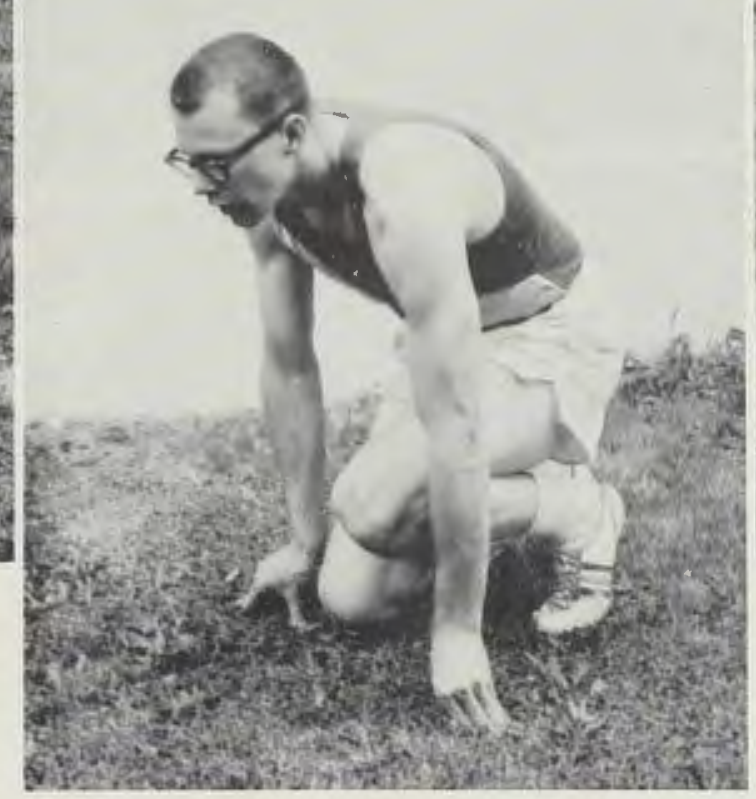

Jerry Peifer

440 Star

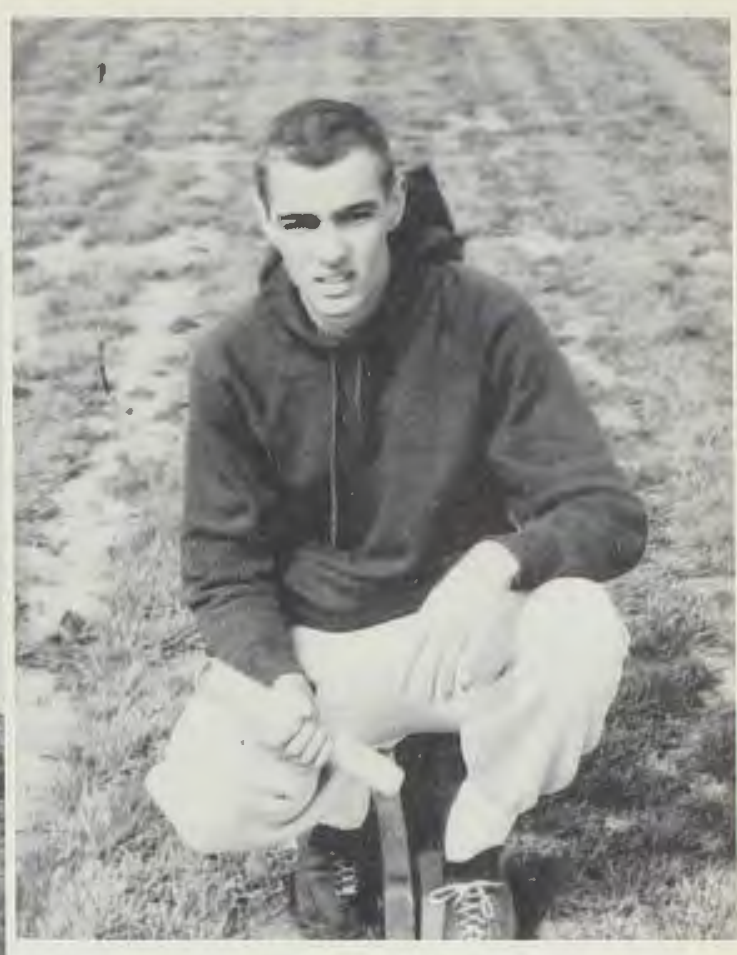

Dave Jeremiah

Half-miler

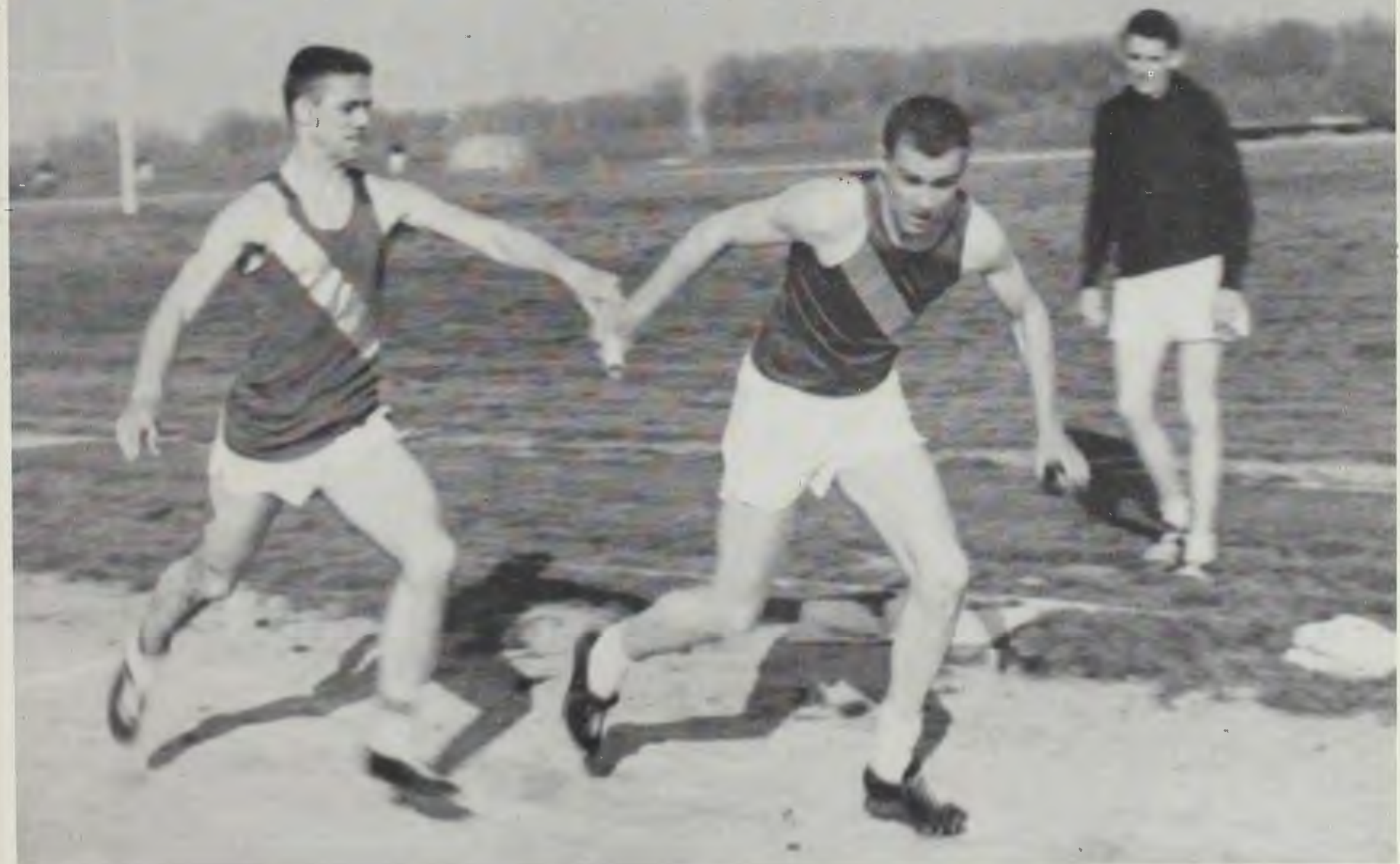

Don Tennant gives the baton to Dave Jeremiah in the mile relay. 


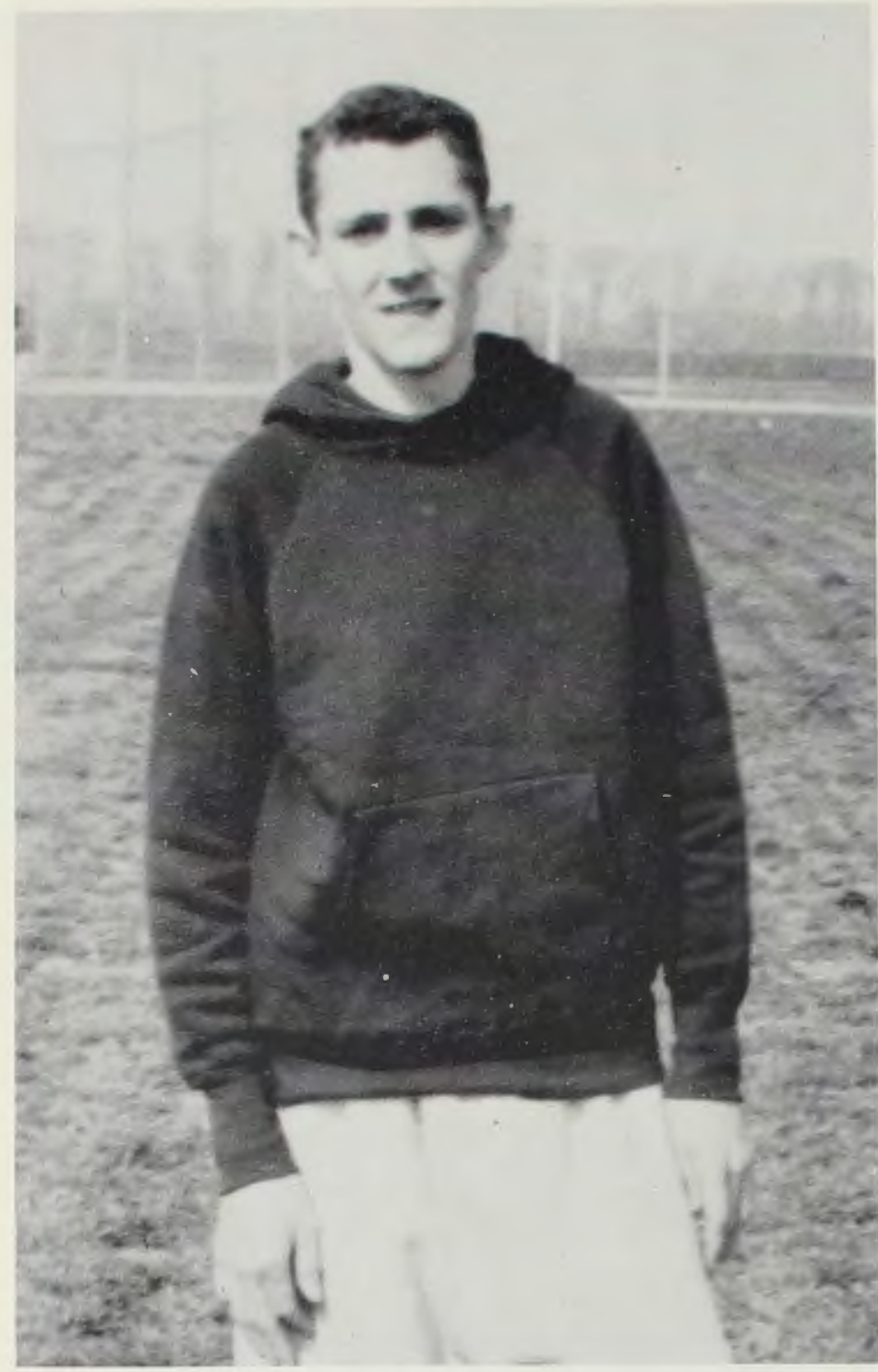

JIM SPRAGUE

M. O. L. Mile-run Champ

\section{Track}

Under the leadership of Coach Callan, the Cedarville Yellowjackets began an intercollegiate track program this year. Although defeat was realized many times, the track team ended the season on a successful note as they outscored two league rivals to finish fifth in the Mid Ohio League track meet.

The season was highlighted by Jim Sprague's record mile run. He set a new record of 4:37, breaking the old record of 4:40 set back in 1956. Jim went on to win the two-mile run to become Cedarville's only double winner.

Paul Warner was the season's high scorer, and he also set a new school record with a sprint in the 100 yard dash.

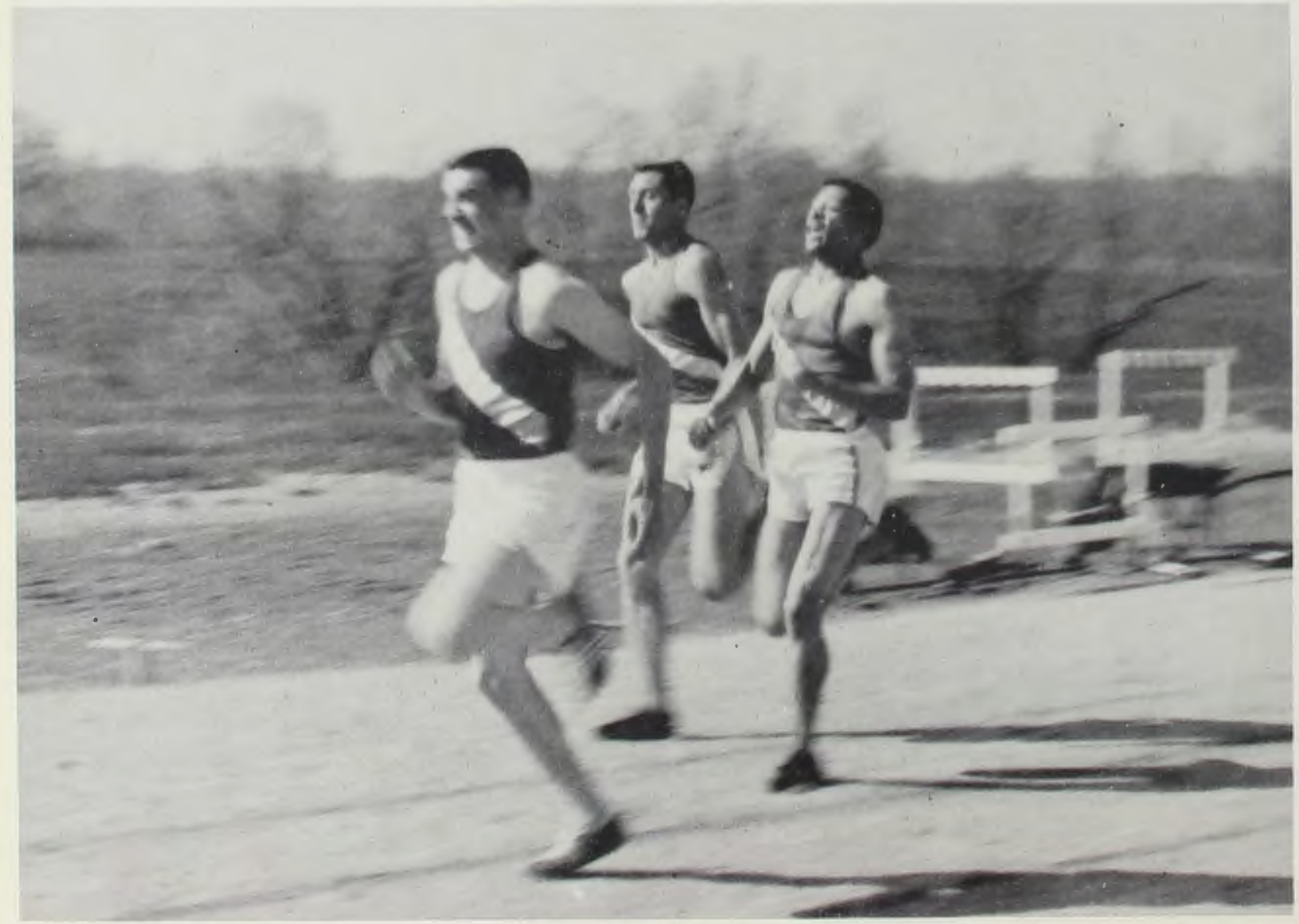

Paul Warner sprints to the finish line. 


\section{Baseball}

Although posting but two wins during the course of the season, Coach Sherm Bowser's Yellowjackets demonstrated plenty of hustle and determination, and provided many exciting moments for their followers. Highlight of the season was a double-header sweep over Wilmington, 2-0 and 6-4. Losing no lettermen through graduation, the Yellowjackets should have a solid, experienced team to present to their fans next year.
For the first time in Cedarville's athletic history, two Most Valuable Players were chosen, Vance Ashley and Tom Delanzo. Vance's fine pitching and first base play, plus his potent bat (.311 average, second only to Tom) earned him a share of the spotlight. Tom won the batting title with a .333 average, and his quick hands and fine speed were a real asset to the Cedarville infield.

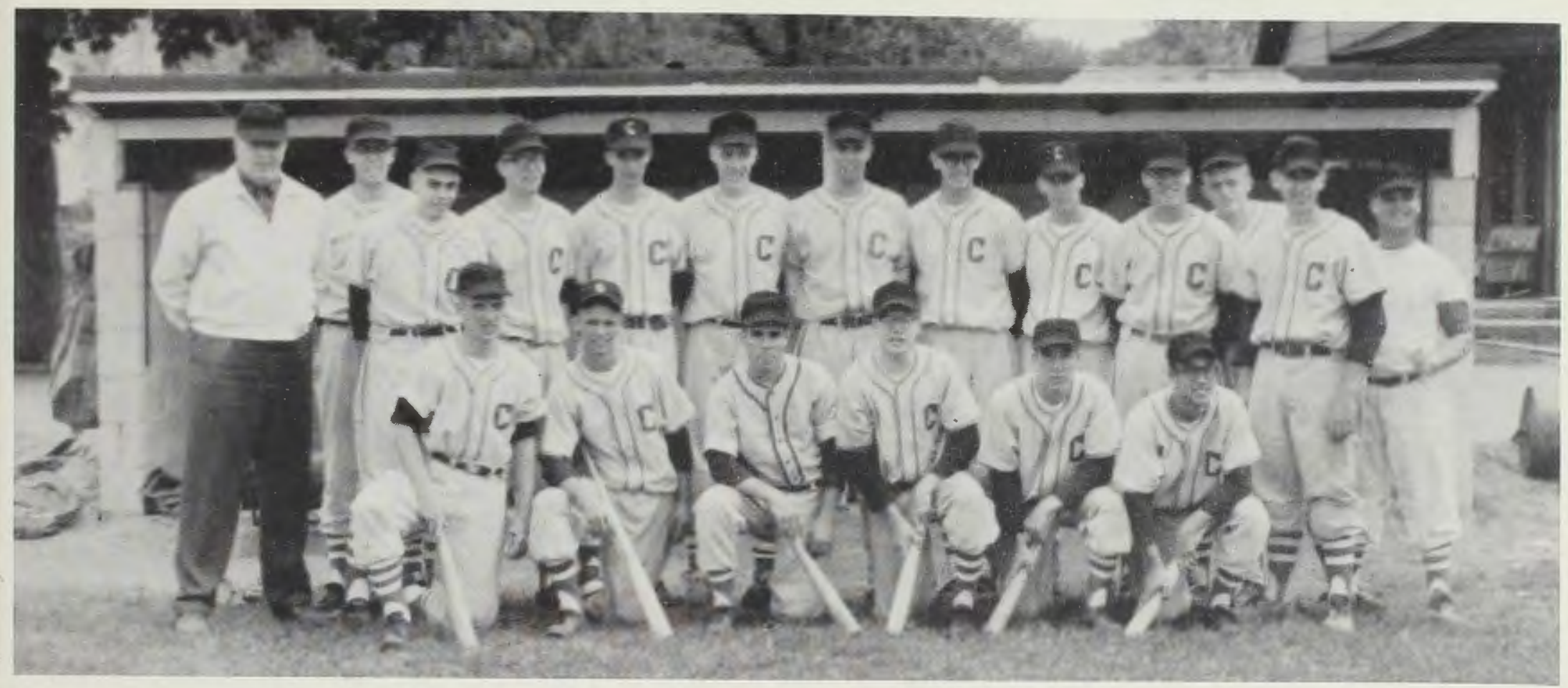

STANDING: Coach Bowser, Bob Fidler, Mark Haseltine, Ed Norris, Norris Smith, Jim Entner, Ronn Mooney, Vance Ashley, Dave Morganti, Al Biddle, Bud Connell,
Denny McDonald, Phil Jewett, Manager. KNEELING: Jim Grafton, 'Ted Ocheltree, Tony Rotondi, Tom Evans, John Moody, Tom DeLanzo.

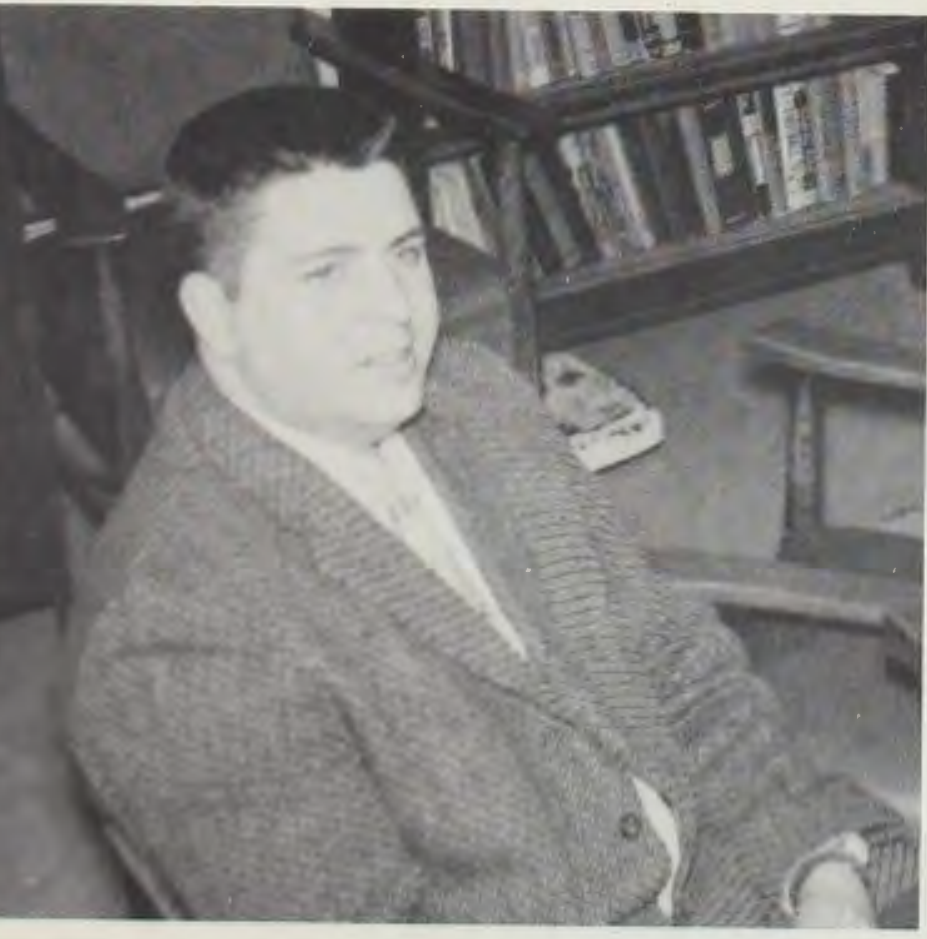

COACH SHERM BOWSER

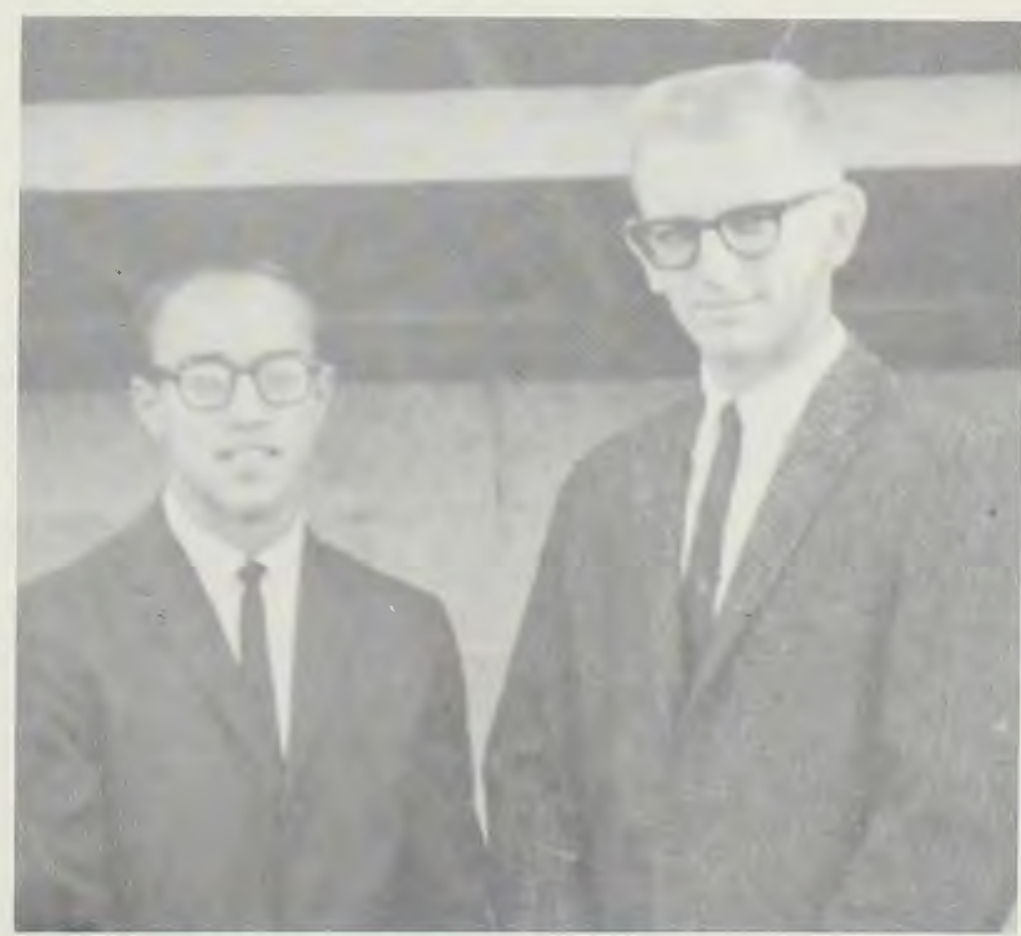

Most Valuable Players: Tom DeLanzo and Vance Ashley 
Norris Smith, P-OF

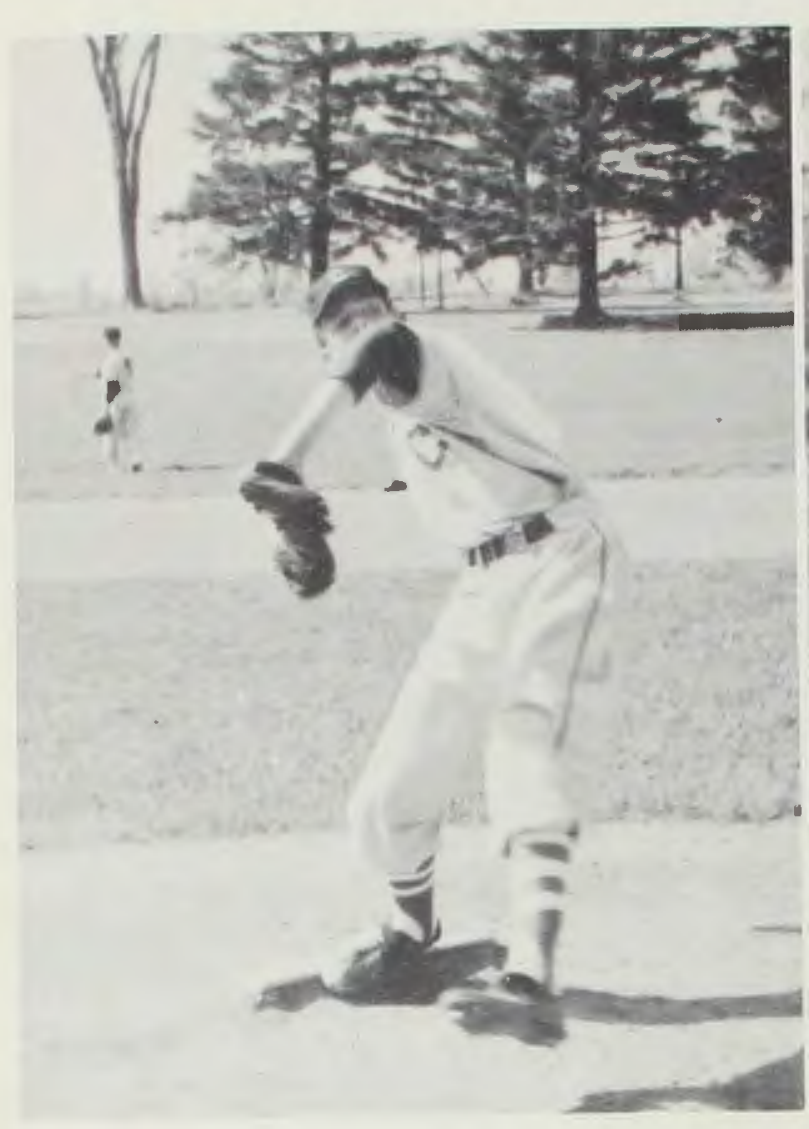

Dennis McDonald, OF

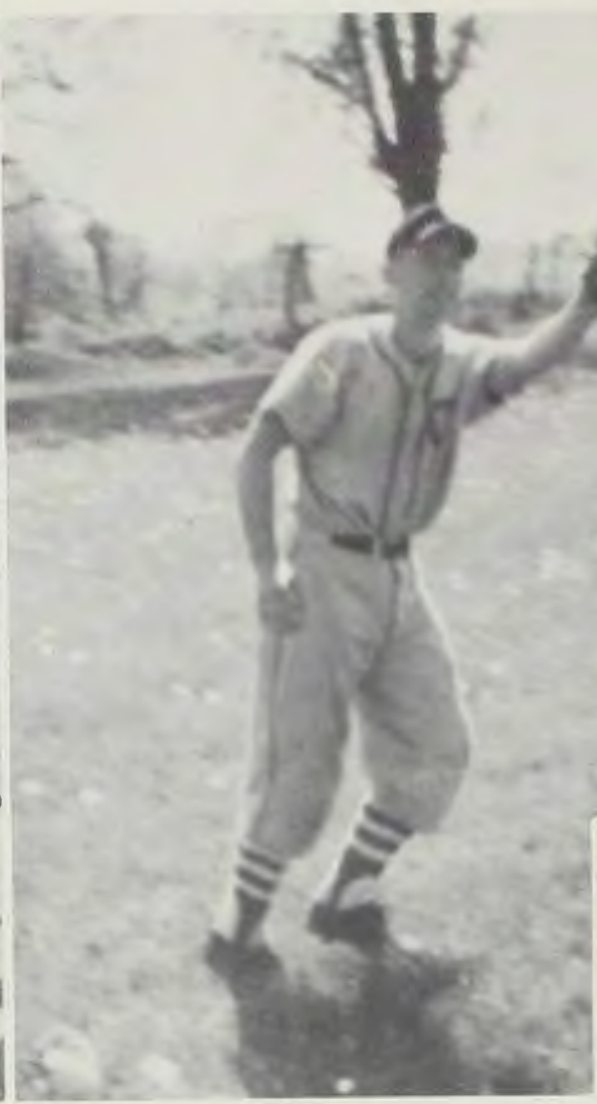

Baseball

The outstanding pitching performance of the season was a twohit, 2-0 shutout over the Wilmington Quakers by Norris Smith. "Smitty" did not walk a man, and he struck out seven in his winning effort. Co-Most Valuable Player Tom Delanzo enjoyed the best day at the plate of any Cedarville hitter, pounding out four hits in five trips in a losing cause in a game played at Findlay.
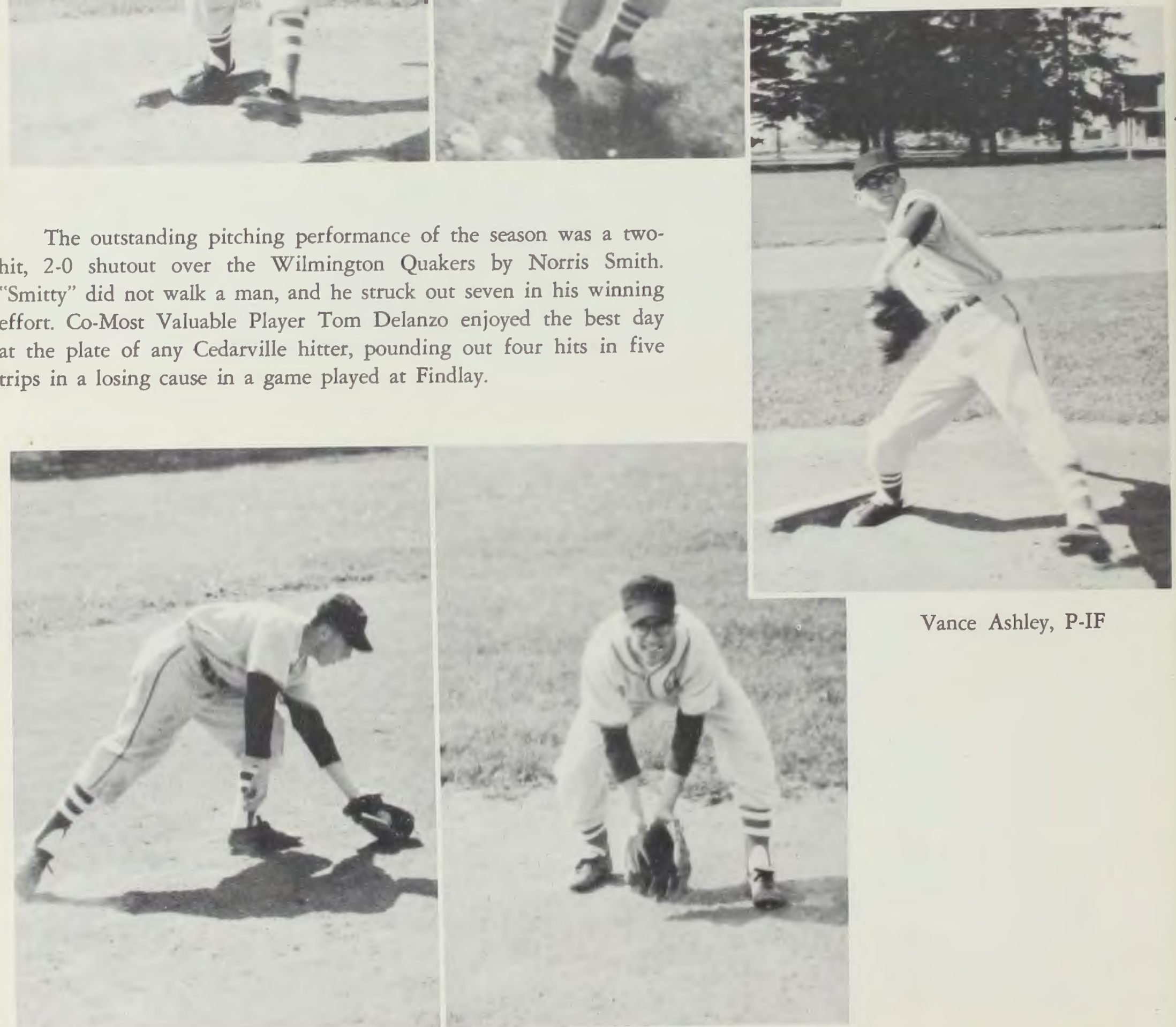

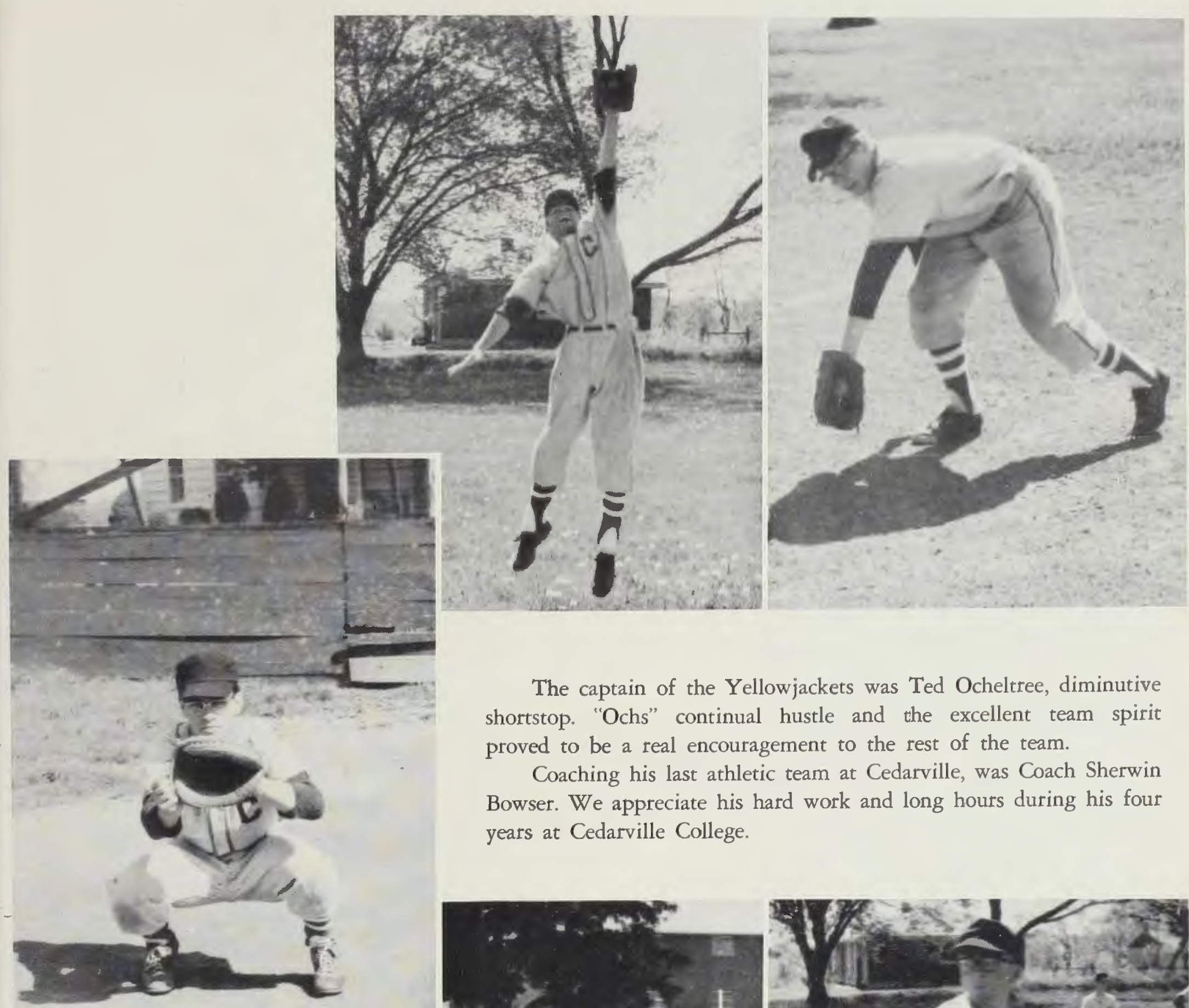

The captain of the Yellowjackets was Ted Ocheltree, diminutive shortstop. "Ochs" continual hustle and the excellent team spirit proved to be a real encouragement to the rest of the team.

Coaching his last athletic team at Cedarville, was Coach Sherwin Bowser. We appreciate his hard work and long hours during his four years at Cedarville College.

Allen Biddle, $\mathrm{C}$
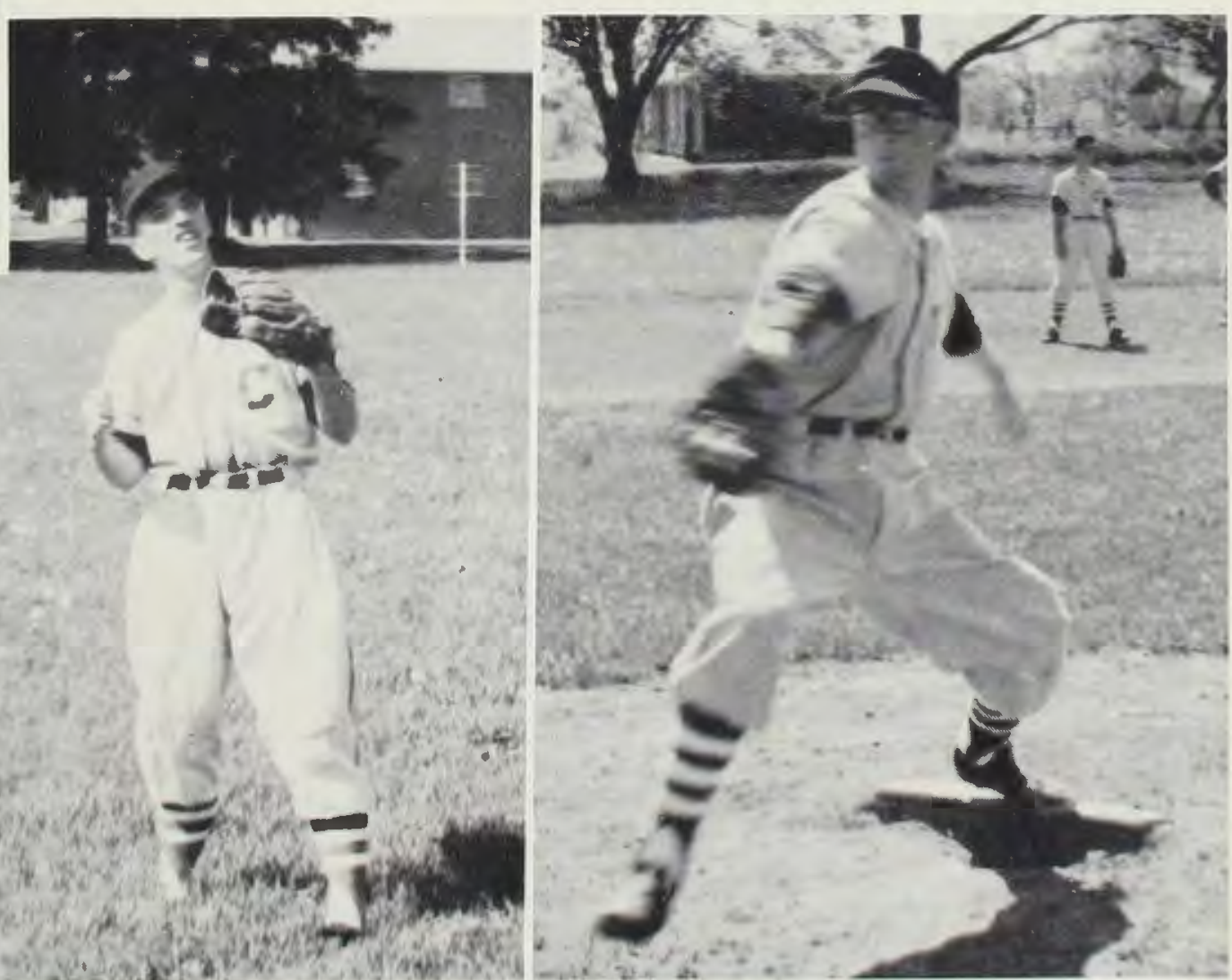


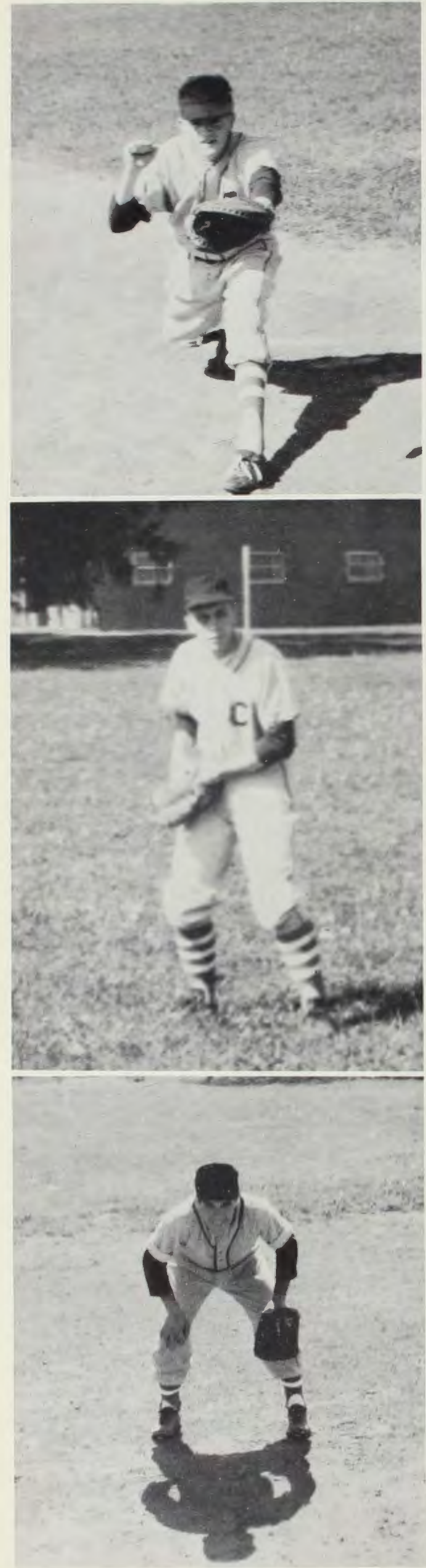

Bud Connell, IF

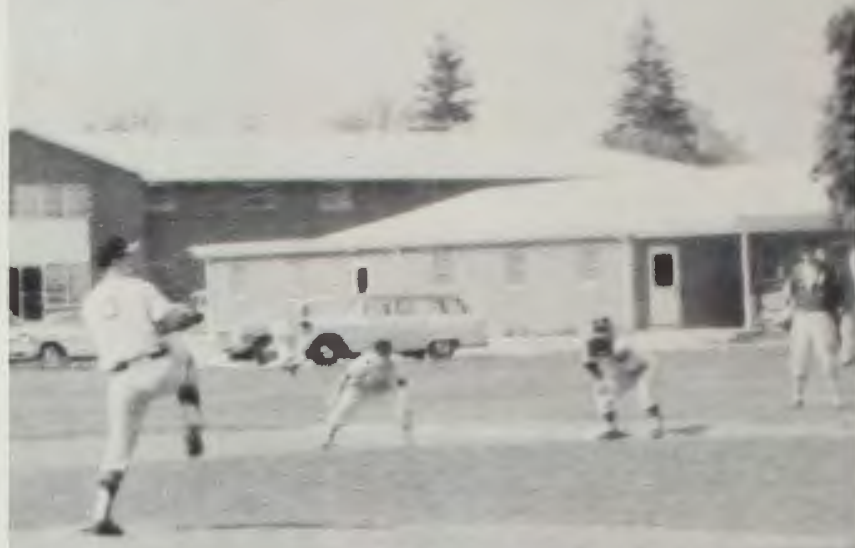

Mark Haseltine, OF

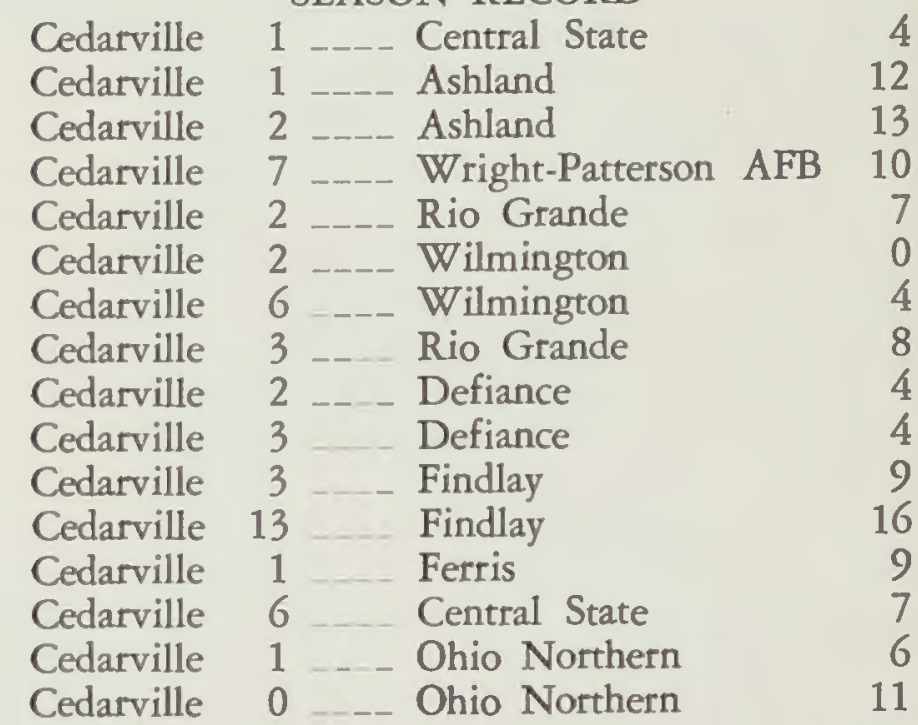

Tony Rotondi, IF

Mark swings at a waist-high pitch.

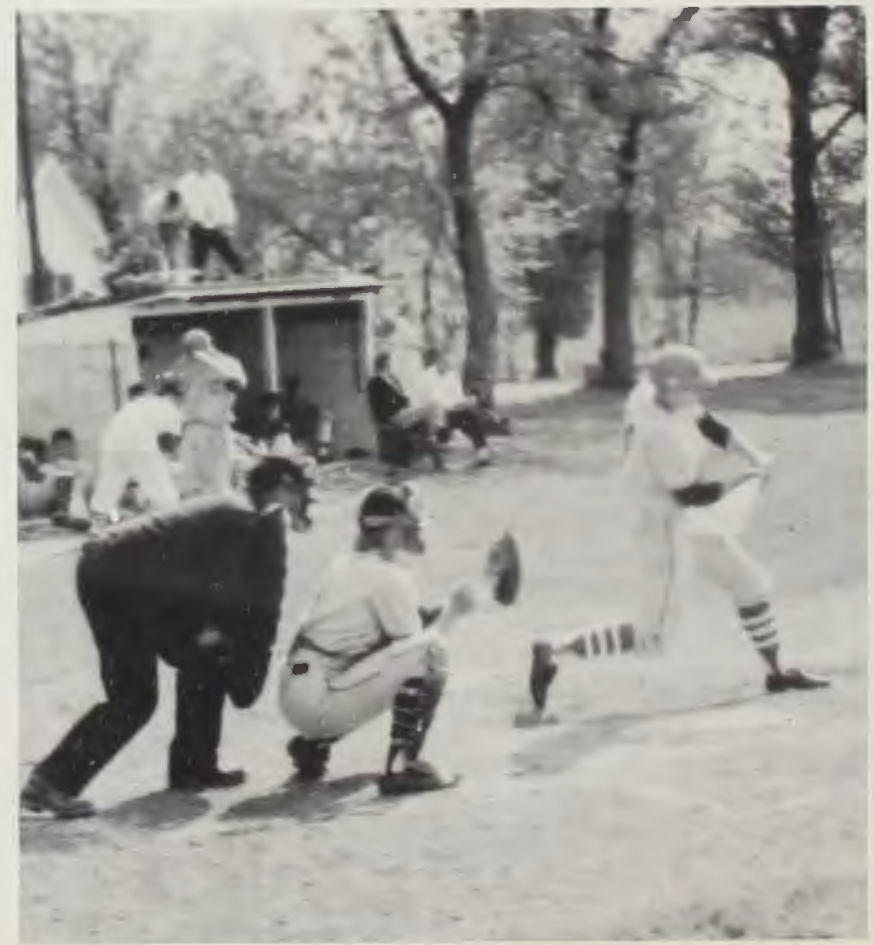




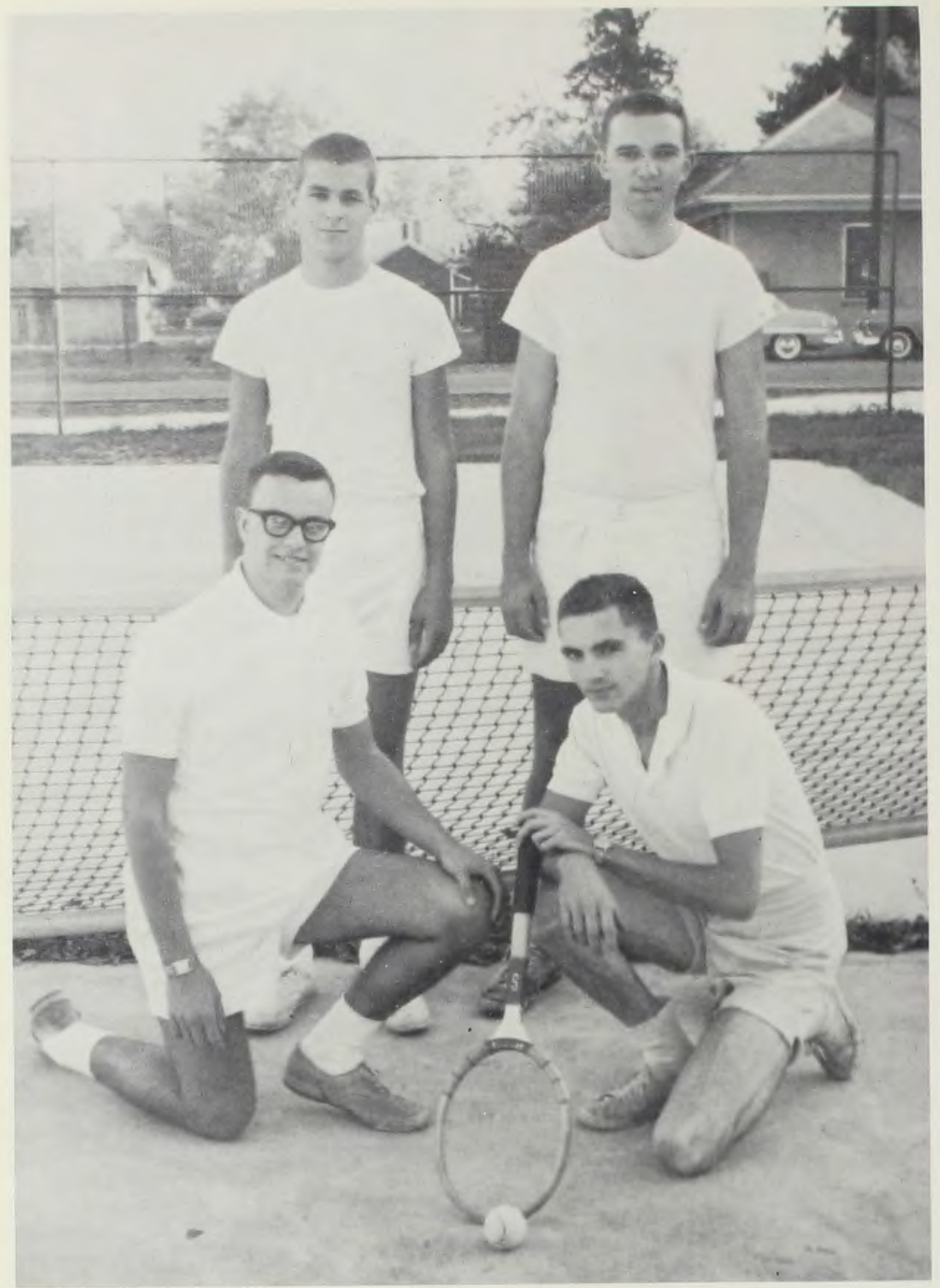

\section{Tennis}

STANDING: Bob Auffort, Jack Moffatt. KNEELING: Ken Atkins, Fred Rolfe.

Lack of experience, and heavy spring rains, which forced the cancellation of over half the scheduled matches, added up to a mediocre showing by the ' 61 Yellowjacket netmen. Only one letterman from the previous season, Jack Moffatt, returned to take up battle in the tough Mid-Ohio League. Although not too successful in the won-lost column, the team is anticipating next season, when veteran ability and a fresh supply of talent are expected to improve the fortunes of Tennis here at Cedarville.
Cedarville 1

Cedarville 2

Cedarville 5

Cedarville 0

Cedarville 2
Bluffton

Wilmington

Ashland

Defiance

Wilmington
8

5

2

7

5 


\section{Golf}

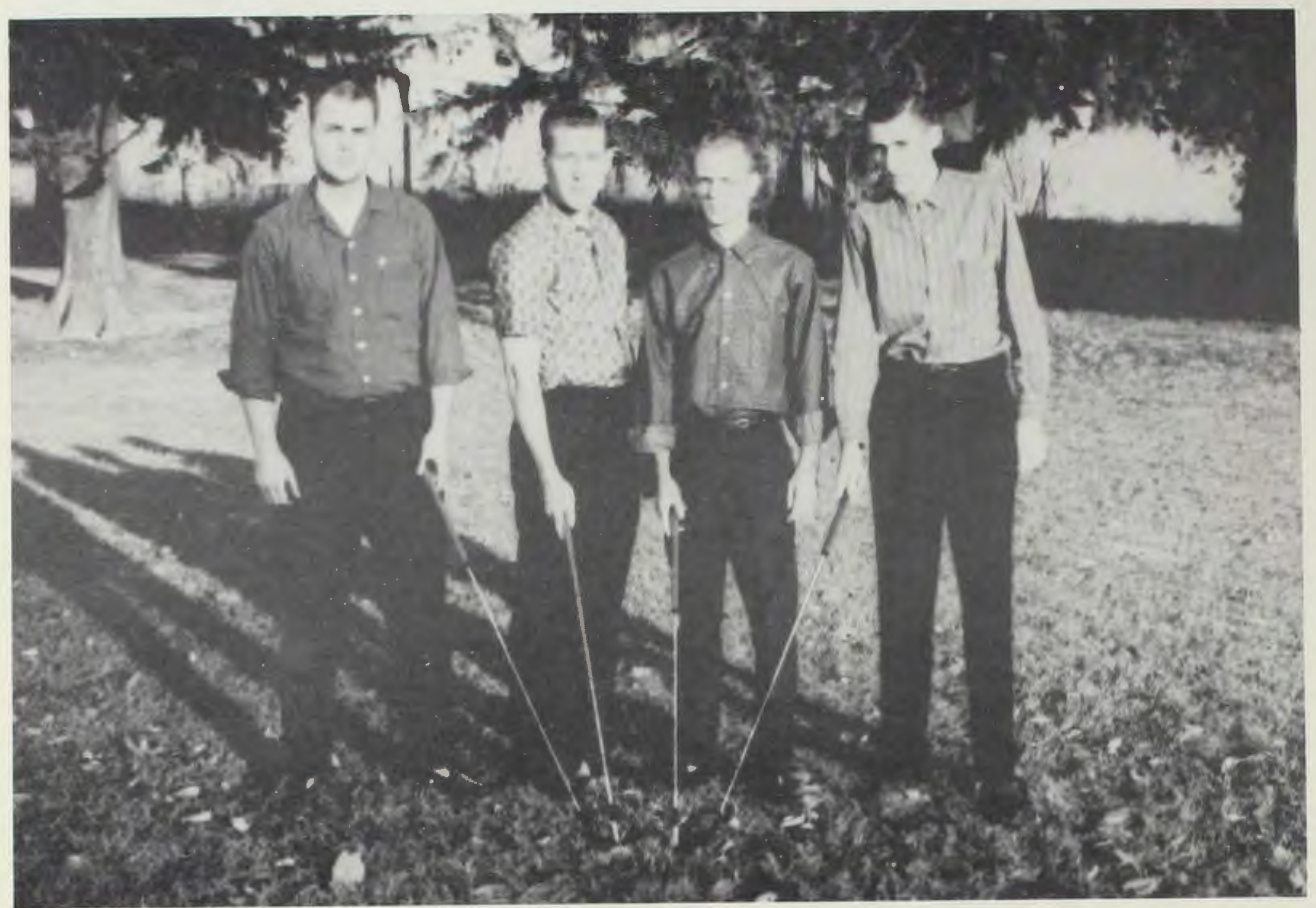

LEFT TO RIGHT: Larry Baker, Steve Nimmo, Ted Ocheltree, Jim Sprague.

Ted and Larry discuss the fine points of driving.

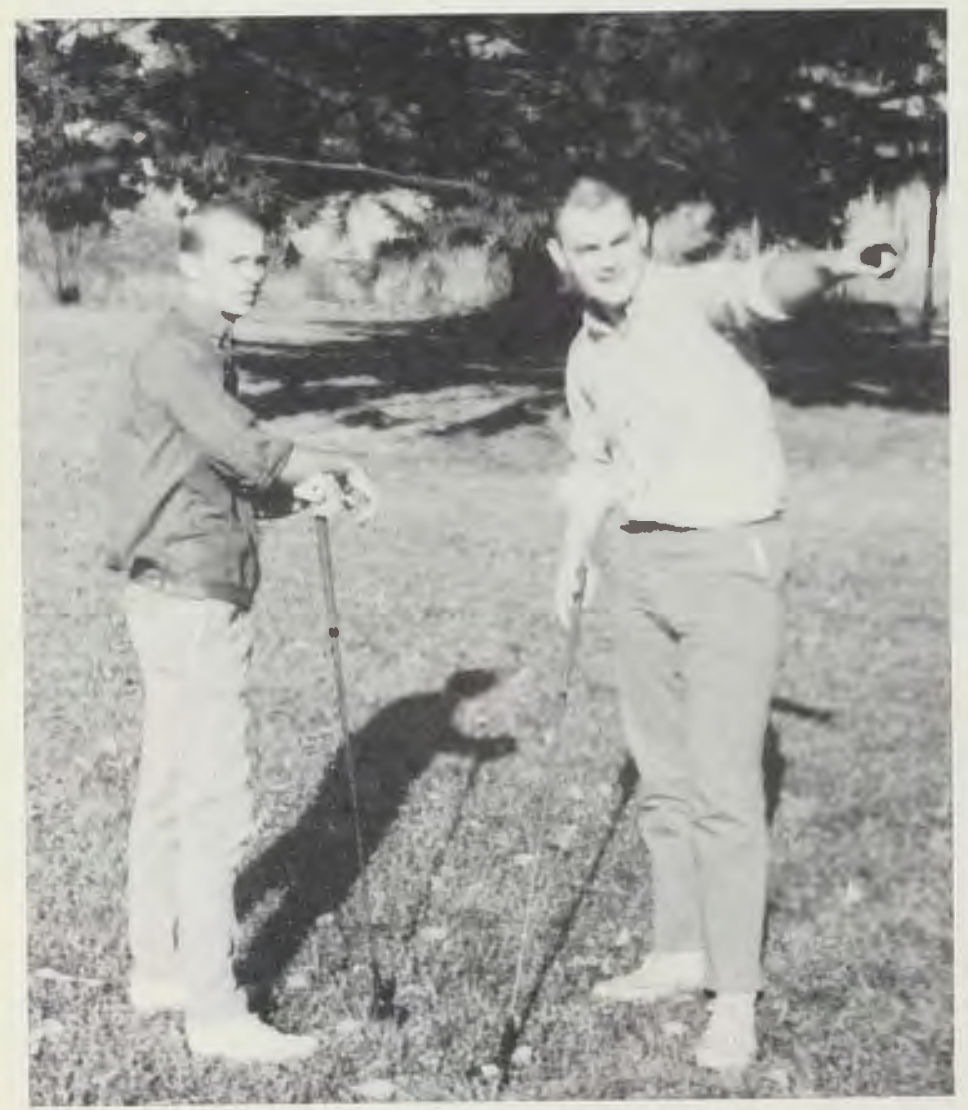

A new spring sport at Cedarville last year was golf. Due to inexperience, and hampered by' bad weather, the team was not able to enter the "won" column during the course of the season, playing all its matches in an experienced Mid-Ohio League. A gleam of hope arises, however, in the fact that all five members of the team have returned to school this year, thus forming the nucleus for possibly a stronger team in the near future. 


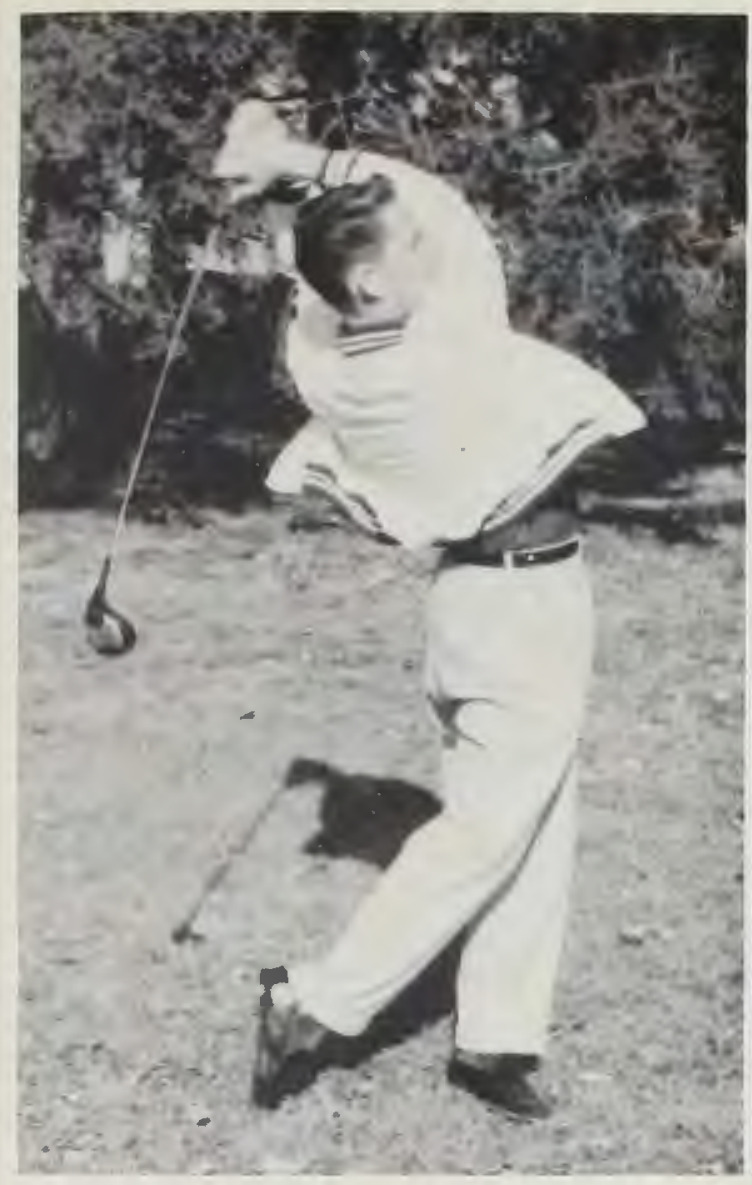

Steve Nimmo

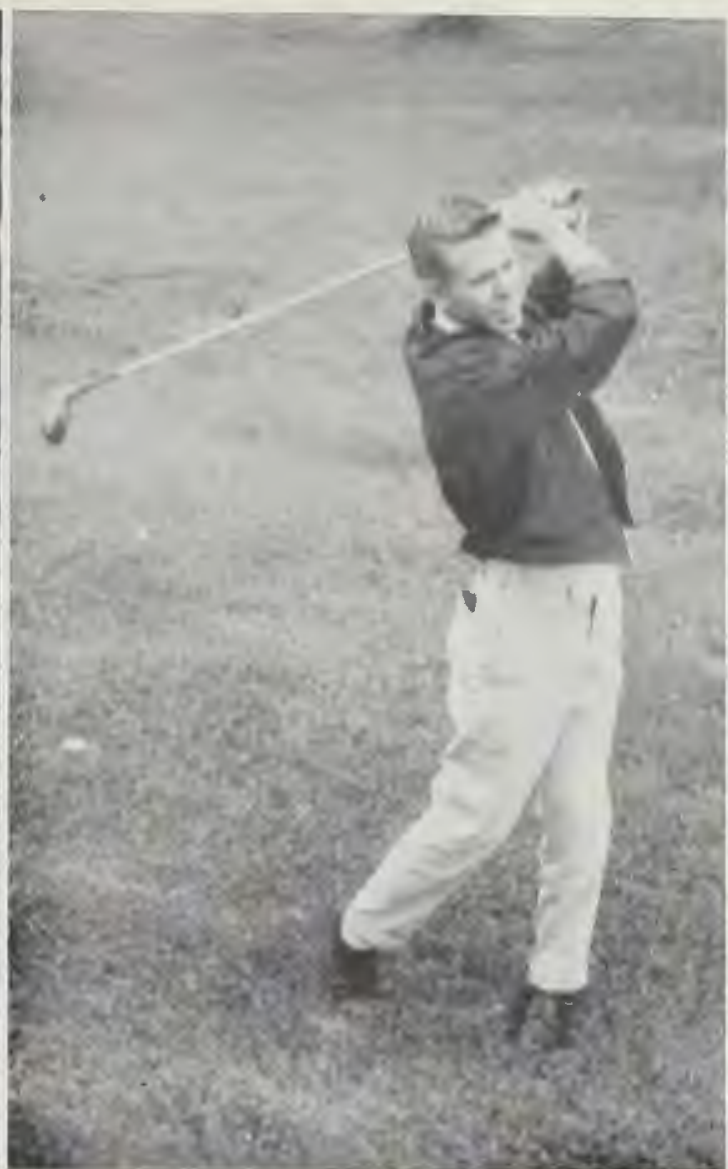

Bogle Standifer

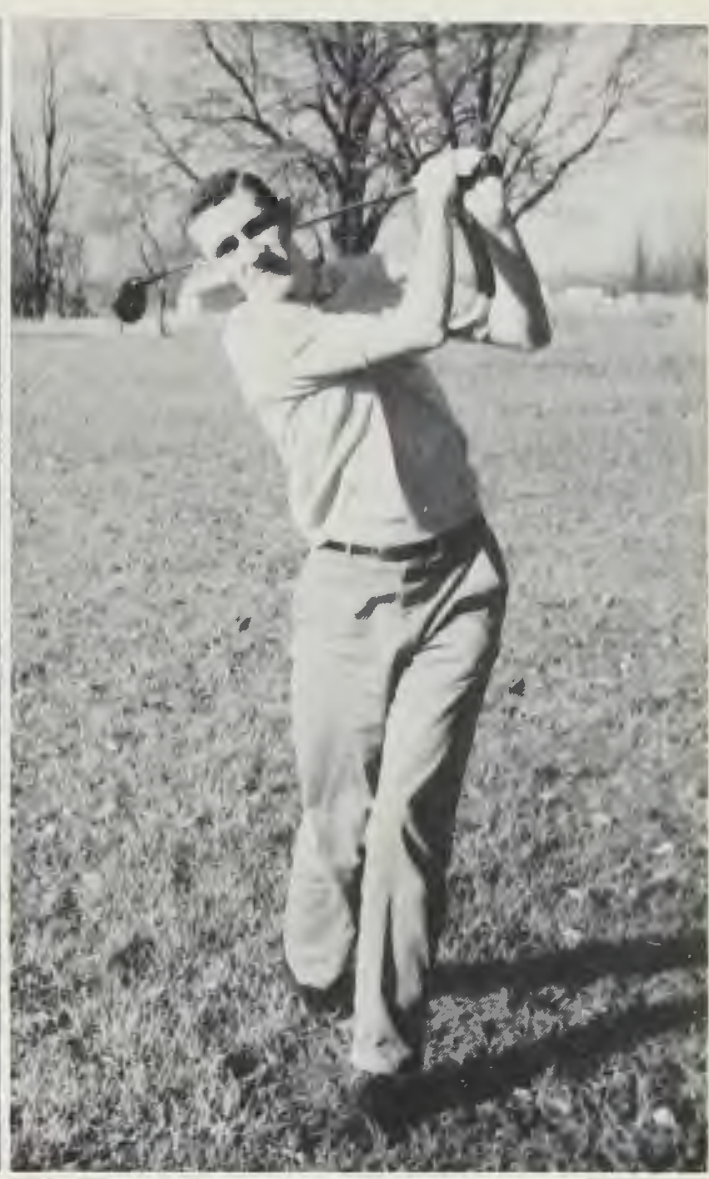

Jim Sprague

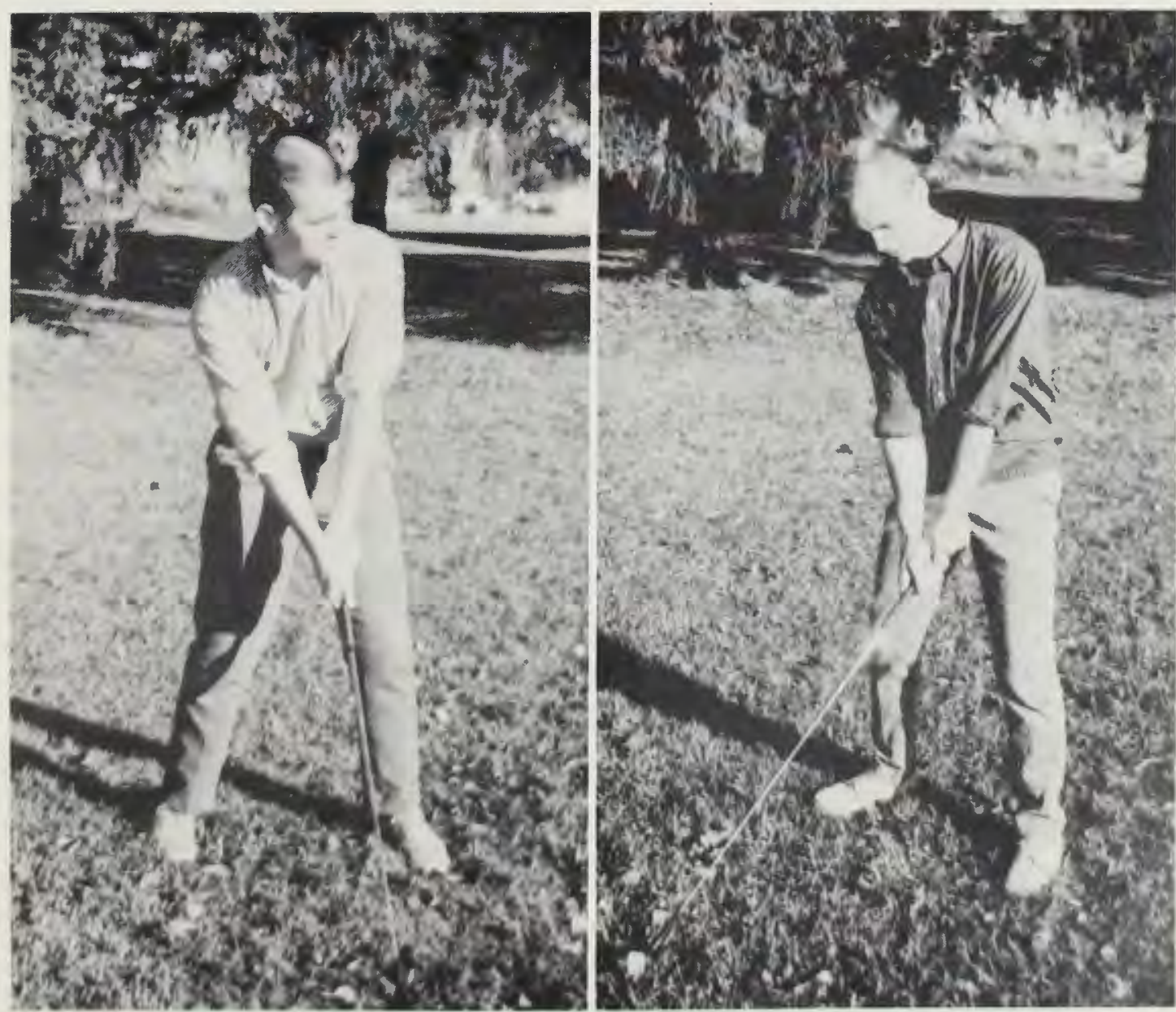




\section{Varsity Basketball}

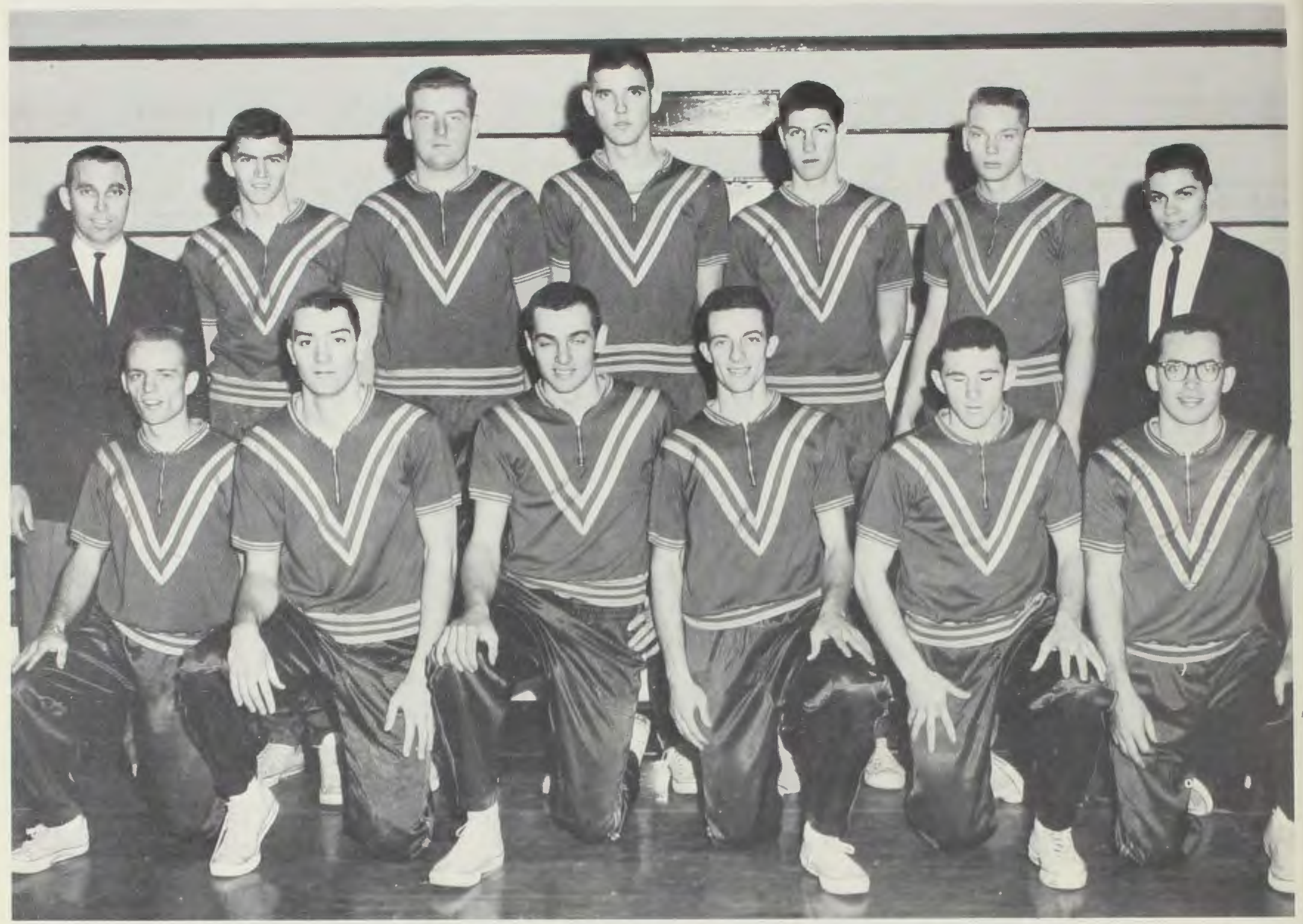

TOP ROW, Left to Right: Coach Don Callan, Rod Lane, Gary Brandes, Gary Walthall, Jerry Stadt, Ray Davis, Mark Haseltine, Manager. FRONT ROW: Ted Ocheltree,
Sam Schwartz, Dave Jeremiah, Norris Smith, Dick Spencer, Bill Elder.
"The New Look" was the theme of the 196162 version of the Yellowjacket basketballers, as Cedarville unveiled one of its most powerful teams ever. Although only 3-9 in a tough $\mathrm{Mid}-\mathrm{O}$ hio League, the Yellowjackets assured its opponents of rough competition in future years.

In his second year as head of Cedarville's hoopsters, Coach Don Callan led his team to impressive victories over Kentucky State, Ohio Northern, and Huntington (Indiana), and to second place in the Taylor University Tournament early in the year.
Outstanding this year were forwards Dave Jeremiah (16.5 points per game) and Dozier Carter (15 rebounds per game); center Gary Walthall (18 points, 13 rebounds per game); and guard Norris Smith (15 points per game. "Smitty" tied an all-school record by scoring 45 points in a home game against Wilberforce.

Chosen as Most Valuable Player by his teammates was center Gary Walthall. Gary's fine scoring and rebounding earned him a place among the MidOhio League leaders in both departments. 


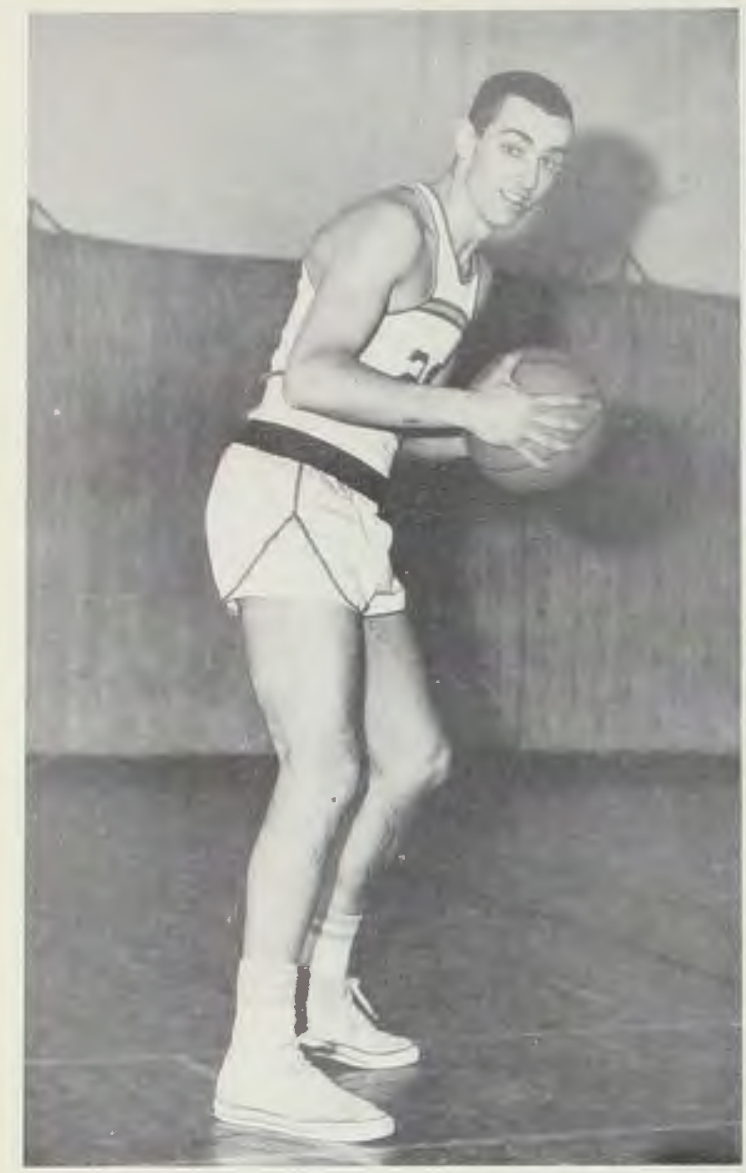

Dave Jeremiah, 6' 2", Junior, Forward

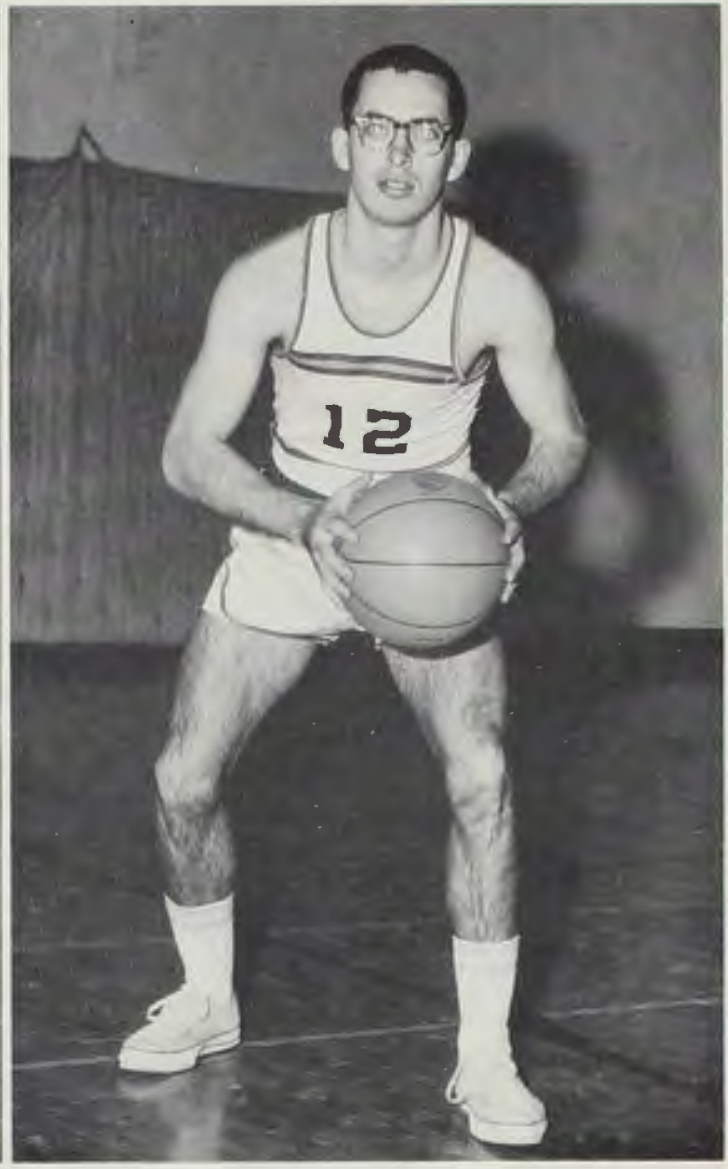

Bill Elder, $5^{\prime} 10^{\prime \prime}$, Junior, Guard

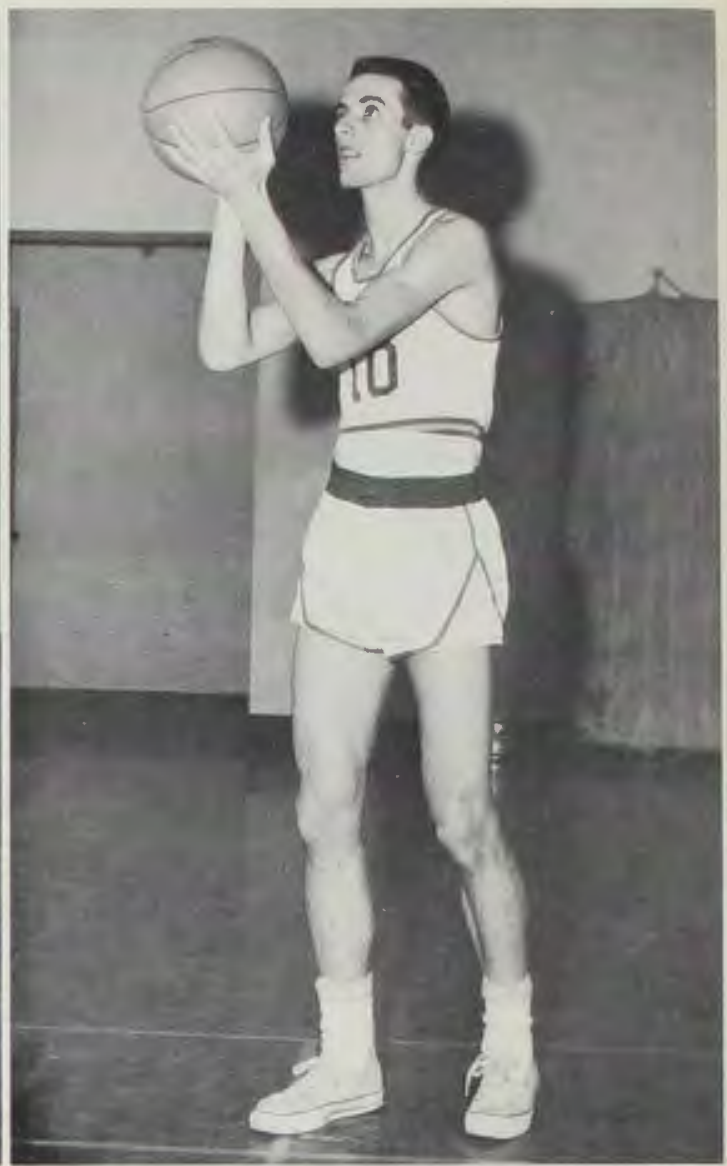

Norris Smith, 5' 11", Junior, Guard
Gary Walthall, 6' 7", Sophomore, Center

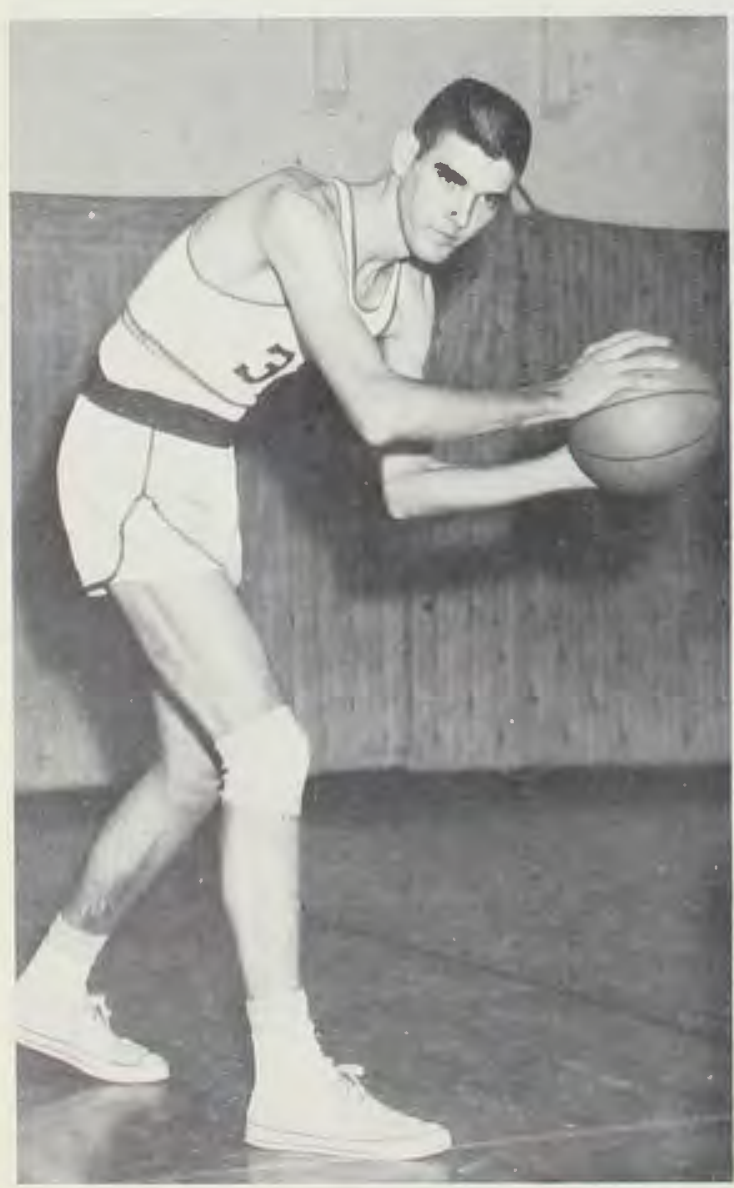

Ted Ocheltree, 5' 7', Junior, Guard

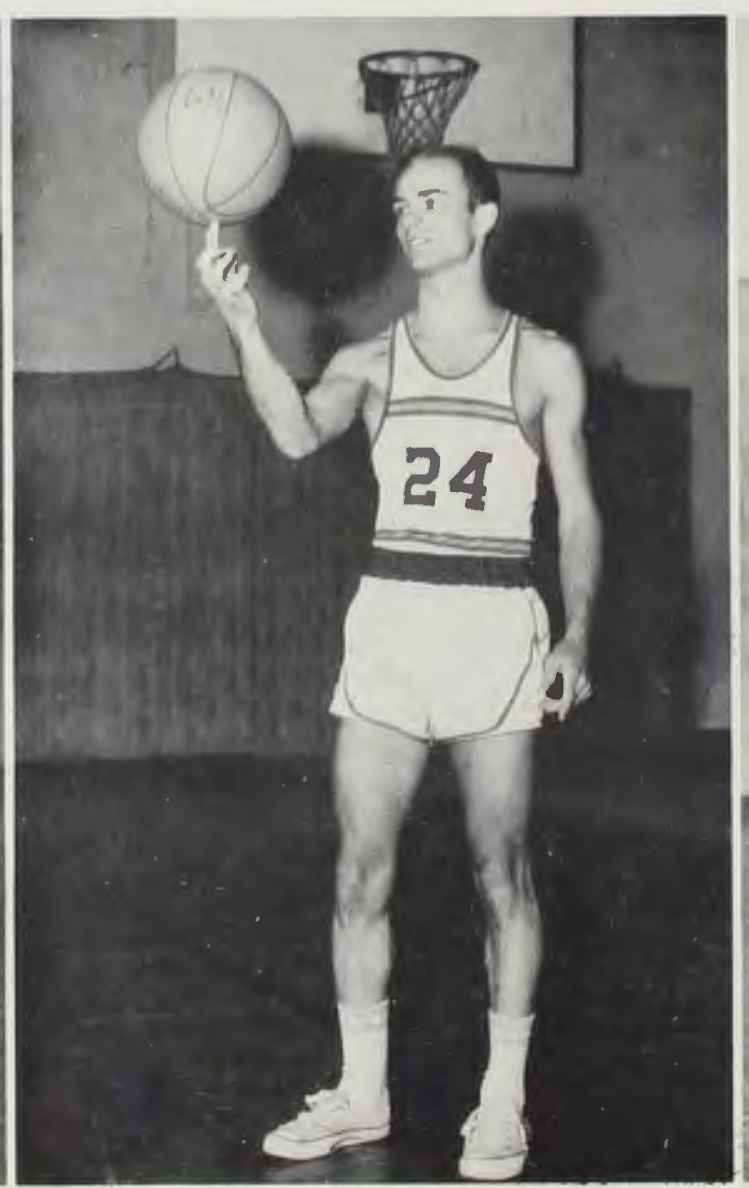

Dozier Carter, 6' 5", Freshman, Forward

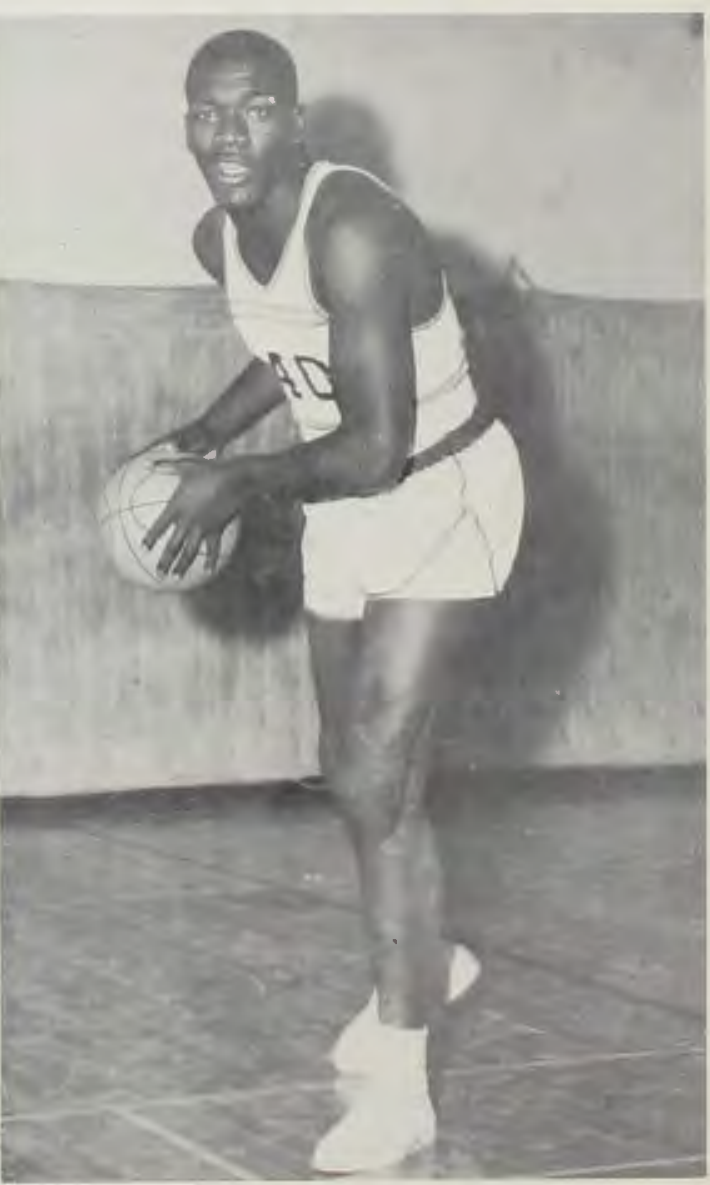




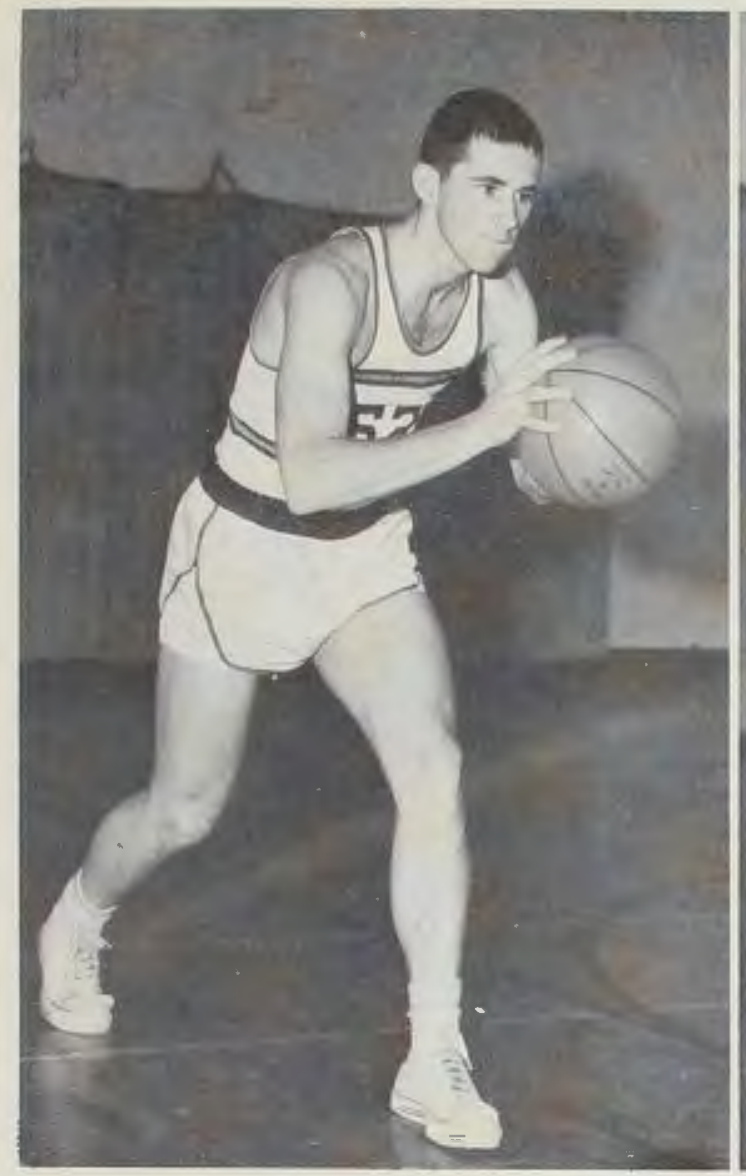

Dick Spencer, 5' 10", Freshman, Guard

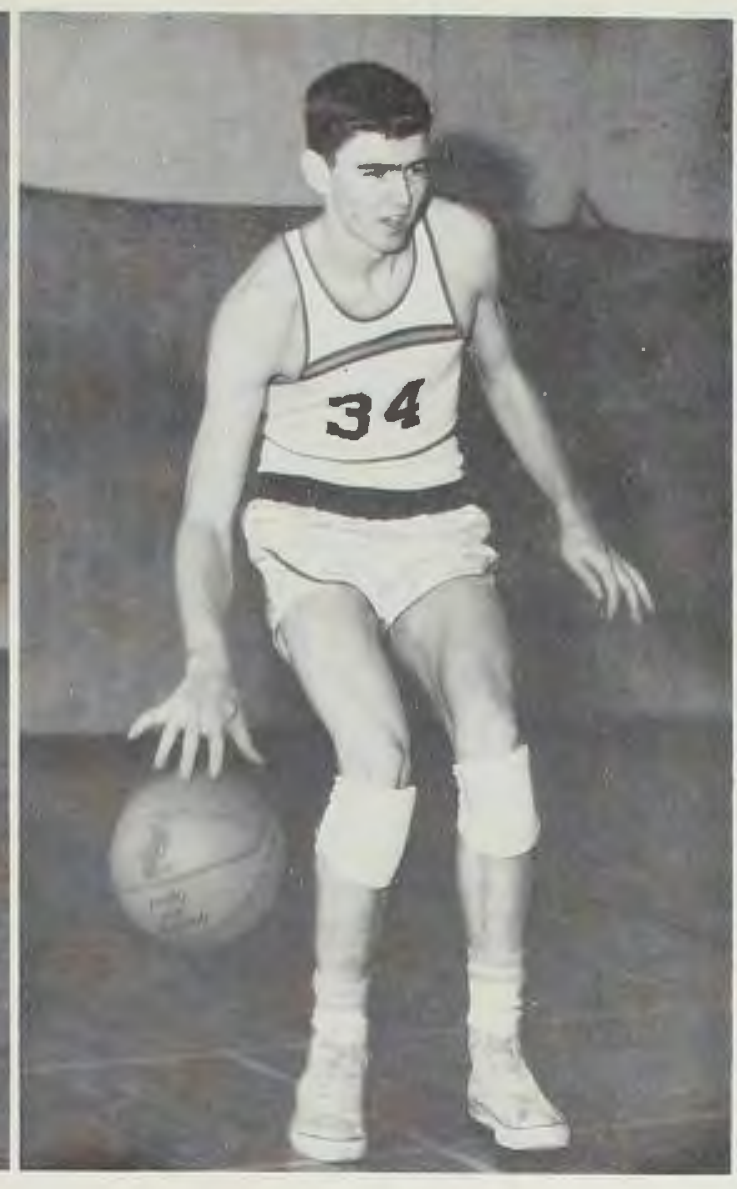

Rod Lane, 6' 3",

Sophomore, Forward

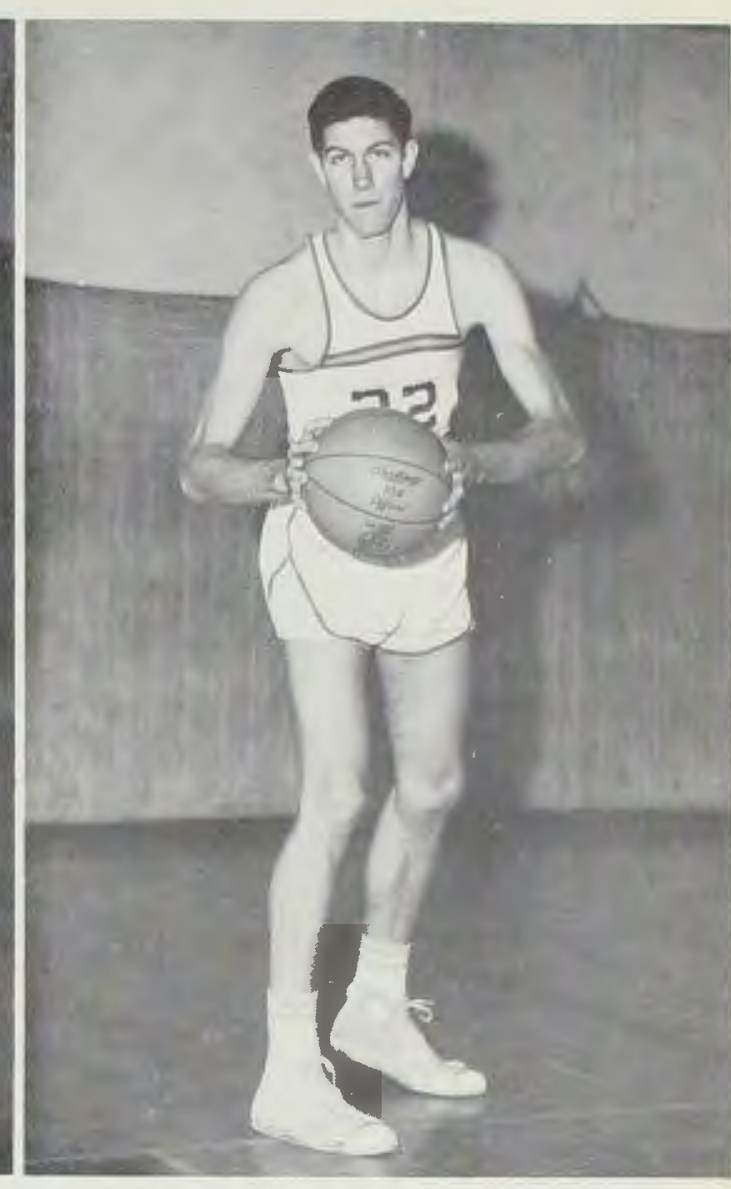

Jerry Stadt, 6' 3", Freshman, Forward
Sam Schwartz, 6' 3", Freshman, Forward

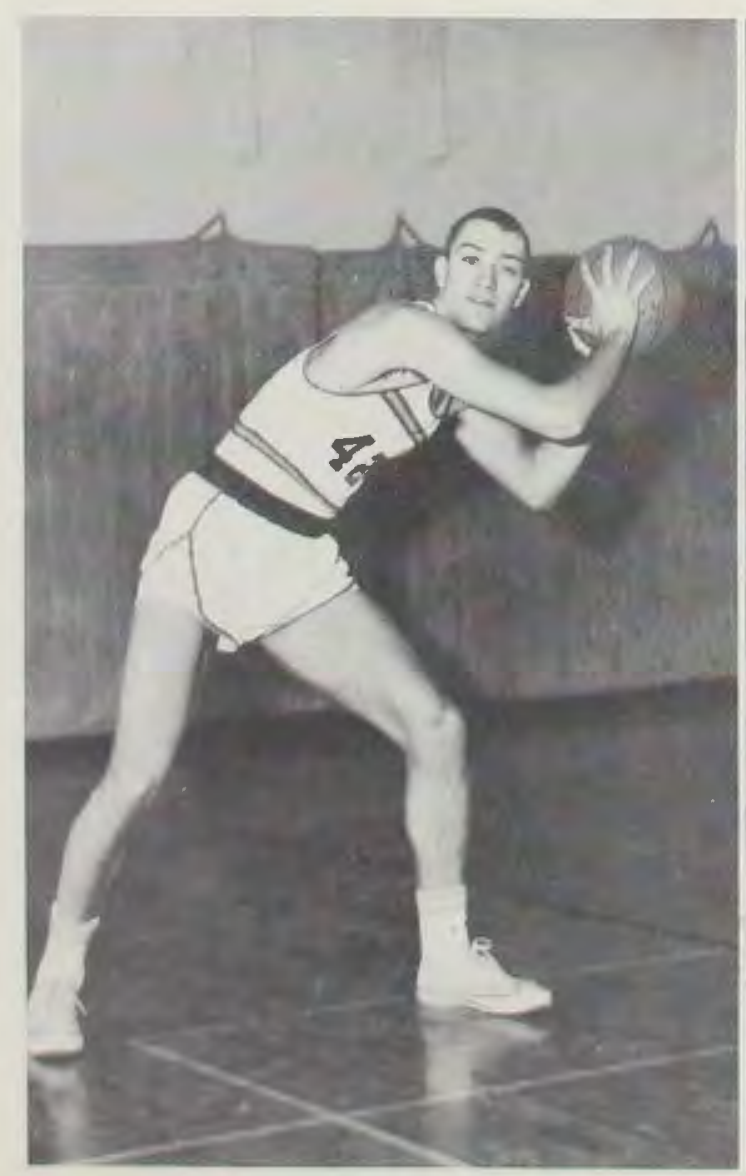

Ray Davis, 6' 3", Freshman, Center

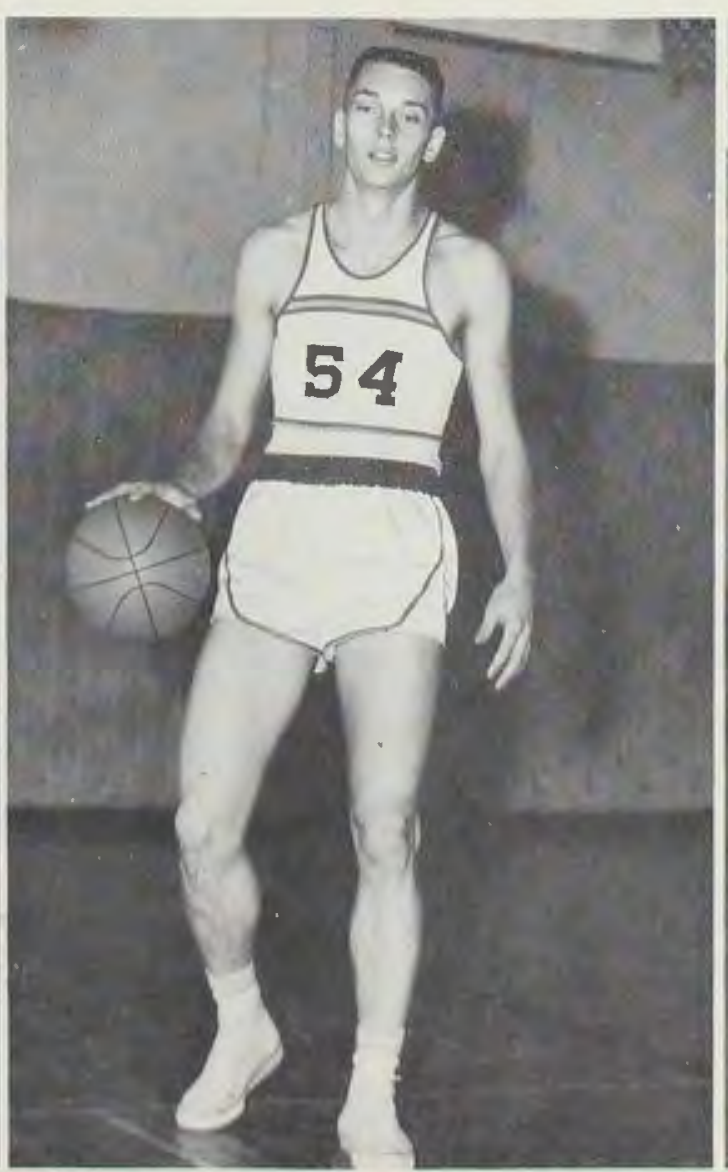

Gary Brandes, 6' 6", Freshman, Center

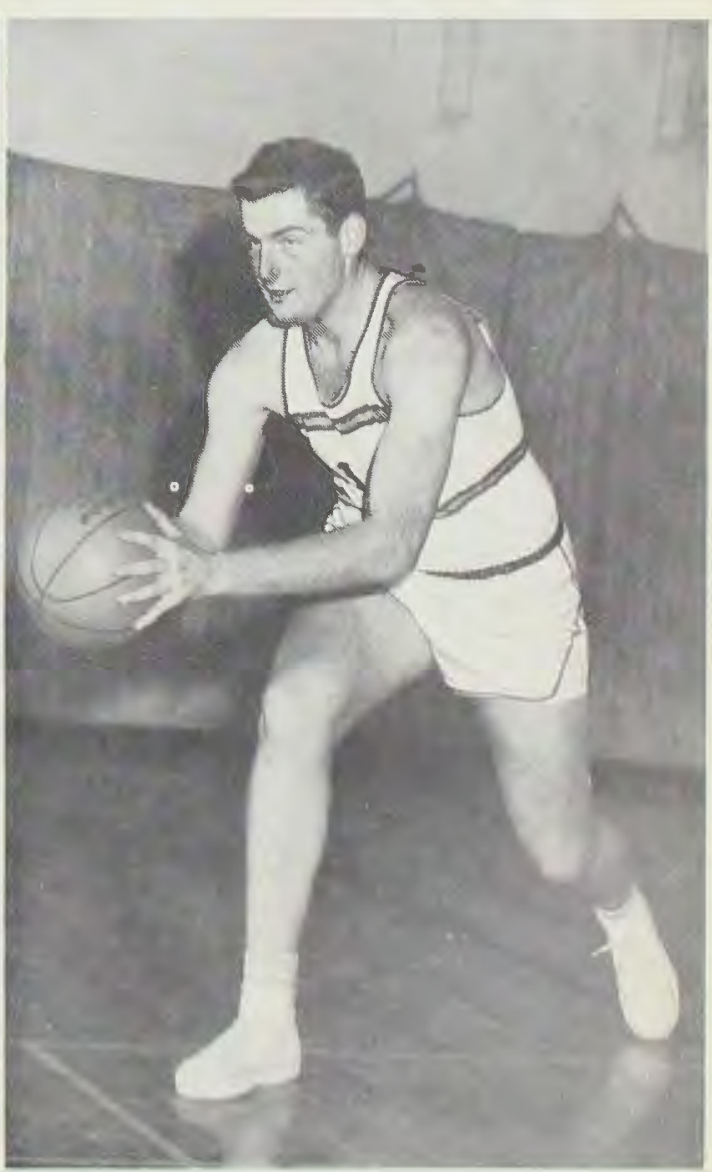




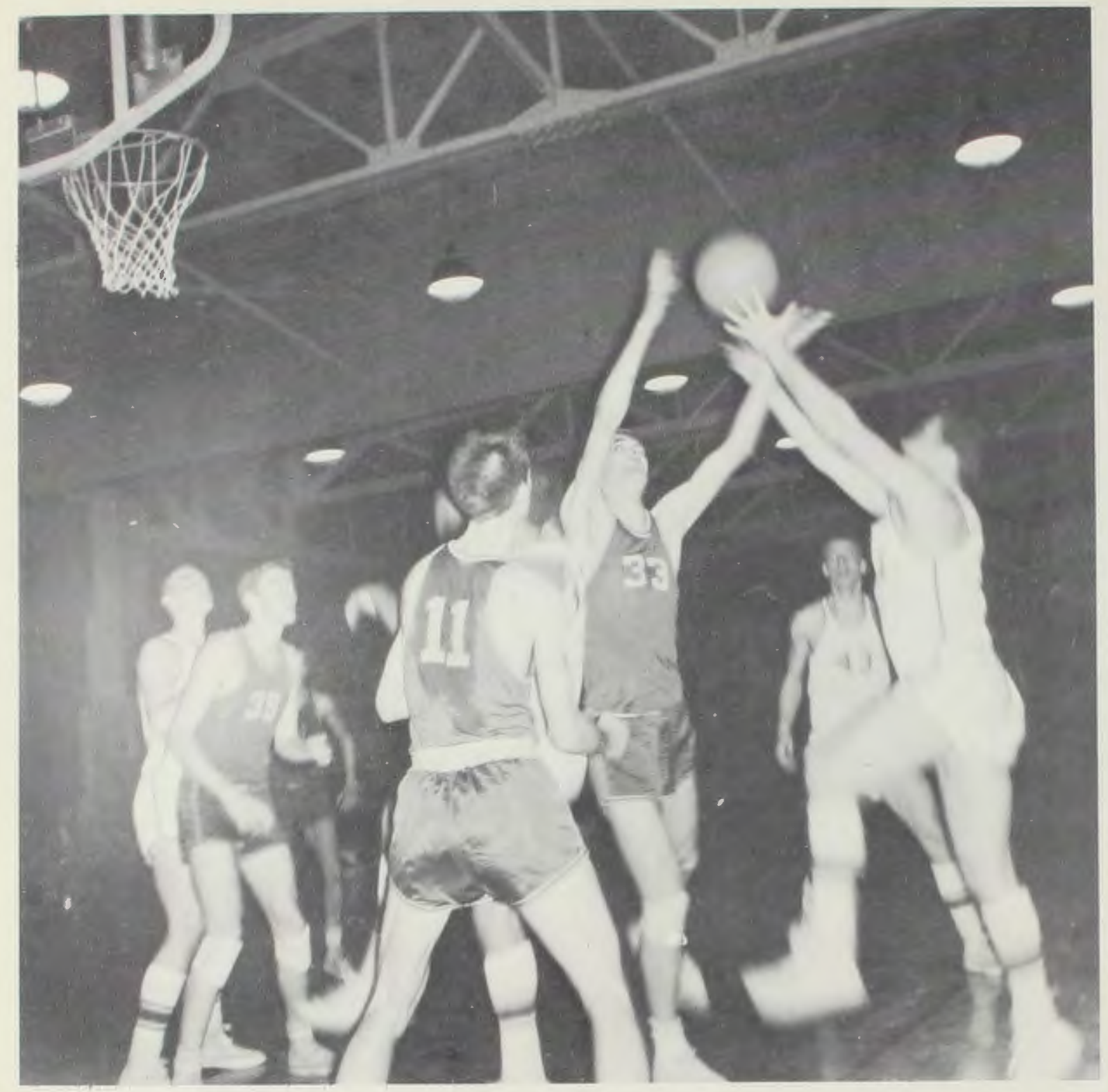

Gary Walthall fights for a rebound with Defiance's Ray Etzler under the Cedarville basket.

\section{Away ...}

\section{Cedarville \\ Yellow-jackets \\ In \\ Action}

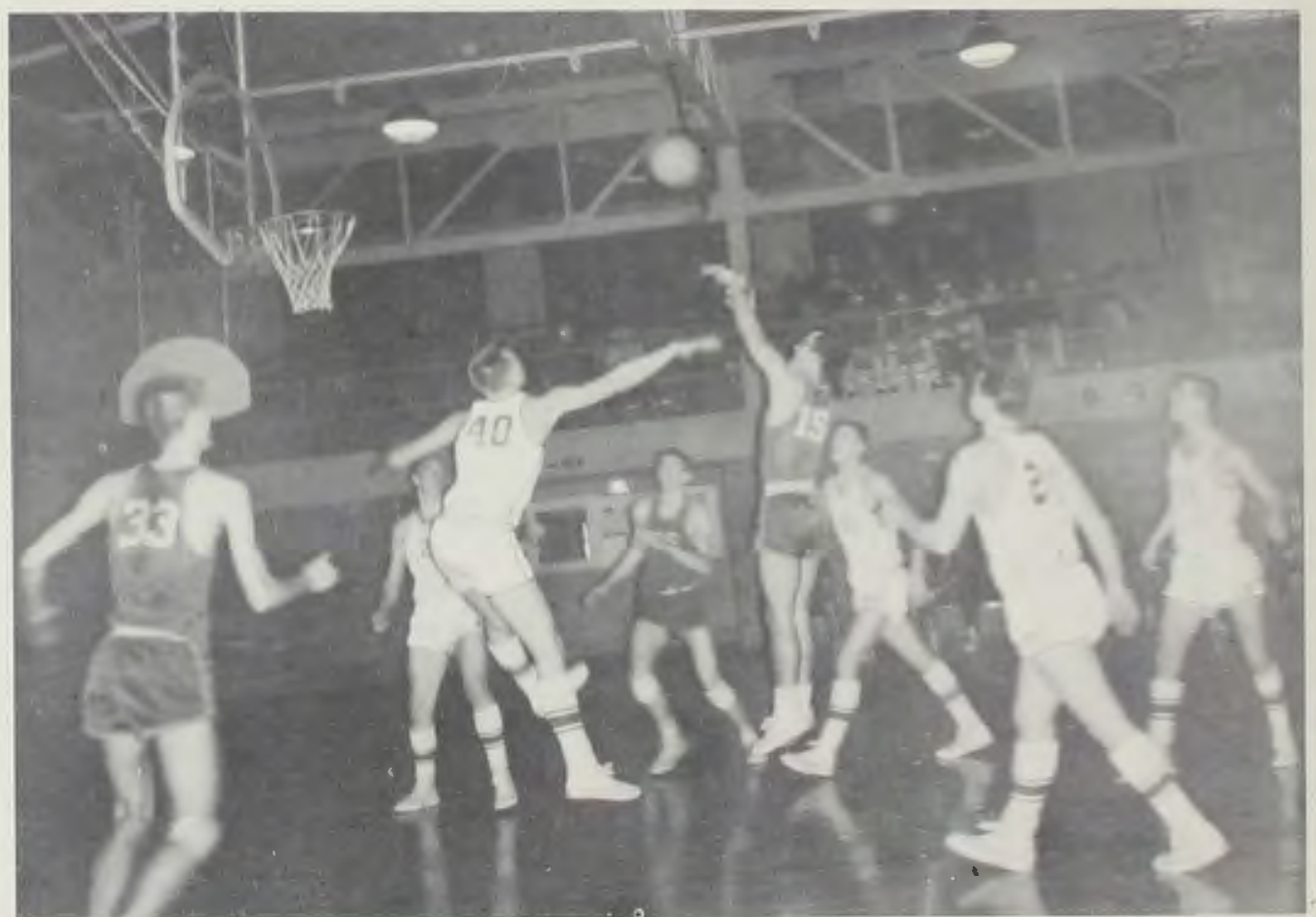

Bill Elder fires a jump shot as the whole Defiance team watches. 


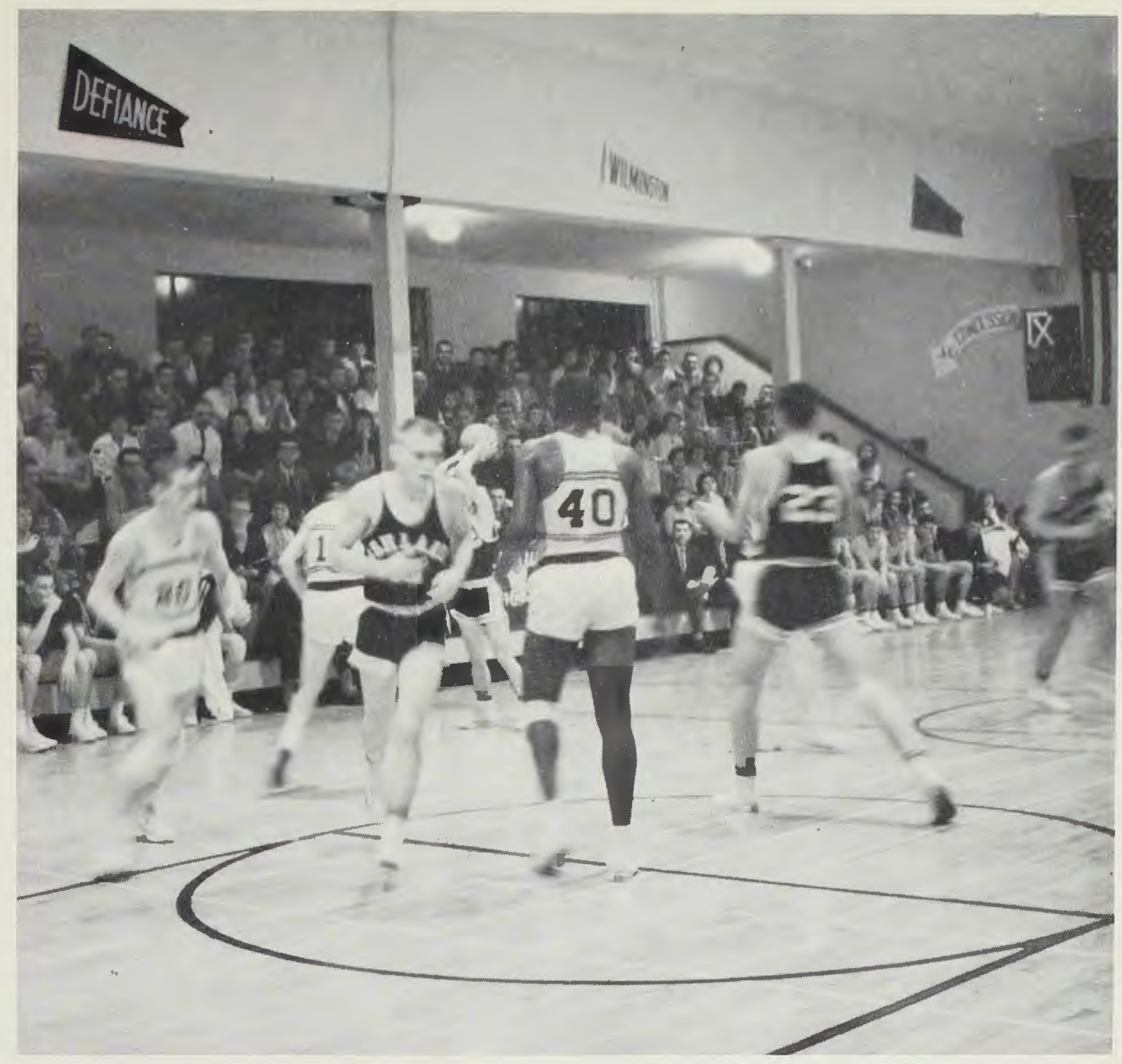

All are tense as Ashland holds the ball.

\section{... Home}

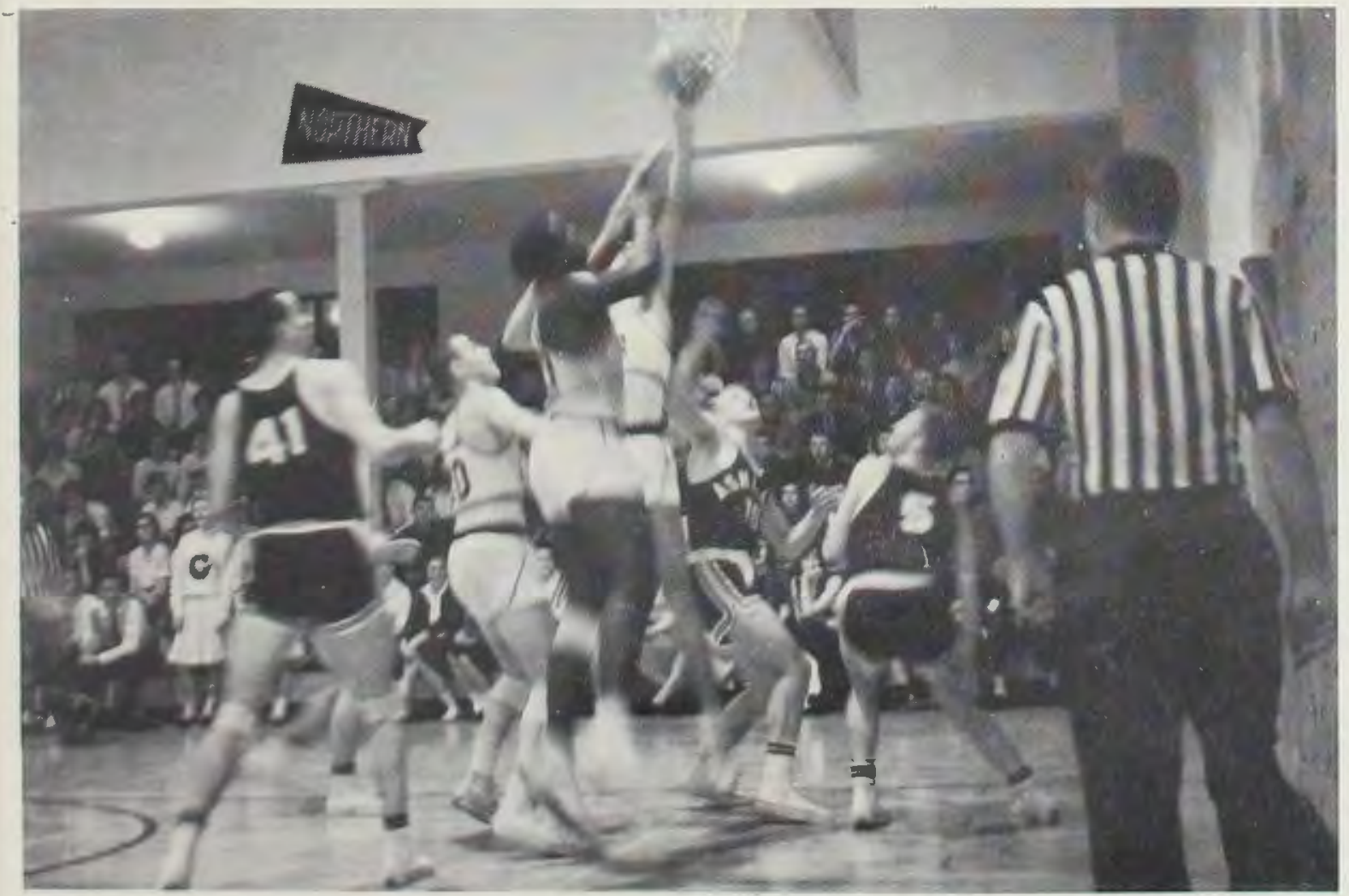

Gary Walthall tips it in after the foul shot. 


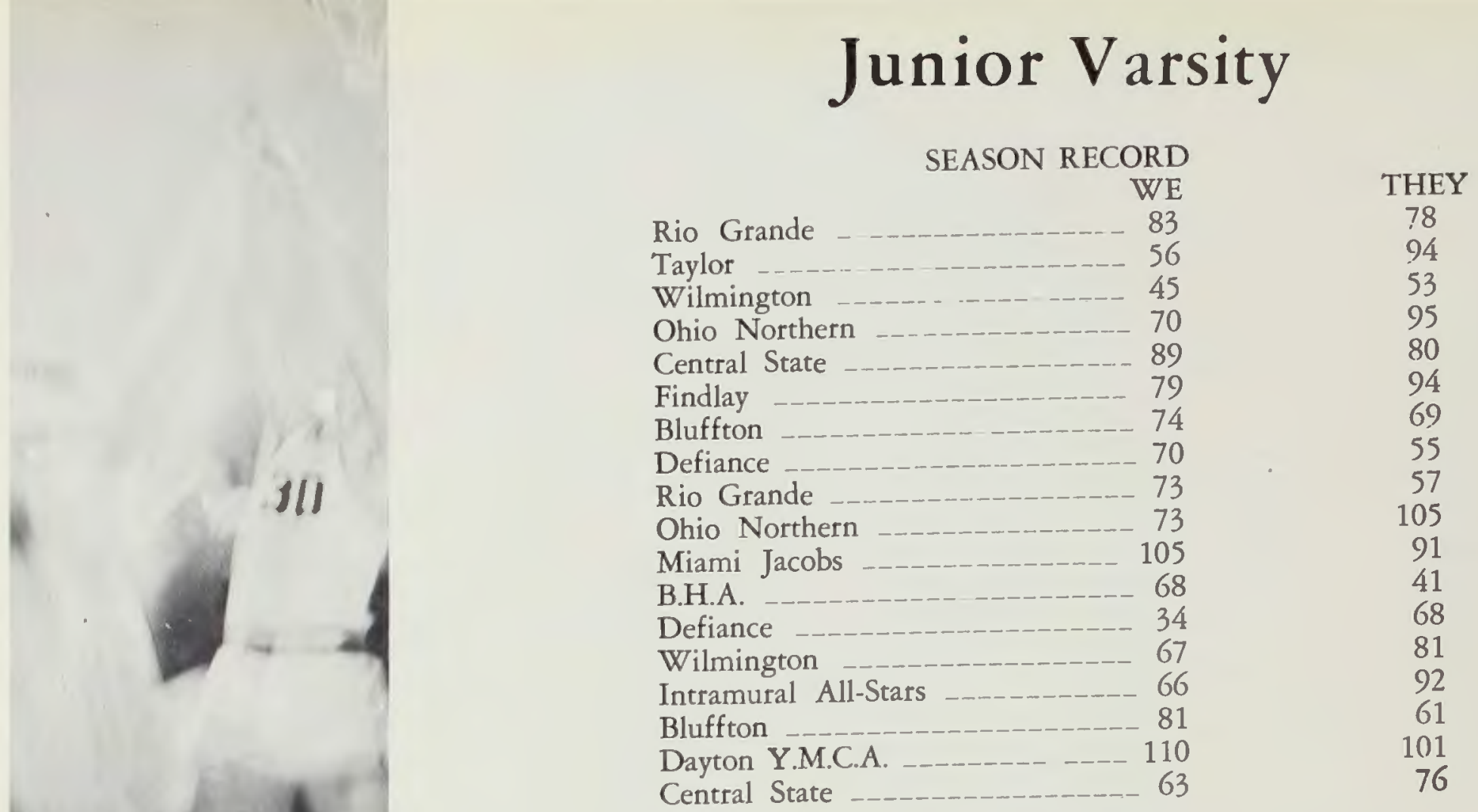

Bud Davis jumps high to tap one in against the Intramural All-Stars.

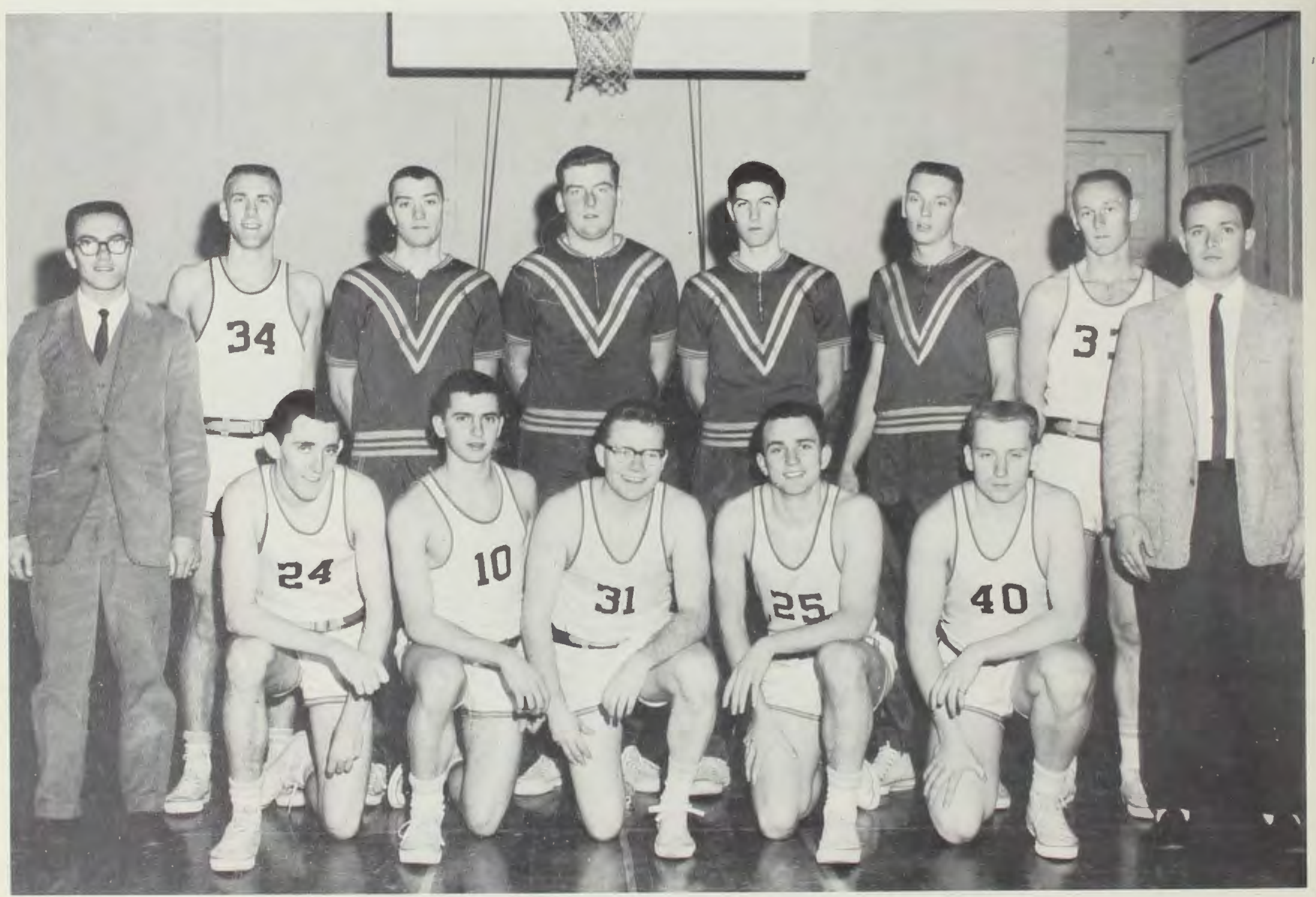

TOP ROW, Left to Right: Howard Day, Manager, Don Entner, Sam Schwartz, Gary Brandes, Jerry Stadt, Ray Davis, Jerry Osborn, Dave Lewis, Coach. FRONT ROW:
Jim Sprague, Paul Brower, Tom Evans, Dave Fisher, Al Merwald. 


\section{Cheerleaders}

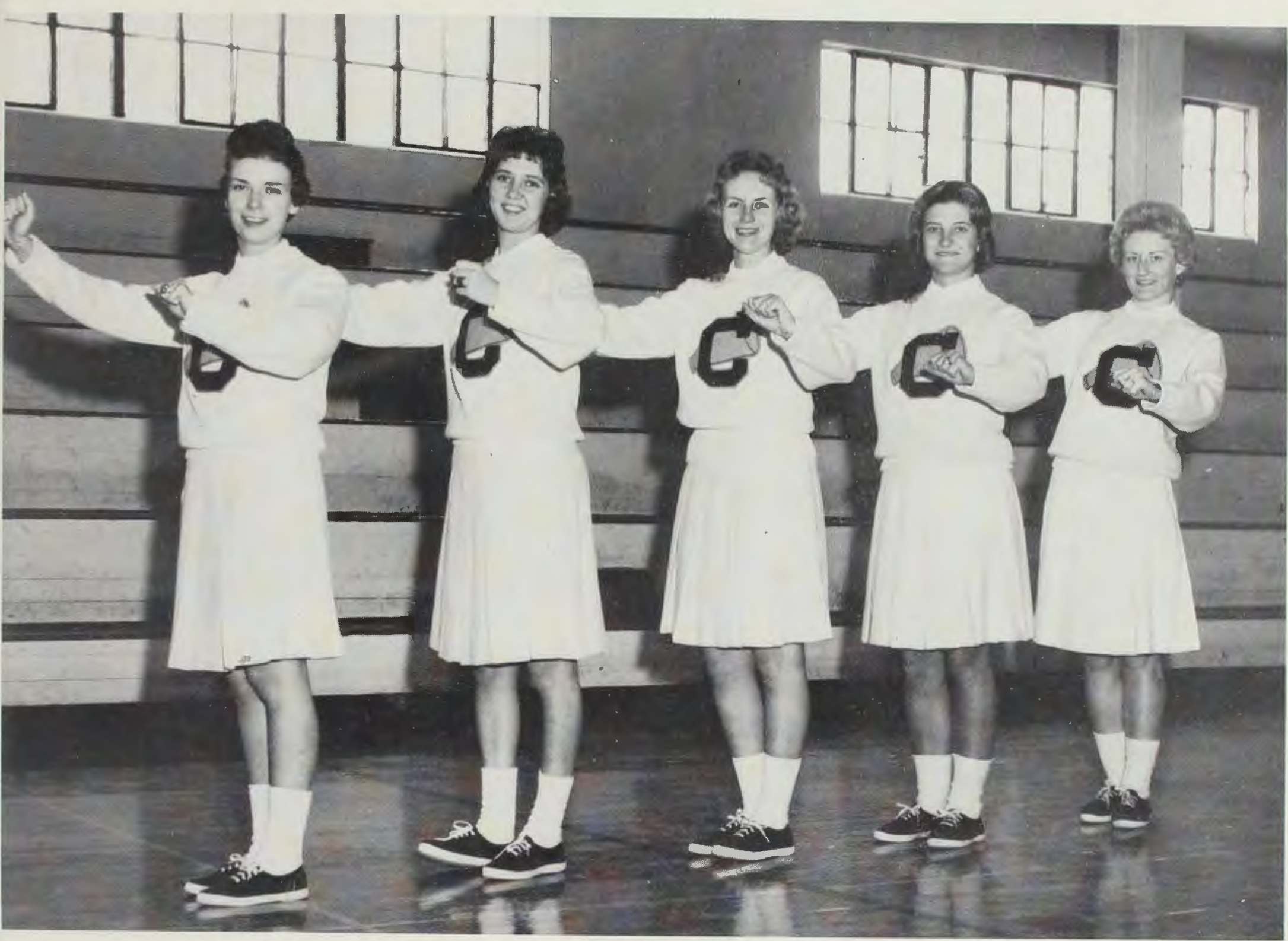

Left to Right: Donna Thompson, Irene Lane, Judy Lachman, Pat Kaster, Bette Adamson.

Donna Thompson, Captain

Two new cheerleaders and three "veterans" were chosen by the student body this year to help lead the team on to greater heights. In line with the "new look", the girls had new uniforms and presented several new cheers to the student body.

With the help of the Pep Club, the cheerleaders provided the encouragement needed by a winning basketball team.

Mrs. Callan is advisor to the cheerleaders. 


\section{Intramural Football}

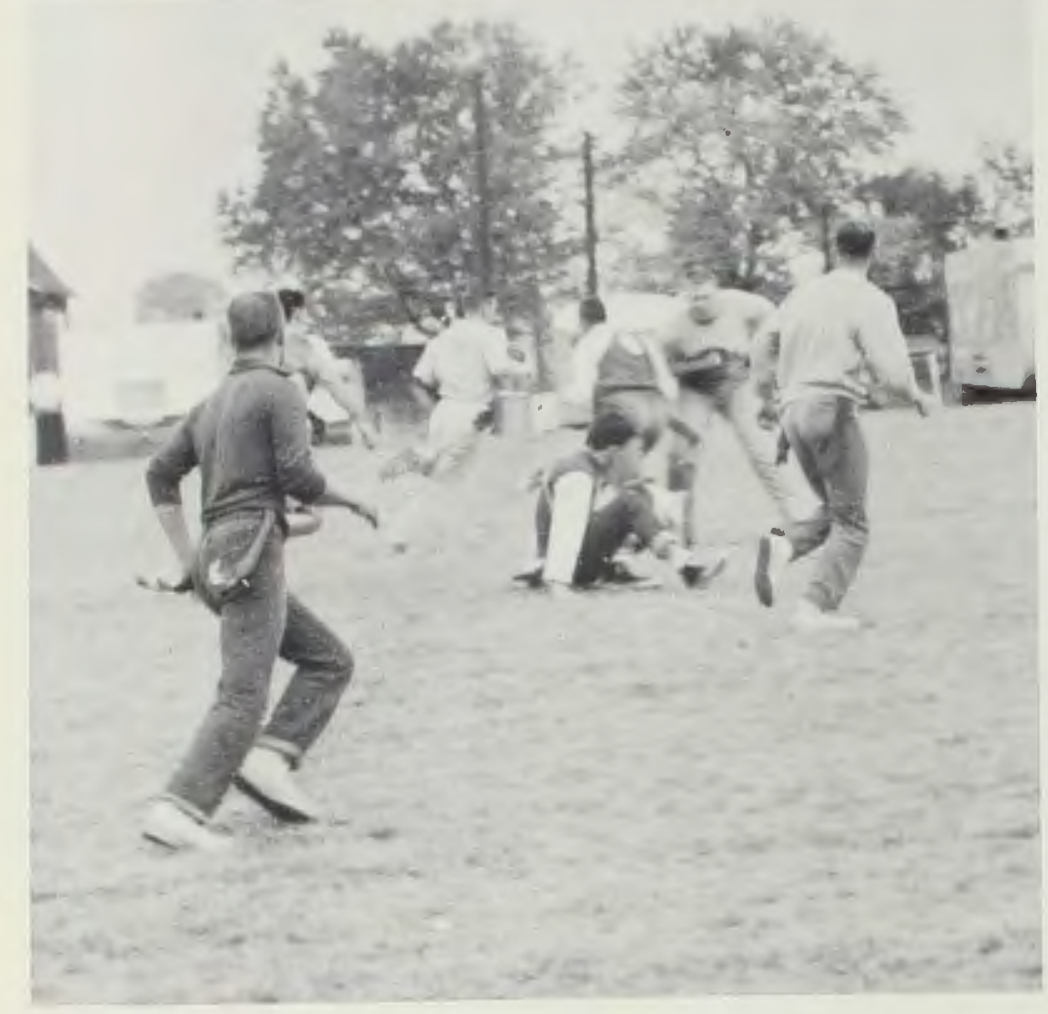

Bethel Hall moves the ball forward around the end.

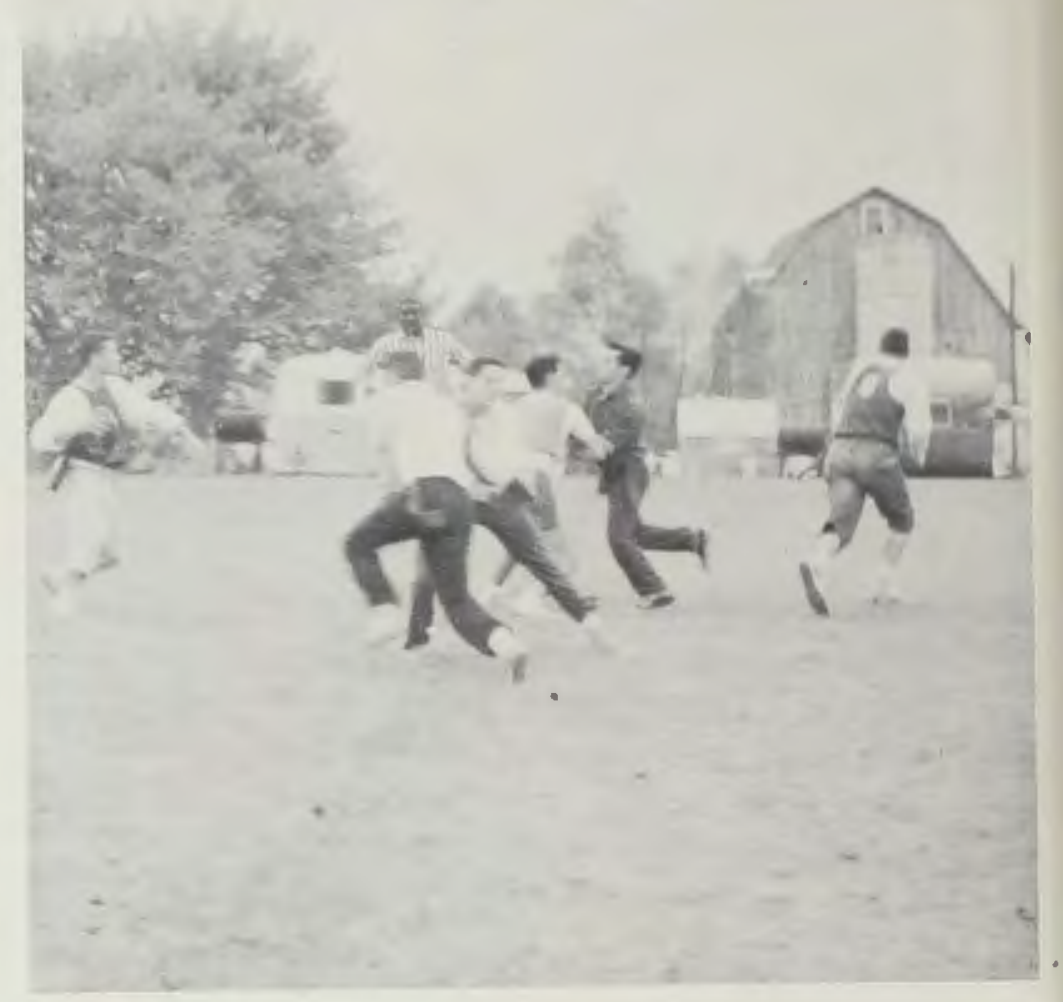

Roger O'Bryon whips a bullet pass to Dave Earnheart.

This game, played between Harriman and Bethel Halls, climaxed an exciting year of intramural football. The combination of passthrowing quarterback Roger O'Bryon and pass-catching end Tom Delanzo led Harriman to the championship of the league.

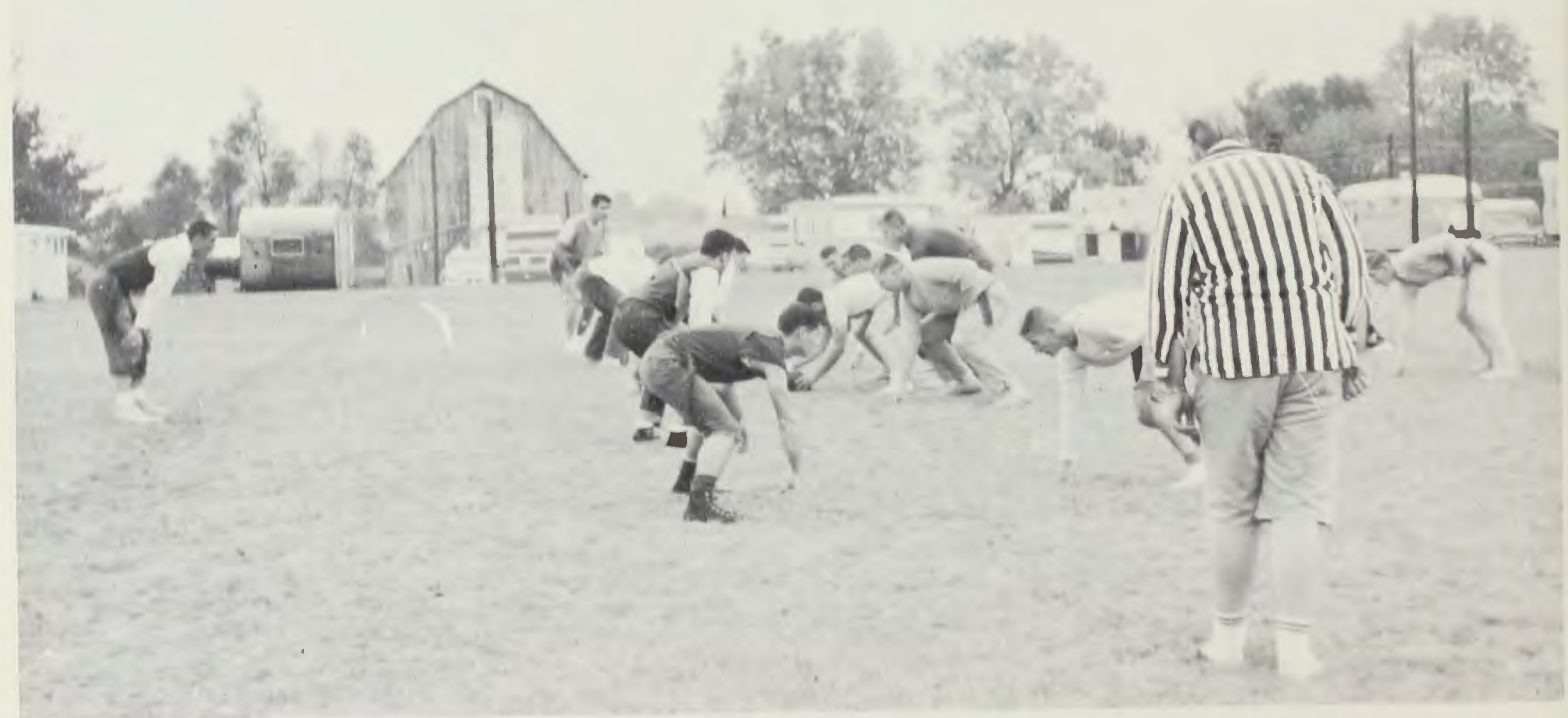

Bethel lines up as they seek to sustain a drive against Harriman. 


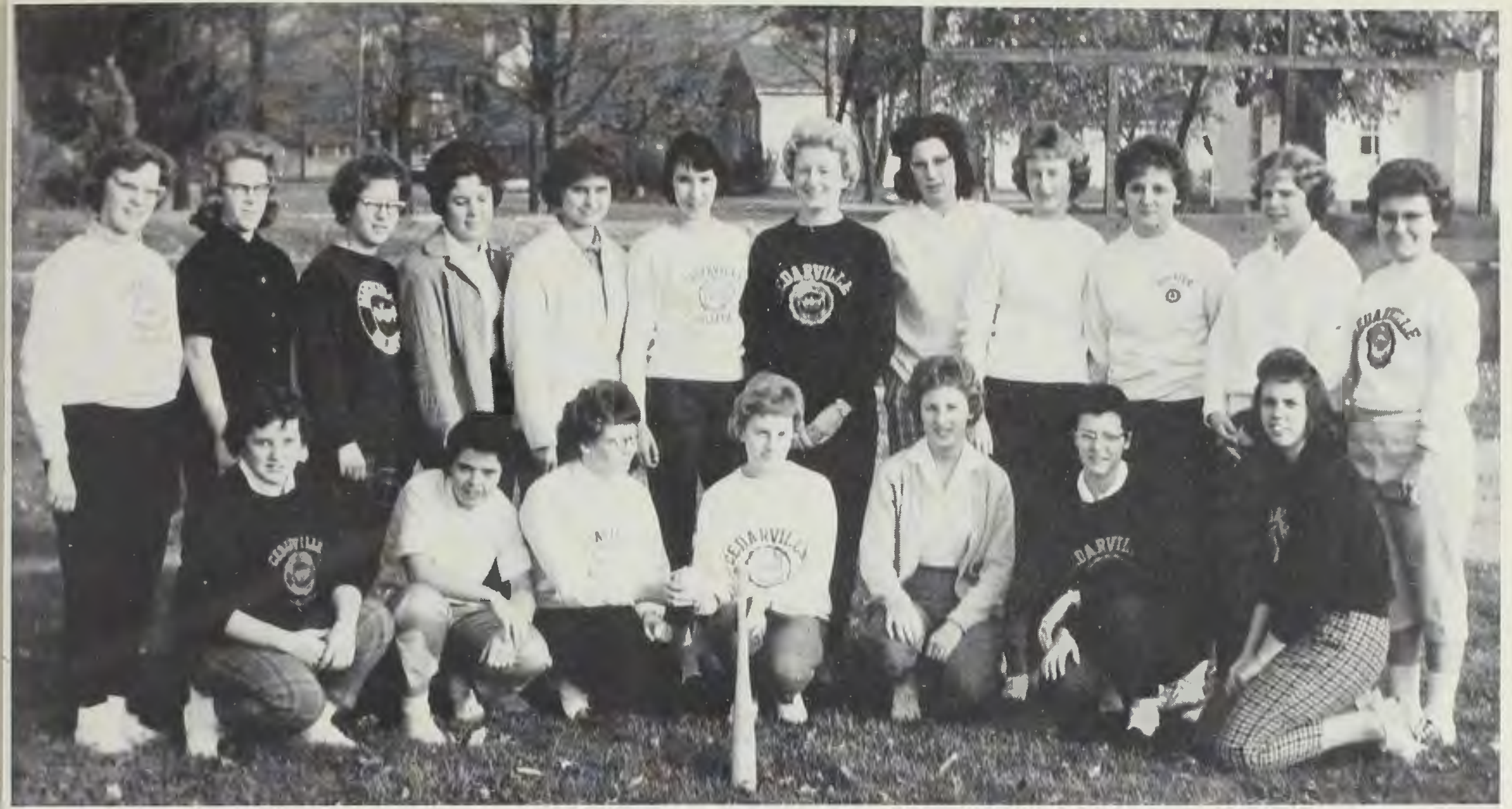

TOP ROW, Left to Right: Nancy Smith, Connie Ward, Sharlene Wellman, Sarah Balke, Eve Tennant, Sylvia Wing, Bette Adamson, Susan Johns, Luann Mundhenk, Bobbie Unzicker, Nancy Kettell, Patricia Schonscheck.
FRONT ROW: Gale Brooks, Janet McClish, Sharon Addleman, Joanne Neely, Liz Price, Sharon Ackerman, Sally Bender.

\section{Girls' Softball}

Softball, for the first time, became a part of our girls' intramural program this year. Four teams entered the contest, three from the New Dorm, whose captains were Gale Brooks, Pat Kaster, and Susan Eckert, and one team representing the Faith Hall and off-campus girls for which Nancy Smith and Janet McClish acted as co-captains. Three teams tied with two wins each, but the play-offs proved the Faith Hall and offcampus girls to be the victors with the final scores of $15-9$ and 7-0.

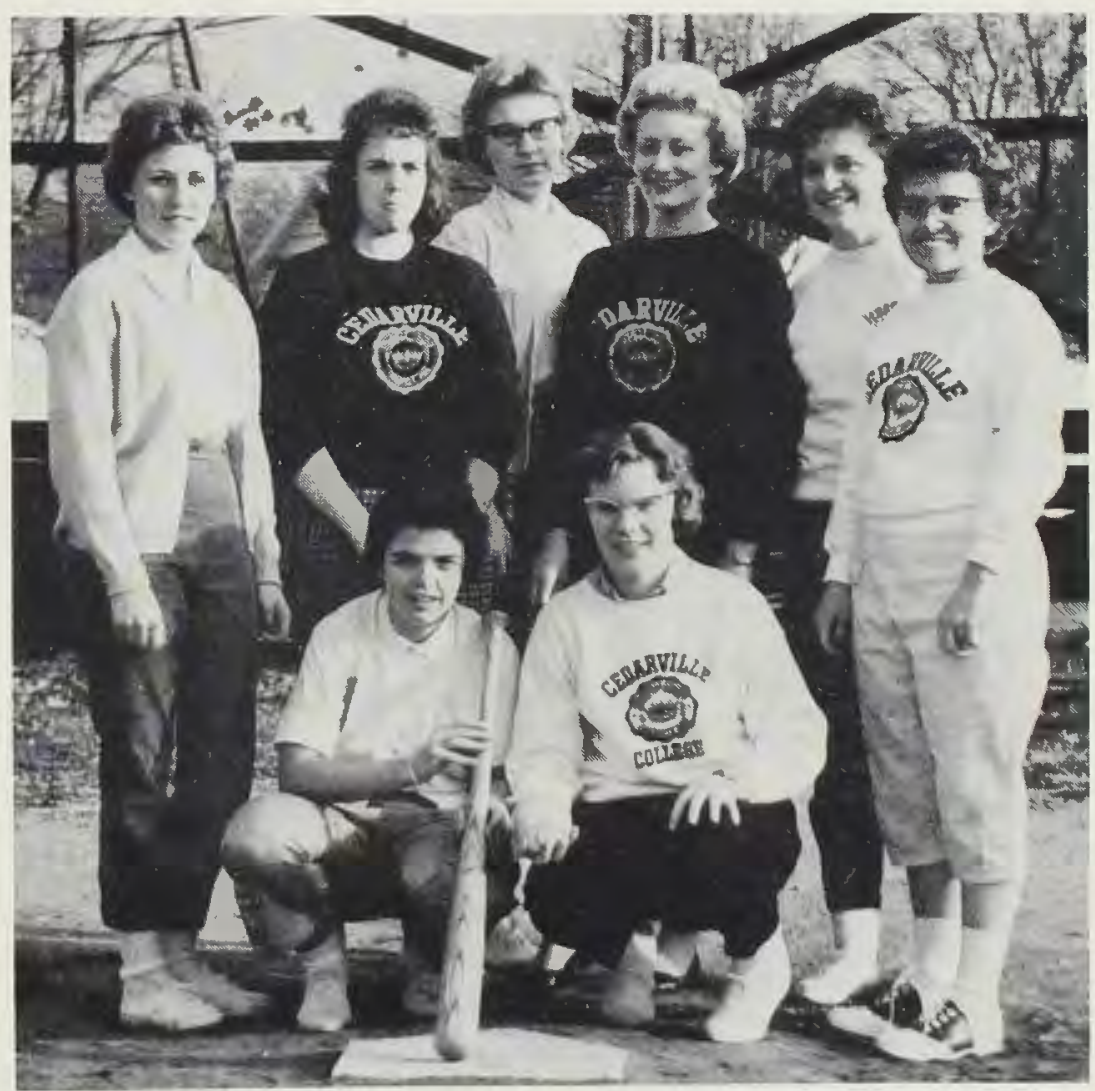

TEAM 1, THE "CHAMPS" FROM FAITH HALL TOP ROW, Left to Right: Liz Price, Sally Bender, Sue Geyser, Bette Adamson, Bobbie Unzicker, Patricia Schonscheck. FRONT ROW: Co-Captains Janet McClish and Nancy Smith. 


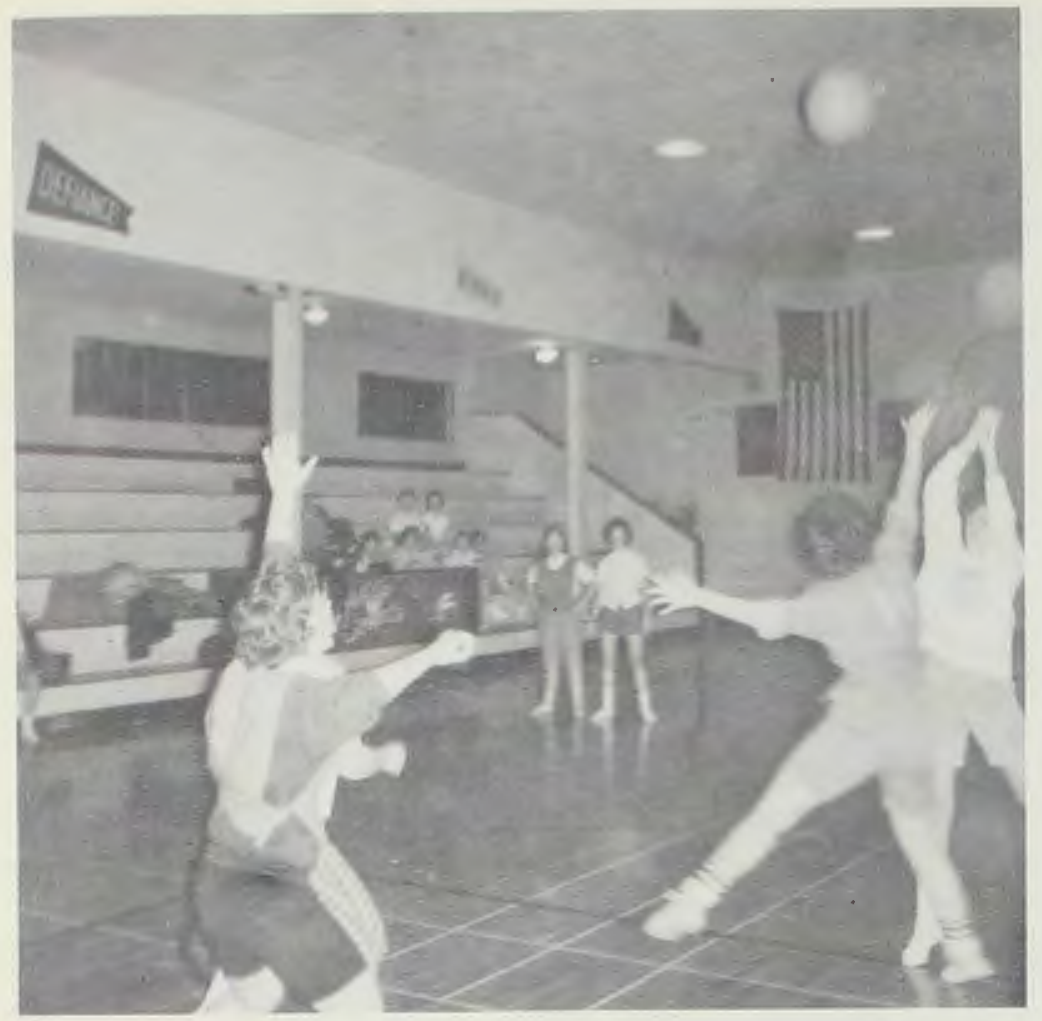

Barb Unzicker watches for a chance at the ball.

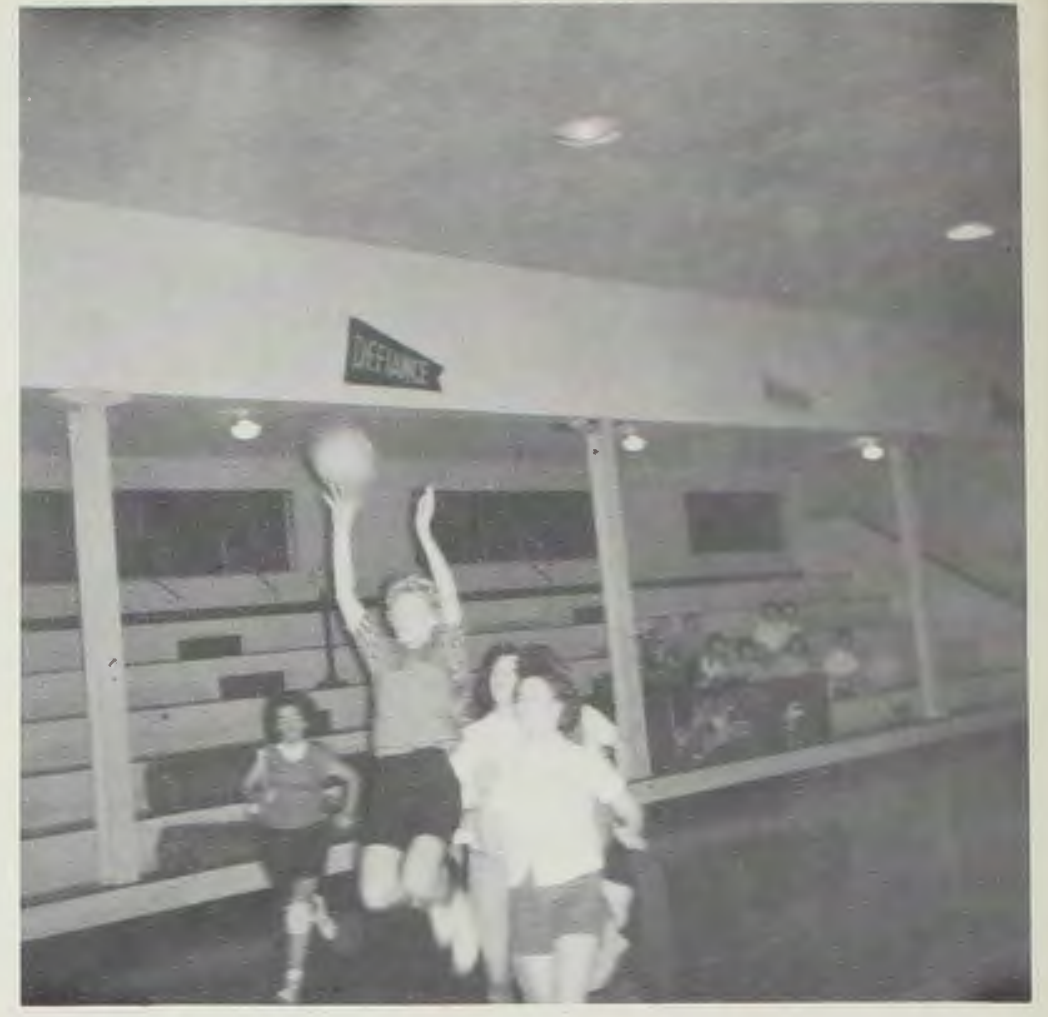

Bette Adamson jumps and sinks it.

\section{Women's}

\section{Intramurals}

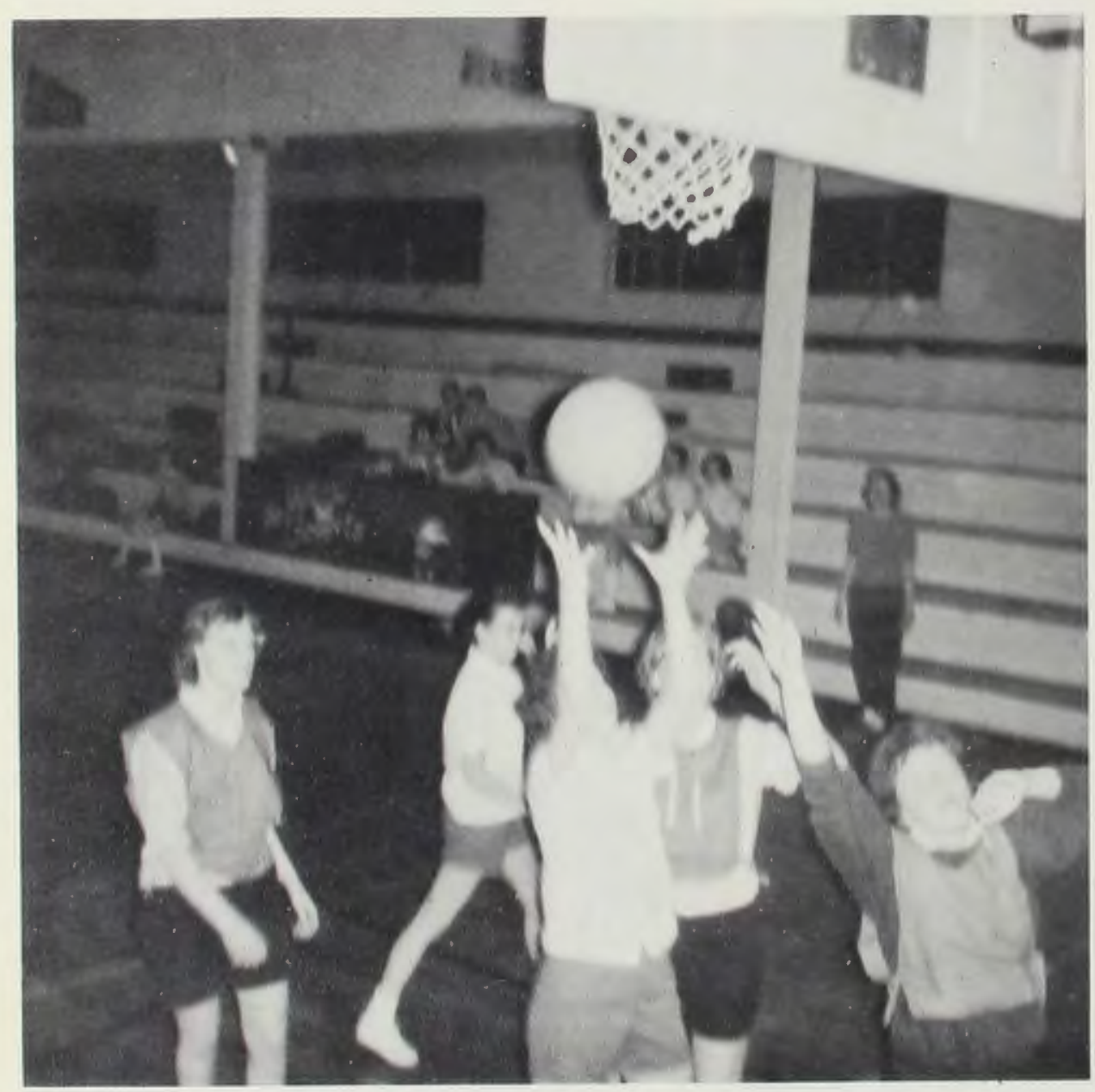

Girls' Intramural basketball opened this year with a game between Faith Hall and the New Dorm on February 10. Janet McCleish headed up the program scheduling the times for the five enrolled teams to play. One team was formed from Faith Hall women, one from both Faith Hall and off-campus women, and three from the New Dorm. Intramurals were played on Saturday afternoons at two o'clock and on Tuesday evenings at seven o'clock.

A slight scramble for the ball. 

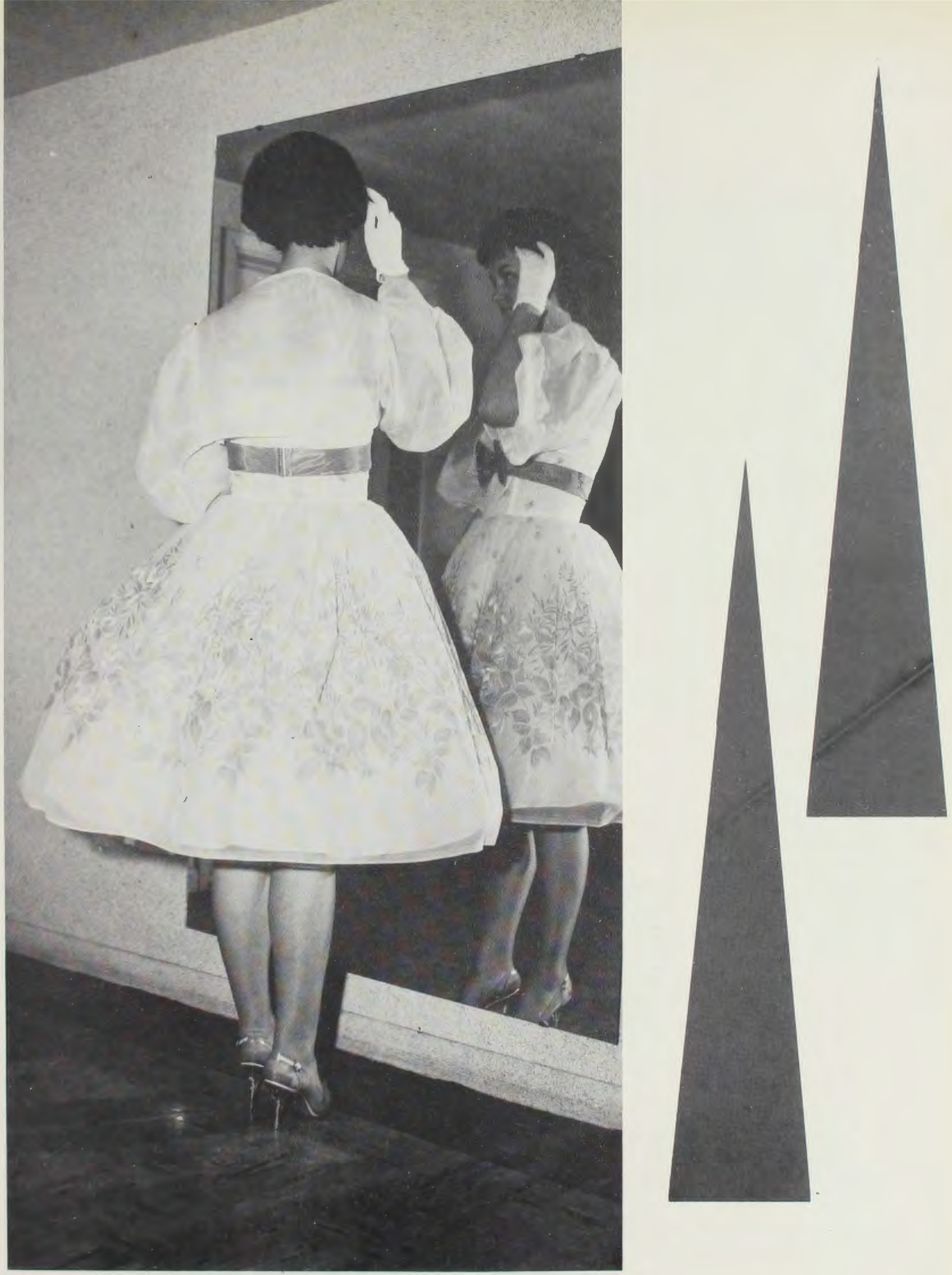

\section{Featuxes}




\section{Missionary}

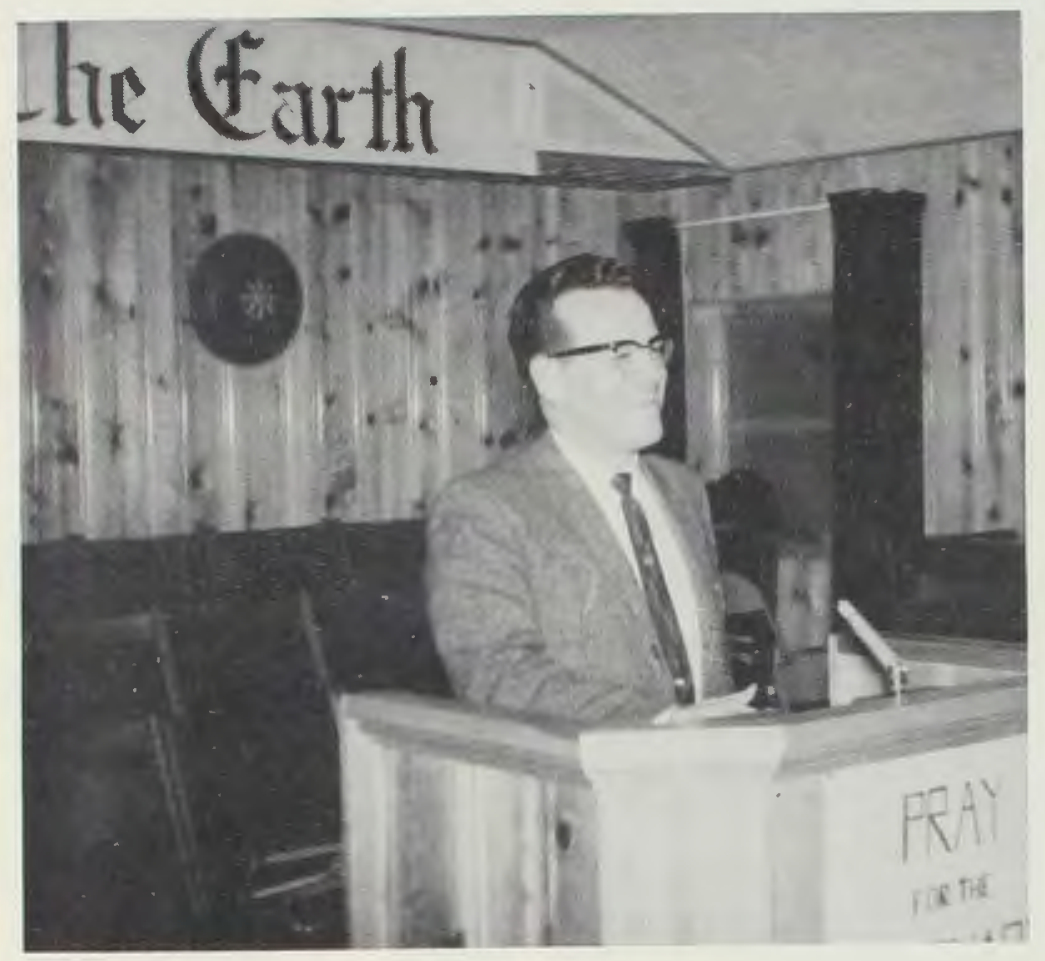

Mr. Fusco, Italian missionary, tells the problems of his field.

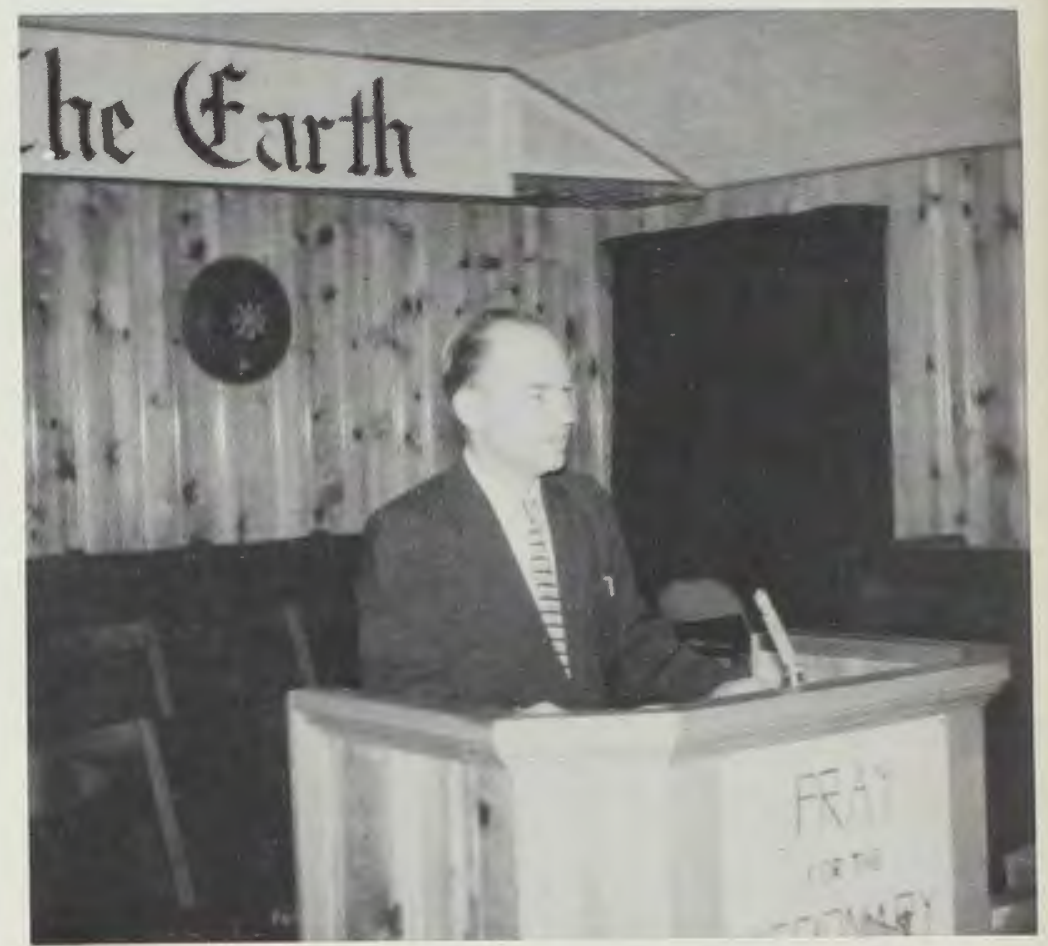

Dr. Fisher stresses the necessity of medical missions.

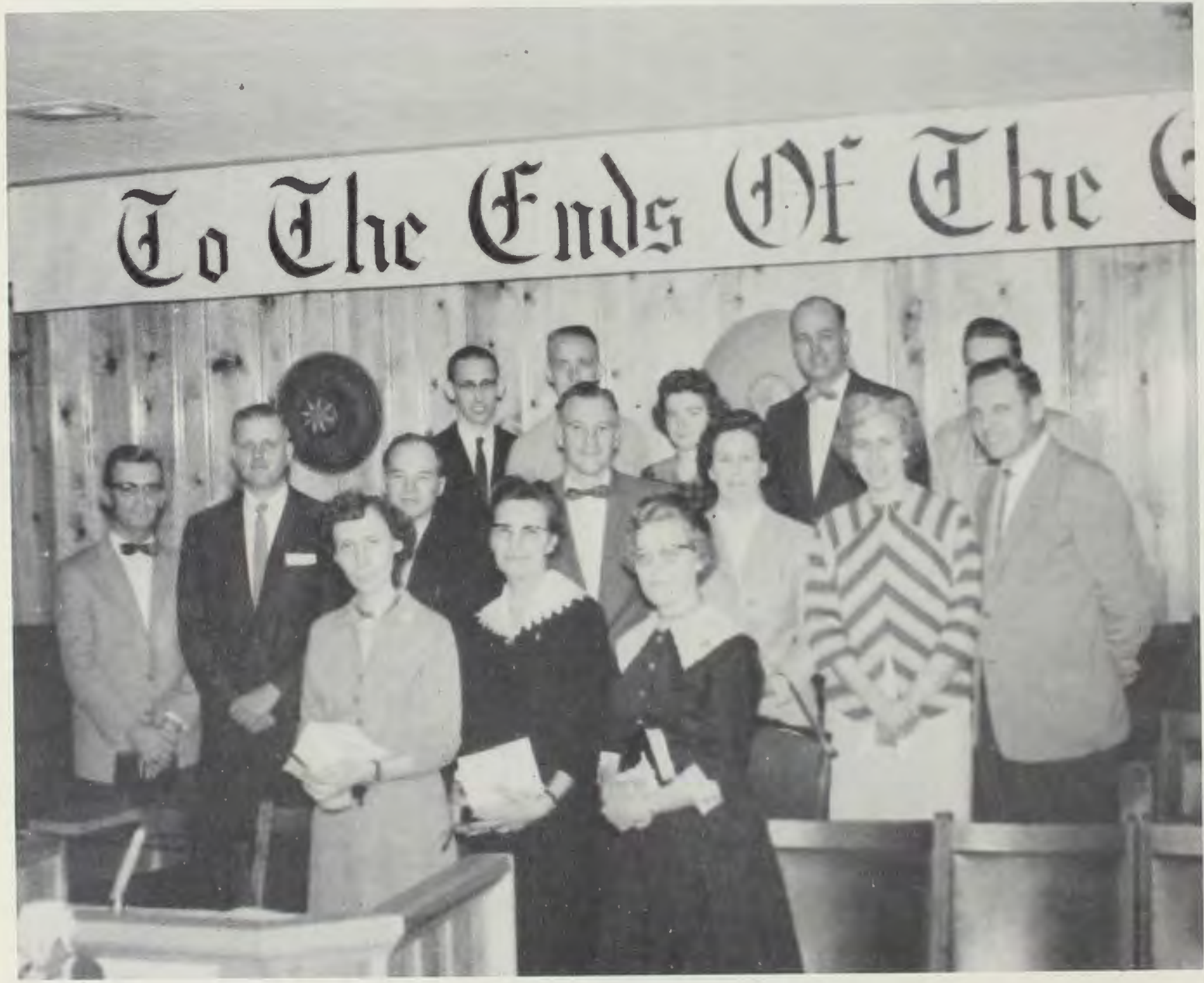

FIRST ROW: Ruth Nephew, Miss Hegy, Mrs. Bea Davis. SECOND ROW: Mr. Bergen, Mr. Alan Metcalf, Dr. Fisher, Mr. Donald Hare, Mrs. Donald Hare, Mrs. Carl Luyben, Mr. Carl Luyben. THIRD ROW: Lauren Schenck, James Entner, Charlene Ressler, Mr. Donald Moffat, Bob Domokos. 


\section{Conference}

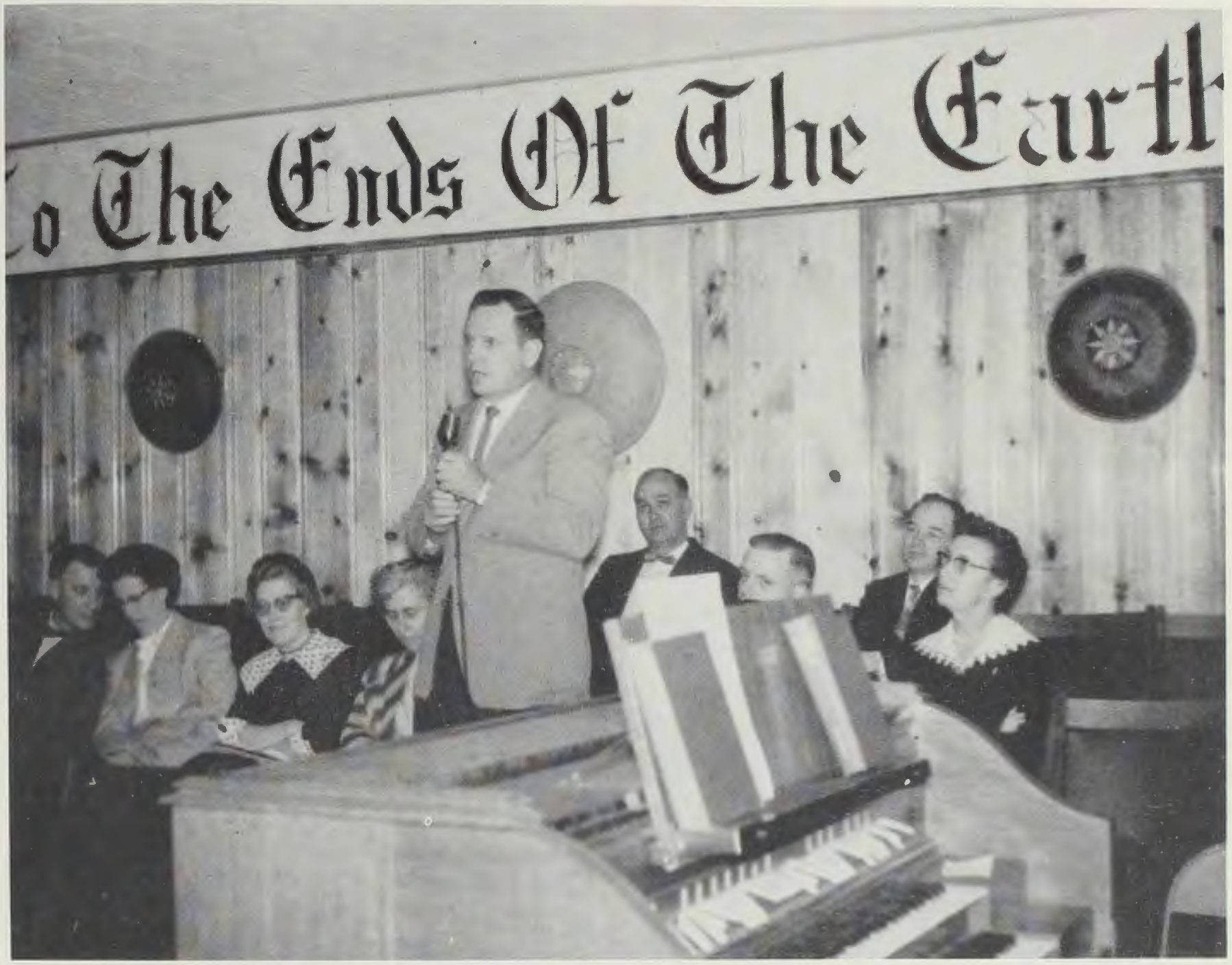

At the Saturday evening symposium, Mr. Luyben from Liberia urges us to fully prepare for the field.

From April 5 to April 9 the Cedarville College Fellowship for World Missions prayer band, in cooperation with the Grace Baptist Church of Cedarville, Ohio, held its annual missionary conference in Milner Chapel. Speakers included Miss Ruth Hegy from the Congo, Mr. and Mrs. Donald Hare from Brazil, Mr. Alan Metcalf from the Cleveland Hebrew Mission, Dr. Gerald Fisher from Africa, Miss Ruth Nephew from the Chad Republic, Africa, Mrs. Bea Davis from Homer, Alaska, Mr. and Mrs. Carl Luyben from Liberia, Africa, and Mr. William Fusco from Italy. The theme of the conference was, "To the Ends of the Earth."

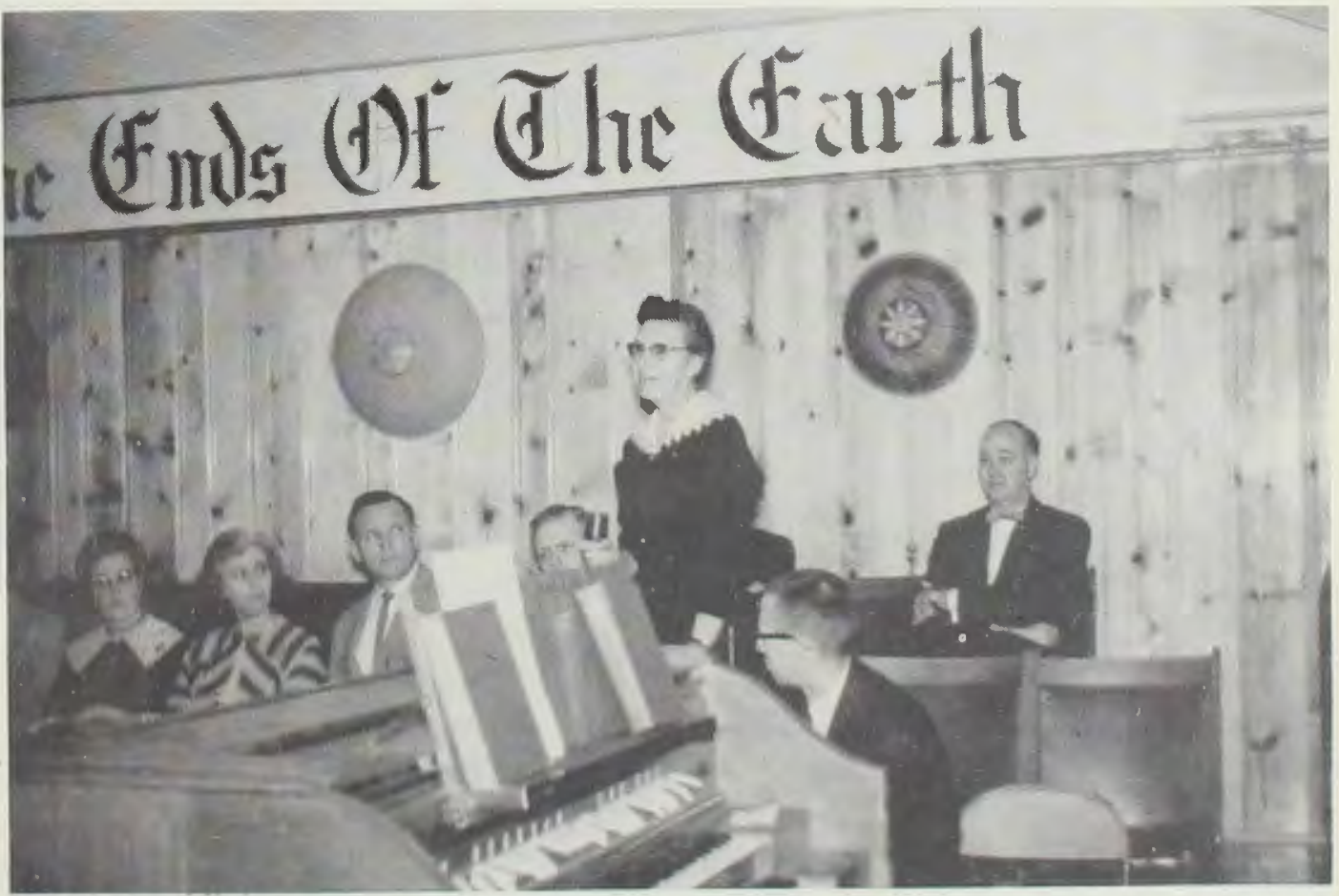

Miss Hegy tells of her experiences with the rioting Congolese. 


\section{Junior-}

\section{Senior}

\section{Banquet}

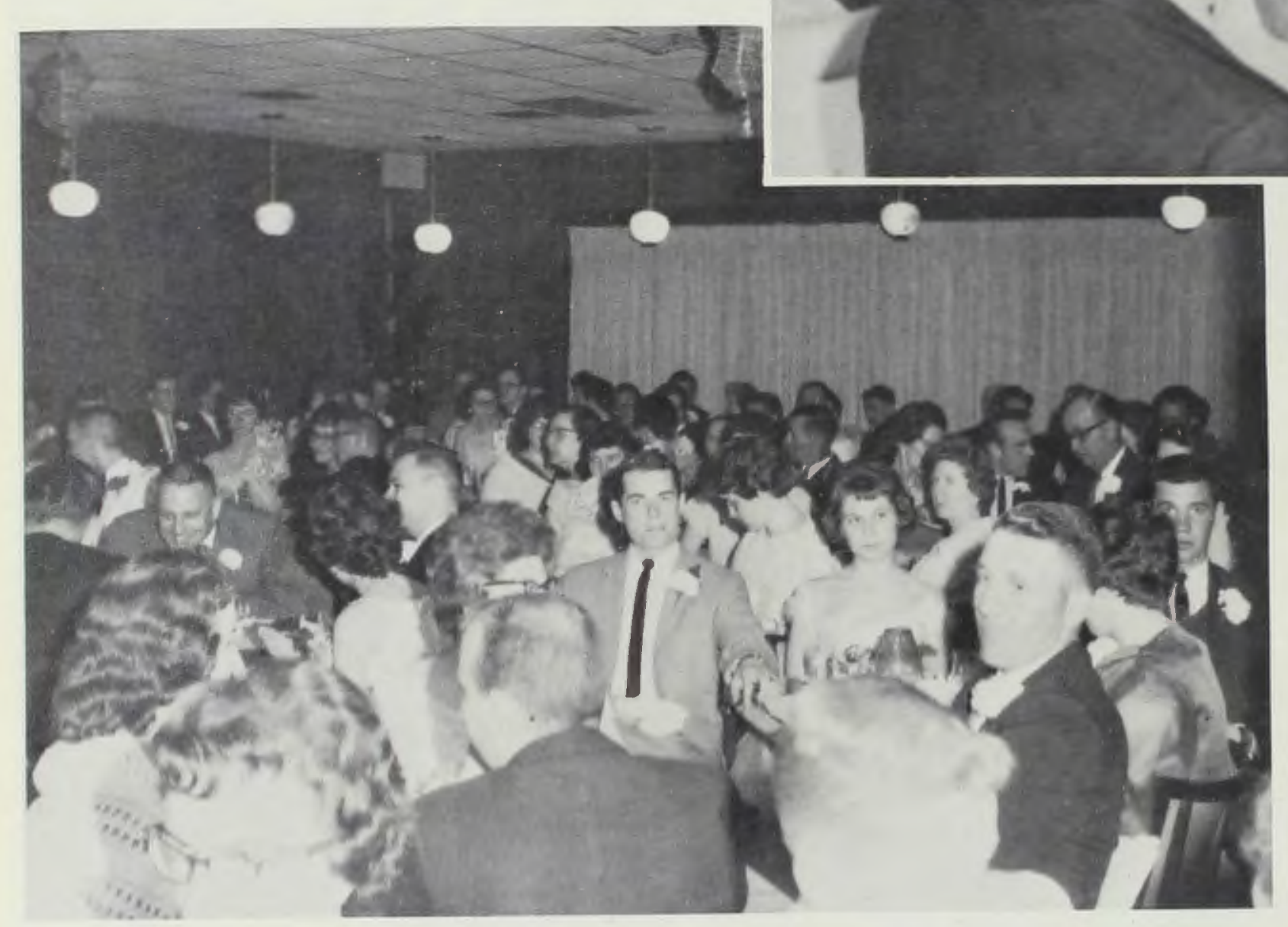

Dr. Milkie relates experiences as a Christian Psychiatrist.

What an intentive looking group!

The Blue Grass Restaurant, Wilmington, Ohio, was the scene of the Junior - Senior Banquet which featured an Oriental theme. Johnny Wheeler, Youth for Christ director from Dayton, Ohio, was Master of Ceremonies and Dr. Fred Milkie, eminent psychiatrist from Toledo, Ohio, highlighted the program. The Senior Class will and prophecy were also included in the program. 


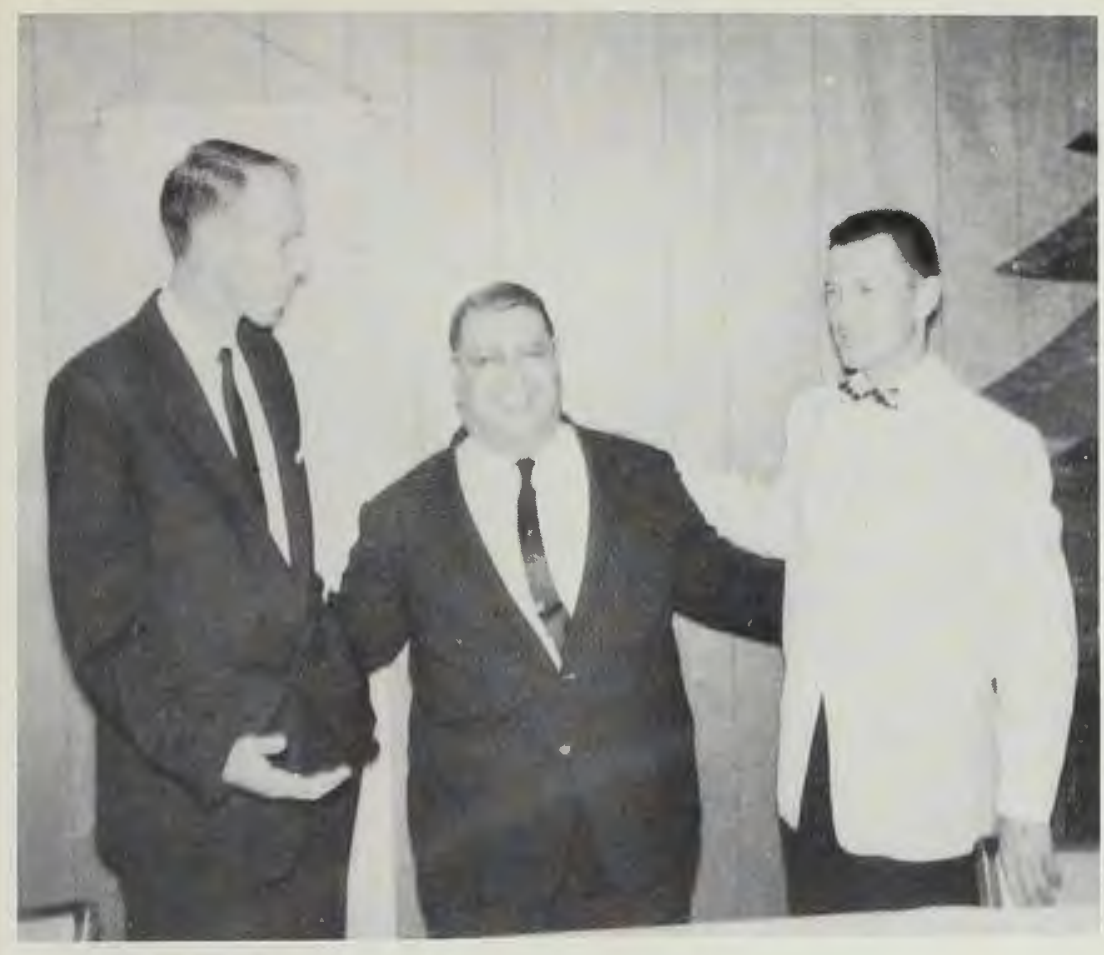

Dr. Milke appears to be amused.

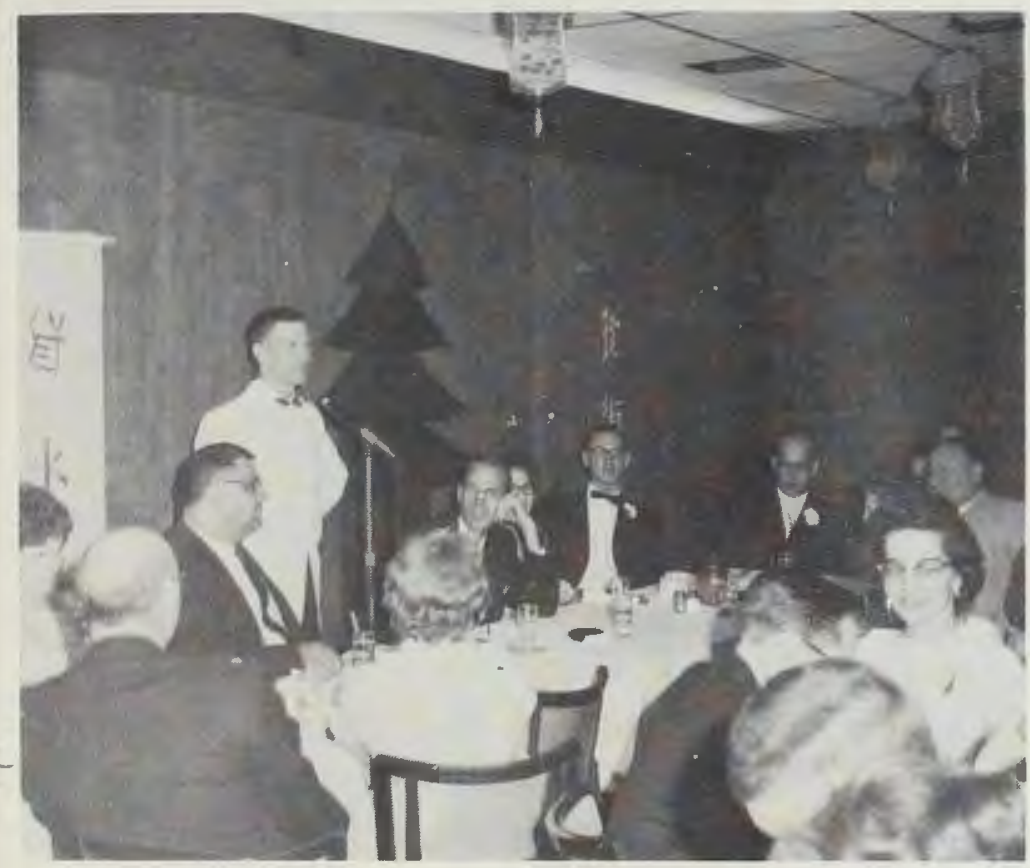

Group listens to Johnny Wheeler, Master of Ceremonies.

Carole Lanius favors the group with a song.

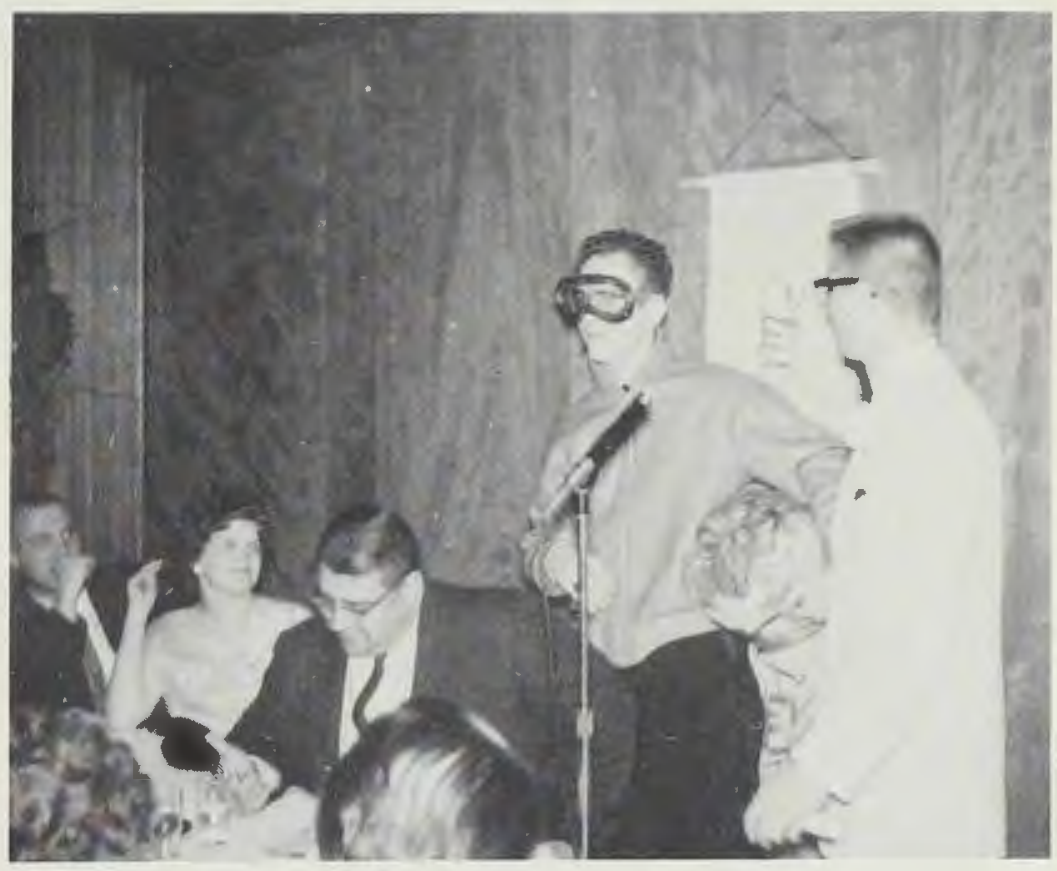

Lon Reising, man from outer space, foretells future of Senior earth men.

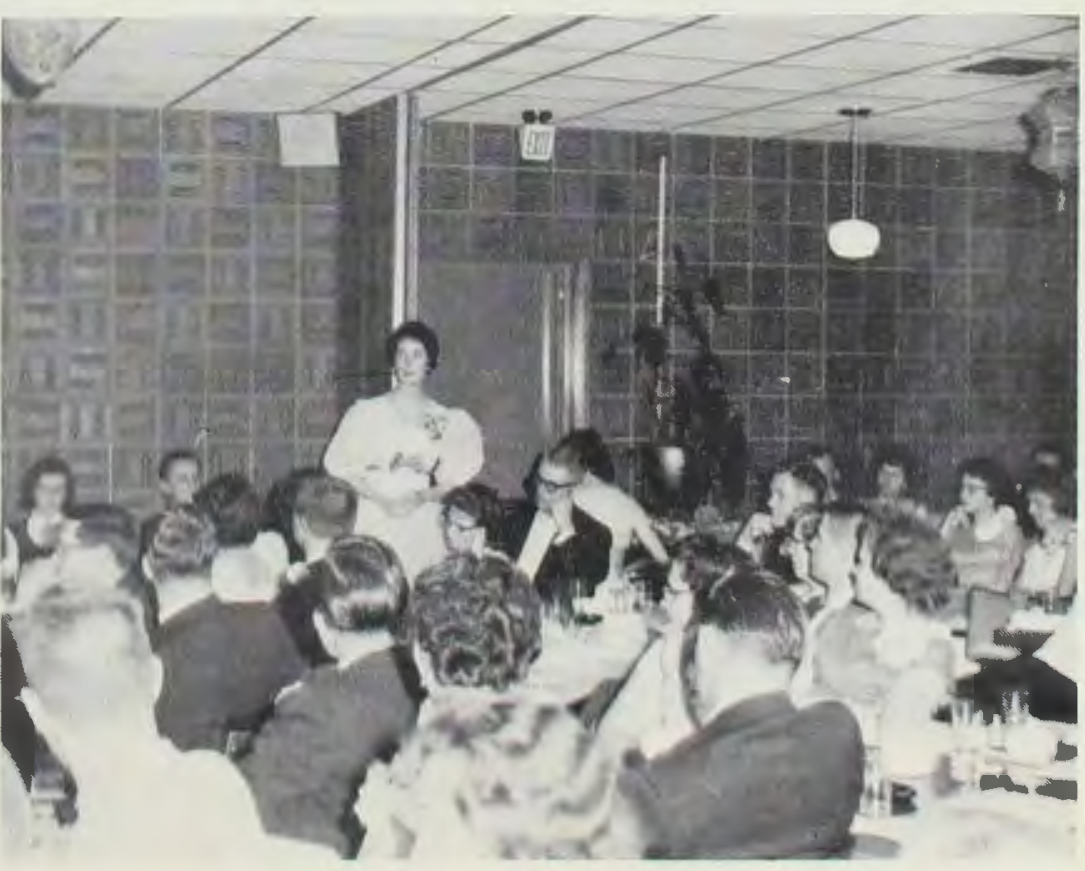




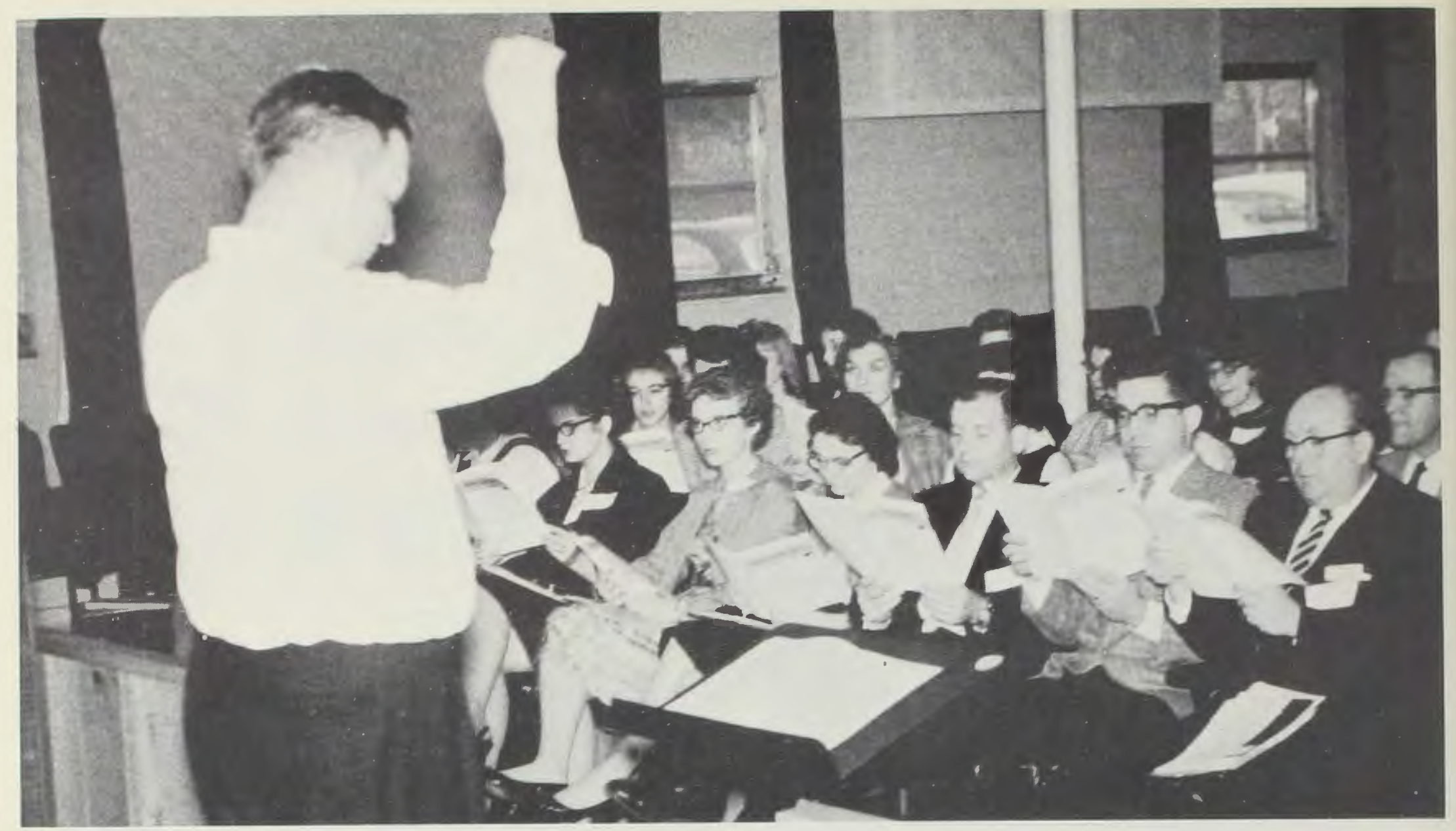

Mr. Cooke demonstrates directing technique.

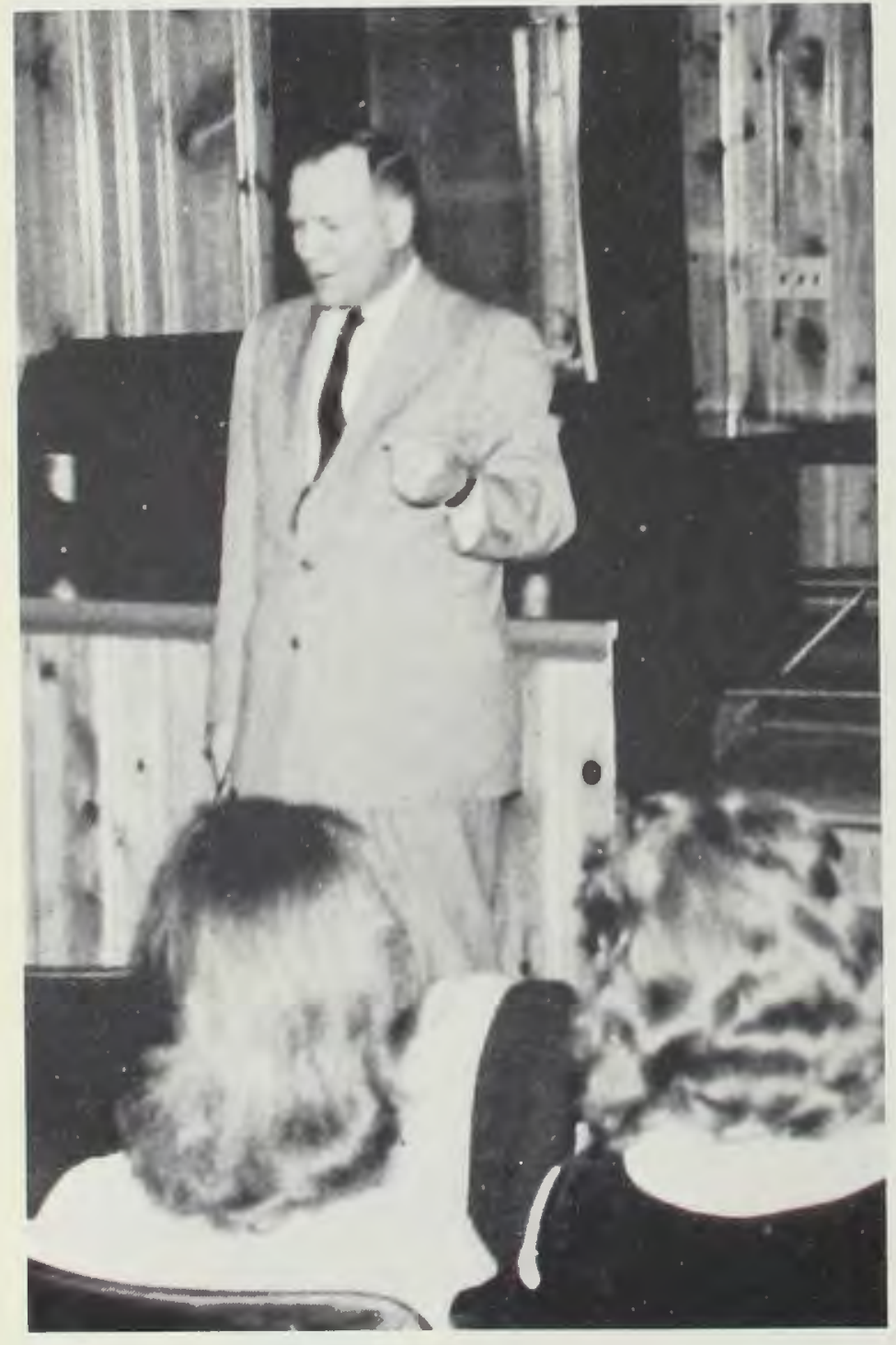

Evangelist Chelsea Stockwell lectures on the purpose of music in the church.

\section{Music Workshop}

Modern Music Masters was the sponsor of a Church Music Workshop in the spring. This was a first for this organization. Panel discussions and lectures were given on various phases of music technique. The day was climaxed by a College Choir concert and a message from Rev. Chelsea Stockwell.

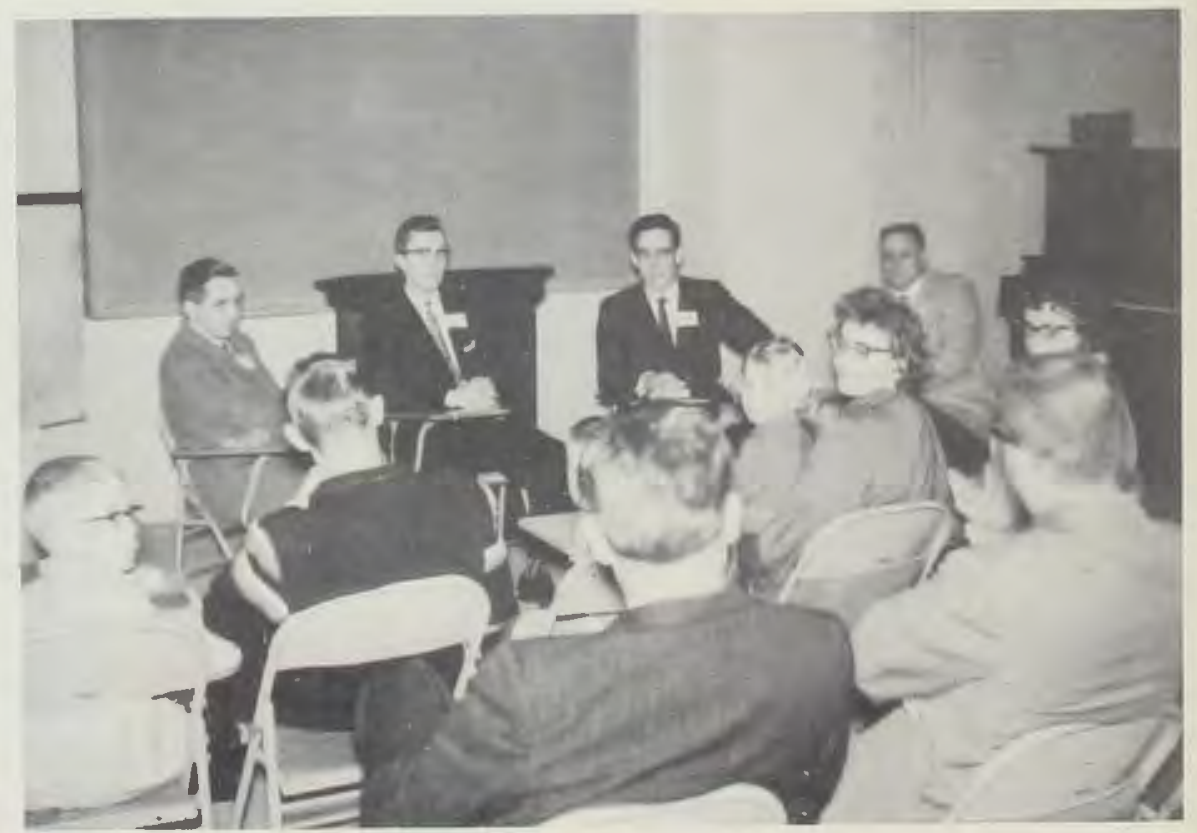

Rev. Vernon Miller, Rev. George Zinn, and Rev. Glenn Greenwood discuss the relationship of pastor and music. 


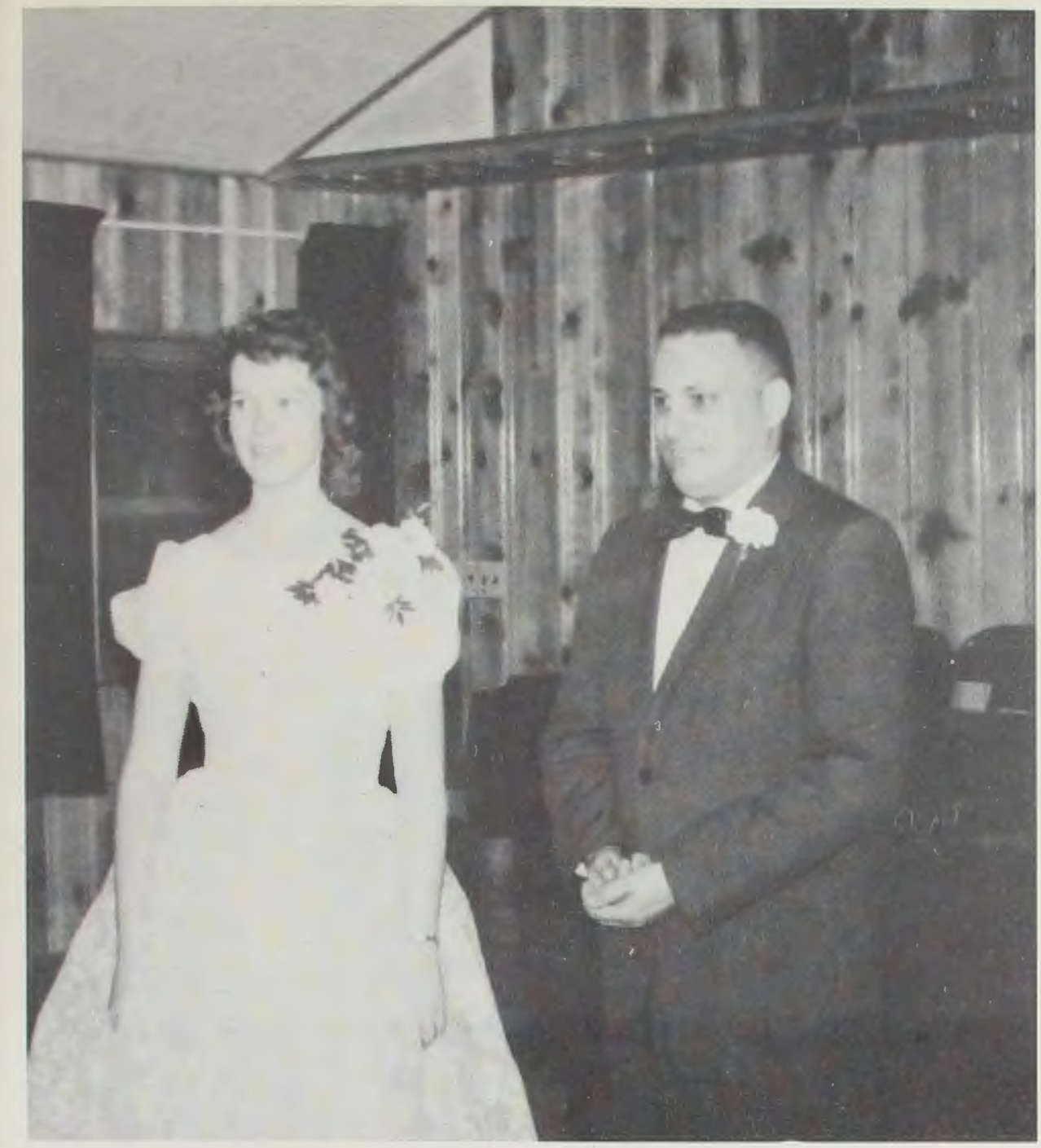

\section{Senior}

Recitals

Climaxing four years of intensive study, the music majors presented their senior recitals to the faculty, student body, and the public. The first of these recitals was given on May 4. Shirley Harrington performed on the piano and organ featuring works by Bach, Buxtehude, and Franck. On May 18 Carol Zoellner presented an organ recital which included her own hymn arrangements besides the works of Cabezon and Schumann. James Neely, tenor, was accompanied by Camilla Shambaugh at his recital on May 12. His performance included selections from Handel's "Messiah" and Kurt Weill's "Down in the Valley."

James Neely and accompanist Camilla Shambaugh

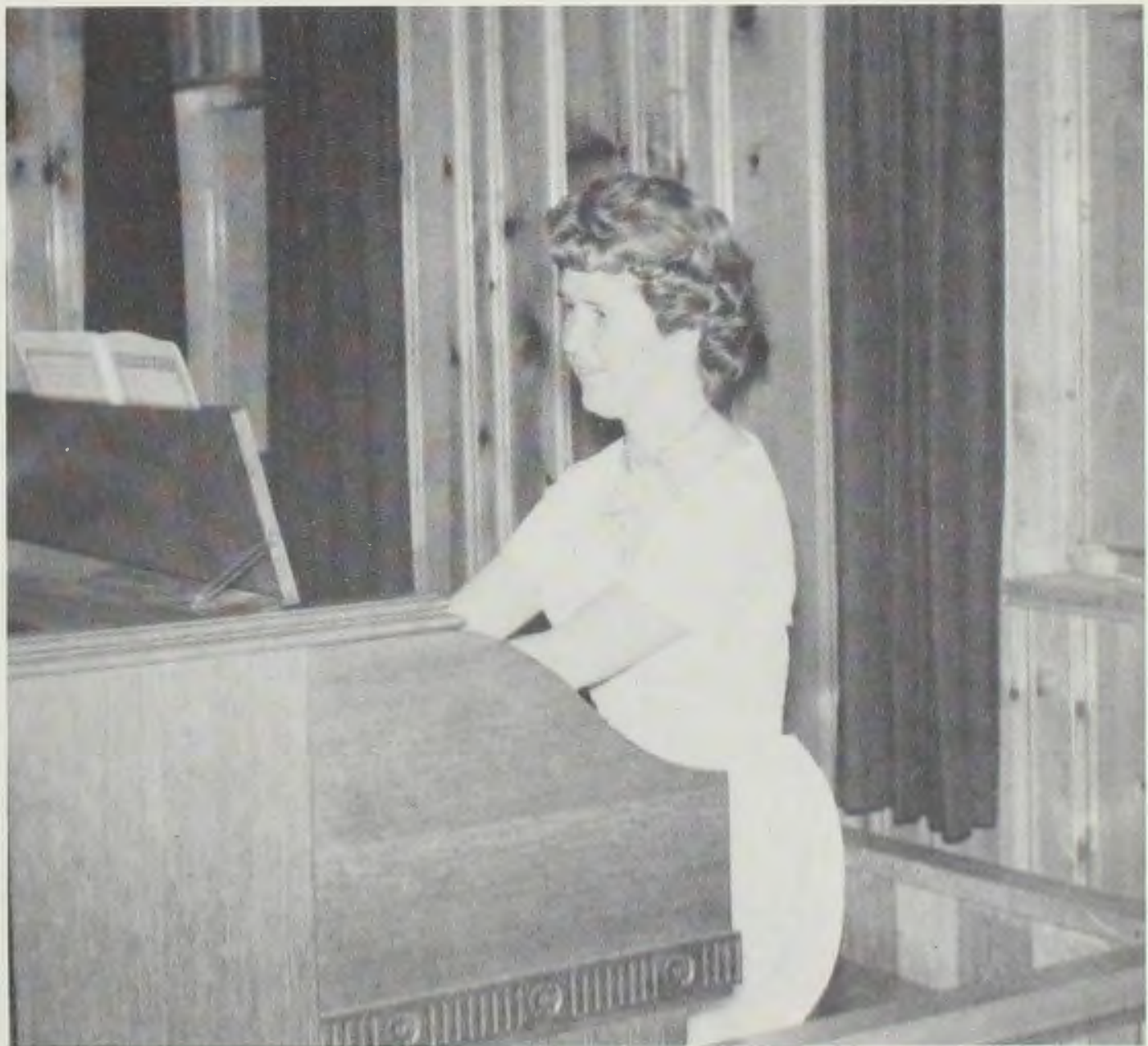

Shirley Harrington plays a selection from Bach. 


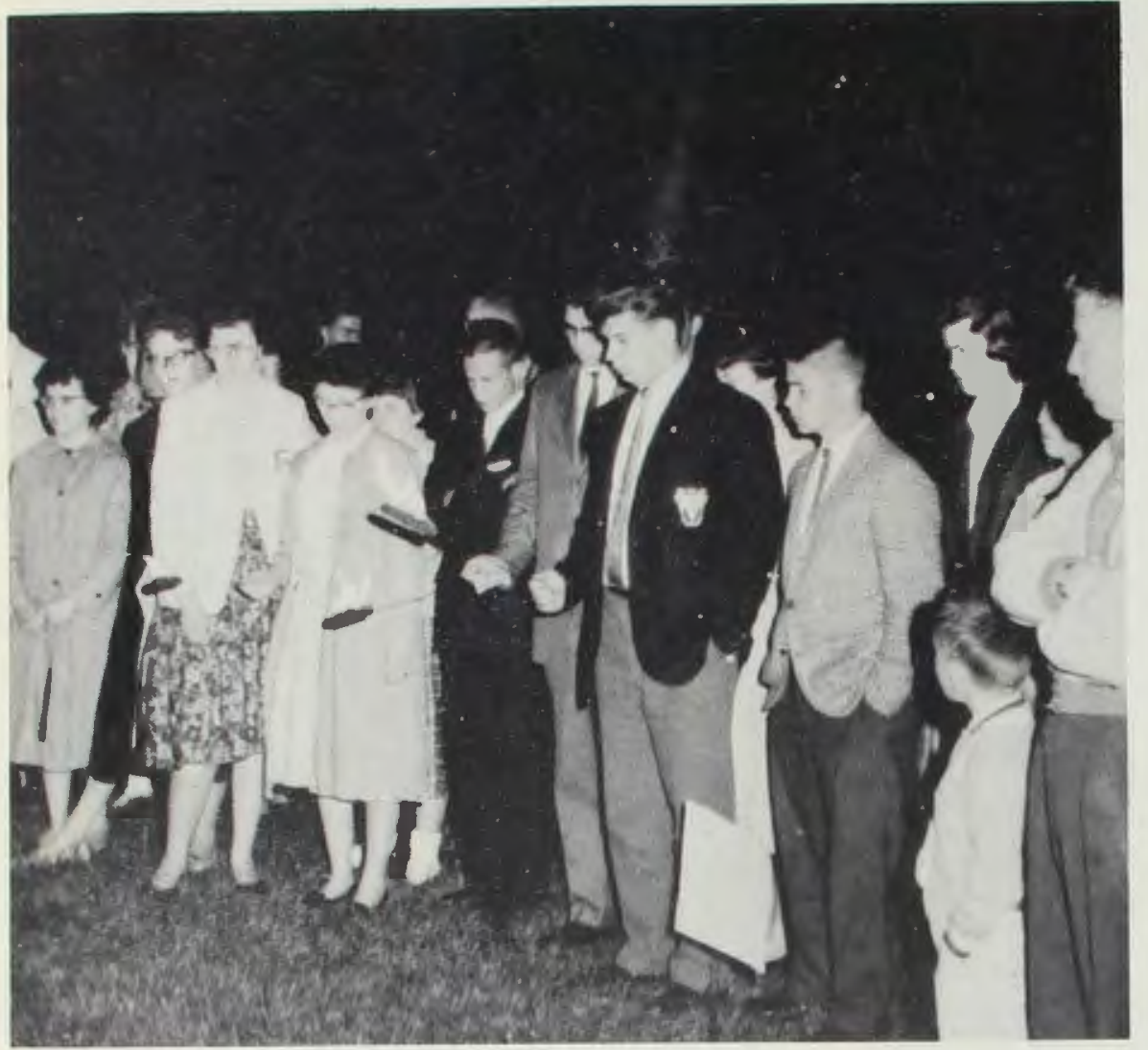

The first annual Installation Service was held in May of 1961. Each new officer of Student Council and each new class officer received lighted torches from the former officers signifying the transferring of responsibility. This was a new event to the campus and was a great success.

The lighted torch signifies the responsibilities taken by each new officer.

\section{Installation of 1961 Officers}

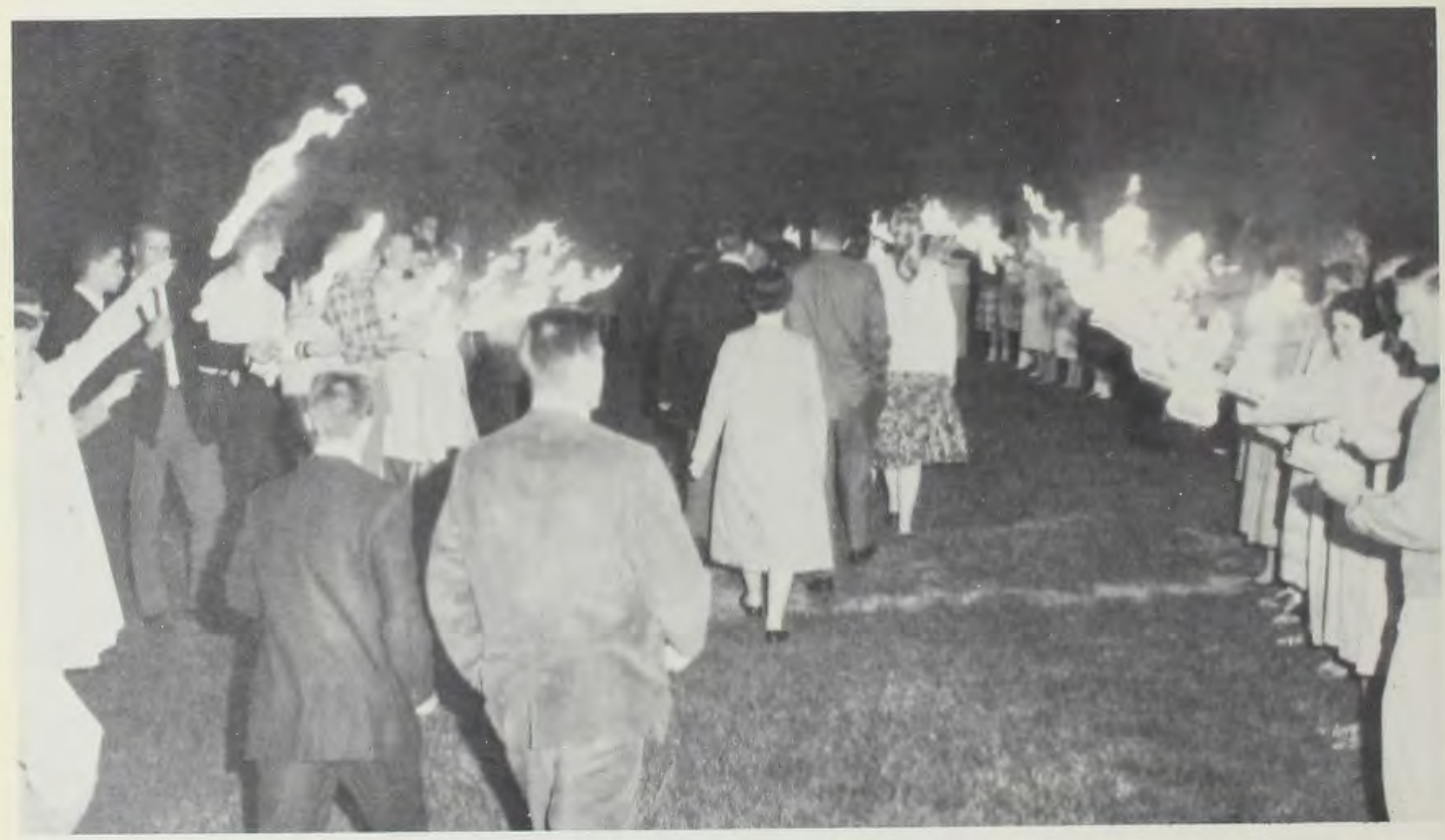

Freshmen with lighted torches form a pathway for the new officers. 
THE BACCALAUREATE SERVICE

Thursday, May 25, 1961 - 7:30 P. M.

Presiding . . President James T. Jeremiah, Th. B., A. B.

Song-leader . . . . Richard A. Cooke, B.S., M.S.

Prelude. . . . . . Warren Webber, A. B., B. M.E., M. M.E.

*Invocation. . . . . . . . . Kenneth St. Clair, B. S.

\#Hymn . . . . . . . . . "All Hail the Power of Jesus' Name"

The College Choir. ...... "Battle Hymn of the Republic" Director, Richard Cooke, B.S., M.S.

Scripture Reading. . . . . Arthur F. Williams, A. B., D. D.

Prayer ........ Rev. W. Thomas Younger Pastor, Immanuel Baptist Church, Fort Wayne, Indiana

The Combined Choirs.

"O God, Our Help in Ages Past"

Baccalaureate Sermon

Rev. J. L. Patten President, Omaha Baptist Bible College

*Hymn

.Lead On O King Eternal"

*Benediction

*Recessional

*Congregation Standing

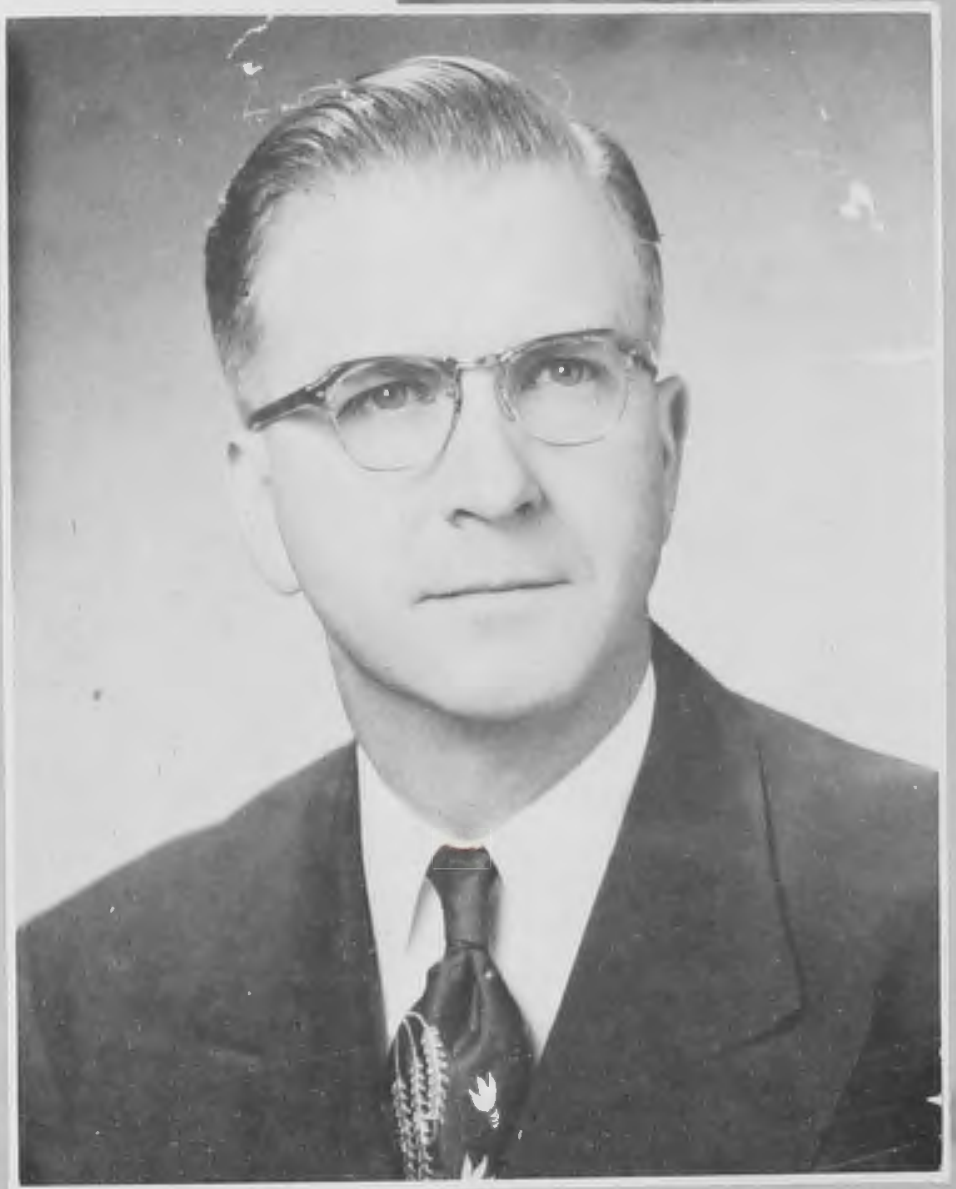

Dr. J. L. Patten 
THE COMMENCEMENT EXERCISES

Saturday, May 27, 1961 - 10:00 A. M.

Presiding . President James T. Jeremiah, Th. B., A. B. Song-leader . . . . . Richard A. Cooke, B.S., M. S.

* Processional. . . . . . . . . . . Cedarville College Band Director, William Thornton, B.S., M.S.

*Invocation ........... G. Paul Wyland, A. B., M. A.

*Hymn . . . . . . . . . . "Crown Him With Many Crowns"

Scripture Reading. . . . . George Lawlor, A. B., B. D., Th. M.

Prayer. . . . . . . . . . . . . Rev. William Brock Pastor, Immanuel Baptist Church, Columbus, Ohio

Announcements . . . . . . . . . Mr. George S, Milner Chairman, Board of Trustees

Kingsmen Quartet ...... "When I Survey The Wondrous Cross"

Commencement Address . . . . . . . Dr. Robert T. Ketcham National Consultant of the General Association of Regular Baptist Churches

The Harmonettes. . . . . . . . . . . . . "His Alone"

Presentation of Class Gift . ... Marvin Troyer, Class President

Response............. President James T. Jeremiah

Presentation of Candidates . . . C. R. Maddox, B.S., M.A., Ph. D.

Conferring of Diplomas and Degrees . President James T. Jeremiah Richard McIntosh, A. B., B. D.

Presentation of Awards....... President James T. Jeremiah

*The Alma Mater

*Benediction ........ . . President James T. Jeremiah

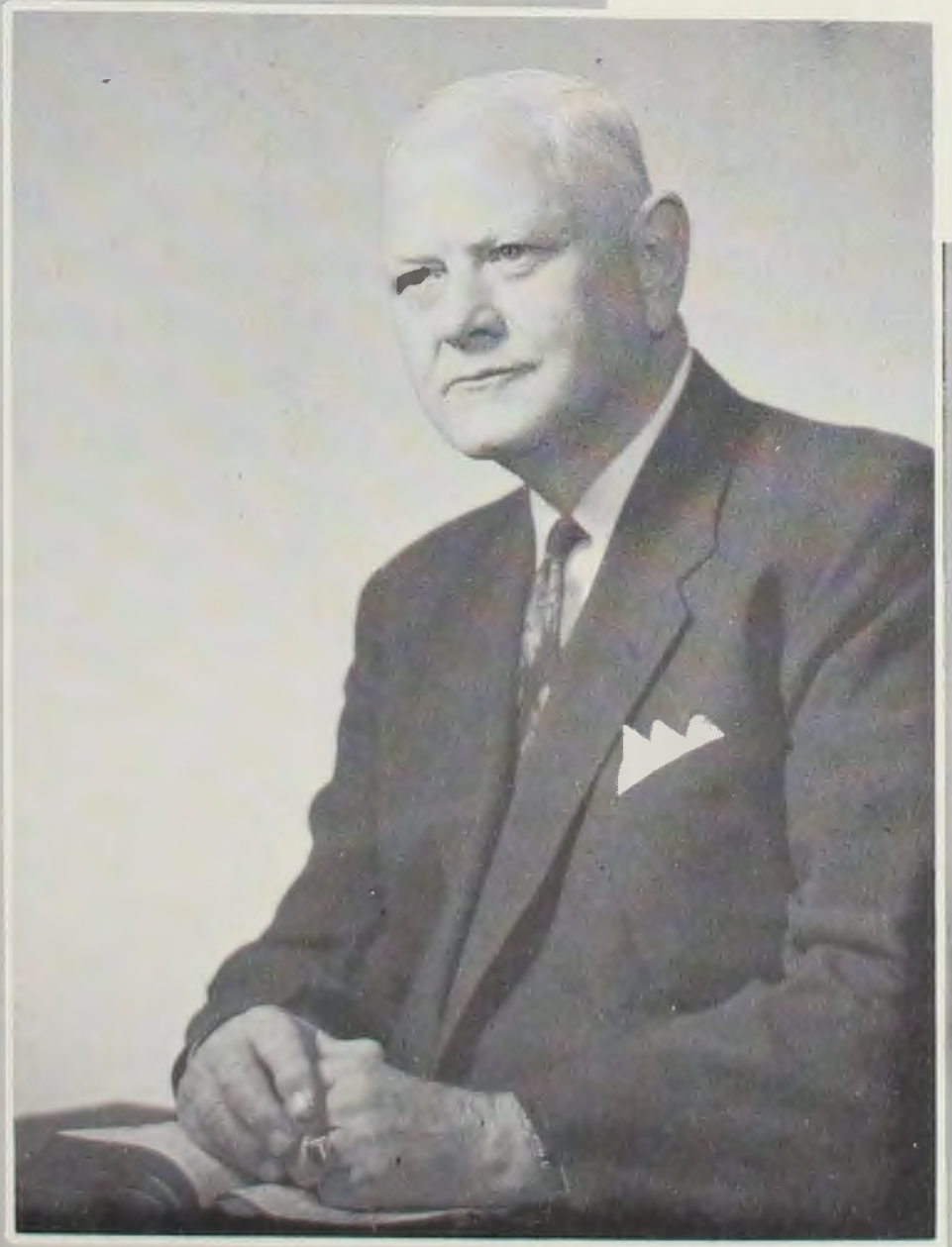




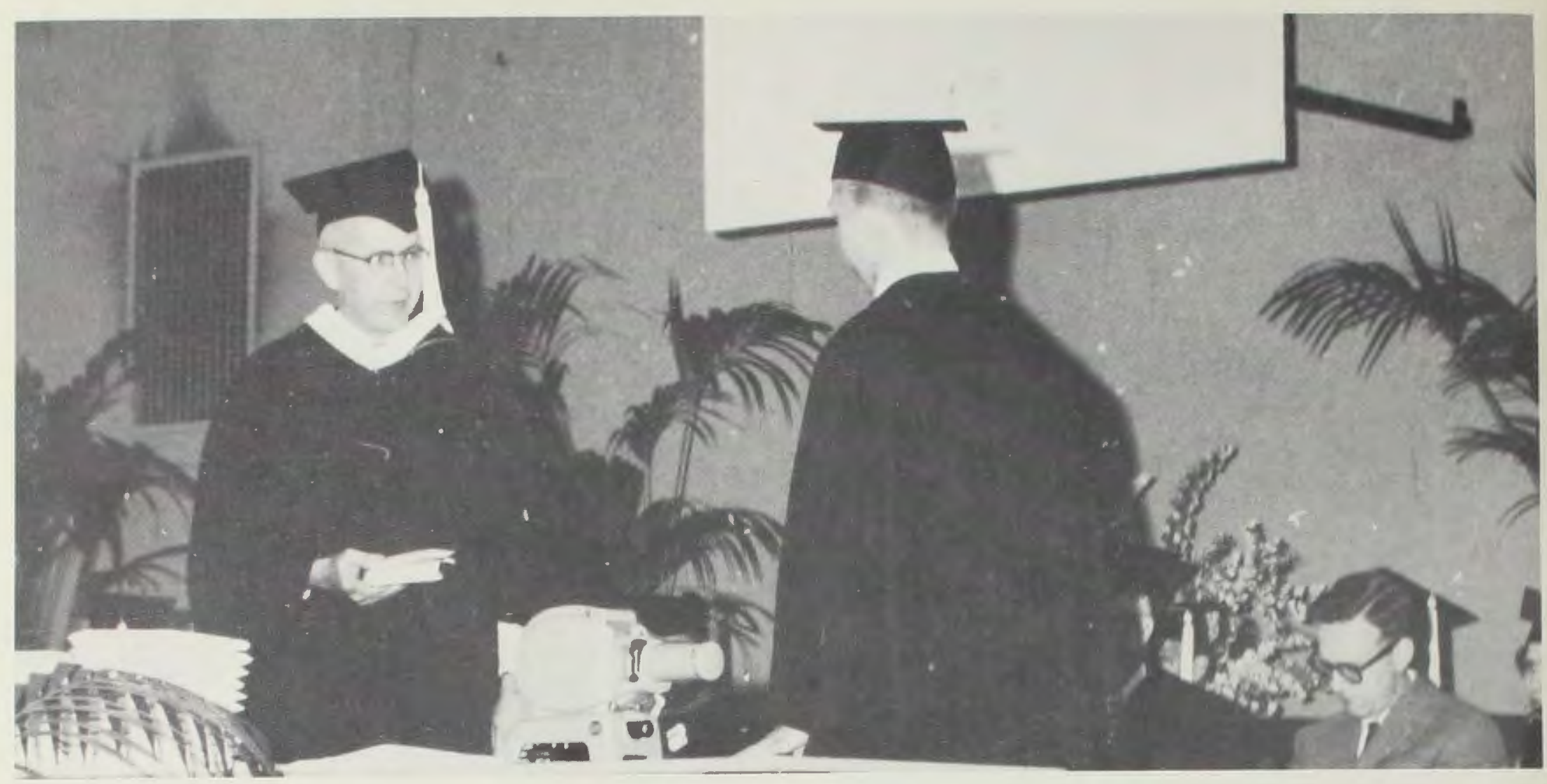

Senior President Marvin Troyer presents class gift to Dr. Jerimiah.

The Senior Class gift was presented by the Class President to the College President in traditional manner during the Commencement ceremonies. The Class of 1961 donated a slide projector and two sets of colored slides (Human Anatomy and Biology) as well as an adaptor which projects microscope slides. This gift was designated for use by the Science Department.

Robert T. Ketcham, D.D., LL.D., the main Commencement speaker, has long been active in the General Association of Regular Baptist Churches. At present he is the National Consultant of the Association and the associate editor of it's official organ "The Baptist Bulletin". Dr. Ketcham is also a messenger from the Association to the American Council of Christian Churches and the International Council of Christian Churches.

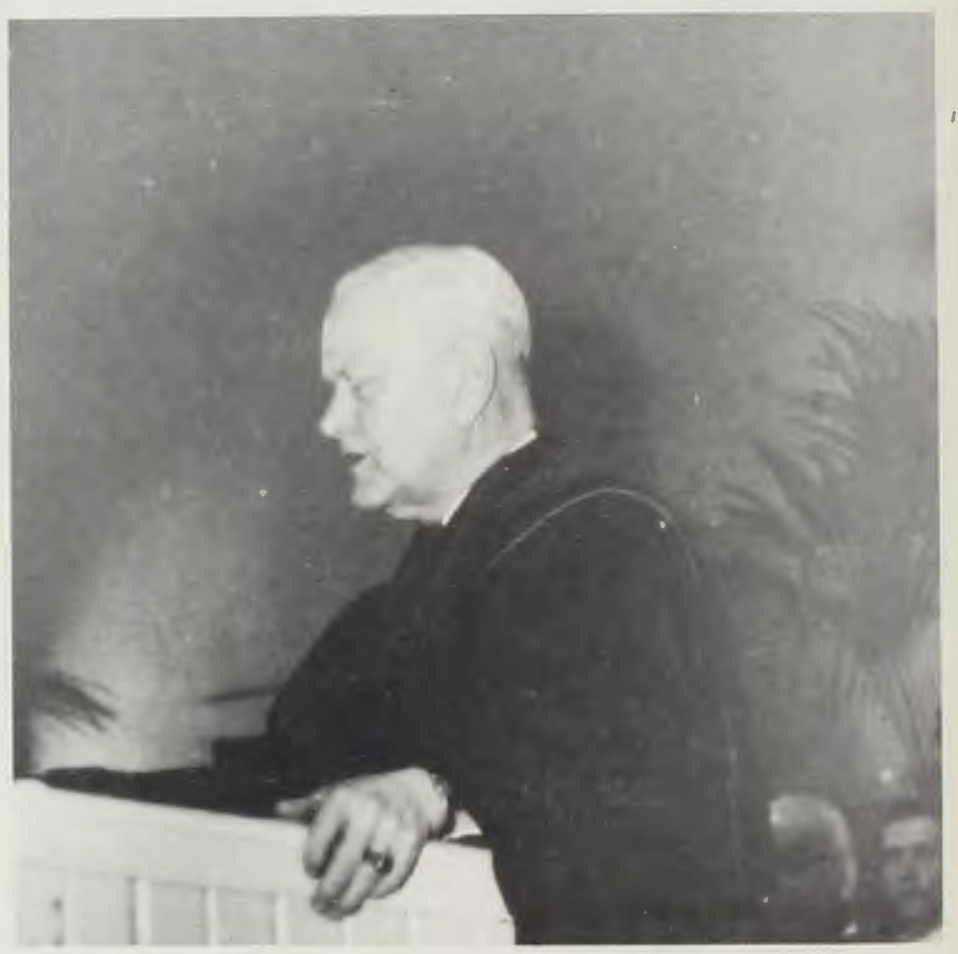

DR. ROBERT T. KETCHEM

\section{Class}
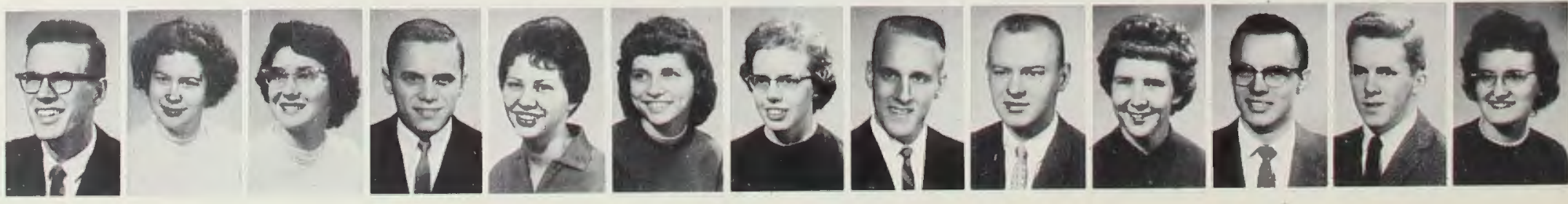


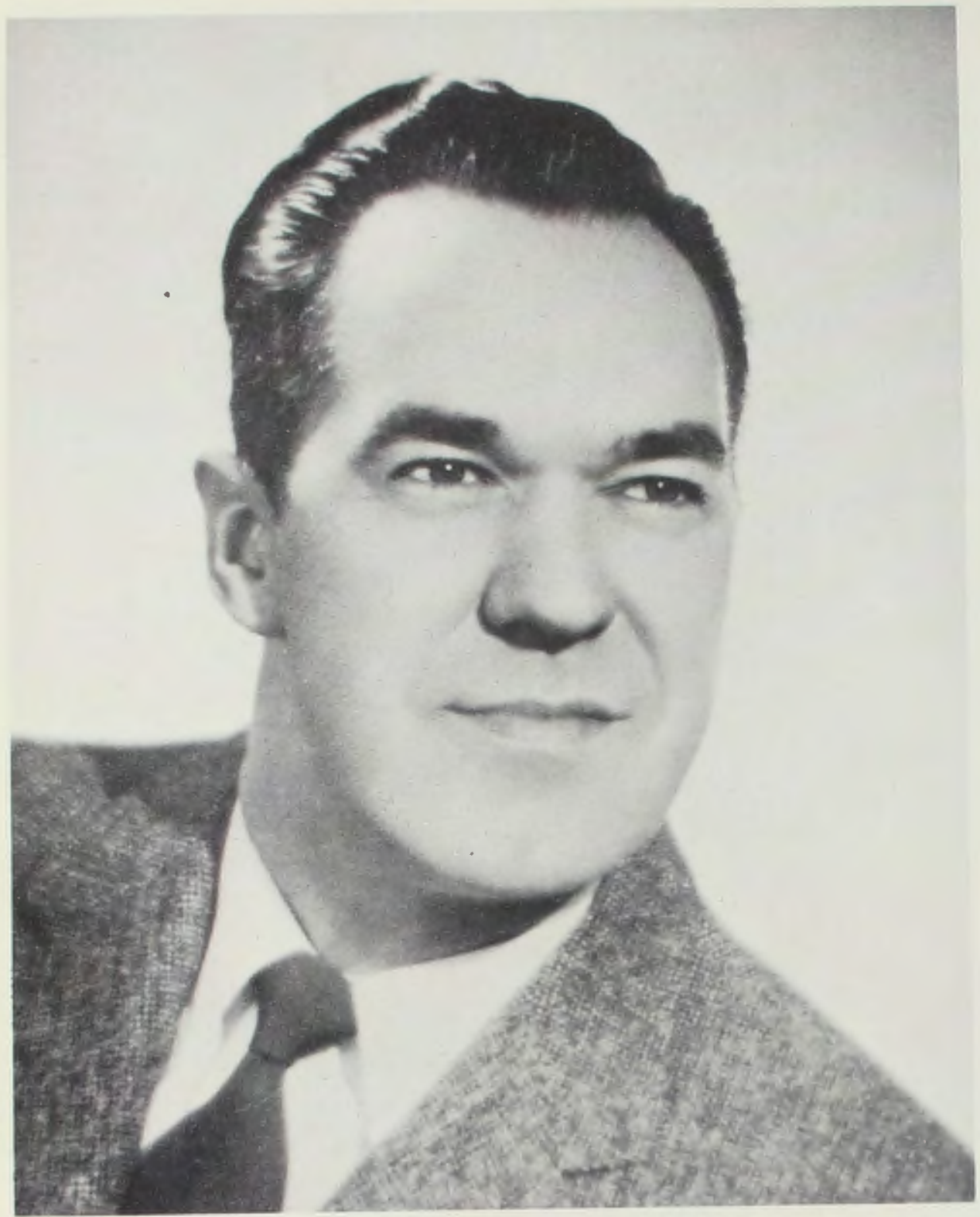

\section{Fall}

\section{Evangelistic}

\section{Services}

Dr. Carl Elgena

Pastor

Grandview Park Baptist Church

Dr. Carl Elgena, pastor of Grandview Park Baptist Church, Des Moines, Iowa, was the speaker for the annual fall evangelistic services. During the morning chapel services he brought a series of messages on "How to be Holy." Each evening he brought a different message.

Mr. Elgena, a graduate of Baptist Bible Seminary, received his honorary Doctor of Divinity degree from Los Angeles Baptist Theological Seminary, and is now taking graduate work at Drake University in Des Moines. 


\section{Freshman Talent Night}

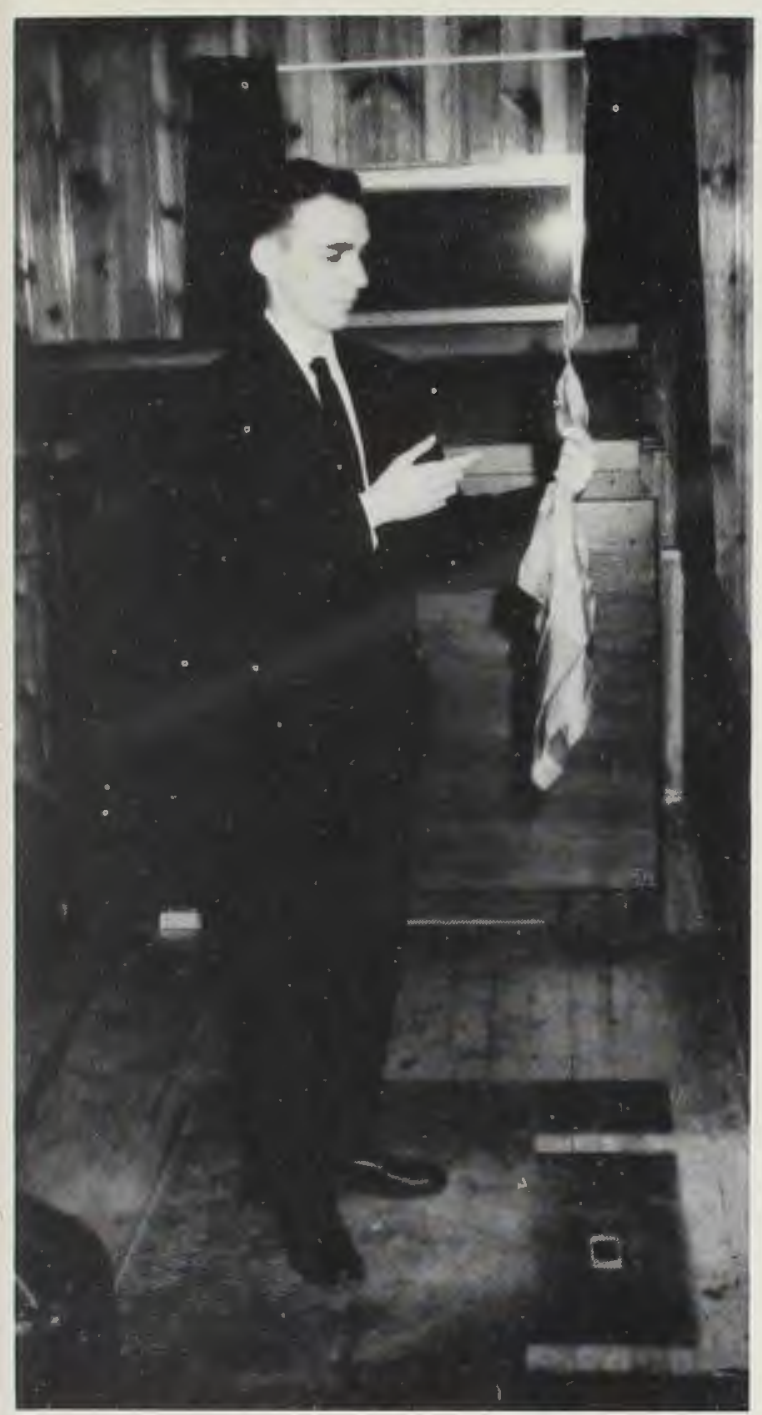

Magician Terry Miller electrifies silk scarf.

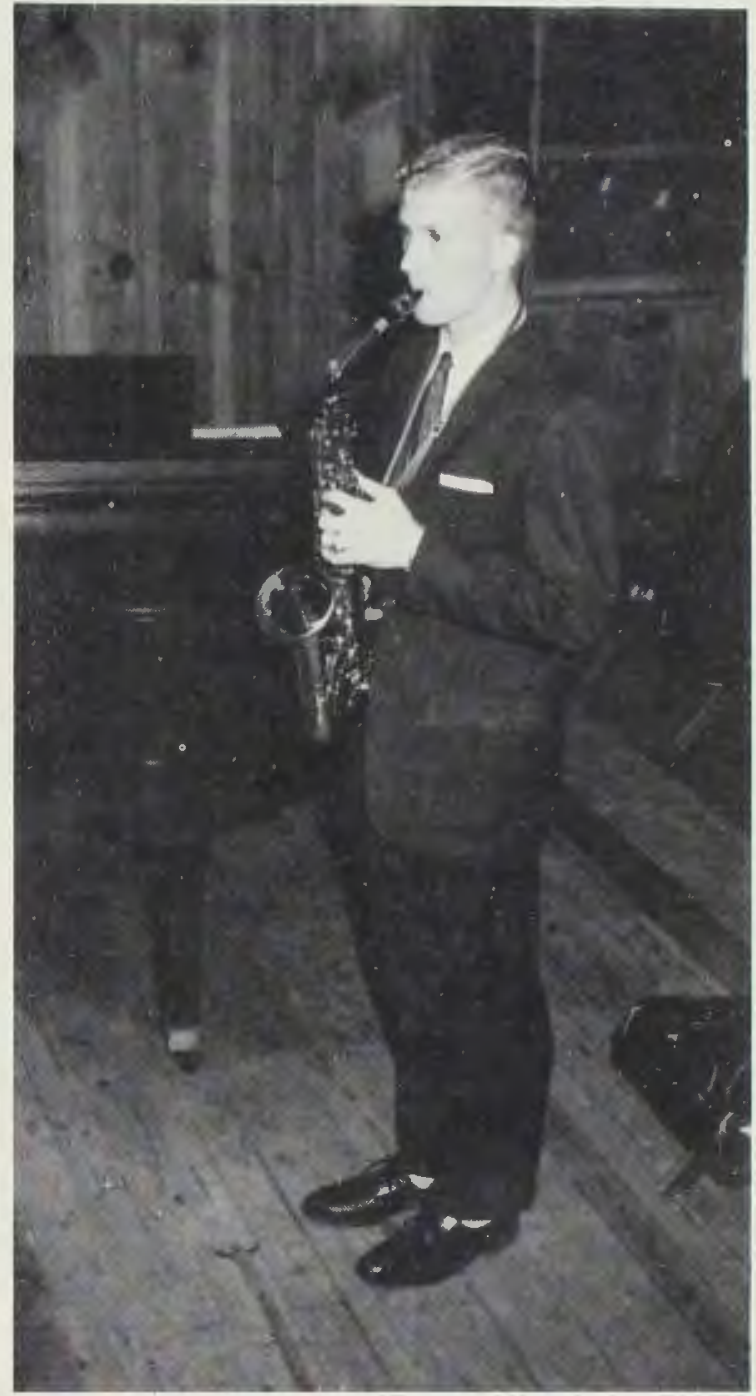

Val Roloff performs on his saxophone.
In an effort to bring the abilities of new students to the front, the Sophomore Class initiated Freshmen Talent Night this year. Sam Schwartz emceed an evening of entertainment that in cluded a trumpet solo, a bass solo, and two piano solos. Miss Ruth Smith, new addition to the music faculty, played "Ritual Fire Dance." Mr. John Reed, also a new member of the faculty, gave his interpretation of " $\mathrm{The}$ Cremation of Sam McGee."
"Why Study?" - Phil Olsen, Dave Jensen, Jerry Stadt, Ron Mathis.
"Sugartime"- Judy Couwenhoven, Martha Ammons, Martha Crill.

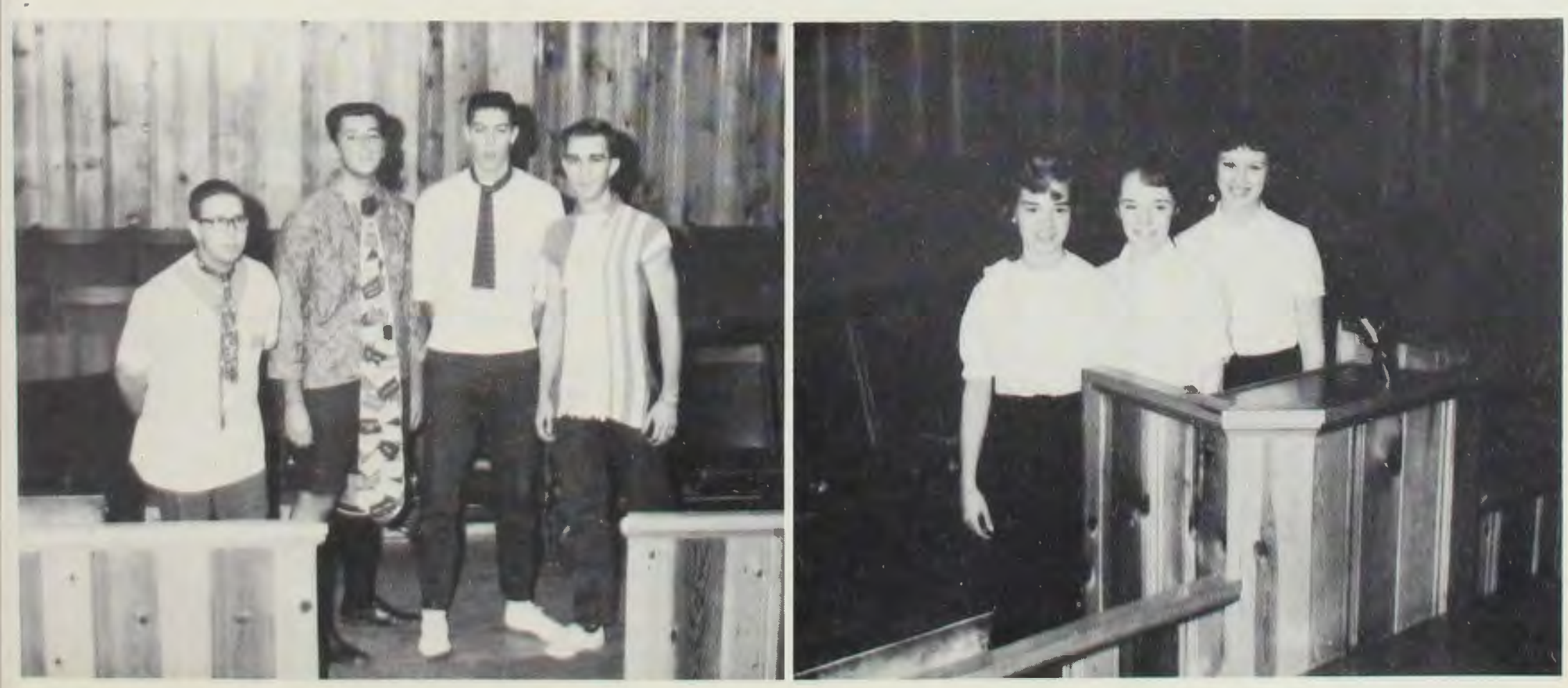




\section{Spring Bible Lectures}

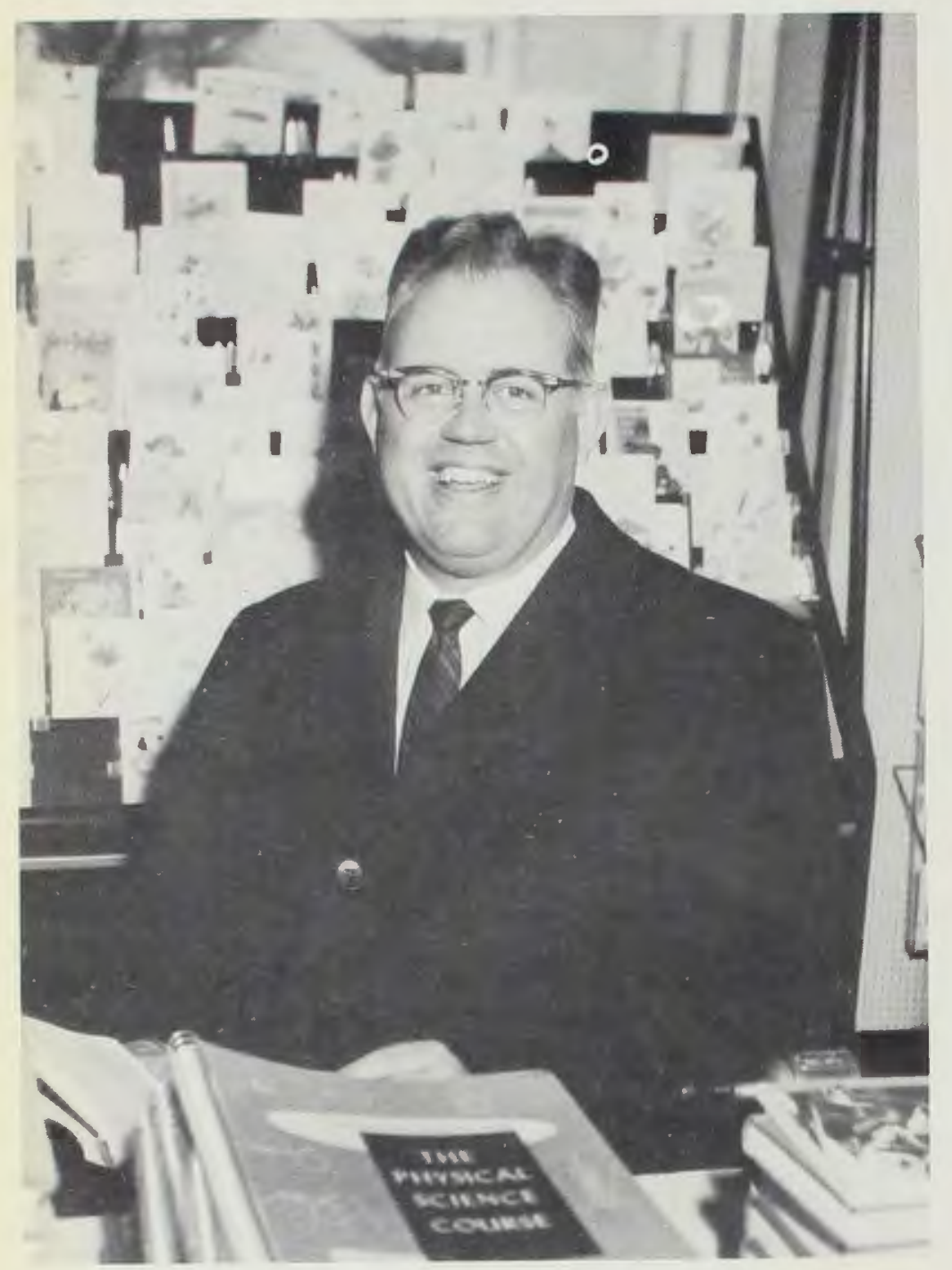

Reverend Rooke, perusing the shelves of our Bookstore, smiles for our cameraman.

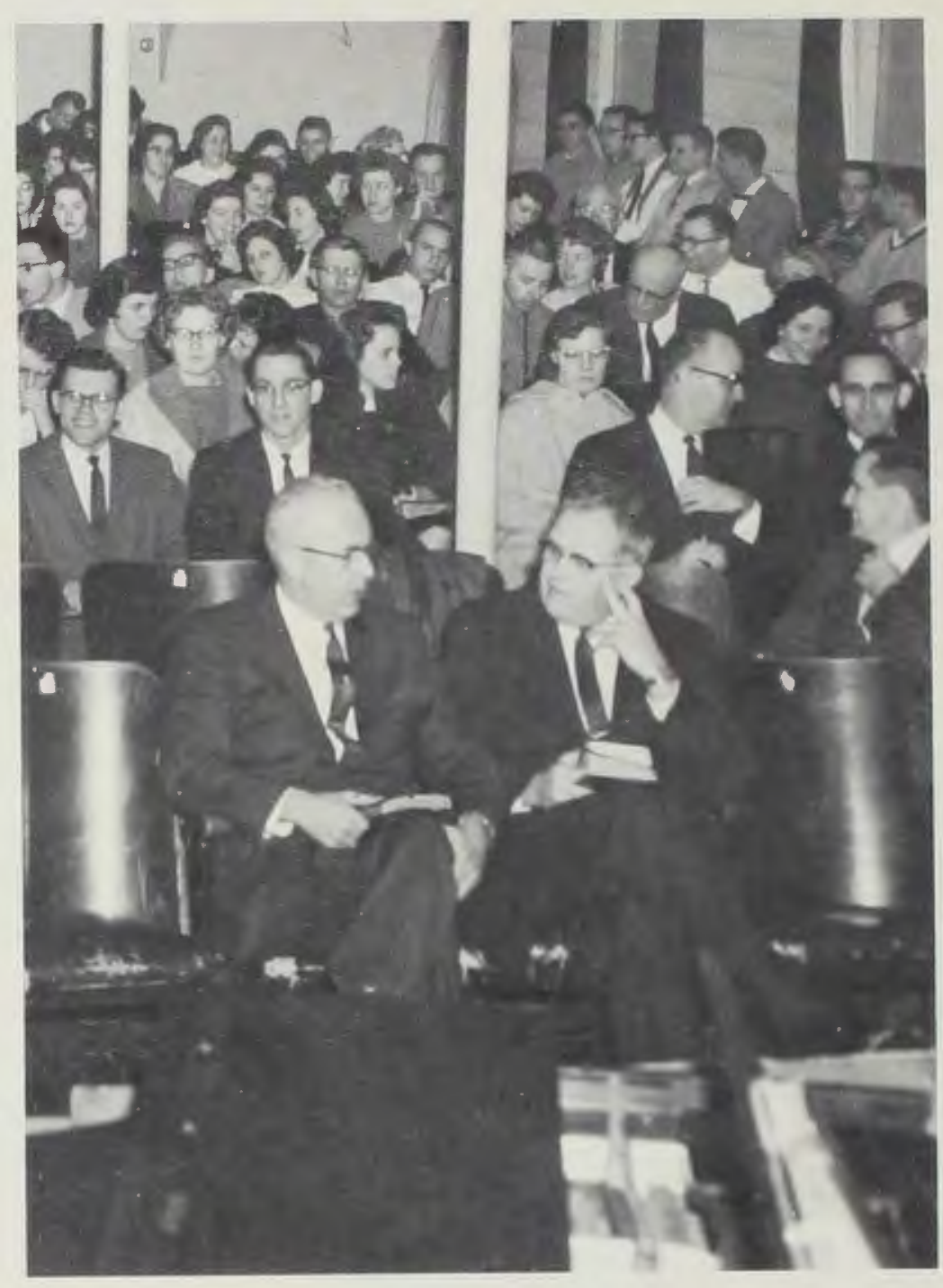

President Jeremiah confers with Mr. Rooke prior to the start of the Tuesday evening service.

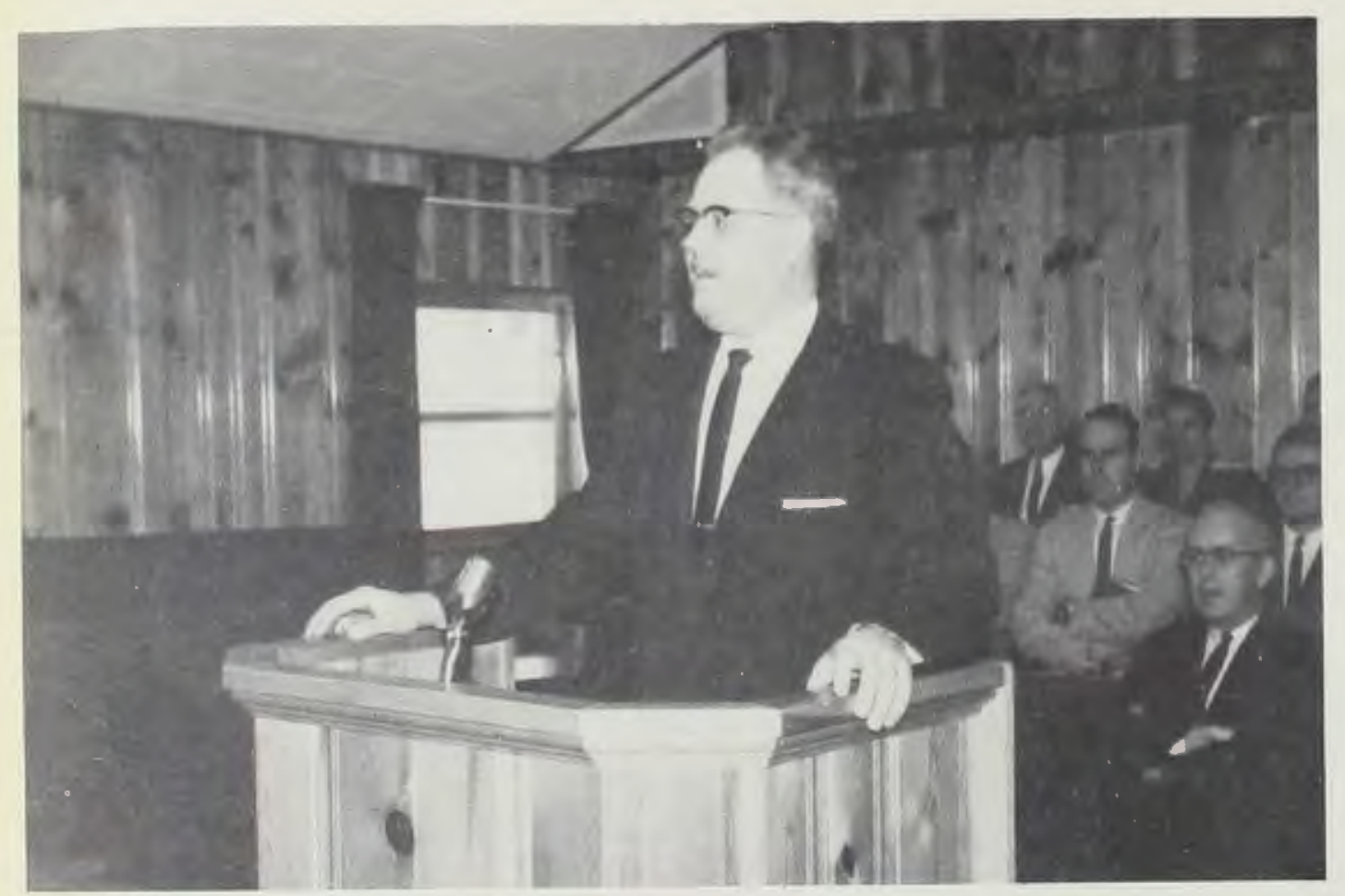

Rev. Wilbur Rooke, pastor of the Central Avenue Baptist Church of Gary, Indiana, spoke, at the Spring Bible Lectures which were held from February 11 through February 16. In the morning chapel services Pastor Rooke brought a series of messages from the Sermon on the Mount, concentrating particularly on the fifth chapter of Matthew. Each evening he addressed the students from the parable of the Prodigal Son in the fifteenth chapter of Luke. Combining southern home-like sense of humor with the unadulterated teaching of the Word of God, he instilled within every heart his favorite motto: "O that there may arise a man in me that the man I am may cease to be." 


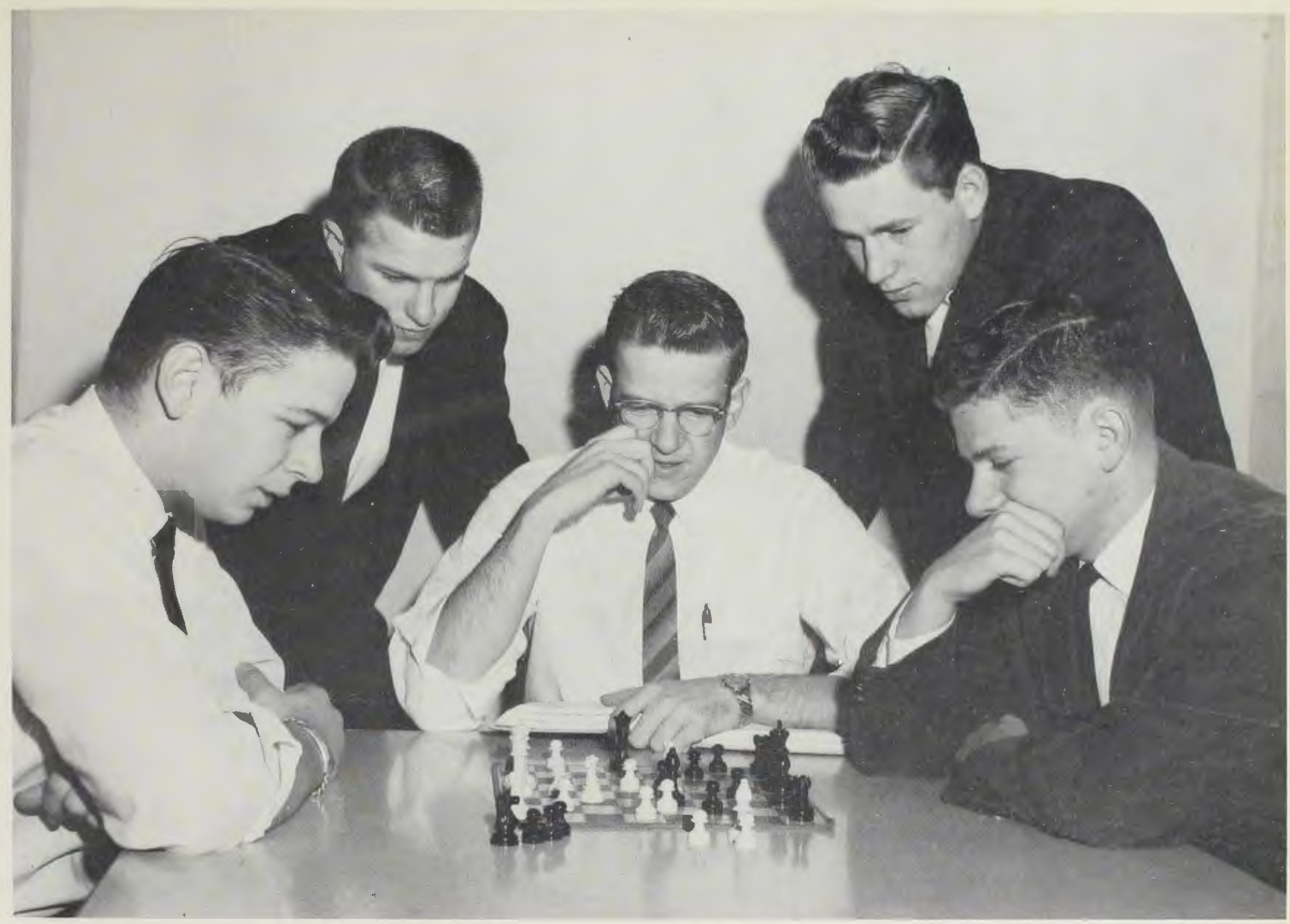

In the men's dorm competition in chess heightens through the winter. Rich Blumenstock and Rich Bresson plan another quick check-mate.

\section{Campus}

\section{Candids}

In mid-October the girls of Faith Hall worked all Saturday morning sprucing up their front yard.

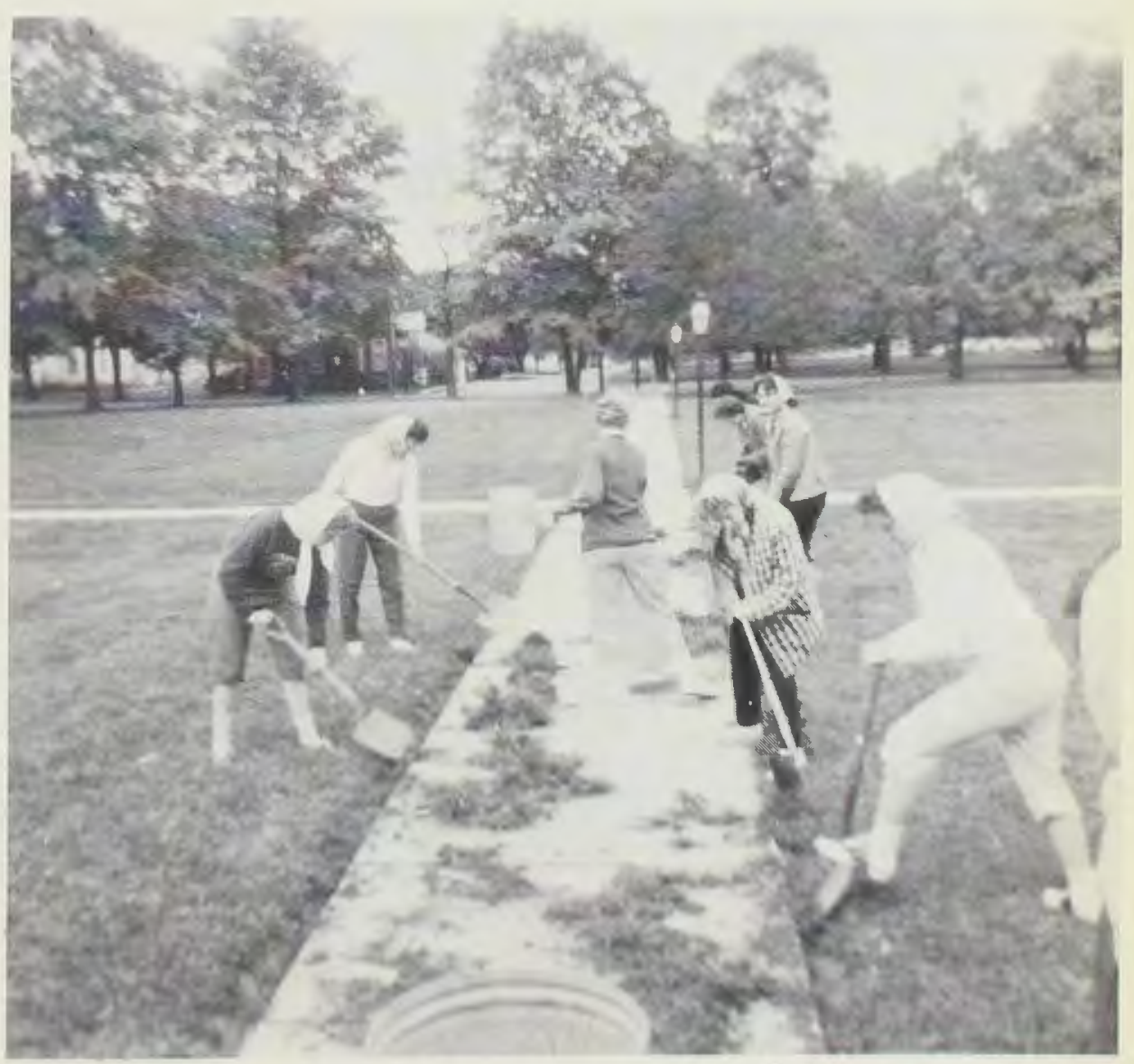




\section{Freshman Initiation}

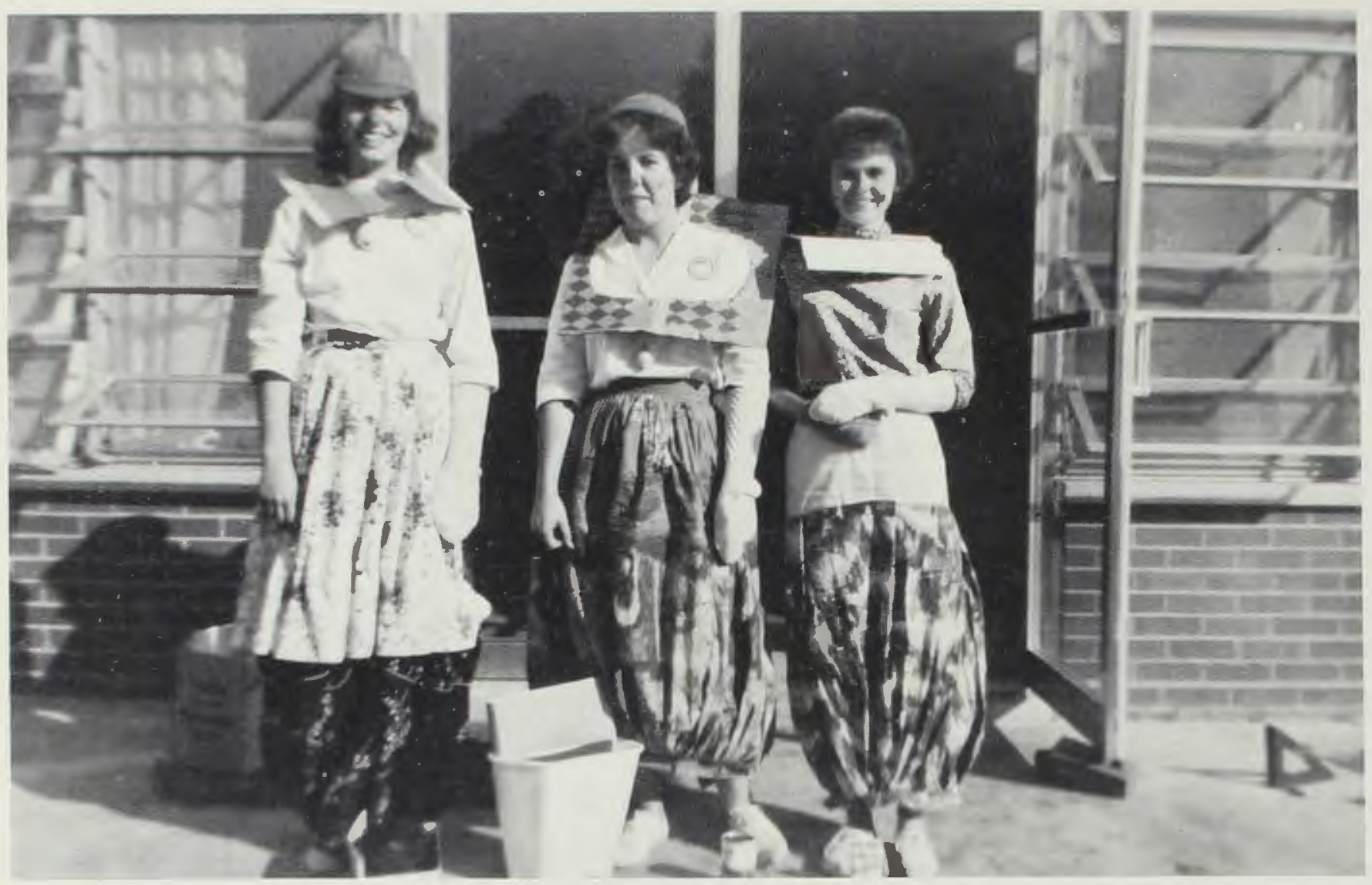

Mick Geeting, Sarah Balke, and Dottie Mitchell still find something to smile about after their early morning rise.

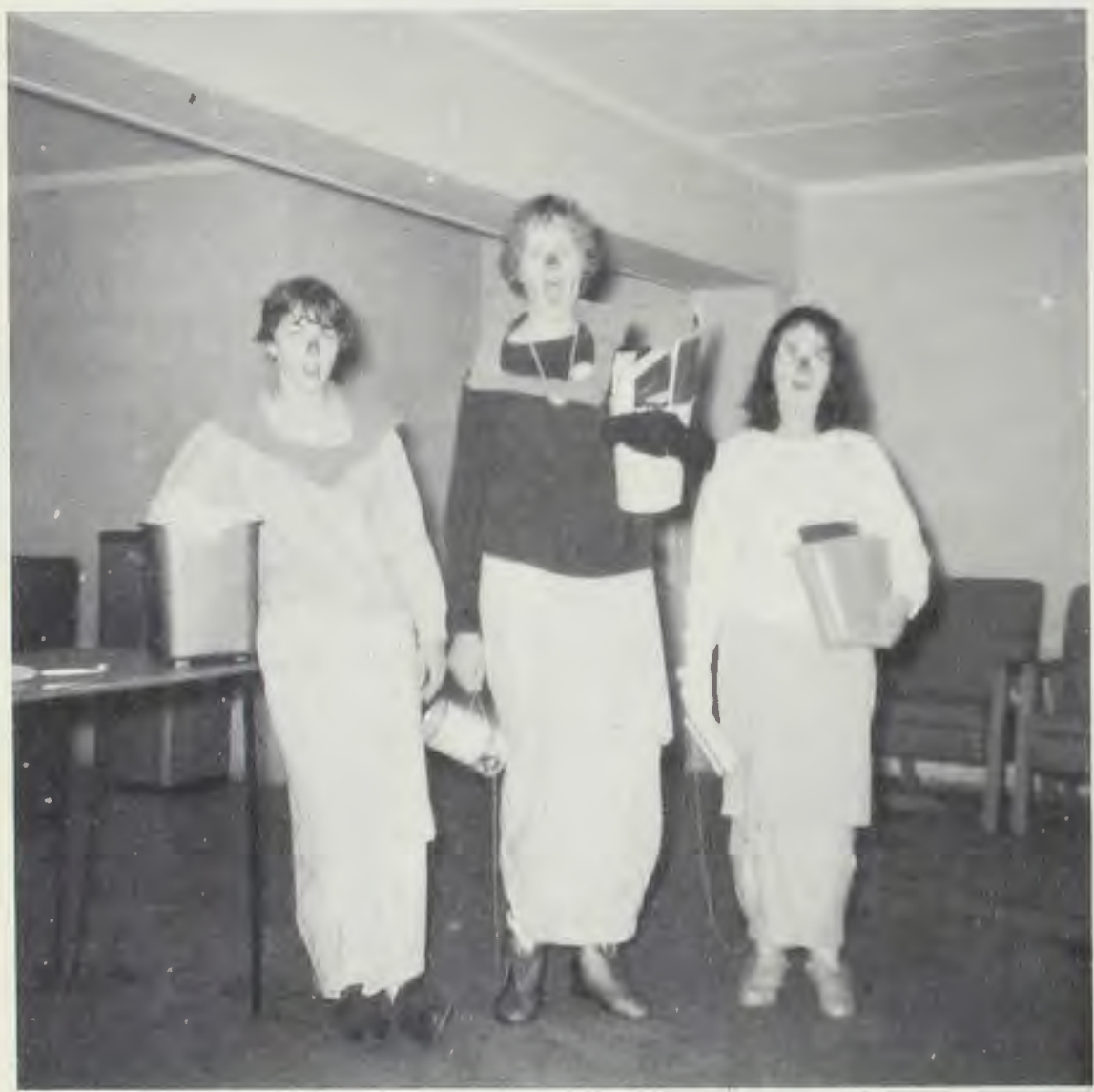

Showing their joy over initiation, Ruth DeVey, Sharon Brown, and Carol Russell obediently sing for a sophomore.

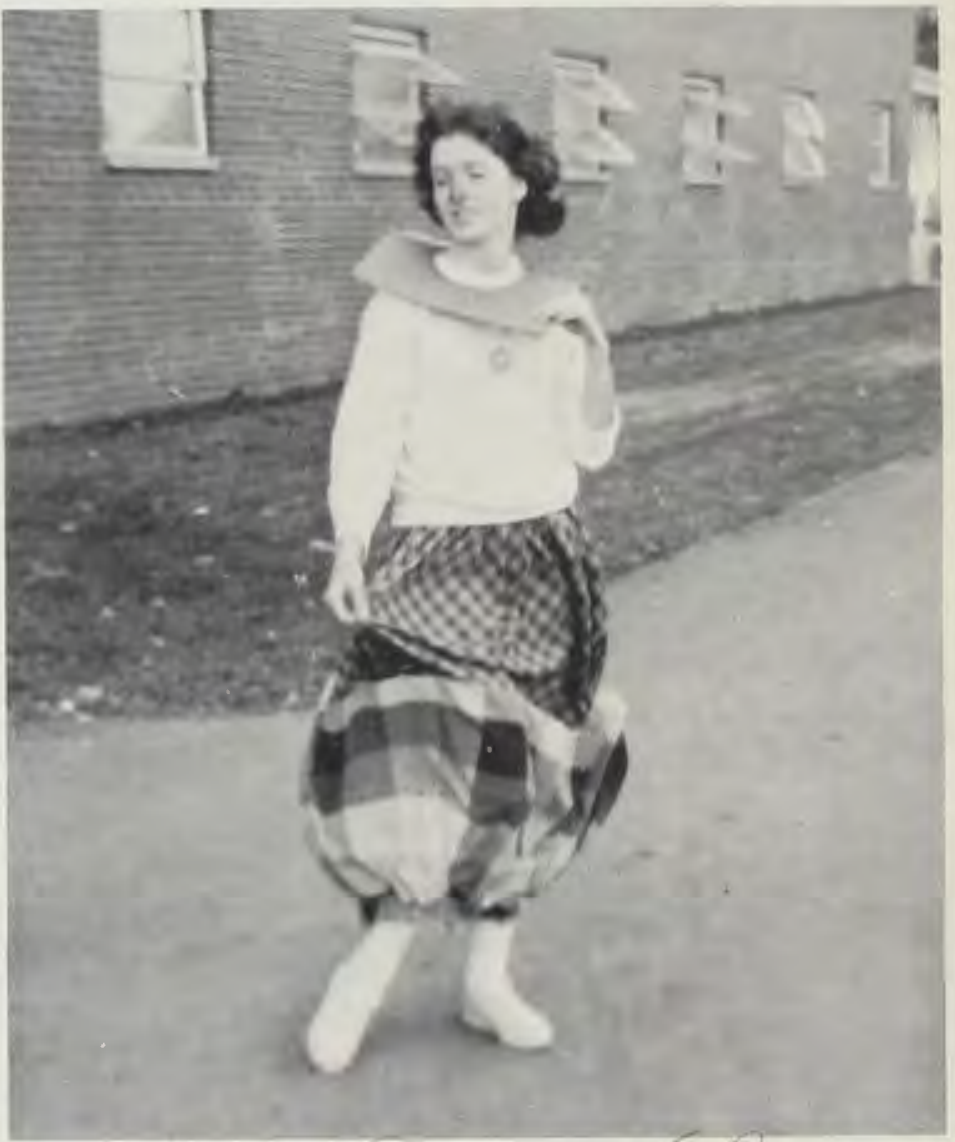

La Ti Da. Raynd Butler is not afraid of the
big, bad sophpmotes. 


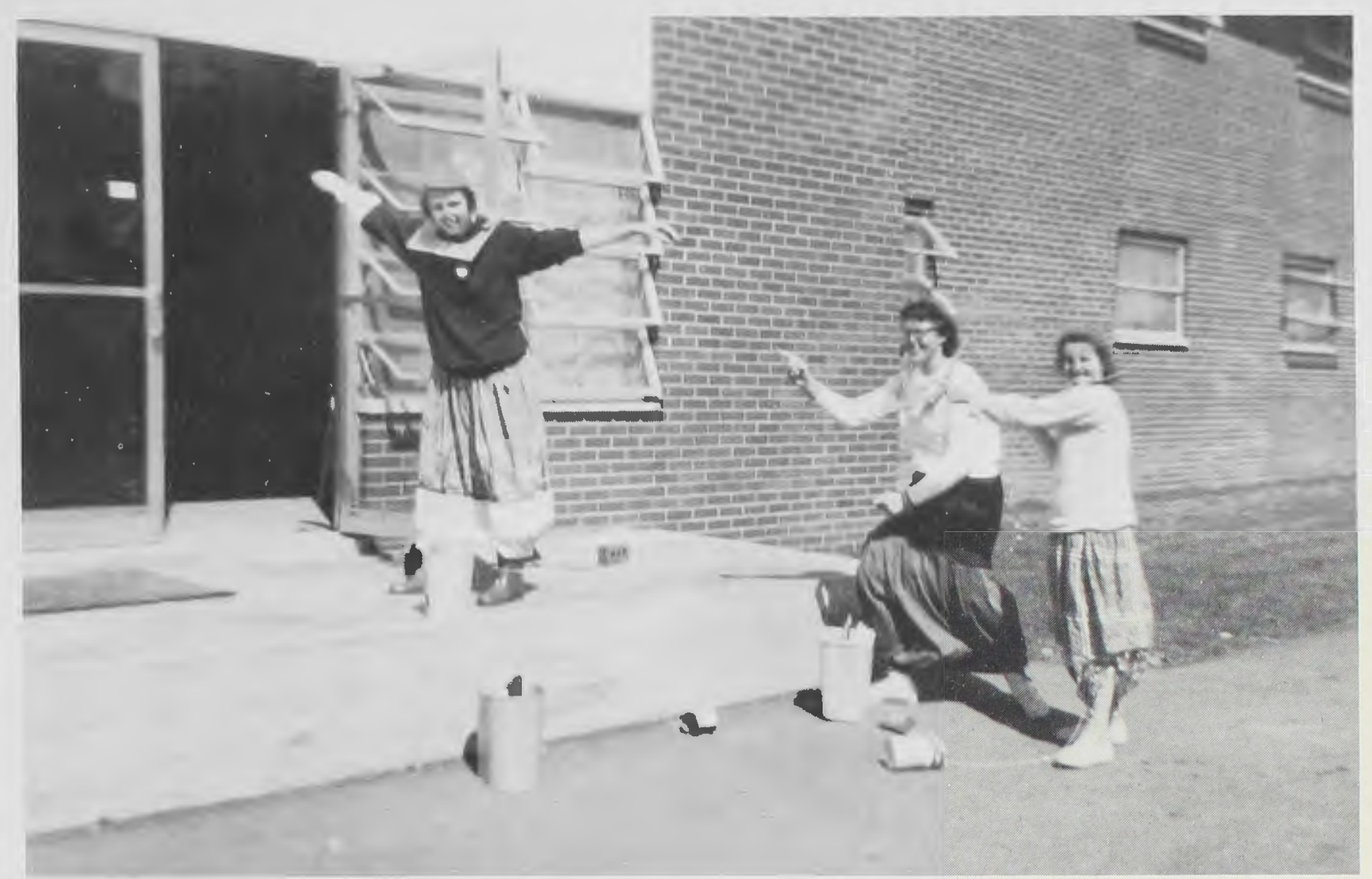

Ready - Aim - Fire - Another freshman, Mary Cunningham, falls at the hands of her classmates, Carol Dykstra, and Barbara Thorne.

Susan Fullhart and Dave Mills acted as chairmen of freshman initiation.

The day opened with the traditional five o'clock rise to do exercises in the football field. Besides the usual costume with green noses and beanies, onions, tin cans, the freshmen had to play airplane and gunners when they heard a whistle.

In the evening, the final initiation was held in the gym where freshmen were put through stunts climaxed by going through Davy Jones' Lockers where they became Joe College.

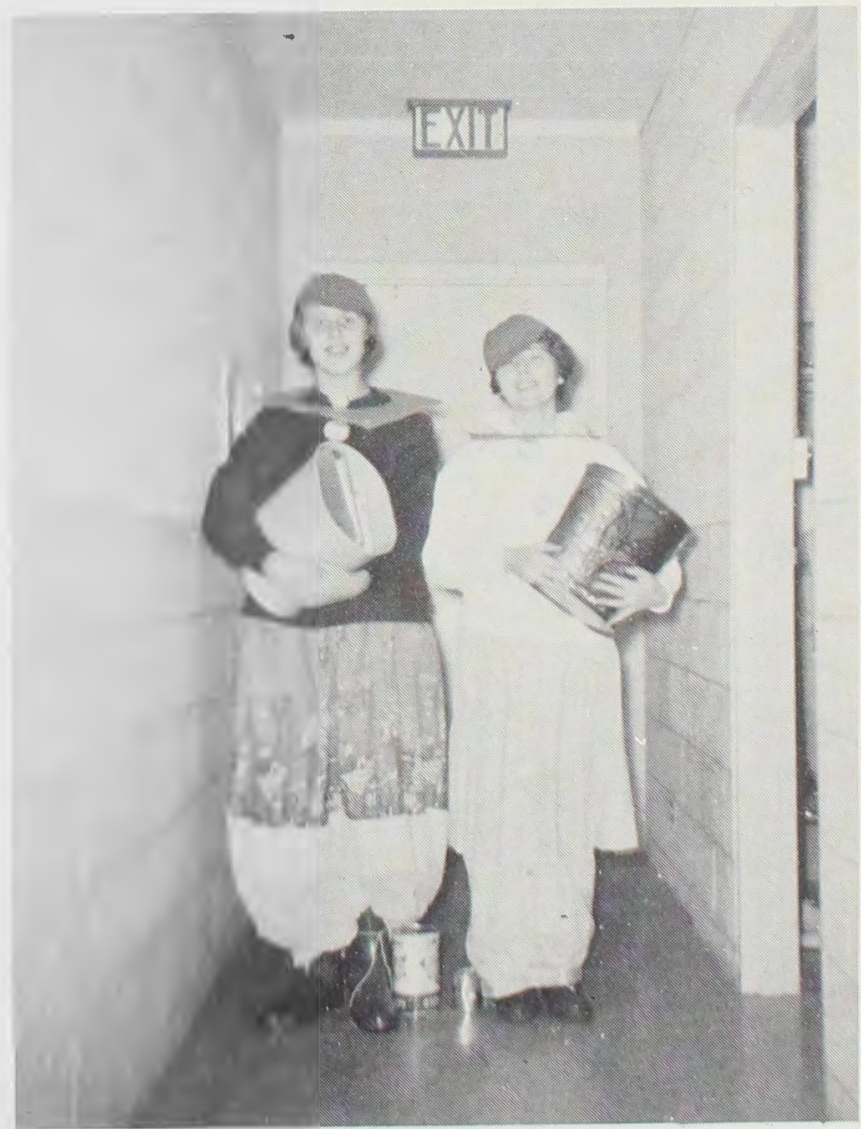

This has been a day that Mary Cunningham and Suzanne Bartheld will long remember. 


\section{Homecoming}

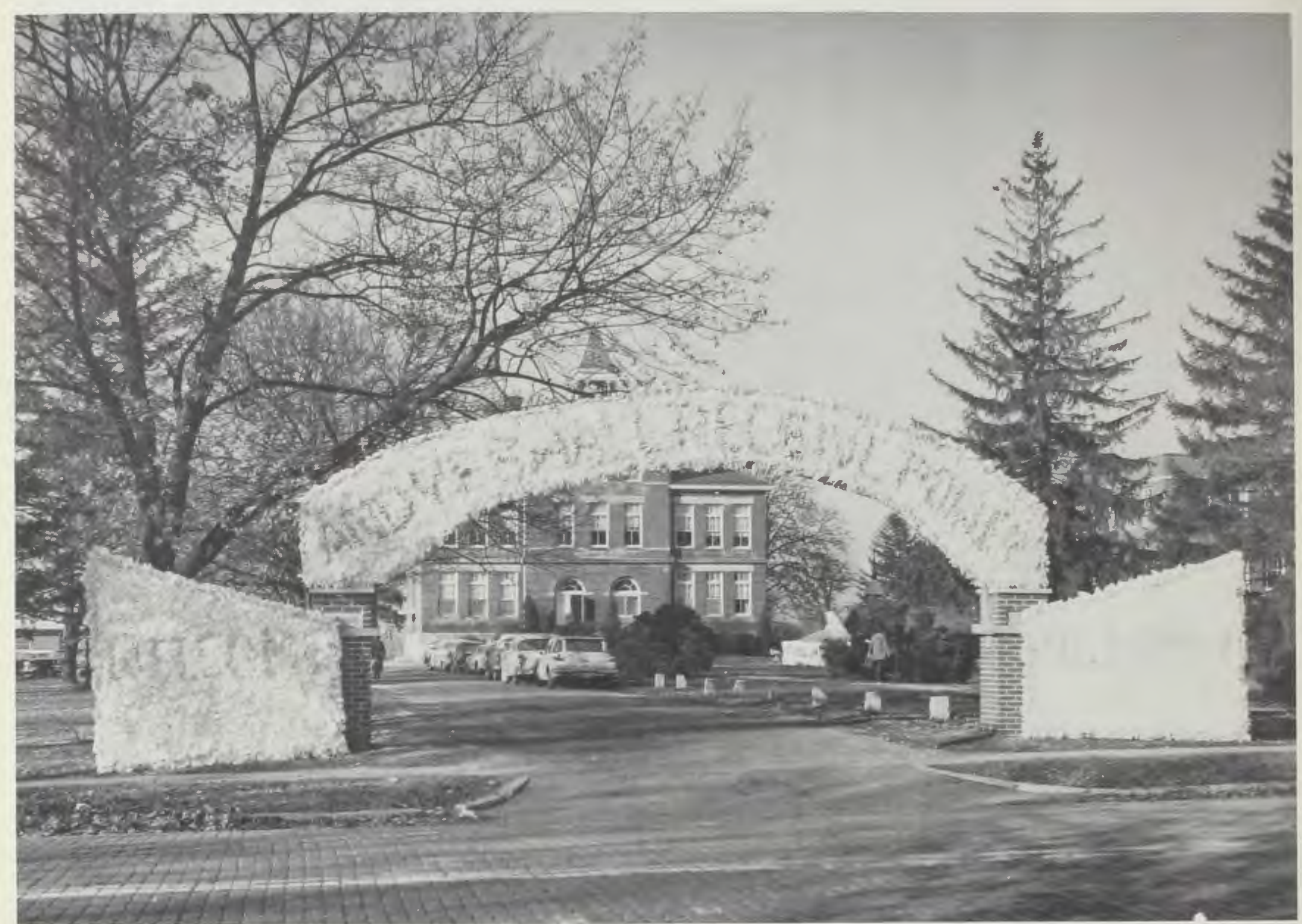

The Student Council Arch welcomes the alumni.

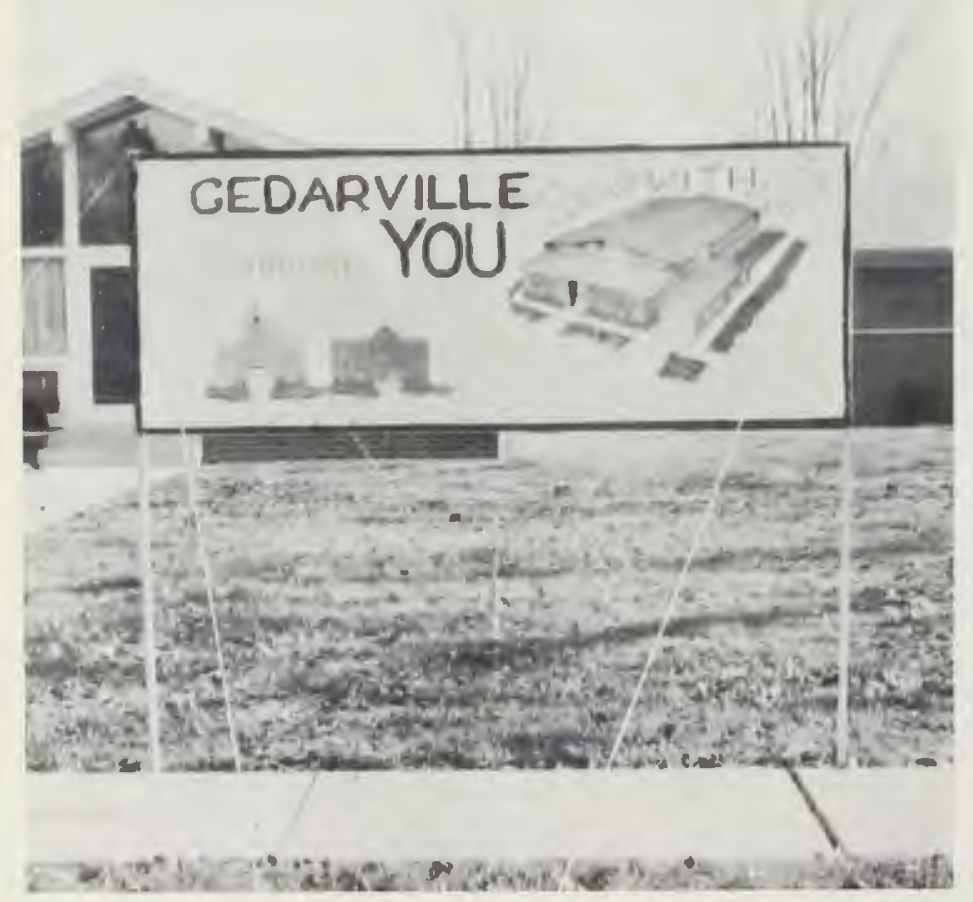

One of the biggest events at Cedarville College during the course of the school year is Homecoming. It is a time for the alumni and Students to renew old friendships, and affords the alumni a chance to see first-hand the many improvements brought to our campus since their graduation.

Homecoming this year was held November 17 and 18. Early on Saturday morning, the alumni began to arrive with friends and families. After registration, a time of food and fellowship was enjoyed in the college snack shop. Later in the day, a luncheon was served in the college dining hall, where the Choralaires and the Faculty Four quartet sang.

The Faith Hall display presents the school's need to the alumni. 


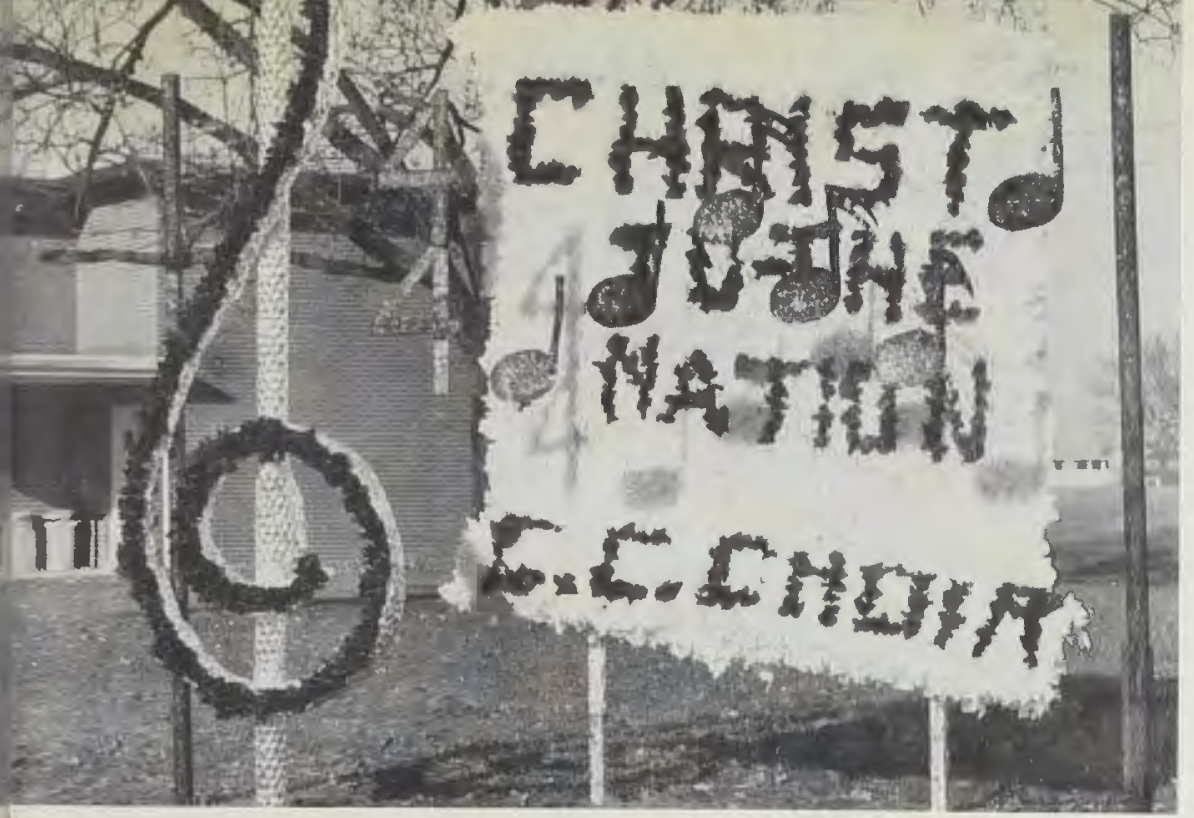

COLLEGE CHOIR DISPLAY

Best Club Display

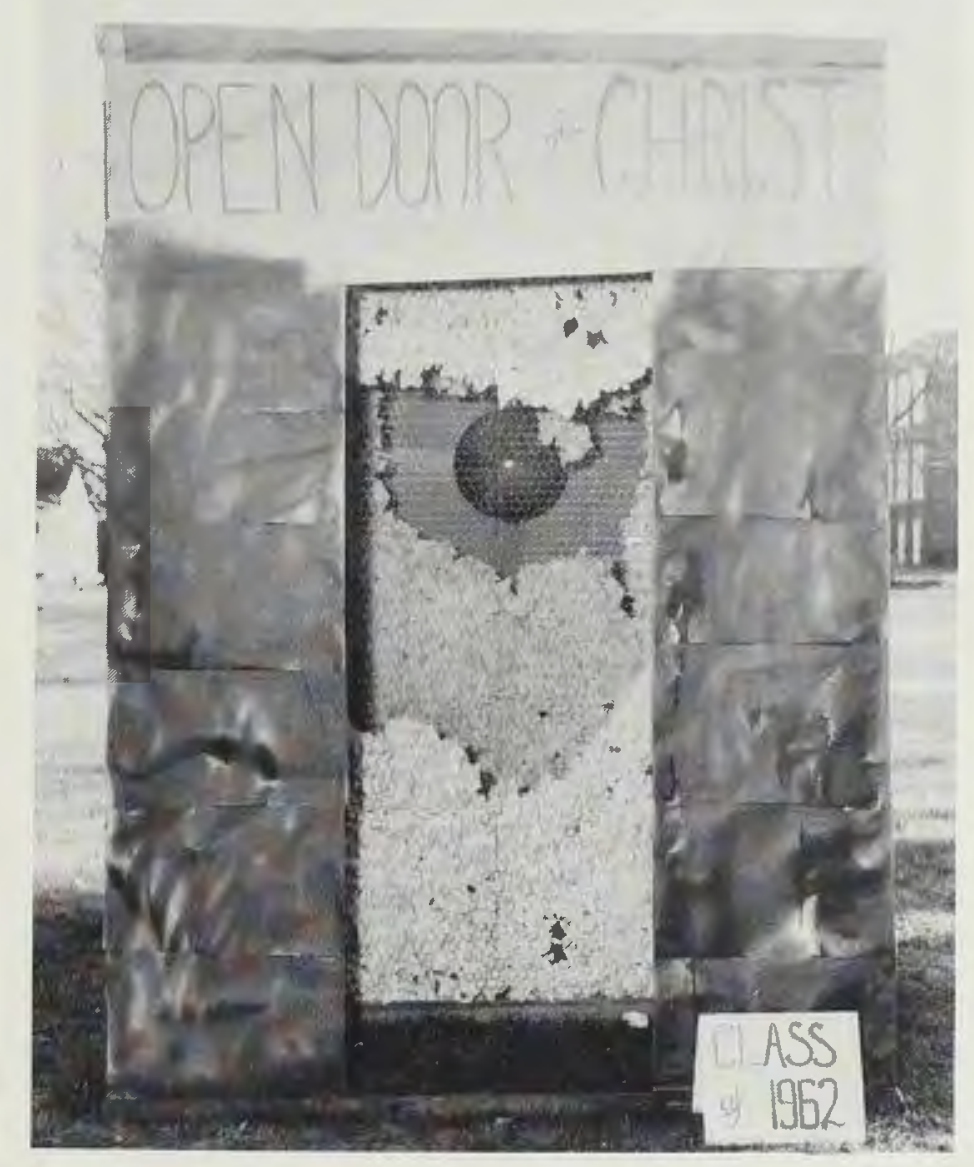

SENIOR CLASS DISPLAY

Best Class Display, Best Over-All Display

SOPHOMORE CLASS DISPLAY Honorable Mention.
Each year, the various campus clubs, dorms, and classes compete for cash awards with homecoming displays. This year the competition was heavy, as a total of 23 displays were entered around the campus and in various parts of town. Winners this year included the Senior Class (best class display), the new Girls' dorm (best dorm display), and the College Choir (best club display). The Senior Class also won an award for the "best over-all display." An "honorable mention" award was won by the Sophomore Class.

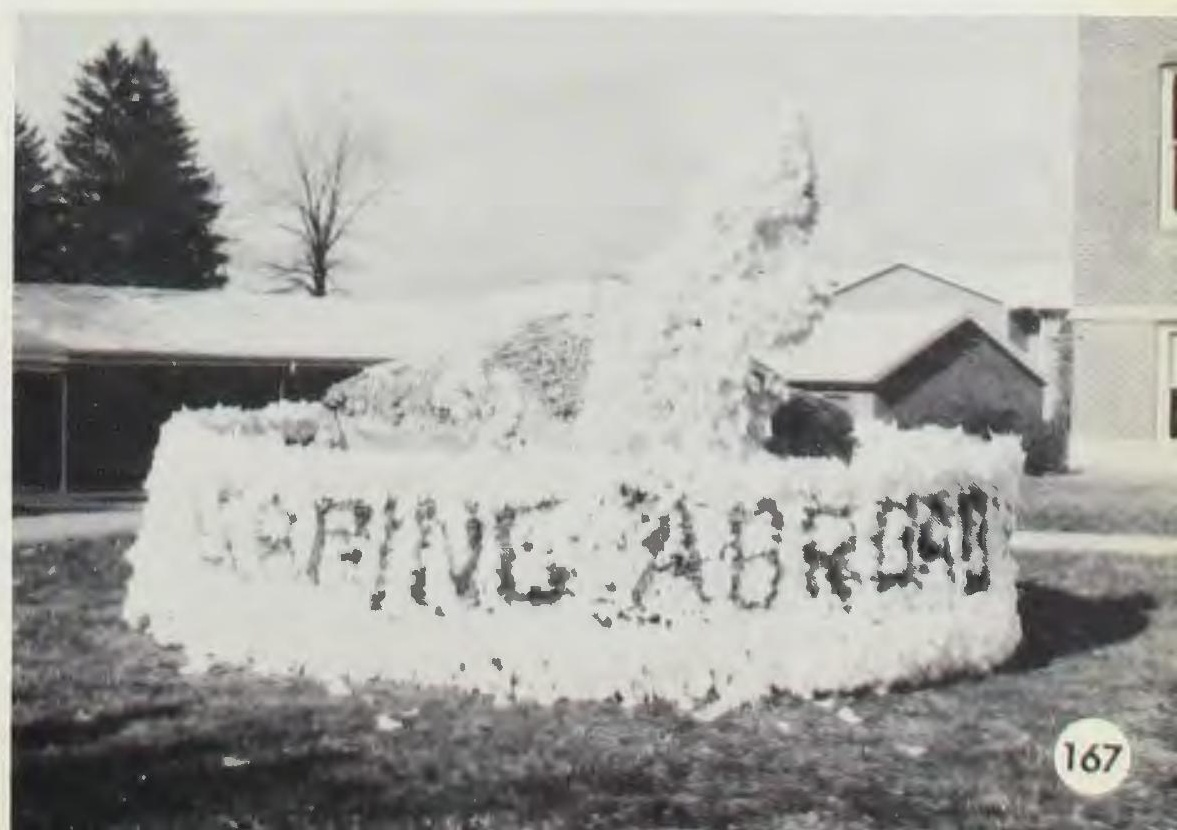




\section{$0.7 \mathrm{M} \times$

One of the highlights of Homecoming is the annual Alumni-Varsity basketball game. This year was no exception, as the Varsity, after a shaky first half, defeated the Alumni 95-67. Former Little All-American Pete Reese led all scorers with 37 points.

After the game, choir practice was held for past and present members of the Cedarville College choir. It was a time for old and new members to become acquainted, and to prepare a number for the Sunday Morning worship service.
Late in the afternoon, a reception was held for former members of Gamma Chi in the annex of the Grace Baptist Church. Past presidents were honored, refreshments were served, and a time of fellowship was enjoyed.

Homecoming ended with the Morning Worship Service on Sunday. Rev. Clifford Boessel of Kouts, Indiana, Class of 1956, spoke on "What doth hinder me?" All in all, homecoming this year can be termed a big success; in fact, many believe it was the very best ever.

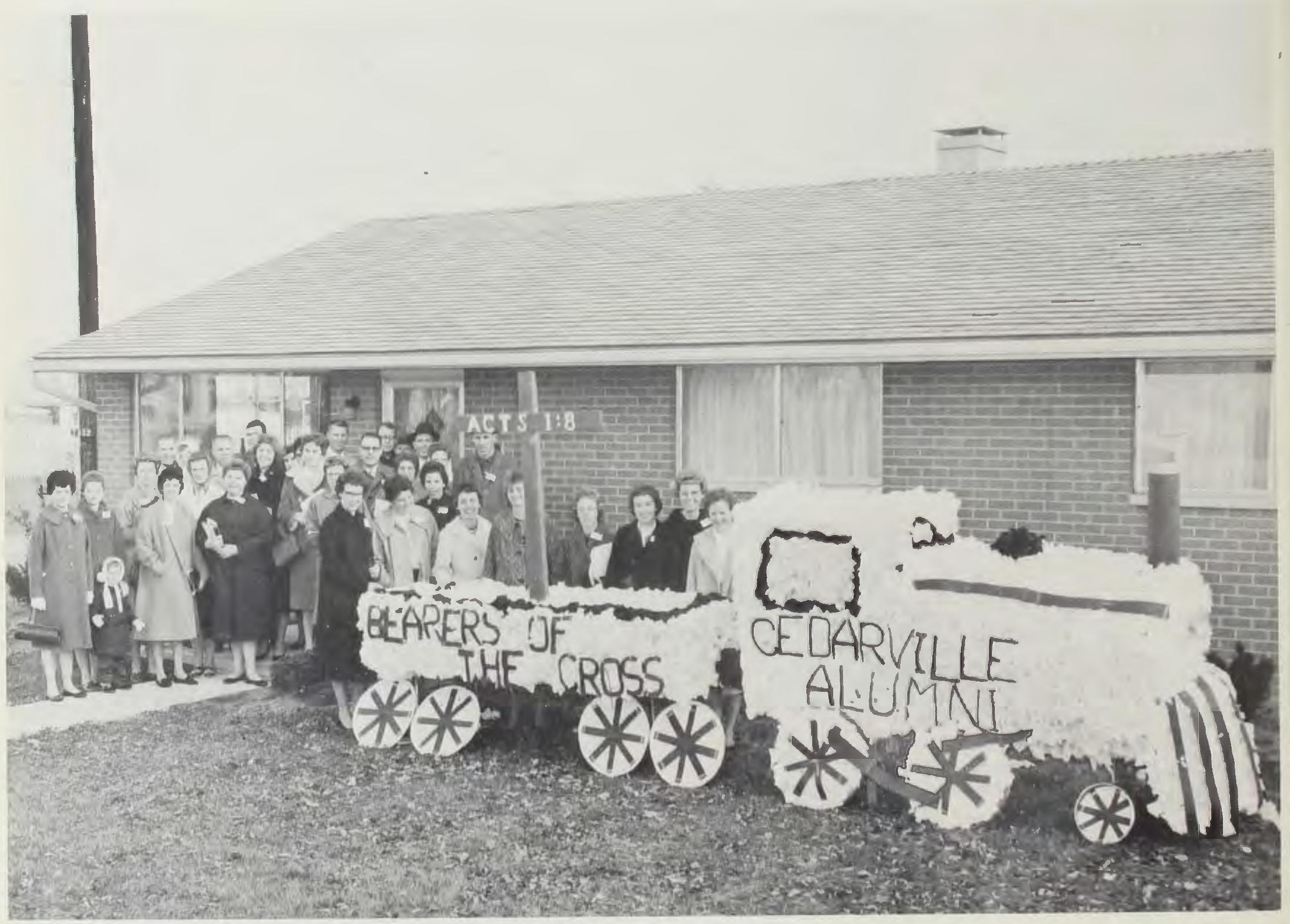

Alumni look at the display of the Junior Class. 


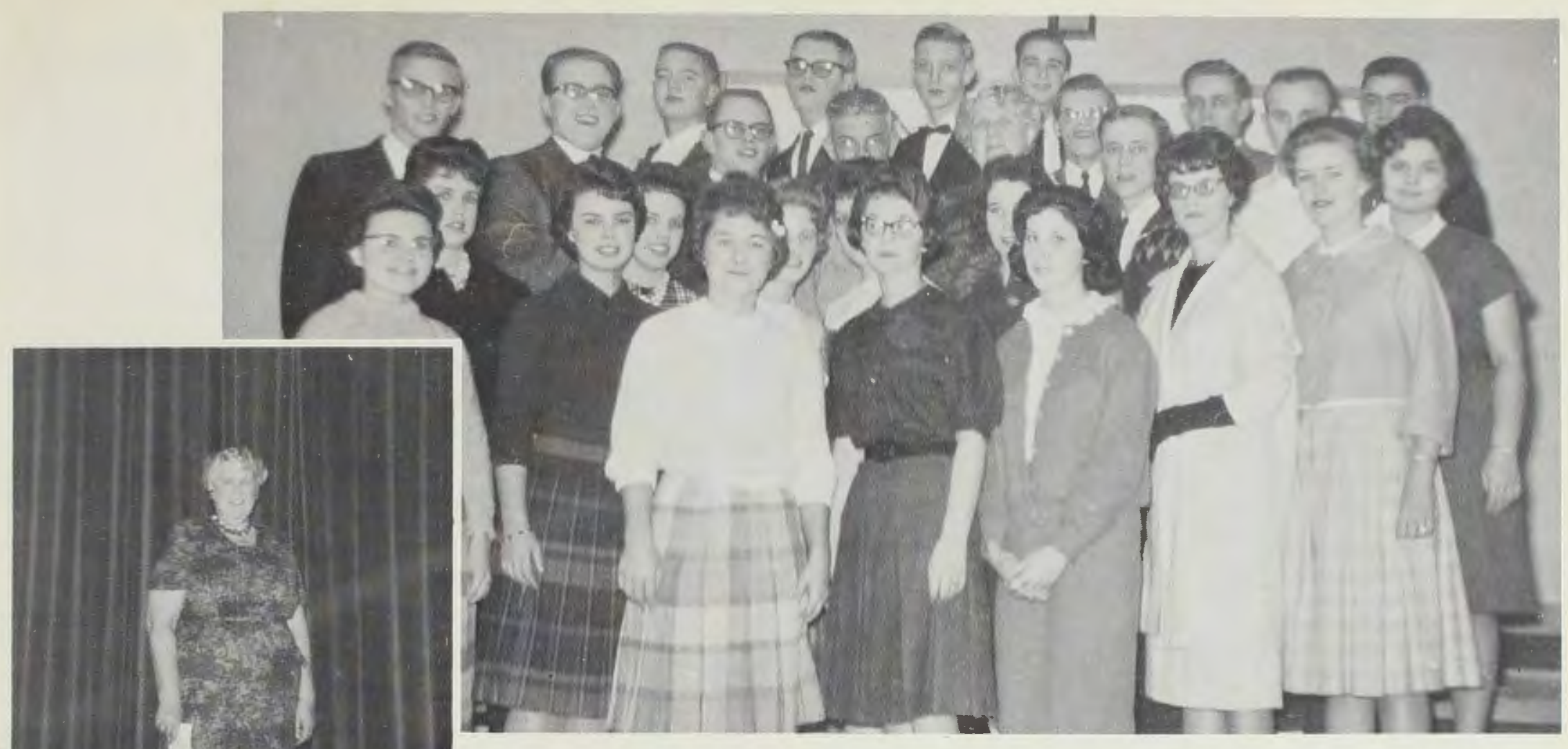

TOP ROW, Left to Right: Dave Warren (Mr. Woodbridge), Rich Davidson (Mr. Wright), Donald Kelly (Bert Hendricks), Larry Baker (Mr. Prince), John Wolfe (Dr. Caldwell), Ron Mathis (Bob McGinnis). SECOND ROW: Steve Luyben (Tommy Prince), Dave Carpenter (Mr. Kovalesky), Mrs. Maddox (director), Keith Webster (Mr. McGinnis), Hank Cook (Bill McGinnis), Steve Nimmo (Mr. Rogers), Bob Ellis (Painter), Gordon Finley (Joey Rogers). THIRD ROW: Elayne Howard (Mrs. Rogers), Sally Bender (Miss Frank), Lois Duddleston (Alice Woodbridge), Elsie Himsel (Mrs. McGinnis), Sylvia Wing (Mrs. Wright). FRONT ROW: Patricia Schonscheck (Carol), Ginny Hindman (Elizabeth Wright), Jeannie DuPre (Madge), Betty Smith (Janet), Pat Adams (Susan Caldwell), Bonnie Hammack (Mrs. Caldwell), Mary Goodwin (Mrs. Woodbridge), Eve Tennant (Mrs. Prince).

Mrs. Maddox, director.

\section{Homecoming Play}

This year's Homecoming Play, "The Remarkable Incident at Carson Corners." by Reginald Rose and adapted to television by Kristin Sergel, held in the Cedarcliff High School Auditorium, was under the capable direction of Mrs. Maddox, a faculty member from our speech department. The uniqueness of the play was evidenced by the aweinspiring effect it had on the audience without the aids of costumes or scenery.

As the play opened. a group of parents of the high school students were gathering for a program which had been prepared by the students for their parents. As the program progressed the parents began to realize the seriousness in purpose of the young people.

The involvement of both the students and the parents in community progress was made apparent in the need of solving the problem of placing the responsibility of a tragedy in the community.

Dave Carpenter, as Mr. Kovalesky - the janitor of the high school, maintained his pose as a benevolent grayheaded old man very convincingly throughout the entire play. Lois Duddleston, as Elizabeth - Kovey's defense attorney. showed startling intensity in her dynamic plea on behalf of Kovey, Dave Warren, as Mr. Woodbridge - principal of the high school, did an excellent job in portraying the dignity and authority of such an important position.

Since it would be impossible to commend each of the twenty-six characters personally on this page, may it suffice to just say that each did a very fine job of maintaining a distinct personality, and the contrast between the behavior of the adults and the students was also presented very nicely.

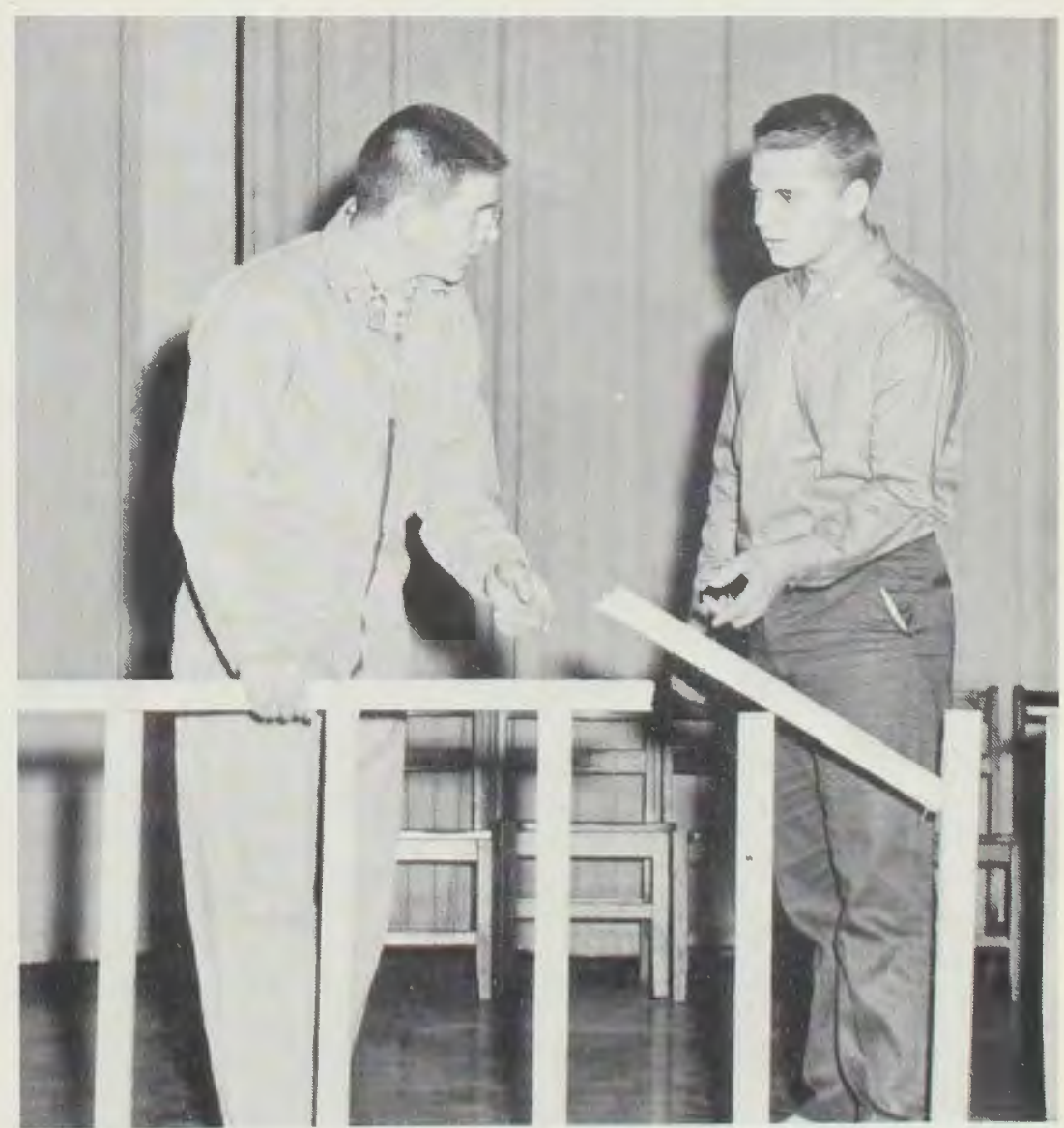

Don Kelly, as one of the students in the play, stunned after almost falling through the broken railing. 


\section{Christmas Concert}

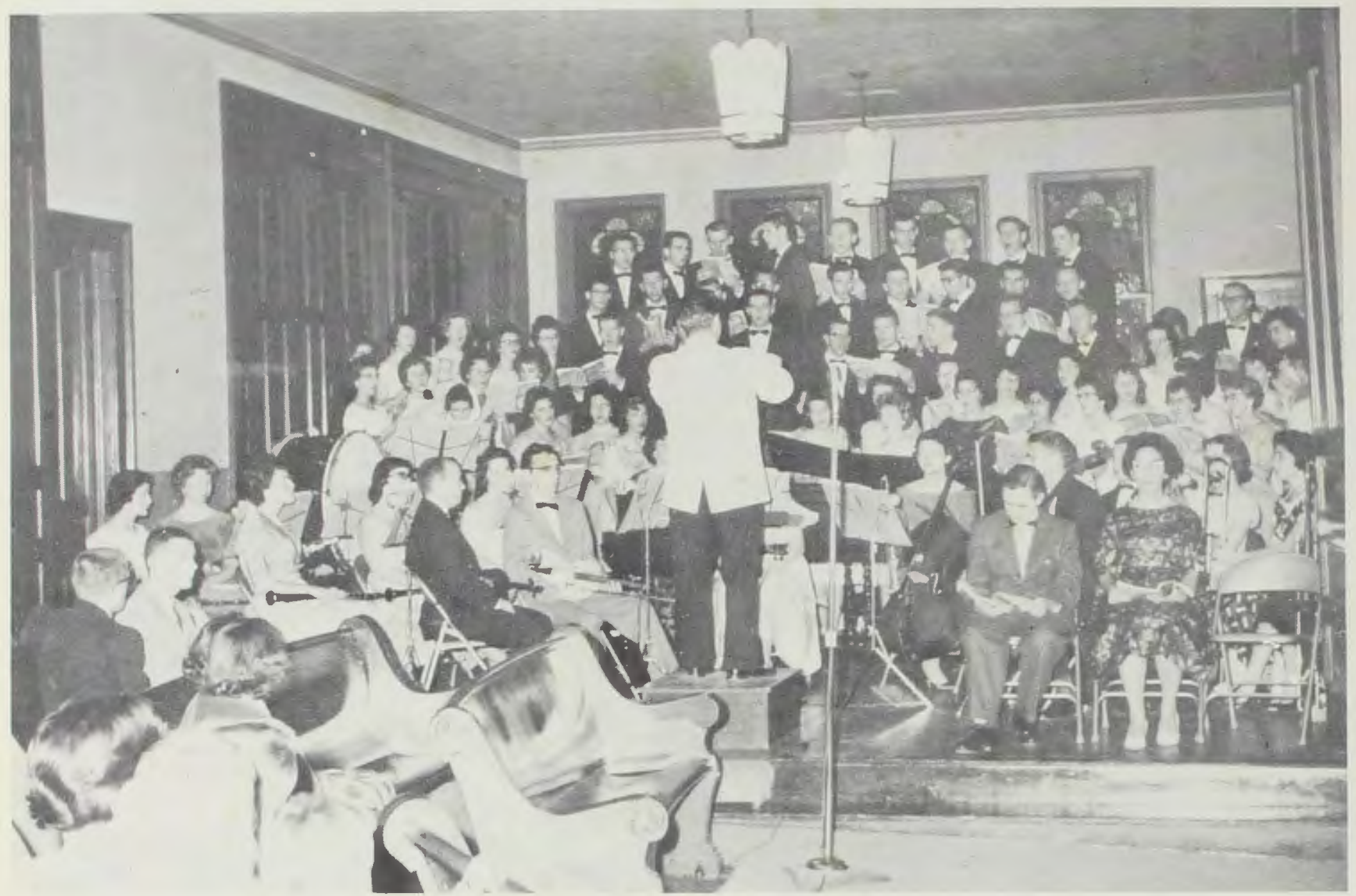

Mr. Cooke conducts the choir and orchestra ensemble.

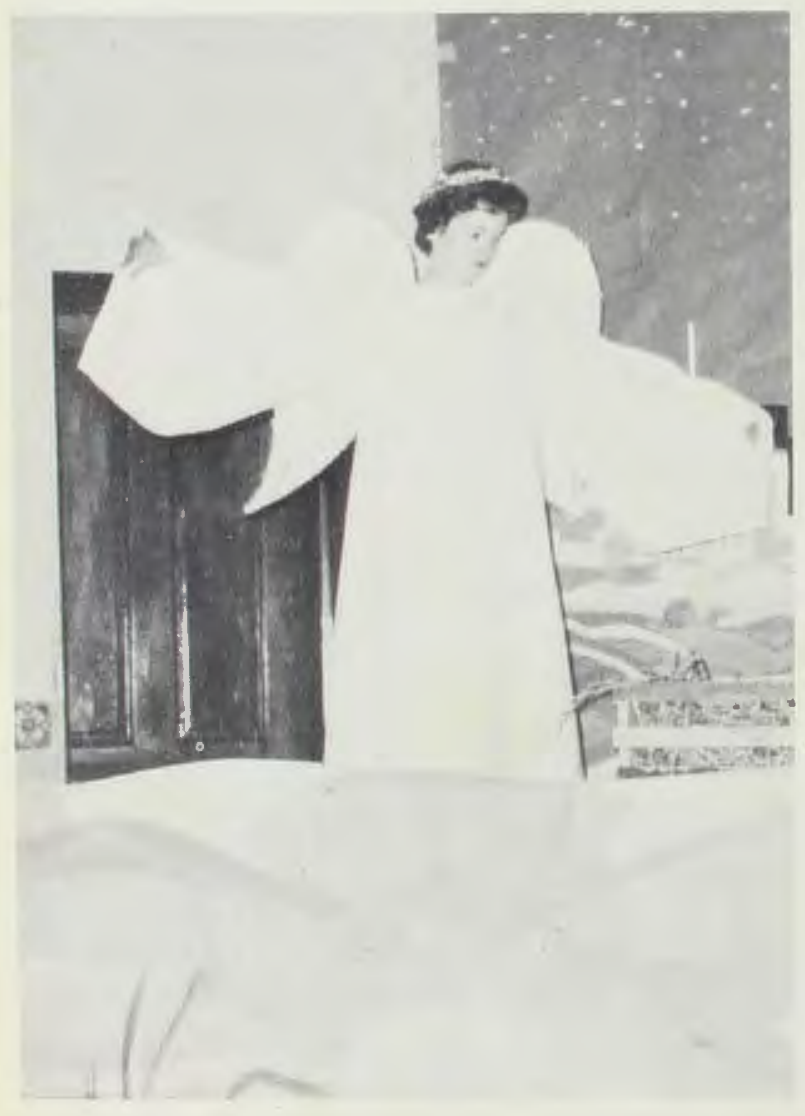

The traditional Christmas Concert, held in the Grace Baptist Church on December 14 and 15, was presented by the Music and Speech departments of the college. The band, conducted by Mr. Thornton, opened the program with a thirty minute concert featuring "The Story of Christmas," "Cantique de Noel," "Christmas Reverence-Processional," and the "Overture to the "Messiah." "

Following the band concert, the combined choirs and orchestra performed "Bethelehem," the Sacred Cantata by Nunn and Maüder with orchestration by Professor Richard A. Cooke, the conductor. Soloists were Ralph Werner, music faculty members Rebecca Cooke and George Zinn, and Registrar Carol Barker. Dramatization was under the direction of Mrs. Maddox, assisted by Miss Smith, costume designer, and Professor Webber and Paul Gathany, in charge of lighting. Mr. Russell designed the background art work.

Judy Dadisman appears as an angel. 


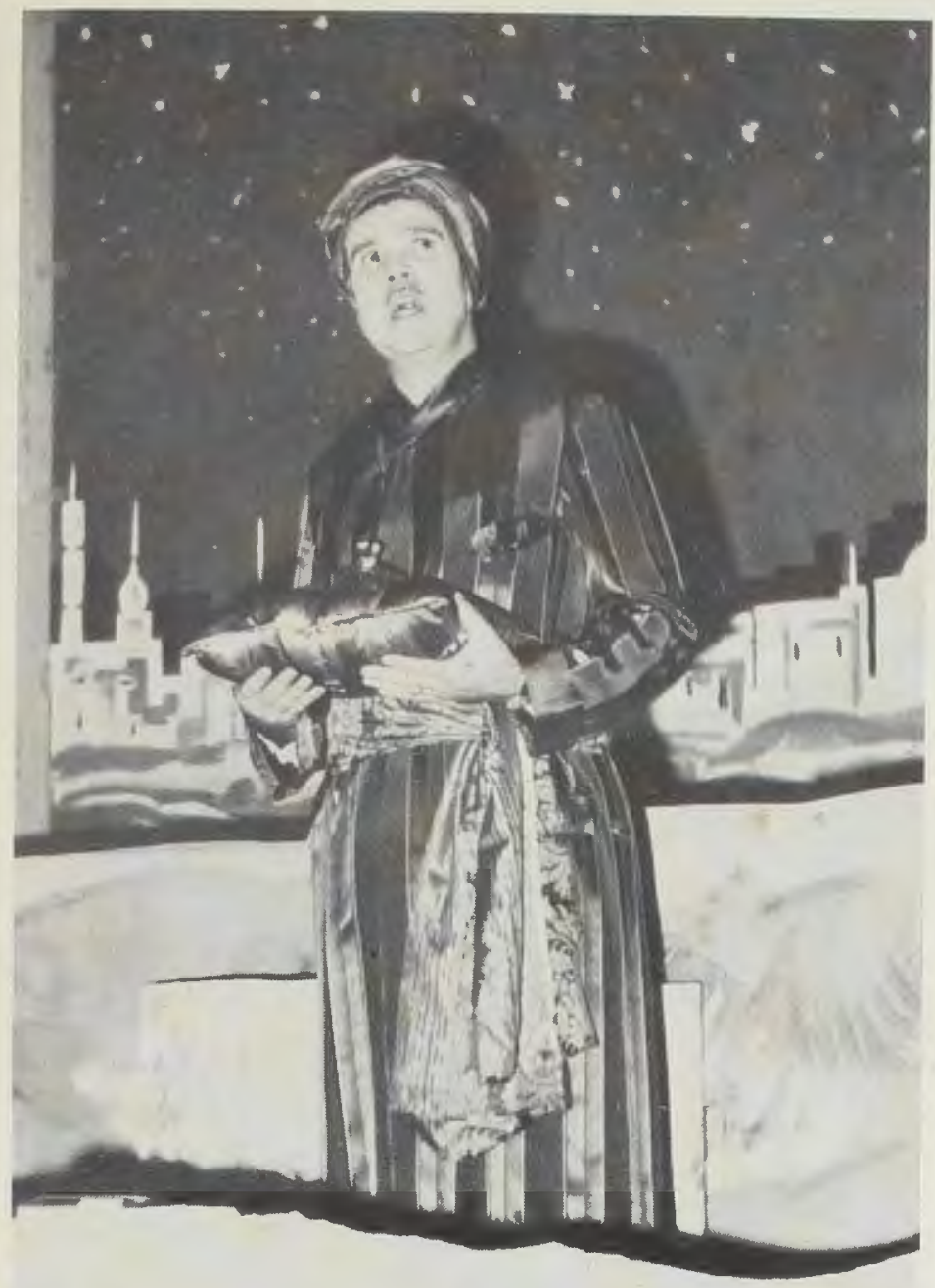

Mr. Barker, one of the wisemen.

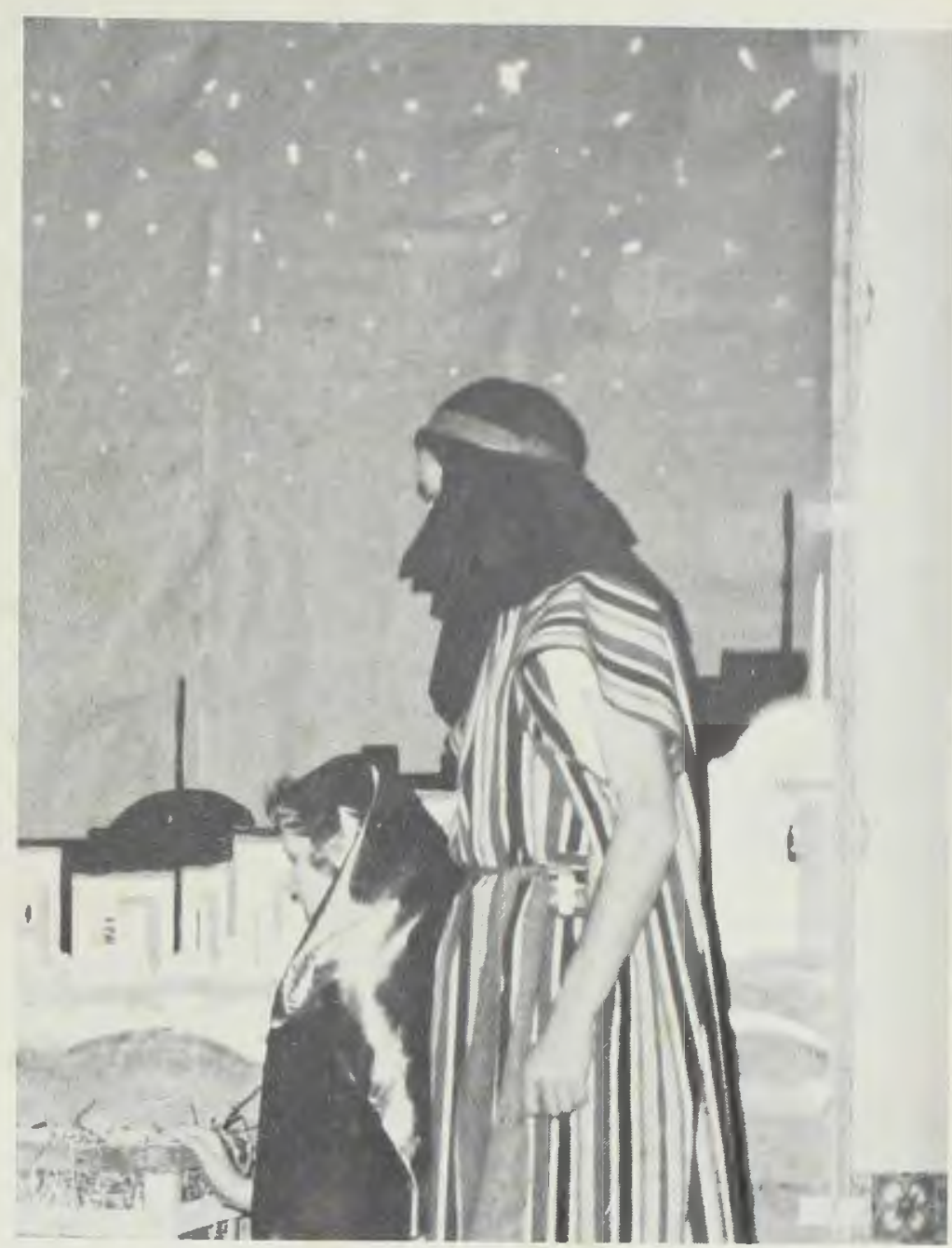

Judy Lachman and Norris Smith, as Mary and Joseph.

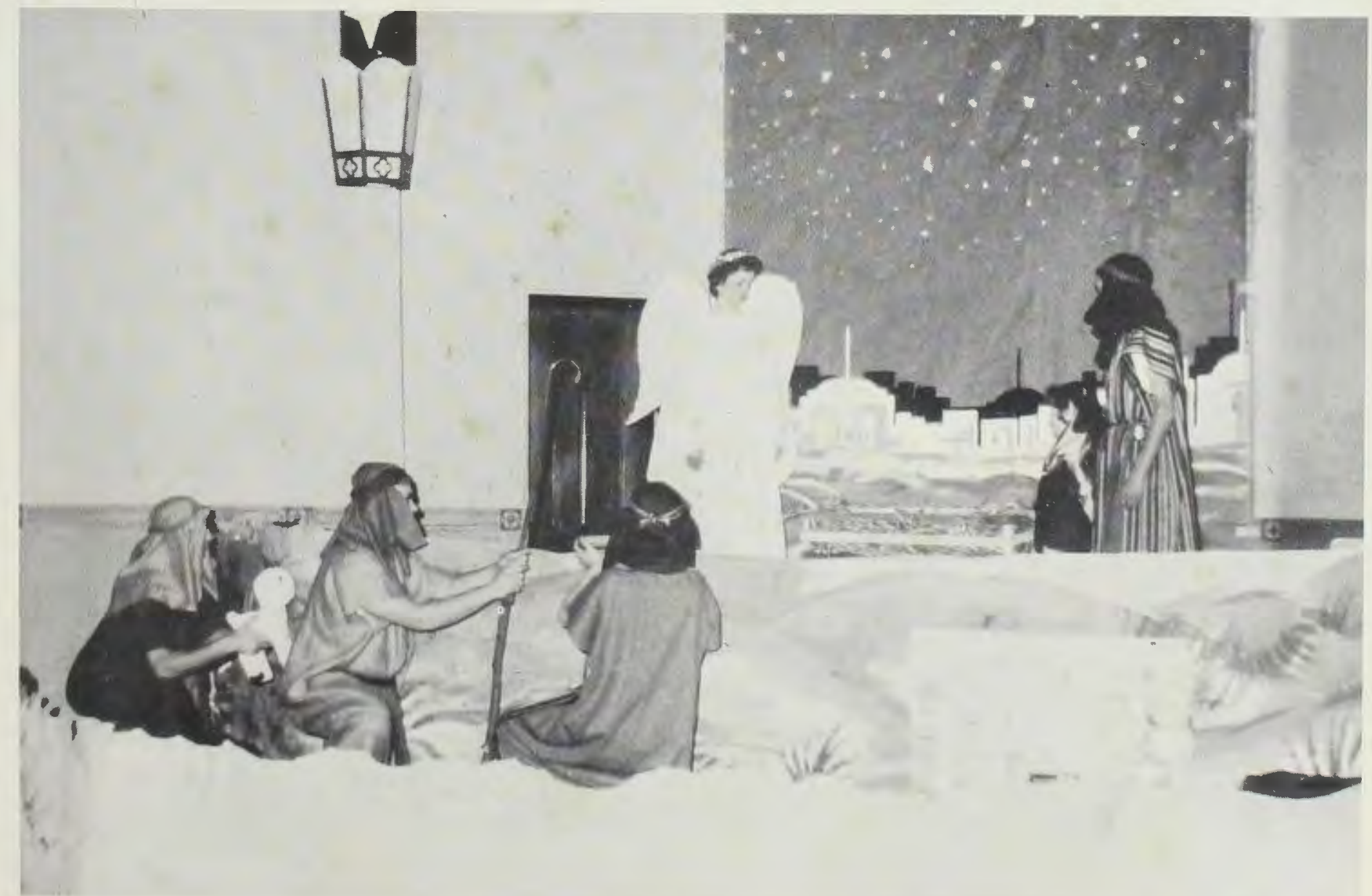

Shepherds, Dave Carpenter, Larry Baker, and Jim Jeremiah, come to the manger. 


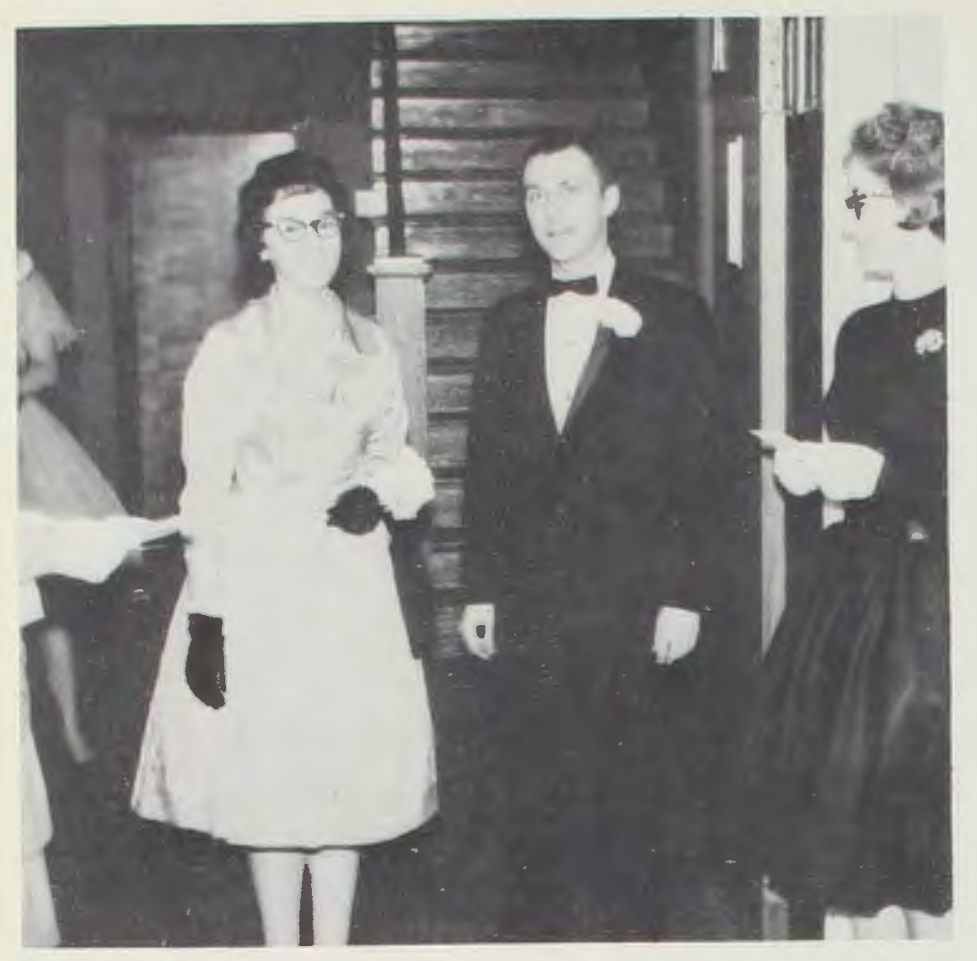

Anticipating an evening of good food, fun and fellowship, Dorothy Roduner and Larry Killian arrive at the Winter Banquet. Hostess Betty Smith is ready to seat them.

The dining room of the Dayton Christian Activities Center was the scene of the Annual Winter Banquet sponsored by Gamma Chi and held on February 24. Seated at tables for four, the guests were entertained by the wit of Master of Ceremonies, Mr. Robert Gromacki,

\section{Winter}

\section{Banquet}

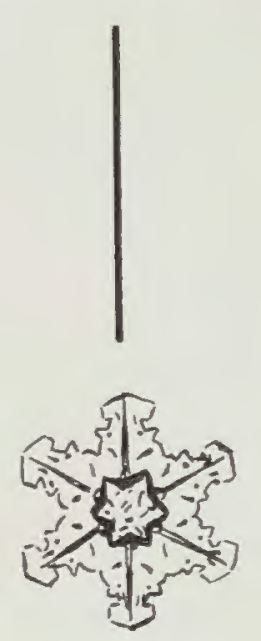

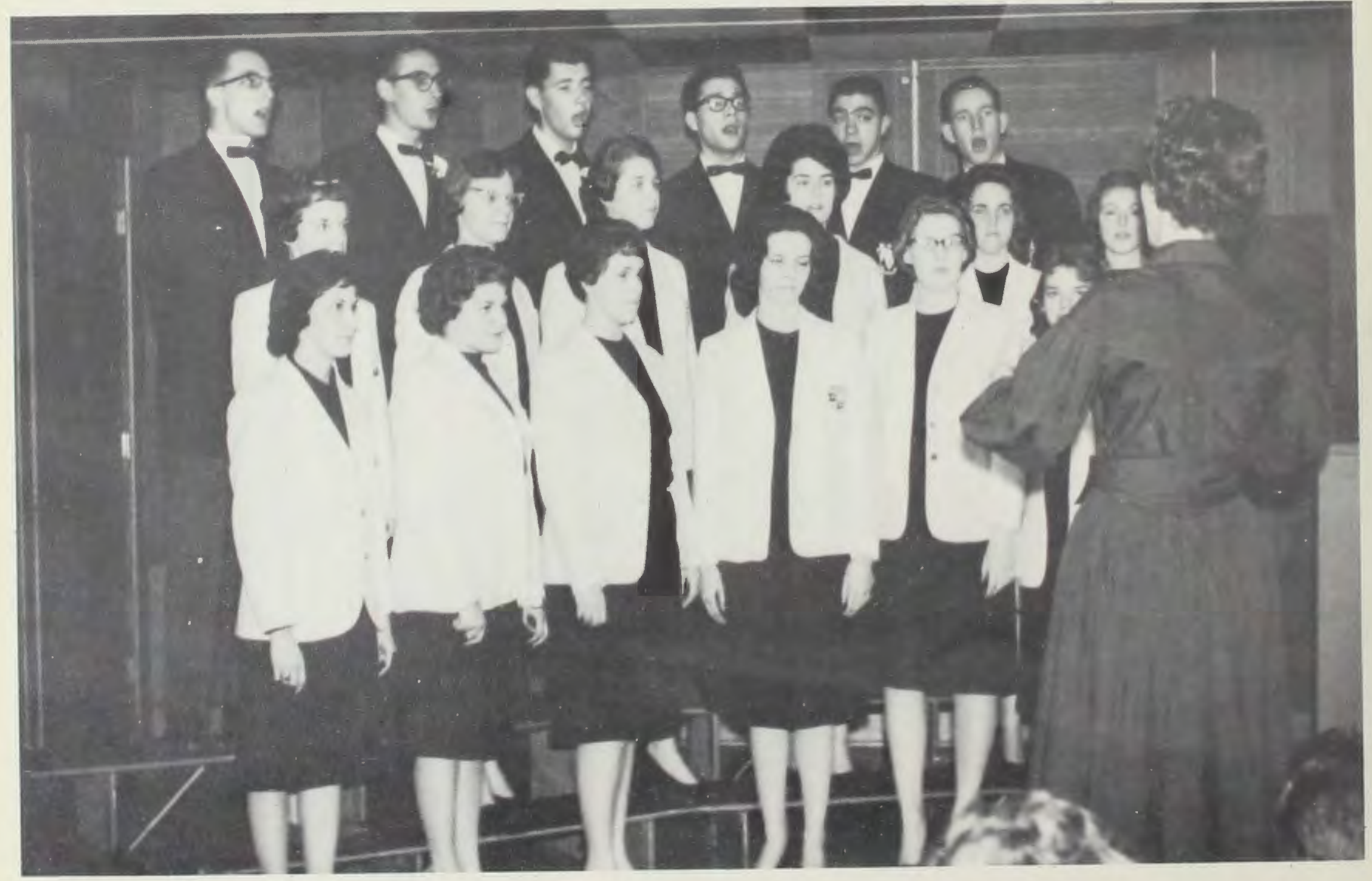

"La femmes" provide a soft background while the men expound on their philosophy of courting in "Say It With Music."

and the excellent concert, including "Inch Worm," "Let's Take an Old Fashioned Walk," and "Say It With Music," presented by the Choralaires under the direction of Miss Ruth Smith. 


\section{All-School Picnic}

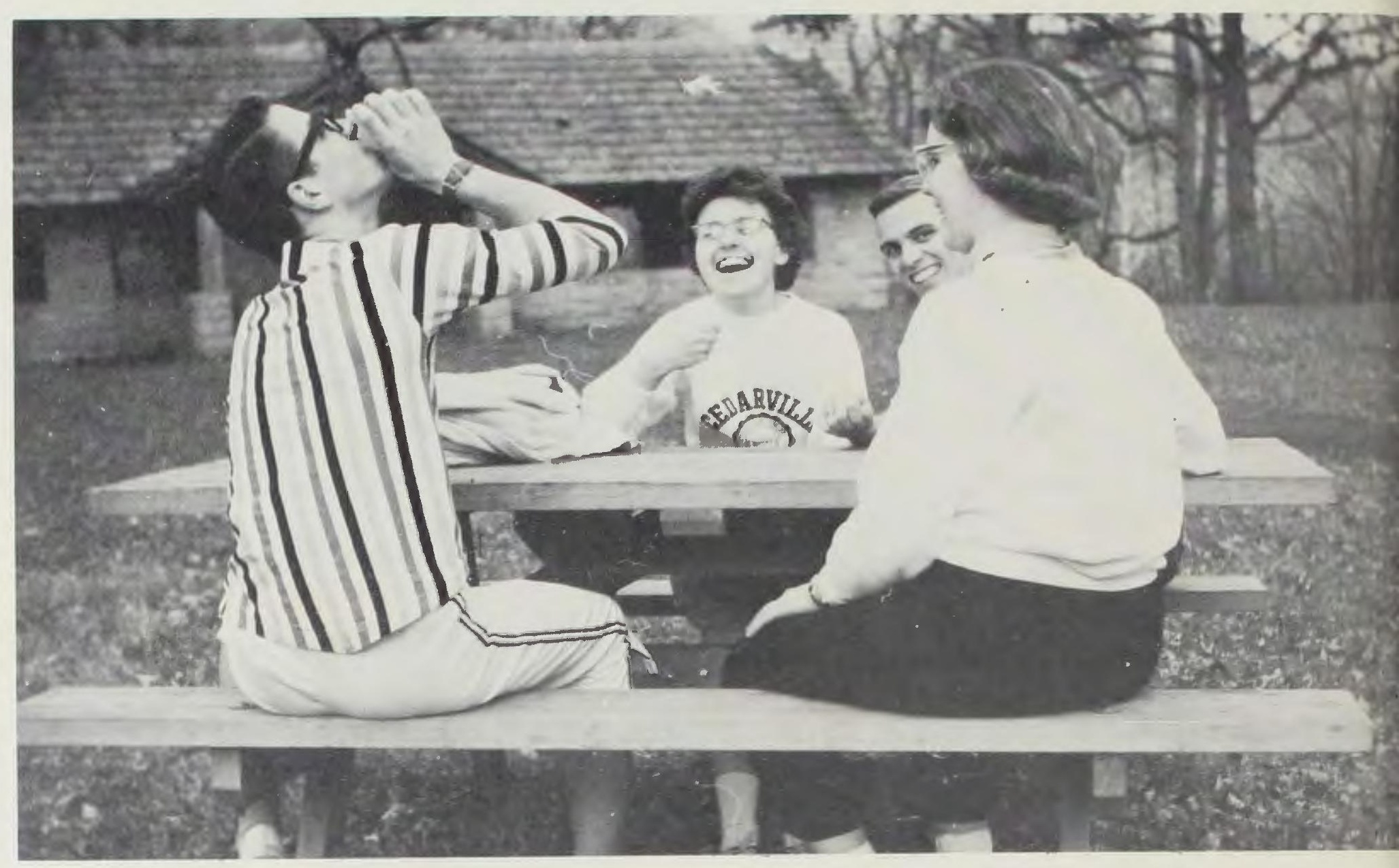

Bill Watson, Nancy Smith, Pat Schonscheck, and Dave Warren enjoy the noon meal.

The annual All-School picnic was held in September at the John Bryan Park. Mr. Callan and Mr. Cook directed the recreational program which included the annual tugs-of-war. Continuing the annual tradition, the Maddoxes provided apples. An excellent noon meal was served after which students and faculty returned with many new acquaintances as a result of the activities of the day.

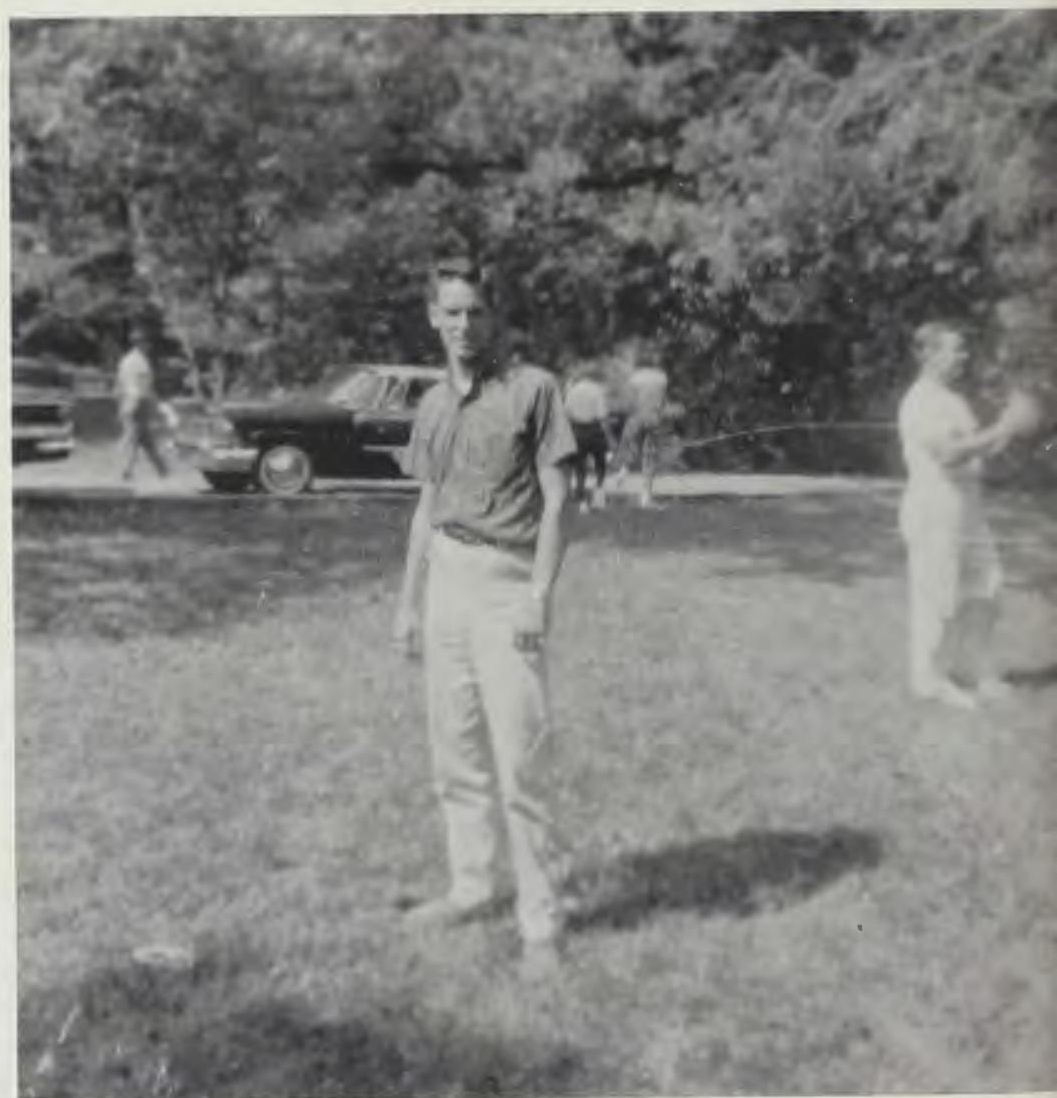

Let's play football. 


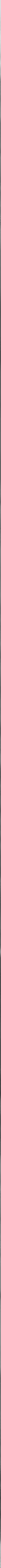


Fellowship with God is not only the center of the college day, it is also the center of our individual lives. Even as we leave the ten o'clock chapel hour refreshed and encouraged, so we will leave Cedarville strengthened in our faith and prepared for a fruitful life.

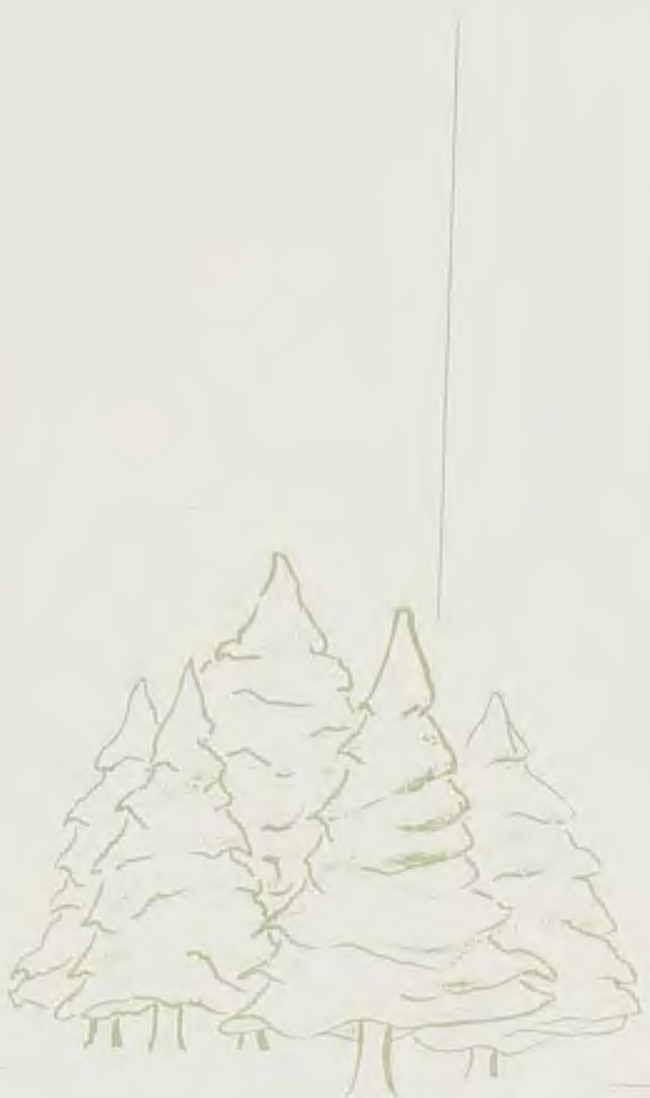




\section{Senior}

$\begin{array}{ll}\text { Class } & \text { MOTTO } \\ \text { Enter to learn } \\ \text { Go forth to serve }\end{array}$

VERSE

That ye might walk worthy of the Lord unto all pleasing being fruitful in every good work, and increasing in the knowledge of God.

Colossians 1:10

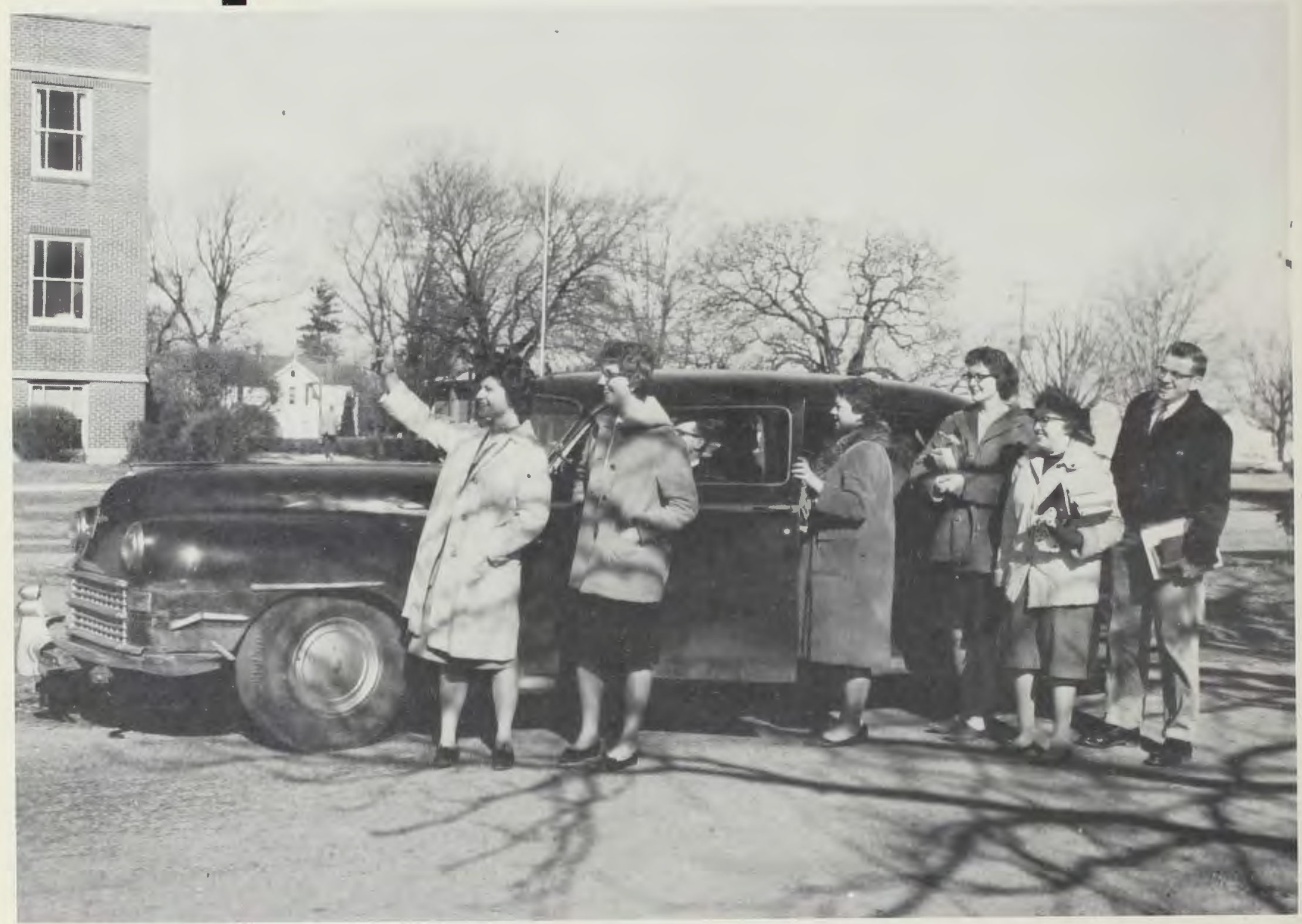

The biggest thrill of the senior year leaving for the sneak with a "fond goodbye" to the juniors. 


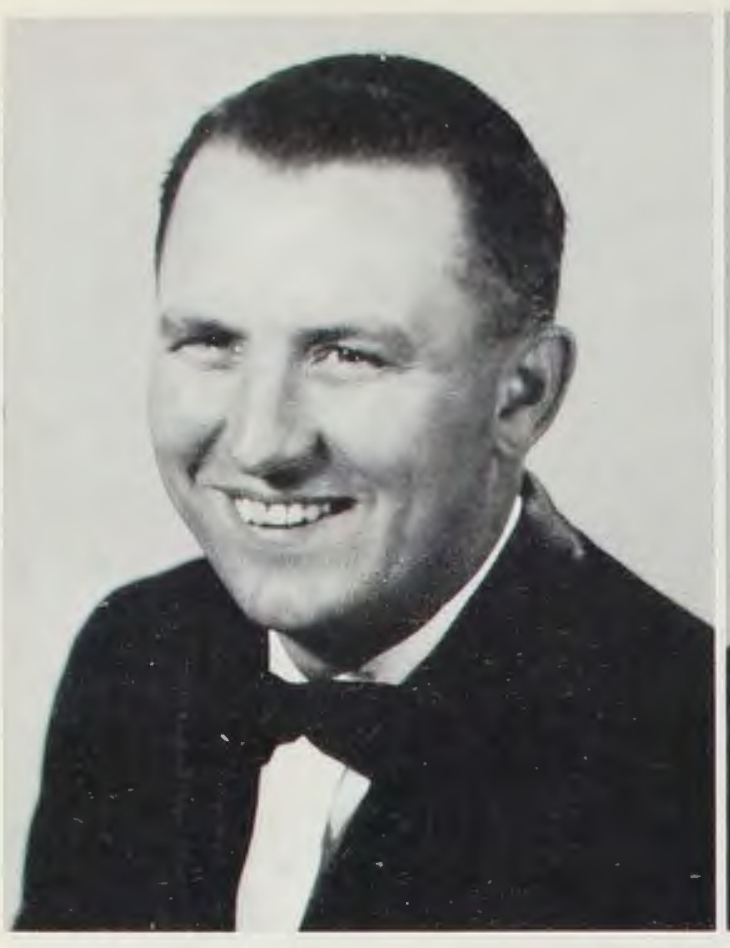

W. E. ALEXANDER

Marion, Obio

Calvary Baptist Church, Marysville, Ohio

A.B., Bible - Baptist Bible School, Pineville, Kentucky '57-'58, Central State College, Summer '60-'61; Student Pastor '60-'61.

\section{LORRAINE CAR'TWIGHT Ewington, Obio}

Grace Baptist Church, Cedarville, Ohio B.S., Nursing and Christian Education - F.W.M. 1, 2.

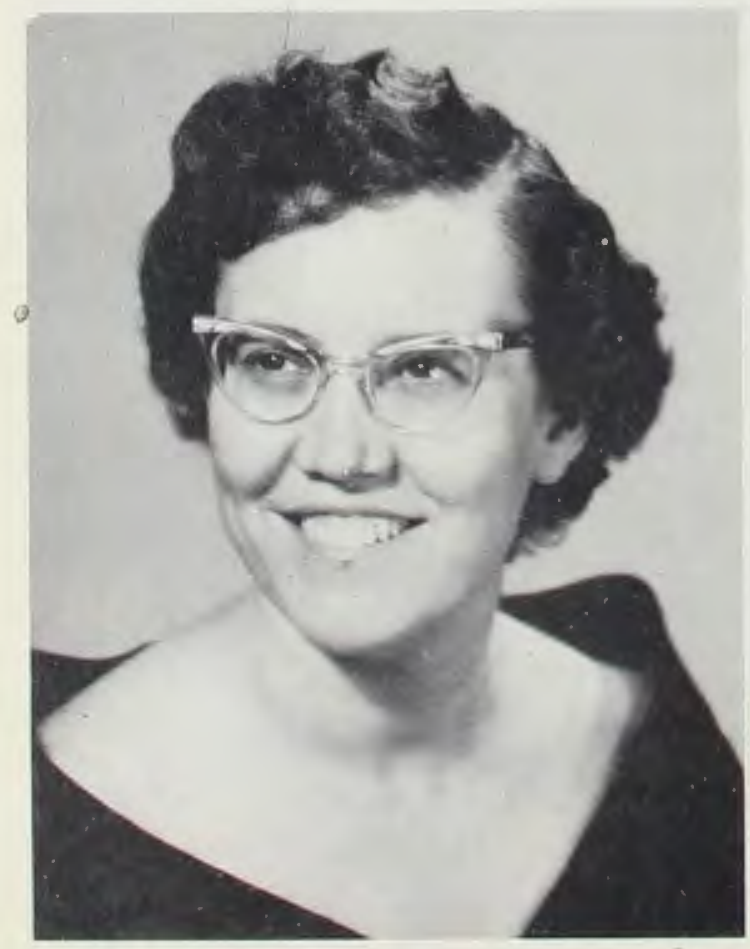

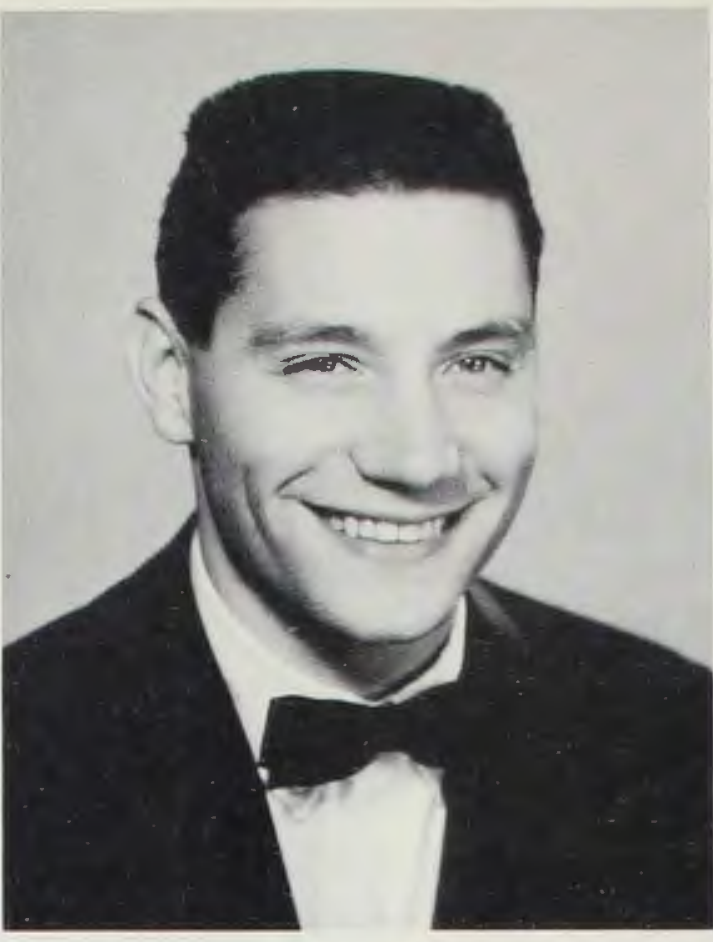

STEPHEN W. BOALT

Cleveland, Obio

Cedar Hill Baptist

B.Mus., Music - Student Council 4; Choir 1; Concert Band 1, 3, 4; Pep Band 1, 3, 4; Trumpet Trio 1; Choraleers President 4; Minister of Music, Blessed Hope Baptist, Springfield, Ohio '61-62.

\section{Seniors}

\section{VIRGINIA LEE COX \\ Russell, Iowa}

Grace Baptist Church, Cedarville, Ohio B.S., Christian Education - Gamma Chi 1; F. W. M. 1, 2, 4.

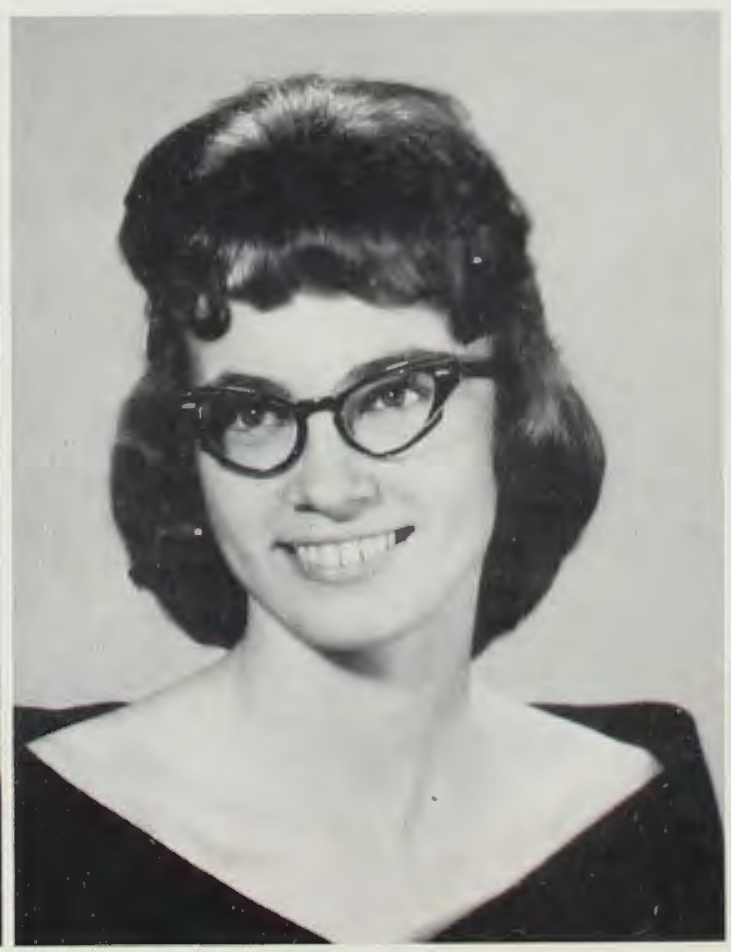

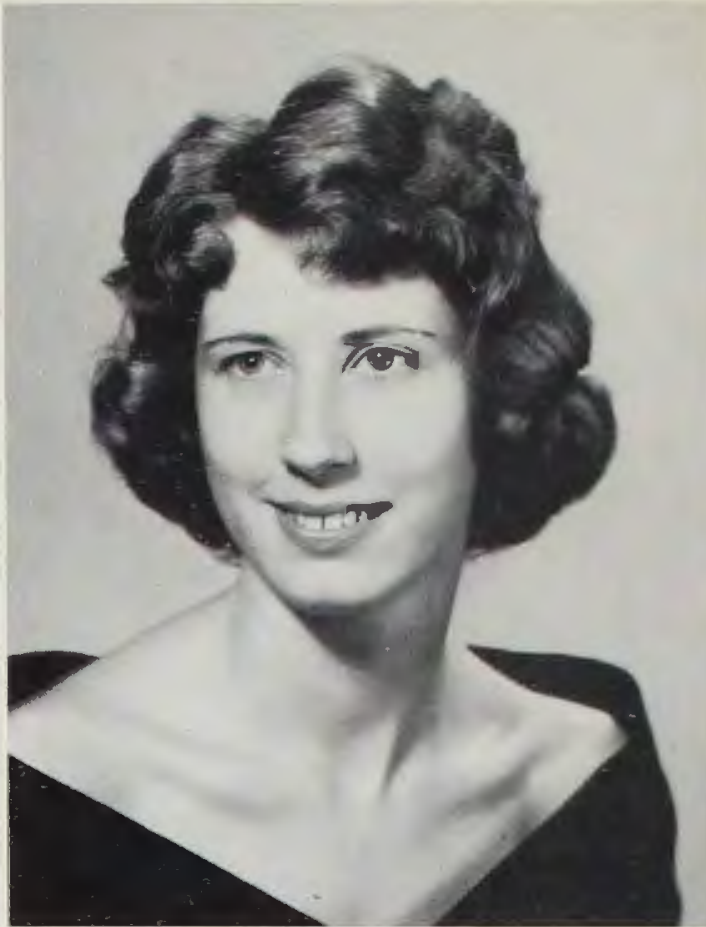

\section{HAZEL MARIE BROVONT} Galion, Obio

The First Baptist Church

A.B., History - Ohio State University '58-'60, Central State College '61-'62; Kappa Delta Xi President 4; Gamma Chi 3; Whispering Cedars Staff 3; Cheerleader, J.V. 3.

\section{ROBERT LEWIS DOMOKOS Windsor, Obio}

Huntsburg Baptist Church

A.B., Bible - Baptist Bible Institute '56, Northern Baptist Theological Seminary (Correspondence) "61; Class Chaplain 1, 2, 3, 4; Student Council 3. President 4; Student Government 1, 2; Future Pastor's Fellowship 3, 4; Dorm Counselor 4.

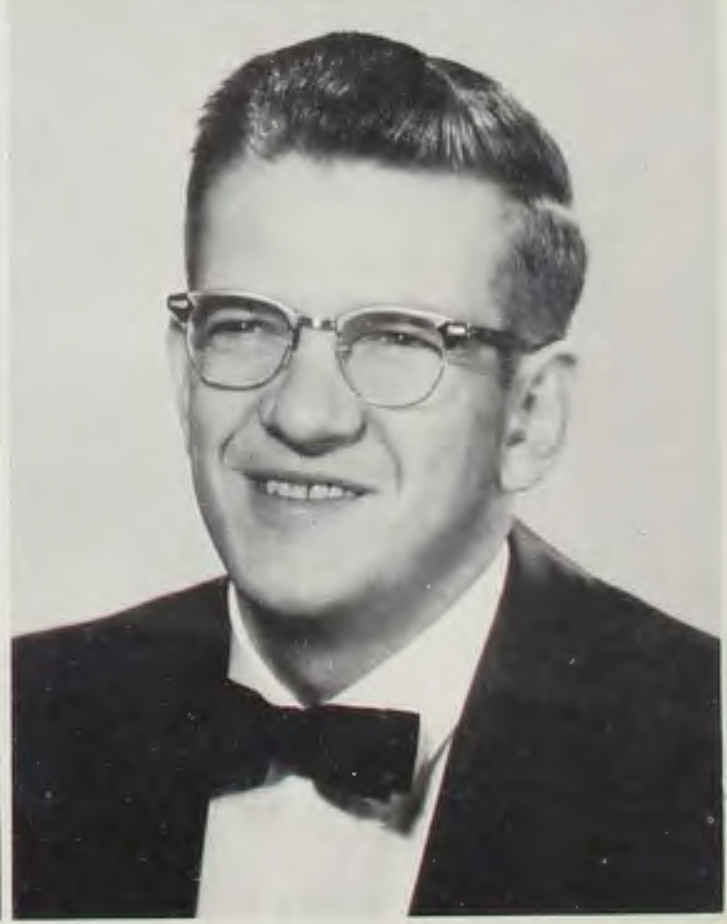




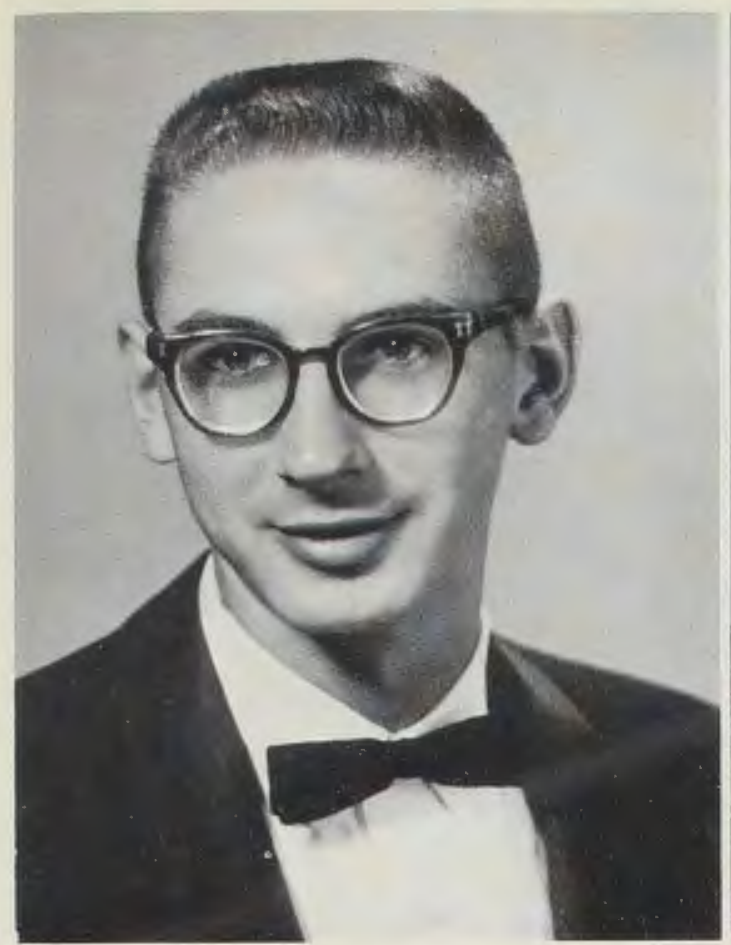

DAVID LEROY EARNHART

Waynesville, Obio

Xenia Emmanuel Baptist

A.B., Music - Class President 2, 3; Class Vice-President 1; Alpha Chi 1, 2, President 3, 4; Homecoming Play 1, 2; Future Pastor's Fellowship 4; Basketball Team 1, 2; Baseball Team 1; Choir 2, 4, President 3; Band 1, 2 , 3, 4; Men's Quartet 2, 4; Xenia Emmanuel Sunday School Superintendent 1, 3, 4; Youth Director 3, 4, Christian Education Director 4.

\section{CAROLINE ELAINE JORDAN \\ Ricbmond, Virginia}

Berean Baptist Church

A.B., History - Kappa Delta Xi 4; Gamma Chi 3.

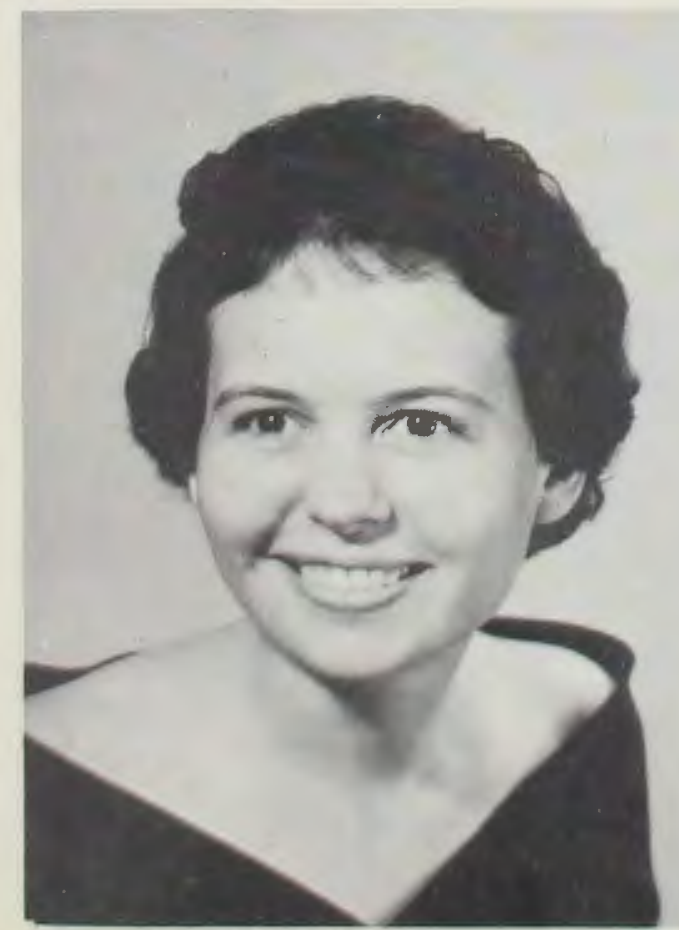

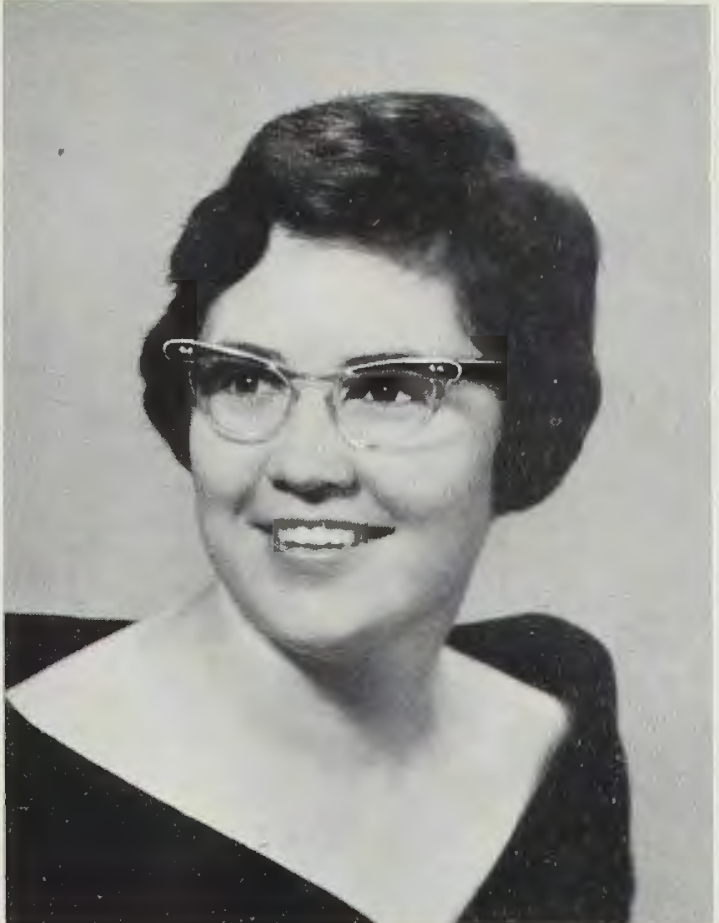

JOYCE C. GRAN'T

East Moline, Illinois

Third Street Baptist

A.B., Elementary Education - Central State College '60-'62; Kappa Delta Xi 5; Gamma Chi 2, Vice-President 3; Whispering Cedars Staff 2; Band 2, 3, 4.

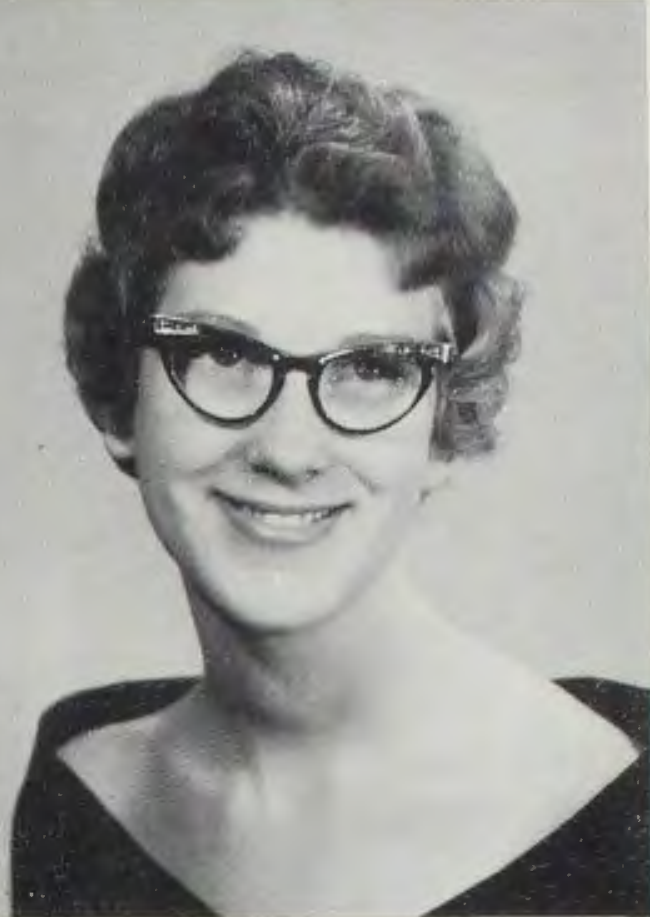

BARBARA ANNE HEMENWAY Austin, Minnesota

Grace Baptist Church

A.B., Social Science - Mankato State College '58-'59; Kappa Delta Xi 4; Gamma Chi 2, 3; F. W. M. 2; Chapel Choir 2.

\section{DORTHEA J. KIDD Elyria, Obio}

First Baptist Church

A.B., Physical Education $-\mathrm{Cl}$ as s Secretary 2; Student Council 4; Choir 1, 2, 3; Trio 1; Quartet 2.

\section{CAROLE SUE LANIUS \\ Covington, Kentucky \\ Calvary Baptist Church}

A.B., Social Science - Central State College, Summer '59; Class Secretary 3, 4; Kappa Delta Xi Social Chairman 4; Choir 1, 3; Trio 1; Cheerleader, J.V. 1; Womens Government VicePresident 3.
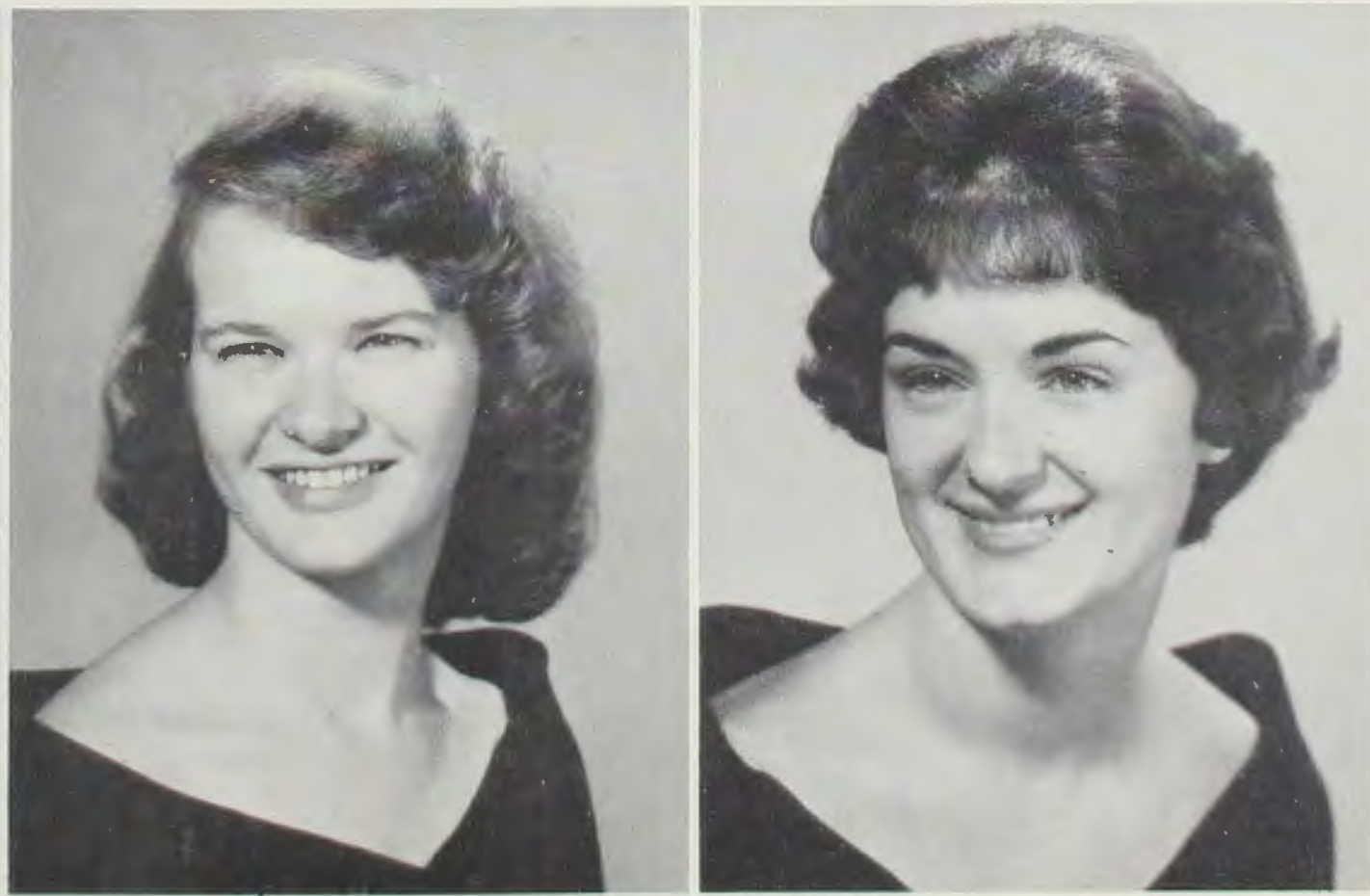


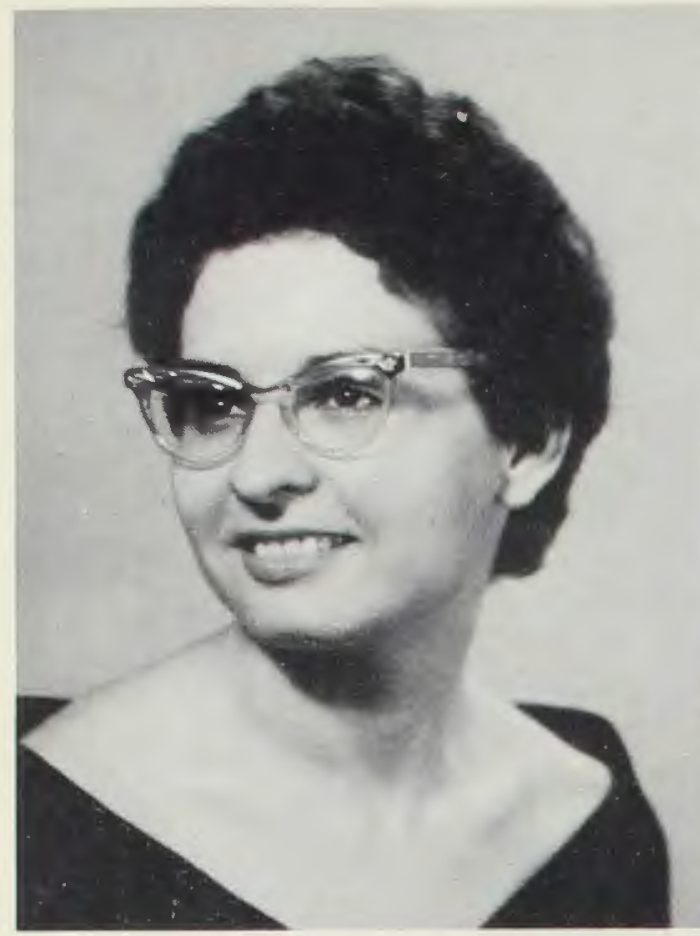

BEVERLY KAY LYON

Crawofordsville,_Indiana

Pleasant View Baptist Church

A.B., Social Science - Student Government 3; Kappa Delta Xi 4; Gamma Chi 1, 3; F.W.M. 1, 2, 3, 4; Dorm Counselor 4 .

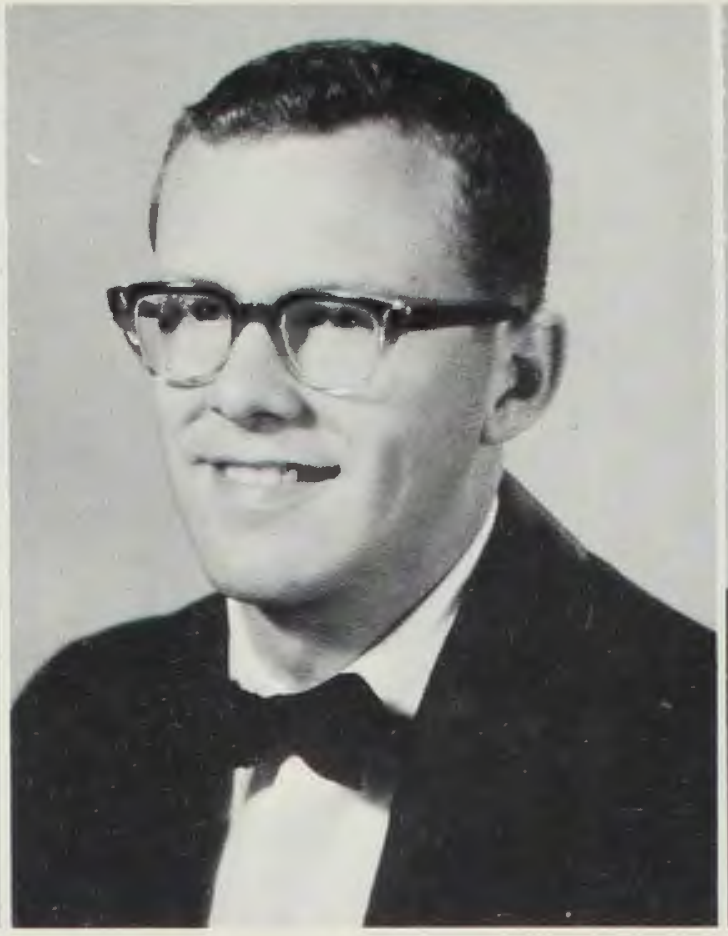

JERRY L. PEIFER

Mansfield, Obio

Emmanuel Baptist Church

A.B., History - Muskingum College '57-'58, Ohio State University '58-'59; Yearbook Staff Art Editor 3; Varsity "C" 4; Dorm Counselor 4; Track Team 3.

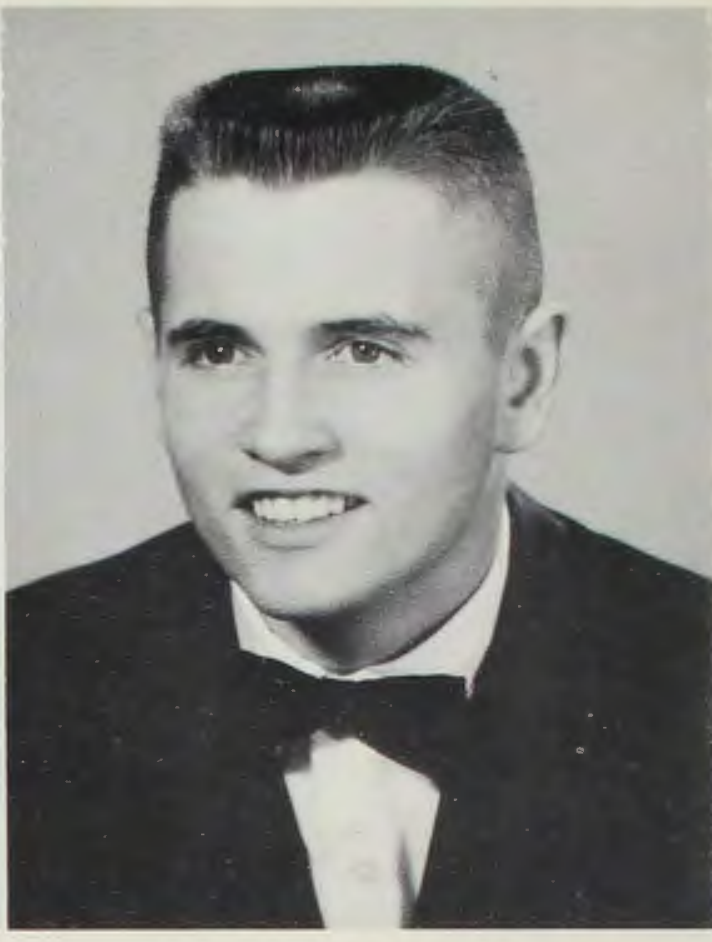

DAVID G. PIPER

Pittsford, Michigan

Locust Corners Baptist

A.B., History - Class Vice-President 3.

\section{Seniors}

\section{DANIEL H. PURDY}

$$
\text { Cedarville, Obio }
$$

Berea Baptist Church

A.B., History - Class Vice-President 1; F. W. M. 1, 2; Future Pastor's Fellowship 4; Varsity " $C$ " 1, 2, 3, 4; Basketball Team 1; Choir 1.

\section{WAYNE E. RADER \\ Renfrew, Pennsyluanic}

First Baptist, Evans City Pennsylvania A.B., Bible - Alpha Chi 1; Homecoming Play 2.
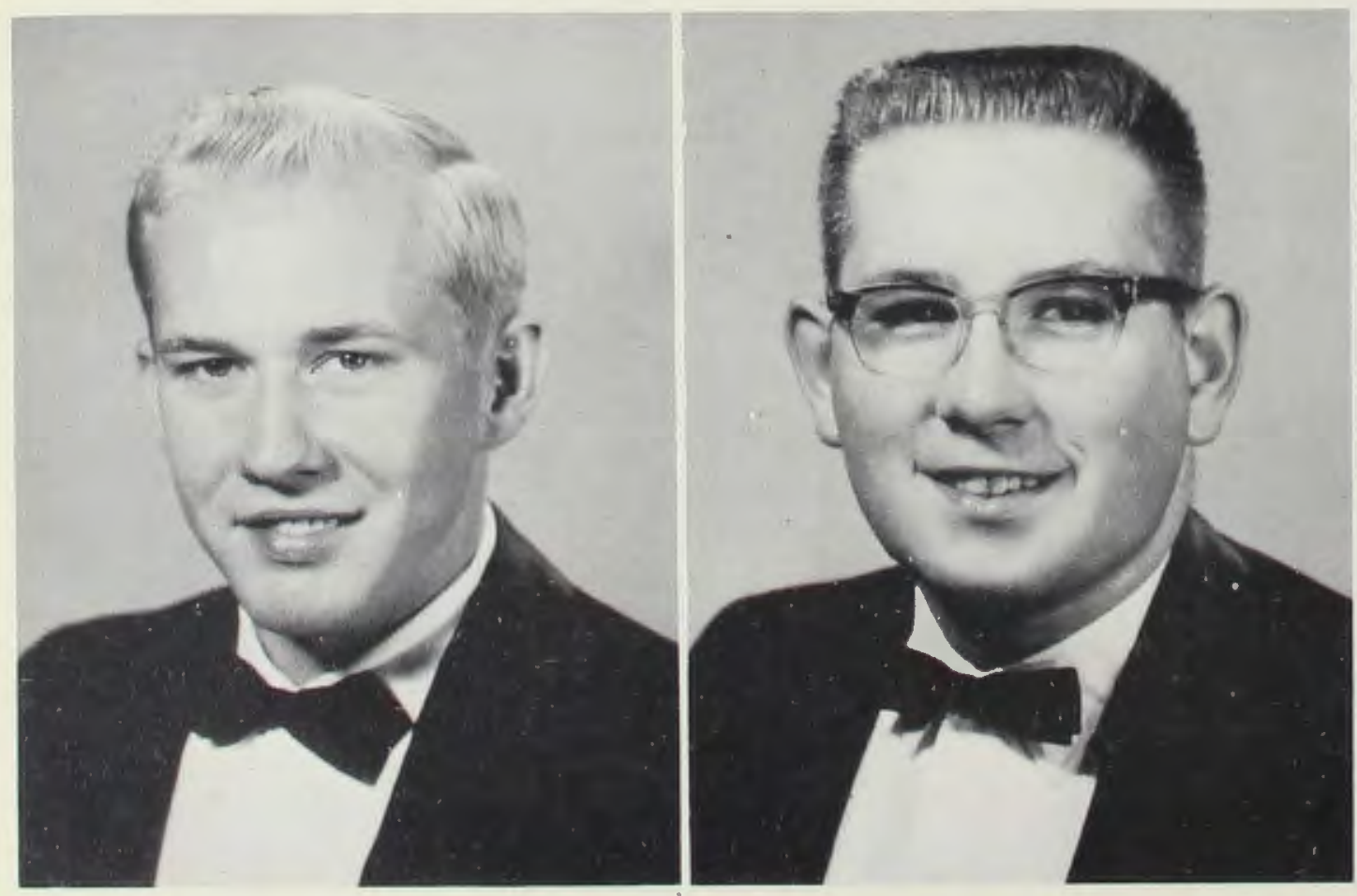

JOAN REITER

Soutbold, Long Island, New York

Hayden Avenue Baptist

B.S., Nursing - New Rochelle Hospital School of Nursing '56-'59. 


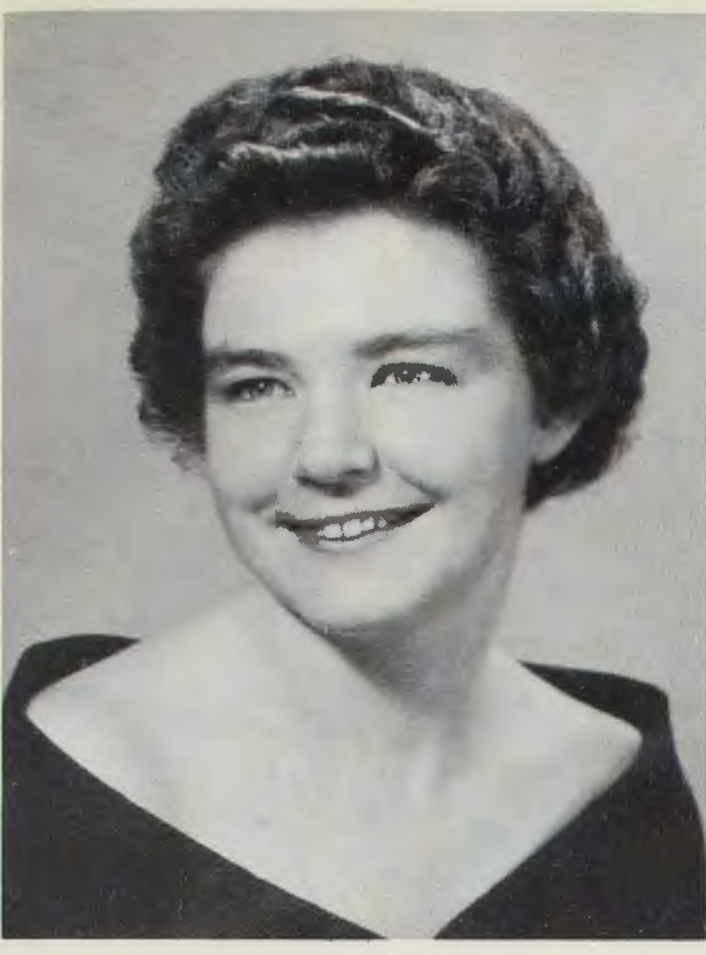

CHARLENE ALICE RESSLER

Sbell Rock, Iowa

First Baptist Church

B.S., Business Administration - Class 'Treasurer 1, 2, 3, 4; Whispering Cedars Staff 1; F. W. M. 1, 2, 3, 4; Dorm Counselor 3.

\section{BETTY L. SMITH}

Austin, Minnesota

Grace Baptist Church

A.B., English - Junior College '58. '59; Student Council Alternate 4; Gamma Chi Publicity Chairman 4; Homecoming Play 3, 4; Yearbook Staff 1, 3; Whispering Cedars Staff 2; F. W. M. 2, 3, 4; Choir 1, 2, 3, 4: Choralaires Accompanist 4; Prospective Students' Day Play 2.

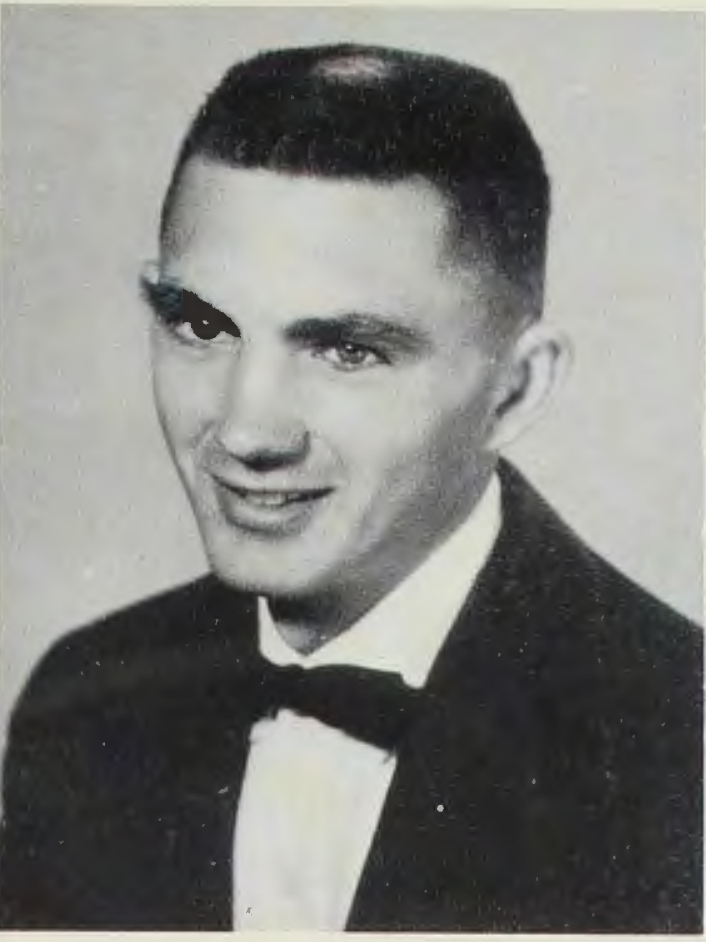

FREDERICK J. ROLFE

Itbaca, New York

Tabernacle Baptist Church

B.S., Business Administration.

\section{LAFAYETTE BOGLE \\ STANDIFER III}

Galion, Obio

Kettering Baptist Church, Kettering, Ohio

B.S., Business Administration - Student Council 2; Alpha Chi 4; Student Council Representative 2; Homecoming Play 1, 2, 3; Basketball Team, J.V. 1; Baseball Team 1, 2; Chapel Choir 2, 3, 4; Golf 3, 4 .

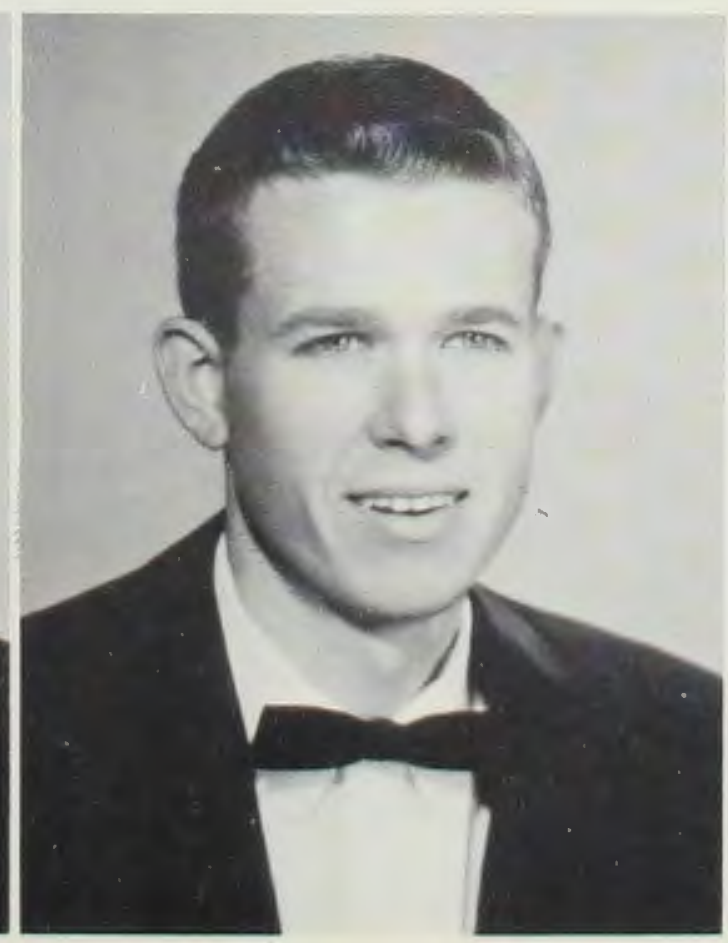

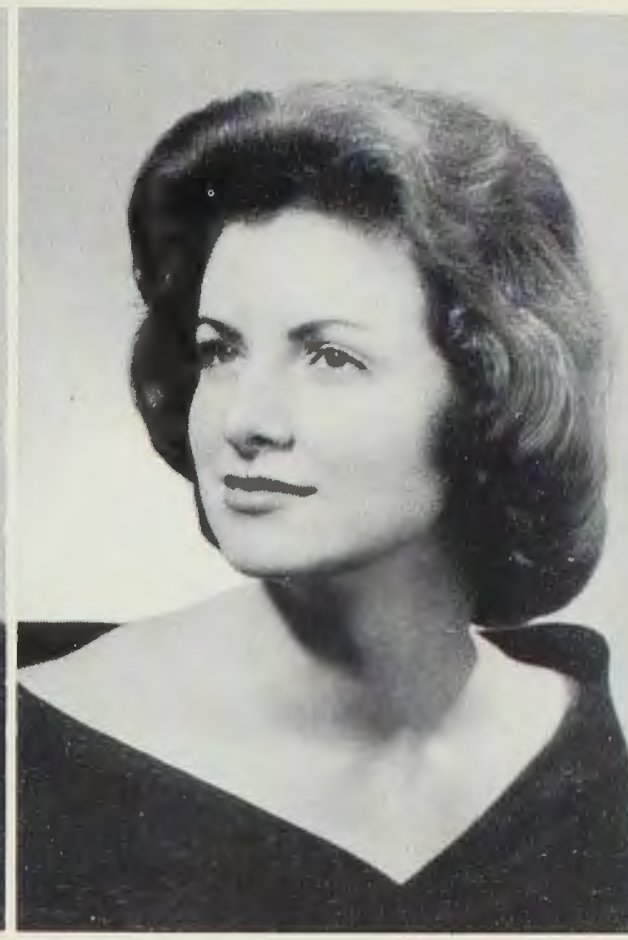

SANDRA M. SHANKS

Belton, South Carolina

Calvary Bible Church, Columbus, Ohio B.S., Christian Education - William Jennings Bryan College '58-'60; Ohio State University, Summer .'61; Kappa Delta Xi 4 .

\section{OTIS R. STONE}

Rochelle, Illinois

First Baptist Chürch

B.S., Christian Education - Class VicePresident 4; Student Council 1; Alpha Chi 1, 2, 3, Vice-President 4; Yearbook Staff 2, Editor 3; Varsity " $\mathrm{C}$ " 2, 4, Chaplain 3; Basketball Team 1; Baseball Team 1; Choir 3.
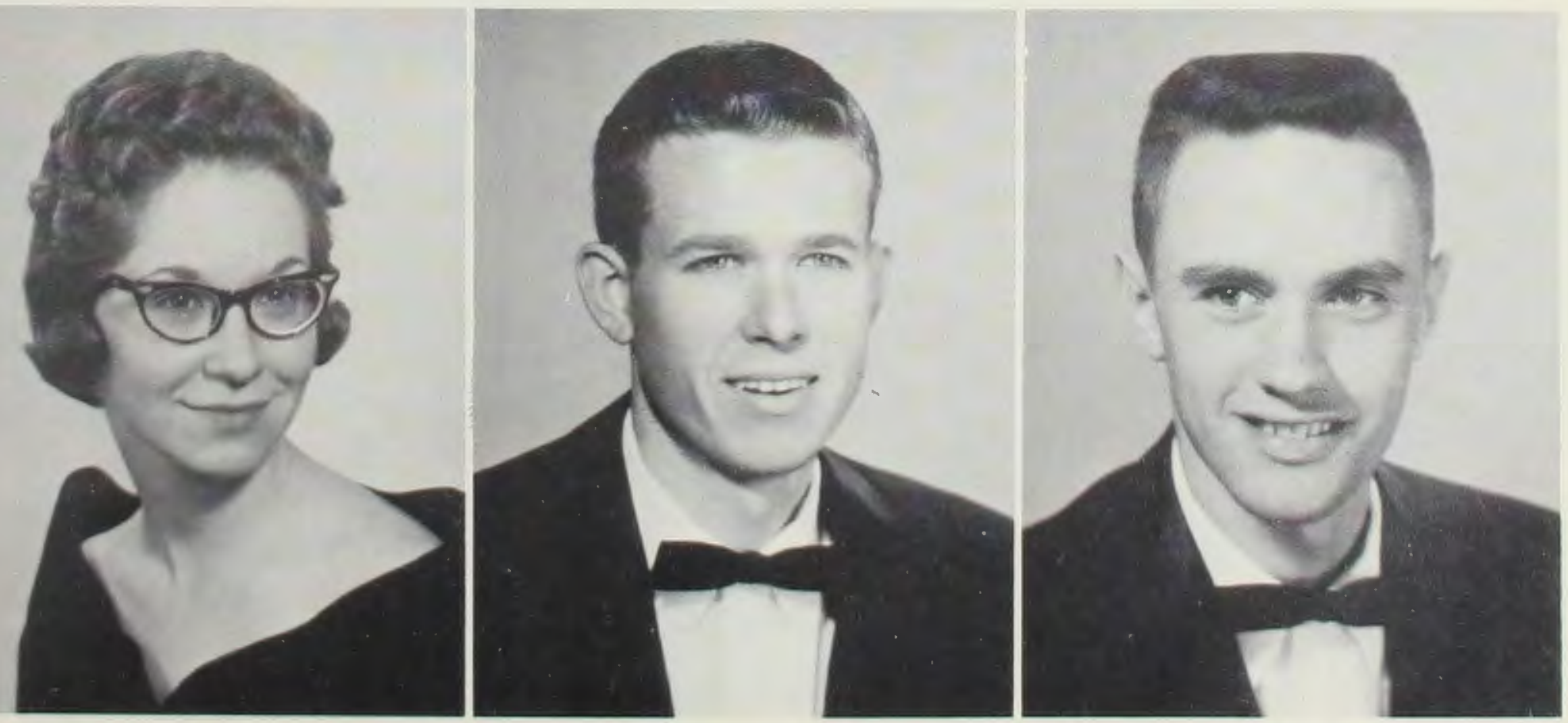


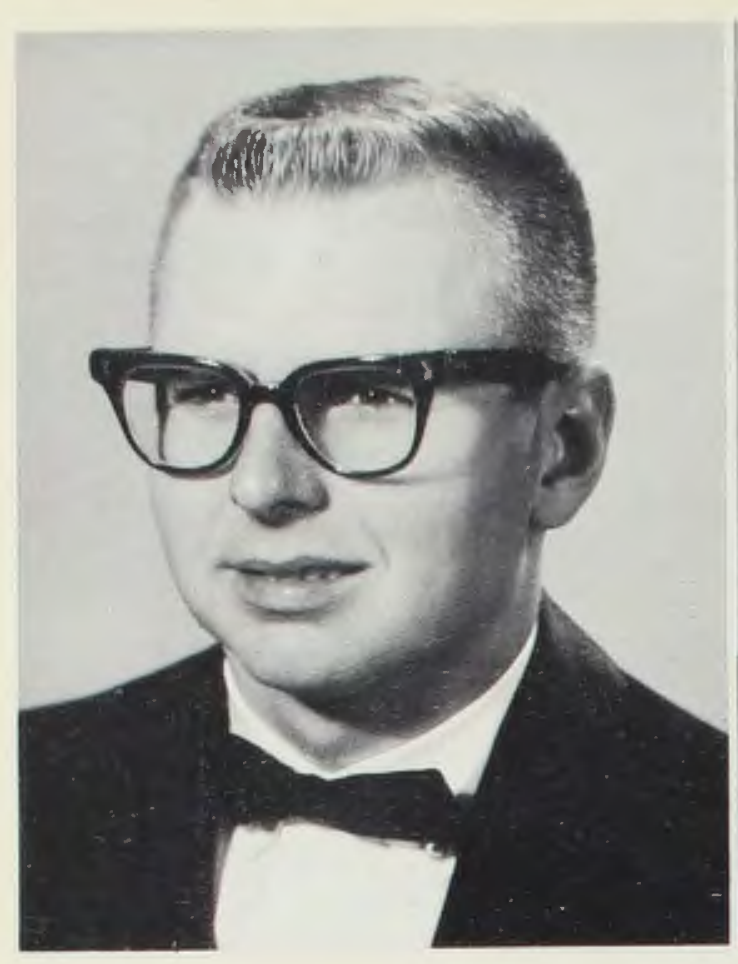

THOMAS CHARLES THOMPSON

Boise, Idabo

Baptist Temple

B.S., Business Administration - Boise Training College '59-'60.

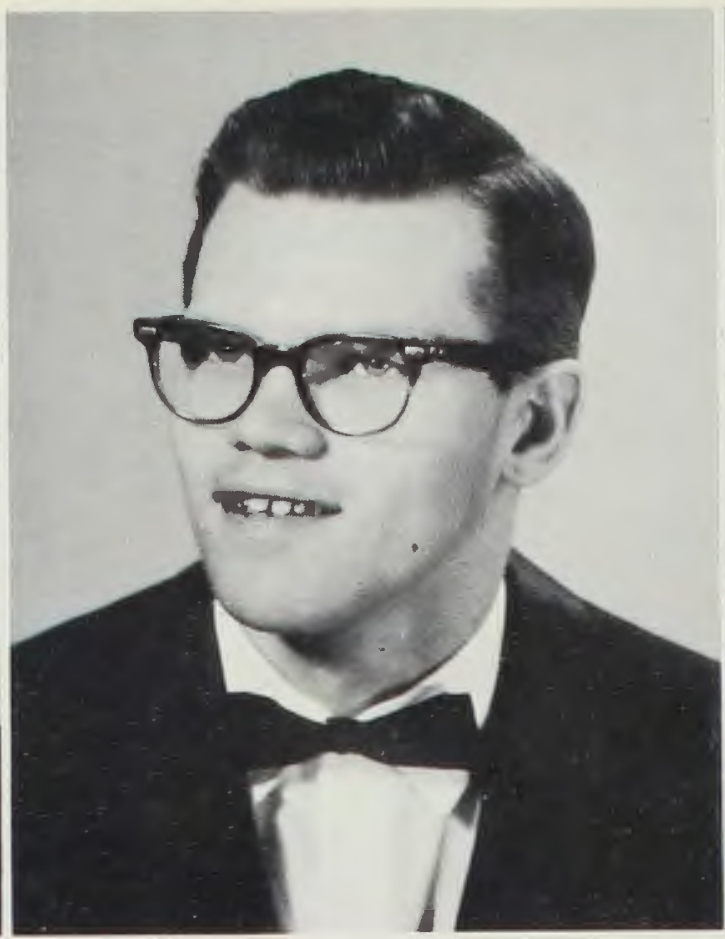

KEITH R. WEBSTER

Bedford, Obio

Bible Baptist

A.B., Bible - Class President 1; Student Council 4; Student Government 4; Alpha Chi 2; Sock 'n Buskin President 2, 3, 4; Homecoming Play 1, 2, 3, 4; F. W. M. 1, 2, 3, 4; Dorm Counselor $2,3,4$.

\section{Seniors}

\section{SANDRA ZERBY}

Nortb Royalton, Obio

North Royalton Baptist

B.S., Christian Education - Student Government 2; Gamma Chi 1, 3, Social Chairman 2; Cheerleading 1, 2.

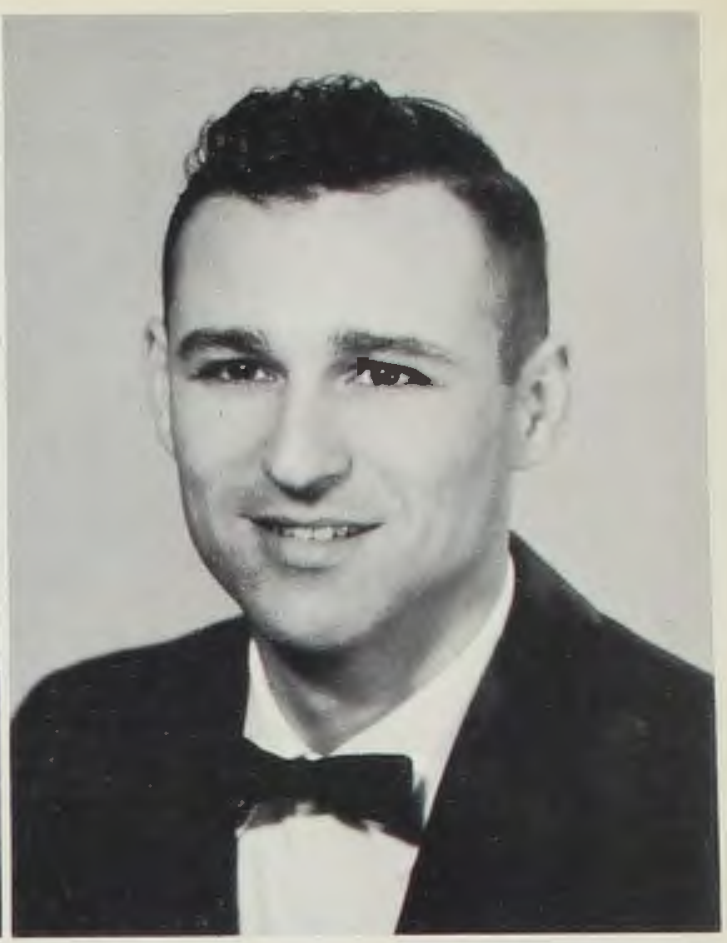

\section{MARVIN WISEMAN Springfield, Obio}

Blessed Hope Baptist Church A.B. History - Furure Pastor's Fellowship 3, 4.

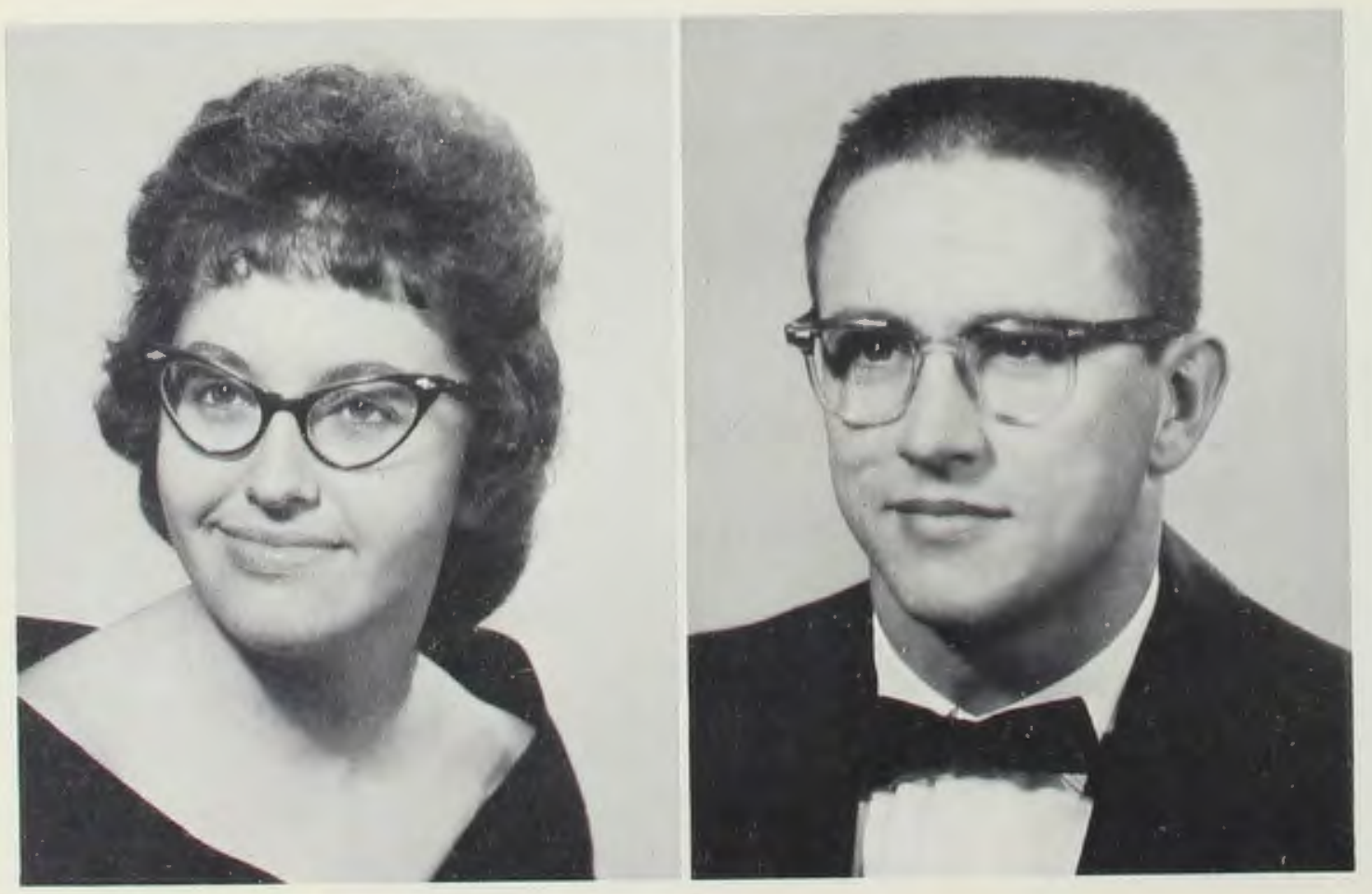


Seniors whose pictures were not available have been listed on this page.

WARREN W. ALLEN
Crewfordsville, Indiana

First Baptist Church, Blanchester, Ohio

A.B., History - Moody Bible Institute '55-'59.

\section{JAMES PARKER \\ Portsmouth, Obio}

Bible Baptist, Cleveland, Ohio

A.B., History - $\mathrm{Oh}$ io University Branch, Baptist School of the Bible.

\section{ROBERT MARK ELLIS \\ Boise, Idabo}

Temple Baptist Church

B.S., Business Administration - Track Team 3, 4; Varsity " $C$ " 4.

\section{HAROLD I. PYLE \\ Xenia, Obio}

Emmanuel Baptist Church

A.B., Bible - Moody Bible Institute '49-'51, '53-'56.
DAVE LEWIS

Portsmouth, Obio

Temple Baptist Church

A.B., History - Basketball Team 2, 3.

\section{MARVIN WAYNE ROYSE}

Logansport, Indiana

Crestline Conservative Baptist Church

A.B., History - Prairie Bible Institute '57-'59; College Choir 2.

\section{ELEANOR A. TAYLOR \\ Cleveland, Obio}

Hayden Avenue Baptist Church

A.B., History - Class Social Chairman 3; Student Government Chairman 2; Yearbook Staff Business Manager 3; Whispering Cedars Staff 1; Choir 1, 2; Women's Council Secretary 1, Vice-President 2, President 3.

Announced to passers-by, noticed by entering Freshmen, but engraved on the hearts of loyal seniors - is the college motto on the north gatepost.

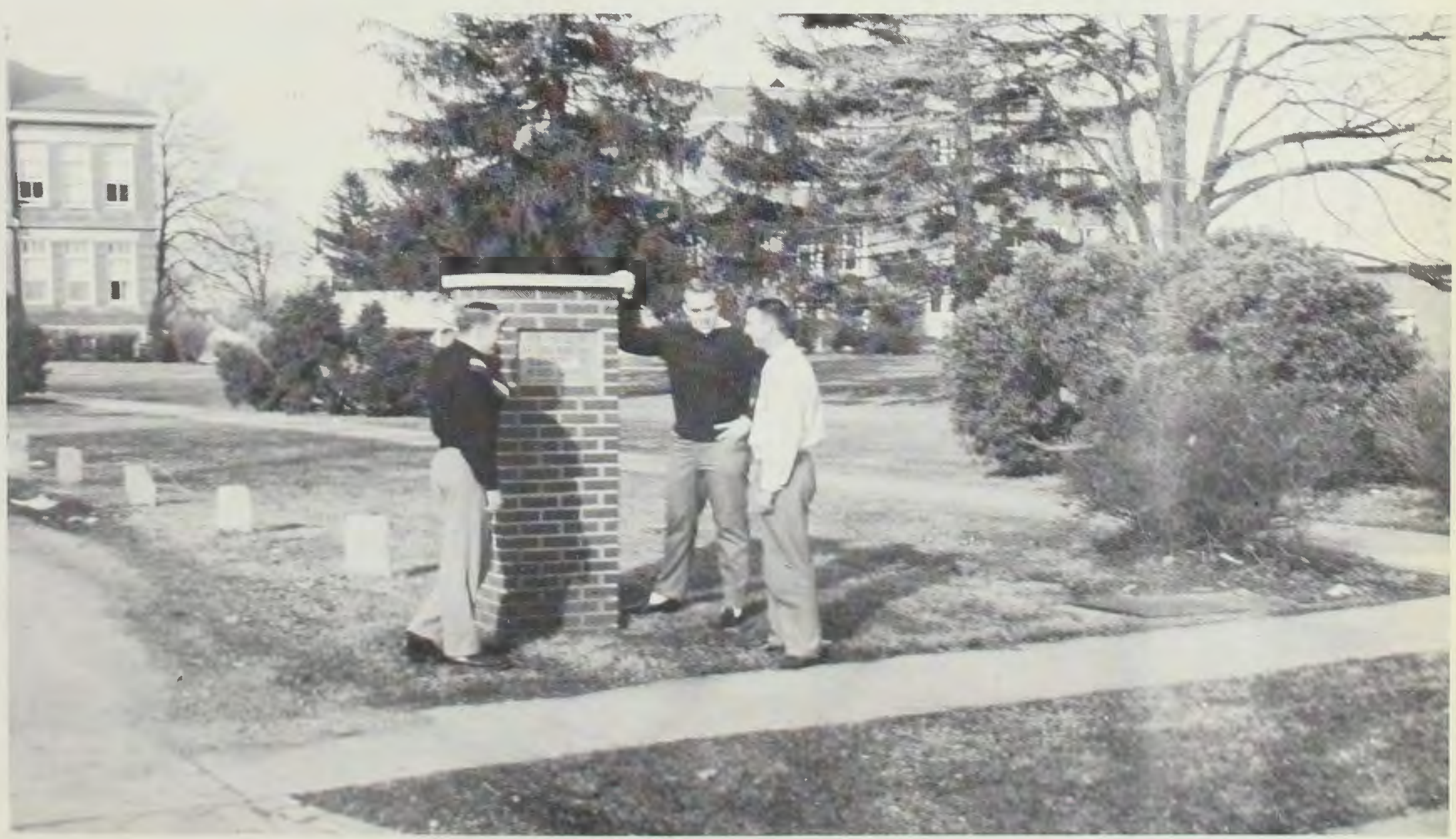




\section{Junior}

\section{Class}

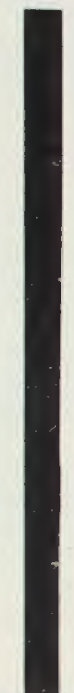

\section{MOTTO}

Our aim is ever upward

Our goal is yet unseen

\section{VERSE}

Stand fast therefore in the liberty wherewith Christ hath made us free.

Gal. 5:1a

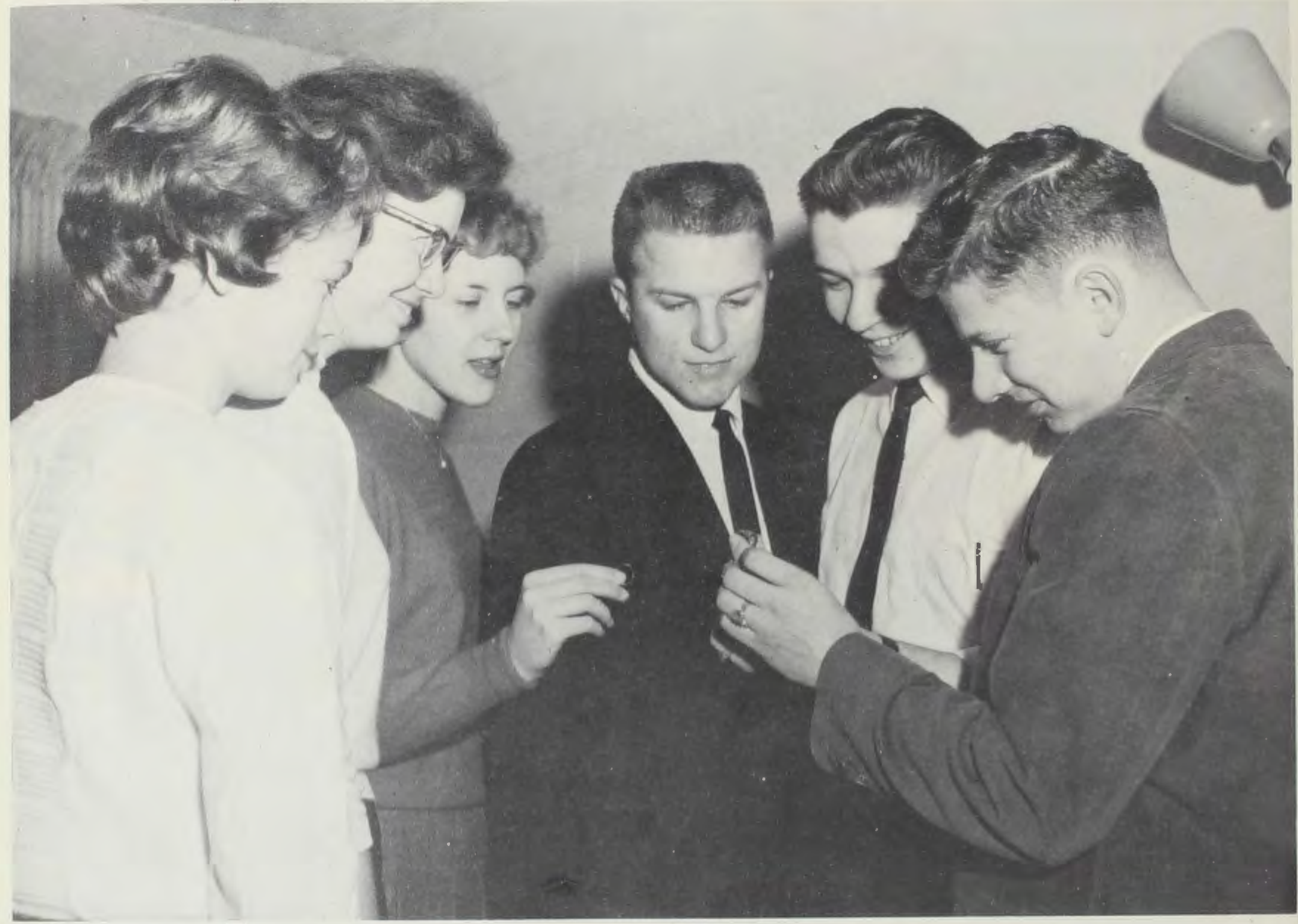

Juniors anticipate receiving the school ring which symbolizes $C$. C. by bearing on one side of the blue stone a yellow-jacket and on the other the school crest. 


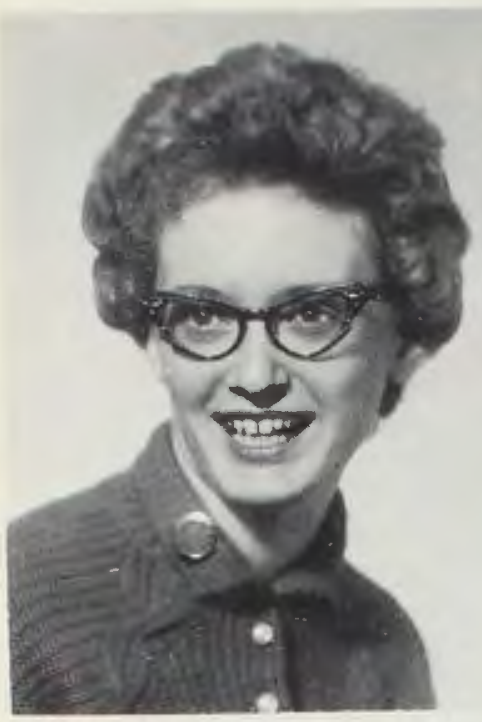

BARBARA ADAMSON

Perry, Iowa

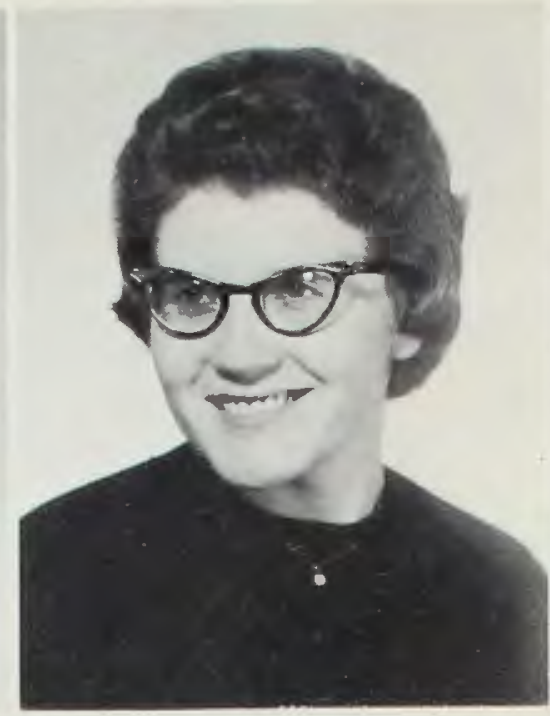

ROSA LEE ALBRECHT

Lakeville, Indiana

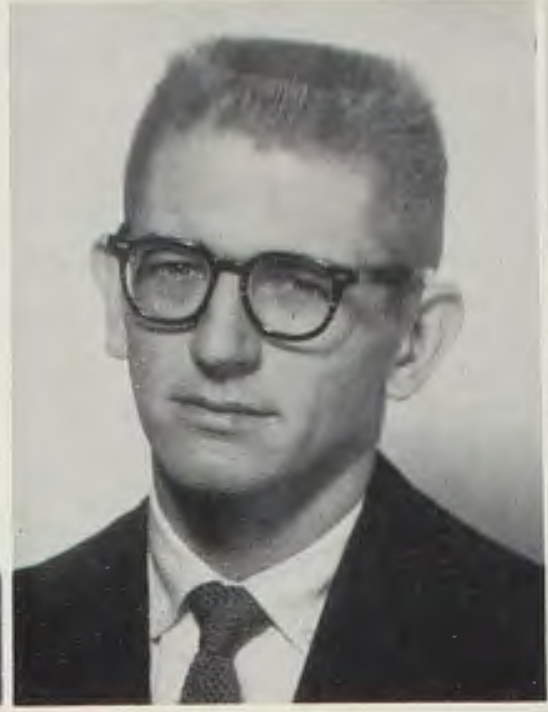

VANCE ASHLEY

Avon Lake, Ohio
ROBERT A. BALDOCK

Rochester, Minnesota

\section{Juniors}

A. LEE BENNETT

Freeport, Pennsylvania

RICHARD ALAN

BLUMENSTOCK

Teaneck, New Jersey
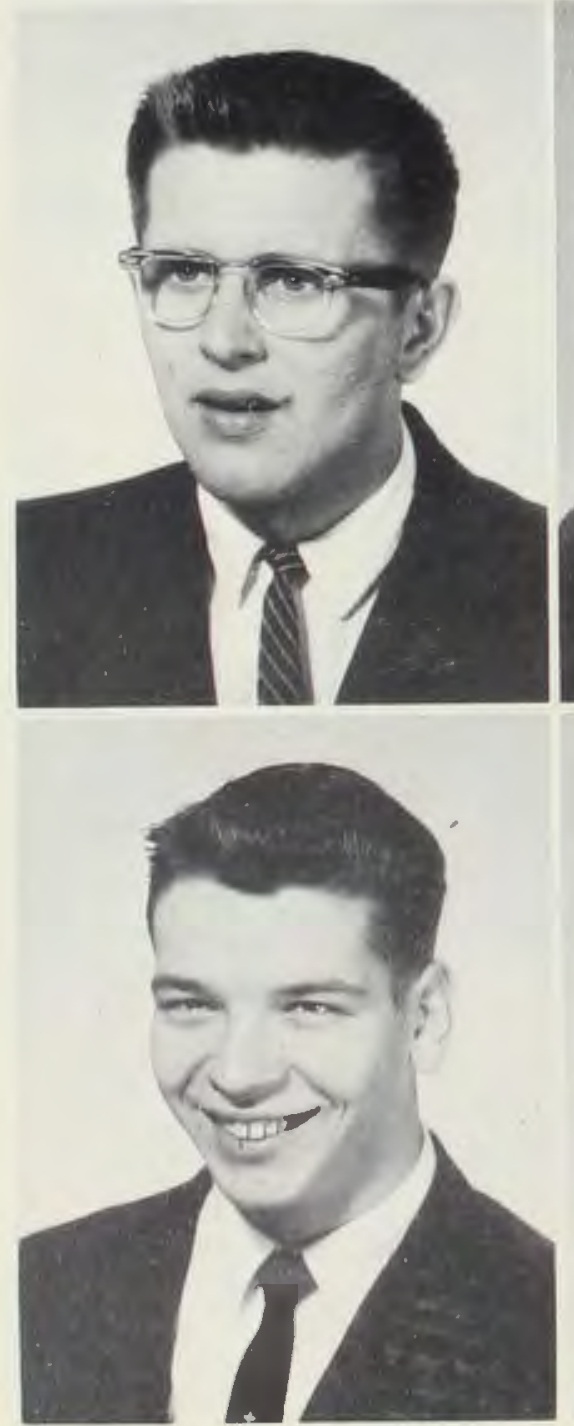

IRENE BENSON

Gary, Indiana

CAROLE ANN BOREN

Niles, Ohio
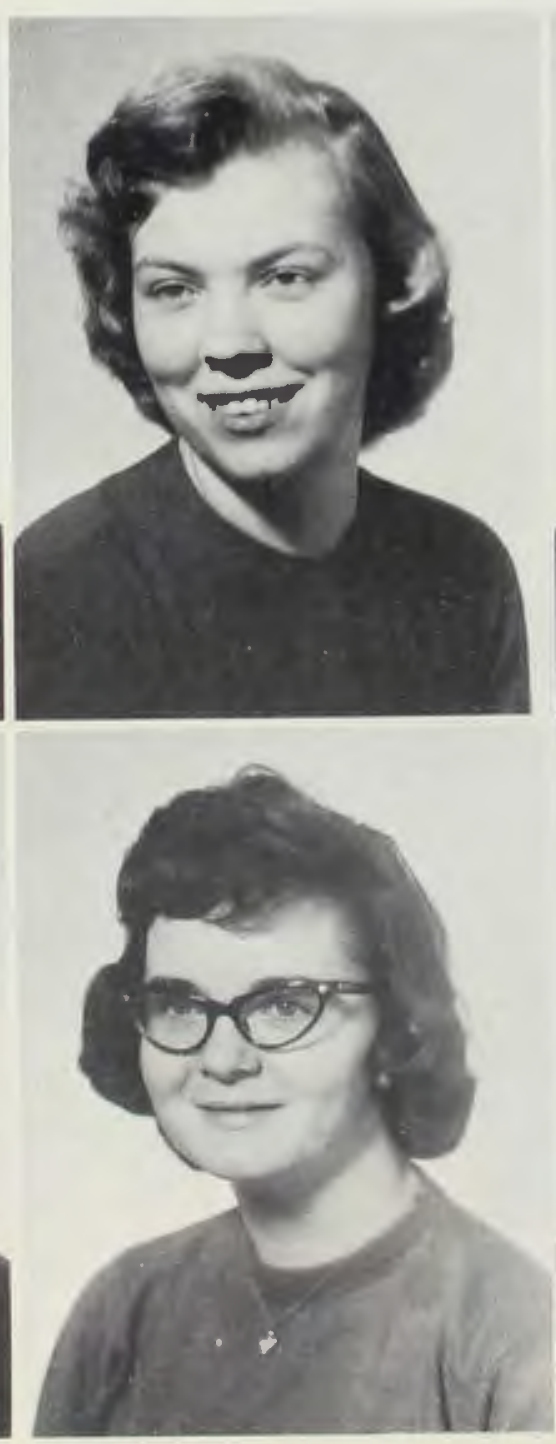

ALLEN BIDDLE

Westville, Ohio

RICHARD BRESSON

Tippecanoe, Indiana
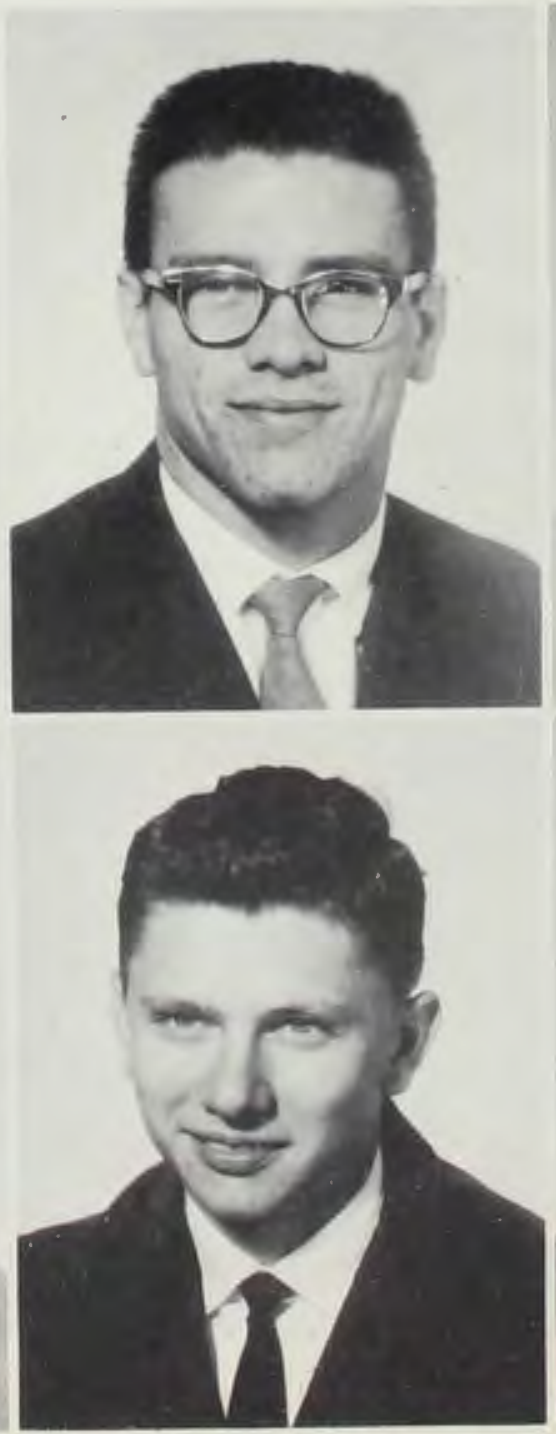

JULIA BIRD

Saline, Michigan

PHIL BROWER

Kalkaska, Michigan 


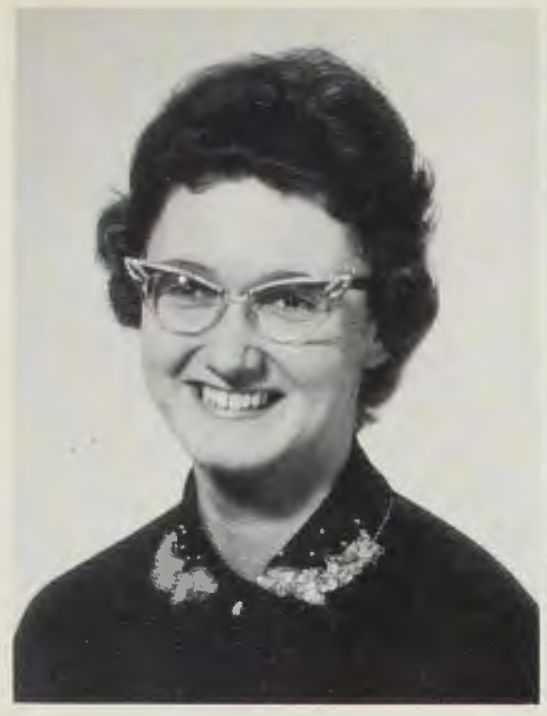

CAROL ANN BROWN

Sycamore, Ohio

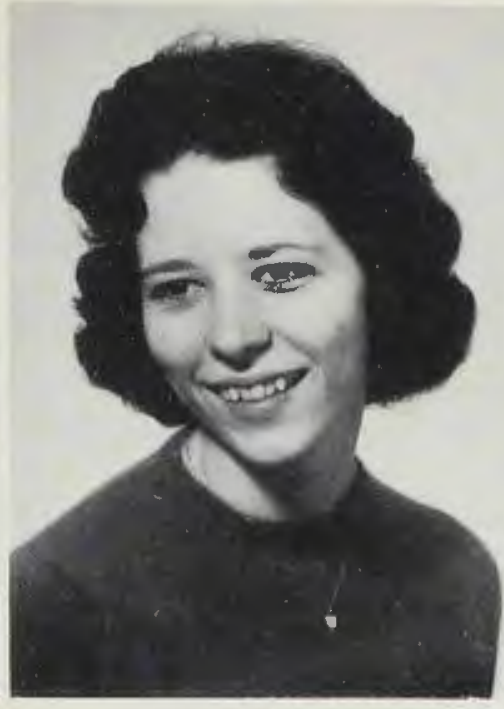

PEGGY BUERER

Elmhurst, Illinois

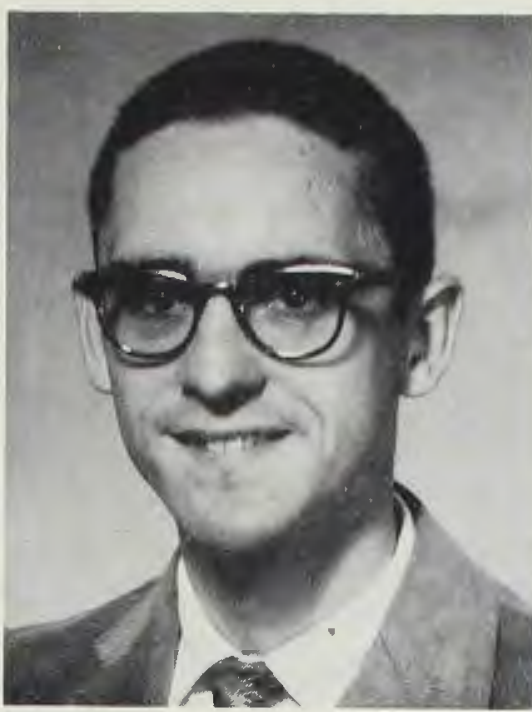

SAM CANINE

Blanchester, Ohio

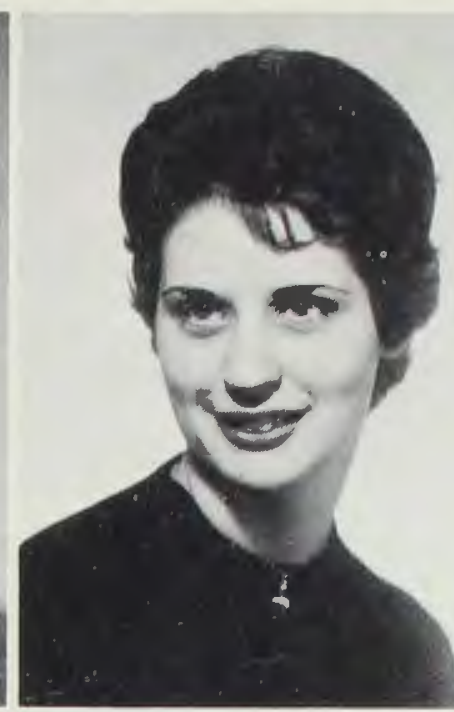

FLORA CANNON

Convers, Georgia

\section{Juniors}

DAVE COCHRAN

Russell, Iowa

DONNA DAVIS

Detroit, Michigan
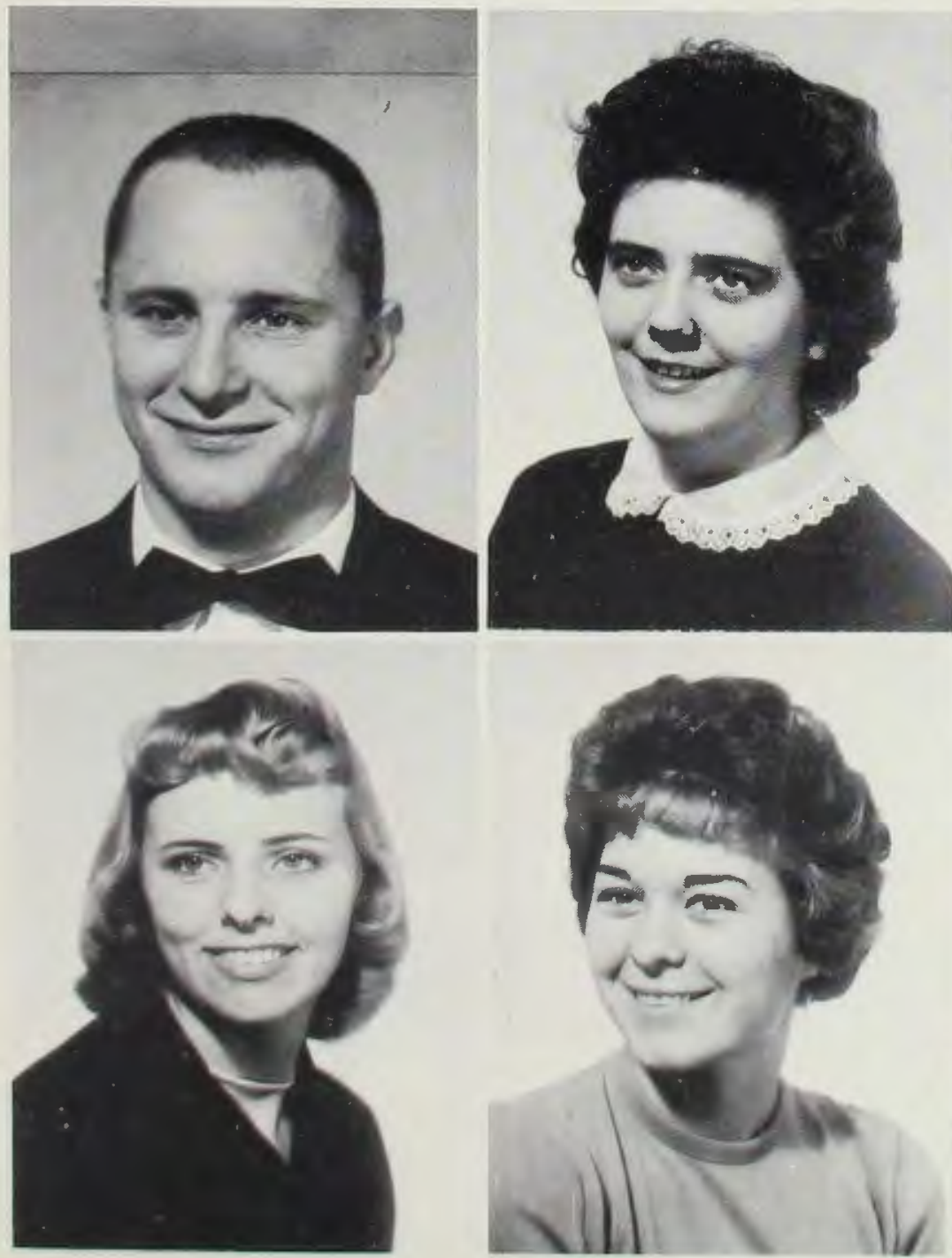

LORETTA CUSHEY

Butler, Pennsylvania

JEÁNNIE DU PRÉ

Washington, D. C.
JUDY DADISMAN

Warren, Ohio

EDWARD EASTMAN

Wiscasset, Maine
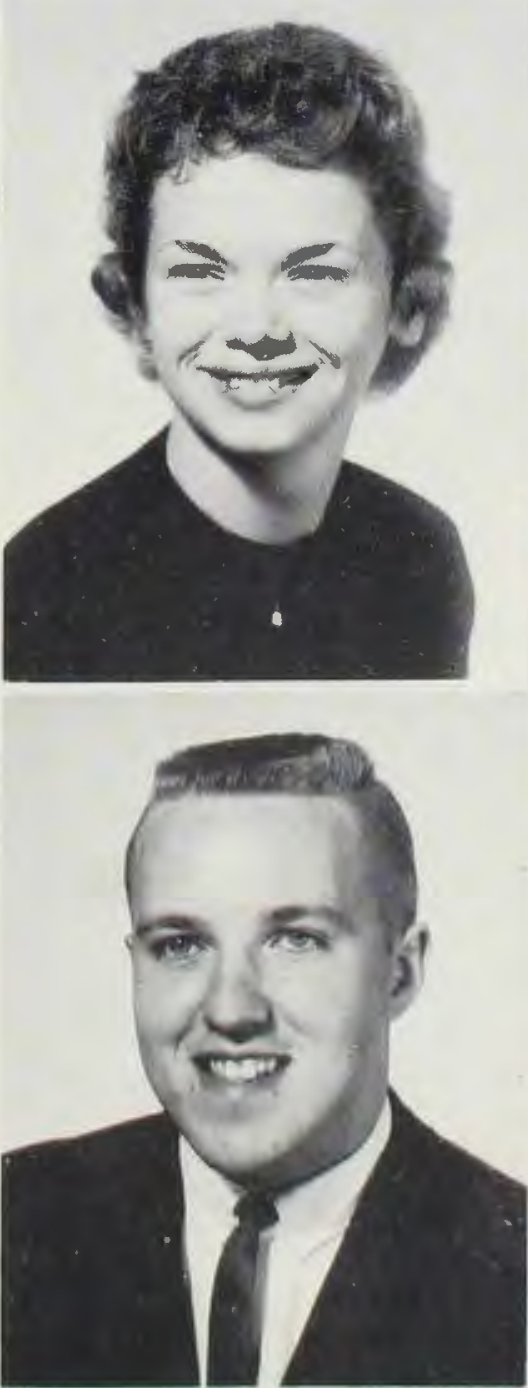

RICH DAVIDSON

Harvey, Illinois

WILLIAM THOMAS ELDER

Bucyrus, Ohio
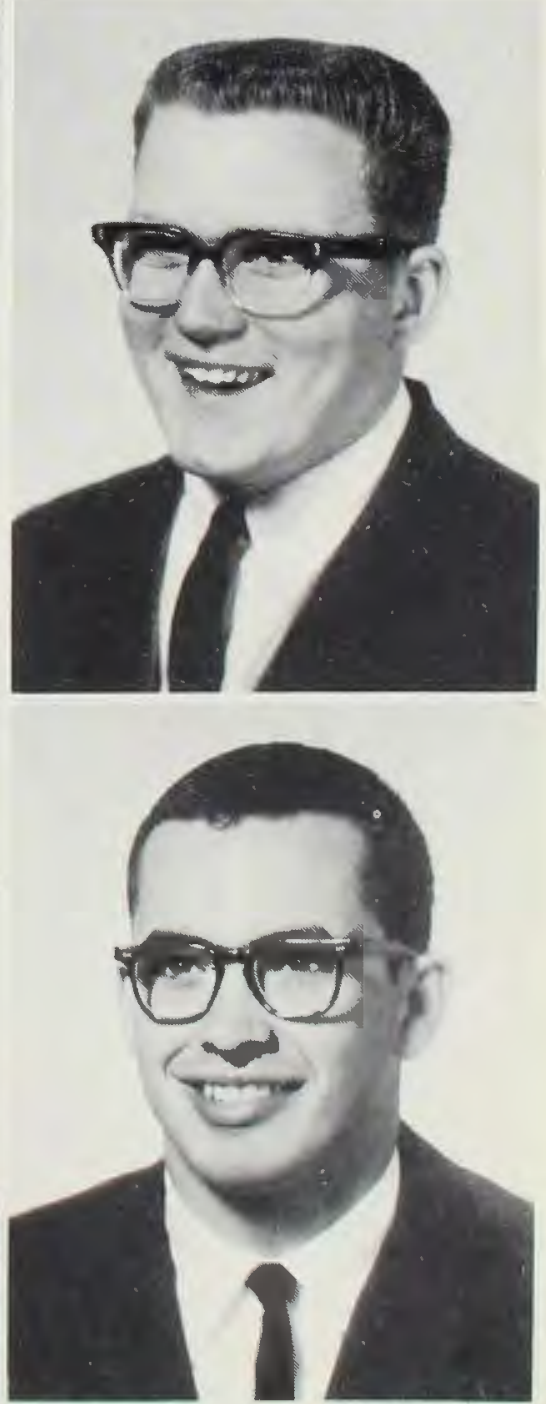


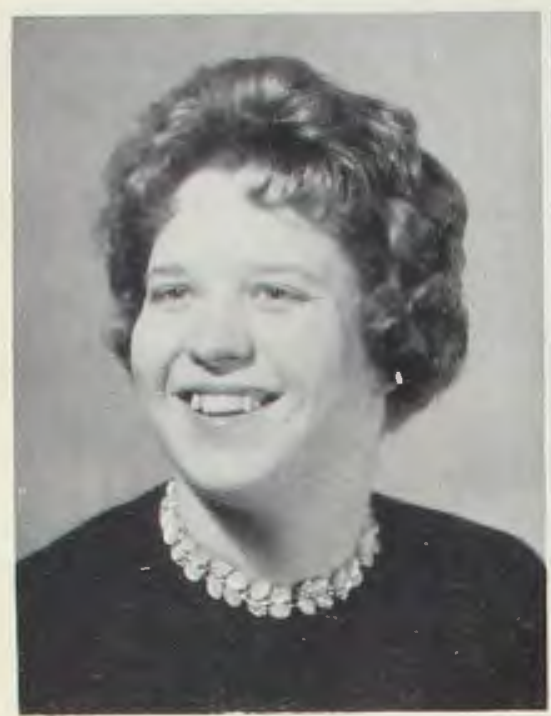

DONNA G. EVERETT

Caro, Michigan

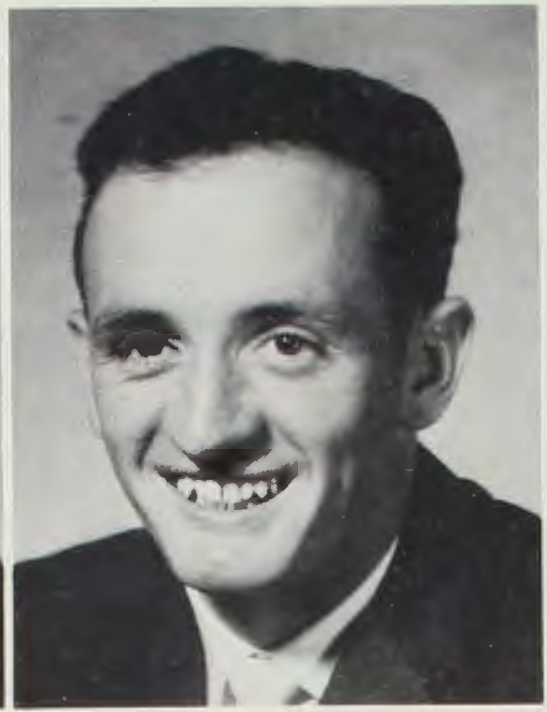

BARNEY

FARNSWOR'TH

Jerome, Michigan

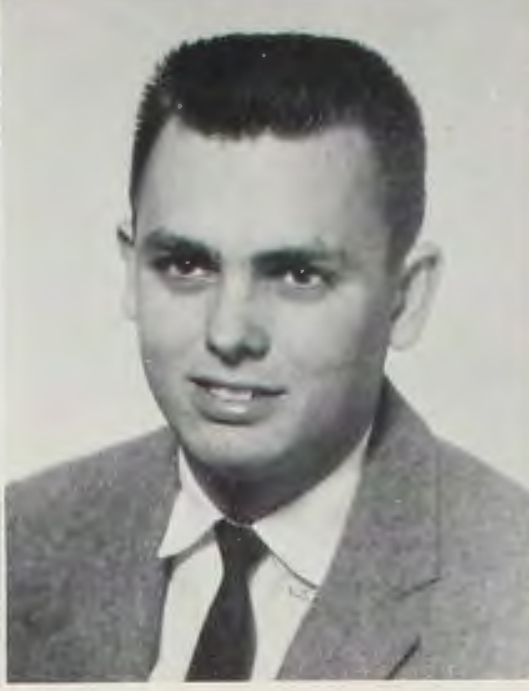

ROBERT FIDLER

Gary, Indiana

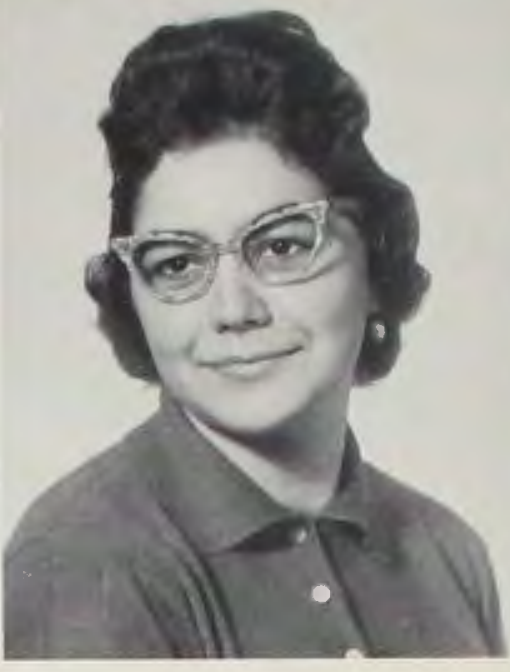

DONNA JEAN FINLEY

Faribault, Minnesota

\section{Juniors}

PAUL GATHANY

Highland, Indiana

PHIL GRAN'T

East Moline, Illinois
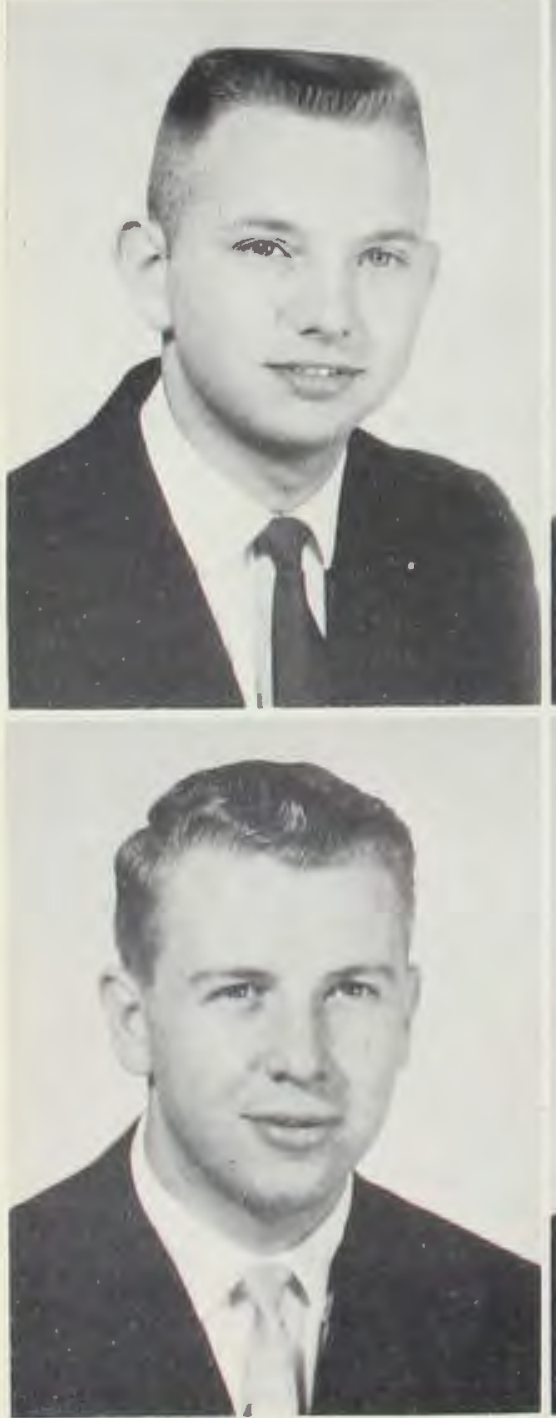

JUNE ELLEN GOLDEN

Stanton, Michigan

Peoria, Illinois

DON HALL

Cedarville, Ohio
MARK HASELTINE

East Butler, Pennsylvania
JIM GRAFTON

Worthington, Pennsylvania

CAROLE HELL

Gladwin, Michigan
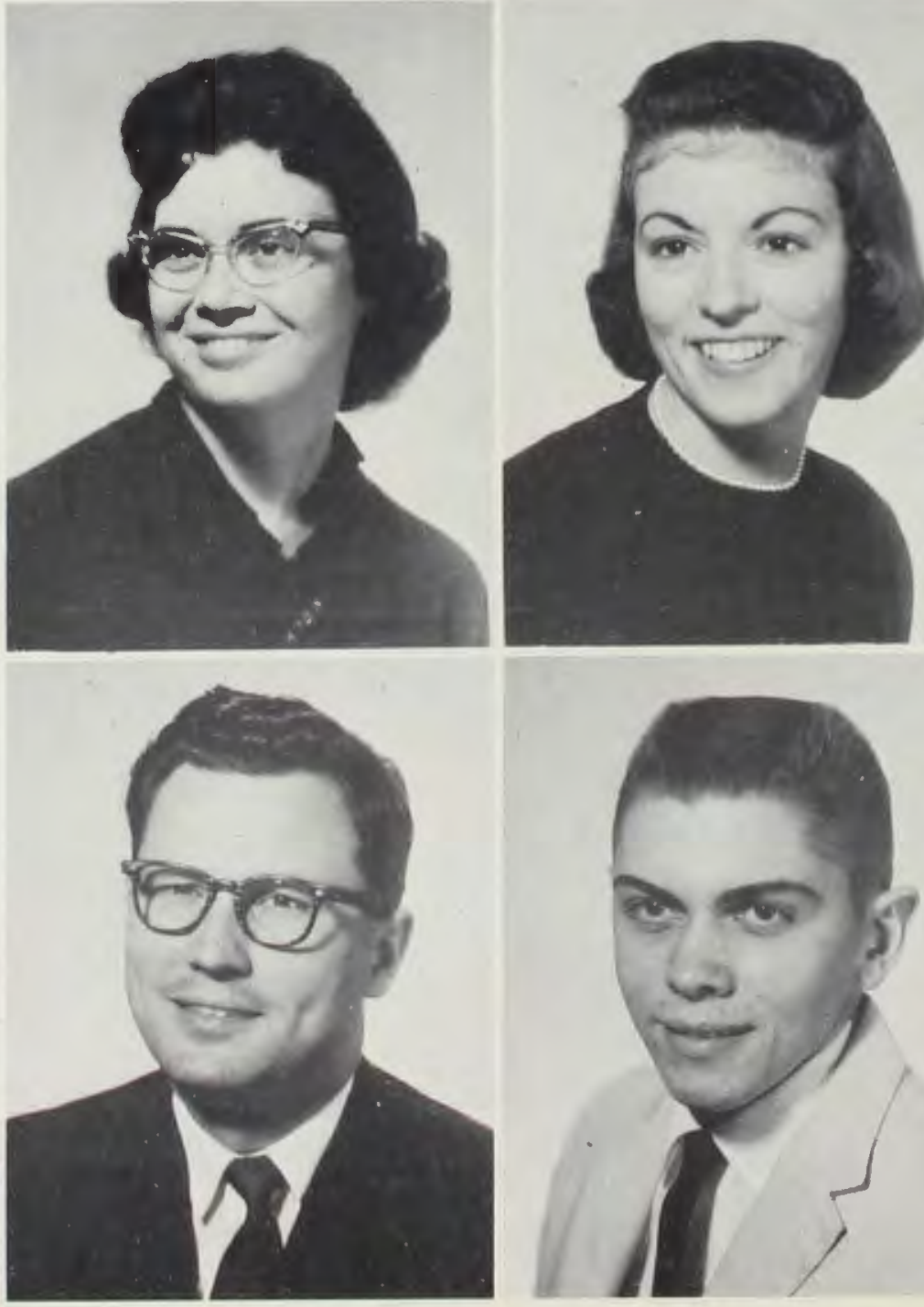

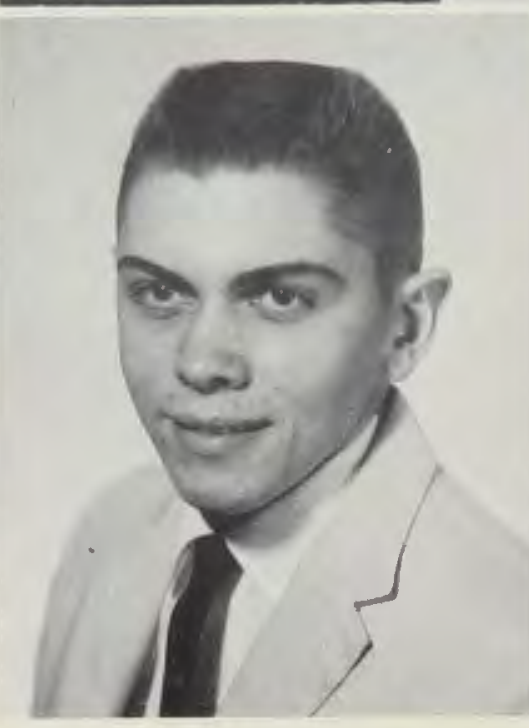

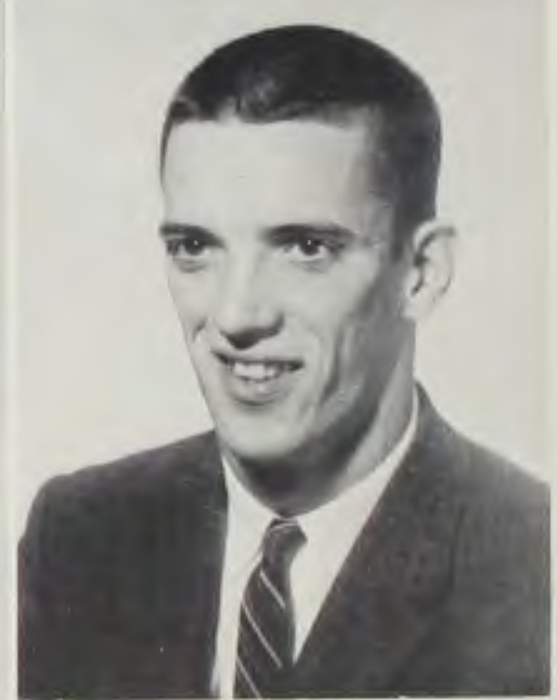

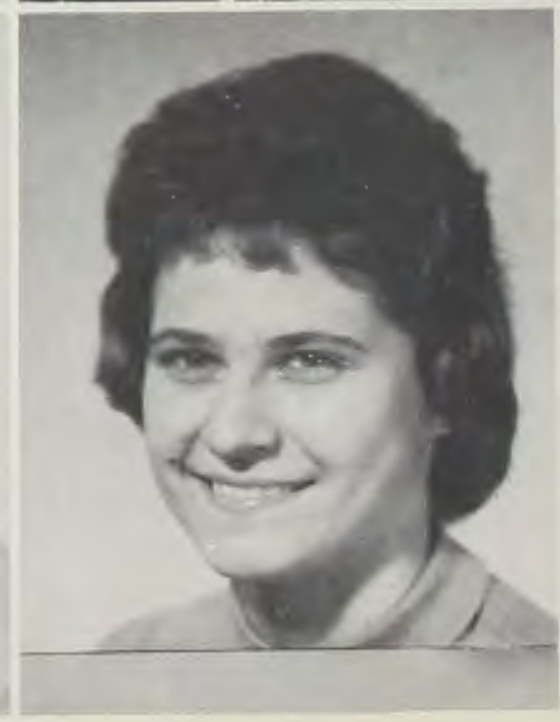




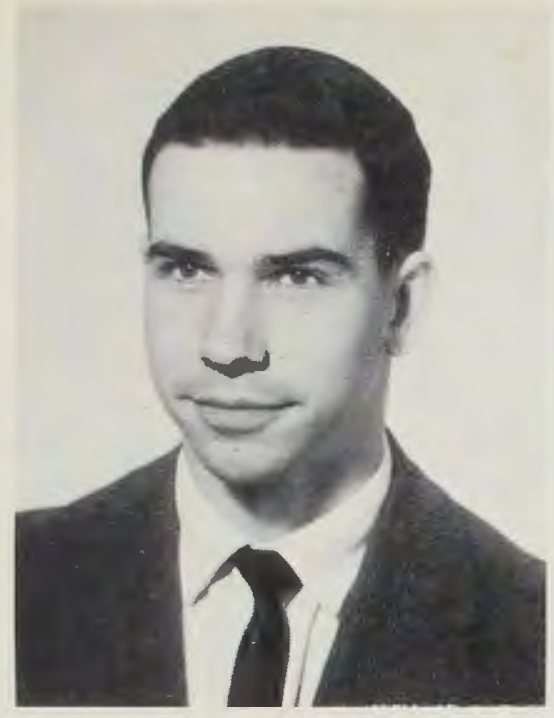

LARRY HELMICK

Traverse City, Michigan

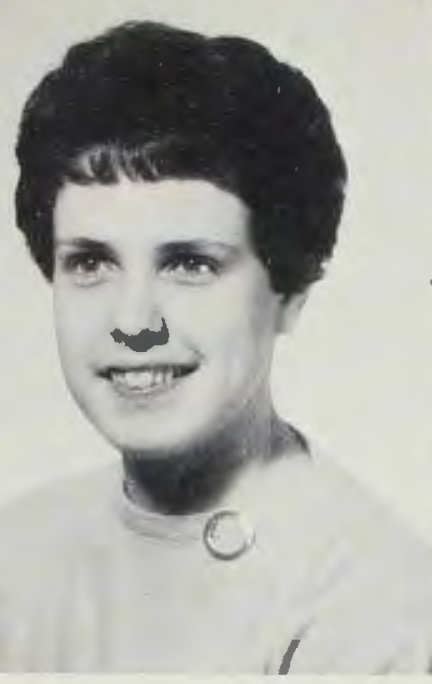

ELAYNE HOWARD Chicago, Illinois

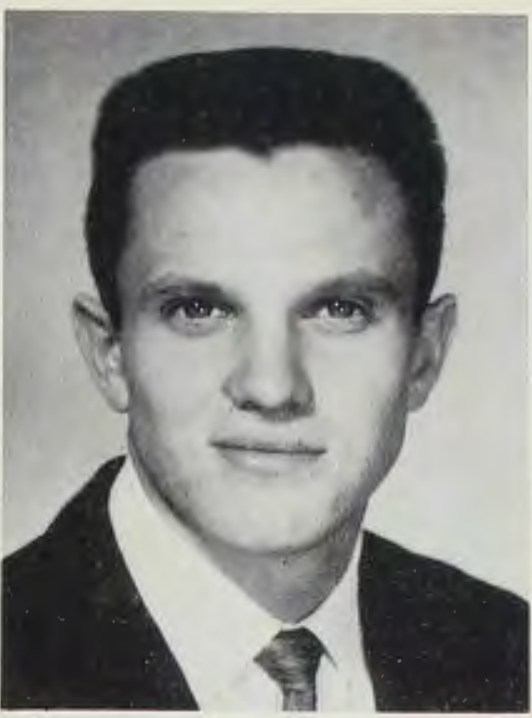

ELLIS HOWARD

Williamston, Michigan

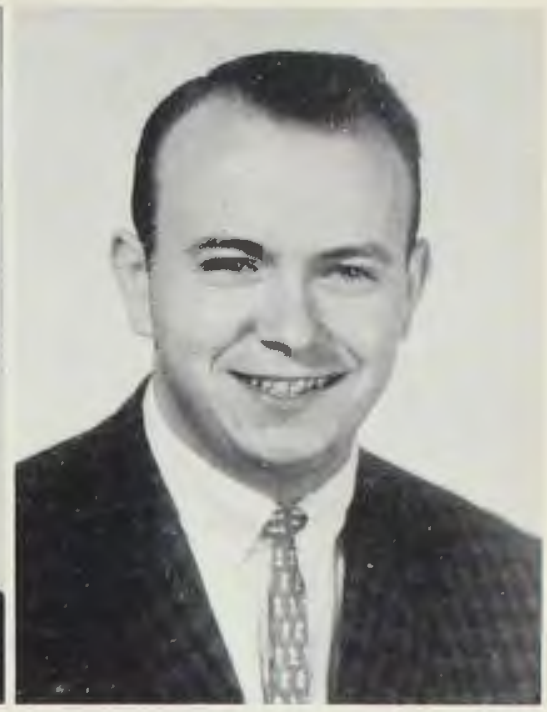

JOHN INGRAM

Columbus, Ohio

\section{Juniors}

LEE IRELAN

Waterloo, Iowa

PRISCILLA JOINER

Cedarville, Ohio
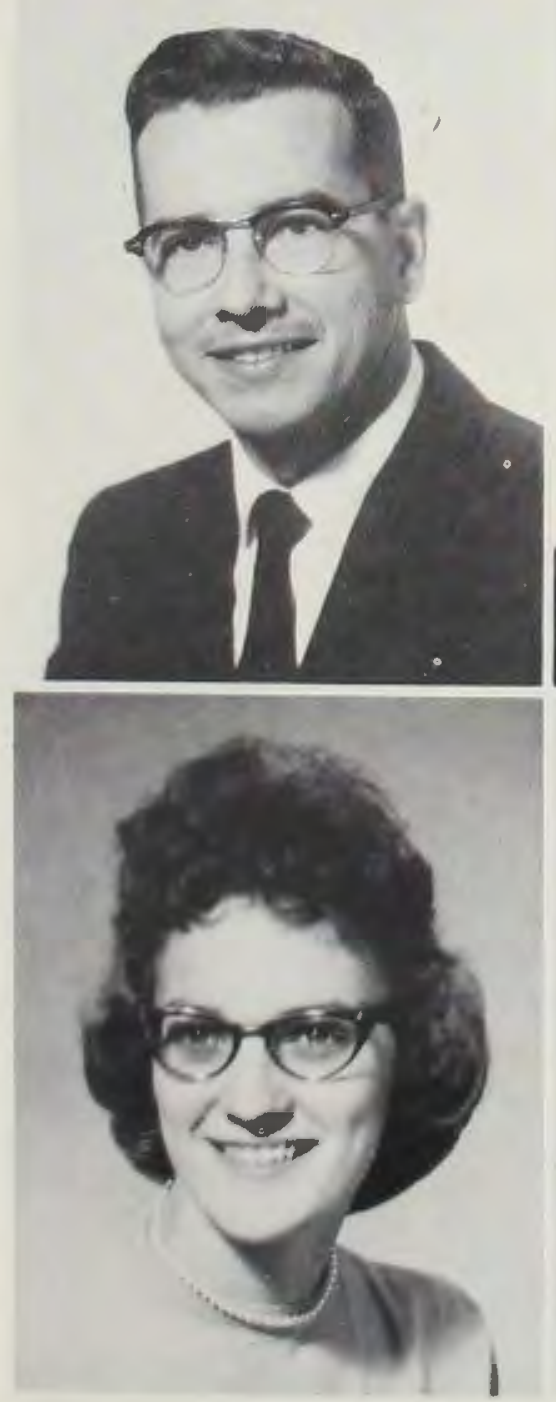

LYNN JEFSON

Forest City, Iowa

MARLIN KING

Dayton, Ohio
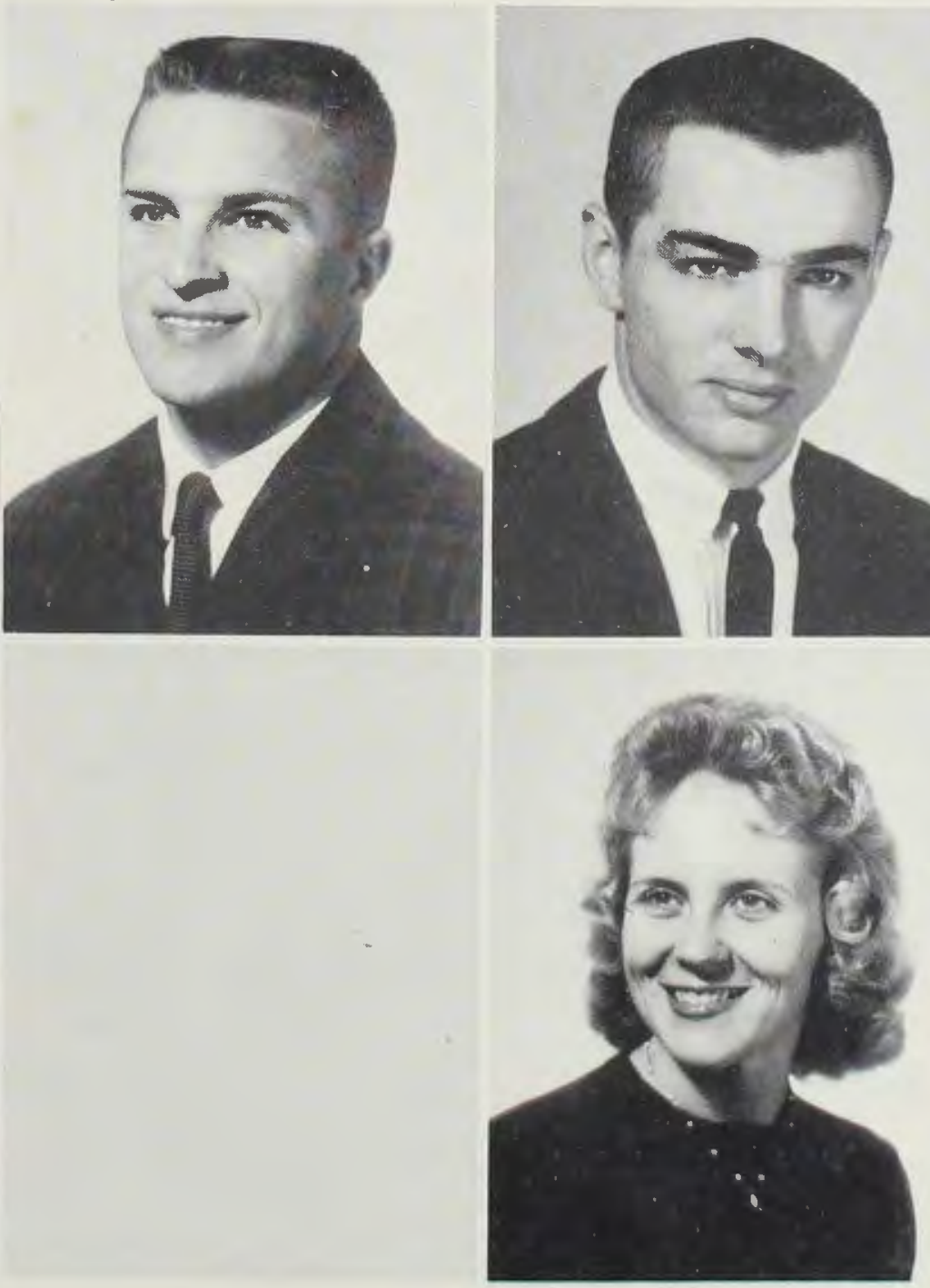

DAVE JEREMIAH

Cedarville, Ohio.

JUDY ANN LACHMAN

Lorain, Ohio
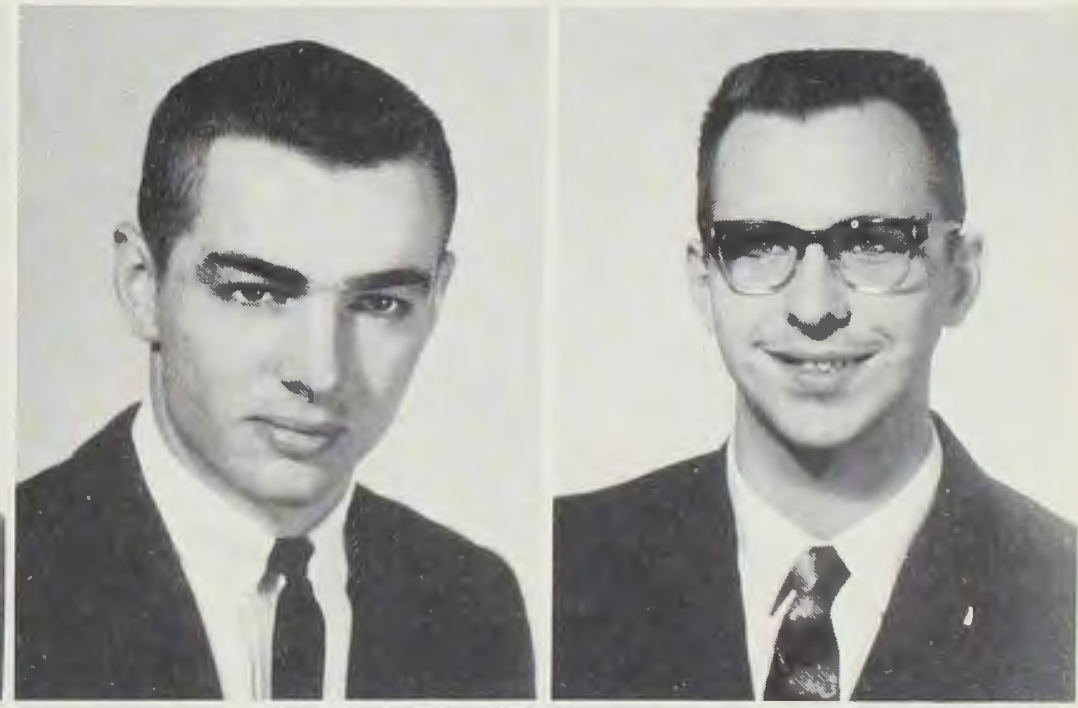

DONALD JOHNSON

Kennedy, New York

IRENE LANE

Cincinnati, Ohio 


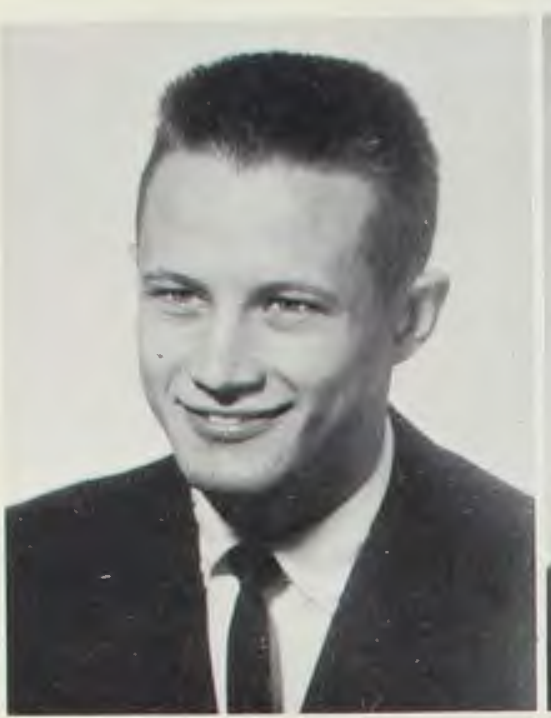

JOHN LAWLOR

Cedarville, Ohio

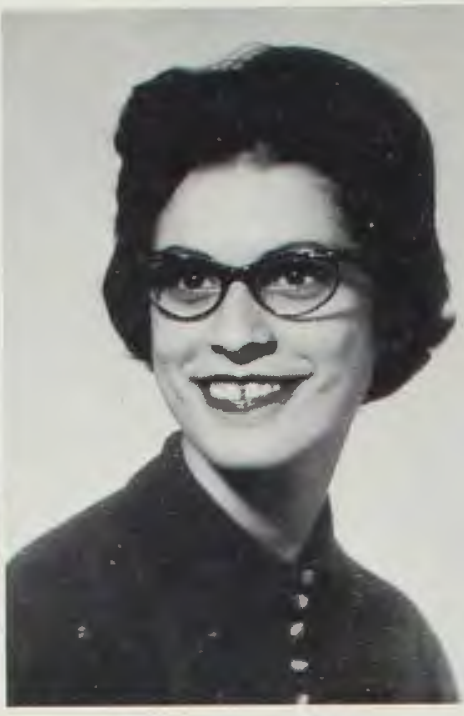

JUDIE LEIBY

Northfield, New Jersey

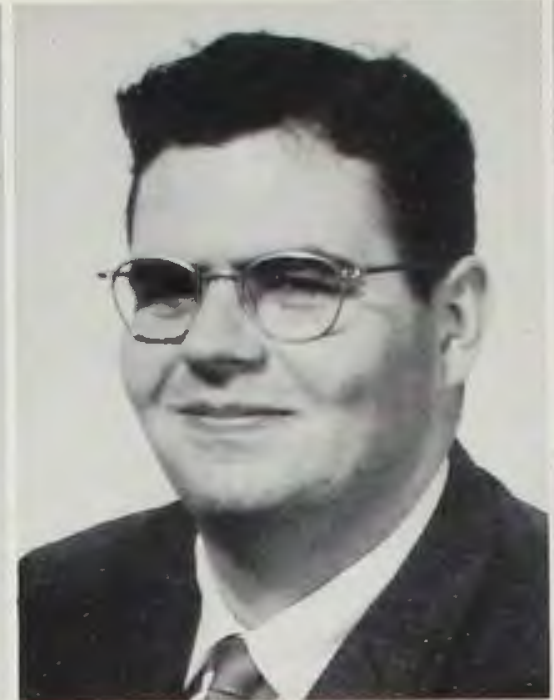

JOSEPH LIOYD

Elyria, Ohio

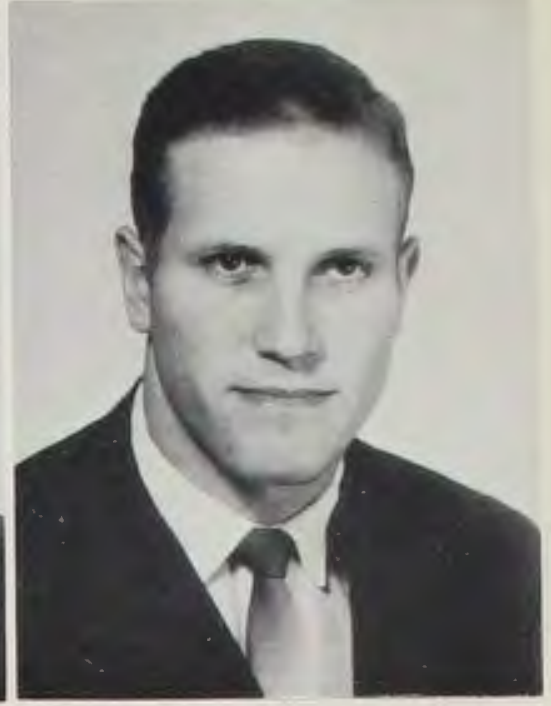

WILLIAM LOBSIGER

Saginaw, Michigan

\section{Juniors}

BETTY MC KEEHAN

Galion, Ohio

CHARLES OEHMCKE

Wauwatosa, Wisconsin
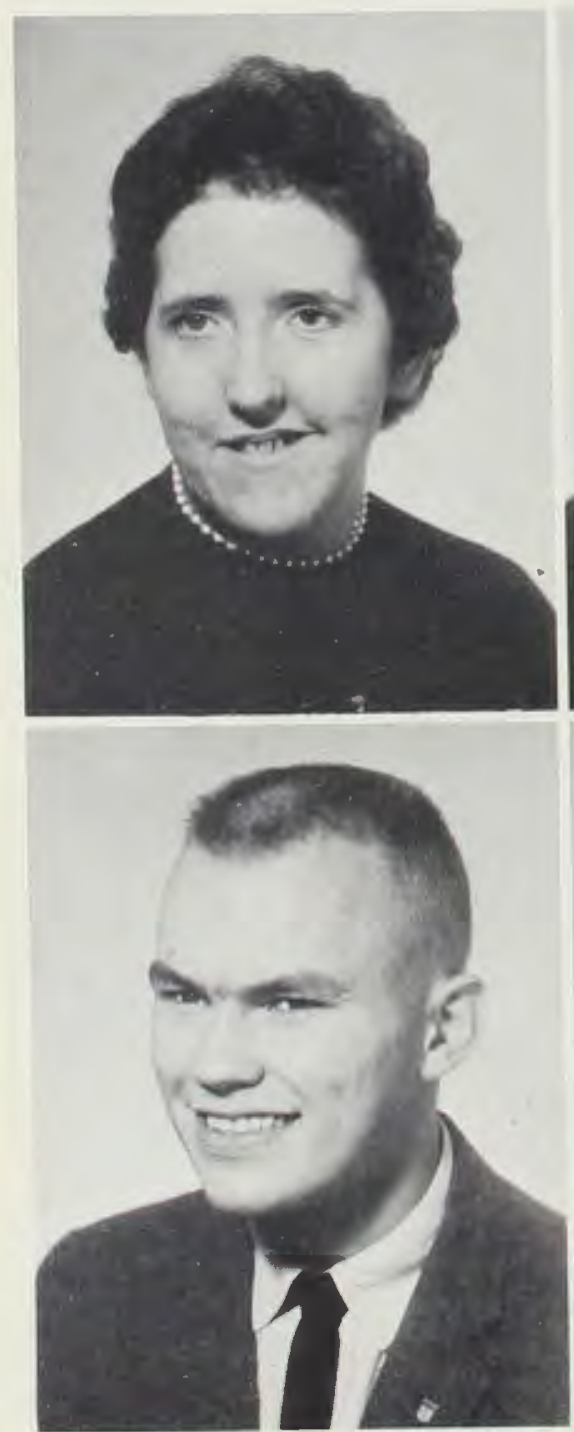

DON MIDDLETON

Media, Pennsylvania

ALOHA PATCH

Austin, Mirinesota
J. W. MOFFAT

Cedarville, Ohio

KENNETH PYCRAFT

Elyria, Ohio
TED OCHELTREE

St. Albans, West Virginia

CLARA QUITER

Allen, Michigan
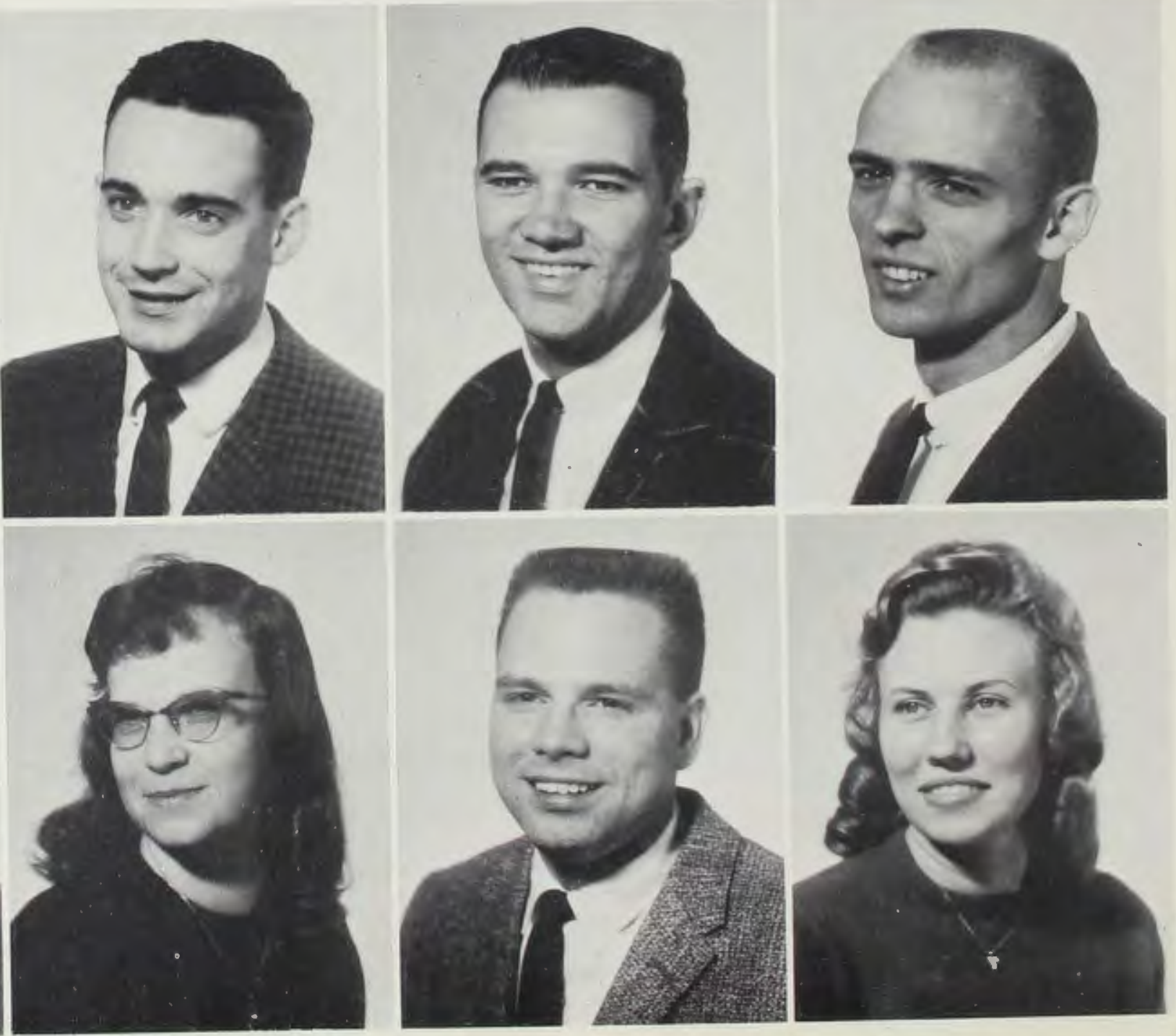


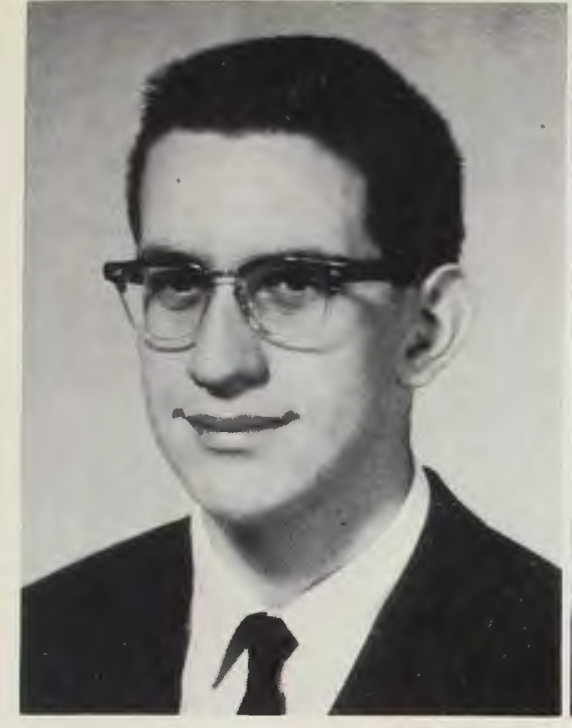

DAVID RIFENBERICK Spartansburg, Penn.

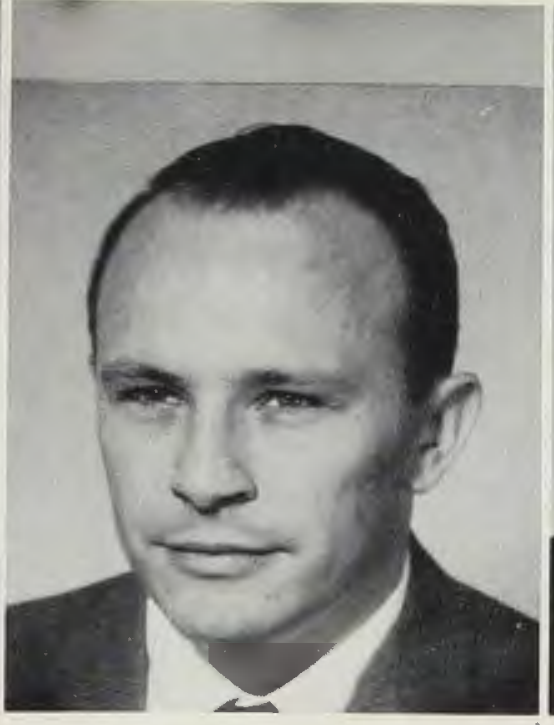

HAROLD RODIN

Cedarville, Ohio

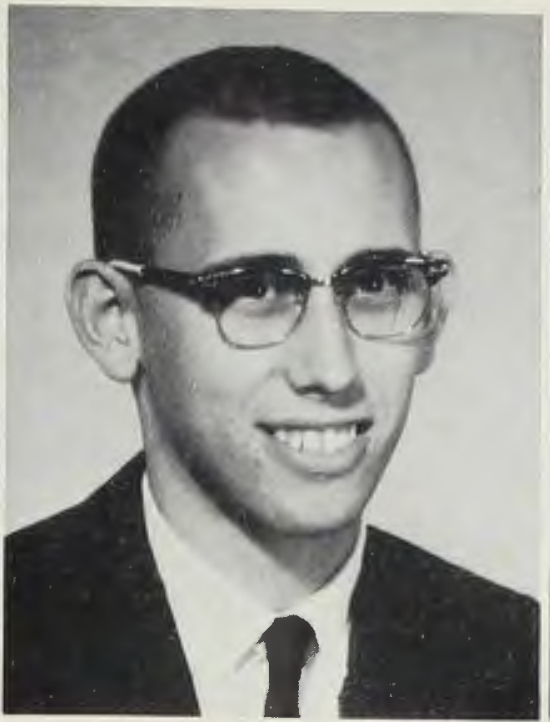

LAUREN H. SCHENCK Cedarville, Ohio

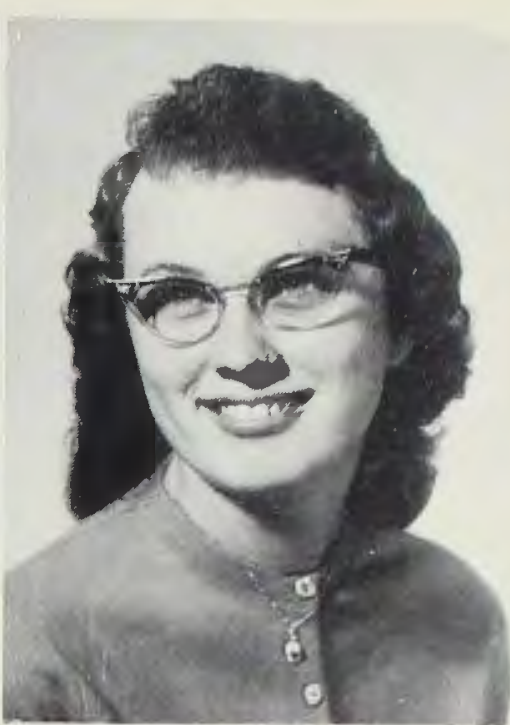

MOLLIE SCHMITT

Hillsdale, Michigan

\section{Juniors}

PATRICIA T.

SCHONSCHECK

Allen Park, Michigan

DONNA MARILYN

THOMPSON

Chesterland, Ohio

\section{CATHERINE SHELTON}

Howell, Michigan

EVELYN THOMS

Sylvania, Ohio
NORRIS H. SMITH

Kirkersville, Ohio

LOUISE VARISCO

Strongsville, Ohio
DON TENNANT

Bellefontaine, Ohio

JERRY WAGNITZ

Wixom, Michigan
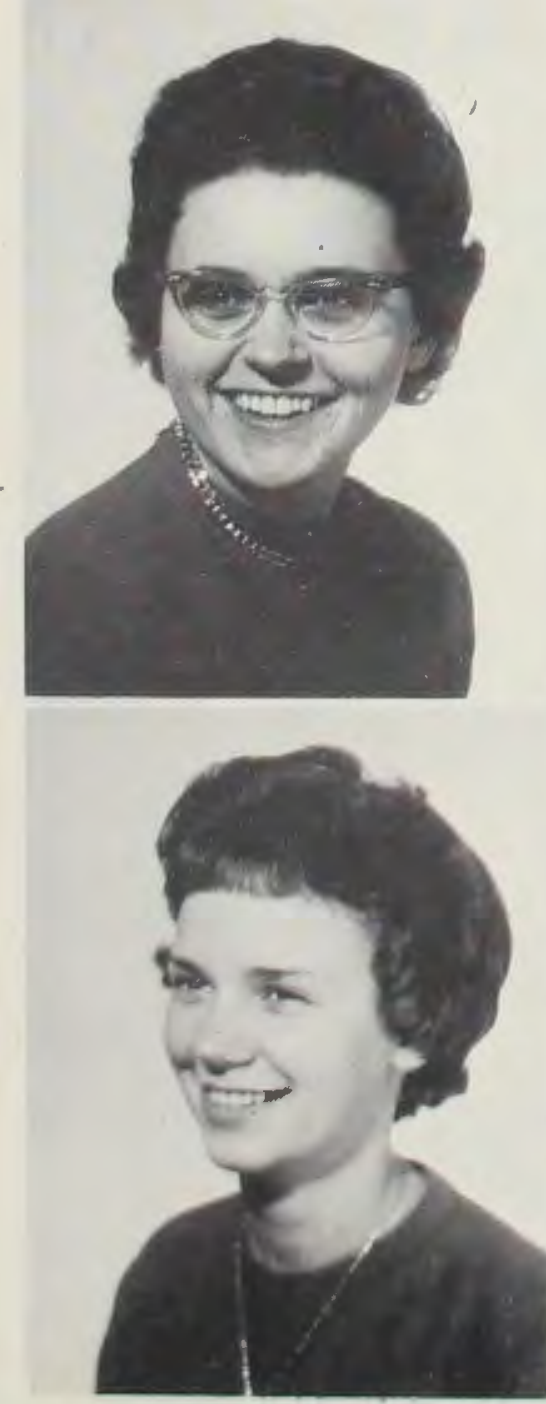

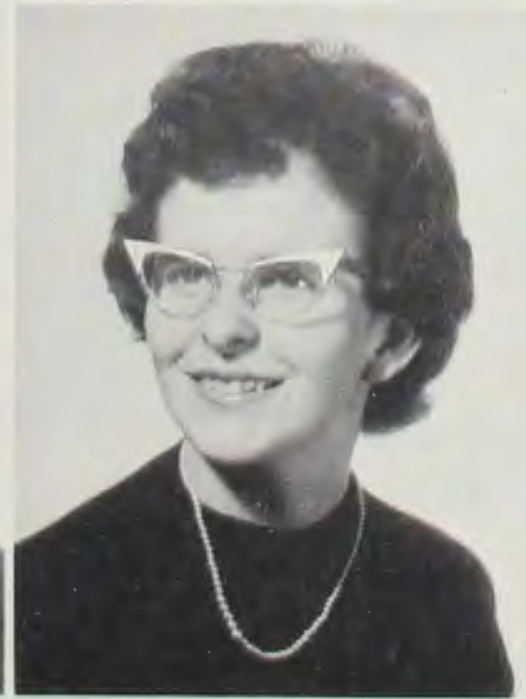

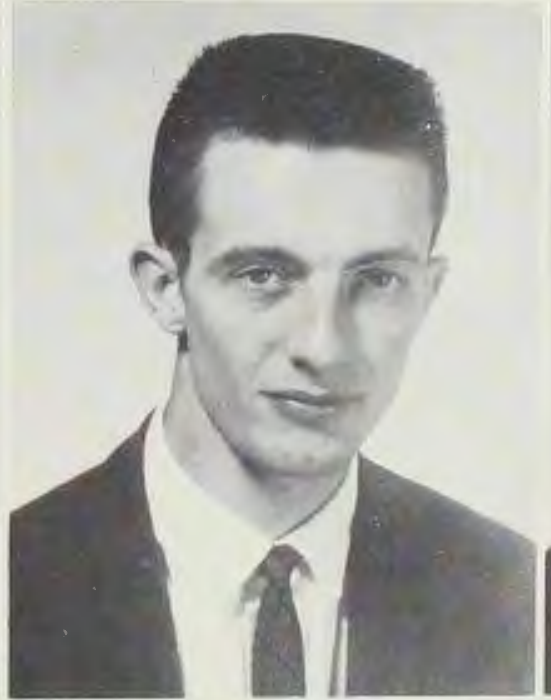
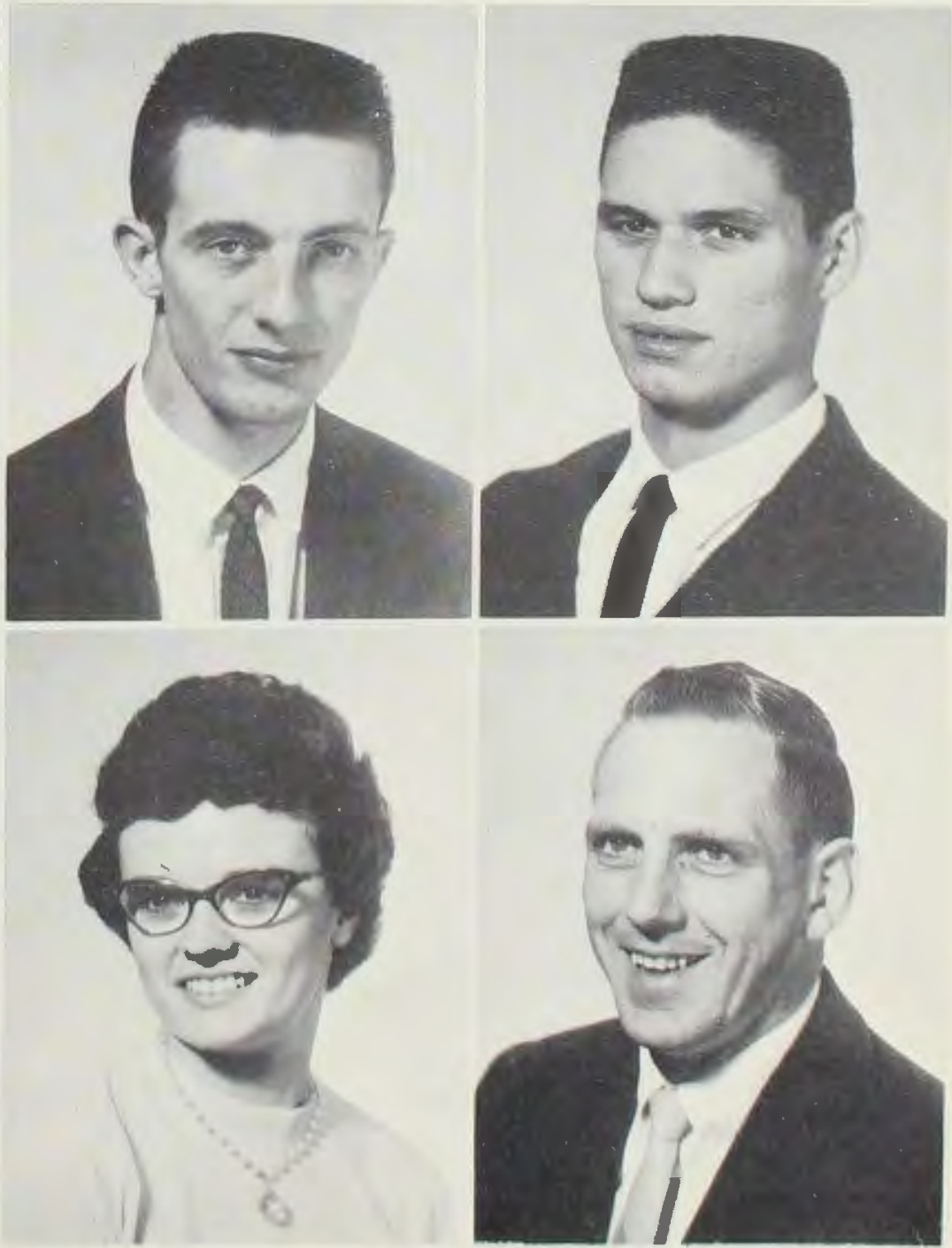


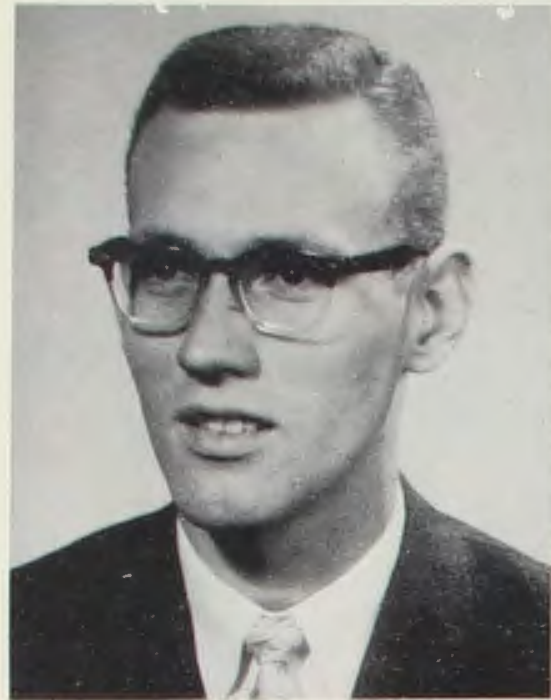

WILLIAM WARFIELD

Elmhurst, Illinois

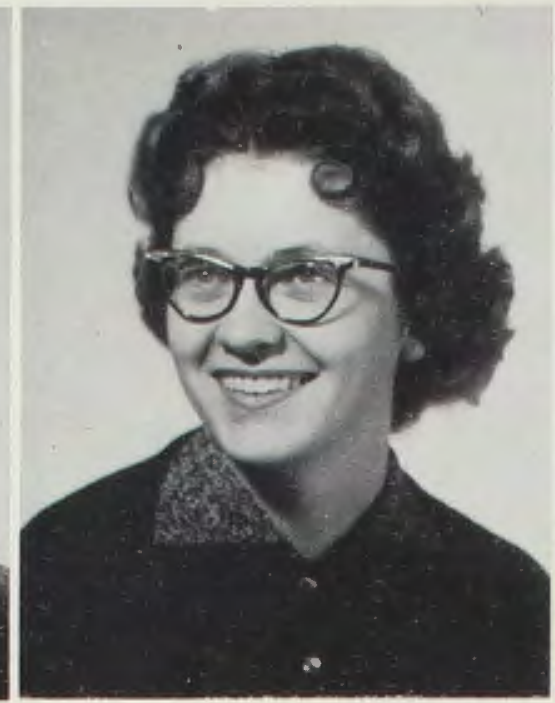

NANCY WARKENTIN

Waverly, Iowa

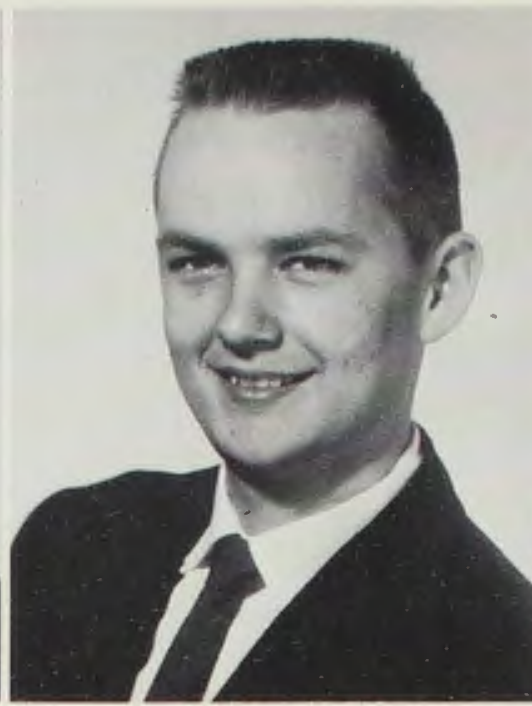

BILL WASHBURN

Xenia, Ohio

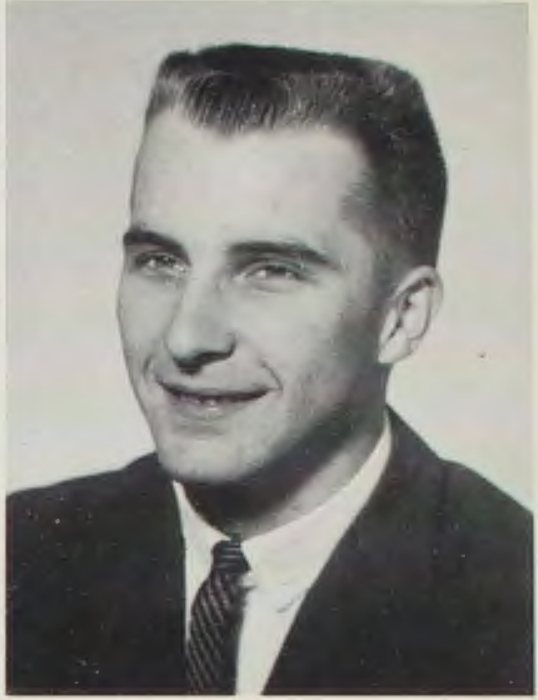

RALPH $\mathrm{H}$.

WERNER, JR.

Columbia Falls, Montana

\section{Juniors}

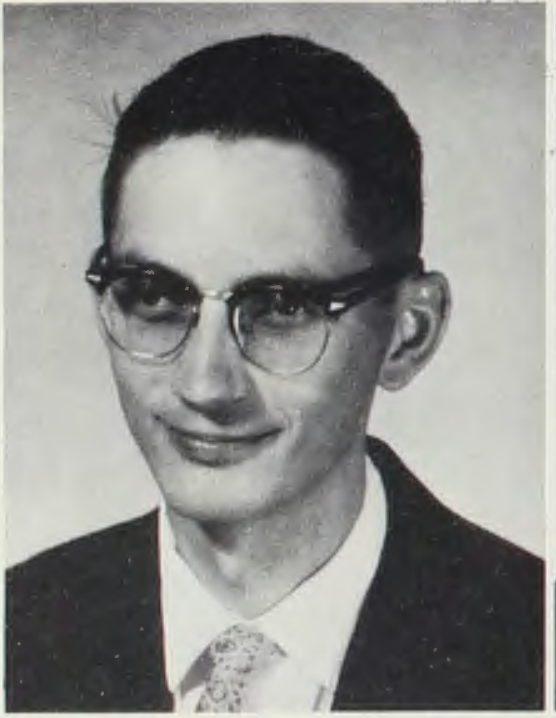

IRVING WOODARD Jamestown, New York

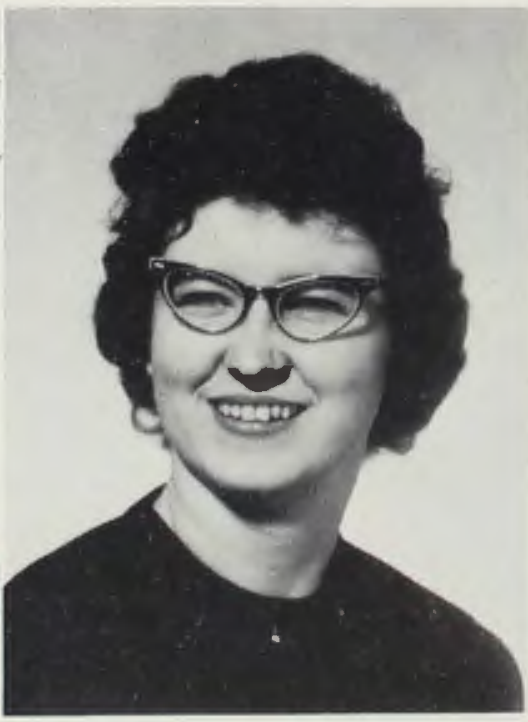

BEVERLY WOODS

Fostoria, Ohio 


\section{Campus}

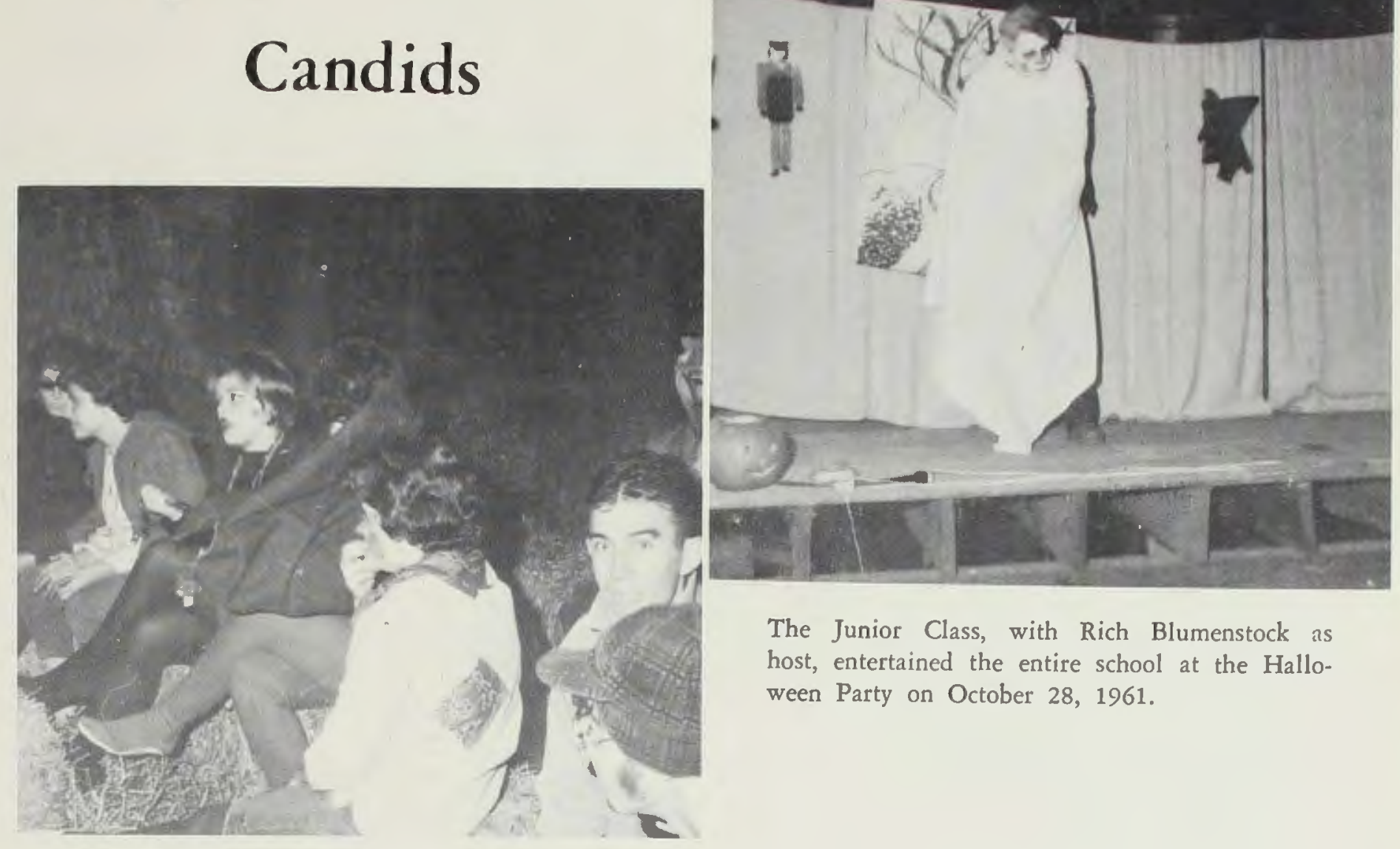

Mr. Wyse, Mr. Cooke, Mr. Barker, and Mr. Thomson delight us all as they sing in the new "Faculty Four Quartet."

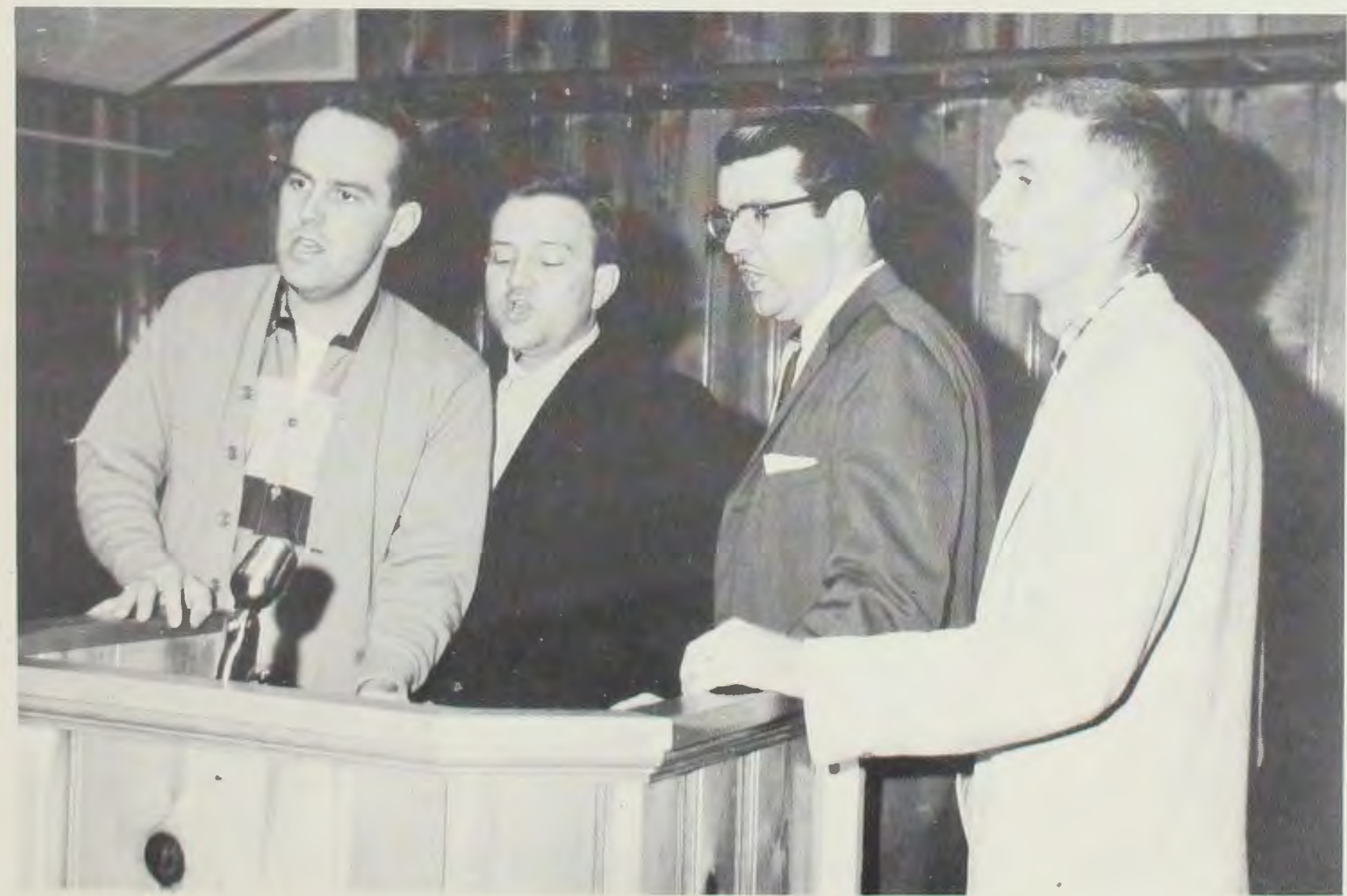




\section{Sophomore}

\section{Class}

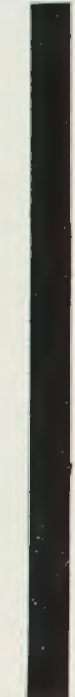

\section{MOTTO}

Those who kneel before God will stand before men.

\section{VERSE}

... that in all things He might have the pre-eminence.

Colossians $1: 18 \mathrm{~b}$

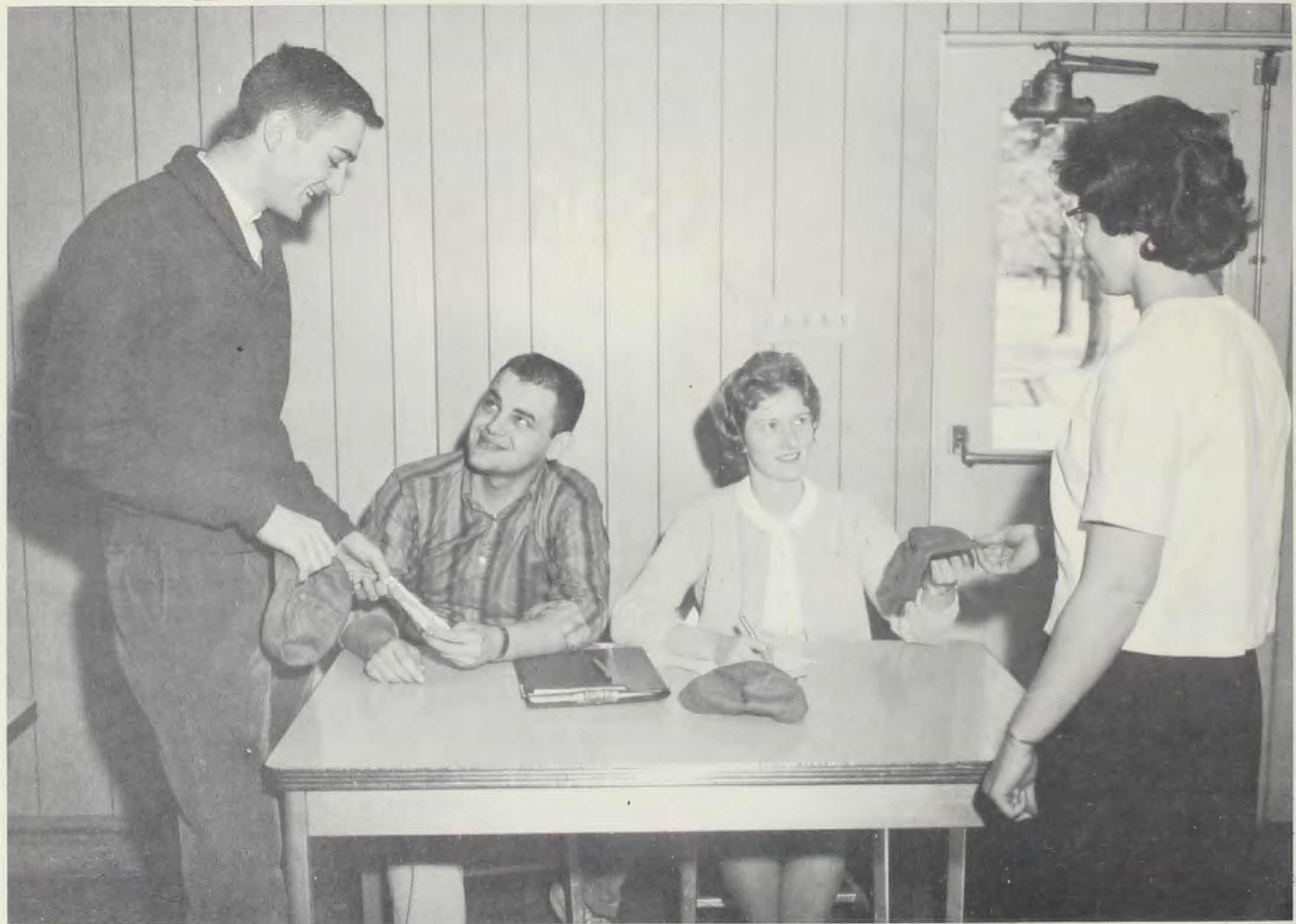

Revenge is found by the Sophomore Class when they have the privilege of initiating the freshmen. 


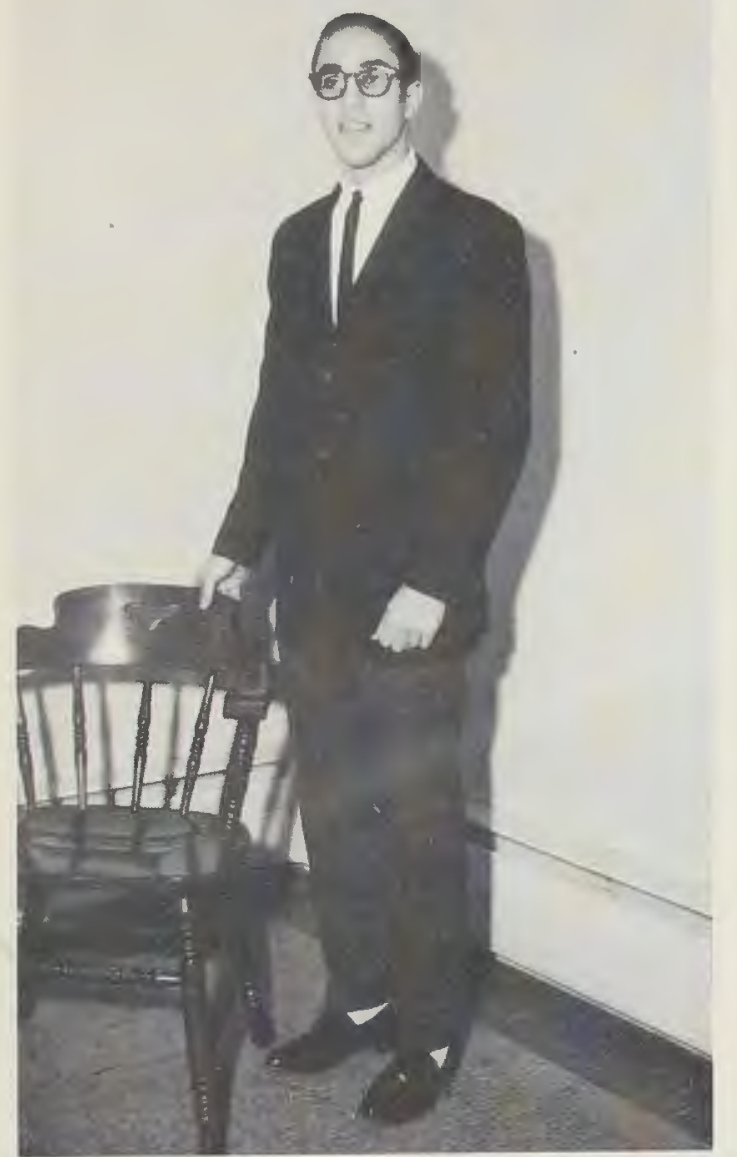

Tom DeLanzo, President.

\section{Class Officers}

For

1961-62
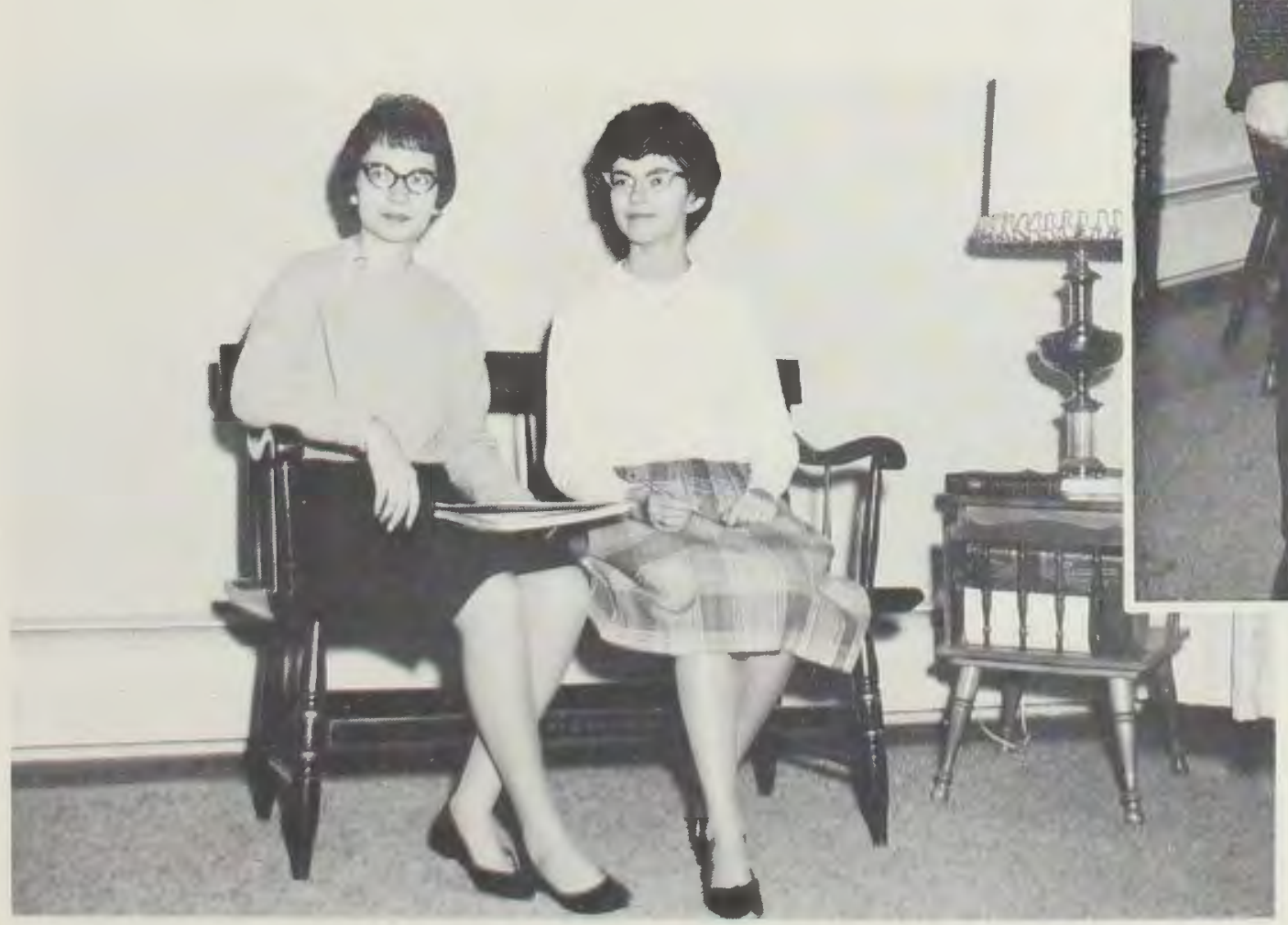

Chet Russell, Social Chairman; John Morgan, Vice-Presi-

dent; Bob Reynolds, Chaplain.

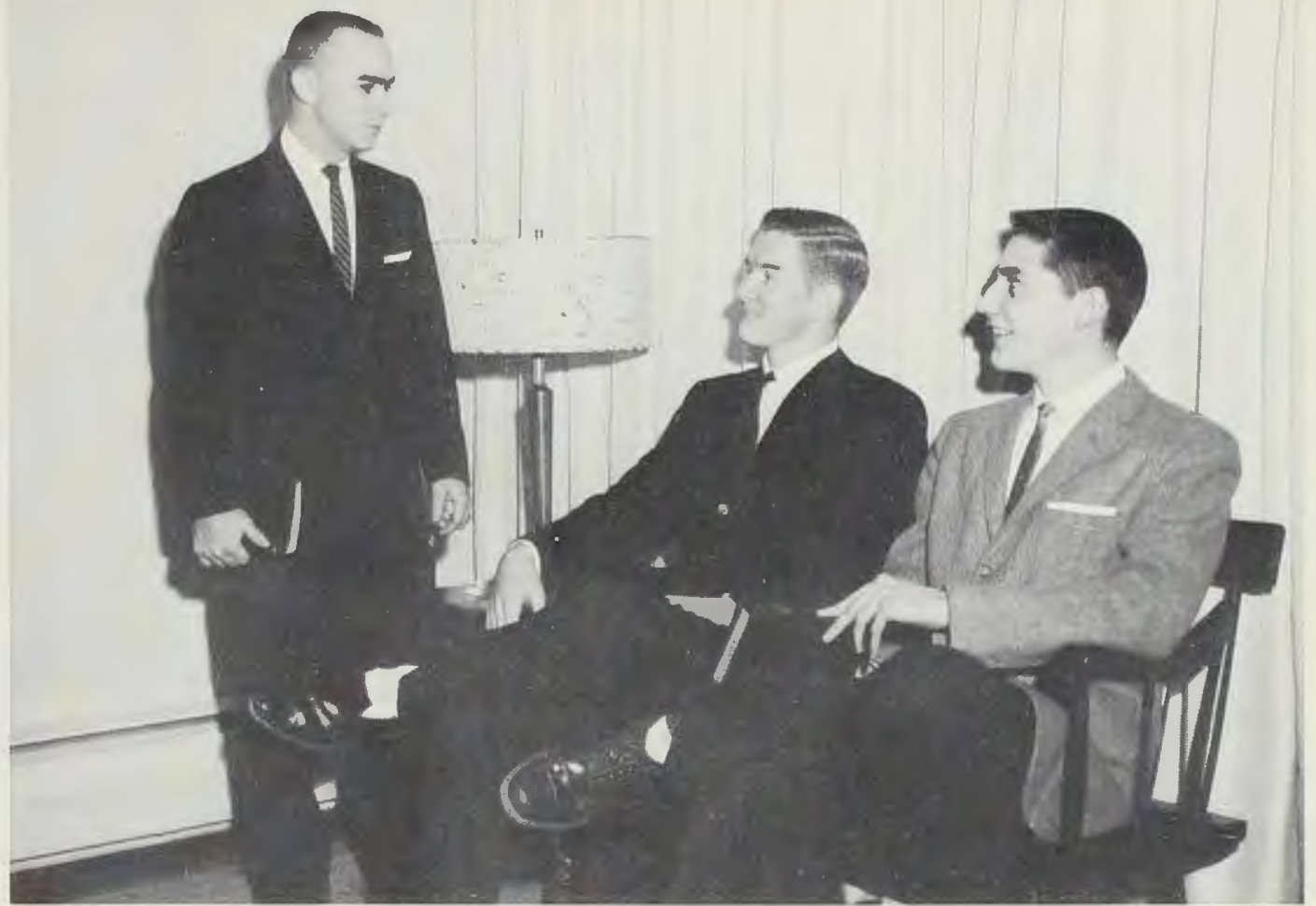

Pat Micka, Treasurer; Betty Wall, Secretary. 

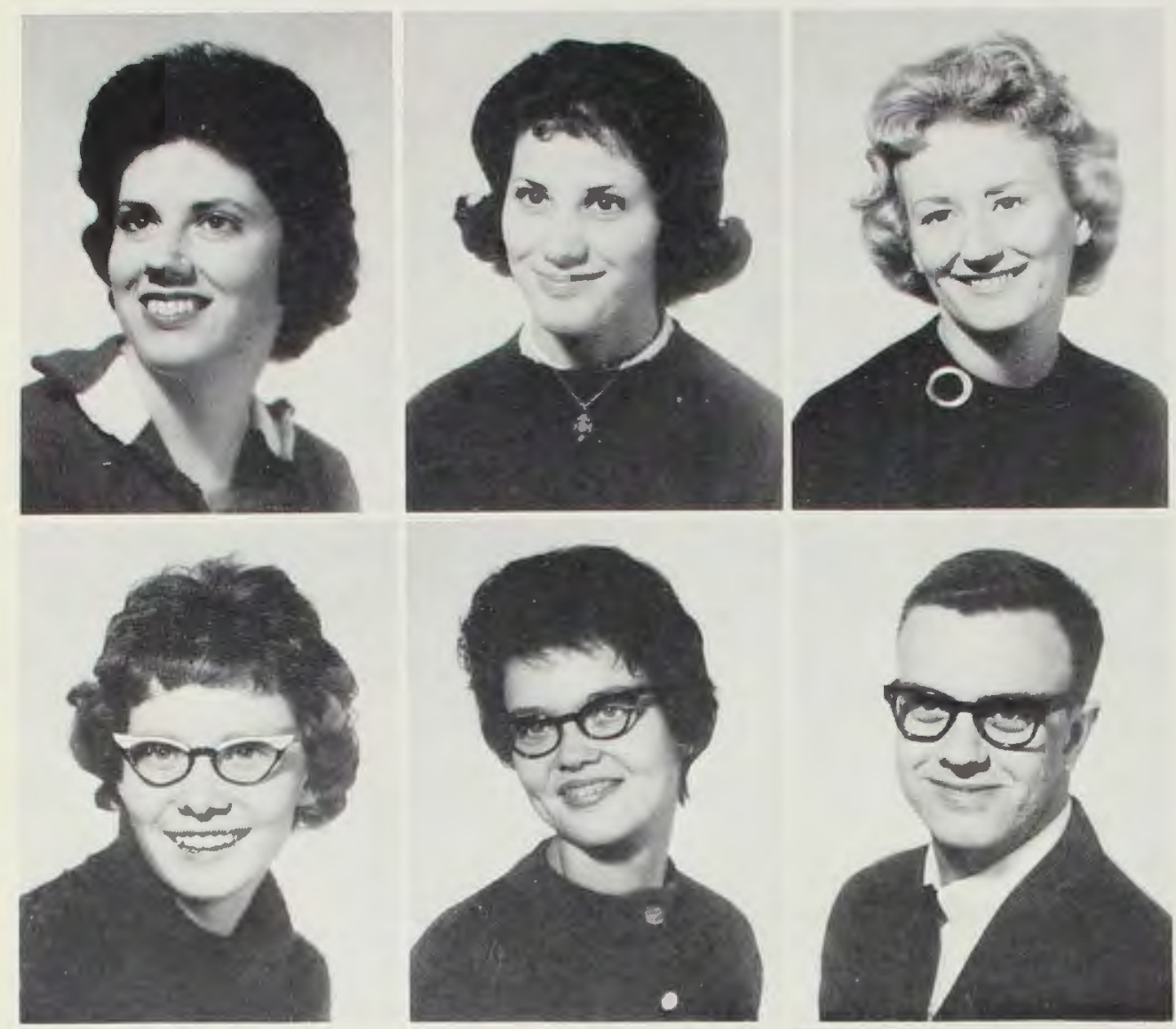

ROBERT G. AUFFORT

Collingswood, New Jersey

LAURENCE BAKER

Taylor, Michigan

PAT BARRETT

Muscatine, Iowa

LOIS BAYLESS

Yuma, Arizona

DENNIS A. BELLEW

Cincinnati, Ohio

SALIY BENDER

Clendenin, West Virginia

CHARLOTTE BET'TS

Rochester, Minnesota

BARBARA BLACKBURN

Elora, Tennessee

MARY BLANN

Bismarck, North Dakota
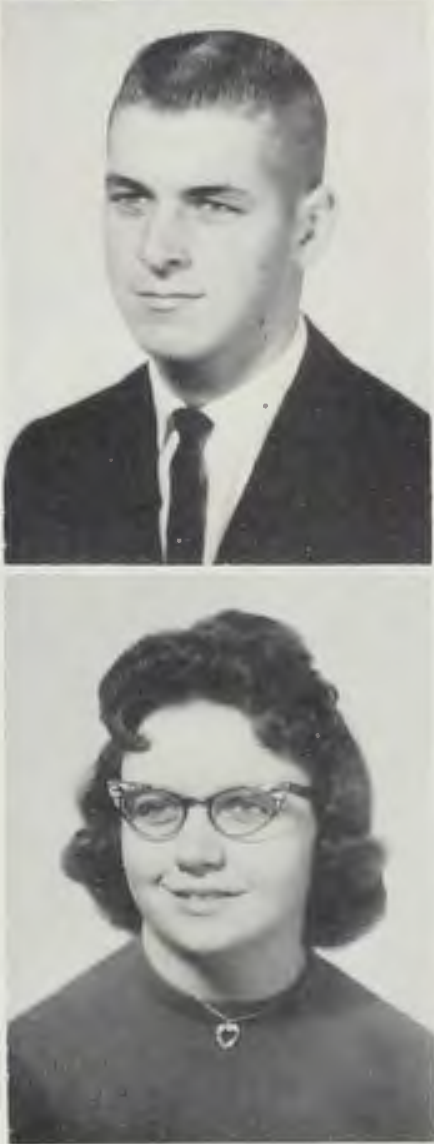

\section{Sophomores}

ELAINE ADAMS

East Brady, Pennsylvania

\section{PAT ADAMS}

Silvis, Illinois

BETTE ADAMSON

Perry, Iowa

SHARON KAY ADDLEMAN

Hillsdale, Michigan

BARBARA ALEXANDER

Bellefontaine, Ohio

KEN ATKINS

Charleston, West Virginia
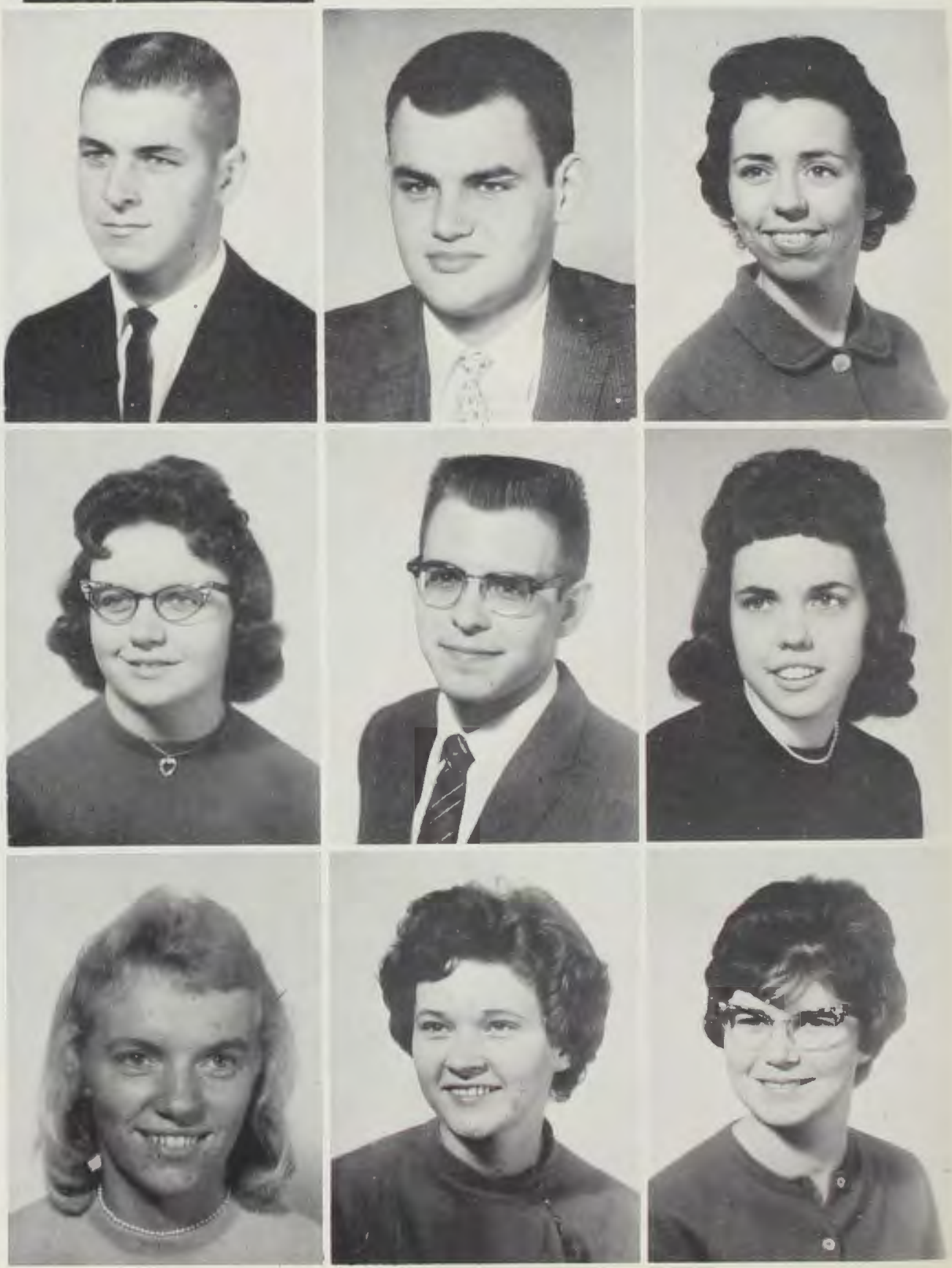
CHARLENE BLOEMER

Covington, Kentucky

GALE BROOKS

Clarion, Pennsylvania

THOMAS W. BROWN

Eagle Grove, Iowa

JOAN BRYANT

Akron, Ohio

TYRONE BRYANT

Akron, Ohio

PHILIP BUCHANAN

Glasgow, West Virginia
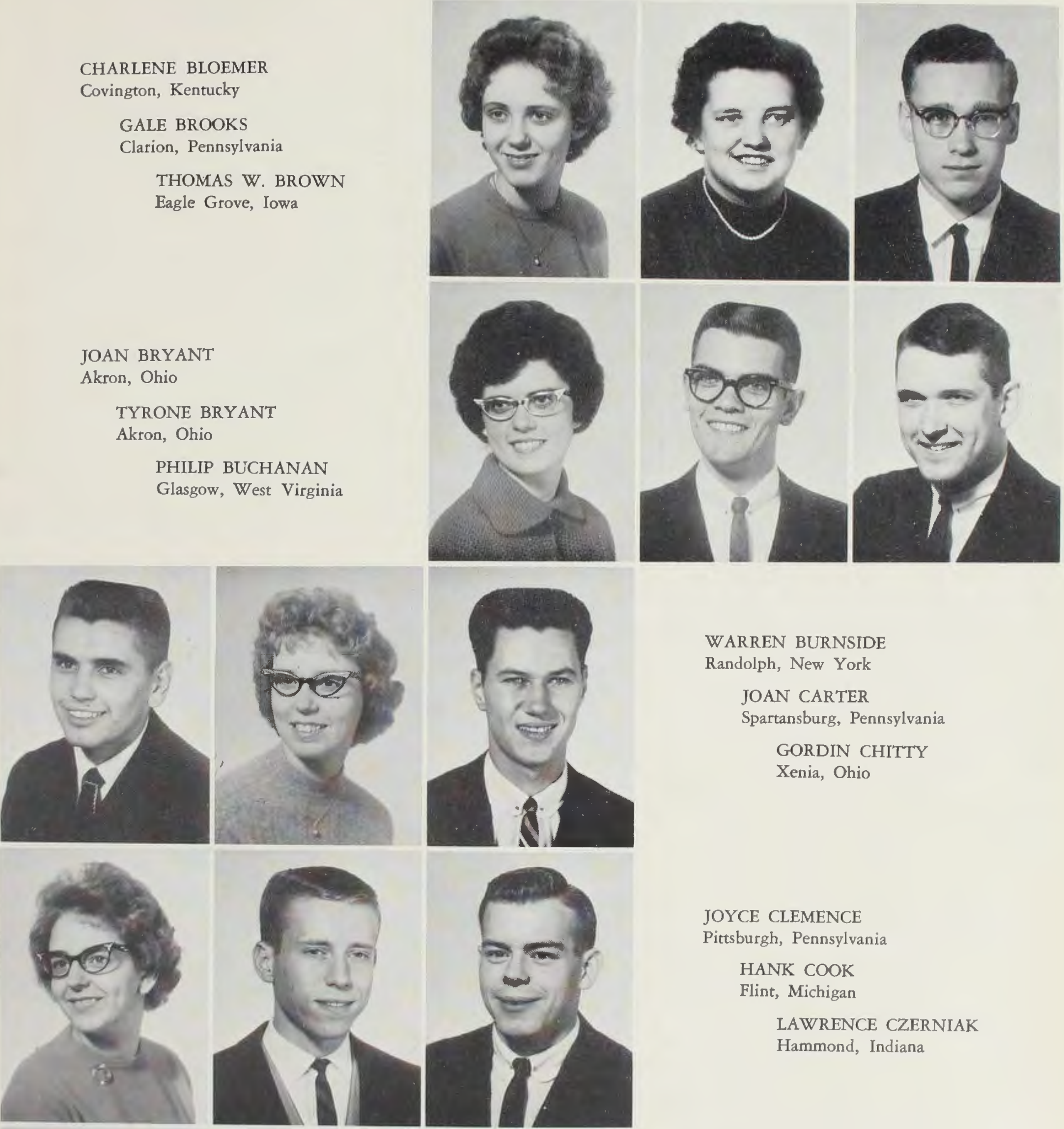

WARREN BURNSIDE
Randolph, New York

JOAN CARTER

Spartansburg, Pennsylvania

GORDIN CHITTY

Xenia, Ohio

JOYCE CLEMENCE

Pittsburgh, Pennsylvania

HANK COOK

Flint, Michigan

LAWRENCE CZERNIAK

Hammond, Indiana

HOWARD L. DAY

Portsmouth, Ohio

TOM DE LANZO

New Castle, Pennsylvania

NANCY DICKSON

DeQueen, Arkansas 

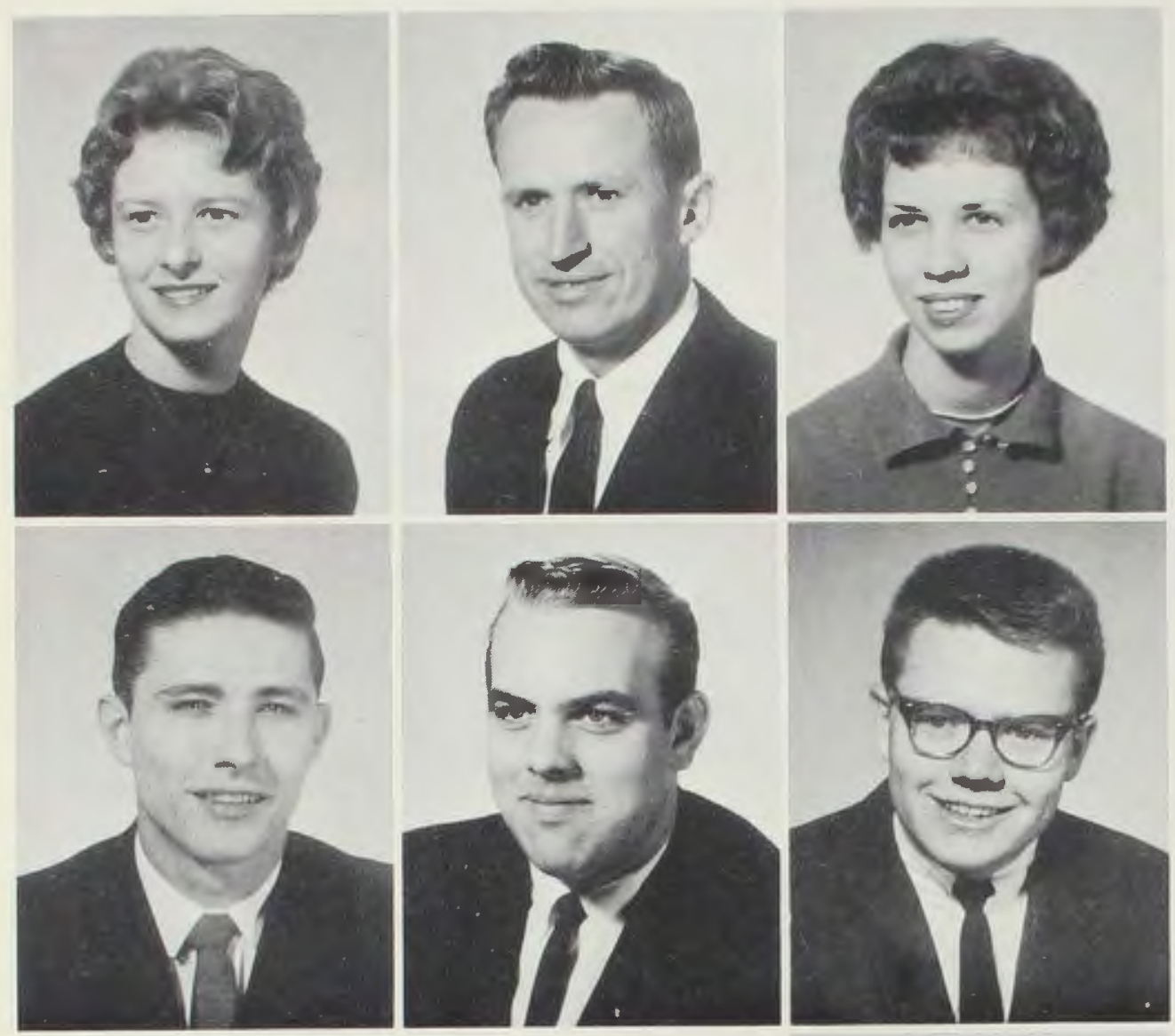

DAVE FETZER

Cleveland Heights, Ohio

GORDON L. FINLEY

Faribault, Minnesota

SUE FULLHART

Perry, Iowa

SUZANNE G. GEYSER

Berea, Ohio

JUDITH MARIE GINGELL Lapeer, Michigan

SHIRLEY GOODMAN Mentone, Indiana

MARY GOODWIN

Oak Forest, Illinois

\section{DAVID GORDON \\ Springfield, Ohio}

CAROL GORTHEY

Broadalbin, New York

\section{Sophomores}

\section{LOIS DUDDLESTON}

Decatur, Illinois

ROBERT E. EDWARDS

Sharon Springs, New York

BETH ELMORE

Cedarville, Ohio

\section{RONALD ENGLAND}

Lancaster, Ohio

MARK EVANS

Allen Park, Michigan

\section{T. I. EVANS}

Columbus, Ohio
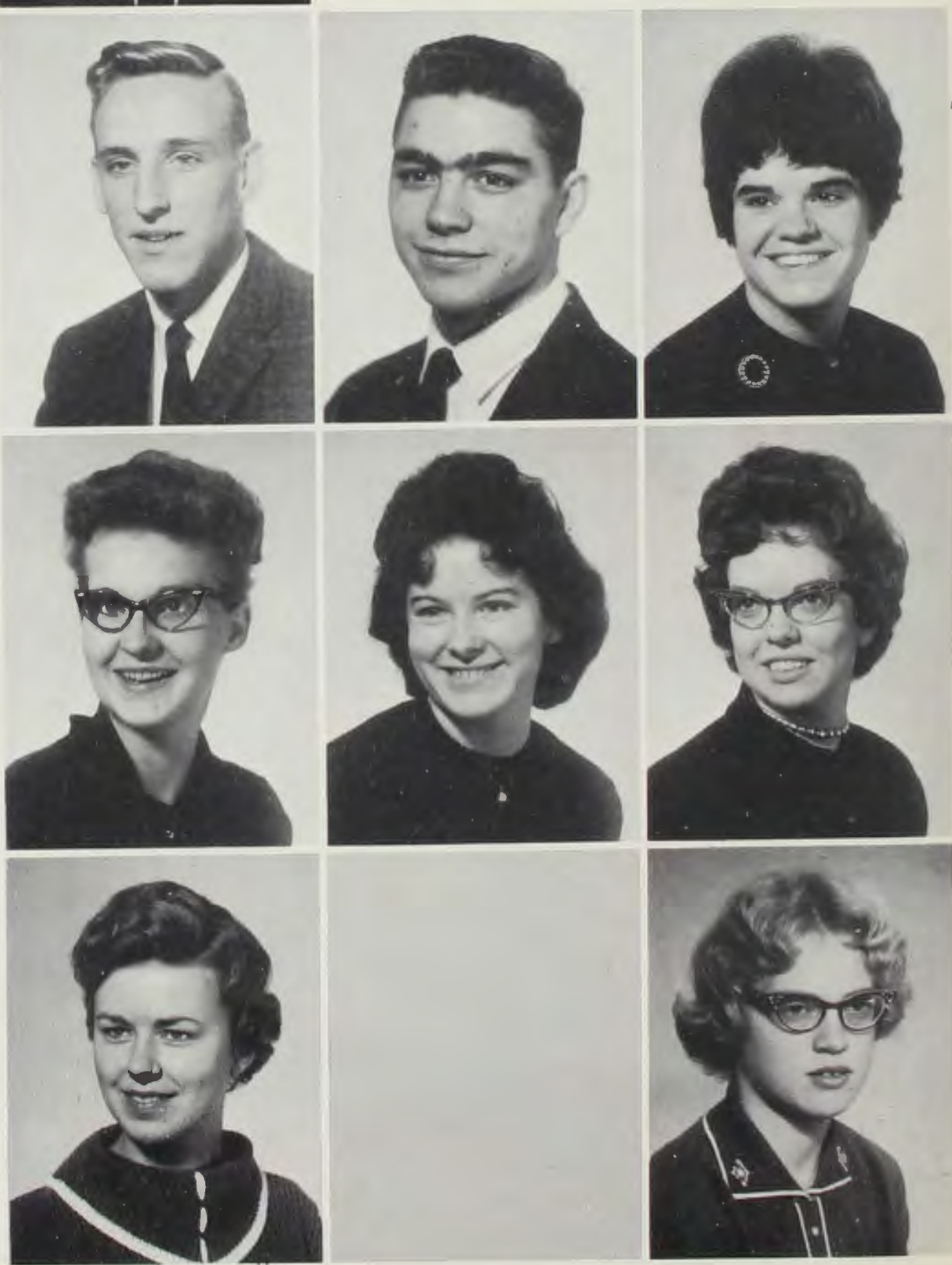
JACK GRAN'T

Miamisburg, Ohio

FAYE MARIE HAAS

Randolph, New York

DARLENE HALE

Toledo, Ohio

JIM HAMILTON

Wilmington, Delaware

DAVID HAMMAN

Mishawaka, Indiana

JEANE HARTSELL

North Adams, Michigan

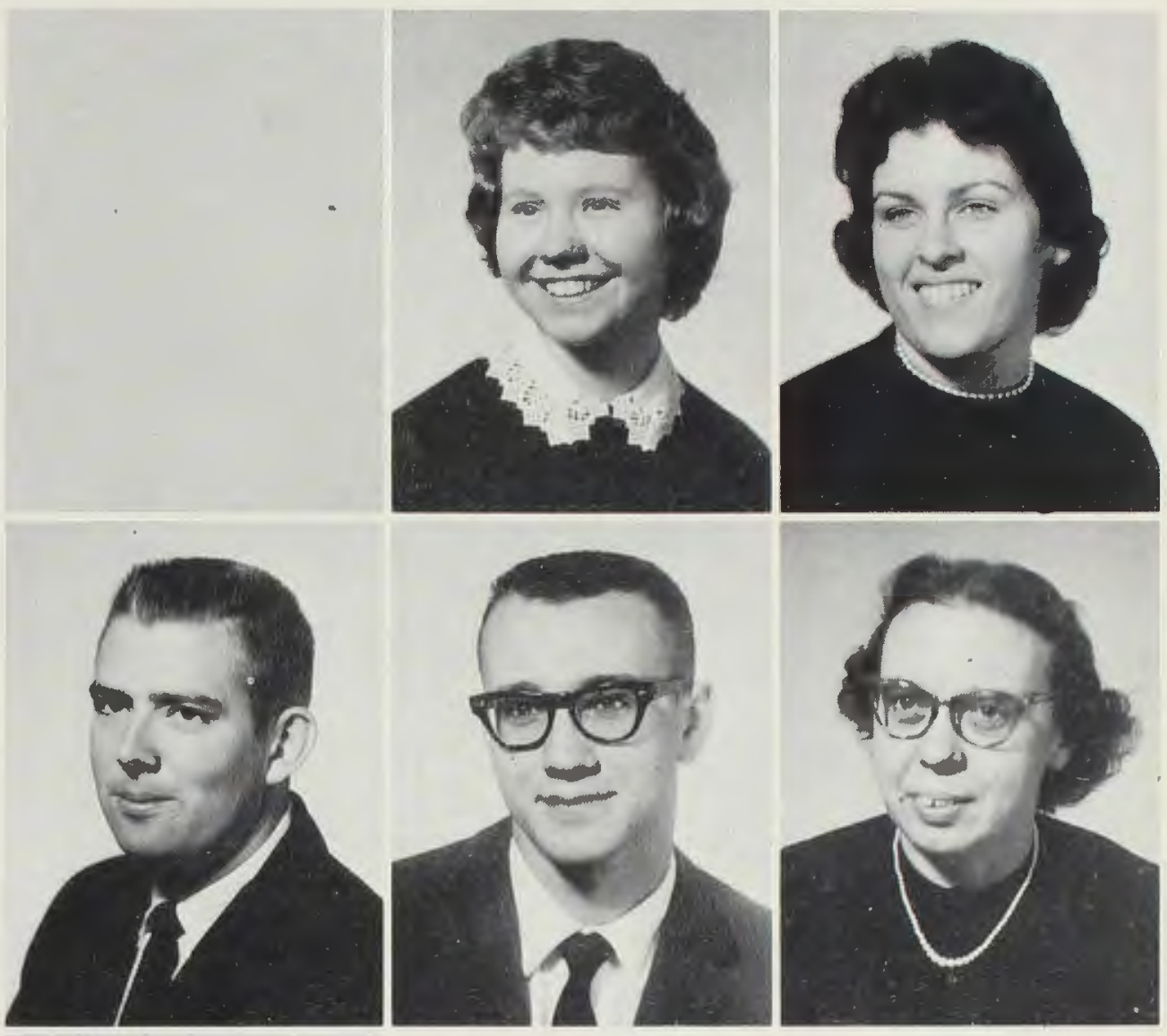

CAROL HENSON

Overland, Missouri

ELSIE MAY HIMSEL
Verona, Wisconsin

ELAINE HIRSCHY

Evans City, Pennsylvania

\section{JUDY HUMPHREYS}

Findlay, Ohio

BONNIE JACKSON

Newark, Ohio

GARY JACOBS

Bay City, Michigan
LOIS JACOBSON

Mt. Vernon, Ohio

DONNA JOHNS

Grove City, Pennsylvania

GARY L. JOHNSON

Silvis, Illinois 

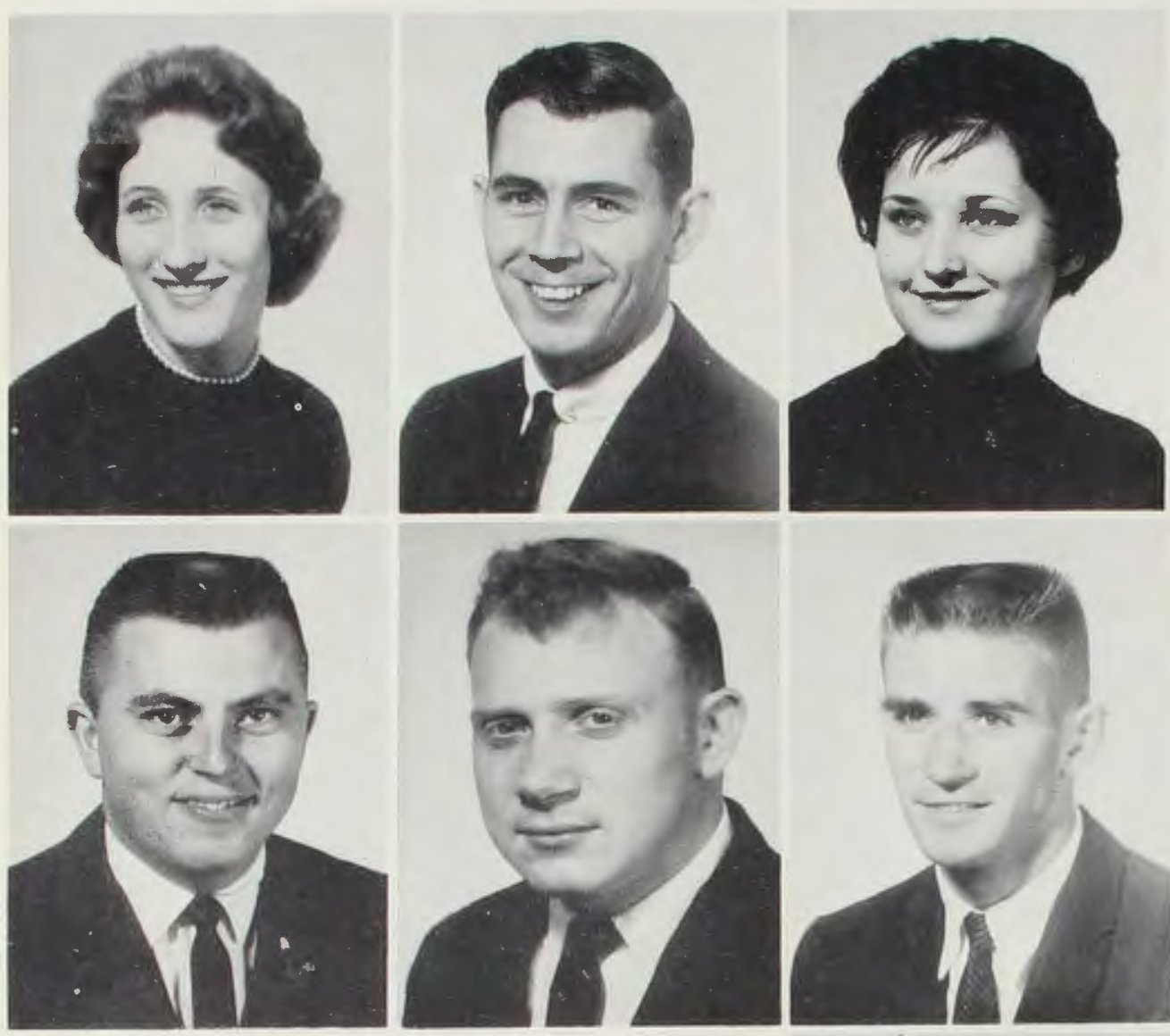

ROD LANE

Midland, Ohio

JANET MCCLISH

Sharon, Pennsylvania

CHARLES A. MC COMBER

St. Clair, Michigan

DENNIS MC DONALD

Lake Orion, Michigan

JAMES MAPLE

Valparaiso, Indiana

SHARON MARKS

Newberry, Michigan

\section{SHERYL MARTIN}

Fort Wayne, Indiana

\section{JUDY MICHAELS \\ Northfield, Ohio}

RONALD MICK

Monroe, Iowa
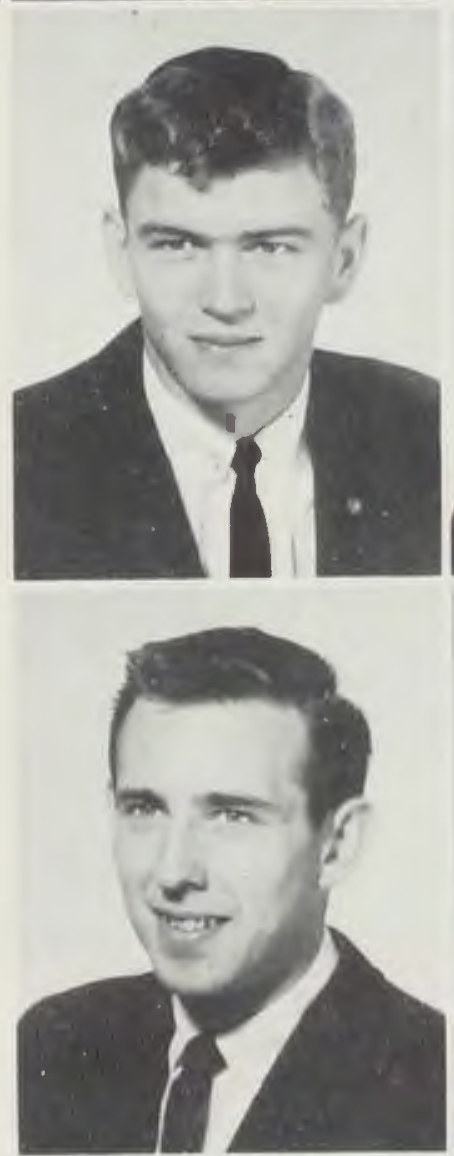

\section{Sophomores}

\section{JOAN ELIZABETH JOHNSON}

Cleveland, Ohio

JAMES JOINER

Cedarville, Ohio

MARIAN KARSNAK

Novelty, Ohio

\section{JAMES KEIM}

Holsopple, Pennsylvania

RICHARD KENSINGER

Grand Rapids, Michigan

ELVIN KING

New London, Ohio
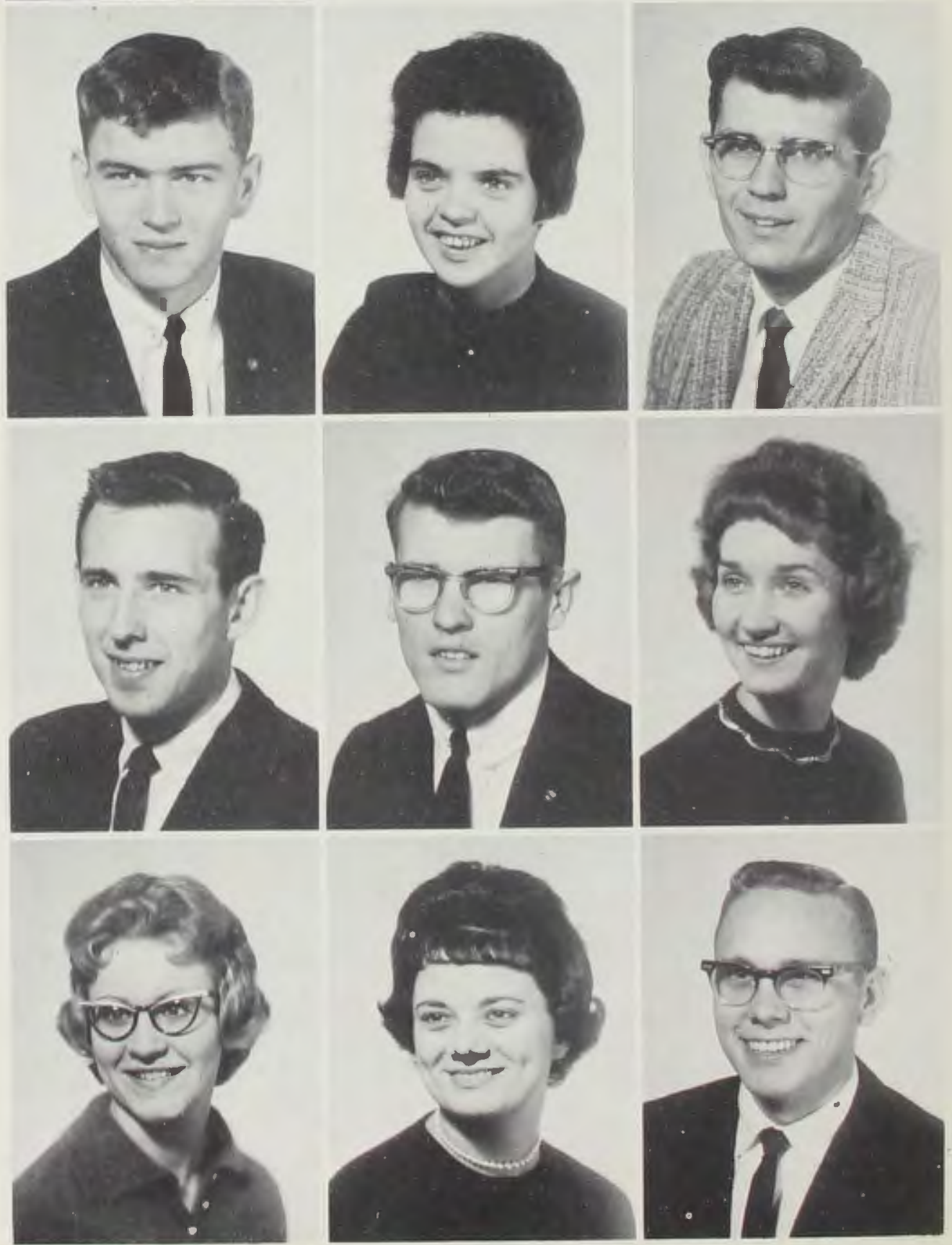
PATRICIA A. MICKA

Ridgefield Park, New Jersey

RITA MILLIKIN

Kalkaska, Michigan

DAVID R. MILLS

Grand Rapids, Michigan

JAY W. MOORE

Verona, Wisconsin

\section{JOHN MORGAN \\ Dysart, Iowa}

BONNIE MAE NASH

Midland, Michigan
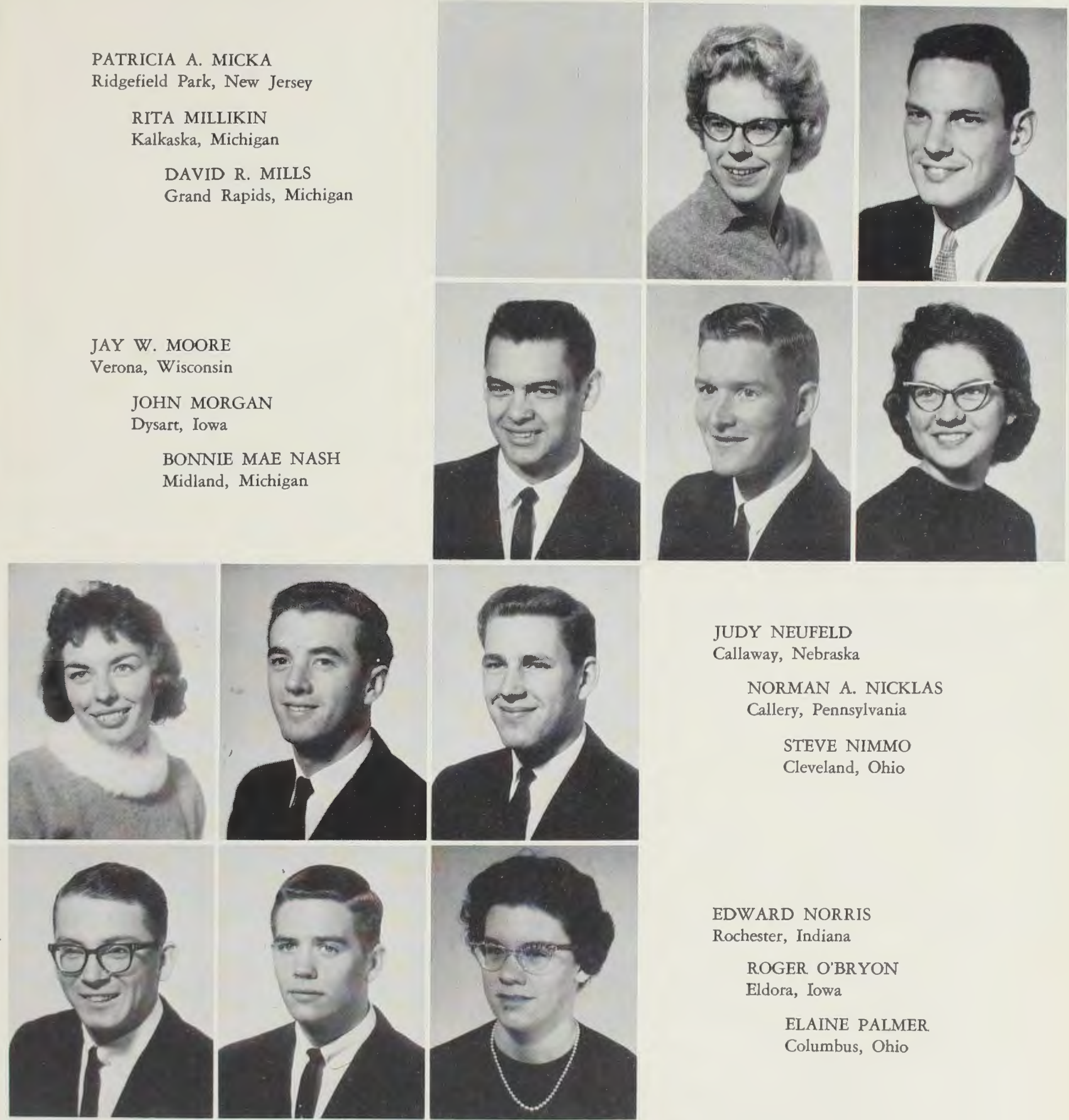

JUDY NEUFELD
Callaway, Nebraska

NORMAN A. NICKLAS

Callery, Pennsylvania

STEVE NIMMO

Cleveland, Ohio

EDWARD NORRIS

Rochester, Indiana

ROGER O'BRYON

Eldora, Iowa

ELAINE PALMER

Columbus, Ohio

R. DEUR PARK

Vassar, Michigan

MARY ELLEN POWELL

Renfrew, Pennsylvania

ROBER'T D. REYNOLDS

Xenia, Ohio 

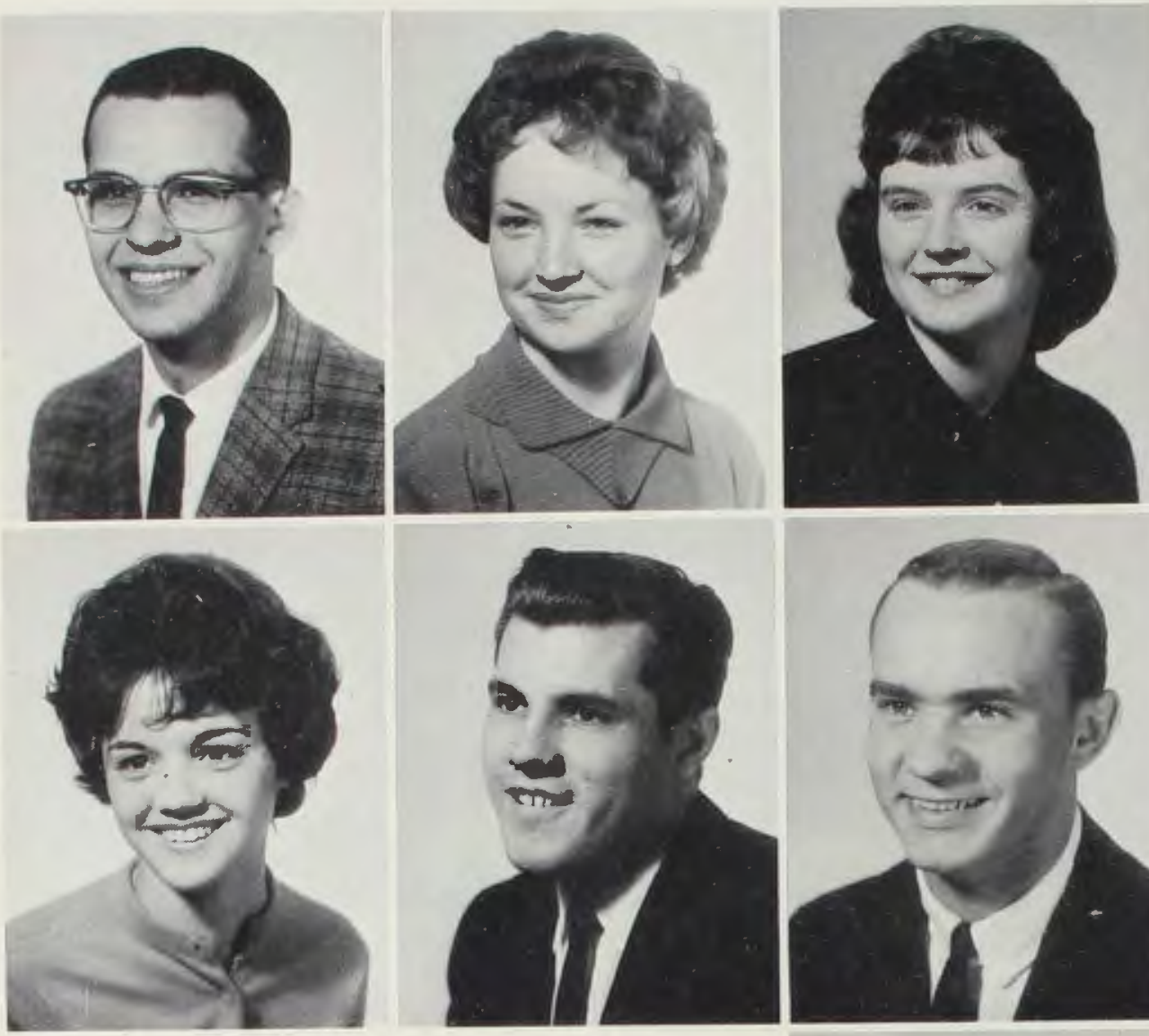

RUTH ANN SCHLOSSER

Cumberland, Maryland

BETTY LOU SCHULTZ

Lapeer, Michigan

DAVID SEARLES

Wellington, Ohio

STAN SEEVERS

Galena, Ohio

RICHARD F. SEIFERT

Washington, D. C.

NANCY SHIMITS

East Cleveland, Ohio

EDNA LOUISE SHRIDER

Fostoria, Ohio

JUDITH ANN SIPLOCK

Chesterland, Ohio

BARBARA SHARON SLAVENS

Crawfordsville, Indiana

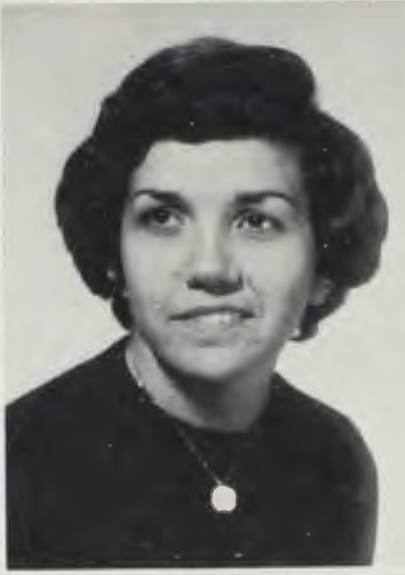

\section{Sophomores}

\section{WILLIAM RITER}

Deerfield, Illinois

AMY ROE

Metamora, Michigan

GLADYS ROSS

Hazel Park, Michigan

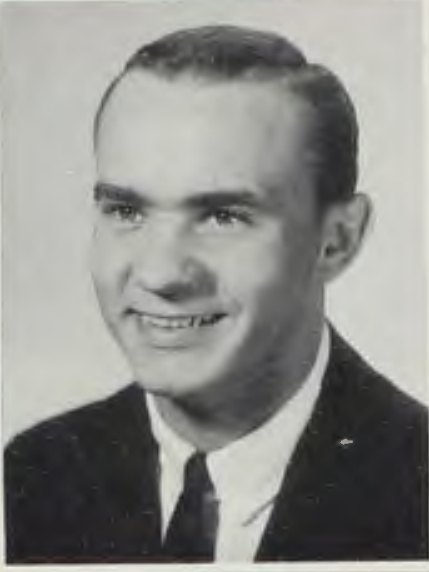

MARIAN ROTHWELL

Oakland, New Jersey

TONY ROTONDI

Teaneck, New Jersey

CHET RUSSELL

Crawfordsville, Indiana
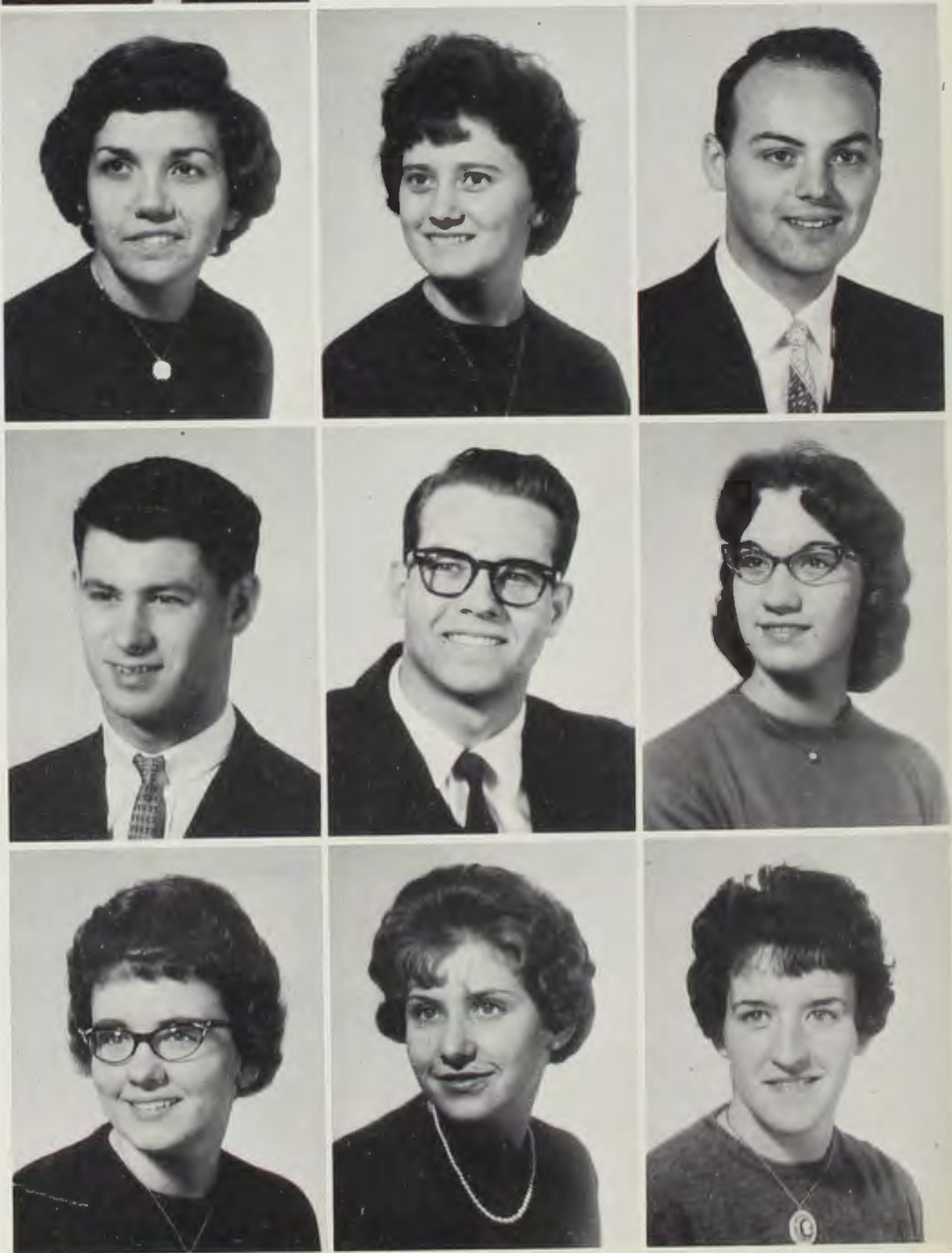
ELEANOR LOUISE SMELSER Medina, Ohio

JUDIE SMITH

Traverse City, Michigan

NANCY SMITH Kirkersville, Ohio

\section{JANE SMOKER}

Elkhart, Indiana

JIM SPRAGUE

South Lyon, Michigan

JERRY STAFFORD

Baltimore, Maryland
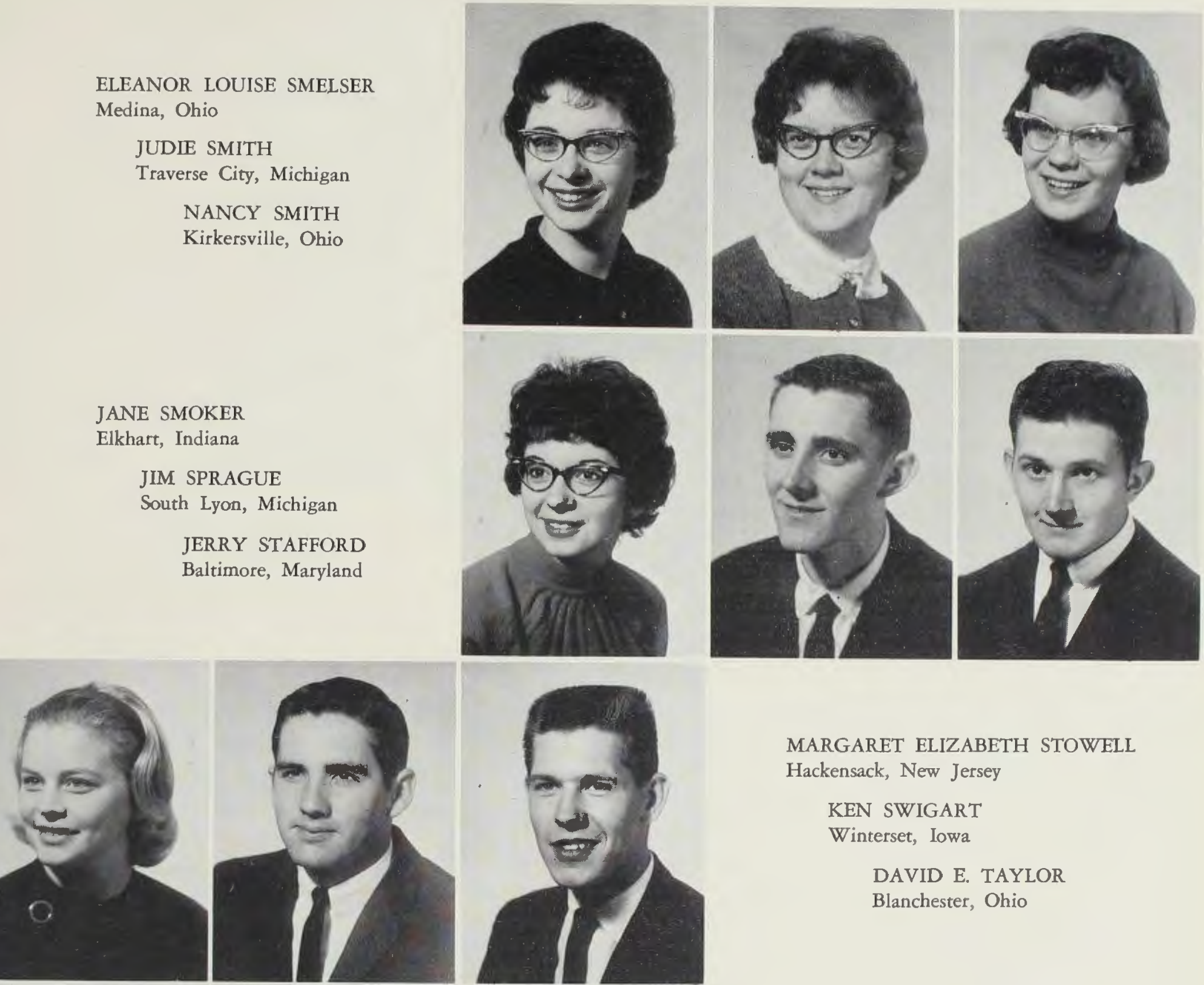

MARGARET ELIZABETH STOWELL

Hackensack, New Jersey

KEN SWIGART

Winterset, Iowa

DAVID E. TAYLOR

Blanchester, Ohio

PAT TERRY

Ypsilanti, Michigan

DAVID TRUMBULL

LaVale, Maryland

BARBARA UNZICKER

Claypool, Indiana

SHIRLEY VAN ALLEN

Caro, Michigan

SHARON JUNE VERMILLION

Cambridge, Ohio

JUDY WALBORN

East Cleveland, Ohio 

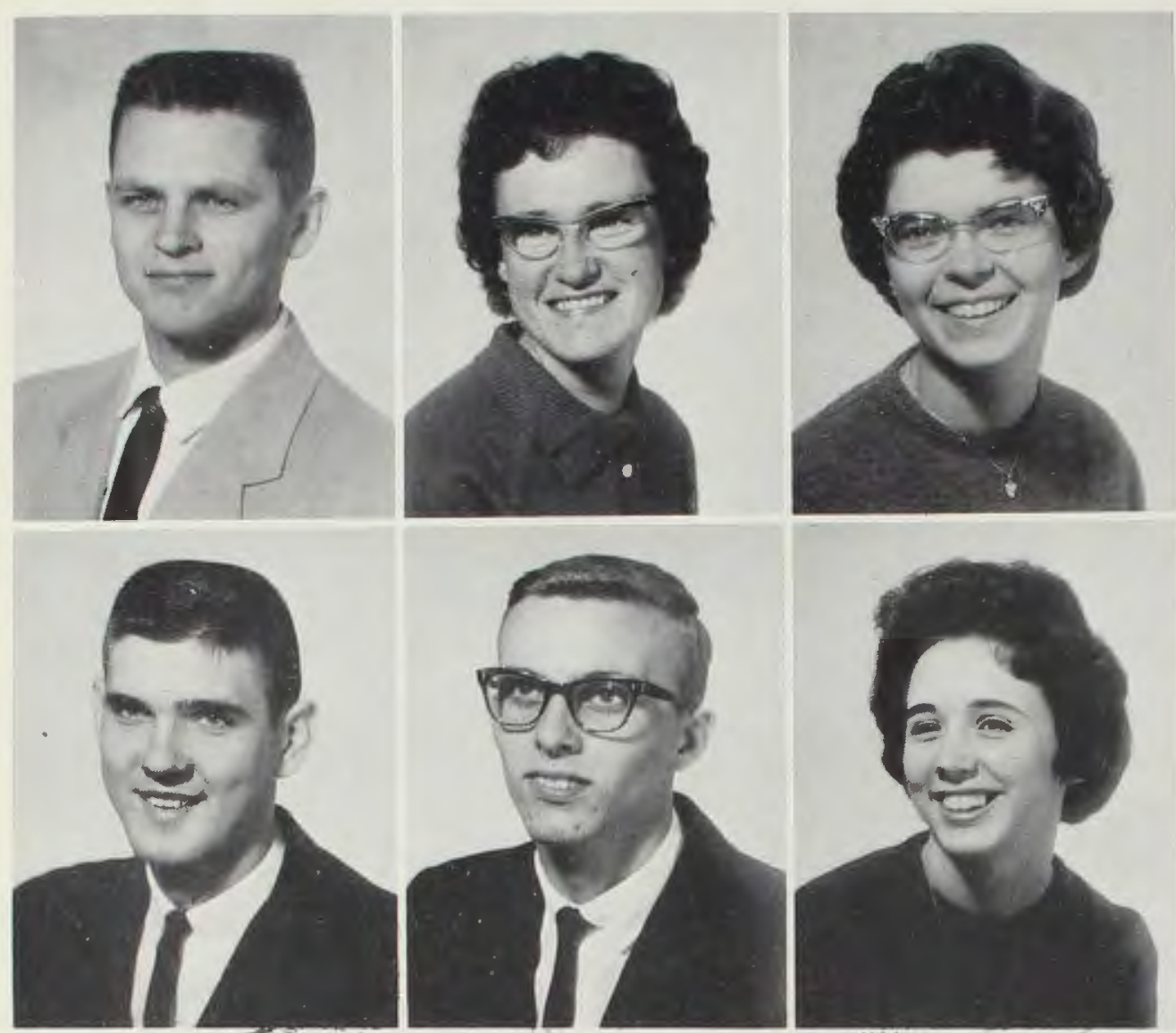

MARY ELLEN WEST Warren, Ohio

JERI WICKELI

Quincy, Illinois

JAY WICKHAM

Boise, Idaho

"Sandy Kidder and Hank Cook enjoy the main attraction of the All School Picnic,"

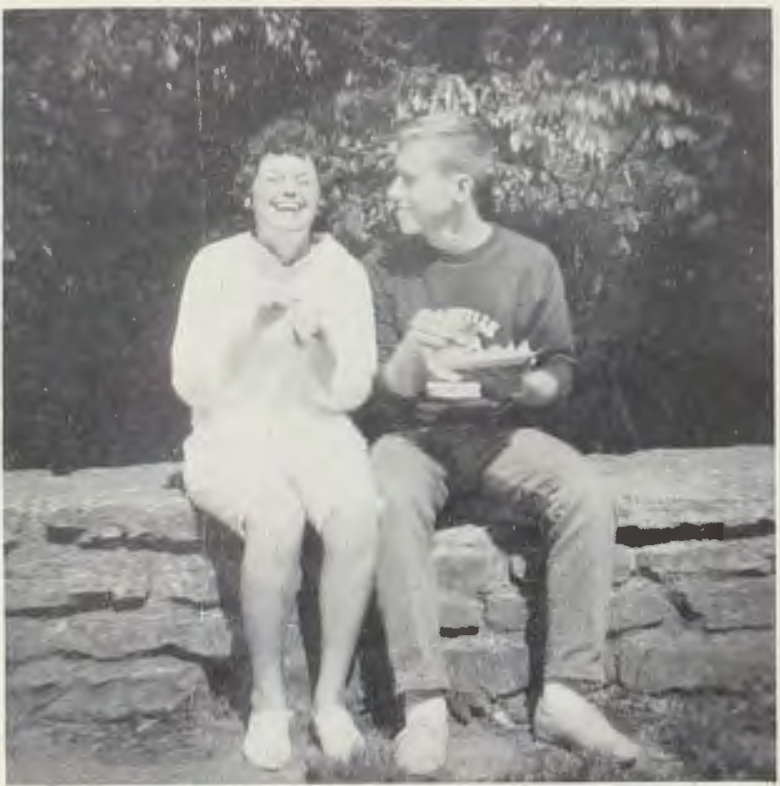

\section{Sophomores}

JAMES WALKER

Soap Lake, Washington

JOYCE WALKER

Bowling Green, Ohio

BETTY WALL

Decatur, Illinois

GARY WALTHALL

Xenia, Ohio

DAVE WARREN

Taylor, Michigan

SANDI WELCH

Bellbrook, Ohio
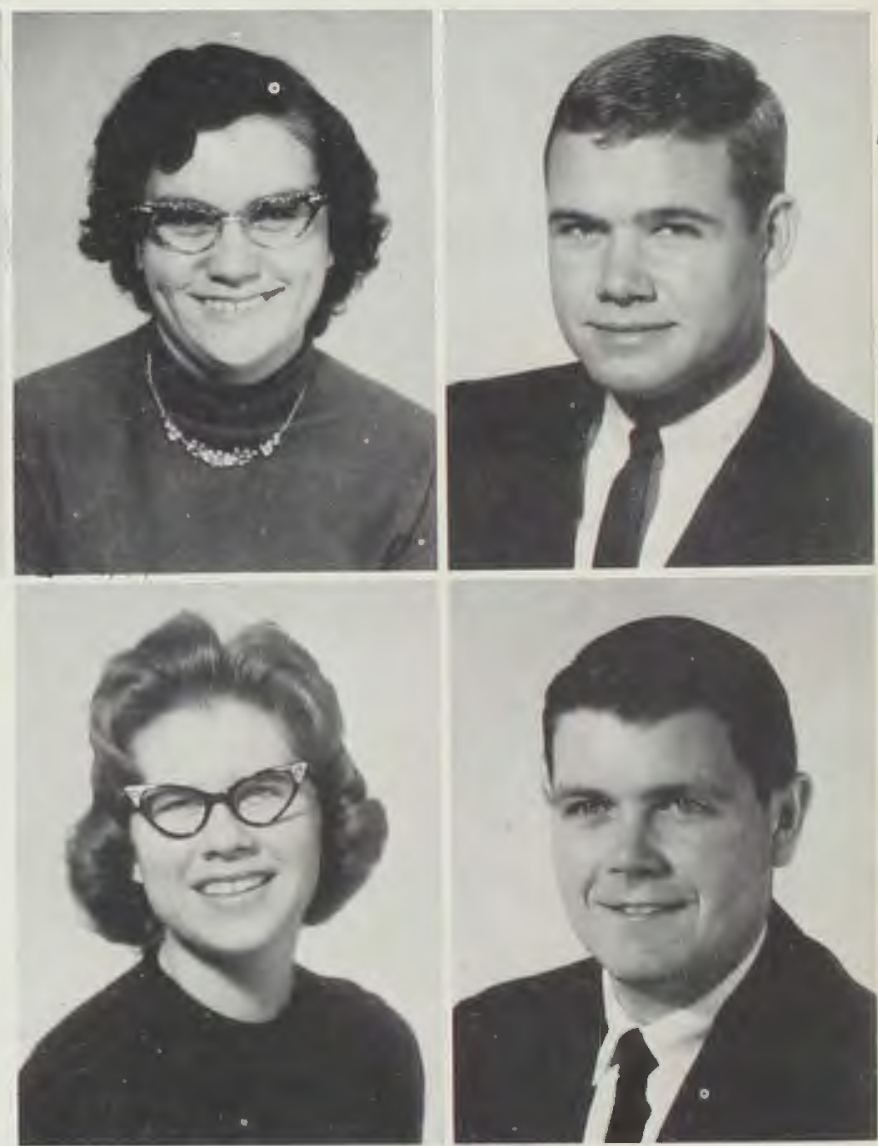

HOPE MARIE WILLIE

DAVID WOODMAN

Faribault, Minnesota - 


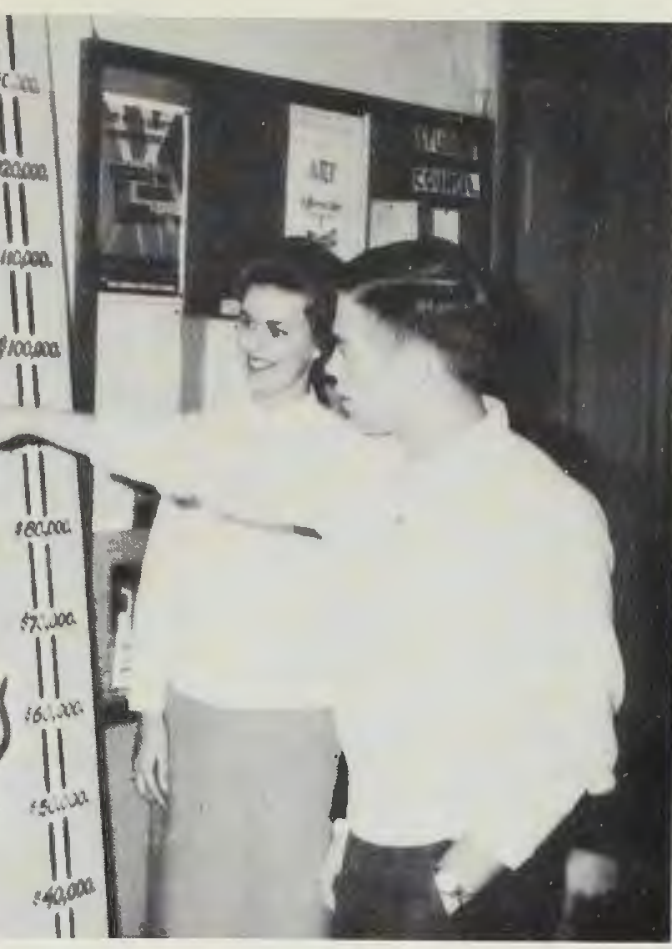

Roger O'Bryan points out an interesting feature of the new Student Center to fellow students.

\section{Campus}

\section{Candids}

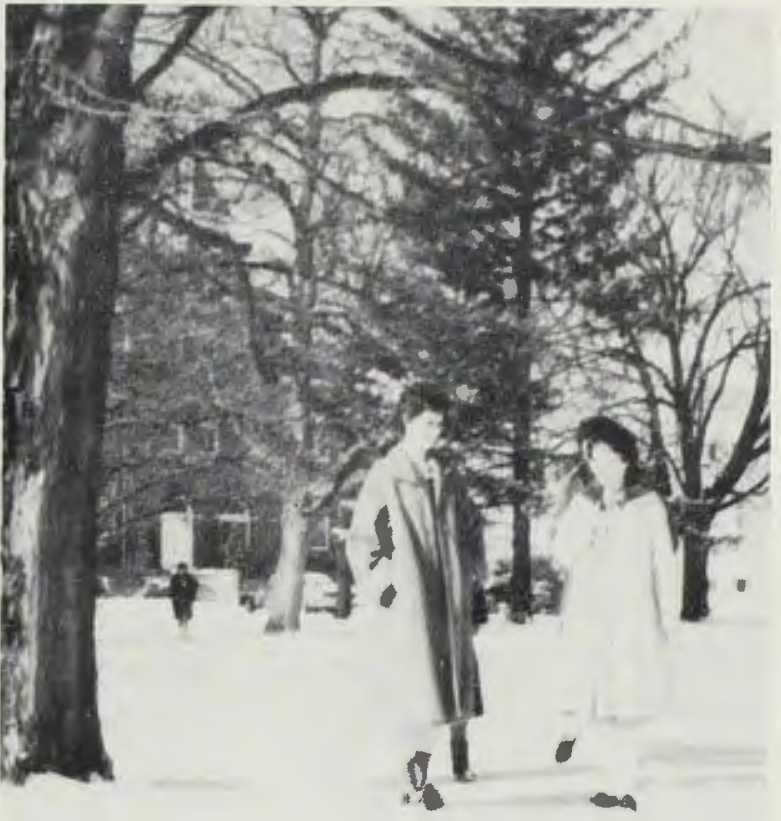

Walking back to the dorm after breakfast on that cold Saturday morning after the Friday snowstorm woke us up enough to study for the exams starting Monday.

One of the most popular places in the world when you're away from home is the mail room, especially after chapel.

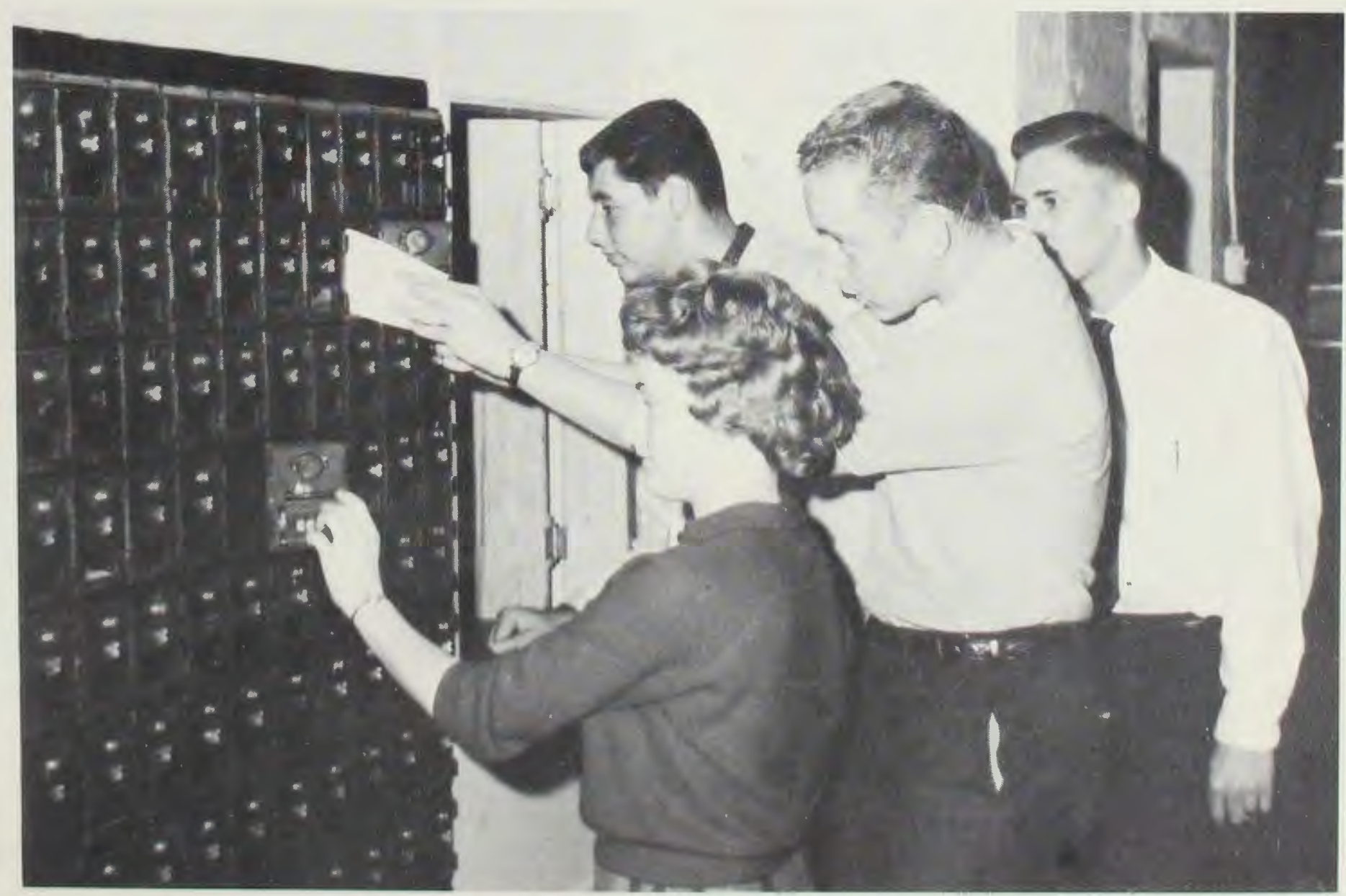




\section{Freshman}

\section{Class}
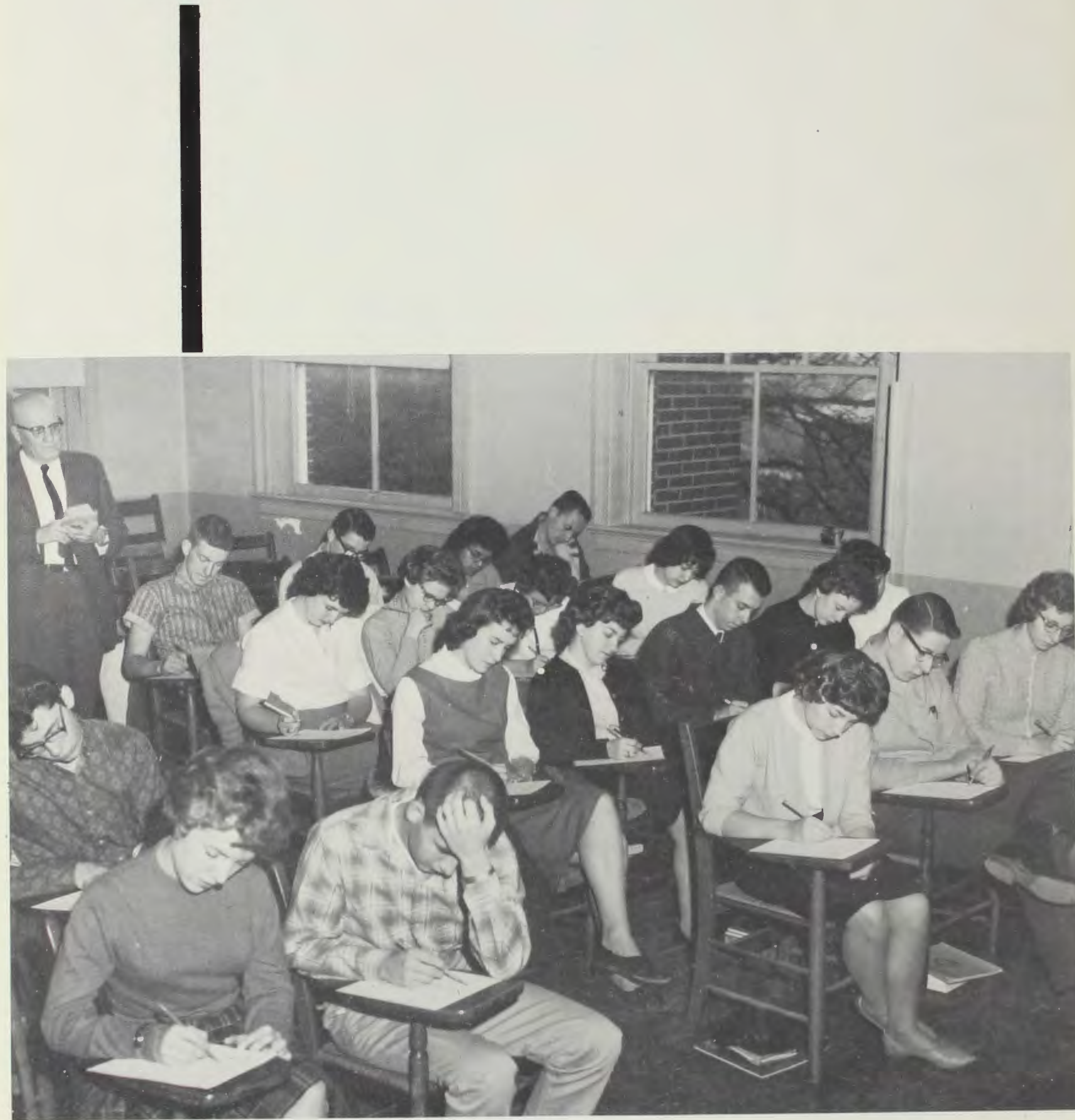

The first trials of the Freshman Class come as they take the many entrance exams under the direction of Dr. Maddox. 


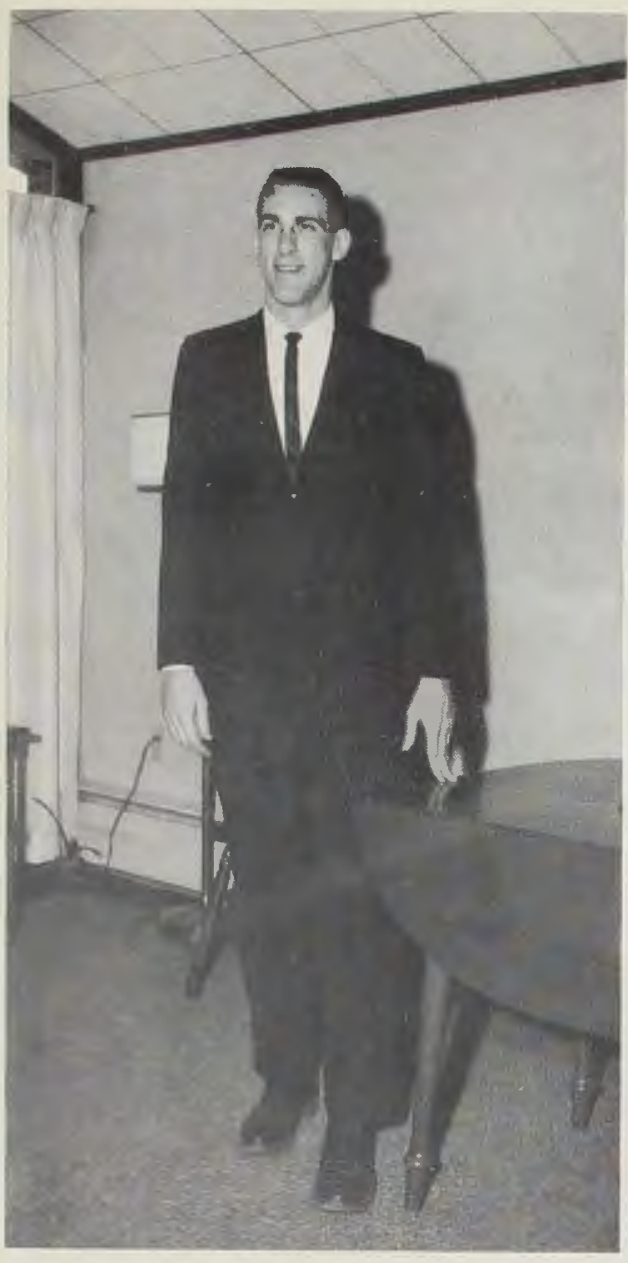

Don Entner, President

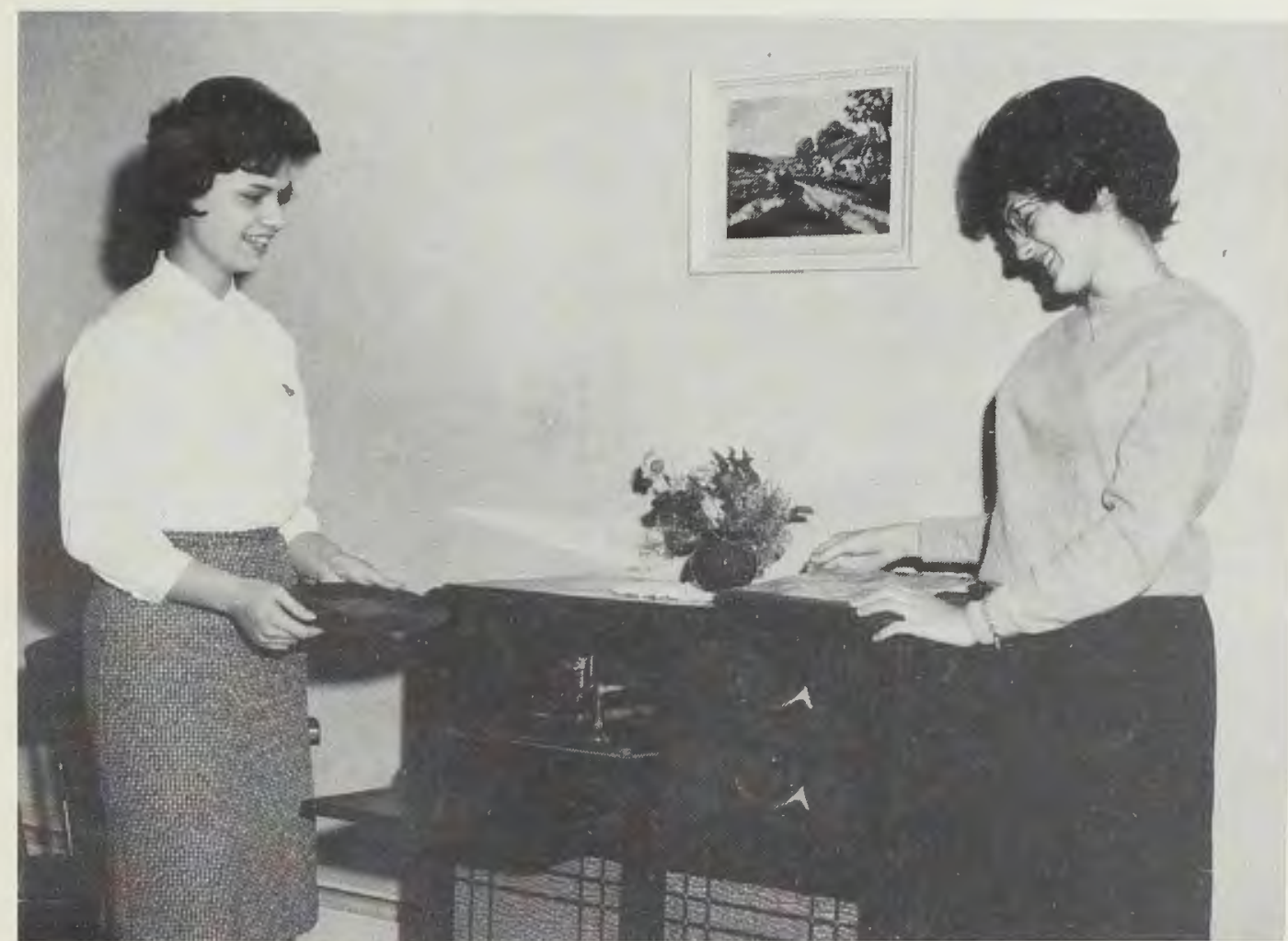

Eve Tennant, Treasurer; Jan Amos, Secretary.

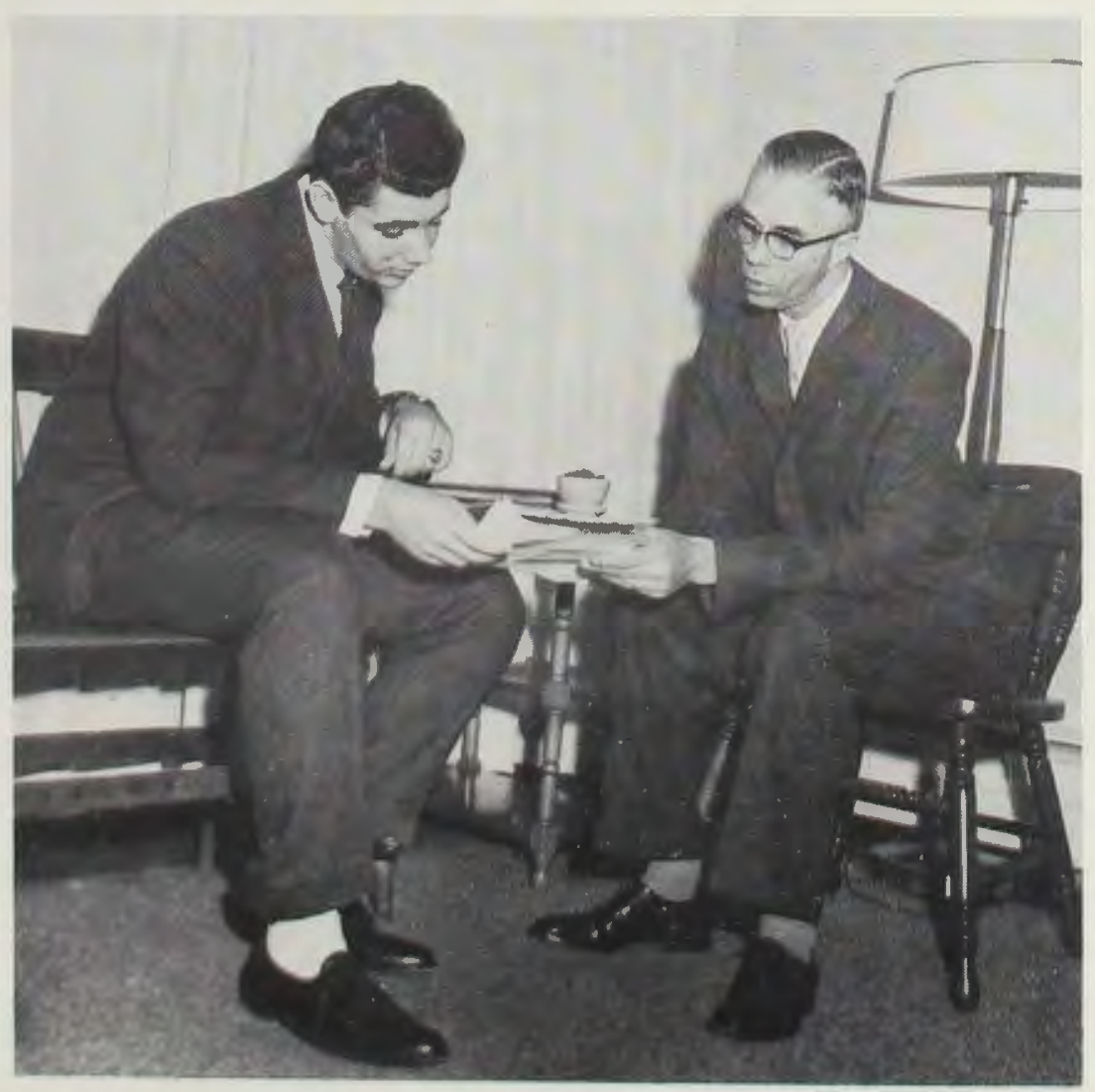

\section{Class \\ Officers \\ For \\ 1961-62}

Dave Jenson, Vice-President; Mr. Elmore, Advisor. 


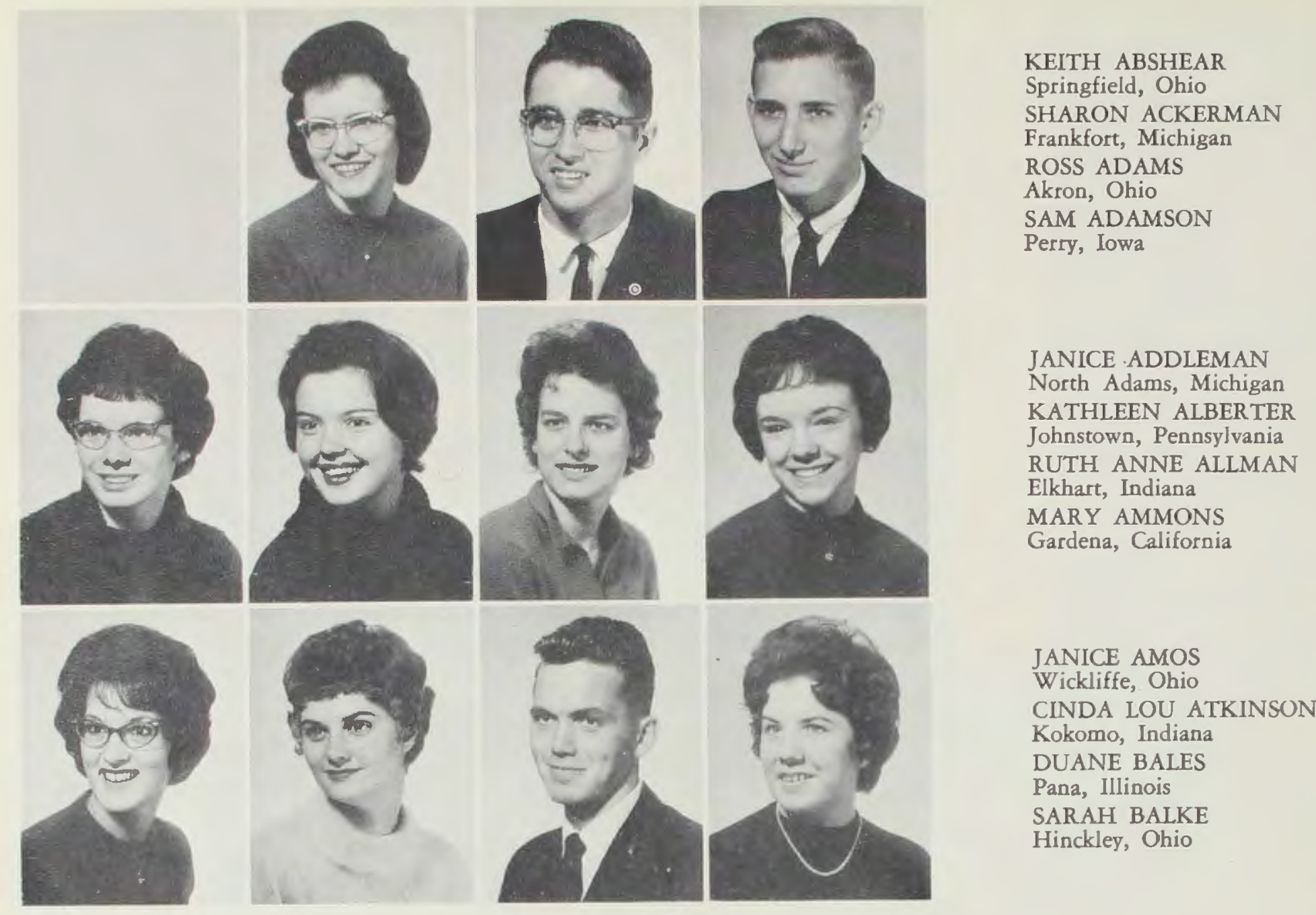

\section{Freshmen}

SUZANNE BARTHELD

Valley Stream, New York LARRY BEARD

Mayville, Michigan

JANET BEDWELI

Hammond, Indiana

ROBERTA BENSON

Enon, Ohio

MARVIN J. BERGSMA

Grand Rapids, Michigan

LEIGH BETTS

Rochester, Minnesota

CHARLES GLEN BINGAMON Xenia, Ohio

GARY BRANDES

West Seneca 24, New York

MARY BRONG

Monroe, Iowa

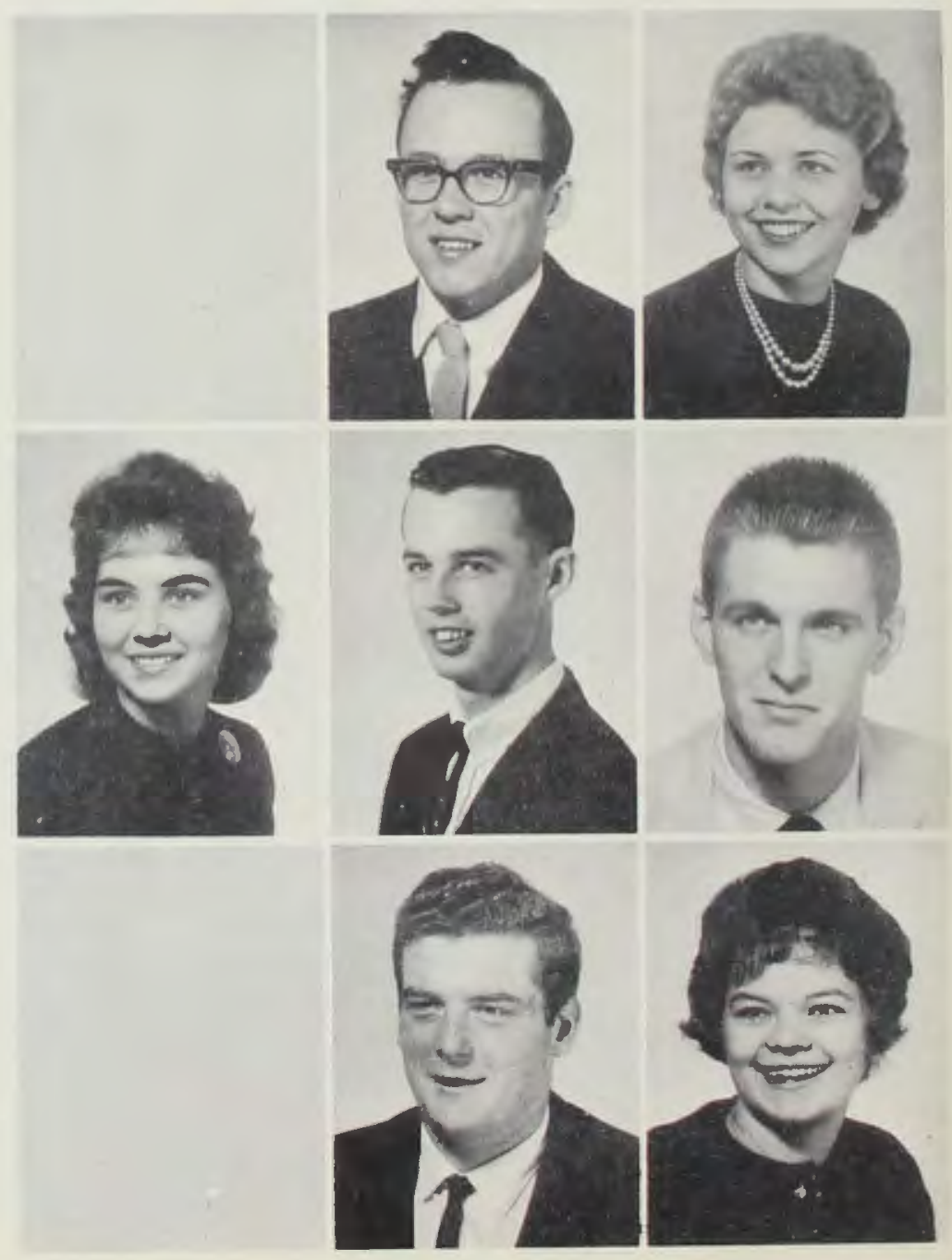



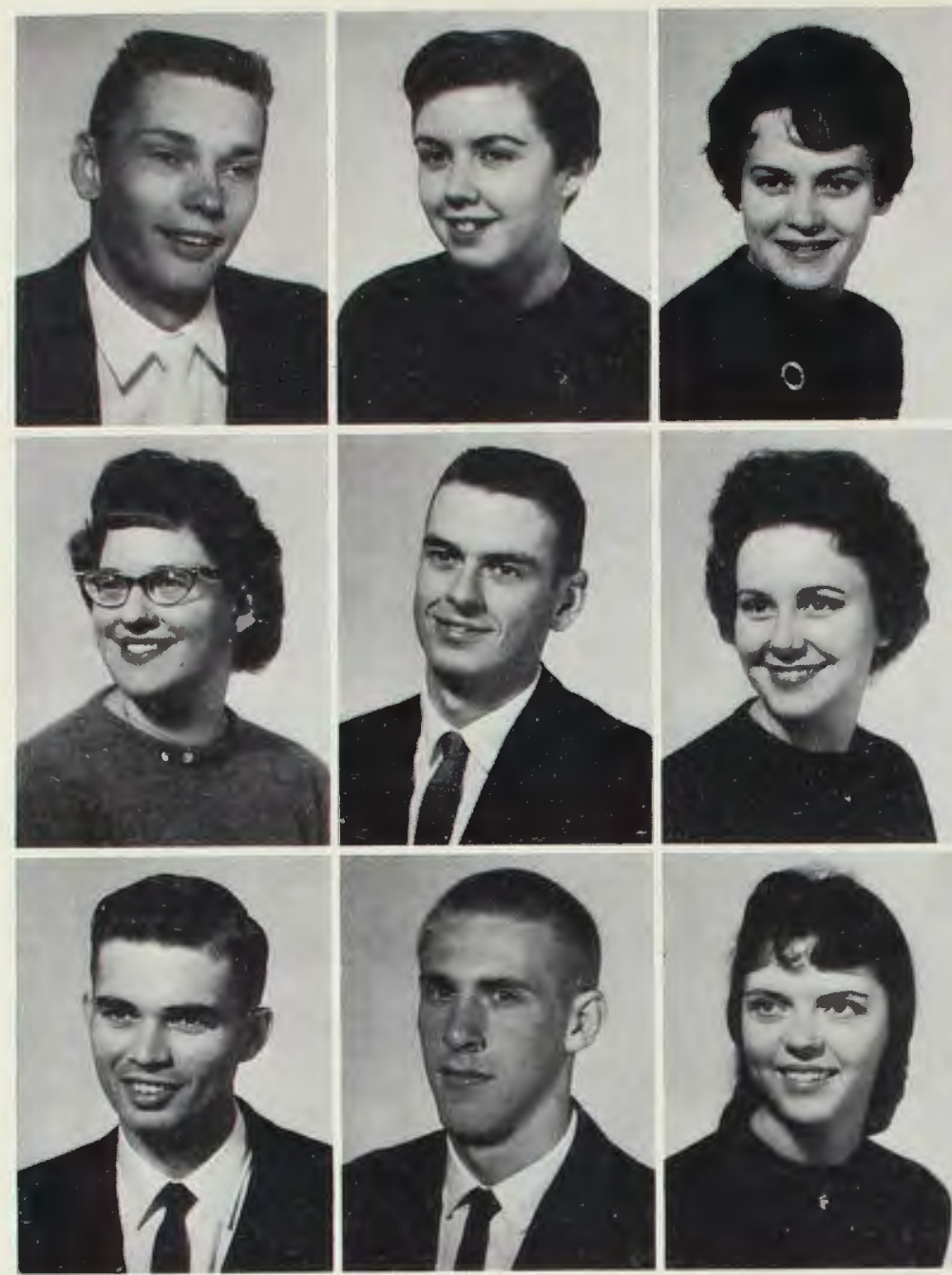

\section{Freshmen}

MARY ELLEN FLOYD

Galion, Ohio

WINNIE FREYTAG

Newberry, Michigan

JOHN R. GAYER

Medina, Ohio

MICHAL GEETING

Wheaton, Illinois JUDY SHARON GOFF Charleston, West Virginia FREDRIC C. GOODWIN Coshocton, Ohio

GAYLE GORDON

Connersville, Indiana

BONNIE HAMMACK

Niles, Ohio

JUDY HARTZELL

Butler, Pennsylvania

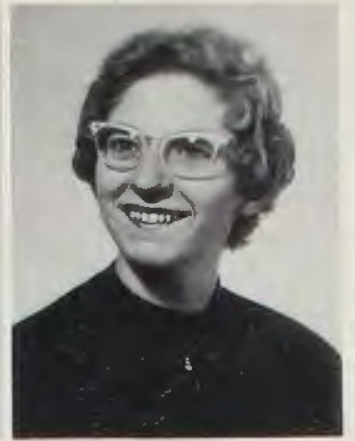

RAY DAVIS

Jamestown, New York

RUTH DE VEY

Chicago, Illinois

FAY DOCTOR

Ellsworth, Michigan

SHARON DYDA

West Middlesex, Pennsylvania

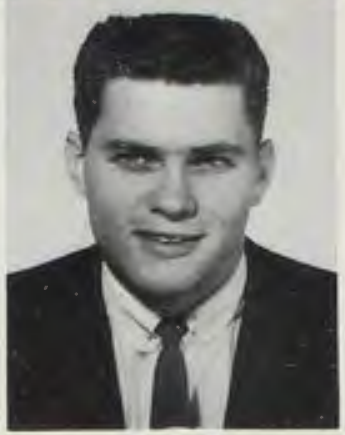

CAROL DYKSTRA

Sparta, Michigan

JERRY M. EATON

Rochester, Indiana

SUE ECKERT

Berea, Ohio

GEORGE EDWARDS

Akron, Ohio

DAVID ELMORE

Indianapolis, Indiana DONALD ENTNER

Dunkirk, Indiana

SUZANNE K. FENNELL

Sturgis, Michigan

DAVID FISHER

Dayton, Ohio
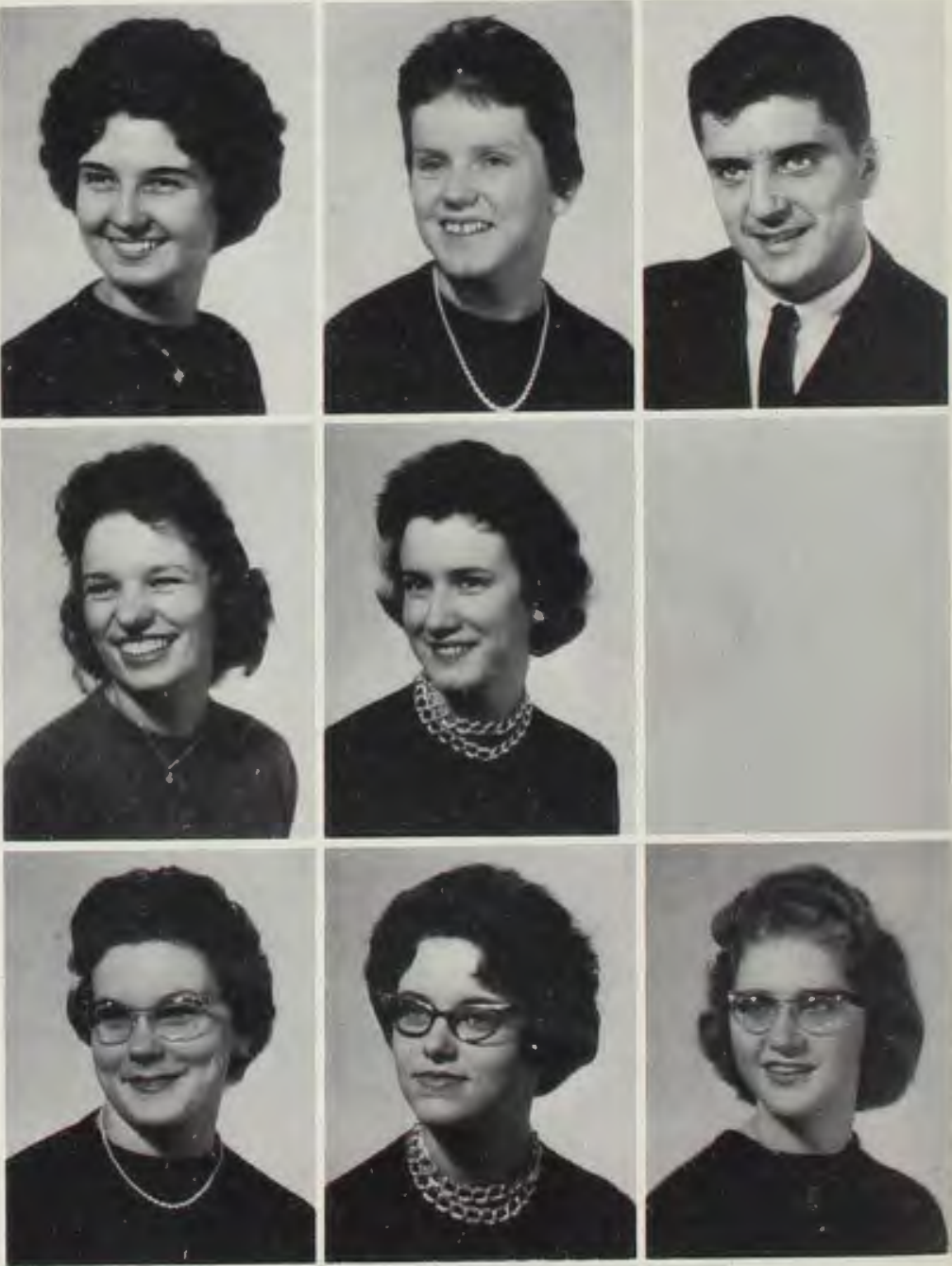
MERILYNN HATFIELD

Elmira, New York

ROY HAYES

Springfield, Ohio

AMY HEIKES

St. Paul, Minnesota

HELENE KAYE HENRY

McBride, Michigan

DONALD EDWARD HIGDON

Glen Burnie, Maryland

VIRGINIA LEE HINDMAN

Limestone, Pennsylvania

JUDY HOFFMAN

Columbus, Ohio

MARV HOLLENBECK

Marlette, Michigan

GLORIA HONAKER

New Richmond, Ohio

PHYLLIS IRISH

Gary, Indiana

DAVE JENSEN

Wellington, Ohio

MARYALICE JEREMIAH

Cedarville, Ohio
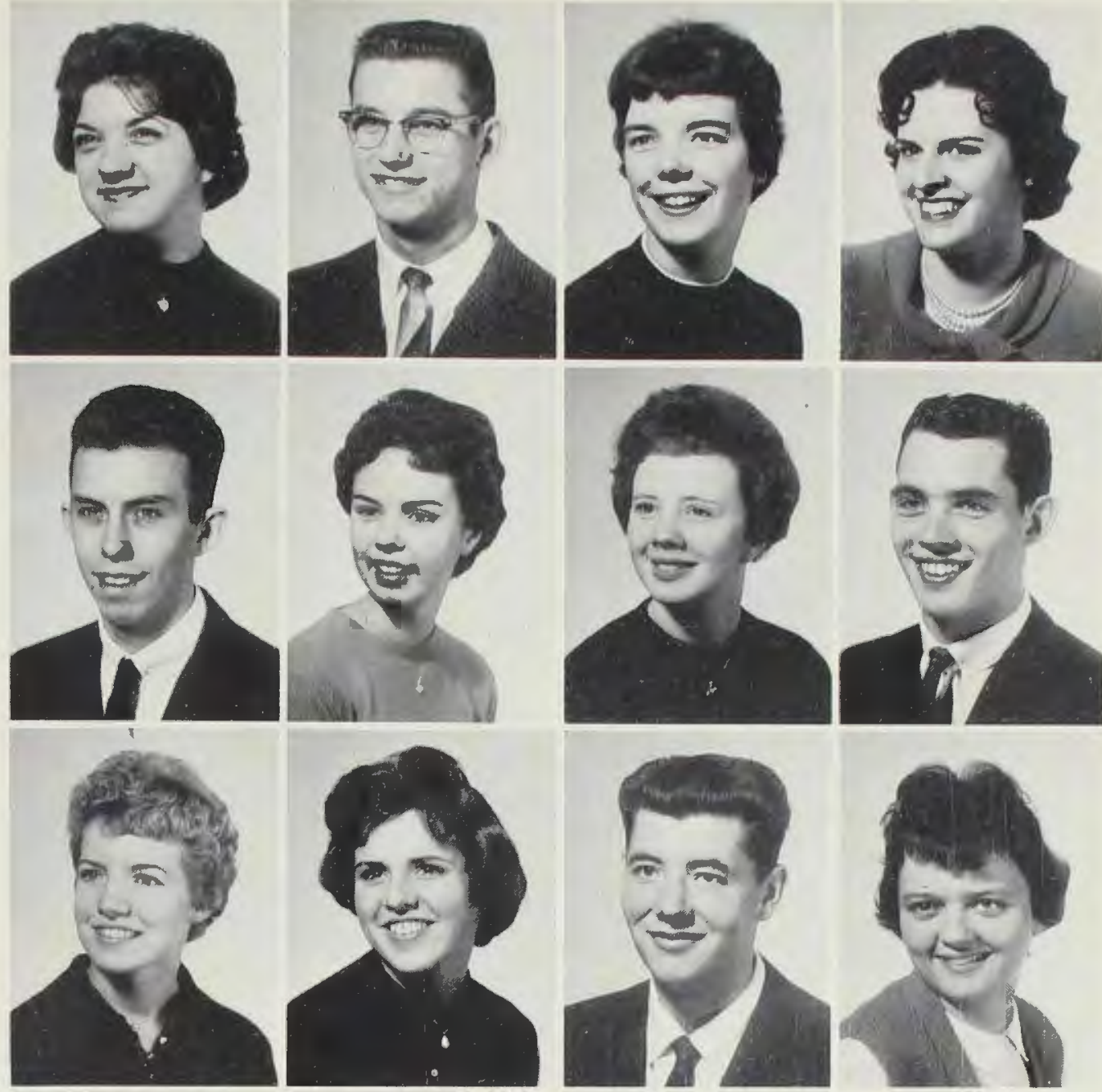

\section{Class of 1965}

PAUL E. JODRY

Stryker, Ohio

SUSAN JOHNS

Randolph, New York

BONNIE JOHNSON

South Bend, Indiana

RUTH ANN JOHNSON

Portsmouth, Ohio

LOIS JOY

Elyria, Ohio

PAT KASTER

Clear Lake, Iowa

DONALD KELLY

Springfield, Ohio

NANCY KETTELL

Falls, Pennsylvania

LARRY RICHARD LAMB

Amelia, Ohio 

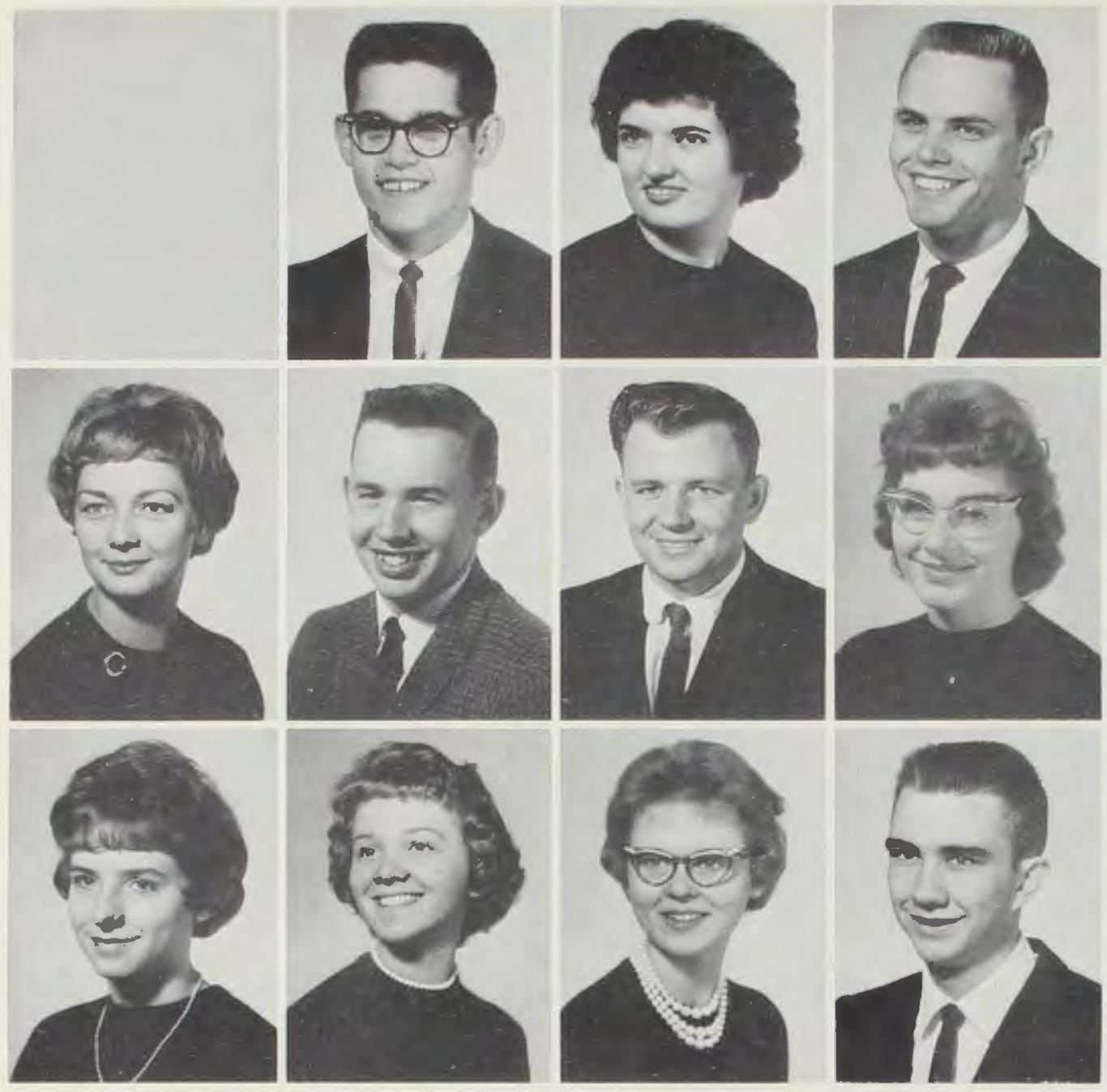

RAY LAMB

Crawfordsville, Indiana

MARK LEIBY

Atlantic City, New Jersey

DOROTHY LIGHTLY

Austin, Minnesota

STEPHEN KARL LUYBEN

Xenia, Ohio

TRUDY MC CONNELL

Tonawanda, New York

RONNIE MC DUGLE

Pontiac, Illinois

DON MC KENZIE

Springfield, Ohio

LEA ANN MC NAMARA

Meadville, Pennsylvania

NANCY MAAG

Marion, Ohio

JEAN MACLAREN

Harpster, Ohio

SUSAN DORIS MARTIN

Bronson, Michigan

RON C. MATHIS

Huron, South Dakota

\section{Freshmen}

STEPHAN JAMES MATIE

Gary, Indiana

LARRY MEEK

Urbana, Ohio

AL MERWALD

Portage, Indiana

JOAN MEYERS

Cleveland, Ohio

BARBARA MILLER

Ypsilanti, Michigan

JANET N. MILLER

Medina, Ohio
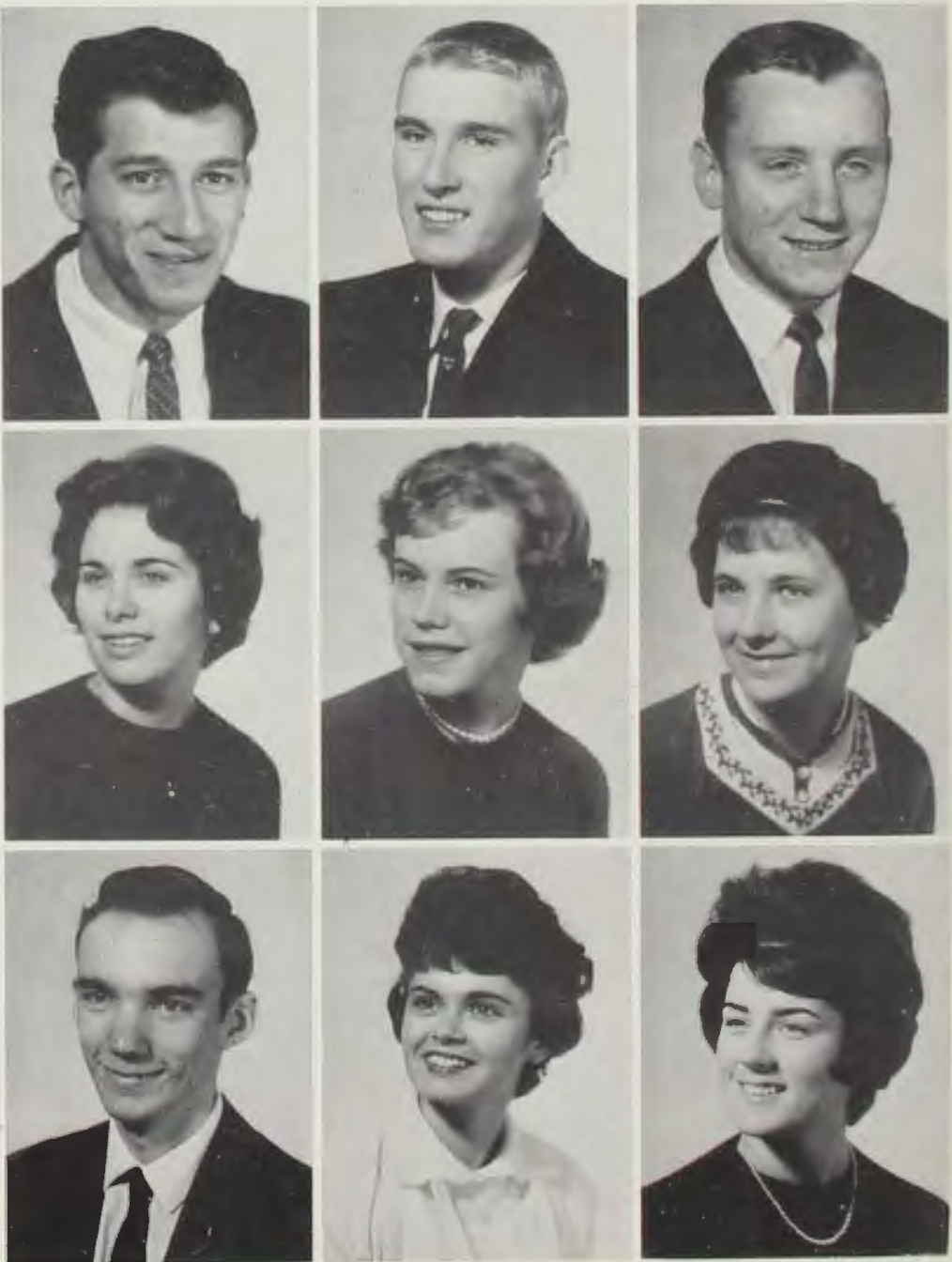

TERRY MILLER

Alliance, Ohio

DOROTHY MITCHELI

Hamburg, New York

MARTHA F. MOTTS

Northfield, Ohio 
LUANN GALE MUNDHENK

Pitsburg, Ohio

JOANNE NEELY

Gary, Indiana

JO-AN NELSON

North Royalton, Ohio

PEGGY NETTILETON

Longmeadow, Massachusetts

SUE ANN NEWCOMER

Medina, Ohio

BOB NEWMAN

Hawthorne, New Jersey

DAVID LEE NORRIS

Rochester, Indiana

JULIA OLIVAS

Elkhorn, Wisconsin

\section{PHIL OLSEN}

Lapeer, Michigan

JERRY OSBORN

Midland, Ohio

JOE OSBORNE

Wheelersburg, Ohio

DENNIS PEARCE

Stanwood, Washington
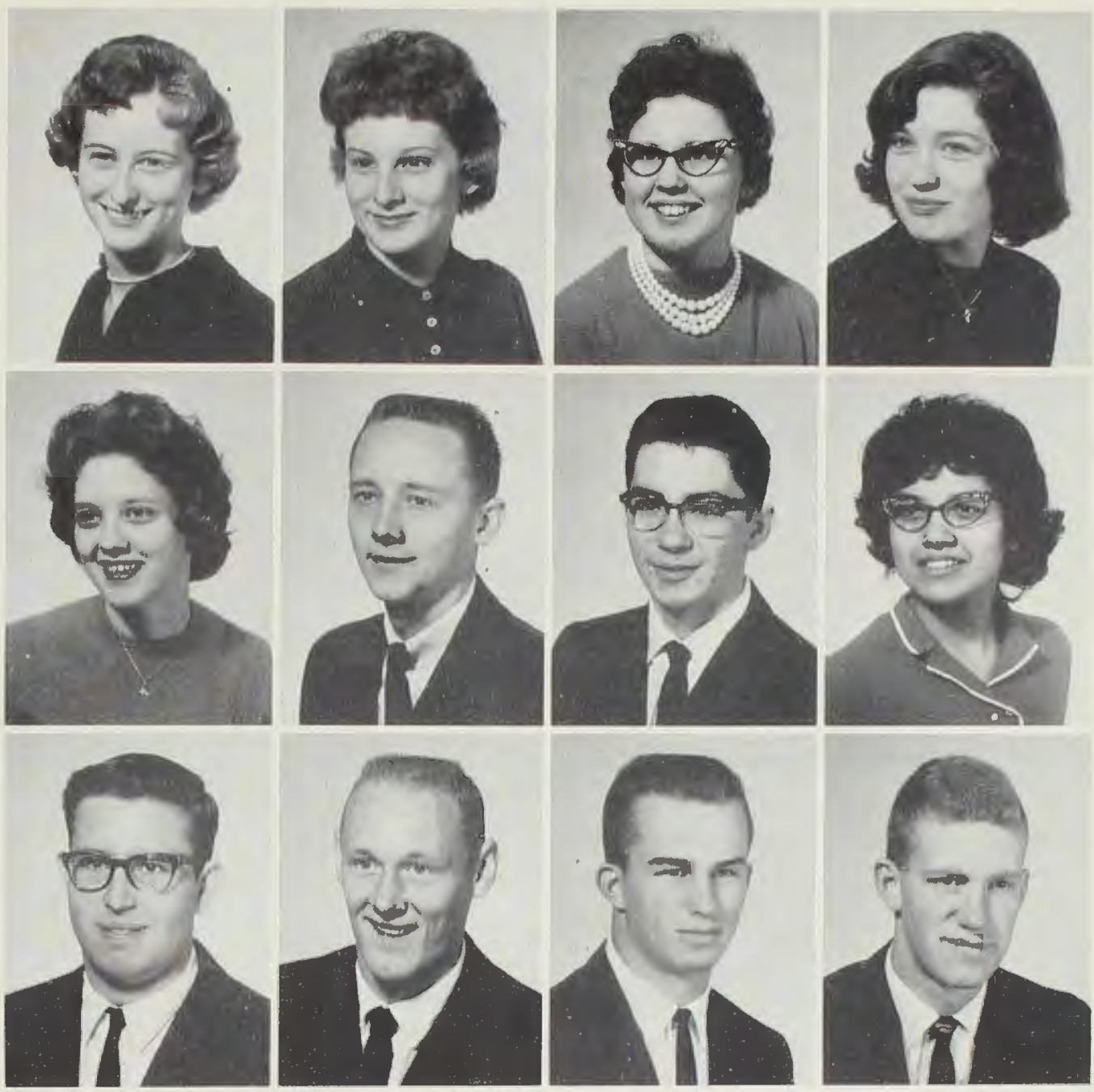

\section{Class of 1965}
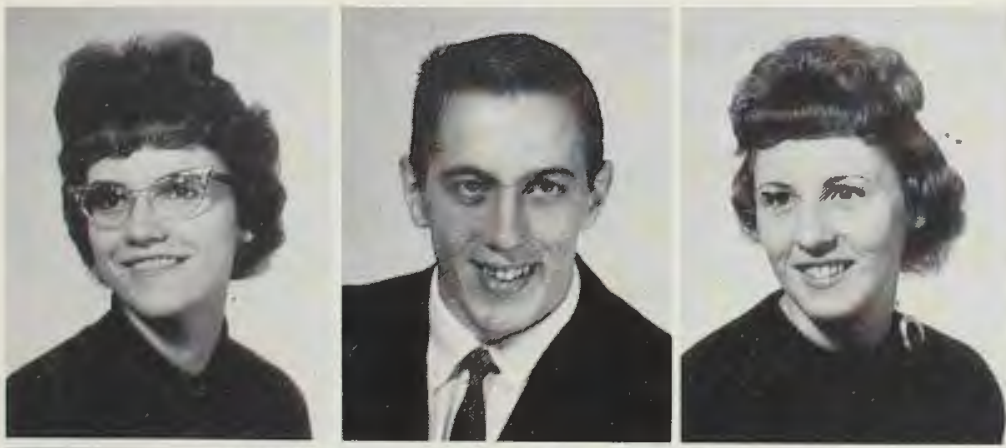

JULIE ANN PETRIE

Milford, Michigan

JOHN A. PRESCOTT

Forest City, Iowa

LIZ PRICE

Columbus, Ohio
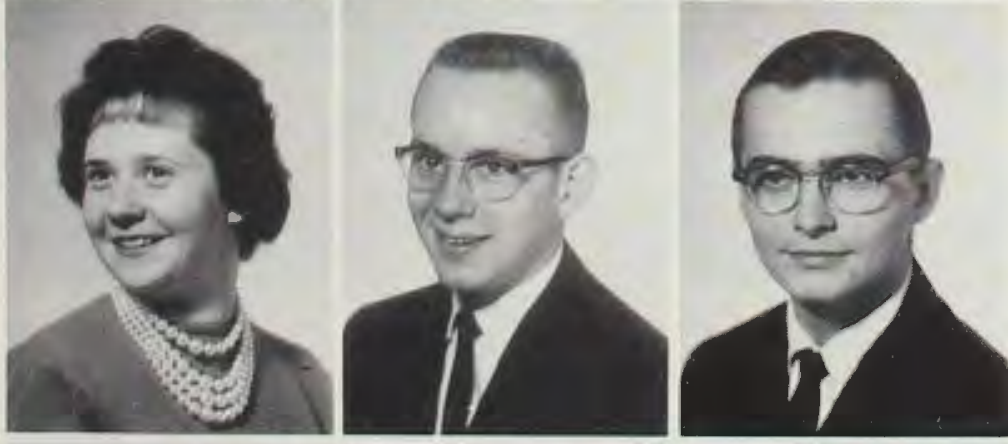

CARROL RAYMOND

Milford, Michigan

EUGENE REAM

Brookfield, Wisconsin

PAUL RENO

Cedarville, Ohio

RICHARD RICH

St. Louis, Michigan

MARSTON VAL ROLOFF

Charles City, Iowa

CLAUDIA ROWLAND

New London, Ohio 

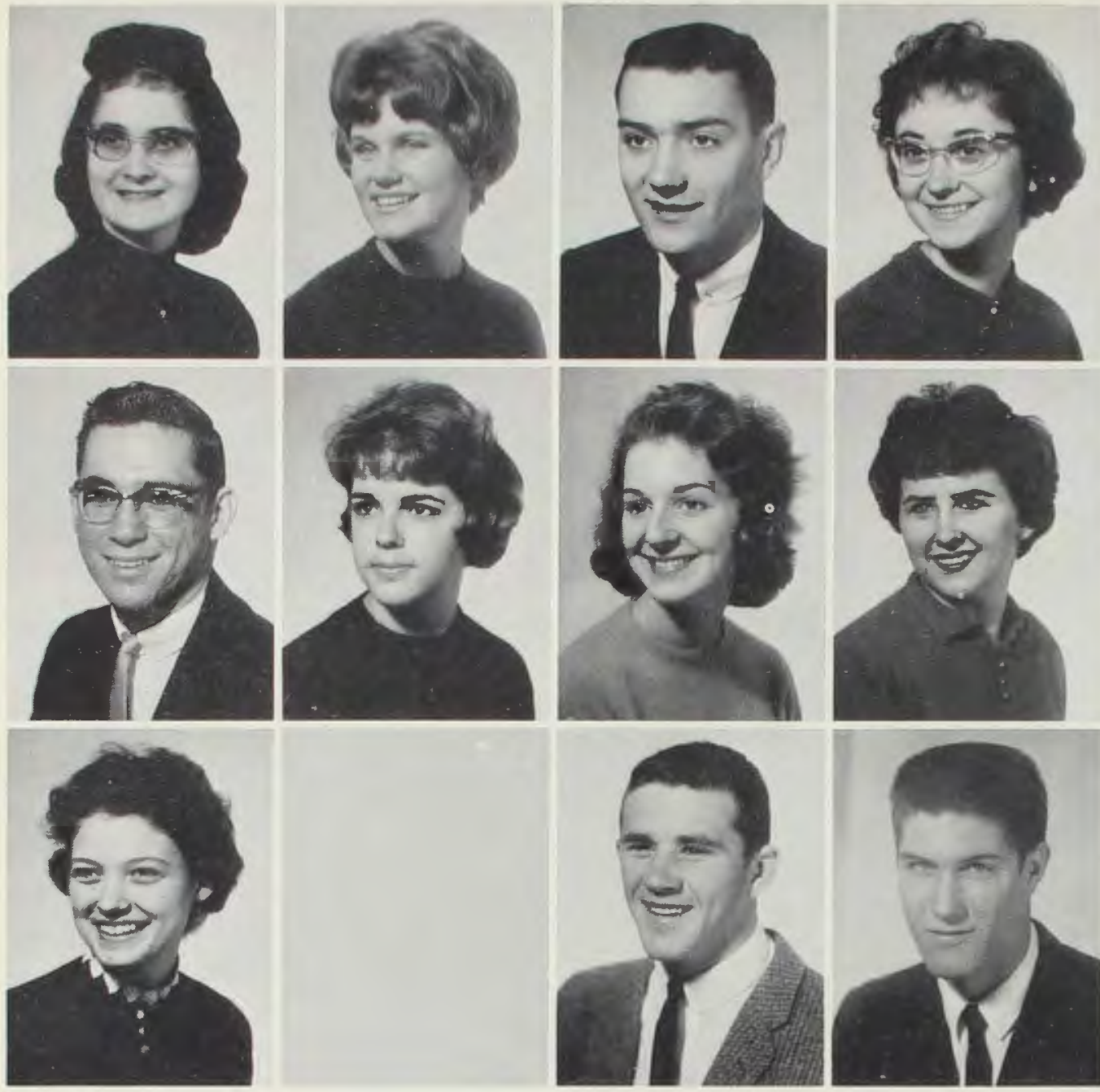

CAROL RUSSELL

Donna, Texas

JUDEE SARVIS

Bothell, Washington

CARLTON S. SCHWARTZ

Springfield, Ohio

MARILYN SHARROW

St. Clair, Michigan

MICHAEL A. SHINGLETON

Indianapolis, Indiana

MARTHA SHORT

Winterset, Iowa

PATRICIA SHULER

Fort Wayne, Indiana

SHIRLEY JEAN SICHTING

Southgate, California

JACOUELYN SIDLE

Bellefontaine, Ohio

PAT SNYDER

Cedarville, Ohio

RICHARD SPENCER

Portsmouth, Ohio

JERRY STADT

Forest City, Iowa

\section{Freshmen}

DAN ELBERT STEPHENS

Lebanon, Indiana

MARVIN W. STEPHENS

Grand Rapids, Michigan

SHARON SURBER

Springfield, Ohio

MARSHA TAYLOR

Alma, Michigan

EVE TENNANT

Bellefontaine, Ohio

ARTHUR DAVID THORNE

Medford, New Jersey
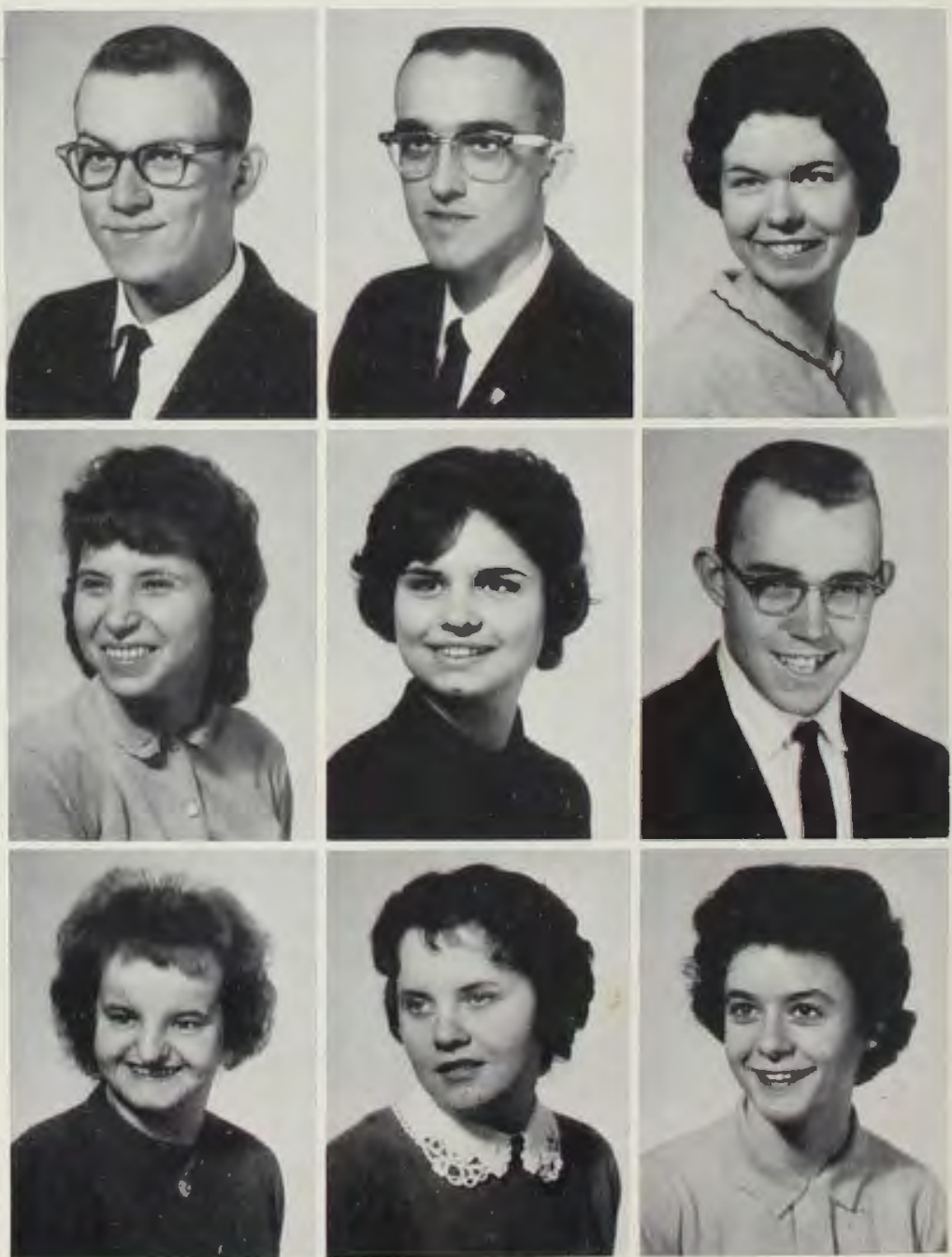

BARBARA THORNE

Medford, New Jersey

JUDY TOBIAS

Muscatine, Iowa

JANET TREMBA

Youngstown, Ohio 
BRIAN TWIEST

Grand Rapids, Michigan

JANE A. VAN NORMAN

Naperville, Illinois

PATRICIA VERSLUIS

Grand Rapids, Michigan

JON WALBORN

Cleveland, Ohio

EUGENE WALLIS

Thurston, Ohio

CORNELIA ANN WARD

East Townsend, Ohio

JEANETTE WARDELL

Fairlawn, New Jersey

BILL WATSON

Taylor, Michigan

CAROLANN WEAVER Sidney Center, New York SHARLENE WELLMAN

Marion, Michigan

DAVID WERNER

Columbia Falls, Montana

L. BRADLEY WEYHE

Olean, New York
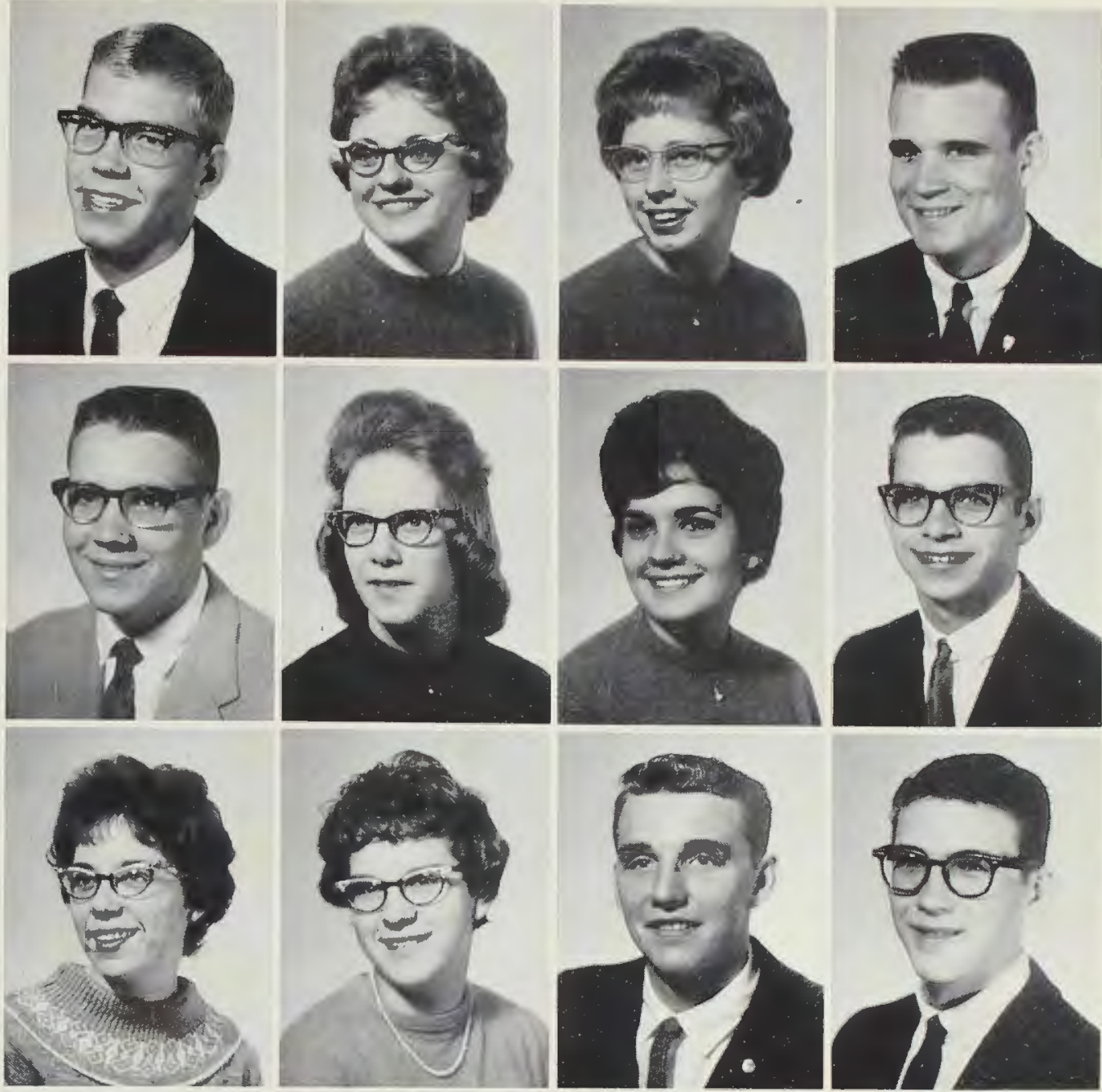

\section{Class of 1965}

DAVID L. WILHITE

Corwith, Iowa

JENEEN WILLIAMS

Silver Lake, Wisconsin

HELEN WING

Grand Rapids, Michigan

SYLVIA WING

West Winfield, New York

CAROL WISEMAN

Springfield, Ohio

JOHN H. WOLFE

Bellevue, Ohio

LINDA WORKMAN

Huntington Park, California

NANCY WRAY

Iloilo City, Philippines

MER VIN ZIEGLER

Wellington, Ohio 


\section{Second Semester Students}
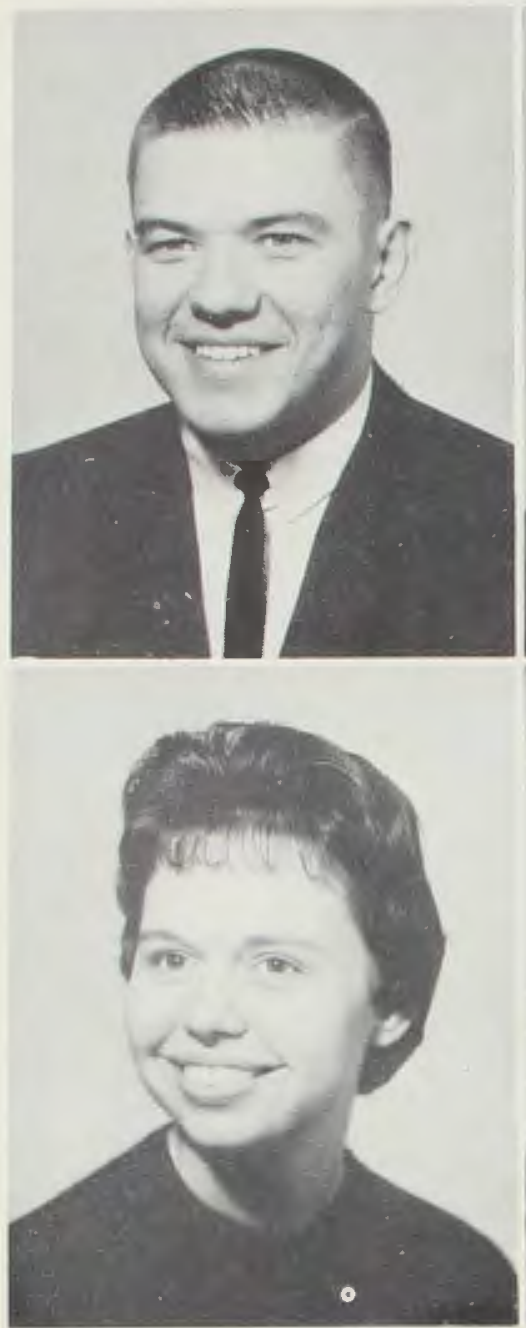

DAVE BLOSSOM

Sophomore

Vassar, Michigan

MEDORA JORDAN

Fresbman

Richmond, Virginia
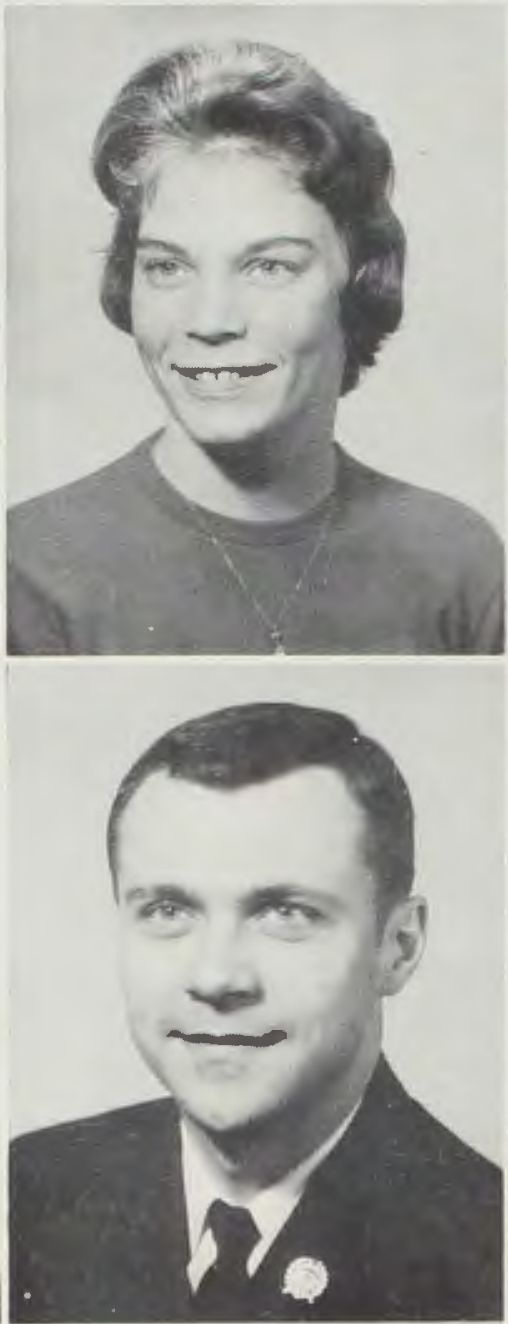

JILL CALL

Sophomore

Medina, Ohio

LAWRENCE N.

KILLIAN

Sophomore

Bedford, Ohio
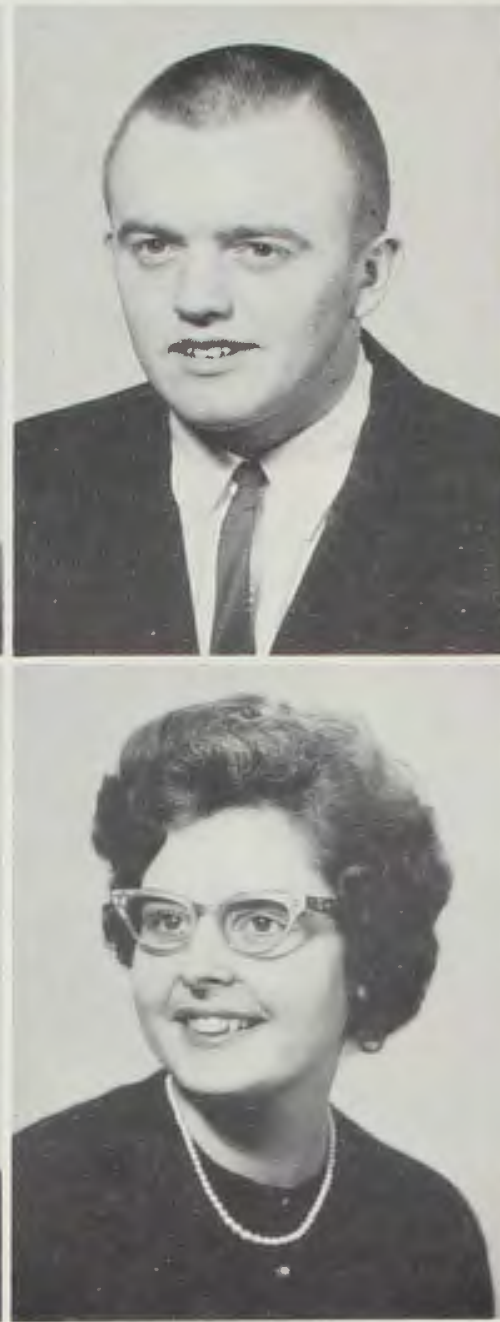

BUD CONNELL

Sophomore

Bay City, Michigan

MARILYN LONG

Sophomore

Altoona, Pennsylvania

(Central African Republic)
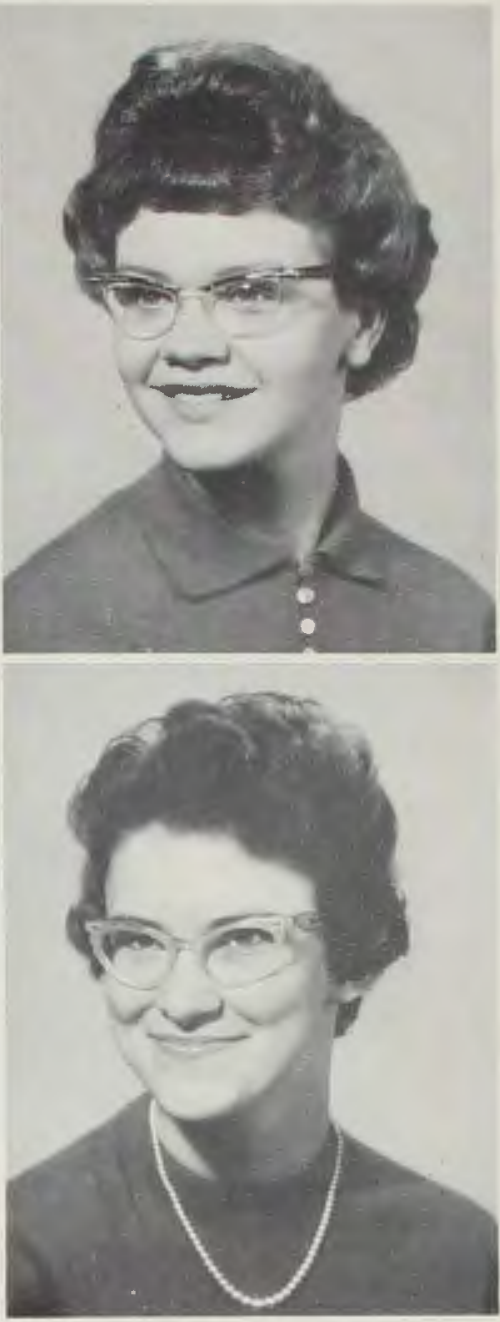

JOANNE HAMILTON Fresbman

Alton, Illinois

ARLENE OEHMCKE

Sophomore

Weuwatosa, Wisconsin

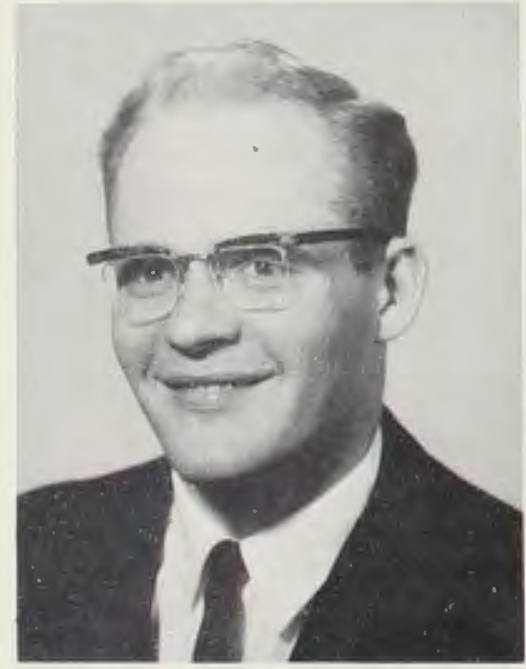

DAVE PERRY

Sopbomore

Homer, Alaska

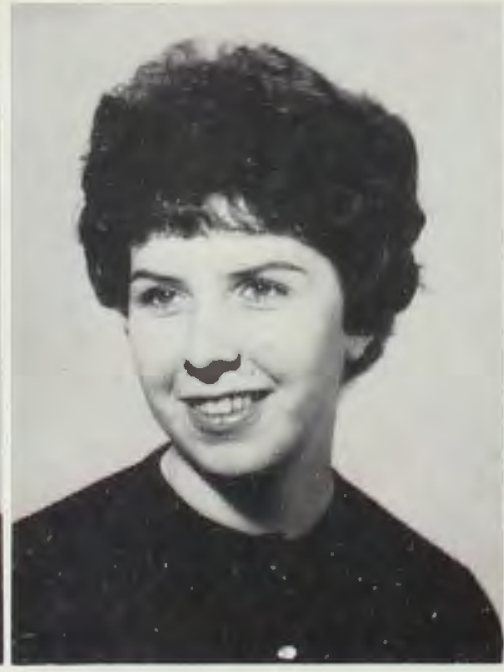

PATRICIA WESTCOTT Fresbman

Seaford, Delaware

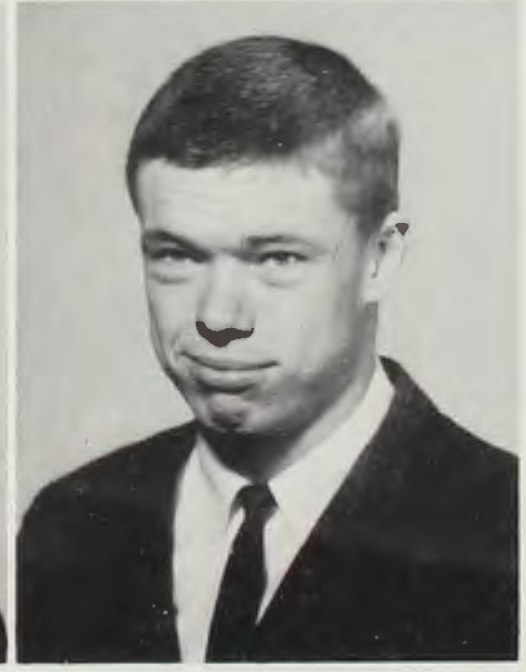

DANIEL WOOD

Freshman

Grand Rapids, Michigan
NOT PICTURED:

Lynne Cayton Sandra Kirisits Nancy Jo Kriner Shelby Mayo David Rape Carolyn Schultz Nancy Schut William Van Crouch Roosevelt Walker Edward Walters 


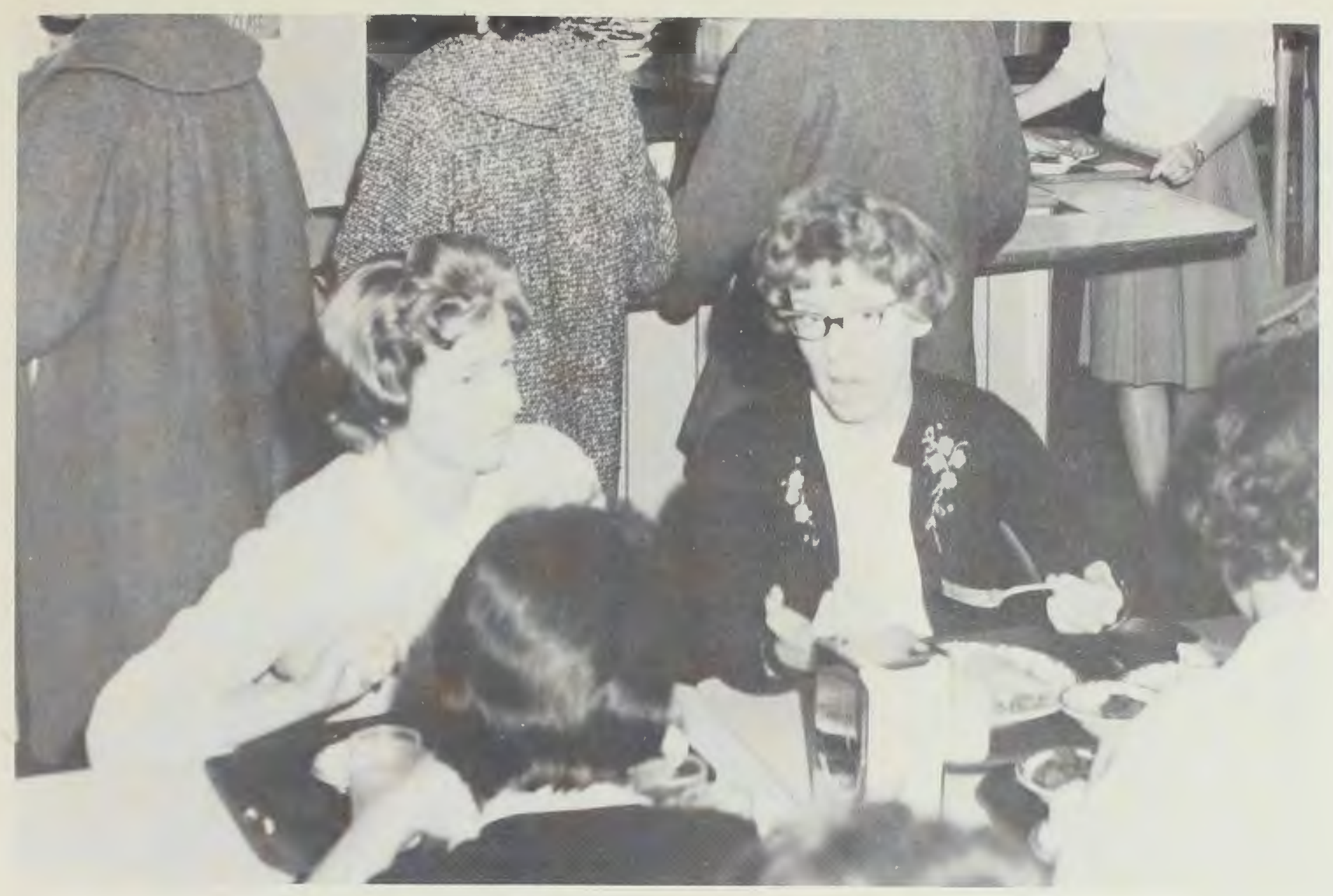

Joan Carter "comments" on the test last hour.

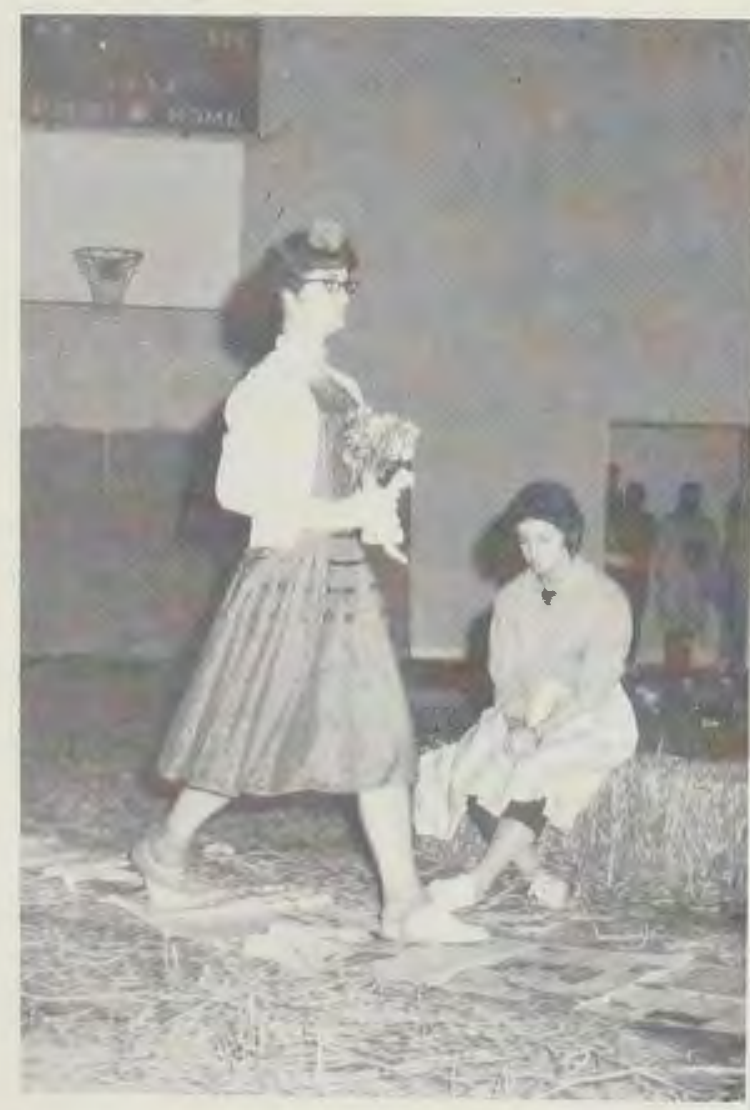

The Senior Class presents a mock wedding at the Senior Class Party, with Lorraine Cantwright and Otis Stone as bride and groom.

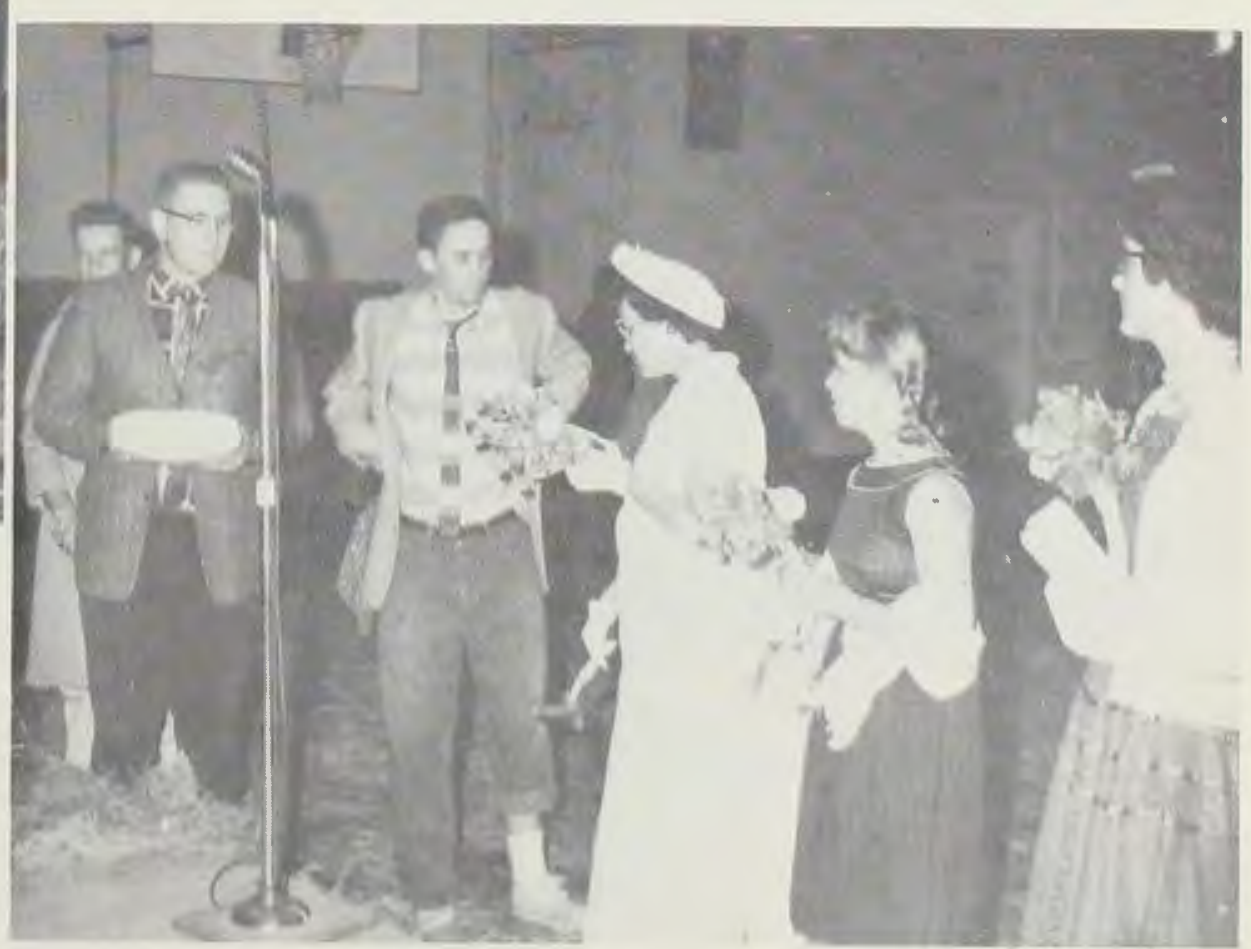




\section{Cedarville College \\ Alumni Association}

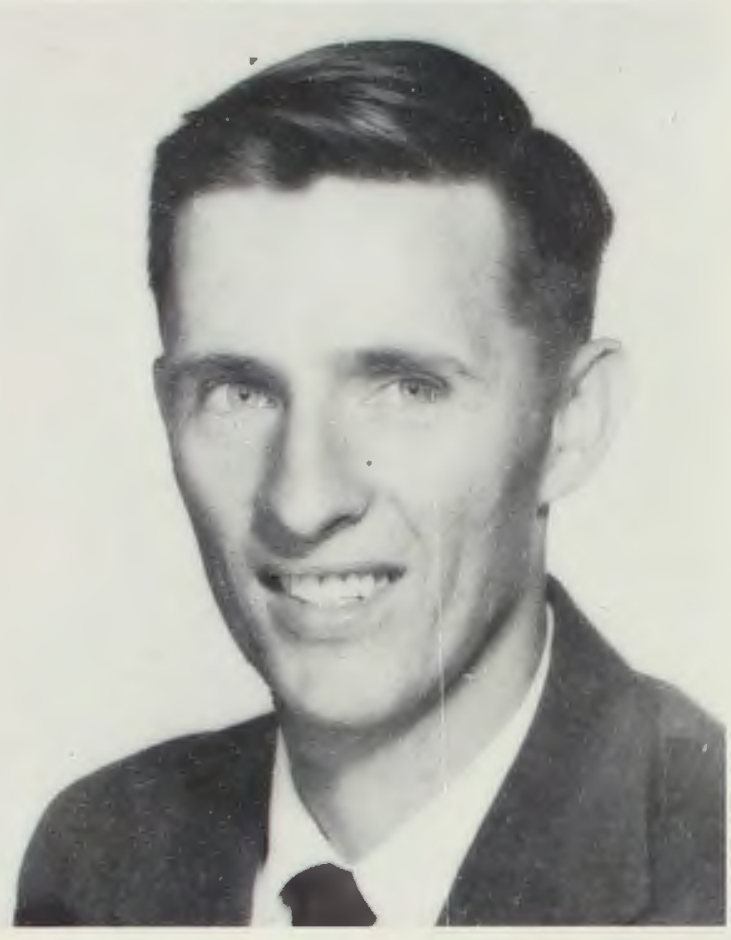

Clifford Boessel President

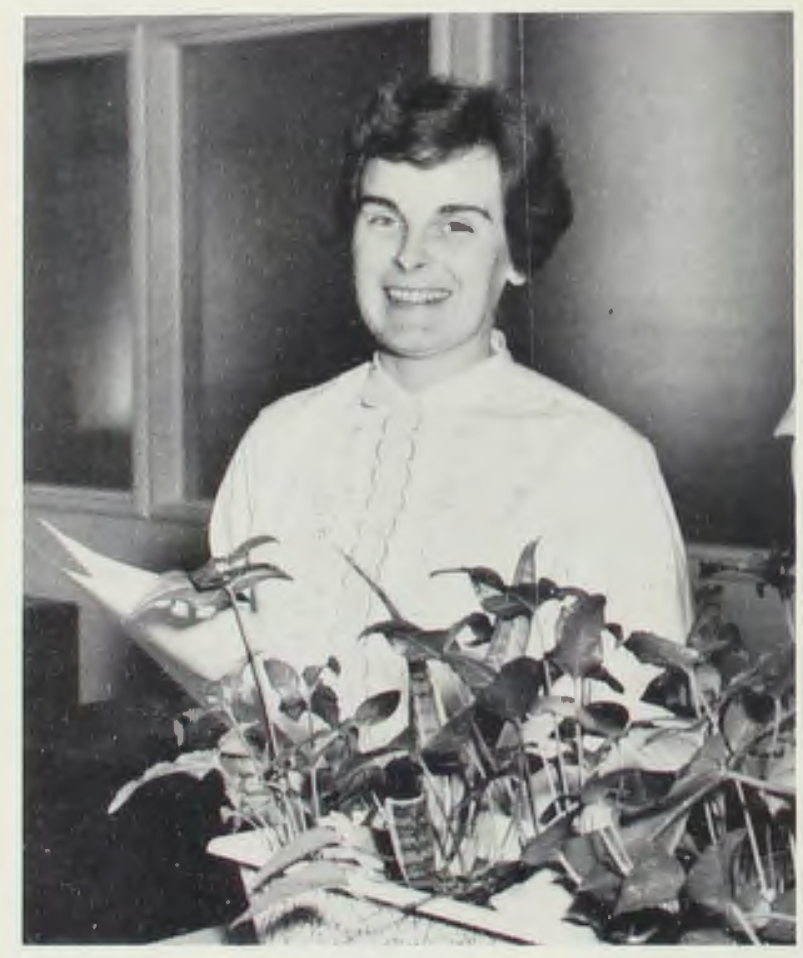

Gerry White

Secretary-Treasurer

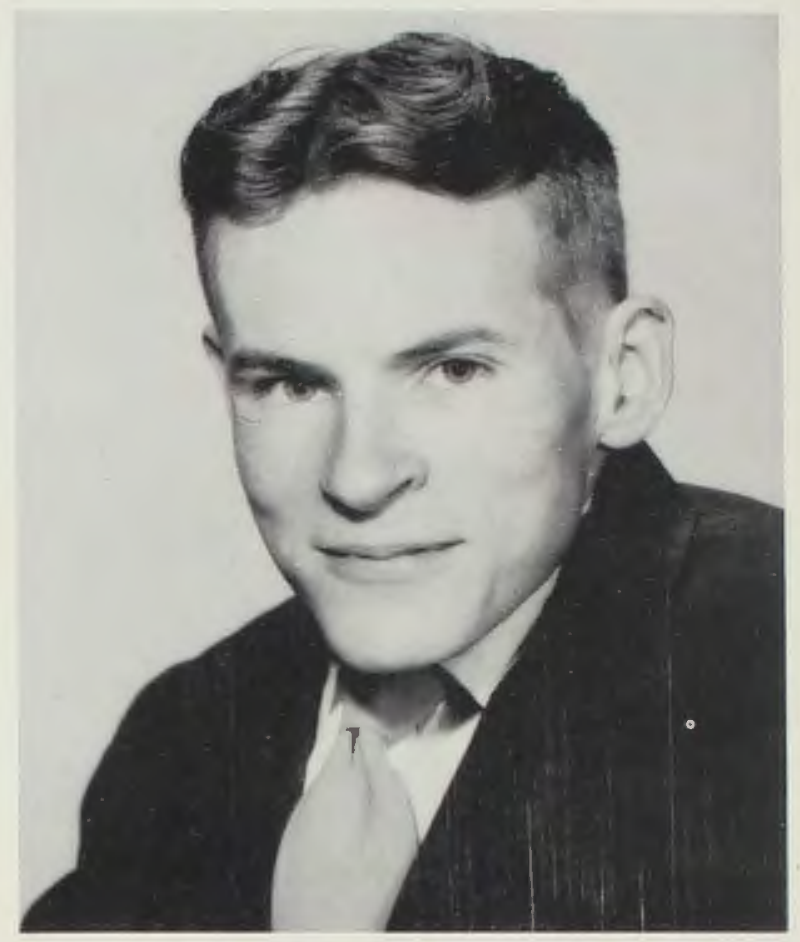

Jack Willetts

Vice-President

\section{ALUMNI ASSOCIATION OFFICERS}

President

Vice-President Cliff Boessel Jack Willetts Gerry White Jerry Throton Grand Rapids Regional V.P. Cleveland Regional V.P. 
1897

John Wilson Bickett

Raymond Porter Gorbold

Homer McMillan

Calvin Crawford Morton

John Alvin Orr 1898

Elmer Anderson Elder

James McMaster McQuilkin 1899

Cornelius Bruce Collins

Clara Belle Conner

Lida Duval Elder

James Heron

Mary Little

Jennie Belle Morton

Thomas Reed Turner

Isabelle Marie Winter 1900

Cora Agnes Anderson

Lulu May Coe

Walter Avis Condon

James Robb Harper

Sarah Elizabeth Hopping

William Wallace Iliffe

Bertha L. Knott

Mary Beatrice Knott

Nellie Byrd Lewis

Anna Myrtle Orr

Barnett McLeod Paul

Nellie Fern Ustick

Clarence Andrew Young 1901

John Frederick Anderson

Olive Davis Coe

Jean Blanche Ervin

Elkanna E. Finney

Robert Clyde Galbreath

John Cecil George

George Andrew Harper

Robert Bigham Wilson 1902

Mary Belle Ervin

Ethel Fields

Homer Burton Henderson 1903

Vera Andrews

Alice Marguerite Bromagem

John M. Finney

Alfaretta Hammond

Lulu May Henderson

Nora Almeda Paullin

Dora Siegler

Lucy Smith

Agnes King Stormont

John Jacob Wilson

Stephen Calvin Wright 1904

James Frederick Barber

Frank Stevenson Bird

Frank Barber Bull

Lillian Lucretia Conner

Joseph Raymond Fitzpatrick

Rachel Marie Garlough

Carrie Eleanor Hutchison

Frank L. Orr

William Allan Pollock

Mary Jane Ramsey

Carrie May Rife

Raymond Bert Shaw

Frank Houston Young 1905

William Renwick Graham

Milton Garfield Hanna

Clarence Dean Liggett

Raymond Hardie Liggett

Samuel J. McMillan

Minnie Ritenour 1906

Effie May Crawford

Claude B. Estle
Joseph Austin Finney

Peter Knott

Martha Pearle McCampbell

Walter Wylie Morton

Jones Emerson Shaw

Walter Rasner Shaw

Louisa Herlihy Smith

Mary Eleanor Smith 1907

Charles Llewellyn Baskin

Fern Clarissa Ervin

Margaret Jane Lackey

Jesse Carl Marshall

Leroy Tate Marshall

Anna Belle Middleton

Ina Mae Murdock

Nellie G. Siebert

George Cameron Stewart

Clarence Gordon Ware

Frederick William Williamson 1908

Caroline Finney

John Frazer Nash

Leroy Spencer Henderson

Florence Russell

Elmer Gideon Spahr

Bessie Sterrett 1909

Lulu Verna Bird

John Lloyd Confarr

Julia Harbison

William Hawthorne

Martha Knott

Ernest Bogle McClellan

Mary Jeanette Orr

William Waide 1910

Ada Allen

Robert Fred Bird

David John Brigham

Anna Alberta Creswell

Andrew Sterrett Cresswell

Howard Chalmers Creswell

Samuel Franklin Creswell

Ruth Alice Flatter

Howard McMillan Harbison

Ralph John Hill

Della May McCann

Ethel Isabell McMillan

William Washington Ritter

Edward B. Shaw

Ella Inez Shepherd

John Kenneth Williamson 1911

Josephine Orr

Frank M. Reynolds

John Orr Stewart, Jr.

Bertha Alida Stormont

Lydia Eleanor Turnbull

Robert Woodbridge Ustick

Florence Jane Williamson 1912

Martha Marie Anderson

Grace Lillian Beckley

Samuel Arthur Dean

Phil DeWitt Dixon

Ethel Viola Anneka Githens

Walter Payne Harriman

Howard Wesley McGaffick

Wilhelmina Edith Mitray

Ila Myrtle Ramsey

William Ream Shroades

Hugh Turnbull

$$
1913
$$

Bertha Isabelle Anderson

Mary Lida Cooper

Samuel Ernest Foster

Wendell Franklin Foster

Mary Ellen Lownes

James Earl McClellan

Raymond Torrence Williamson

Laura Belle Wright
1914

Robert Bruce Anderson

Clara Lillian Boase

Nancy Ethalinda Finney

Anna Mary Hastings

Ralph Clare Hofmeister

Hazel Virginia Lowry

Grace Morton

Mary Edna Stormont

Thomas Whyte 1915

Harry Freeman Bird

Rea Cecil Burns

Inez Erma Conner

Clarence Joseph Loyd

John Roscoe McCorkell

Cameron McKenzie Ross

Wilmah Spencer

William Dwight Sterrett 1916

Mary Edna Bird

David Collins Bradfute

Mary Dorothy Collins

Mildred J. Corry

Mildred E. Crouse

Ralph Stewart Elder

William Allen Hastings

Gladys Beatrice Post

John Merle Rife

Margaret Belle Rife

Carey Paton Ritchie

Orland Melville Ritchie

George Frederick Siegler

Ada Frances Wallace 1917

Donna Hall Burns

Mary Elizabeth Chesnut

Anna Dinsmore Collins

John Wallace Collins

Mrs. Charles E. Payne

Ruth Ramsey

Florence Enid Somers

Mabel Lillian Stormont

Lorena Belle Taylor

Mildred Trumbo 1918

Mrs. Leroy Allen

James Lyons Chesnut

William Rife Collins

David Linton Doherty

Ruth Rosetta Harris

Robert Linton Hutchinson

Mrs. R. L. Hutchinson

Daniel Lawrence Kennon

Sherman Liming

Janet Eliza McClellan

Carrie Olive Northup

Helen Pauline Oglesbee

Mary Louetta Taylor

Naomi Irene Wright

19,19

Andrew Roger Collins

Helen Creswell

Margaret Ellen Elder

Margaret Louisa Finney

Olive Eunice Finney

Marguerite Marie Gilkey

Mary Lucile Johnson

John Harvey Rickenbach

Freda Frances Trumbull

Allen Bird Turnbull 1920

Robert Nicol Colman, Jr. S. Morton Creswell

Walter Chang Tong Chu

Norman Baird Foster

Reba Irene Harbison

Rebecca Fay Marsh

Malcolm Nicholson

Dorothy Oglesbee

Dorothy Smithson

Ellen Elizabeth Tarbox

Mary Hester Townsley

Mrs. Anna O. Wilson 1921

Leslie Scott Dean

Paul Warren Duncan

Margret Louise Greer

Millie Mae Parker

Helen Marie Stewart

Dorothy Tarr

1922

John Edwin Bradfute

Helen Elizabeth Bradfute

Riley Walter Clarke

Lucille Colterell

Lillian Alice Daines

David Harold Hammond

Lena Hastings

Willard Haines Kyle

Margaret Elizabeth McCarty

Edith Ramsey

Josephine Randall

David Cecil Rife

Ralph Leroy Rife

Mabel Strobridge

Marion Earle Collins

Mrs. D. C. Davis

Eloise Davis

A. Cecil Ewbank

Mary Lucille Flanagan

James Colver Kyle

Alice K. Lackey

Marjorie D. McClellan.

E. D. McKune

Ruth Elsie Shaw

Florence E. Smith

Robert W. Stewart

Albert Wright

Marjorie Wright

1924

Harper Bickett

Lucinda Caskey

Thelma Deacon

Lois Elder

Helen Iliffe 
Harriet Kyle

Lloyd McCampbell

Mae McKay

Lois E. Manor

Paul Orr

John E. Rockhold

Carl Shanks

Lorena A. Sharpe

William E. Snell

Marguerite Spraclen

Robert A. Turnbull

Malcolm R. Turner

Susannah West

Marvin Williams

Frederick Wills

1928

David Adair

Wilda M. Bickett

Verna Boase

Paul J. Brown

Ruth Anne Burns

Mary Ciminelli

Ruth G. Collins

Marguerite B. Donaldson

Mary Lois Estle

A. C. Ewbank

Ernest R. Gibson

Alberta Marie Hemphill

Calrabel Hunt

Helen Margaret Iliffe

John E. Johnson

Day Kennedy

J. Herman Lemar

Lelia D. Lemar

Kenneth Little

Lois McFarland

Ada Lovella McKay

James C. McMillan

Gladys Hill MacDonald

William Nagley

Mary C. Webster

Calvin T. Weimer

Edward Simeon Wones 1929

Frances Belle Anderson

Harvey C. Auld

James S. Beam

Margaret Alice Chandler

Glenn D. Coy

Robert M. Dean

Bertram B. Fleming

Carl C. Frazier

Robert B. Jacobs

Herber E. Keach

James A. Lemon

Calir V. McNeel

Irene May Wigal

Nedra Elizabeth Wilson 1930

Josephine Auld

Hazel McCoy Barber

Garnet Barnhart

Gladys Beatty

Verla Bishop

Blair Brasel

Robert Bratton

Roy Elston Corrill

George W. Davis

Dorotha Fanning

Eleanor Finney

Lillias Mae Ford

Mrs. Cammie Lee Gormley

Frank L. Graham

Elizabeth Haydock

Lois B. Hutchison

McGarvey Ice

Willis C. Kenney

Stella A. Kirby

Herbert L. Main

Wesley Newton Mantle

Dallas Marshall

Frances McChesney

Martha Jean Morton

Arcelia Phillips

Harry B. Pickering

Hilma M. Raisanen

Marian Roseberry
Roger V. Stormont

Lucille Tanner

Rebecca Trumbo

Mary Ruth Wham

Dorothy Louise Wolff 1931

Walter W. Boyer

Wendell Boyer

Bernice Leah Bryant

Mildred M. Carle

J. Robert Collins

Wilma Curry

Edith Elizabeth Foster

Joseph Foster

Carmen Frazier

J. Vernon Hickman

Helen K. Powers

Christine Rife

Sarah Rumbaugh

James Stormont

Irene Tobias

Alfred Townsley

Brenton R. Turner

Wilda Auld

Mrs. Alice M. Borst

Sarah Margaret Chance

Rachael C. Douthett

Bernese E. Elias

Marion S. Hostetler

Edward Irons

Esther Leitschuh

Ruth Marshall

Gertrude Martin

Eloise McLaughlin

Leo Reed

Ida Rees

Alpha Sheely

Lenora Skinnell

Rodney Taylor

Mildred Trumbo

Robert Lane White

James Otis Young 1933

Mae Agle

Mrs. Alyce Brill Allen

Charles E. Bost

Gladys Bumgarner.

Mary Crawford

Kenneth Ferryman

Mary Eleanor Ford

Joseph M. Free

Marjorie Gordon

Willis Gormley

Viola Harbaugh

Mrs. Blanche Rihl Hines

Clyde A. Hutchinson, Jr.

Helen L. Jones

Florence McLaughlin

Helen Reddington

Robert Richards

Irma Jean Spahr.

Frances Straley

Doris Swaby

Edward Tedrick

Mrs. Esther Tiffany

Wanda Turnbull

Louise Waddle

Elizabeth Walker

$$
1934
$$

Glenia Basore

Margaret Berk

Dorothy Corry

Lois Cultice

Kenneth Ferryman

Raymond Hargrave

Doris Hartman

George Kenfield

Walter Kilpatrick

J. Paul McLaughlin

John Mills

George Moody

Homer Murray

John N. Murray

Beatrice Pyles

Lloyal Ross
Robert Ross

Regena Smith

Nina Stevenson

Virginia Watkins

Jane West

Ruth West

1935

Maxine Bennett

Ronald Boyer

Eleanor Bull

Gilbert Christian

Allan Copeland

Annabel Dean

Arthur Donaldson

Carl Fergerson

Robert Harriman

Edgar Hinton

Carma Hostetler

A. Ferman Kearney

Walter Linton

Mary Lou McLaughlin

Carrie Mount

Paul Rife

Luella Robe

Eugene Spencer

Robert Taylor

Ralph Tindall

Franklin L. Trubee

William Waddle 1936

Donald Beuhler

Olive Brill

Donald Burkert

Dorotha Corry

Eugene Corry

Verner Garlough

Mildred Labig

Julia McCallister

Russell Murray

Paul Reed

Joseph A. West

Anna Jane Wham 1937

Dorothy Anderson

Paul Angell

Mildred Beard

Mary Helen Creswell

Betty Fisher

Albert Grubbe

Ruth Kimble

John Richards

Gale Ross

Robert Thompson

John Tobias

Esther Waddle

Joseph Waddle

Harry Wallace

1938

James Anderson

Martha Bryant

Rachel Creswell

Herbert Cummings

Wilmott Fisher

John Gillespie

Justin Hartman

Mary Johnston

Roy Linton

Mildred McKibben

Kenneth Sanderson

Betty Shaw

Harold Shaw

Harry Sinks

Howard Swaim

1939

Kenneth Deeter

John Fox

Jane Frame

Arema Hays

James Jackson

Orval Labig

Fred Lott

Beatrice McClellan

Bennett McNeal

Kenneth McNeal

Angus Murray

Noah Sharpe

Vic Shaw

Raymond Sisson

Cecil Thomas

Melvin Thompson

Clyde Walker

1940

Grace Bickett

Pauline Ferguson

Donald Foulks

Eldon Gillespie

Irene Goodin

Royden Johnson

Jean Maddock

Russell Roberts

Elwood Shaw

LaVerne Whipp 1941

Elizabeth Anderson

Ned Brown

Helen Chitty

Rolland Flory

Arthur Geake

Neil Hartman

Naomi Hoke

Ted James

Eugene Kavanagh

Everett Keener

Jean Maddock

Justin Northup

Doris Ramsey

Theodora M. Smithers

Harold Thomas 
Ted Frank Harsh Raphael Hofman Jesse Virgil McNeilty Guy S. Potts Thomas W. Rudisill Edna Claire Stormont Montgomery West

Keith Dewitt Wright 1948

Willis Anderson

Mary Jane Cabender

Wesley Dutiel

Ellen Smith Hawker

Frederick Huish

Clarence Jewell

John Krumm

George Lipp

Conner Merritt

Ruth Reiter

Edwin Ryan

William Troute

Carl Watkins

Donna Watkins 1949

Donald Barger

Rollie Barton

Max Bitler

Richard Brown

John Jay Check

William Clark

Kathleen Evans

Robert Filer

Rachel Guthrie

John Hawker

Marjorie Hill

Columbus Hines

Kenneth E. Judy

Arthur Lewis

Allen Loos

Mrs. J. Milton Miller

Raymond Mullen

Norman Potts

Paul Price

James Rowe

Eugene Sallie

Harold Warix 1950 - Summer

John Bauman

Bion Bradbury

Phyllis Bryant

Clay L. Cottle

Raymond Glenn

James Wm. Haley

William Hammond

Aldon Archie Justus

James Lewis

Joanne Sanderson

- Clara Squires

Donald R. Strasburg

Roger W. Ulsh

Gordon Williams

James F. Wisecup 1950

Emory Beireis Marianna Beireis

Walter Blateric

James Burns

Livia Check

Naomi Conner

Bill Cunningham

Charles Davis

William Dunlap

James Dunn

Wayne Evans

Marie Fisher

Floyd Gothard

Louise Harner

Kenneth Huffman

Carl Jones

Ruth Neatherton

Robert Rader

James Ross

Edith Rutan

Eugene Sallee

Leo Shaughnessy
Ernest Stanley

John Stewart

Martha Tannehill

Tay Thompson

Viola Thurman

John Townsley

George Watt

Daniel Webster

Eleanor Weismiller

Kenneth Wilburn

$$
1951 \text { - Summer }
$$

Emerson Ackison

Ray Carter

Garland Cox

Gene Cultice

Eugene Fisher

Paul Klontz

Mary Arnett Miller

Thomas Osborne

Robert Peters

Frank Pickens

Alson Scrivner

Walter Sewak

Glen Shumate

Richard Smith

Carol Warix

Richard Wright

1952

Eric Bauts

Kenneth Carpenter

Earl Downs

James Dull

Paul Dunn

John English

Richard Evans

Paul Fiedler

Vernon Francis

Edward Goodwin

James Hartman

Vernon Hooper

David King

David Spitzer

Donald Staggs

John Syrek

Charles Thomas

Jimmie Trinkle

James Wagner

Kenneth Woods

Betty Yeider 1953

Walter Banks

Zenas Corell

Phyllis Cunningham

James Douglass

Raymond Fellenger

Rose Haley

Martha Hall

Harold Hasse

Edward Helmick

George Hunt

James Johnson

Richard Johnson

J. Howard Jones

Nancy Kalmus

Samuel Kalmus

Leslie Koskovics

Robert McGrew

E. Ann McLallen

Ted Mohat

Mary Ann Morrin

Charles Owens

Max Tucker

Helen Wellman

Jack Yardlay

Charles Paine

Dale Tilton

Jean Hothem Ames

Arthur Anderson

Matilda Blanton

William T. Carter

Walter E. Garland

Donald J. Guarnere

Laurine M. Gullette

Harold Hukill
Leigh Hunt

William Patterson, Jr.

Donald F. Rettger

Lynn Robers

Barbard Hill Rogers

Bernadette Coon Schenck

Ethelmae Shisler (Mayo)

Dorothy J. Smith

Gail E. Smith

James Spaulding

Patricia Stockin

James O. Taylor

James A. Varga

Bradley J. Wolcott

William Yost

1955

Alice Austin

Nelson Collins

Martin Edwards

Melvin Entingh

Harold House

James Johnson

Verne Kirby

Ted Lemaire

Robert McGrew

Bernice Mick

William Patterson

Robert Rogers

Glenn Saunders

Paul Schenck

David Seldon

James Shaw

Carol Wilson (Willetts)

Gordon Wimer

Shirley Wolcott 1956

Roger W. Ames

William Brown

Barbara J. Ferry

Leon Franck

David L. Gardner

Ellen Hornbrook

Sam C. Hornbrook

Wanda Panter

Margaret Spaulding

Virginia Stubbs

Dale Thomson

Gerry White

1957

Raymond Bartholomew

Florence Bockhold

Eladio Bolanos

Dale H. Breedlove

Wendell Capron

Harold Carpenter, Ir.

Nancy Jane Cope (Payton)

Doris Deken

Raymond Erickson

Delbert Geer

Tom George

Glenn Greenwood

James Sherwood Hartman, Jr.

Harold Hukill

Patsy Yvonne King

Robert Kissinger

Richard Lapp

Linda Marshall

Allen Oaks

Roy Shelpman

Shirley Shirley

Howard Shumate

James G. Spaulding

Albert S. Yost

William Yost

Veda Belle Young 1958

John Brumbaugh

Esther Chesebro

Keith Coakley

Frances Cooper (Cook)

James Erskin

Elmer Evans

Robert Marcellino

Edward Mawhorter

Lowell C. Miller

Lane Moody

Joe Raymer

Maurice Stone

Jerry Thorton

Richard Wentzel

John Willetts

Albert Yost

1959

Clifford Boessel

Eugene Christian

Sandra Millikin Entner

Robert Howder

Dick Johnson

Carol Johnson Reiner

Raymond Reiner

Jerrold Root

Mary Smith

David Thomas

Paul VanKleek

Marshall Watson, Jr.

Lester Webster

Grace Willetts

Ruth Yost

Merlin 1960

Paul Anderson

Howard Andrus

Ruth Boalt

Alberta Chaffe

Stuart Chaffe

Keith Collett

David Dautel

John Dowden

John Entner

Phyllis Ernst

Bill Evans

Dwayne Frank 


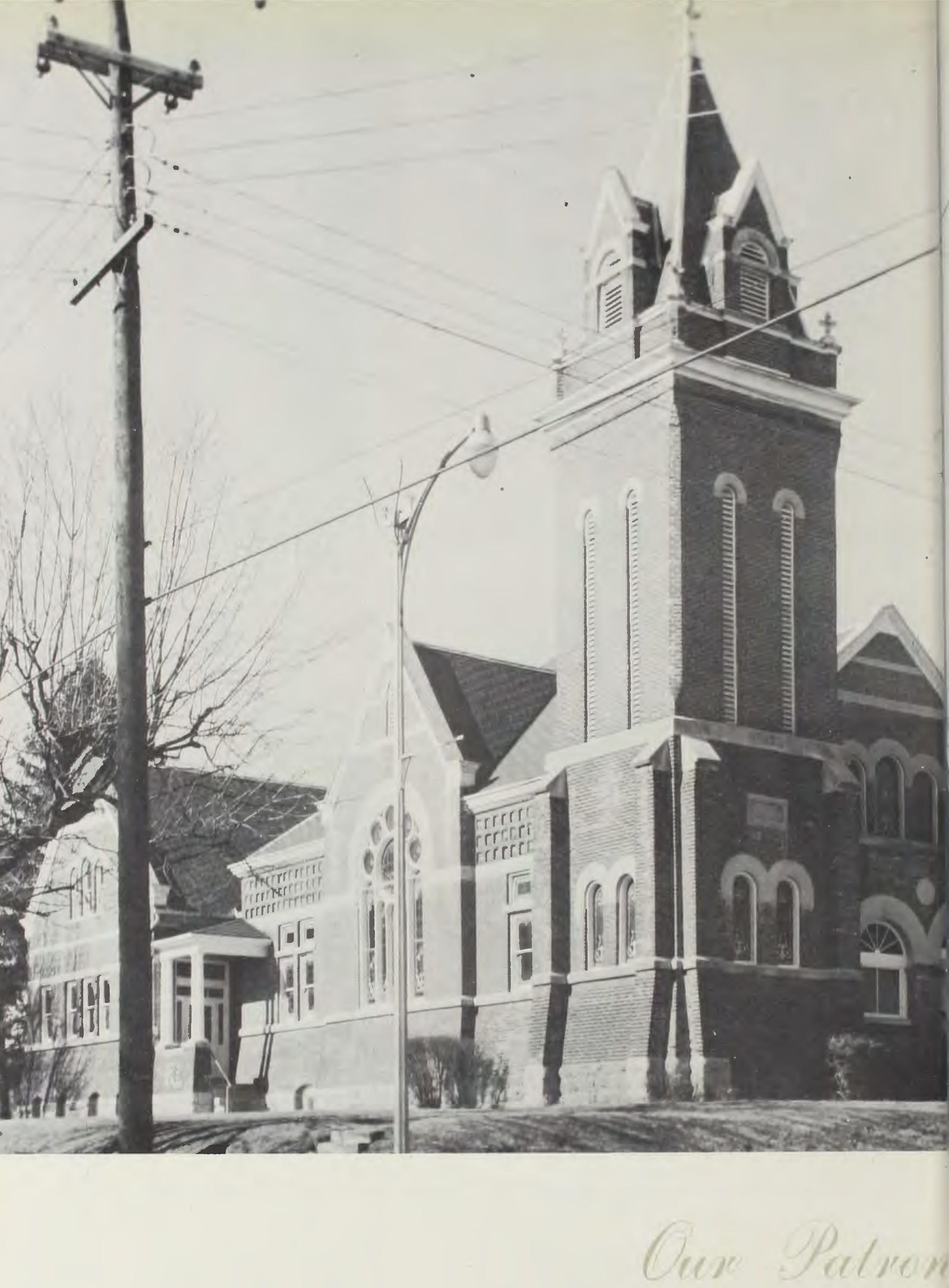


Grace Baptist Church, our home church during student days, is typical of the churches across the nation who support our college with prayers and gifts. Although the General Association of Regular Baptist Churches constitute the major consistent support for our college, local individuals and businesses also have shown their interest through the years. 
CONGRATULATIONS

TO THE

CLASS OF '62

\title{
FIRST BAPTIST CHURCH
}

154th and Lexington

Harvey, Illinois

Rev. Hall Dautel, Pastor

A cordial welcome awaits you bere

when in Cbicagoland

\author{
Sincere \\ Best Wishes \\ to the Class of ' 62
}
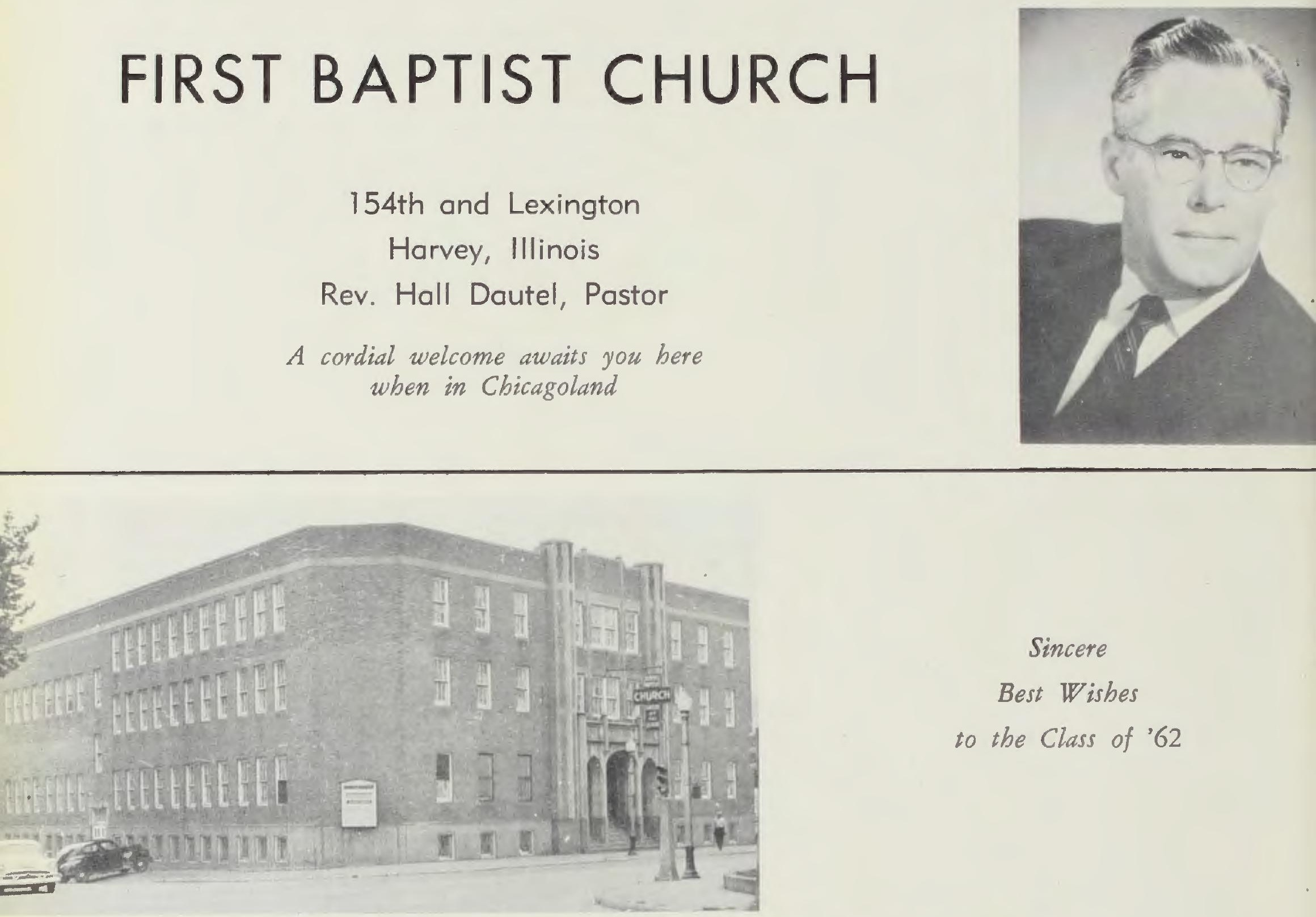

TEMPLE BAPTIST CHURCH

Portsmouth, Ohio

9:15 A.M.

Sunday Services

10:30 A.M.

Bible School

Morning Worship

Broadcast over WNXT, Portsmouth (1260 on your dial)

5:30 A.M.

6:30 P.M.

Broadcast over WPKO, Waverly, Ohio

7:30 P.M.

(1380 on your dial)

Youth Groups

9:30 P.M.

Evening Service

Delayed broadcast of evening service WNXT, Portsmouth 
CONGRATULATIONS

AND

GOD'S RICH BLESSINGS UPON YOU FROM

FIRST BAPTIST

$\mathrm{CHURCH}$

120 Main Street

Hamburg, New York
WE PRAY FOR CEDARVILLE WE GIVE TO CEDARVILLE WE SEND OUR YOUTH

TO CEDARVILLE

FIRST

BAPTIST

$\mathrm{CHURCH}$

Medina, Ohio

R. Kenneth Smelser, Pastor

\section{SOUTH BAPTIST} $\mathrm{CHURCH}$

191 Main Street

Tottenville, S. I. 7, New York

Rev. James M. Grier Sunday School and Bible Class 10:00 Morning Worship $11: 00$

Young Peoples

Evening Gospel Service $7: 30$

Wednesday Prayer Service

\section{FIRST BAPTIST $\mathrm{CHURCH}$}

Third Avenue at Locust Street Gallipolis, Ohio

Rev. Howard G. Young, D.D., Pastor Residence: 459 Third Ave.

"In the HEART of the City with the City on its HEART."

When in our Area

You are cordially invited to attend our: Bible School at Morning Worship at Young People's Meeting at Evangel Hour Service at Prayer Meeting, Wednesday 9:30 A.M. 10:30 A.M 6:30 P.M. 7:30 P.M. 7:30 P.M.

We Preach Christ Crucified, Risen, and Coming Again! 
Congratulations and the Lord's Blessing Class of 1962

\section{THE FIRST CHRISTIAN BAPTIST CHURCH}

Corner Seventh and Poplar Sts. HARRY E. COLE, Pastor

"For I am certain of this very thing, that $\mathrm{He}$ who began the good work in you will go on until the day of Jesus Christ to complete it."

Philippians 1:6 Williams Translation

\section{BAPTIST CHURCH}

\author{
Butler, Pennsylvania
}

"The Whole Christ In The Whole Bible For The Whole World"

REGULAR SERVICES

Sundays 9:45 A.M. Bible School

11:00 A.M. Morning Worship

(Broadcast on WISR)

6:30 P.M. Evening Fellowship Hour

7:30 P.M. Evangelistic Service

Wednesdays 7:30 P.M. Prayer Service

Clayton Gray, Pastor

\section{CEDAR HILL \\ BAPTIST CHURCH}

12601 Cedar Road

Cleveland, Ohio

Rev. John G. Balyo, Pastor CHRIST CENTERED, BIBLE BASED

\section{LIFE RELATED}

Attending Cedarville from Cedar Hill

Steve Boalt

Dave Fetzer

Joan Johnson

Judy Walborn

Janice Amos

Steve Nimmo

Jon Walborn
ON THE AIR EVERY SUNDAY

8:30 A.M WGAR 1220 kc A.M. 99.5 Meg. FM

7:30 P.M. WDOK 1260 kc A.M.

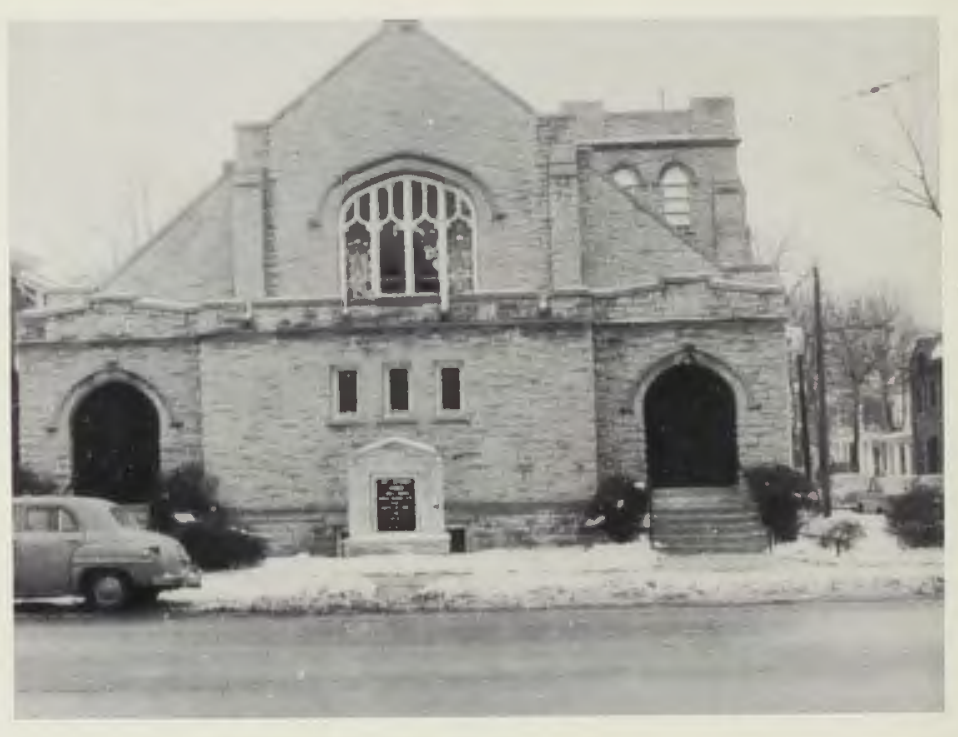

\section{FIRST REFORMED $\mathrm{CHURCH}$}

Detroit and Church Streets

Xenia, Ohio

Russell Mayer, Pastor 
Greetings and Best Wishes

From the

\section{FIRST BAPTIST \\ $\mathrm{CHURCH}$ OF \\ PARMA, OHIO}

5994 Ridge Road

Elliott Horton, Pastor

Parma 29, Ohio

TUxedo 4-2990

Parma 34, Ohio

Sunday School 10 A.M.

Bible Preaching 11:00 A.M. 7:30 P.M. Mid-Week Service __ 7:30 P.M. Wed.

"A Christ Centered Church With a Bible Teaching Ministry"
When In The St. Louis Area Visit The

\section{LACKLAND ROAD BAPTIST CHURCH}

10308 Lackland Road Overland, Missouri "The Friendly Church

Where Visitors Are Always Welcome" Sunday Bible School 9:30 a.m. Sunday Preaching Services 10:45 a.m. 7:45 p.m. Bible Training Union 6:30 p.m. Mid-Week Bible Study \& Prayer Meeting $\quad$ 7:30 p.m. Youth Meetings - Sunday 6:30 p.m. Mon., Tues., Wed. 7:00 p.m.

"Bus Transportation Furnished to Those in Need"

C. S. Henson, Pastor (Two Nurseries) Phone HA 7-7455
WE DESIRE

THE LORD'S BLESSING

TO BE UPON THE GRADUATES OF 1962

AS THEY CONTINUE FORWARD WITH CHRIST

\section{HUNTSBURG}

\section{BAPTIST CHURCH}

Route No. 322

Huntsburg, Ohio

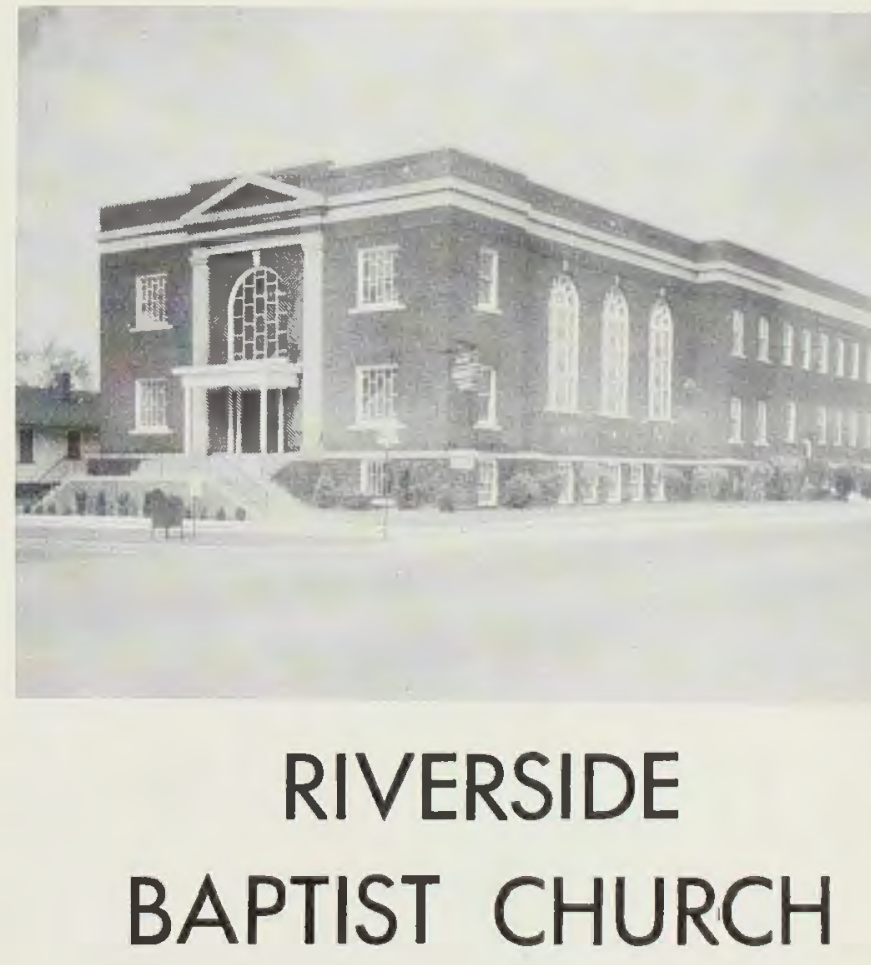

Decatur, Illinois

George A. Bates - Pastor Helen Lapp - Pastor's Secretary Jim Christensen - Youth Director

"As my Father bath taught me, I speak these things... for I do always those things that please Him." 
CONGRATULATION FROM BEREA

\section{BAPTIST CHURCH}

250 West Street

Berea, Ohio

Earl V. Willetts, Pastor

Residence Phone BE 4-9311

Church Phone BE 4-9798
FIRST BAPTIST

$\mathrm{CHURCH}$

2626 Prairie

Elkhart — Indiana

Rev. Hugh T. Hall, D.D. - Pastor

Rev. Marvin Kanengieter -

Ass't. Pastor

* * * * *

A Fundamental, Bible-believing Church in the Band Instrument Capital of the World.

In Fellowship with the General Association of Regular Baptist Churches.
CONGRATULATIONS

TO THE CLASS OF '62

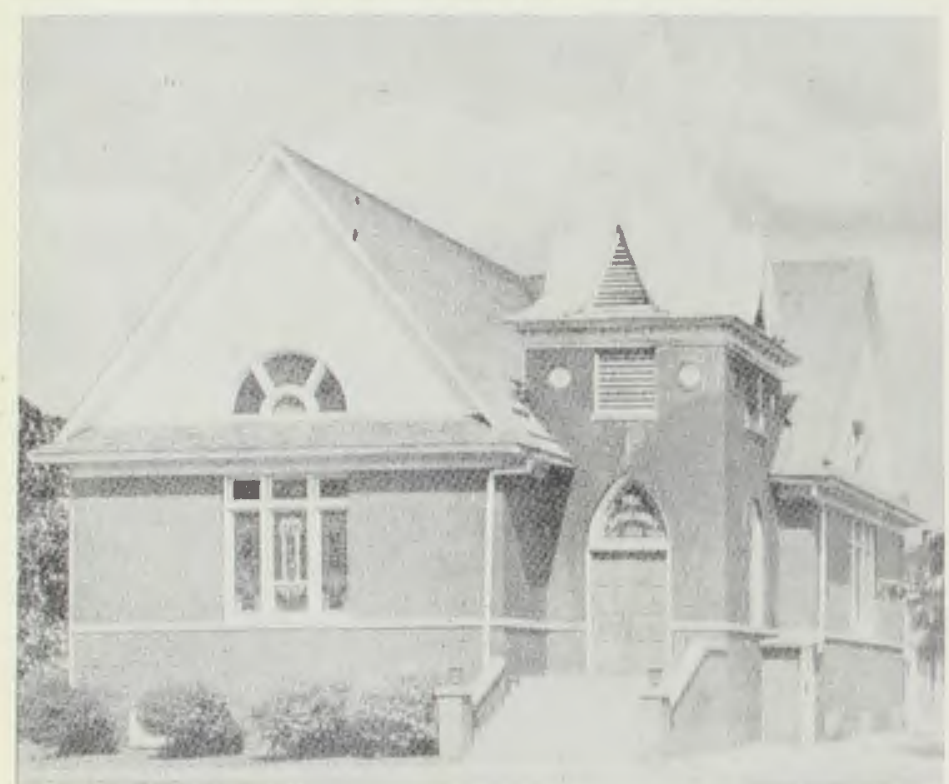

FIRST BAPTIST CHURCH

Monroe, lowa

A FRIENDLY CHURCH with

A BIBLICAL MESSAGE and an

ACTIVE PROGRAM for

EVERY MEMBER OF THE FAMILY

*****

You Are Always Welcome

\section{BLESSED HOPE \\ BAPTIST CHURCH}

315 S. Kensington Place Springfield, Ohio * * * * *

Glenn Greenwood Pastor

SUNDAY SERVICES

9:30 Sunday School

10:45 Morning Worship

6:15 Youth Groups

7:15 Evening Service Midweek Prayer Hour -

Wednesday 7:00

RADIO MINISTRY

7:30 - 8:00 Sunday evening WIZE - $1340 \mathrm{kc}$.

6:45 - 7:00 P.M., Mon., Wed., Fri.

WEEC-FM - $100.7 \mathrm{mg}$. 


\section{NOW! Enjoy the Finest \\ in Dairy Products... Produced in \\ Springfield's Most Modern Self-Serve \\ Home-Owned Dairy!}

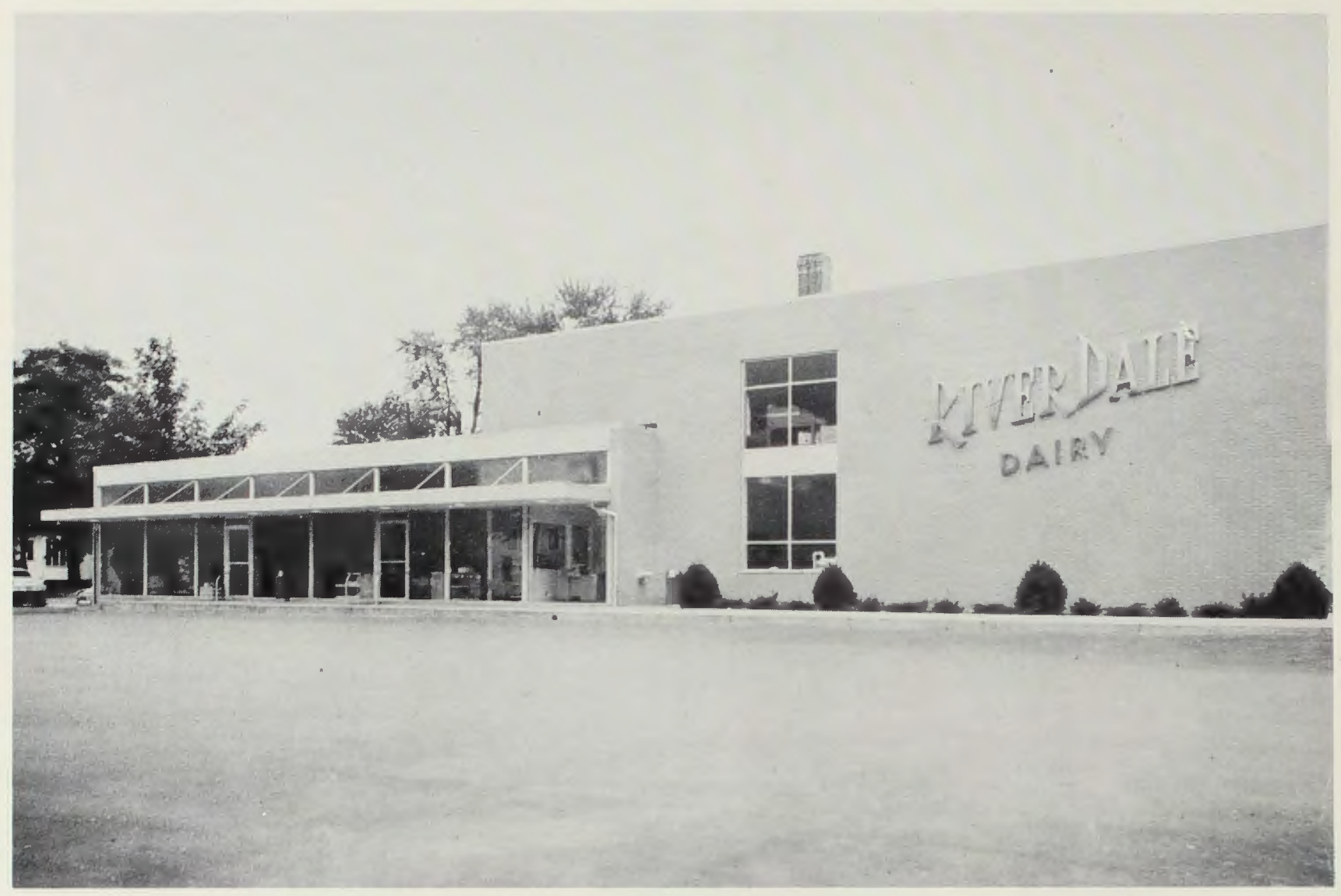

\section{BUY WHERE YOU SAVE}

Springfield's Home-Owned, Home-Operated

Corner Selma Road and Oak Street

Open Daily 8 A.M. Till 9 P.M. Plenty of Parking Space 
Congratulations to the Class of ' 62

CEDARVILLE COLLEGE BOOKSTORE

Student Supply Center

BERNICE MICK, Manager

\section{IRVIN DAIRY ISLE}

North Main St.

Ice Cream

Sandwiches

Sodas
Cedarville, Ohio

Soft Drinks Candy Sundaes

Shakes

Pizza Burgers

CHAPLIN CLEANERS

LAUNDRY SERVICE CLEANING SHOE REPAIR PRESSING

Tel. SO 6-3871

CEDARVILLE, OHIO

\section{RANDALL STORMONT, INC.}

Phone SO 6-1031

CEDARVILLE

$\mathrm{OHIO}$

Compliments

of

\section{MORRIS BEAN}

AND COMPANY 


\section{HAROLD'S \\ SOHIO SERVICE}

Batteries

Lubrication

Harold Rodin, College Student

Proprietor

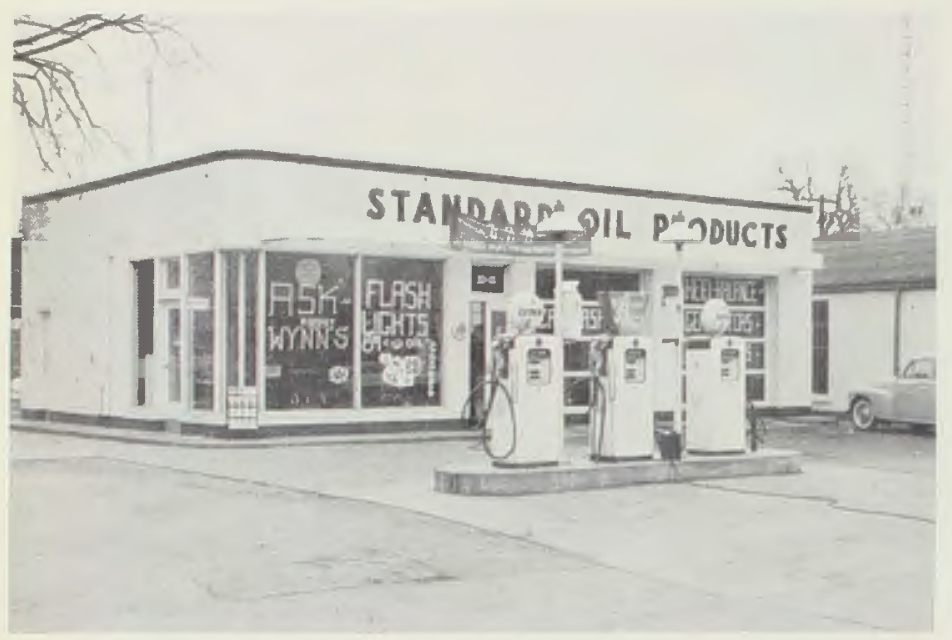

RECO

SPORTING GOODS

AND

GIFT STORE

UNIFORMS

JACKETS

SWEATERS

SPORTS EQUIPMENT

COME IN AND BROWSE AROUND

113 E. High St.

\section{MIAMI DEPOSIT BANK}

Complete Facilities

Ready to Serve You

CEDARVILLE, OHIO

and

YELLOW SPRINGS, OHIO

Member of the

FEDERAL DEPOSIT

INSURANCE CORPORATION

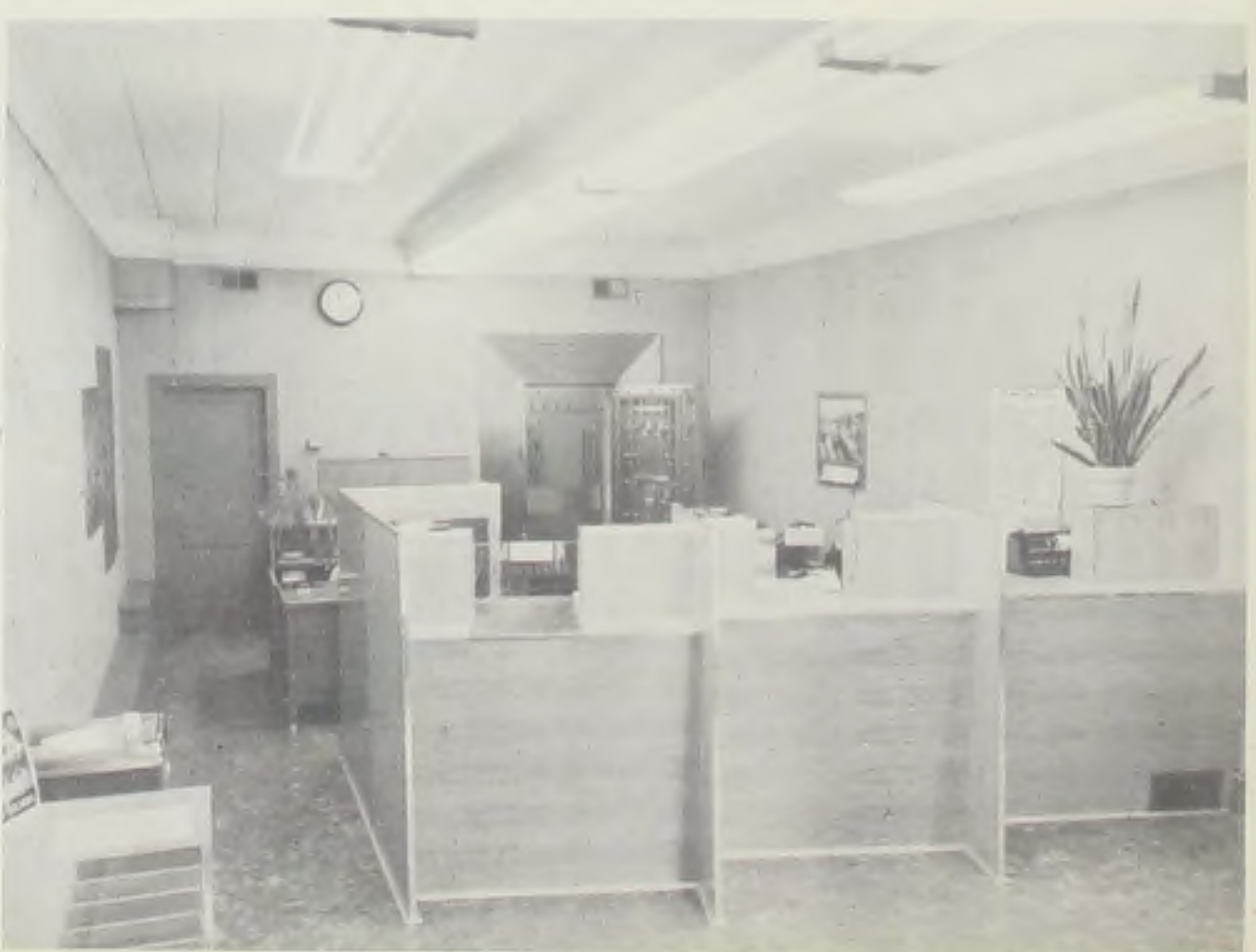




\section{PICKERING ELECTRIC}

CONTRACTOR AND DEALER

Cedarville, Ohio

SO 6-5191
Compliments of

CEDARVILLE HARDWARE

PROGRESSIVE HARDWARE SERVICE

CEDARVILLE, OHIO

Phone 766-1941

YOUR GE APPLIANCE DEALER

\section{RHEUBERT'S MARKET}

GROCERIES \& MEATS

18 North Main Street

SO 6-2151

CEDARVILLE, OHIO
CEDARVILLE

FEED \& GRAIN

GRAIN, FEED, SEED, COAL, SALT,

WOOL, FERTILIZER,

BUILDER'S SUPPLIES \& FENCING

CEDARVILLE, OHIO

Phone: Dial SO 6-2021

\section{HOAK'S GREENHOUSE}

\section{FLOWERS \\ FOR \\ EVERYONE}

Fairborn

Phone TR 8-8453

\section{CEDARVILLE MARKET \\ MEATS \\ PRODUCE \\ GROCERIES}

Phone SO 6-1201

CEDARVILLE, OHIO

\section{THE CRITERION}

$$
\text { Xenia, Ohio }
$$

MEN'S CLOTHING

AND FURNISHINGS

Varsity Town - Arrow - McGregor Freeman - Palm Beach — Stetson 
FIRST BAPTIST CHURCH

\section{SHELL ROCK, IOWA}

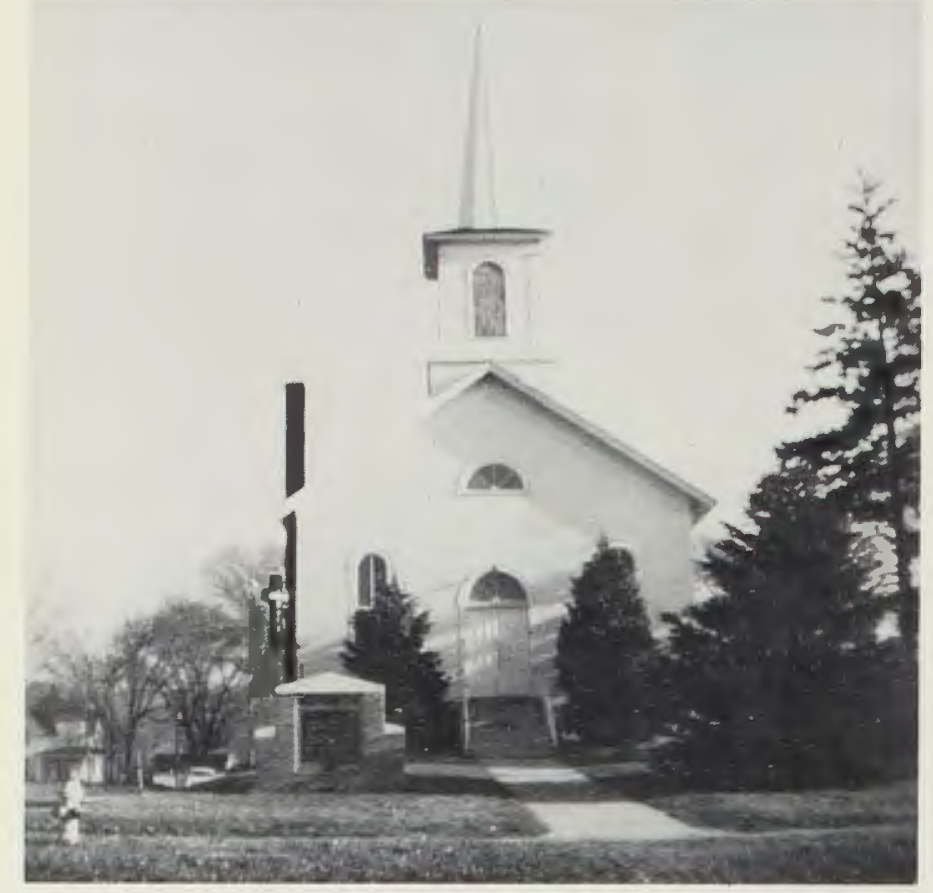

Sunday School

Morning Worship

Young People

Evening Worship

Midweek Service
10:00 AM

$11: 00$ AM

7:00 PM

8:00 PM

8:00 PM

FIRST BAPTIST $\mathrm{CHURCH}$ WILLOWICK, OHIO

Vine and E. 315th St. Willowick, Ohio

Rev. Paúl M. Cell, Pastor SUNDAY SERVICES

Bible School

Morning Worship

Youth Groups

Evening Worship

THURSDAY

Prayer Service

"A church with a warmth and a welcome for all"

REV. HARRY STICKLE, Pastor

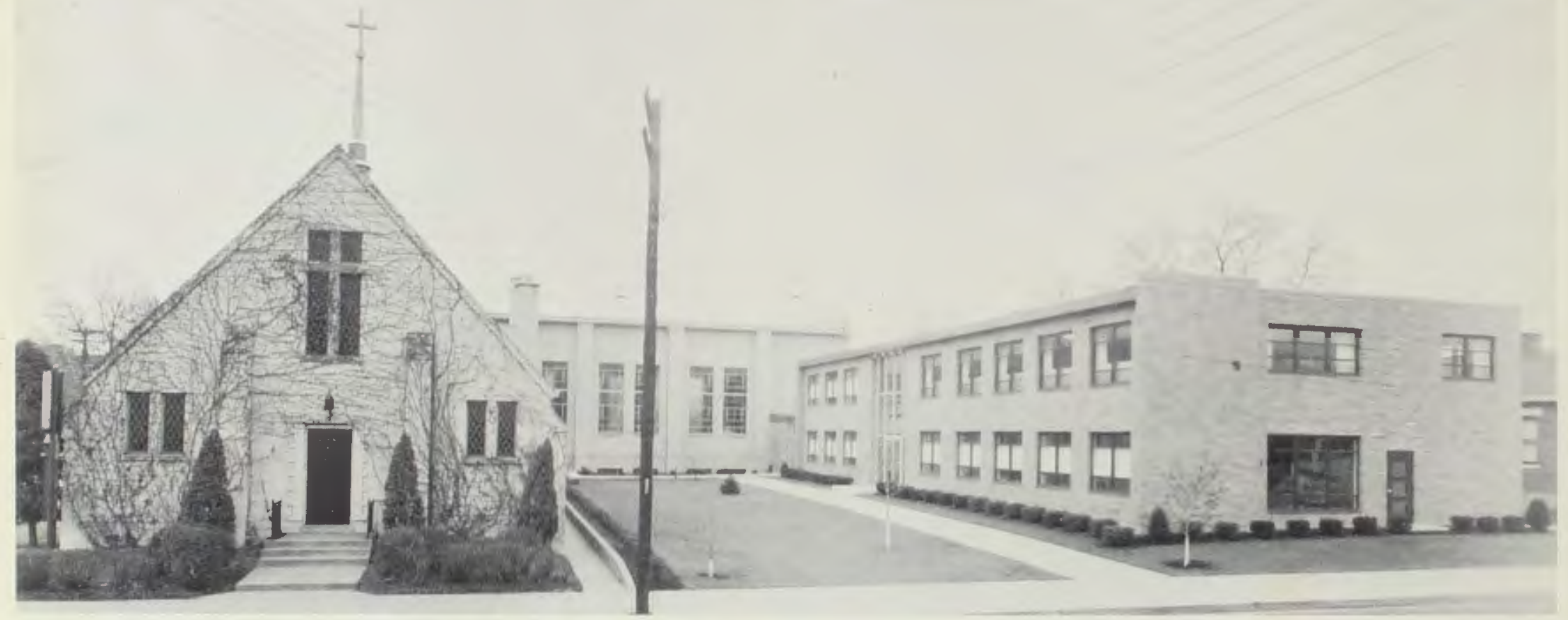

Welcome to

\section{CALVARY BAPTIST CHURCH}

"THE CHURCH WITH A HEART

IN THE HEART OF LATONIA"

Covington - Kentucky

D. B. EASTEP - PASTOR 


\section{FIRST BAPTIST}

\section{CHURCH - ELYRIA}

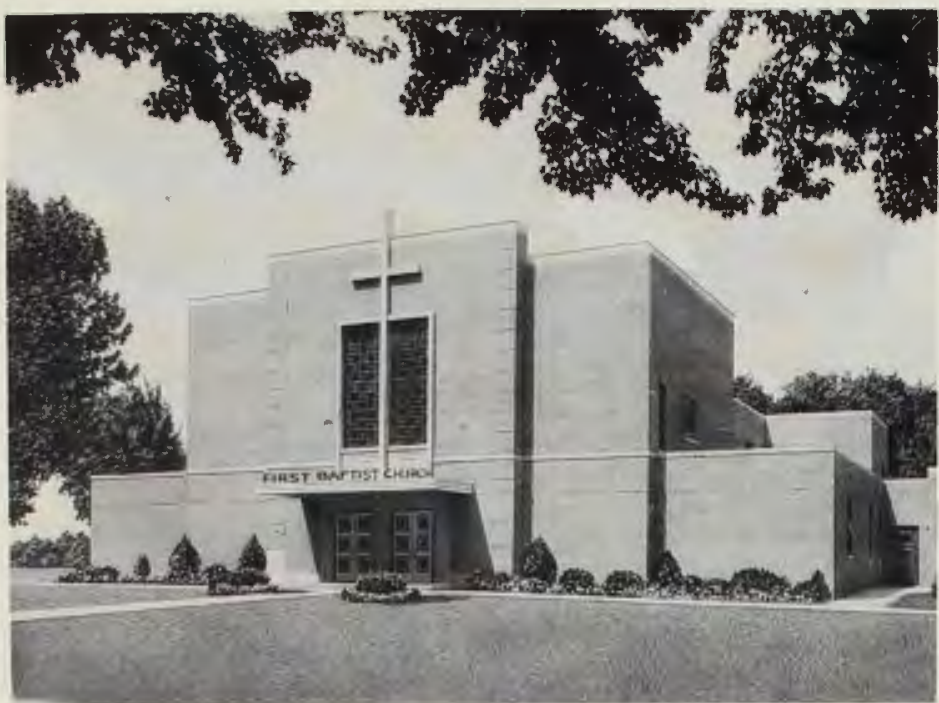

extends Best Wishes to the 1962 graduating class of Cedarville We invite you to worship with us when in Elyria.

Morning Worship ____ 8:30 \& 10:50 Sunday School ___ 9:45 AM Baptist Training Unions _-_ 6:15 PM Evening Worship ________ 7:30 PM WOODROW W. MCCALEB, PASTOR

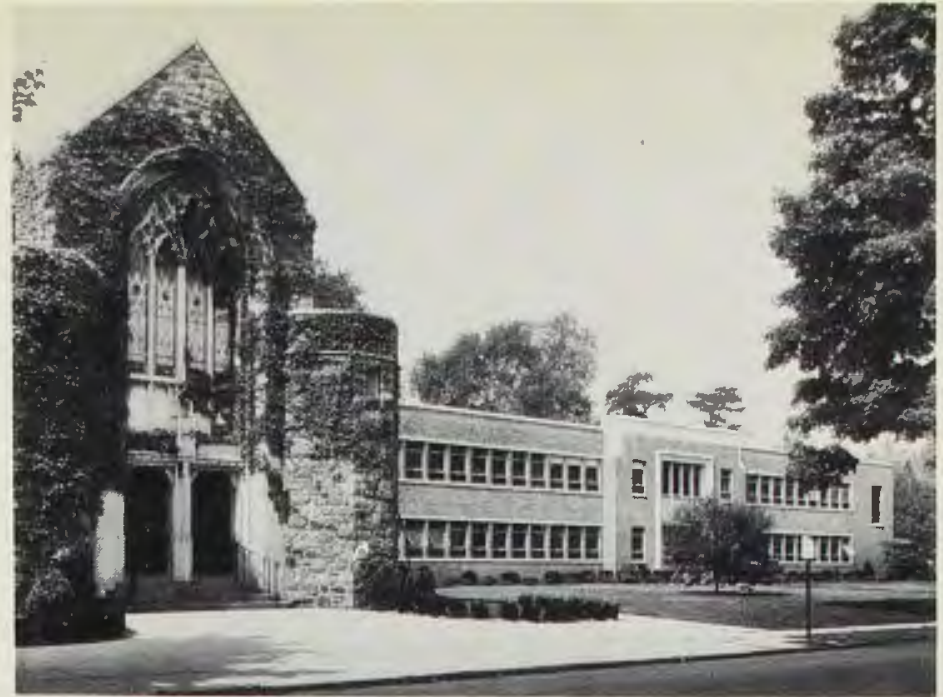

\section{FIRST BAPTIST $\mathrm{CHURCH}$}

Anderson Park

Hackensack, N. J.

Joseph M. Stowell, M.A., D.D., Pastor Charles S. Wilkes, M.S., Minister of Music

Warren E. Simmons, B.R.E., Christian Ed. Director

We believe God has a great future for Cedarville

The

\section{STUDENT'S CHURCH}

away

from home

SERVICES

Church Worship

Evangelistic Hour

$8: 30 \& 11: 00$ AM

7:30 PM

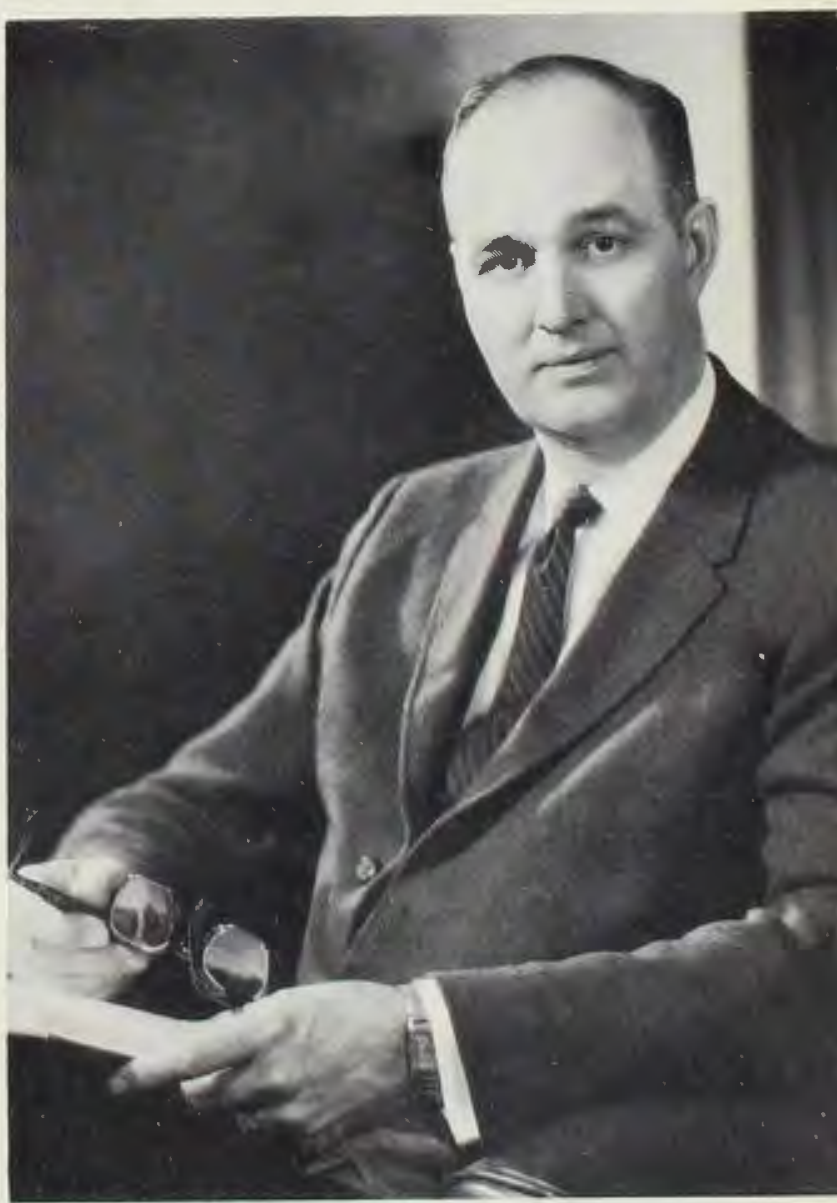

Rev. A. Donald Moffat, Pastor

\section{GRACE BAPTIST CHURCH}


Congratulations

and

Best Wishes

To The

Seniors

From Your Friends

MILNER

ELECTRIC CO.

Cleveland 14, Ohio

\section{IMMANUEL \\ BAPTIST CHURCH}

3417 Palmetto at Derrer Road Columbus, Ohio

William A. Brock, Pastor

\section{HADDON HEIGHTS}

\section{BAPTIST CHURCH}

Third and Station Aves.

Haddon Heights, New Jersey

"Holding Forth The Word of Life"

Rev. Kenneth W. Masteller, Pastor

Laurence E. Smith, Minister of Christian Education

- Weekly Schedule of Events -

\section{Sunday}

9:45 A.M. - Bible School (Departmentalized and Graded for All)

11:00 A.M. - Morning Worship Service

6:30 P.M. - Six Thriving Y.outh Groups Convene

7:30 P.M. - Gospel Service

Monday

7:30 P.M. - Visitation Program

Wednesday

Friday

8:00 P.M. - Prayer Meetings (Youth and Adults)

7:30 P.M. - Fun Night for Youth 


\section{CONGRATULATIONS \\ CLASS OF 1962 \\ FROM THE \\ CEDARVILLE COLLEGE ALUMNI ASSOCIATION}

\section{PORTRAITS - WEDDINGS \\ GROUPS

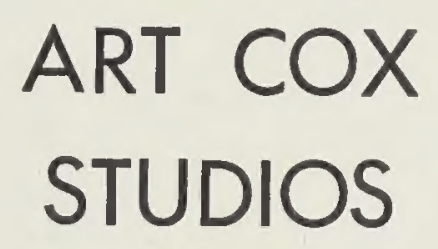 \\ 210 Weaver St., Xenia, Ohio \\ DR 2-1241}
Pastor H. O. Van Gilder, Jr. and
Members of the

\section{MEMORIAL BAPTIST CHURCH}

201 South Main Street

Verona, Wisconsin

(6 miles SW of Madison on US 18, 151) offer

CONGRATULATIONS to the

GRADUATES OF 1962

Regular services for all each Lord's day. Attending Cedarville from Verona:

Elsie Himsel, Jay Moore.

A WELCOME waits you and your family as you plan a vacation to AMERICA'S DAIRYLAND 


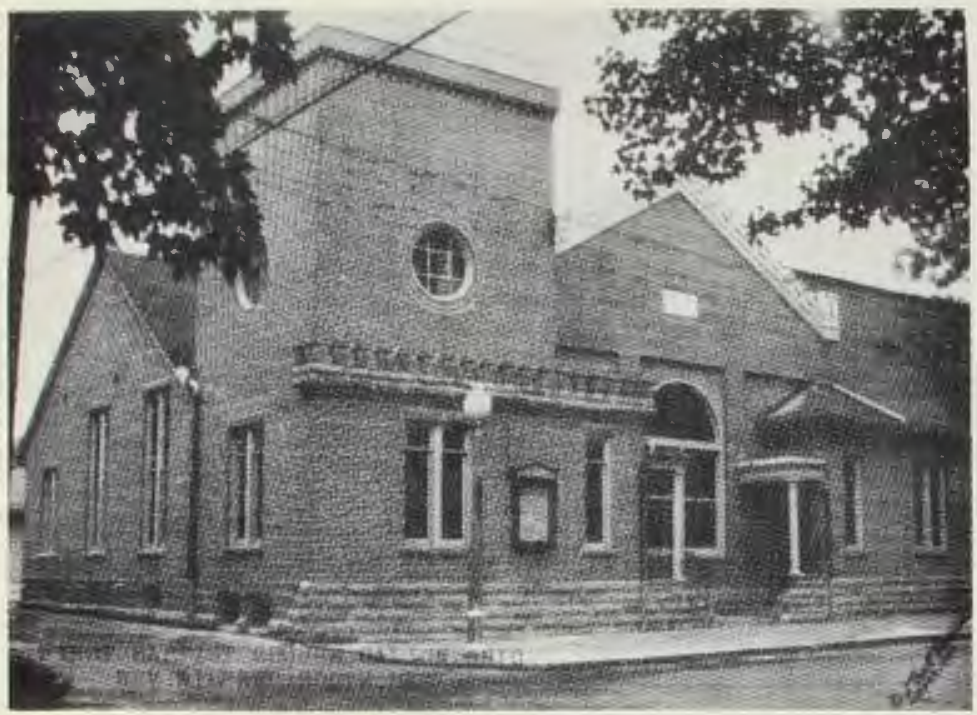

\section{FIRST BAPTIST $\mathrm{CHURCH}$}

Galion, Ohio

118 West Walnut Street

\section{PASTOR - Wilfred Booth}

SUNDAY

Bible School

9:30 A.M

Worship Service

10:30 A.M.

Baptist Youth Fellowship

6:30 P.M.

Gospel Service

7:45 P.M.

WEDNESDAY

Prayer and Bible Study

7:30 P.M.

You Are Always Welcome At The

1701 E. 33rd Street

Des Moines 17, lowa

CARL E. ELGENA, D.D., Pastor

sili/4

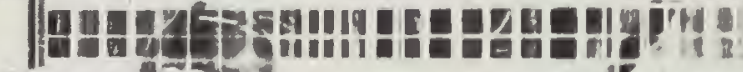

iNT $=-2$

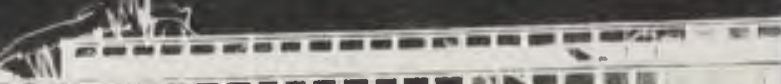

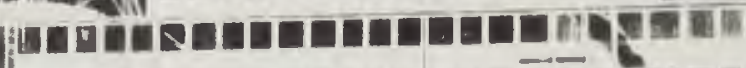

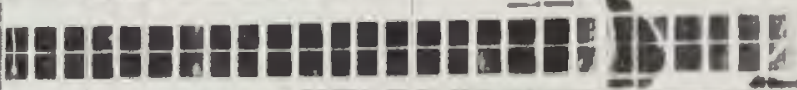

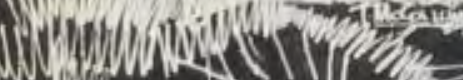

Minister of Music and Pouth

Mary Jo Short, B.A.

Director of Christian Education
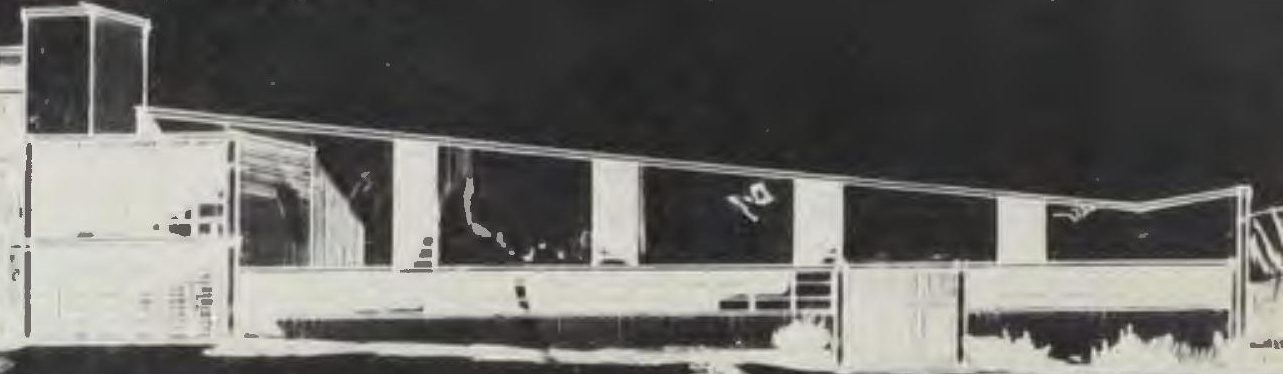

Regular Setvices:

for all each Lord's day.

FIRST BAPTIST CHURCH

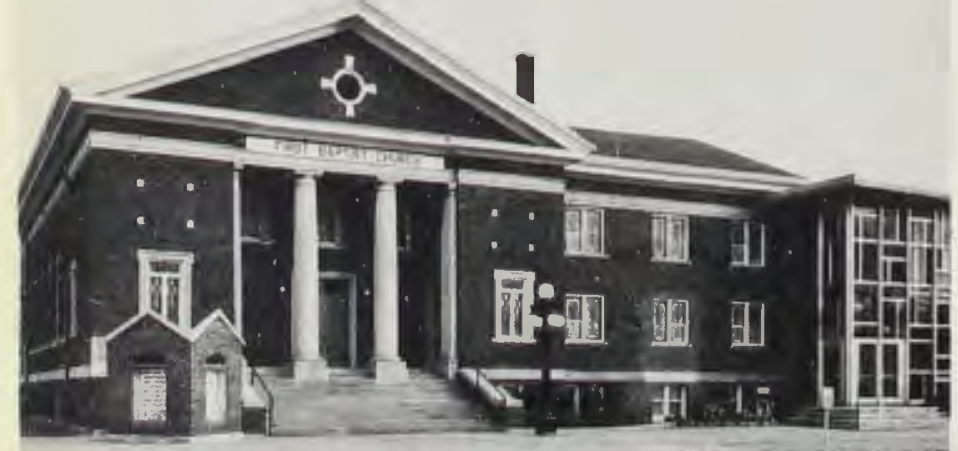

Moin and Lowrence

Mishowoko, Indiano

REV. ROY G. HAMMAN, Postor

REV. ROBERT C. MESSNER,

Minister of

Education, Music, and Youth SUNDAY

Bible School

Morning Worship

Youth Groups

Evening Service

-WEDNESDAY

Victory Hour
9:25 A.M.

10:30 A.M

6:30 P.M

7:30 P.M

7:30 P.M 


\section{We salute the seniors - -}

Congratulations, Class of 1962

FAITH BAPTIST CHURCH

Ashland, Ohio Kenneth Durtshe, Pastor

EMMANUEL BAPTIST CHURCH

North Main and Fairview Street

Marion, Ohio

Congratulations

GERMANTOWN BAPTIST CHURCH

E. Peoria, Illinois Rev. Bob Buda

BAPTIST BIBLE CHURCH

4th Avenue at 21 st Street

Yuma, Arizona

COMMUNITY BAPTIST CHURCH

637 McConn Street

Connersville, Indiana

CALVARY BAPTIST CHURCH

Cresaptown, Maryland

Harold Allem, Pastor

CHERRELYN FIRST BAPTIST CHURCH

4300 South Lincoln

Englewood, Colorado

CALVARY BAPTIST CHURCH

1647 N. Ellsworth Ave.

Salem, Ohio

FIRST BAPTIST CHURCH

7th at Alton Streets

Beech Grove, Indiana

CALVARY BAPTIST CHURCH

E. Washington and Center Streets

Ashland, Ohio Fred Alexander, Pastor
FIRST BAPTIST CHURCH

330 Trowbridge Street

Allegan, Michigan C. L. Saliers, Pastor COMMUNITY BAPTIST CHURCH

19688 Kern Road

South Bend 14, Indiana

CALVARY BAPTIST CHURCH

Marion Road and Beal Avenue

Bucyrus, Ohio

WINDSOR VILLAGE BAPTIST CHURCH

2151 North Kitley

Indianapolis, Indiana

Young Peoples Class

WALNUT STREET BAPTIST CHURCH

Lebanon, Indiana

FT. MC KINLEY BAPTIST CHURCH

3526 Detroit Avenue

Dayton, Ohio

PENFIELD JUNCTION BAPTIST CHURCH

5046 Broadway

Lorain, Ohio

FIRST BAPTIST CHURCH

2nd and Clark Street

Pasco, Washington

CALVARY BAPTIST $\mathrm{CHURCH}$

Forest City, lowa

M. W. Stadt, Pastor

SHARON BAPTIST CHURCH

319 Stambaugh Avenue

Sharon, Pennsylvania 


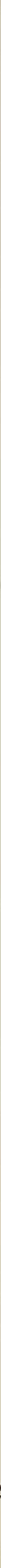




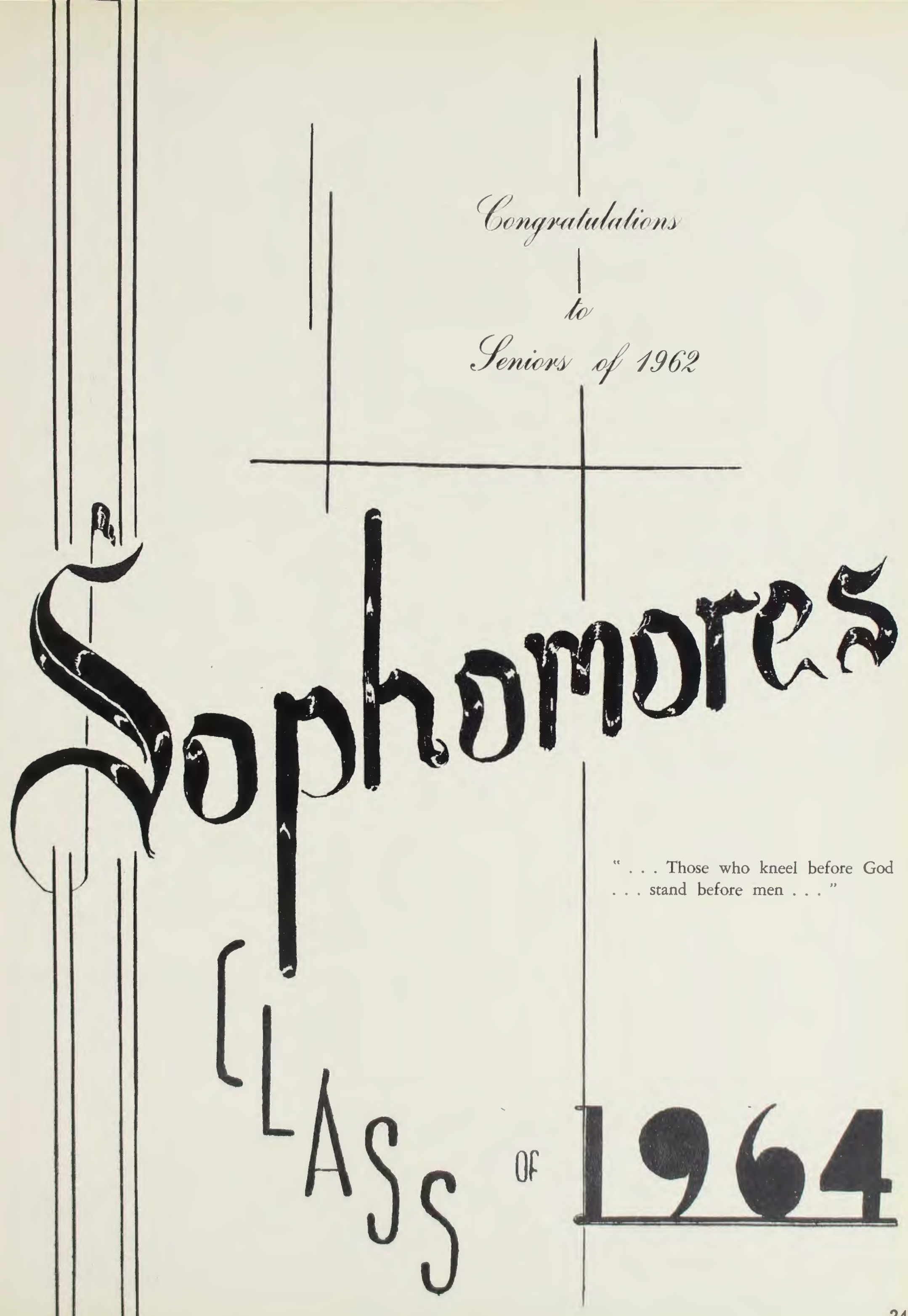




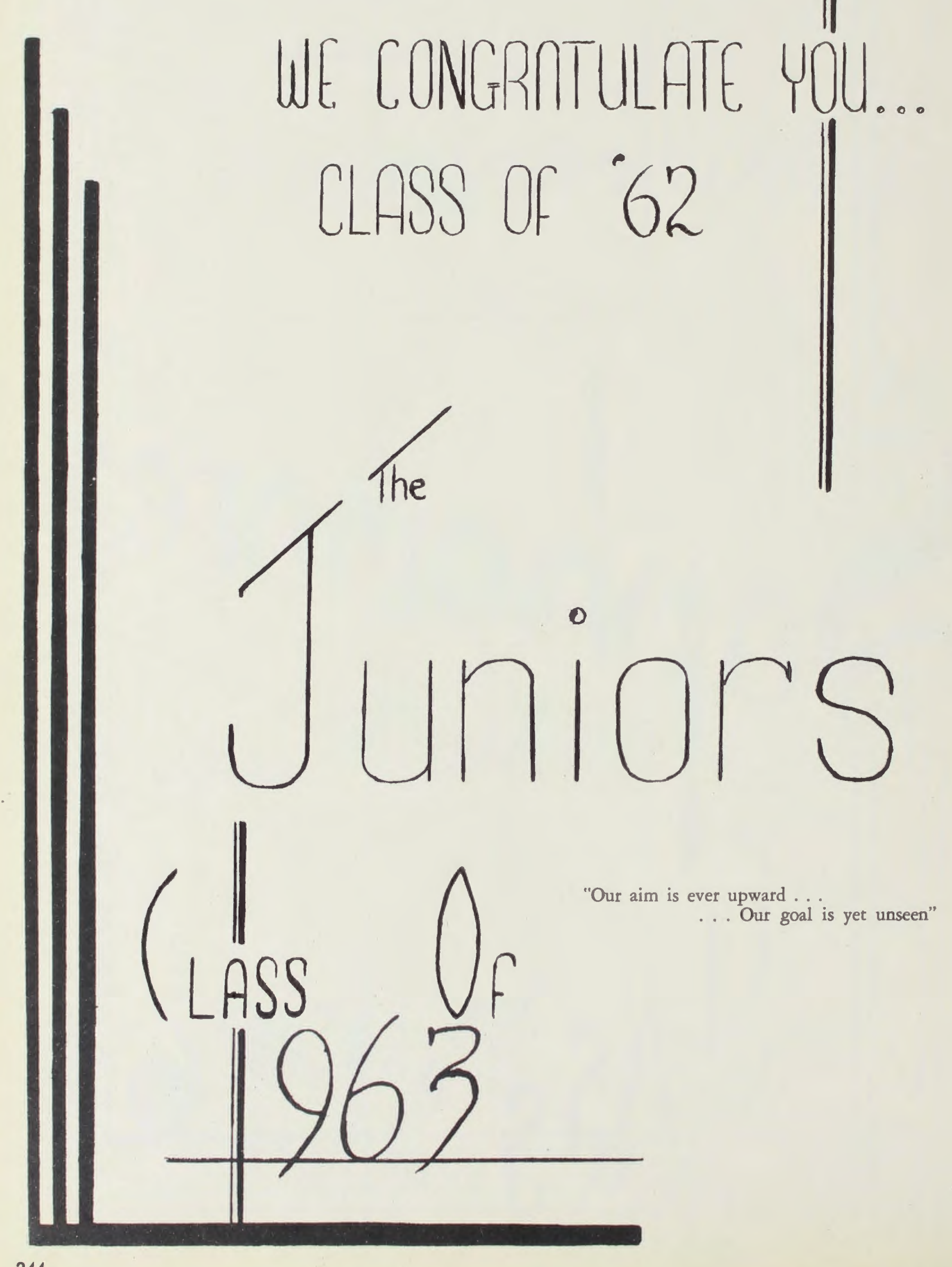




\section{Congratulations to the Class of ' 62 .}

\author{
RAY COX INSURANCE \\ 127 E. Main \\ Xenio - DR 2-7666 \\ MONTGOMERY WARD \\ 45 E. Main \\ Complete Department Store
}

CENTRAL BARBER SHOP 3) E. Main

Jerry - Gary - Phil

\section{CORNER PHARMACY}

Detroit and Main

"Three Decades Of Service"

\section{MODERN SHOE}

REPAIR SHOP

25 W. Main

Xenia, Ohio

\section{BAND BOX MUSIC} CENTER

31 W. Main

Xenio - Foirborn

\section{ANCHOR PAINT STORE} 33 W. Main

Xenio - DR 2-0785

\section{GEYER'S RESTAURANT}

15 W. Main St.

Xenio, Ohio

\section{THE CARD SHOP}

Hallmark Cords and Gifts

5 E. Main

\section{TIFFANY JEWELRY} STORE

65 Detroit Street

Hamilton, Bulova, Craton Watches
ROGER'S JEWELRY

STORE

22 S. Detroit

DR 2-7681

DAUM AND SON

120 S. Detroit St.

DR 2-5231

\section{JAY'S SINCLAIR SERVICE 138 S. Detroit St.}

Motor Tune Up

\section{SERVICING ENGRAVING \\ 19 Leomon St. \\ DR 2-4771}

\section{XENIA DAILY GAZETTE \\ "Growing with all \\ Green County"}

PENNEY'S DEPT. STORE

Xenia, Ohio

$372-6976$

\section{XENIA AREA CHAMBER \\ OF COMMERCE}

Your Partner in Business

Wishes Your Success.

\section{EICHMAN'S APPLIANCES}

52 W. Main Street

Xenia, Ohio

NILSON-BONE FLORISTS

44 W. Main Street

DR 2-4211

\section{CHERRY'S FURNISHINGS}

$36 \mathrm{~W}$. Main

\author{
MAIN AUTO SUPPLY \\ 28 W. Main Street \\ "Everything For The Cor and Home"
}

\section{HAZEL'S MILLINERY}

6 W. Main

"Foshion Wise People"

\section{BRAUN'S JEWELERS}

Registered Jeweler

Xenio, Ohio

\section{THE SHERWIN} WILLIAMS CO.

10 North Detroit Street

"Free Delivery"

\section{TASTY PASTRY}

30 North Detroit

"Baked today and sold today"

THE STANDARD OIL CO. Market and Detroit St.

Across from the Courthouse

\section{REECE PAINT AND \\ WALLPAPER CO. \\ 36 East Moin St. \\ Xenia, Ohio}

\section{HOME FURNITURE}

\section{E. Main}

Where service comes first.

Depend on

THE CAMERA SHOP 22 W. Main

\section{XENIA SCHOOL AND OFFICE SUPPLY \\ 35 Greene Street}




\section{A Closing Wond}
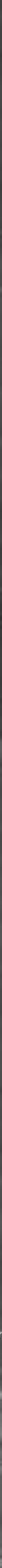
In appreciation to oun friends

ART COX STUDIOS

FELLOWSHIPING CHURCHES

LOCAL PATRONS

INTER-COLLEGIATE PRESS

We, the staff, thank you for your kind and patient help in producing this 1962 MIRACLE.

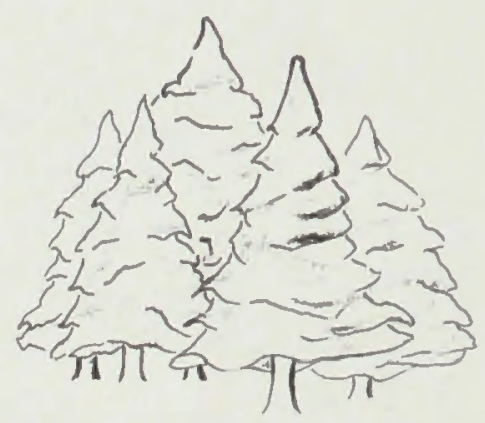

1887-1962 
Abshear, Keith -- 210

Ackerman, Sharon - 99, 145, 210

Adams, Elaine -- 44, 89, 198

Adams, Patricia -- 85, 101,102,108,110,112, 169, 198

Adams, Ross -- 210

Adamson, Barbara - 91, 188

Adamson, Bette - 91, 99, 143, 145, 146, 198

Adamson, Samuel -- 117, 210

Addleman, Janice - 109, 210

Addleman, Sharon - 44, 102, 109, 145, 198

Alberter, Kathleen - 99, 210

Albrecht, Rosa Lee -- 89, 188

Alexander, Barbara -- 198

ALEXANDER, Mrs. W. E. - 43

Alexander, W. E. - 115, 180

Allen, Warren - Senior - Not pictured

Allman, Ruth Anne - 210

Ammons, Martha - 107, 108, 110, 113, 161, 210

Amos, Janice - 209, 210

Ashley, Vance - 111, 127, 128, 131, 188

Atkins, Kenneth -- 132, 133, 198

Atkinson, Cinda Lou -- 210

Auffort, Robert - 108, 132, 133, 198

Baker, Lawrence - 58,134, 135, 169, 171, 198

Baldock, Robert -- 97, 99, 188

Bales, Russell Duane - 109, 210

Balke, Sarah -- 89, 145, 164, 210

BARKER, Mr. Carol -- 38, 52, 53, 171, 195

Barrett, Patricia -- 89, 198

Bartheld, Suzanne - 99, 165, 210

BAR'THOLOMEW, Mr. Raymond - 56

Bayless, Lois - 92, 93, 198

Beard, Lawrence - 210

Bedwell, Janet -210

Bellew, Denn is - 198

Bender, Sally - 44,59, 108, 145, 163, 169, 198

Bennett, Lee - 188

Benson, Irene - 96

Benson, Roberta -- 188, 210

BERGEN, Mrs. H. - 42

BERGEN, Mr. Harmon -- 56

Bergsma, Marvin -- 210

Betts, A. Leigh -- 210

Betts, Charlotte - 198

Biddle, Allen -- 98, 127, 129, 188

Bigelow, John -- Second Semester Student - Not Pictured

Bingamon, Charles -' 210

Bird, Julia - 44, 188

Blackburn, Barbara -- 117, 198

Blann, Mary -- 99, 100, 120,198

Bloemer, Charlene - 122, 199

Blossom, Dave -- 218

Blumenstock, Richard -- 73, 175, 187, 188, 195

Boalt, Steve -- 109, 180

Boren, Carole - 53, 85, 112, 188

Brandes, Gary -- 139, 142, 210

Bresson, Richard - 175, 188

Brong, Mary - 210

Brooks, Gale -- 145, 199

Brovont, Hazel -- 80, 90, 91, 180

Brower, Paul -- 142, 211

Brower, Philip - 137, 188

Brown, Carol - 96,101,102, 189

Brown, Penelope - 89, 108, 112, 211

Brown, Sharon - 102, 111, 164, 211

Brown, Thomas -- 199

Bryant, Joan - 89, 199

Bryant, Tyrone - 199

Buchanan, Philip - 199

Buerer, Nancy - 44, 107, 110, 211

Buerer, Peggy - 43, 189

Burlingame, Ardith - 211

Burnside, Warren - 45, 87, 99, 107, 199

Butler, Rayna -- 164, 211

Byrd, Shirley -- 89, 99, 113, 211

CALLAN, Mr. Donald - 54, 98, 124, 137

Call, Alice Jill - 218

Canine, Sam -- 111, 189

Cannon, Flora - 91, 100, 189

Carlson, Paul - 45, 103, 211

Carpenter, Dave - 169,171, 211

Carpenter, Sharon - 211

Carr, Alberta - Not Pictured

Carter, Dozler - 138, 211

Carter, Joan - 91, 107, 199, 219

Cartwright, Lor raine - 121, 180, 219

Cayton, Ardith -- 99, 102, 211
Cayton, Lynne -- Second Semester Student - Not Pictured

CHAFFE, Mrs. S. L. -- 43, 66, 67

Chitty, Gordin - 108, 199

Clemence, Joyce -- 199

Cochran, Dave -- 120, 189

Connell, Bud - 127, 130, 218

Cook, Henry - 77, 169, 199

COOKE, Mrs. R. - 60

COOKE, Mr. Richard -- 60,103, 152,170, 195

Coppock, Carolyn - 42, 107, 211

Couwenhoven, Judy -- 107, 110, 113, 161, 211

Cowen, James -- Night Student - Not Pictured

Cox, Virginia -- 180

Coy, Jeffery - 107, 109, 110, 111

Crabb, Alvah - 211

Crull, Martha -- 107, 109, 113, 161, 211

Cunningham, Mary -- 107, 110, 165, 211

Curcio, Victoria -- 99, 102,113, 211

Cushey, Loretta -- 189

Czerniak, Larry -- 75, 103, 199

Dadisman, Judy -- 89, 170, 189

Davidson, Donald - 95,211

Davidson, Richard -- 92, 93, 103, 111, 169, 189

Davis, Carol -- 116, 211

Davis, Donna -- 91, 189

Davis, Janice -- 107, 211

Davis, Ray -- 139, 142, 212

Day, Howard -- 44,142, 199

DeLanzo, Tom -- 98, 127, 128, 130, 197, 199

DeVey, Ruth - 102, 164, 212

Dickson, Nancy - 199

Doctor, Fay - 108, 212

Domokos, Robert -- 84, 85, 96, 97, 148, 179, 180

Duddleston, Lois -- 91, 100, 169, 200

DuPre, Jeannie - 85, 95, 169, 189

Dyda, Sharon -- 212

Dykstra, Carol -- 100, 165, 212

Earnhart, David -- 86, 87, 97, 103, 108, 111, 144, 181

Eastman, Edward -- 189

Eaton, Jerry -- 212

Eckert, Susanne - 107, 108, 112, 212

Edwards, George -- 212

Edwards, Robert -- 107, 200

Elder, William -- 98, 138, 140, 189

Ellis, Robert - 98, 124, 169

ELMORE, Mrs. A. -- 41

ELMORE, Mr. Austin - 63, 64, 95, 209

Elmore, Beth -- 200

Elmore, David - 212

England, Ronald -- 200

Entner, Donald -- 95, 142, 209, 212

Evans, Mark - 200

Evans, Tom -- 98, 127, 129, 142, 200

Everett, Donna - 190

Farnsworth, Leon - 190

Fennell, Suzanne -- 99, 212

Fetzer, David -- 200

Fidler, Robert - 92,127, 190

Finley, Donna-89, 101,102, 11, 190

Finley, Gordon - 103, 110, 111, 169, 200

Fisher, David - 103,111, 142, 212

FISHER, Miss Jean - 49, 121, 122

Floyd, Mary Ellen -- 107, 212

Frazier, Rush - Special Student -- Not Pictured

Freytag, Winnie - 109, 212

FRYE, Mr. Bert -- 63, 65

Fullhart, Susan 89, 200

GALE, Mrs. R.--42

GALE, Mr. Ralph -- 66

Gathany, Paul -- 62, 94, 194

Gayer, John - 212

Geeting, Michal -- 89, 99, 164, 212

Geyser, Suzanne -- 44, 99, 107, 163, 200

Gingell, Judith - 91, 200

Ginz, Jane - 85, 88, 89, 92, 93, 107, 190,1173

Goff, Judy $-43,212$

Golden, June - 51, 57, 110,112, 190

Goodman, Shirley - 44,107, 200

Goodwin, Fredric - 212

Goodwin, Mary - 99, 169, 200

Gordon, Dave - 200

Gordon, Gayle - 99, 212

Gorthey, Carol - 200

Grafton, James - 127, 129, 190

Grant, Jack - 201

Grant, Joyce - 181

Grant, Phillip - 44, 109, 112,190 
GROMACKI, Mr. Robert - 49, 97, 197, 173

Haas, Faye $-91,101,107,108,112,201$

Hale, Darlene - 201

Hall, Donald - 190

Hamilton, James - 45, 201

Hamilton, Joanne - 218

Hammack, Bonnie -- 108, 169, 212

Hamman, David - 201

Hartsell, Jeane - 41, 201

Hartzell, Judy - 212

Haseltine, Mark - 85, 87, 98, 127, 130, 187, 190

Hatfield, Merilynn - 213

Hayes, Roy - 213

Heikes, Amy - 213

Hell, Carole - 80, 91, 96, 179, 190

Helmick, Larry -- 191

Hemenway, Barbara - 91, 181

Henry, Helene - 213

Henson, Carol - 78, 201

HES, Miss Marjorie - 41

Higdon, Donald - 213

Himsel, Elsie - 44, 107, 120, 169, 201

Hindman, Virginia - 169, 213

Hirschy, Elaine - 201

Hoffman, Judy -- 213

Hollenbeck, Marvin - 103, 108, 111, 213

Honaker, Gloria - 213

Howard, Elayne -- 101, 102, 110, 111, 169, 191

Howard, Ellis - 191

Humphreys, Judy - 201

Ingram, John -- 43, 103, 191

Irelan, Lee - 191

Irish, Phyllis - 107, 113, 213

Jackson, Bonnie - 43, 67, 107, 201

Jacobs, Gary - 201

Jacobson, Lois - 201

Jefson, Lynn - 111, 187, 191, 213

Jenson, David - 99, 107, 110,111, 161, 209

Jeremiah, David - 98, 101, 103,111, 125, 137, 138, 191

JEREMLAH, Mrs.J. -- 41, 100

JEREMIAH, Dr. James - 30, 36, 49, 174

Jeremiah, Maryalice - 41, 102, 213

Jodry, Paul - 213

Johns, Donna -- 89, 96, 201

Johns, Susan -- 109, 145, 213

Johnson, Bonnie - 213

Johnson, Donald - 191

Johnson, Gary - 99, 201

Johnson, Joan - 91, 202

Johnson, Ruth -- 102,113, 213

Joiner, James - 202

Joiner, Priscilla - 191

Jordan, Elaine - $67,91,181$

Jordan, Medora - 218

Joy, Lois - 213

KAN'TZER, Miss Ruth - 56, 92, 93

Karsnak, Marian -- 202

Kaster, Patricia -- 99, 117, 143, 213

Keim, James - 202

Kelly, Donald - 169, 213

Kennedy, Lois - 80

Kensinger, Richard - 202

Kettell, Nancy - 99, 145, 213

Kidd, Dorthea - 85, 181

Killian, Lawrence - 218,172

King, Elvin - 45, 99, 124, 197, 202

King, Marlin - 191

Kirisits, Sandra - 96

Lachman, Judy - 99, 101, 102, 143, 171, 191

Lamb, Larry - 213

Lamb, Ray - 214

Lane, Irene - 89, 99, 143, 191

Lane, Rodney -- 73, 98, 139, 202

Lanius, Carole - 91, 151, 179, 181

LAWLOR, Mr. George -- 49

Lawlor, John - 85, 192

Leiby, Judy -- 112,192

Leiby, Mark -- 214

Lewis, Dave - 98, 142

Lightly, Dorothy -- 99, 214

Eloyd, Joseph - 44, 192

Lobsiger, William - 44, 82, 192

Long, Marilyn - 218

Luyben, Stephen - 44,169, 214

Lyon, Beverly - $91,96,182$

McClish, Janet - 145, 202

McComber, Charles - 202

McConnell, Gertrude -- 214

McDONALD, Mr. Cleveland -- 49, 66, 67

McDonald, Dennis - 98, 127, 128, 202

McDugle, Ronald - 44, 214
McIntosh, Barbara -- Not Pictured

McINTOSH, Mr. Richard -- 38, 49, 85

McKeehan, Betty -- 96, 192

McKenzie, Donald - 214

McNamara, LeaAnn - 107, 214

Maag, Nancy - 214

Maclaren, Jean - 214

MADDOX, Mrs. C. $-56,89,94,169,173$

MADDOX, Dr. Clifford - 39, 52,173

Maple, James - 202

Marks, Sharon -- 102, 113, 202

MARSHALL, Mrs. C. -41

MARSHALL, Mr. Gerald - 45

Martin, Sheryl -- 202

Martin, Susan - 99, 214

Mathis, Ron - 107, 110, 111, 161, 169, 214

Matie, Stephan - 214

Mayo, Shelby - Not Pictured

Meek, Larry - 214

Merwald, Al -- 107, 142, 214

Meyers, Joan -- 214

Michaels, Judith - 102, 113, 202

MICK, Miss Bernice - 42

Mick, Ronald - 81, 202

Micka, Patricia - 91, 197, 203

Middleton, Don - 192

Miller, Barbara - 62, 107, 113, 214

Miller, Janet - 214

Miller, Terry - 161, 214

Millikin, Rita - 89, 102, 203

Mills, David - 203

Mitchell, Dorothy - 164, 214

Moffat, Jack - 98, 103,132, 133, 192

Moore, Jay -- 45, 95, 99, 203

Morgan, John - 101, 103, 120, 197, 203

Motts, Martha - 108, 110, 113, 214

Mundhenk, Luann - 85, 99, 145, 215

Nash, Bonnie - 85, 89, 96, 102, 203

Neely, Joanne - 107, 145, 215

Nelson, Joan - 99, 107, 215

Nettleton, Peggy - 215

Neufeld, Judy - 203

Newcomer, Sue - 107, 111, 215

Newman, Robert - 215

Nicklas, Norman - 44, 96, 97, 203

Nimmo, Steve $-103,110,111,134,135,169,203$

Norris, David - 215

Norris, Ed - 127, 129, 203

O'Bryon, Roger - 103, 144, 203, 207

Ocheltree, Ted $-84,85,98,111,127,129,134,135,138$ 187,192

Oehmcke, Arlene - 218

Oehmcke, Charles - 192

Olivas, Julia - 99, 107, 215

Olsen, Philip - 107, 11 1, 161, 215

Osborn, Jerry - 99, 142, 215

Osborne, Joe - 215

Palmer, Elaine - 203

Park, Dan - 203

Parker, James-Senior-Not Pictured

Patch, Aloha - 192

Pearce, Dennis - 215

Peasley, Byron - Not Pictured

Peifer, Jerry - 98, 124, 125, 182

Perry, David - 218

Petrie, Juliann -- 96, 99, 215

Piper, David - 182

Powell, Mary Ellen - 99, 112, 203

Prescott, John - 215

Price, Elizabeth - 107, 145, 215

Purdy, Daniel - 182

Pycraft, Kenneth - 192

Pyle, Harold - Not Pictured

Quiter, Clara - 91, 192

Rader, Wayne - 182

Raymond, Carrol - 215

Ream, Eugene - 215

REED, Mr. John - 56

Reiter, Joan - 182

Reno, Paul -- 85, 95, 103, 215

Ressler, Charlene - 96,148,179, 183

Reynolds, Robert - 109, 197, 203

Rich, Richard - 44, 85, 96, 97, 215

Rifenberick, David - 45, 95, 193

Riter, William - 108, 124, 204

Rodin, Harold - 193

Roe, Amy - 204

Rolfe, Fred - 132, 133, 183

Roloff, Val - 64, 108, 161, 215

Ross, Gladys - 108, 204 
Rothwell, Marian -- 99, 204

Rotondi, Tony - 45, 87, 96, 97, 99, 127, 130, 204

Rowland, Claudia - 215

Royse, Marvin -- Not Pictured

RUDER, Mrs. Esther -- 43

Russell, Chet - 107, 197, 204

Russell, Carol -164, 216

RUSSELL, Mr. Emerson -- 56, 60, 61

St. CLAIR, Mrs. K. - 43

St. CLAIR, Mr. Kenneth - 68, 187

Sarvis, Judee -- 216

Schenck, Lauren - 51, 96, 97, 115, 148, 187, 193

Schlosser, Ruth Ann -- 44, 204

Schmitt, Mollie -- 96, 192

Schonscheck, Patricia -- 85, 92, 102, 145, 162, 169, 193

Schultz, Betty Lou -- 91, 204

Schultz, Carolyn - Not Pictured

Schwartz, Carlton S. -- 139, 142, 216

Searles, David -- 204

Seevers, Stanley - 107, 204

Seifert, Richard - 204

Shanks, Sandra - 91, 121, 183

Sharrow, Marilyn - 216

Shelton, Catherine - 44, 76, 193

Shimits, Nancy -- 85, 100, 204

Shingleton, Michael -- 216

SHIRLEY, Mrs. J. - 44

Short, Martha - 113, 216

Shrider, Edna -- 44, 204

Shuler, Patricia - 216

Sichting, Shirley 44, 99, 216

Sidle, Jackquelyn - 109, 216

Siplock, Judy -- 91, 204

Slavens, Barbara --96, 204

Smelser, Eleanor - 107, 205

Smith, Betty $-82,107,110,115,169,183,172$

Smith, Judy -- 44, 205

Smith, Nancy -- 59,109,112,145, 162, 205

Smith, Norris - 98, 127, 128, 137, 138, 171, 193

Smith, Patsy - 44

SMITH, Miss Ruth -- 60, 61

Smoker, Jane - 204

Snyder, Ellis Patton -- 216

SPAULDING, Miss Margaret -- 41

Spencer, Richard - 139, 216

Sprague, James - 53, 98, 124, 126, 134, 135, 142, 205

Stadt, Jerry -- 73, 103,112,139, 142;161, 216

Stafford, Gerald -- 117,205

Standifer, Bogle - 135, 183

Stephens, Dan - 216

Stephens, Marvin -- 96, 216

Stone, Otis - 87, 98, 121, 171, 183, 219

Stowell, Margaret - 89, 205, $\mid 173$

Surber, Sharon - 216

Swigart, Kenneth - 77, 103, 205

TARTER, Mrs. C - 44

TARTER, Mrs. Charles -- 45

Taylor, David - 45, 92, 93, 97, 205

Taylor, Eleanor - Not Pictured

Taylor, Marsha - 216

Tennant, Don -- 85, 98, 124, 125, 193

Tennant, Eve -- 107, 145, 169, 209, 216

Terry, Patricia -- 89, 205

THOMSON, Mr. Dale -- 63, 195

Thompson, Donna -- 91, 99, 102, 143, 193

Thompson, Tom -- 184

Thoms, Evelyn -- 78, 193

Thorne, David -- 216

Thorne, Barbara -- 165, 216

THORNTON, Mrs. W. -43

THORNTON, Mr. William -- 60, 109

Tobias, Judith - 99, 216

Tremba, Janet - 216

Trumbull, David - 103, 205

TURNBULL, Mr. Bruce -- 63

Twiest, Brian -217

UNDERWOOD, Mrs. Ruth -- 41

Unzicker, Barbara - 91, 99, 145, 146, 205

VanAllen, Shirle - 205

Van Norman, Jane - 217

Varisco, Louise - 193

Vermillion, Sharon - 205

Versluis, Patricia - 99, 216

Wagnitz, Gerald - 96, 97, 193

Walborn, Jon - 217

Walborn, Judy - 107, 205

Walker, Joyce - 78, 101, 107, 108, 112, 206

Walker, James - 82, 109, 206

Walker, Roosevelt -- Not Pictured

Wall, Betty - 85, 91, 197, 206
Wallace, Eugene -- 217

Walthall, Gary -- 138, 140, 141, 206

Ward, Cornelia -- 99, 145, 217

Wardell, Jeanette - 217

Warfield, William -- 194

Warkentin, Nancy -- 194

Warren, Dave - 85, 92, 98, 103, 124, 162, 169, 206

Washburn, William -- 107,109, 116, 194

Watson, William -- 162, 217

Weaver, Carol - 217

WEBBER, Mrs. W. -- 68

WEBBER, Mr. Warren -- 60

Webster, Keith -- 44, 85, 94, 96, 119, 169, 184

Welch, Sandi - 206

Wellman, Sharlene -- 99, 145, 217

Werner, David - 44, 107, 217

Werner, Ralph -- 103,109, 110, 111, 194

West, Mary Ellen -- 206

Westcott, Patricia -- 218

Weyhe, Bradley -- 217

WHITE, Miss Gerry -- 41, 220

Wickell, Geraldine - 44, 115, 206

Wickham, Jay - 206

Wilhite, David -- 217

WILLIAMS, Dr. Arthur - 49, 50179

Williams, Jeneen -- 98, 217

Willie, Hope Marie -- 44, 206

Wing, Helen -- 99, 102, 120, 217

Wing, Sylvia -- 99, 145, 169, 217

Wiseman, Carolyn -- 217

Wiseman, Marvin -- 184

Wolfe, John -- 44, 107, 169, 217

Wood, Daniel - 218

Woodard, Irving -- 194

Woodman, David -- 82, 206

Woods, Beverly - 41, 51, 92, 187, 194

Workman, Linda - 217

Wray, Nancy -- 43, 217

Wright, Barbara - Not Pictured

WYSE, Mr. Rodney - 68, 69, 195

Zerby, Sandy -- 42, 184

Zerby, Terry -- 179, 184

Zeigler, Mervin - 44, 217

ZINN, Mr. George -- 60, 106, 152

\section{PA'TRON INDEX}

Allegan First Baptist - 241

Ashland Faith Baptist - 241

Beech Grove First Baptist - 241

Berea Baptist Church -- 229

Bucyrus Calvary Baptist - 241

Butler First Baptist - 227

Cedarville

CC Alumni Association -- 239

CC Bookstore -- 233

Feed \& Grain -- 235

Hardware -- 235

Chaplin Cleaners -- 235

Freshman Class -- 242

Grace Baptist Church - 237

Harner's Market -- 235

Harold's Sohio Service - 234

Irvine Dairy Isle -- 233

Junior Class -- 244

Miami Deposit Bank - 234

Miracle Staff -- 240

Morris Be

disregard to which are not indented

Miracle Staff -- 240

Morris Bean and Company

Pickering Electric - 235

Randall \&Stormont, Inc. - 232

Rheuberts' Market -- 235

Sophomore Class -- 243

Cleveland Cedar'Hill Baptist -- 227

Cleveland Milner Electric Co. -- 238

Columbus Immanuel Baptist -- 238

Connersville Community Baptist -241

Covington Calvary Baptist -- 236

Cresaptown Calvary Baptist -- 241

Dayton Ft. McKinley Baptist -- 241

Cecatur Riverside Baptist - 228

Des Moines Grandview Park Baptist - 240

East Peoria, Germantown Baptist - 241

Elkhart First Baptist -- 229

Elyria First Baptist -- 237

Englewood Chevelyn First Baptist - 241

Euclid Nottingham Baptist - 230

Fairborn Hoak's Greenhouse -- 235 
Forest City Calvary Baptist - 241

Gallipolis First Baptist - 226

Hackensack First Baptist --237

Hadden Heights Baptist -- 238

Hamburg First Baptist -- 226

Harvey First Baptist -- 231

Huntsburg Baptist -- 228

Indianapolis Windsor Village Baptist -- 241

Lebanon Walnut St. Baptist - 241

Lorain Pennfield Junction Baptist - 241

Marion Emmanuel Baptist -- 241

Medina First Baptist -226

Mishawaka First Baptist -- 240

Monroe First Baptist -- 229

Oberl in Lackland Road Baptist -- 228

Parma First Baptist -- 228

Pasco First Baptist -- 241

Pontiac Calvary Baptist - 230

Portsmouth Temple Baptist -- 231

Salem Calvary Baptist -- 241

Shell Rock First Baptist - 230

South Bend Community Baptist -- 241

Springfield

Blessed Hope Baptist - 229

Reco Sporting Goods--234

Riverdale Dairy - 232

St. Louis Regular Baptist Children's Home -- 230

Tottenville South Baptist -- 228

Verona Memorial Baptist -- 239

Willowick First Baptist - 236

Xenia

Anchor Paint Store -- 245

Art Cox Studio -- 239
Band Box Music Center - 245

Braun's Jewelers - 245

Camera Shop, The -- 245

Card Shop, The -- 245

Central Barber - 245

Chemp Furnishing - 245

Corner Pharmacy--245

Criterian, The - 245

Daum \& Sons - 245

Eickman's Appliances - 245

First Reformed Church - 227

Geyer's Restaurant - 245

Hazel's Millinery - 245

Home Furniture - 245

Jay's Sinclair Service - 245

Main Auto Supply - 245

Modern Shoe Repair Shop -- 245

Montgomery Ward - 245

Nilson-Bone Florists - 245

Penny's Department Store -- 245

Ray Cox Insurance - 245

Reese Paint \& Wallpaper Co. - 245

Roger's Jewelry Store - 245

Service Engraving - 245

Sherwin Williams Co., The - 245

Standard Oil Co. -245

Tasty-Pastry--245

Tiffany Jewelry Store - 245

Xenia Area Chamber of Commerce - 245

Xenia Daily Gazette - 245

Xenia School \& Office Supply - 245

Yuma Baptist Bible Church - 245

First Christian Baptist - 227 




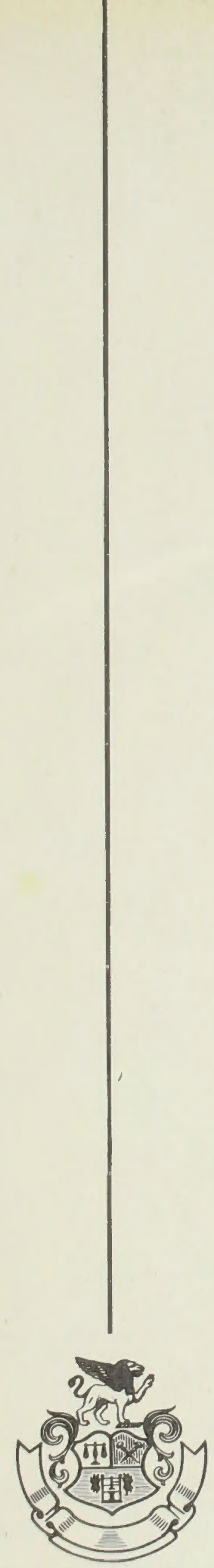

\section{INTER-COLLEGIATE PRESS}

Kansas City - Winnipeg

Publishers - Monufacturers

Yeorbooks - Yeorbook Covers

Diplomas - Groduation Announcements

USA 


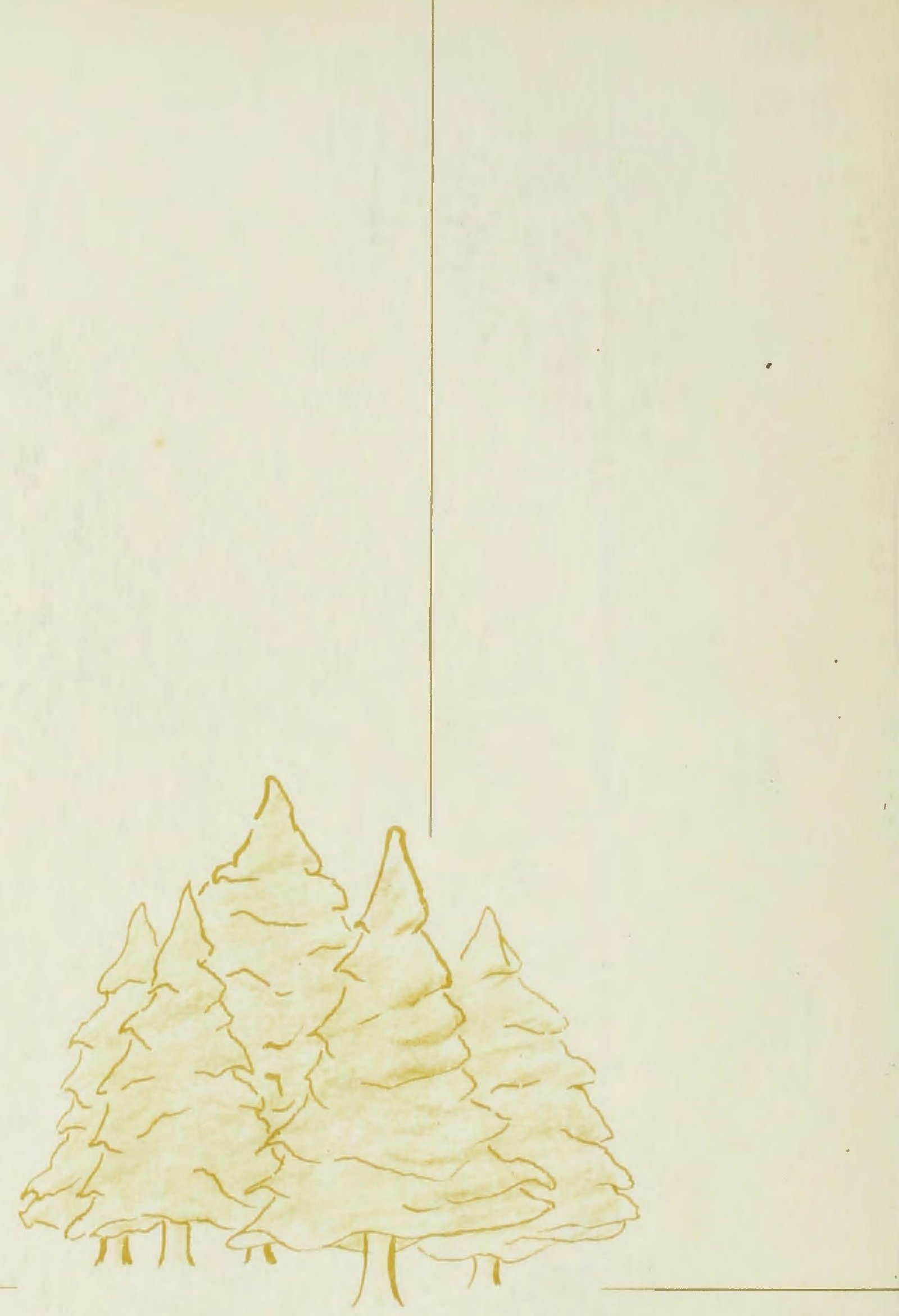

$1887=1962$ 


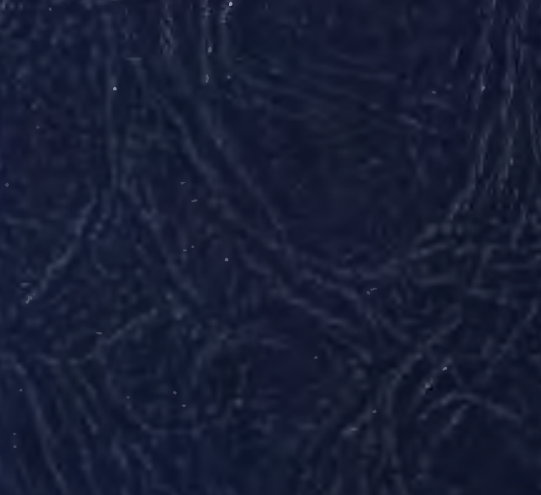

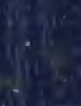
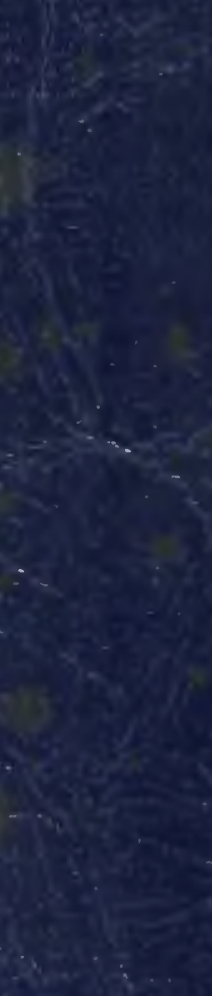

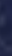
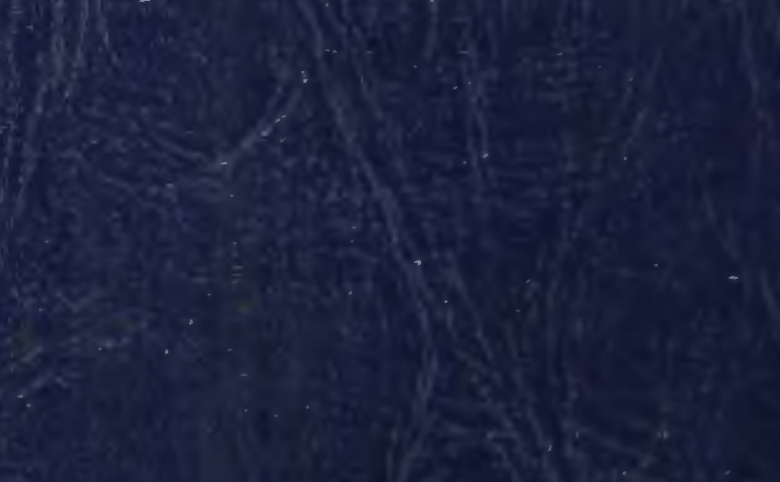

.

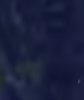
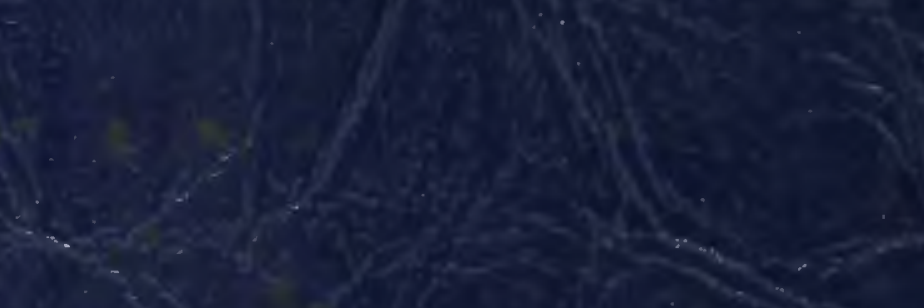

3

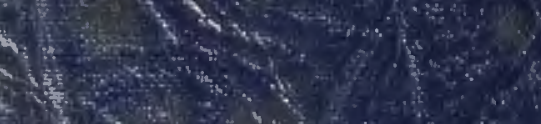

(2) fic it $=0$ 